\title{
THOUGHTS
}

\section{UPON SPORT}




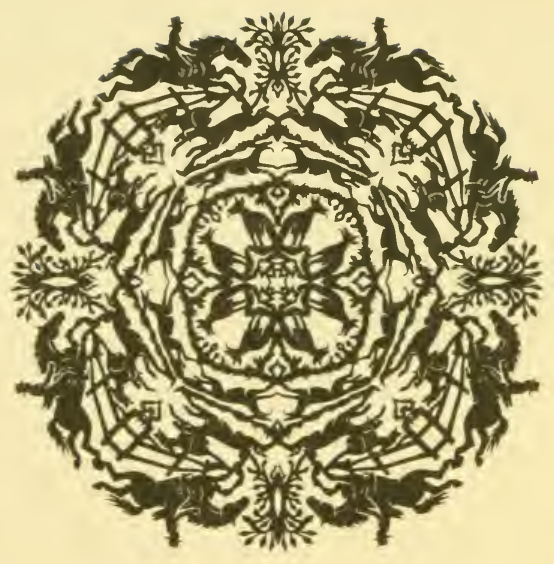

JOHN A.SEAVERNS 
Webster Family Library of Veterinary Medicine Cummings School of Veterinary Medicine at Tufts University 200 Westboro Road North Grafton, MA 01536 

THOUGHTS UPON SPORT. 




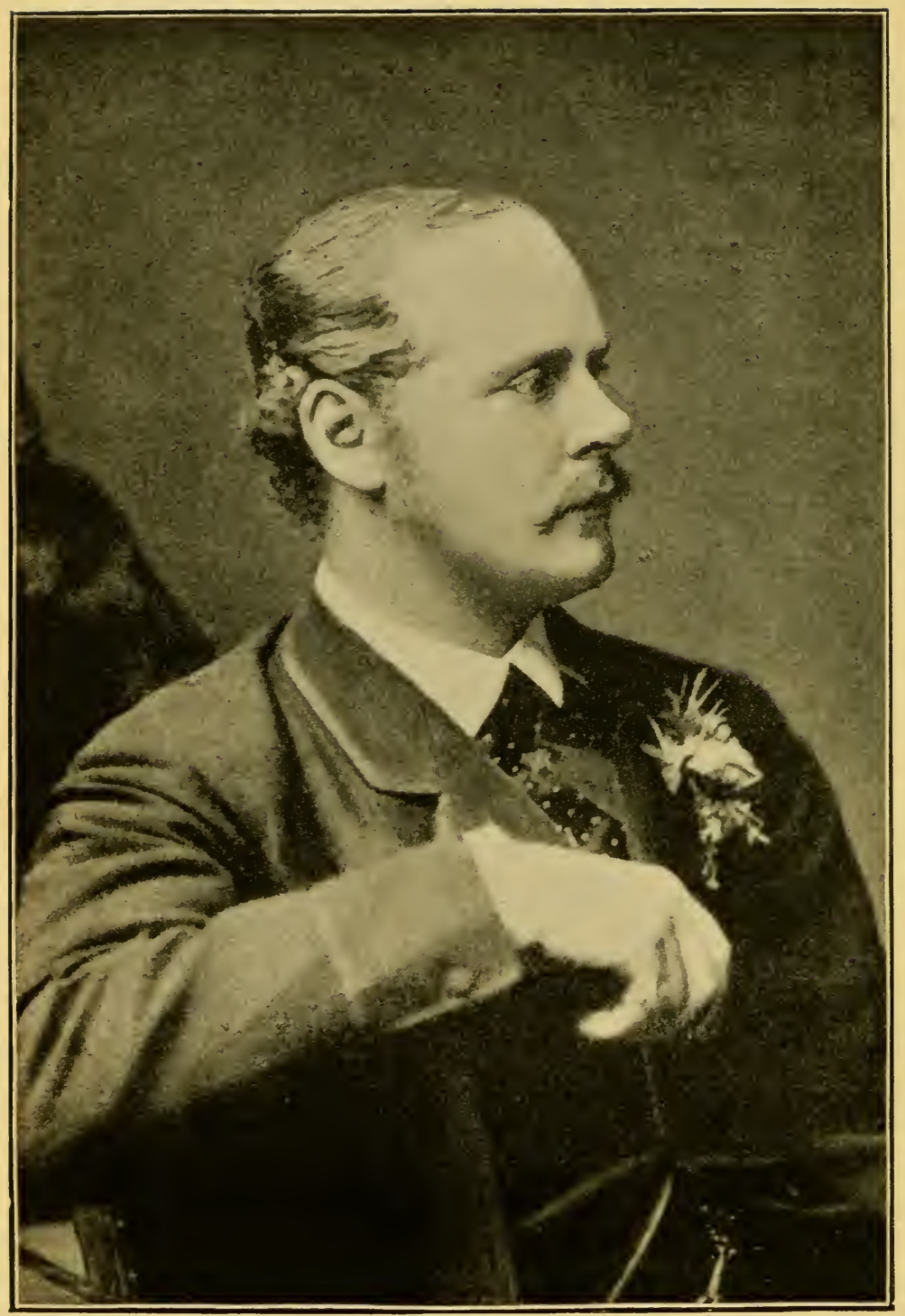

$$
\begin{gathered}
\text { ves incentrami } \\
\text { Vaterind }
\end{gathered}
$$




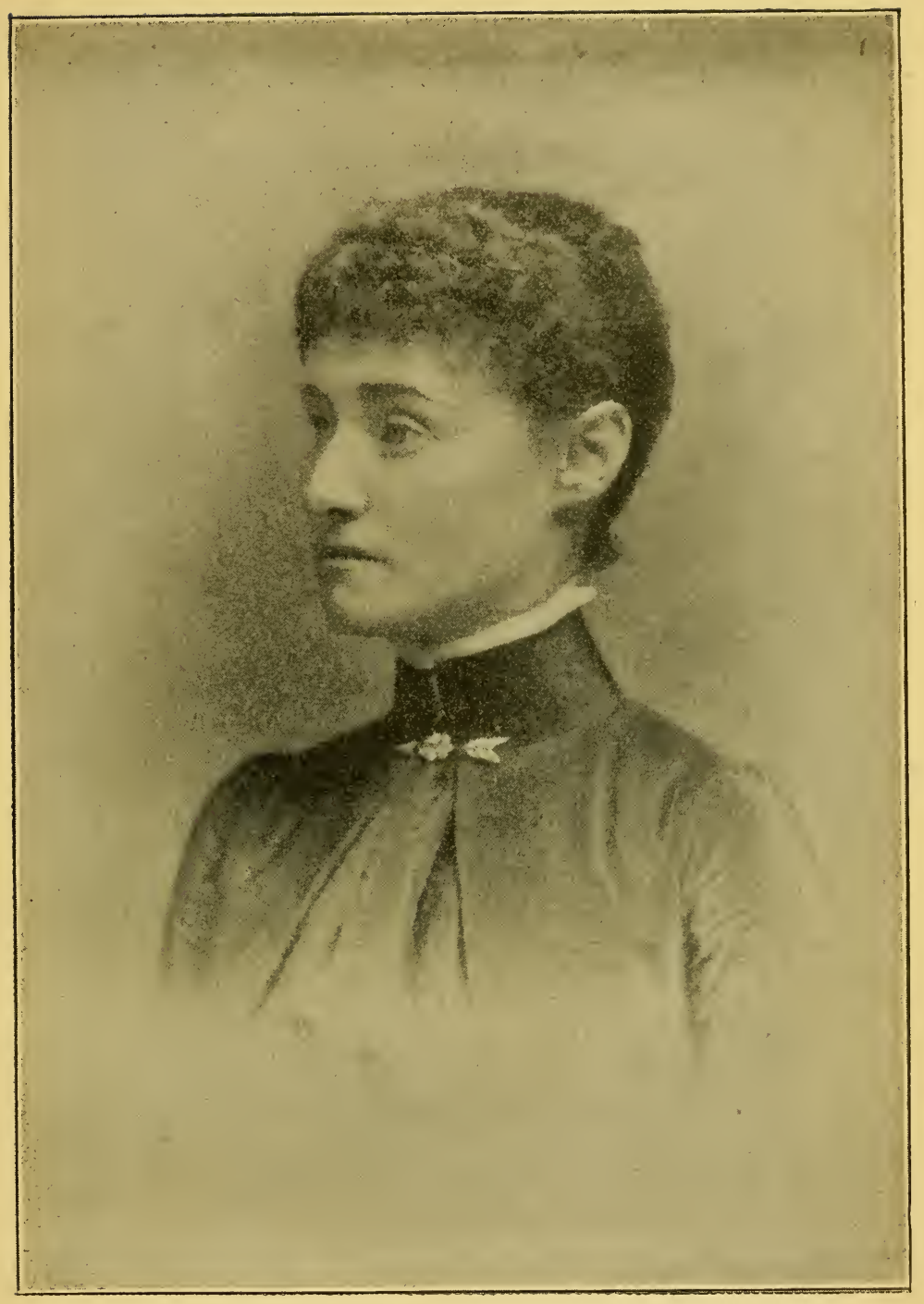

Beleve \&u Youss sucierely Blauche Watuford. 



\section{THOUGHTS UPON SPORT.}

BY

\section{HARRY R. SARGENT.}

A WORK DEALING SHORTLY WITH EACH BRANCH OF SPORT, AND SHOWING THAT AS A MEDIUM FOR THE CIRCULATION OF MONEY, AND AS A NATIONAL BENEFACTOR,

$$
\text { S P O R T }
$$

STANDS UNRIVALLED AMONG THE INSTITUTIONS

OF THE KINGDOM.

TO WHICI ARE ADDED

A COMPLETE HISTORY OF THE CURRAGHMORE HUNT AND MEMOIRS OF NOTABLE SPORTSMEN.

"No man is so foolish but he may give counsel at a time, no man so wise but he may err if he takes no counsel but his own."

LONDON :

SIMPKIN, MARSHALL, HAMILTON, KENT, \& CO., LTD., 4, Stationers' Hali Cotrt, Pateryoster Row.

$$
1 \overline{895} \text {. }
$$



TO THE

\title{
SiDarquis and Marcbioness of valaterforo,
}

\author{
BY THEIR KIND PERMISSION, \\ THIS BOOK
}

IS DEDICATED

BY THE AUTHOR.

Remembrance still duells on the days which are past, On runs we have ridden, the long and the fast;

Our horses-on eanvas-now hung to the wall,

Remind us of triumphs-prime sport they recall. 

SeEing how easy it is to interfere with Hunting, so that the King of Sports might at any time be annihilated, as was the case with the Curraghmore, with which Hunt I was personally identified for over a quarter of a century, and fearing, perhaps, that an epidemic of antipathy to sport, such as we for a time suffered from in Ireland, might break out in England, I was induced to begin this book as far back as the wenk of Frigate's Grand National. My primary object being to strive to once more establish the popularity of hunting in Ireland, and perpetuating other sports in England, I approached each branch of my subject from a point of view which I am not aware was ever taken by any other author-viz., that of showing how Sport, quite irrespective of amusement, benefits our nation and has brought about our individuality. While doing so I have sandwiched personal experience and anecdotes, from which a moral bearing upon the object may at times be deduced. And, as a pattern for young fellows to follow, I have alluded in short memoirs to some of the most notable sportsmen of the century. According to my lights and to the best of my ability I have suggested reformation where I considered it was desirable or absolutely required; and in doing so, being a plainwriting man, as I am a plain-spoken one, I have had at times to hit hard, therefore my remarks will not be agreeable to some people. That I cannot help, however sorry I may feel. I have written my book as best I could in the interests of Sport pure and simple, so I have not paid attention to interests, which, however individual, are to my mind of secondary consideration.

All through life I have been engaged in some active pursuit or other which left me little or no time to devote to literature; therefore any knowledge which I may possess has been acquired in my daily walk, only by the study of mankind and animals, the fields, 
the woods, and the mountains. If, therefore, I have reproduced matter already, and perhaps long since, before the public, no one can charge me with plagiarism. Except where acknowledged, what I have adduced in this book is the outcome of my own experience or observation, and those who have followed Sport in nearly all its branches for as long as I have done, will, I daresay, have come to sume of my conclusions, and if they have put their ideas on paper coincidence is inevitable.

Deficient as I am as a scholar, but refusing to have it edited, I am not such a fool as to think that my book deserves commendation from a literary point of view-the subject dealt with, and that upon my first attempt at a book, being one which, to treat adequately, would require the powers of a Whyte-Melville or a BromleyDarenport. Be it of what merit it may, the book should have been published more than two years ago by those to whom $I$ had first entrusted it; however, they have been got rid of, and the wellknown firm of Simpkin, Marshall, and Co., Ltd., Paternoster Row, are now my publishers.

Harry R. Sargent.

51, Pahl Mill, J.กxdox, August, 1895 . 


\section{CONTENTS.}

PAGE

$\begin{array}{lllllllllll}\text { Preface } & \ldots & \ldots & \ldots & \ldots & \ldots & \ldots & \ldots & \ldots & \text { vii }\end{array}$

Notice to the READER, WHICH HE WILL PLEASE REFER

TO BEFORE HE BEgINS THE RESPECTIVE CHAPTERS xiii ERRATA

... xlvii

CHAP.

I. The Curraghuore Huxt-

$\begin{array}{llllllr}\text { First SECtion } & \ldots & \ldots & \ldots & \ldots & \ldots & 1 \\ \text { SECoNd SECtion } & \ldots & \ldots & \ldots & \ldots & \ldots & 15 \\ \text { ThiRd SECTION } & \ldots & \ldots & \ldots & \ldots & \ldots & 22 \\ \text { Fourth SECTION } & \ldots & \ldots & \ldots & \ldots & \ldots & 49\end{array}$

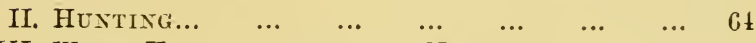

III. What HuNtiNg is to the Nation $\ldots . \quad \ldots \quad 79$

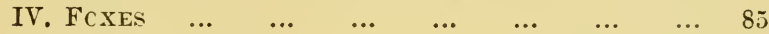

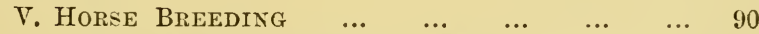

VI. BUYING AND CARE OF A HUNTER... ... ... 104

VII. Hexry W. Briscoe, EsQ, D.L., M.F.H. ... $\quad \ldots \quad 119$

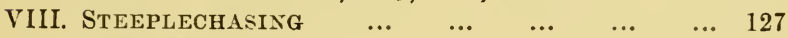

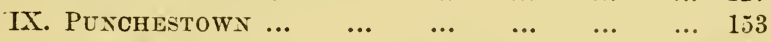

X. The Marquis of Drogheda, K.P... $\quad \ldots \quad \ldots \quad 165$

$\begin{array}{llllllllll}\mathrm{XI}, \mathrm{KACING} & \ldots & \ldots & \ldots & \ldots & \ldots & \ldots & \ldots & 171\end{array}$

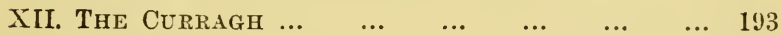

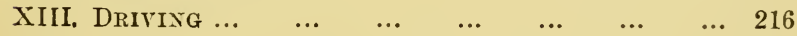

$\begin{array}{lllllllll}\text { XIV. FISHING } & \ldots & \ldots & \ldots & \ldots & \ldots & \ldots & \ldots & 229\end{array}$

$\begin{array}{llllllll}\text { XV. Sноотіх } & \ldots & \ldots & \ldots & \ldots & \ldots & \ldots & 234\end{array}$

$\begin{array}{lllllllll}\text { XVI. Coursixg } & \ldots & \ldots & \ldots & \ldots & \ldots & \ldots & 273\end{array}$

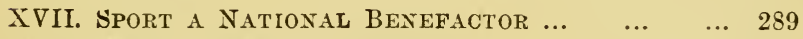

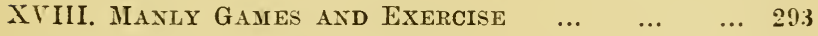

XiX. The Prize Ring and Cock Pit... $\quad \ldots \quad$... 308

$\begin{array}{lllllllll}\text { XX. Bettixg ... } & \ldots & \ldots & \ldots & \ldots & \ldots & \ldots & \ldots & 334\end{array}$

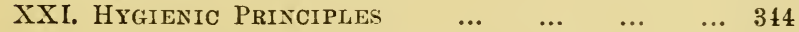

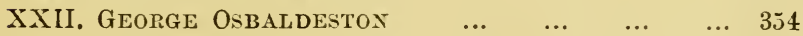

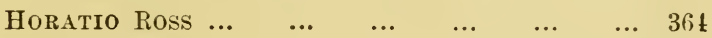

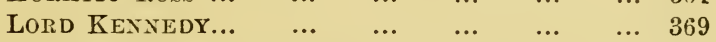

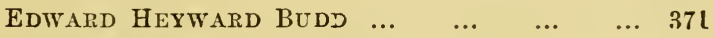

CAPTAIN BARCLAY-ALLARDICE $\quad \ldots \quad \ldots \quad \ldots \quad \ldots \quad 371$

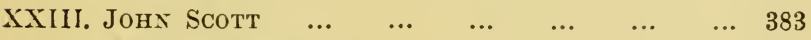

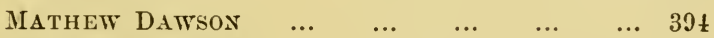

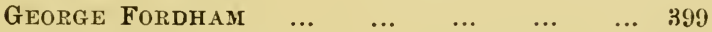

$\begin{array}{llllllll}\text { FRED ARCHER } & \ldots & \ldots & \ldots & \ldots & \ldots & \ldots & 402\end{array}$

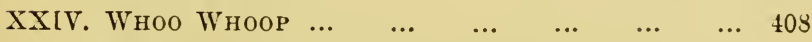

APPEN $L$ IX TO RACING (TO BE TAKEN UP AFTER

THE THIBD PARAGRAPH AT PAGE 18S) $\ldots \quad 421$

$\begin{array}{lllllllll}\operatorname{INDEX} & \ldots & \ldots & \ldots & \ldots & \ldots & \ldots & \ldots & 427\end{array}$ 



\section{ILLUSTRATIONS.}

$\left.\begin{array}{l}\text { The Marquis of Waterford } \\ \text { The Marchioness of Waterford }\end{array}\right\} \begin{array}{lllll} & \ldots & \ldots & \ldots & \text { Frontispiece }\end{array}$

$\begin{array}{llllllllllll}\text { The CURRaghmore FAMiLY } & \ldots & \ldots & \ldots & \ldots & \ldots & \ldots & 1\end{array}$

$\begin{array}{llllllllllll}\text { LUNGEING A HORSE } & \ldots & \ldots & \ldots & \ldots & \ldots & \ldots & \ldots & \ldots & 116\end{array}$

$\begin{array}{llllllllllll}\text { Punchestown Double } & . . & \ldots & \ldots & \ldots & \ldots & \ldots & \ldots & 147\end{array}$

$\begin{array}{llllllllllll}\text { Punchestown Courses } & \ldots & \ldots & \ldots & \ldots & \ldots & \ldots & \ldots & 157\end{array}$

$\begin{array}{lllllllllllll}\text { So-NoT So } & \ldots & \ldots & \ldots & \ldots & \ldots & \ldots & \ldots & \ldots & \ldots & 295\end{array}$ 



\section{NOTICE TO THE READER.}

OWING to the publication of this book having been delayed for over two years by those parties to whom I originally entrusted it, matters with which I dealt in the future tense have since become history. I have therefore to adopt this method for the purpose of bringing the book up to date, and $I$ take the opportunity to amend parts and add to others, while a copious index has been supplied. My readers will therefore be kind enough when reading any particular chapter to see if reference to it has been made in the following addenda, which the various sideheadings will facilitate.

\section{THE CURRAGHMORE. Chapter I.}

Although the history of the above once celebrated bunt has been faithfully recorded by me in the above chapter, I have recollected other particulars and incidents since writing it which I would fain record here, but space does not permit of my doing more than to correct a few typographical errors and add what is absolutely requisite.

To the list given at p. 4 of those who hunted in old times with Lord Waterford should be added Joseph Osborne, who knows the Stud Book by heart, and was a great friend of the Marquis; John Walshe, of Fanningstown, Clement Sadlier, Robert Cooke, of Kiltinane, John Congreve Fleming and his son Arthur, Capt. Dick Kellett, Ned Courtenay, Ned Clibborn, and Johnny Webb of the R.I.C., who was as bard-riding a welter as ever I saw, while Trant-McCarthy, a brother officer of his, in after years enlivened us with his wit and his stories. They are all dead now, except Osborne, Cooke, and Webb.

Samuel Ussher Roberts.-On top p. 5 has occurred a horrible blunder in making it appear that one of the very best sportsmen in Ireland, and one of the most useful public men, was dead ! Long may it be before my old friend Sam Roberts shall be gathered to his fathers.

ConRections. - The Errata deals with other printer's errors, but I must repeat that near the foot on page 16 " $£ 850$ " should be read as the yearly sum given to $\mathrm{Mr}$. Briscoe, instead of $£ 580$, and that the eighth line from foot of p. 20 should begin as a paragraph.

The point-to-point of the four Annfield runs, alluded to at p. 19, were respectively $8,11,8$, and 9 miles. 
Interchange of Meets.-I omitted to make mention in Section II of the interchange of meets which we had with the Tipperarys in Briscoe's time. We used to go to Fethard with the Curraghmore, and that prince of good fellows, John Going, used to bring his pack to Carrick. This was done by each Hunt once every season for several years, and on one occasion we paid the Wexford a visit at Stokestown, Mr. Beatty returning it at Glenmore. By good luck we nearly always had capital sport on those great days, despite the crowd and the hard riding. The idea was excellent, and might with advantage be followed, for nothing tended more to cement the good fellowship which always existed between us and our neighbours than this selfsame interchange of meets. Another time I may give the particulars of some of them for I took very good care to be at them all.

DUKE's Death.-Duke, as stated at page 28, became kennel huntsman in 1877 , and continued so until Mr. Springfield took the hounds to Tinvane in 1882, when Lord Waterford gave him a pension, and he continued to live at the kennels. A few couple of hounds were got together in about 1885, with which Duke initiated young Lord Tyrone into foxhunting, but had of necessity to confine his operations to the woods and demesne of Curraghmore. These hounds in turn were disposed of when the young Earl went to school, and on the 12th December, 1892, poor Duke died, aged fifty-three years, thirty-two of which were practically spent with the same pack.

Mr. Strangmax's Death. - With deep regret I have to record also the death of my old friend Mr. Joseph Strangman, which occurred on 2nd May, 1895, in his sixty-fifth year. Good man to hounds as he undoubtedly was, no one ever heard him talk about what he did. Though fond of all sorts of sport he did not practically engage in any but hunting. Poor Joe! Many a jolly day we spent together, and many were the long rides home we had.

\section{H U N T I NG.}

Chapter II.

"Sport a Natioval Benefactor."-Owing to my book not being published as it should bave been long before the Anti-Gambling League began its onslaught upon our sports and pastimes, I was obliged last Christmas to bring out in a pamphlet, entitled "Sport a National Benefactor," calculations as to the money spent upon Hunting, Shooting, Fishing, Racing, and Yachting, similar to those which I had previously put together for this book, and which are to be found in their respective chapters. Subsequently I brought out another pamphlet dealing in the same way with our minor sports and manly games. Both little books have been published by the Sporting League, 46a, Pall Mall, London, where they are to be had for three pence each. They 
show in more concise and perhaps better style than that adopted by me for this book some four years before, what an inestimable benefit sport is to the country quite irrespective of amusement, while they deal much more exhaustively with the glorious subject, bringing out, as the second pamphlet does, a total of $£ 47,313,000$ as the sum permanently invested in sport, with an annual expenditure of $£ 46,042,000$, which, as I say, is nearly half the National income, and more than double the total charge for the National Debt!

Feelivg of Animals.-- "Humanitarians" have also recommenced to attack our sports, and in doing so they show themselves to be as ignorant on the subject they deal with as are all other bigots and faddists; but as this book is one of reference and not of story, and as this matter is of importance, I shall refer shortly to it, even though the suhject has been often threshed out by others. We all know that the mental feeling of animals is vastly less acute than that of human beings. For instance, in a day or two they will have forgotten the young they had hitherto cared, perhaps "loved," so tenderly. Sights horrible to us have, of course, no effect upon brute beasts, while such fear of death as we have, although careful of their safety, can never occur to them. Besides, when death comes suddenly, or after any great shock, we don't even ourselves feel it much. We have good reason to suppose that their bodily feeling is equally obtuse, for in the case of the horse, whose cutaneous sensitivity is remarkable, he will, without wincing or showing the least sign of feeling, put up with a broken leg or other accident which would be to us such excruciating agony that we would howl again. A cow, a sheep, and an ass, who we all know have not nearly such thin skins as a horse, show the same indifference. A pig, however, will kick up a bobbery, but he would do the same if he got the prod of a stick! A hare will squeal when being killed by greyhounds, but as that timid creature will sometimes do so before she is caught it is just as likely as not that she cries from fear alone. Surely a bird with a broken wing does not suffer like a man with a broken arm. I saw a cock grouse picking heather tops half an hour after having been wounded so.

Fish, we may take ir, are all constituted alike as regards bodily feeling, and while I don't know if a salmon or the nimble trout would do so, a pike will, in a few minutes after, go at the same bait which conceals the hook on which, by the nose, he had been pulled at for perhaps a quarter of an hour! Does that indicate that he had suffered much pain or was very much tormented, or even frightened, by the angler?

Numerous instances have been related which show how little fear a fox has when being hunted. I myself saw one run fifty yards out of his way to get at a flock of geese, although the hounds were hunting his line not two fields behind. This he evidently did only for a lark, for he made no attempt to catch one, and pursued his course with a whisk of his brush after having scattered them cackling in all 
directions. He then passed quite close to where I was ensconced in a deep ditch behind a fence, and, not seeing me, he listened for a moment to the hounds, then sat down and scratched his ear with his hind pad, after which he leisurely cantered along the grip and went off for Glenbower, two miles away.

Don't let any one tell me that that fox was frightened of the hounds, but the sight of me would have made him run for his life, and if I had shouted at him he would have been more terrified than if the hounds were racing him in view. Nor was that a bad scenting day, on which foxes don't usually hurry themselves, for thehounds ran fairly fast.

Foxes Axd Sheep. - With reference to what I say at p. 85 about foxes not as a rule killing lambs, and that those put down to their account are ninety-nine times out of a hundred killed by dogs, we have primce facie evidence in the fact that sheep show no fear of a fox, but follow him slowly in a flock, with feet stamping and ears cocked, as he passes through their walk; but, if a strange dog appears they fly from him in confusion, even though he may not go near them, or appear in the least inclined to.

\section{HORSE-BREEDING.}

Chapter V.

Hackseys at Dublin Show.-I see in the papers some controversy arising out of the decision of our Royal Dublin Society not to give prizes this jear at the Dublin Horse Show for Hackney stallions. As far as I am a judge, I think the Committee have done perfectly right to eliminate from the catalogue of our great hunter show that class of horse. We Irish, as I say in another chapter, are not drivers, and as an art or an institution I don't think driving will ever rise much towards perfection in my country. What we want, and what we know more about than any other people, is the hunter, and him we can breed and train to, not alone gallop and jump, but to walk and trot, and so carry a man as safely along a road in the dark as he can over a country in the day. The system pursued of late years by my countrymen in breeding hunters has worked amazingly well, therefore it should be stuck to, and to import the hackney class into Ireland would tend directly to alter that system, for assuredly the breed would get mixed with that of our hunters. Stick to your own opinions, my friends the Committee of the Dublin Horse Show, and don't be influenced by parties who know nothing about Irish horse breeding, although they may talk and write a lot about it. Men who know most talk least, so you have not heard much from those who are in thorough accord with you, not alone upon the question of hackneyz, but upon the whole system of your management, including that excellent i Jea of giving prizes for well turned-out jarveys, the competition for which affords one of the most interesting exhibitions witnessed at our 
carnival. One of the great features of our Show is that what I may call the "professional horse" is never seen there. Open the gates to hackneys, and we shall see plenty of the professionals stepping needlessly high, and led by athletes at fifteen miles an hour in the arena hitherto sacred to the hunter and the horseman-an exhibition which is all very well for Islington, but it won't do for Dublin.

\section{CARE OF A HUNTER. \\ Cillpter VI.}

Correction.-On the fifteenth line of page 106 there is a stupid mistake, which my readers will kindly correct by reading "top of the shoulder," instead of point thereof.

\section{STEEPLECHASING. \\ ChAPTER VIII.}

Conrection.-Through a clerical error the famous Quorn covert is spelt at p. 130 "Barkly" instead of "Barkby."

Grand National Record.-The record wh ch I gave in this chapter of ouc Irish horses in the Grand National, ending as it did, after a sequence of three wins, with Comeaway in 1891, happily for the renown of old Ireland, but not for that of my book, is now a long way behind time, so I must bring it up.

Although his name denotes otherwise, and, strange to say, is the only one with Celtic significancs to be found among all the winners of the Grand National, Father O'Flynn was an English horse, and neither through owner, trainer, or jockey was connected with the old country, but he won in 1892, and thus broke the chain of a remarkable record, for the blue riband came to Ireland every year since then, as it did for the three years previously. Cloister, by Ascetic--Grace II., carrying to victory for the first time 12st. 7 lbs., won in 1892, as described in the postscript, p. 152. Why Not, bred by my friend Mr. Percy Nugent, who has the love of sport engrafted in him as deep as any man I know, won in 1893 in the hands of Arthur Nightingall after a good race with the Irish horses Lady Ellen II. and Wild Man from Borneo. The latter, after one of the finest finishes ever seen at Aintree, won this yearthe second being Cathal, another Irishman-amidst a scene of enthusiasm and applause the like of which was never seen on a racecourse except when Lord Rosebery won the Derby with Ladas, and the Prince of Wales won the Manchester Handicap last June with Florizel II. Instead therefore of the Irish record in the annals of the Liverpool Grand National standing as it did in 1891, when I wrote it up for this book, we now have twenty wins out of fifty-eight races, and running. into a place nearly every year. 
As I have expressed myself elsewhere, give me the man who breeds his own horse, trains him, and then wins his race on him-but such a man is not easily found. With Liberator, his own property and trained by himself, Mr. John Hubert Moore won the National in 1879, his son Garrett being the jockey-a fine performance, and the best record of the sort which I know of connected with that race, save and except that of Mr. John Widger in March last. Wild Man from Borneo (such a name!) was purchased by the eldest brother of the Widger family for the purpose of winning the Grand National, with his brother Joe in the saddle, after having been trained by his other hrother Michael. That praiseworthy ambition was achieved to the letter, and thus was realised the day-dream of that happy band of brothers, whose history, written by me, appeared in The Sportsman of April 13th, 1895.

CloIster.-Cl ister's time was put down at 9 minutes 32 seconds immediately after the race, but 9 minutes $42 \frac{2}{5}$ secs. were afterwards recorded, and so it now stands at; but giving him even 10 minutes to have won in with such a weight, although the going was perfection, I adhere to what I stated at the time, and is related at p. 152. That Cloister, over the Grand National course, was one of the best horses ever seen there is no manner of doubt, but I think there is a doubt whether he was better than The Colonel, Congress, Comeaway, or Royal Meath, while little Seaman, if he could have been trained to concert pitch, or perhaps St. Marnock, who was killed at Manchester, might have stretched his neck over the selfsame course. Anyway I hope to see Cloister win for Mr. Duff the Sefton in November and the National again in March, prepared, as he no doubt will be, by Harry Lindé, at Eyrefield.

Father Mathew.-The first Irish horse that won the Grand National is recorded in the calendars as Matthew, and sometimes Mathew ( $p$ 131), but his right name was Father Mathew, called after that "apostle of temperance" who did for Ireland more real good than perhaps any other man thit ever lived, be he clergyman or layman, in that he converted from drunkenness to sobriety tens of thous tnds, very few of whom ever "broke the pledge" they had voluntarily given to that paragon priest.

\section{PUNCHESTOWN.}

Cinspter IX.

Puxchestown Double.-Like many other things, the old double at Punchestown when looked at on paper, as a section of it can be done at page 147 , is very different to what it is in reality ; so in case any of my readers might take the shadow for the substance, I may tell them that that fence, while it is both safe and fair, is one of the stiffest to be found in any course in the world, notwithstanding its apparently 
insignificant height. To get well on to it horses have to jump some ten to eleven feet, then, in about four feet and a-half, they "change," which gets them to the top, from which, to clear the off grip, they have to jump at least another seven feet, the whole performance occupying three-quarters of a second. To fly the fence from field to field requires a horse to cover at the very least twenty feet in an arc of from twenty-five to twenty-six feet, which in itself is a very big jump indeed, and if he takes off further than a foot from the near grip, as most of them do, it is a pound to a penny that he comes a purler upon landing. I may add to what I say at p. 147 that the width of the top, which is formed on a slant, and must be viewed in connection with the depth and width of the grip, either when approaching the fence or standing close, is what causes people to be deluded into the idea that the fence, as it has to be jumped, is five or six feet high.

Regimental LUNCheons.-Owing to the MSS. having been lost by my first publishers, what I had written about the regimental luncheons at Punchestown has not appeared in Chap. ix. I am glad, however, to be able to rectify the error, even though it be not (in the proper place, for to have made no mention of these luncheons in a history of Punchestown would indeed have rendered the work incomplete. For the last thirty years it has been the custom of every cavalry regiment stationed in Ireland at the time, and many of the infantry regiments, to entertain their friends at luncheon during Punchestown, and this they did in regal fashion with hospitality as lavish as it was genuine. The space set apart for these entertainments is situated, as most people know, at the back of the Stand, and, covering nearly an acre, is enclosed with corrugated iron paling ten feet high. Within this space some twenty marquees were usually pitched, and in them nearly everyone who had Stand tickets got entertained upon both days, rendering it quite unnecessary for those who were at all known to bring luncheon to Punchestown. The generosity of our soldiers was, however, abused of late years and tickets misappropriated, which, coupled with the fact that the expense, which was enormous, fell heavily upon officers of moderate means, an order came from the General that such broadcast distribution of invitations should be curtailed, and at the last meeting, 1895, he forbade the luncheons altogether-an order which was not alone righteous, but was absolutely requisite. Thus, however, ended, perhaps for ever, an institution which had for over a quarter of a century become proverbial all over the world. Free luncheons are, however, plentiful enough still at Punchestown for the members of the Kildare Street Club, as well as the representatives of the great Guinness family, Lords Ardilaun and Iveagh, erected years ago permanent houses of corrugated iron adjoining the enclosure, where they entertain their friends by the hundred, and in style equal to that adopted by the soldiers, but with better management.

The Weather.-Of course we have had bad weather at Punchestown, 
and at times very bad, notably in 1856 and 1894, but with an experience of the dear old place a long way greater than most people's, I can state that on the whole we have had no reason to complain of the elements, while a fog-think of this, Aintree!-has never upon any one occasion of the great carnival visited our princely plains-since 1861 at all events.

The LARAgh RuN.--The Laragh run is not quite correctly described at p. 164, but was so in an article which appeared from me in Baily's Magazine of February, 1895. This famous hunt took place on the 26th November, 1859, and from Laragh House, where the fox wheeled to the right after going a mile from the gorse, until he was pulled down in the open close to the fence of Swainstown covert-a thirteen mile point-the line was almost as straight as it could possibly be, and all over grass without the semblance of a cbeck. The distance covered was about eighteen miles, and the time, including fifteen minutes in. Collestown, which was the only covert touched, was one hour and fiftyfive mins. Besides those enumerated at p. 164, I have found since that the Baron de Robeck, Mr. Michael Aylmer, Mr. Henry Meredith, Sir James Higginson, and Captain Frank Kennedy, with Gaffney, who was, and still is, Mr. Blacker's groom at Castle Martin (not Mr. Tuthill's), rode and finished the run, and Lord Naas, who, owing to an accident, was out on wheels that day, got there in time to see the fox broken up. Some one connected with the Magazine alluded to altered my MS. so that I am made to state that the celebrated Will Goodall was huntsman of the Pytchley insteax of the Belvoir ; and sporting phraseology which I had employed was also changed with disadvantage to the article.

Gestlemen Riders.-Among the gentlemen who rode at Punchestown thirty years agn, I wish to chronicle those I remember to have been the best. Messrs. Tom Pickernell ("Mr. Thomas"), George Ede ("Mr. Edwards"), George Knox, Willie Long, "Pig" Laurence, Pdt and Dan Russell, Dan Canny, Christopher Ussher, Pritchard-Rayner, Thompson, John Hutchinson ("Mr. Appleton "), Dominick Murphy, Jimmy Shee ("Mr. Hume "), and Hickman of the 8th Hussars, Captains Tom McCraith, "Curley" Knox, Tom Townley, who died only a few months ago, Harford, "Doggie" Smith, Shaw, Bernard, Tempest, Trocke, Barclay, Hutton, Candy, Warburton, Ricardo, "Joey" Little, Coventry, and last not least, Sir Richard de Burgho, Bart. Then came to the front the men whose names my readers all know, Messrs. Garrett Moore, W. B. Morris, Murland, the Hon. Reginald Greville-Nugent ("Mr. St. James"), Burn-Nurdock, Captains Lee Barber, Orr Ewing, "Bay" Middleton, and later still, Mr. Tommie Beasley, perhaps the most accomplished of them all, bar Tom Pickernell. Then followed his brothers and the many other fine horsemen whose names being constantly chronicled in the daily papers need not here be mentioned.

Professional Riders.-Among the old professionals were Dan 
Meany, Denny and Joe Wynne, John Doyle, John Debeau, James Monaghan, John Noble, Johnny Whelan, Larry Hyland, Dan and Jim Broderick, William Cusack, Johnny Hanlon, Tom and William Ryan, Tom Kelly, John Connolly, John Igoe, Stephen Kelly ; while of later date came Davy and Wılliam Canavan, Paddy Gavin, and George Gray.

Punchestown and Horse SHow.-Punchestown owes its patronage to the same section of Irishmen as does the Dublin Horse Show, which I describe at page 103. And in these, our two great national carnivals, the world has object examples which demonstrate plainly to what supreme excellence we Irish can bring great projects of our own conception when we are left untrammelled with politics or religion, and are not harassed by the interference of designing agitators.

\section{LORD DROGHEDA.}

Chapter X.

His Marriage and Successor.-I should add to the short memoir of Lord Drogheda which I give in Chapter x. that in 1847 he married Mary Caroline, daughter of the second Lord Wharncliffe, but left no issue, so that the marquisate became extinct, and he was succeeded by his cousin, Mr. William Ponsonby, as Earl of Drogheda.

And, reminded of the incident by the General Election which has just taken place, I may also add that shortly before his death our great chief told me that at one time he thought of going in for politics, to which I replied that I was glad he did not carry out his intention, for he would have had to do for expediency and for "party" what he never did, and never would do, when left to his own instincts. $\mathrm{He}$ made no reply, but well do I remember the piercing look he gave me and the significant smile which passed over those features, the expression of which was never indicative of anything save honesty of principle with independence of purpose.

\section{RACING.}

\section{Chapter XI.}

Nota Bene, p. 188-Appendix.-When they have read the paragraph, "Give heed, all Radicals, to this assertion," at head of p. 188, my readers are particularly requested to take up the Appendix to Racing, which they will find at p. 421 , for it is a continuation of what I may call the homily I began at p. 187.

Forebodivgs Fulfilled.-They will also see how strangely some of my forebodings have come true. The Duchess of Montrose not alone broke up her breeding establishment in July, 1894, but was on the point of giving up racing altogether, a loss which the Turf was saved 
from for only four months. for the lamented death of the poor old ady on November 16 last brought it about. The Hampton stud was broken up at the same time, a proceeding which was deemed ill-advised. The Duke of Beaufort soon after sold off both his racing and breeding studs, and many others since then have had to curtail expenses. Before then came the general reduction in the fees of high class stallions, with allowances to be made to owners whose mares had proved barren, which I had said was imperatively necessary (vide pp. 421, 422).

Financial Position of Racing.-The entries for the classic races of 1896, which closed in August, 1894, and those for the autumn handicaps, which closed about the same time, prove how correct I was in what I said about the stability of the Turf at present. Owing to a great. increase from abruad the classic races have more entries than usual, but if so the patrons are almost entirely confined to our wealthiest ownersscarcely a single small man is to be found among the lot. On the other hand the autumn handicaps of last year showed a lamentable falling off. In former years these ever-popular events were supported by the rank and file quite as much as by the great owners, but in 1894 the absence of the former was as conspicuous in the handicaps as in the classics. Strange to say, in Ireland it is quite the reverse. Very few of our wealthy country gentlemen now patronise tither recing or steeplechasing, nearly all our support comes from the middle classesnot so formerly, however. Thus is shown, in addition to what I say in the appendix and elewhere, how racing in England is going to the bad, despite the fact that never was the sport nearly as universally popular as it is at present, nor had we ever in the annals of the Turf such attendances at meetings as we have had the last two or three years, that at last Ascot being hugely greater than was ever before known. At Waterloo Station on the Cup day 900 tickets more were issued than upon any other Cup day since the railway was opened.

Let not these records delude the authorities into the belief that racing is in a good monetary position, for it is not, and I write again what I wrote at Christmas, 1892, and appzars in the appendix, that if something be not doae by the Jockey Club to relieve owners of expenses. the days of racing are numbered, and if ten times as many outsiders. were to go to meetings as $g$, at prese the downfall would not be averted for twenty-four hours!

What have the Royal processions, the drags, the luncheons, the ladies? lawn, or the ladies' dresses to say to the bills which the owners have to pay? But they have a great deal to say to the profits of the Race. Companies!

If our rulers should, of their clemency, take the matter up, it would be well for them to recognise the fact that we have, at present, too many horses, too many meetings, and too many races a day. Fancy eight. meetings in the year, even at Newmarket, extending over twenty-nine days, with six or seren races on each! The consequence is, that with 
all our horses, the fields at headquarters, as well as elsewhere, are ridiculously small, while meetings held all over the country for the benefit of outside interest in such superabundanc 3 as they are is positively a prostitution of the noble sport of racing-I state so advisedly.

Jockeys' Riding.-Not alone is the system of racing changed from what it was, but the riding is changed too. Long ago jockeys, sitting firm in the saddle, rode with their hands and knees, driving their horses. home without much aid of whip or spur. Now we see them coming in with loose rein, wabbling all over their horses, which they flog and spur unmercifully, and at times when there is no chance of winning. Many a race has been lost by undue punishment, while thousands of horses have been ruined by it; and if some of our present jockeys were taught that a prick of the spur will make nearly every thoroughbred horse give his running quite as well as excoriation of it, it would be a sound lesion.

Two-YEAR-OLDs.-Not long ago I showed a well-known trainer, who. also breeds extensively, what I wrote at p. 173 about working two-yearolds, and having the whole system changed as regards racing our youngsters. After having read it all over twice he took off his spectacles, and moodily said to me, "Yes, yes, it is all true, but if such a system was adopted all the breeders in England would be ruined." "Why?" asked I. "Because," said he, "horses would then last until they died of old age, and we breeders wou'd not have to provide one quarter of the young ones we do now." I don't think if he talked for an hour he could have given more commendation to my remarks.

The Duchess of Montrose-An Oversight.-When at Newmarket last Whitsuntide I discovered a mistake, which, although plain enough to be seen, was never observed before, at least so the clergyman of St. Agnes' Church told me when I drew his attention to it. The name of the Duchess of Montrose's second husband, Mr. William Stirling. Crawfurd, is spelt wrong on the tomb her Grace erected to his memory in the little churchyard on the Bury Road. There it is : $\mathrm{C} \mathrm{r} \mathrm{a} \mathrm{w} \mathrm{f} \mathrm{o} \mathrm{r} \mathrm{d}$. How it was that the Duchess, with that quickness of perception which was peculiarly her own, could have failed to have discovered the mistake: upon any of many scores of times she visited the tomb of the man she loved so devotedly was a problem the vicar, at all events, could not solve. Had she discovered it what would the poor sculptor have come in for? The mistake will, however, I daresay, be now corrected, for the same man, I was told, is erecting a tomb of similar design over the remains of her Grace, which lie alongside those of Mr. Crawfurd.

Morny Cannon's Doncaster.-Great as were Archer's achievements I doubt if he or any other jockey ever did better at one meeting than did Mornington Cannon at the Doncaster Autumn Meeting of 1894, when that jockey's wins were as follows:-First day:Stand Plate (9), Rowallan, 100 to 8 against; Champagne Stakes (5), Solero, 10 to 1 against; Great Yorkshire Handicap (16), Bushey Park 
100 to 12 against; Doncaster Welter (13), Lumberer, 100 to 8 against. Second day :-Milton Stakes ( 7 ), Newmarket, 5 t 34 on ; St. Leger (8), Throstle, 50 to 1 against. Third day :-Juvenile Selling (10), Queen Saraband, 9 to 4 against ; Rous Plate (6), Matabele, 100 to 30 against ; Portland Plate (15), Grey Leg, 8 to 1 against ; Corporation Selling (10), St. Ignatius, 11 to 8 against. On the fourth day he did not win, but he was second in the Cup on Portland with 100 to 6 against. Th re were twenty-six races in the four days, and Cannon rode in them all except the Fitzwilliam Stakes, Rufford Plate, Cleveland Plate, Bradgate Park Plate, and Prince of Wales Nursery, with a result of ten wins, four seconds, two thirds, which left only five "duck eggs" to his debit; besides which he rode a dead heat for the Tattersall's Stakes on The Brook, the decider being won by Finlay on Florendean. As is seen be won all the principal events except the Park Hill, the Stakes and the Cup, in which latter he was second, and many of his mounts were outsider, while Throstle created the most remarkable surprise perhaps ever recorded in the Leger. The twenty-one races which he rode covered exactly twenty-two miles and a half, and those who "followed" this able and popular jockey by putting one sovereign at s. p. to win on each of his mounts netted exactly $£ 98$ 9s. 2 d., i.e., won $£ 109$ 9s. 2 d. and lost $£ 11$, a result which came to the share of few others, for never was there a more disastrous meeting for backers than was the one under reference. If, therefore, this riding of Morny Cannon's has not established a record among "jockeys' mounts," I am very much mistaken. Even at a small meeting it would have been marvellous, not to speak of the Doncaster September, which I maintain is the most important we have in the calendar. So little was thought of Throstle's chance that it was intended that she should be used as a pacemaker for Matchbox, but at the last moment Cannon requested to be allowed to ride the mare as he liked, hence the result. His riding in some of the other races was also remarkably brilliant, particularly on Queen Saraband and Grey Leg.

\section{THE CURRAGH.}

\section{CHAPTER XII.}

The Beasleys-Corrections pp. 203, 205, 206.-At page 203 the rotation of the brothers Beasley is given wrong-they came as follows:--Tom, John, Harry, James, and Willy. And two pages on I should have said that the Stand House is a little short of three miles, instead of nearly four, from Eyrefield House. Again, Charley was old Canavan's name, and not Davy ; while by a printer's mistake, in not putting a comma after "off" in the last line of p. 206, it would appear that the fox covert was not on the Curragh, which it is, and close to the railway on the opposite side from the Stand House.

EcLIPSE.-At page 211 is made a mistake about Eclipse which I 
can't account for, as I knew well enough that he was not an Irish horse, being by Marske out of Spiletta, and bred by e Duke of Cumberland in 1764 .

Crotanstown Stud.-When I wrote my nistory of the Curragh there was no one living at Crotanstown, and old Brownstown was in dilapidation, but since then Captain Greer has started stud farms at both places, and after last Punchestown I had the pleasure of being shown over them by the owner. I don't think I ever enjoyed a visit of the sort more, for there I saw everything done as it should be. The stabling and sheds, which are all new, are laid out upon the most convenient plan and built in style as substantial as it is picturesque. The paddocks at both establishments are numerous and not too large, as they are in many places, while in all of them are found that undulation of ground which is so beneficial to foals and yearlings, while the herbage, springing from generous limestone soil, shows by its abundance how carefully the paddocks with their neatest of hedges are attended to. Captain Greer started only six years agn, but being wonderfully endowed with brain-power, and thoroughly master of his business, he has got together within that short time some twelve brood mares which for quality and breeding cannot be surpassed in any other breeding establi:hment that I know. His foals and yearlings, bred for his own racing, were also gocd, and are got by the best and most fashionab'e sires of the day, many of them being by his own hore Gallinule. I had a long look at this $\mathrm{h}$ ree, and certainly he is the sort to beget alike race-horses, steeplechasers, and hunters, and he is as quiet as a lamb. He was not sent many good mares in his first season; his stcck, however, showed from the beginning that they were capable of winning, and since then he has been mated with the very best mares in Ireland, so that last season Gallinule stood high in the list of winning stallions. Captain Greer p'aces a high value upon this horse, and so he may, for his reputation as a sire has been established, and the source of a nice income will he be to his popular owner for, let us hope, many a year to come.

Waterford Lodge was also empty at the time I wrote, but that fine horseman, Mr. Willy McAuliffe, has recently resumed training, and has now a select stud under his charge at this once famous stable.

\section{DPIVING.}

\section{CHAPTER XIII.}

London CoAchmen.--Since I wrote as I did at p. 218 about London traps and private coachmen I have altered my opinion on the subject. We can see many a badly turned-out private trap in London, and many a man driving it whom you would imagine spent most of his time at work in the garden. What has struck me lately-and I have seen more 
of the Park duriog the past two years than I have done since I was a. boy-is that not one private coachman in a hundred drives without the assistance of the $r^{\prime}$ ght hand, not even when ging slowly one carriage after another, and invariably will they pull the right rein out of the: left hand to get hold of it with the right. With the reins thus held and the fellow trying to use his whip, see what an exhibition he makes of himself! You also see some of them with a rein in each hand same as a coxswain uses the yoke lines from behind. No, no, the English private coachmen don't drive as well as I thought they did four or five years ago, but the busmen and hansom cabmen do, and they, as a class, are the very best drivers in the world. They are also, as a lot, honest, civil, and respectable, but, as I say at p. 219, they are intensely stupid in conversation, and not even a surgical operation would extract wit. from or inoculate them with it. So different from our own jolly, jovial. Dublin jarvies!

Waterford, Duvgarvan, and Lismore Coach.-It is not to besupposed by what I say at p. 223 that the old Dungarvan coach was badly horsed as a rule, for it was not, but the teams were not to say "handy." And here I shall relate something more about that famous. old coach, the last representative we had of an institution which was in its day probably as famous in Ireland as it was in England, and answered the requirements of the age quite as well as do railways. now; while, by means of four spanking horses, whose hoofs rattled in time to the clanking bars and ringing pole-chains, a halo of romance surrounded the whole affair, the like of which can never attach itself to. a shrieking locomotive or cumbersome train, much less surround it.

The Waterford and Lismore road, as far as coaching gofs, has. records as remarkable as any in the kingdom. The west of our county from Lismore, through Cappoquin, Dungarvan, and on to Waterford was opened up to the public towaro's the end of the thirties by Mr. Charles Bianconi, by means of his well-known long cars which. took his name, and to which two, three, or four horses were put according as the weight-bill required. The first man put on the box was Tom Keogh, and from 1837, or perhaps a year earlier, until 1861 he drove the whole way from Lismore to Waterford and back every week: day, except from about 1852 to 1858 , when he drove only from Dungarvan and back. The distance from Lismore to Waterford is fortythree miles, and from Dungarvan it is twenty-eight, therefore, for some eighteen years, he drove eighty-six miles a day, and for six years drove fifty-six.

There were three (perhaps four) stages between Lismore and Waterford, leaving two from Dungarvan, so, allowing that "unicorn :" was his average team, Tom Kecgh has a record of having driven 101,412 horses, with 33,804 changes, 502,052 miles, or more than twenty times round the world !-a feat which knocks into a cocked hat that of the Guard immortalised in Baily, vol. 55, p. 358. "Bian's Car" 
started from Lismore at 5 a.m., and reached Waterford at 11 a.m., returning at 3 p.m., and got back to Lismore at 9 p.m. ; therefore, for eighteen years, Keogh was twelve hours a day on his box, and could not have had more than six hours in bed, except on Sunday, when, small blame to him, he stayed in it nearly all day. During these fourand-twenty years this wonderful man was never off duty for a single day, except a few just before he gave up. He was most abstemious in drink, if not a teetotaller, but he eat heartily, particularly before starting in the morning. Mr. Bianconi was not in favour of long stages, so it may have been that there were four stages along the line. Anyway, Tom was so wonderfully punctual that "Bian," rather than their clocks, denoted to the country folk the time of day. Although he carried a little horn, slung by a strap round his shoulder, it was his stentorian voice and thundering oaths that notified to those who might be obstructionists to faugh a ballagh, and this they hastily did, knowing that Tom would drive over them if they did not.

In about 1861 Bianconi disposed of the "road" to the late Mr. William Cummins, at whose brother's hotel the car was always put up in Waterford, and a coach was then substituted for the long car. John Bates drove it for about twelve years, and Pat Thornton for five, until August, 1878, when the railway was opened, but neither of these men went further than Dungarvan. During the forty odd years that this road was driven over there was only one serious accident to either the car or the coach, and that was near Kilmacthomas in about 1860, a fact which speaks volumes to the skill of the drivers, for there was a great deal of traffic along the route, and upon fair or market days drunken. people were plentiful; and although a guard was never employed, neither car nor coach was ever attacked, even in the troub?ous times of 1848 and 1866.

Mr. William Cummins, a respectable and worthy citizen of Waterford, horsed and turned out the coach well, and when it was run off the road by the railway it was the last of the long distance coaches which we had in Ireland. This quondam representative of a grand old institution has, however, gone to posterity with a record of safe travelling, which is not likely to be accorded to its iron successor, while Tom Keogh has a history, perhaps, unparalleled in the history of coaching. He was-and so were Bates and Thornton-as respectful and respectable as they were skilful. A surly chap, whose name I forget, drove the coach for a few months before it stopped, but he need not be counted.

\section{SHOOTING.}

Chapter XV.

Osbaldeston's Shocting.-The feat recorded at p. 248 of the tro noblemen having a few years ago shot between them 98 pheasants out of 100 shots, bird for bird and shot for shot, wonderful work no doubt, was not nearly as fine a performance as that of George Osbaldeston. 
nearly seventy years ago as recorded at p. 361 , for to his own gun-and that a flint-lock-he bagged the same number, missing also only two shots.

Record Hind Shooting.-I find that it was by fair stalking alone, for driving was not resorted to at all, that my friend and his companion shot the twenty-two hinds in five days at Christmas, 1892.

Prevention of Accidents.-This being the glorious "Twelfth," and I not on the moors as I should like to be, I may add something to what I have already written at pp. 236,237 , about caution with firearms and tell of other big bags made up to date.

To the three golden rules given at p. 236 I shall add: Never fire at anything that you cannot see far beyond except it be well over the height of a man. Another measure of precaution, when not actually engaged in firing, is to unlock the barrels and hang the gun over the arm, and in a second it can be shut and ready for use. This is a plan I often adopted, and I saw it advocated in the Field last September. Men should be careful with a gun even when it is not loaded, so as to render the custom habitual, and directly they take hold of one they should examine whether it is loaded or not. Boys should be taught these safety methods and made to follow them, and so should those who nowadays begin shooting late in life, for they are the gentlemen who are the most dangerous of all.

My own opinion is that a man who can't handle his gun properly or is over excitable, be he young or old, host or guest, should not be allowed to shoot in company with others, for he is to a party even more dangerous than a bad rider is to good horsemen in a race or a hunt.

TURNED-DOWN HARES. - With regard to what I say about turneddown hares at p. 211, I may add that as hares are very fond of salt it would materially tend to induce them to stay where they are turned down if large lumps of rock salt were plentifully strewn about; or better still, if it could be done, have the hares in the first instance let loose in a walled-in paddock with the rock salt strewn there, and after a few days let them go in the open, leaving small holes for them to get into the paddock to lick the salt when they choose, or to take refuge.

Remarkable Shooting.-Before dealing with the last couple of jears I must add some more records of remarkable shooting made years ago which I have got hold of lately, for they are even greater than those given in Chap. $\mathrm{xv}$.

Two very interesting letters appeared in the Field last September in which are recorded the first-rate sport which was had over dogs nearly fifty years ago on Dalnaspidal Moors, the Duke of Athole's property in Perthshire. The game book of the Lodge records it as follows, the bags being made in 1846 by the five well-known sportsmen, Mr. Robert Fellowes, Mr. Stirling Crawfurd, his brotherin-law Mr. Everard, Mr. Willoughby, afterwards Lord Middleton, and Mr. W. Little Gilmour. 
August 12. - Messrs. Gilmour and Crawfurd . 190 brace

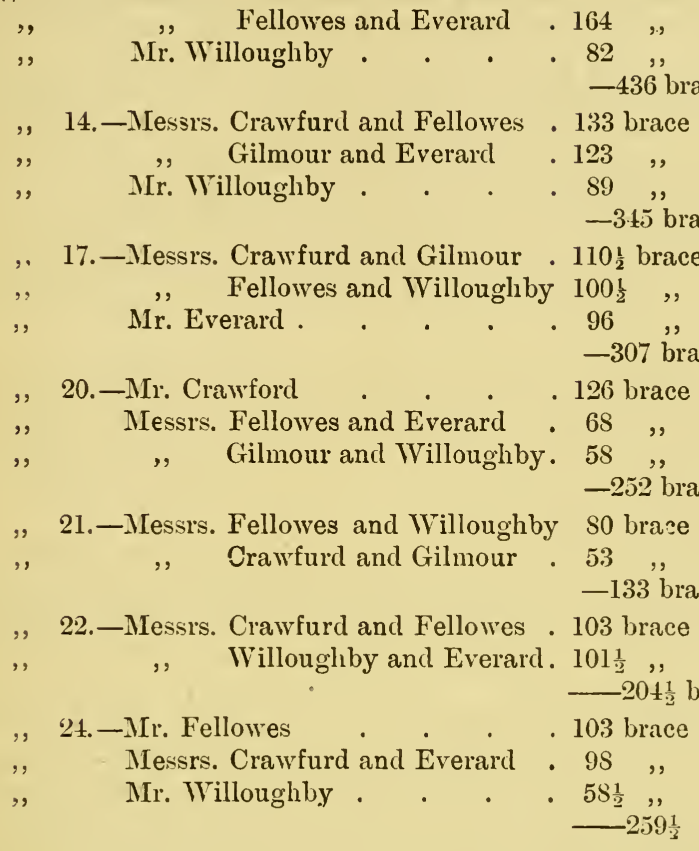

Total of fire guns for four days and four for three days 1,937 brace

Their bag for the season was, grouse 5,778, black game 20, ptarmigan 187 , hares 107 , wild duck 7 , sundries 8 , a grand total of 6,107 head. These moors, which haveal ways been some of the very bestin the kingdom, afforded in 1850, again to Mr. Stirling Crawfurd and party, 1,100 brace of grouse in nine days, and the following year the bag, in five days with five guns, was $931 \frac{1}{2}$ brace. In those days the rental of that fine shooting was only about $£ 350$, now it is perhaps twice or three times as much, and the sport is not better, or may be as good.

Better even than the Maharajah's shooting over dog's is the following record, given by a sporting correspondent of The Daily Telegraph in its

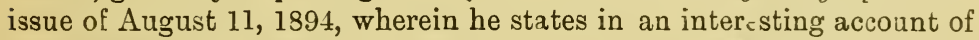
The Twelfth that "The late Colonel Campbell, of Monzie, on his own moors and to his own gun on August 21, 1813, bagged $184 \frac{1}{2}$ brace of grouse, and on September 4, 1846, he beat that performance by kiling 191 brace." The County Gentleman of September 1, 1894, records that he shot $222 \frac{1}{2}$ brace about the same time. This the gallant Colonel did, shooting alone and no doubt over dogs, and probably with flint guns. The big bag, however, was not made fairly, and a number of cheepers were shot which were all counted. At the present time, with grouse. 
much more plentiful than they were fifty years ago, and having breechloaders which eject cartridges as fast as they are fired, and can be re-cartridged in a brace of seconds, men can't beat this splendid record over dogs, simply because those who have really good moors don't go out as early and can't walk so hard or continuously as their fathers, whilst those sportsmen of the present day who never tire but work hard from daylight till dark and are good shots have not such moors to shoot over as Colonel Campbell's, and until they get a chance over them the Colonel's records are likely to remain undisturbed, for, under the circumstances, they are far and away better than Duleep Singh's.

I have not read Mr. Stuart Wortley's books, but from a review of the first volume I learn that a wonderful bag of partridge was made at The Grange in Hampshire in October, 1387, when seven guns in four days' driving got no less than 4,109, being an average of 1,027 a day, 587 a gun, or 147 per gun a day!

In the opening week of the season 1888 the Comte de Paris, who died last year, and party of nine guns killed 1,269 brace of grouse over dogs on the Moness and Loch Kennard moors in the Breadalbane district of Perthshire, which is considered the best grouse land in Scotland.

At Merton, Lord Wal-ingham's place in Norfolk, about Christmas, 1893, the Duke of Cambridge, Lord Huntingfield, Lord de Grey, Mr. Archibald Stuart Wortley, Colonel Bateson, and two other guns killed in one day 1,572 pheasants, 235 hares, 90 rabbits, and 5 woodcock, and repeated almost the same bag for four consecutive days, until at the close of the fourth it was found that nearly 4,000 pheasants had fallen to the guns of seven well-skilled sportsmen. Such a bag would have been impossible thirty or forty years ago, when pheasants were not reared by hand and turned down in such quantities as they are now.

Over the Elveden estate, which was purchased last year by Lord Ireagh, in the season 1892.93 , the bag for 22 days' shooting was 10.745 head, including 5,258 cock pheasants and 2,237 partridge. Upwaras of 21,000 pheasants have been brought up by hand there in a single season, nor does that extensive breeding prevent 150,000 pheasants' eggs being usually sold every year off the same preserves.

And in the season 1893, which will be ever memorable for big bags of grouse, probably the greatest was that of Mr. Rimington Wilson's party of nine guns on the 30th August, when over the Brombeid moors, near Sheffield, they shot 1,324 brace-of course, driving-thus beating his own record made in 1872, as given at p. 246 ; but there I find I gave Mr. Wilson's christened name incorrectly as "Kennington."

The best bag of grouse made over dogs in 1894 which I have heard of was that recorded in The Field of September 1, where Mr. Roger K. Cross with party of four guns got 1,549 grouse over the Inverlair moors in Inverness-shire up to the 27th of August, and the best bag made 
by driving tw ts that made by The Mackintosh and party, averaging eight guns, over his own moors, Moy Hall, in Inverness-shire, when no d ss than 2,467 grouse were got on August 21 and three following days, of which 1,222, or nearly half, were $g$, t on the first day. The Mackintosh also made an extrdordinary bag to his own gun over dogs in August, 1894, but I don't know the exact score.

In his wonderful performance relat-d at p. 247 Lord Walsingham fired 1,510 shots ; once he killed three birds in ore shot and a brace three t.mes, not through means of "browning" or by chance, but by taking them intentionally at the proper instant.

GuNs.- Not many years ago a first-rate gunmaker considered it good business if he sold during the season a hundred new guns at an average 0 30 guineas ; now double that number are turned out by several of the good makers, while some of them sell three hundred in a season ranging from 50 guineas to 80 guineas apiece.

Mr. Winans.-Since I wrote what I did about Mr. Winans at p. 260 he has let some of his Highland shootings, and remarkable sport has, naturally, been had over both his forests and moors, upon which, for many years, he had kept at tremendous expense an army of keepers and watchers without allowing a shot to be fired.

Deer Forest Commission.- It will be observed how the report of the Deer Forest Commission, which was made this summer, bears out exactly the remarks which I made three years ago about the croftiny of deer forests and grouse moors as recorded at pp. 261-263.

Finding their game of injuring the landlords by trying to spoil the shootings in having them turned into farms and sheep walks was being played out, agitators have taken up another means. They now want to have tourists allowed to roam all over the deer forests, knowing well that red deer love solitude and quietness, and being the shyest of all animals, and hating the sight of a man, would fly from any place which would be disturbed by very much less noise than that which is cause $\mathrm{I}$ by a party of howling and horn-blowing tourists. People can enjoy mountain scenery in abundance elsewhere than upon our Highland deer forests, and I hope it will be many a long year before liberty will be granted them, much less the right, to invade the regions where the antlered monarchs from time immemorial have enjoyed their long lives in peaceful solitude. At the same time it would be diplomatic and wise if the area of our forests and moors was not further extender. If "Humanitarians" knew what they were talking about they would know that to be scared out of their wits by tourists would be far more hurtful to the feelings of a wild red deer than is death caused instantly by a bullet.

\section{COURSING.}

Chapter XVI.

Codrsing versus Hunting. - When reviewing the edition of my book, which the first publishers sent out in such incomplete style, all 
the papers were complimentary of it as a whole, but some took exception to what I said about coursing, alleging that because I did not crre about it I abused it as a sport. Certainly I don't care a great deal about coursing, but if fair play was given to the hares I most assuredly would not say a word against it; on the contrary I should stick up for it the same as I do for other branches of sport which personally I don't care much for. Let us take coursing as carried out at Altcar and described at pp. 285 and 286, which is typical of other public meetings, in comparison with hunting, and also with what may be called wild coursing. A fox when found goes away with an odds-on chance of escape of at least 10 to 1 . A deer let loose from a cart, being worth about $£ 50$, is never allowed to be killed if it be possible to save him, so he is enlarged at the betting of 20 to 1 on his being taken even unhurt. Wild deer are killed, if they can be, but that is not often, so they have as much chance as a fox. A hare hunted by harriers starts with at least 5 to 1 in her favour; and a hare started on the wolds, not to talk of a mountain, if she gets a fair chance of the hill, will beat the best brace of greyhounds in England three times out of four, or may be four times out of five. According to the records of the Waterloo meeting described in Chap. xvi. a layer of odds would have won $£ 109$ if he had bet in sovereigns 109 to 1 against the hares in every course run at the meeting!

WATERloo CUP.-It may interest some people to know that the Waterloo Cup was first run at Altcar in 1836, and was for eight dogs only, the winner being a bitch named Milaine, the property of Lord Molyneaux, but ran in the name of Mr. Lynn, the runner-up being Mr. Norris' Unicus. Next year it was made a 16-rog stake, and in 1838 it was increased to 32 dogs, and so continued until 1857 , when it became the 64-dog stake it has ever since remained.

I was wrong in stating at p. 288 that the Derby was never won by a Lord Derby, for it was won in 1787 by Sir Peter Teazle, the property of the twelfth Earl, who instituted the race, but never since or before.

\section{SPORT A NATIONAL BENEFACTOR. \\ Chapter XVII.}

Advice to READER.-For reasons already stated at p. xiv of these addenda my readers are requested to get a copy of the pamphlets which I wrote under the above title in December, 1894, and July, 1895 , and read them instead of this chapter. They are $3 \mathrm{~d}$. each, and can be had at the offices of the Sporting League, 46, Pall Mall, London, or I will send them gratis to whoever buys this book and applies for them. 
THE PRIZE RING.

Chapter XIX.

Sayers and Heenay.-Bob Brettle was the only man Sayers ever fought who was lighter than himself, and the two fights he had with Aaron Jones summed up 148 rounds of five hours' fighting, and they were going to tackle each other for the third time when Heenan came on the scene, as is related at p. 323.

Colours, Umpires, and Referee.-I have not described the men's colours quite accurately at p. 326. Sayers' colours were-Standard of England in the centre, British lion rampant in each corner on cream coloured ground, with crimson border; while Heenan's were red, white, and blue borders, surrounding thirte $\leqslant n$ stars on white ground, and bearing the motto "May the best man win." Mr. George Wilkes, of the New York Spirit of the Times, was umpire for Heenan, Mr. "Farmer" Bennett acted for Sayers, while Mr. Frank Dowling, editor of Bell's Life, was the referee. It was the rule of the P.B.A. that if a man held the Belt for three years in succession against all comers it became his absolute property. I can't, therefore, understand why Sayers was not given the original Belt two months after his fight with Heenan, having won it from The Slasher on 16th June, 1857, and it was never taken from him, but that question was no doubt settled by Mr. Dowling when he brought about the arrangement mentioned at p. 331. If, however, Heenan's eyes had been lanced same as were Keates' in his fight with Flowers ( $p$ 318), perhaps poor Tom might have had a different record.

FARnborough Field.-The scene of the great battle between Sayers and Heenan was named after the little railway station on the SouthEastern line, which is only a quarter of a mile off-the village of Farnborough being much further away, and was not in those days run close to by any railway as it now is, and can be got to from Waterloo in about thirty miles; whereas the old road from London Bridge viâ Guildford is over fifty, which explains the length of time the journey took (p. 326.)

To visit the scene of any great event is to me at all times most enjoyable, so, in July, 1894, being at Aldershot for a day or two, I went off to see again the famous Farnborough Field, and in case any of my readers might like to do the same, all they have to do is to find their way to the Ship Inn, which is about two miles and a-half from the North Camp at Aldershot, and just beyond the Empress Eugenie's beautiful demesne. They will find, about thirty yards on the near side of the inn a small gate which opens on to a pathway, following which they will come to Hook Cottage at the end of the field. Here, unless they choose to go out of their way by continuing the path, they must get as best they can across the railway, and, directly at the other side, in Hampshire, is "Sayers' Meadow." In the snug little recess at the top is where the ring was pitched, surrounded, as it still is, by 
the trees which grew there at the time of the fight, from the boughs of which many scores of prople from the neighbourhood got a tip-top view. The little stream close by, called the Blackwater, divides Hampshire from Surrey, and for being carried across it on the morning of the fight many a half-sovereign had to be paid.

Again was the day charming, as it was of old ; but sad recollections of various nature occurred to me as, for nearly an hour, I roamed about and rested upon the spot which, over five-and-thirty years before, had been the centre of the ring on that memorable morning. The place for many years was marked by four posts, 24 feet apart, until they rotted away lately. They ought to be replaced.

JiM MACE.-Next to Sayers I think Mace was about the best man we ever had. On "book form" he was better than Heenan, for with as much difference in height and weight as there was between Sayers and Heenan, Mace beat Tom King in their first battle, which was a fair stand-up fight, and in the second he was having altogether the best of it when King, by a chance blow, knocked him out. King then fought Heenan, both men being fairly matched as regards height, weight, and age, when the latter was beaten, fair and square, in a comparatively short time. Therefore, as I say, Mace was, on paper, a better man than Heenan. But was he as plucky?

HaRRy BRUNTON aNd Toy SAyers.-Harry Brunton was a skilful boxer and a courageous man, but having soft hands he could not hold his own in the prize-ring. He was, however, one of the best seconds ever known, and was selected by Sayers in all his battles, subsequent to that with Perry. Between the two men there existed the greatest friendship, and over his signboard at the "George and Dragon" in Beech Street, Barbican, Brunton had himself described as "Tom Sayers' favourite second." Soon after his fight with Heenan, Tom presented Harry with a handsome silver cup, which on one side bore the inscription, for the copy of which I am indebted to the editor of the Licensed Victuallers' Gazette, "This trophy was presented to Harry Brunton by his old frieed, Tom Sayers, for faithful services rendered throughout his great fights." On the other side were the following lines from the facile pen of "Chief Baron" Nicholson :-

"In those happy hours when man seeks relief

From the backfalls of sorrow and cross-counters of grief,

When joy fills the heart and puts the crook on our cares,

Drink deep from this goblet and think of Tom Sayers."

The presentation was made by the "Chief Baron " at Brunton's house, and the ceremony derived additional interest from the fact that Heenan was present, and with Sayers and Brunton drank from the magnum that christened the bowl.

Soon after poor Tom's death, Brunton purchased for his own grave the piece of ground which adjoined Tom's, and changed his residence from the Barbican to the more secluded quarters of the Nag's Head, 
Wood Green, which is close to Highgate Old Cemetery, where he could be the nearer to the remains of the man who was the object of his fervent and life-long admiration. Brunton survived his principal for twenty-one years, during which time it is recorded that no one dared say a word in his presence derogatory of the champion. This I can well understand from the manner in which he spoke of Sayers upon the one occasion when I paid him a visit. Brunton died at the Nag's Head, June 9, 1886, aged sixty, and now the two friends rest alongside each other until "Time" shall be called by the Great Referee.

\section{B E T T I N G. \\ Chapter XX.}

Heavy BetToRs.-Besides those mentioned at p. 335 the following were some of the heaviest backers of horses of their day : Lord Barrymore, Charles James Fox (Prime Minister), Colonel Anson, Hon. Richard Vernon, Lord Kennedy, General Berkeley Craven (who shot himself the evening of Bay Middleton's Derby), Mr. George Payne, Mr. Fred Gretton, the Marquis of Ailesbury, and for a time Capt. Machell. Lord George Cavendish, early in the century, also betted heavily, and in the memor. able match (referred to at p. 385) between Sir Joshua, of which he was part owner, and Filho da Puta, which took place at the Craven Meeting at Newmarket in 1816 , he won nearly $£ 50,000$ from the Yorkshiremen, taking all the bets offered at 5 to 4 , then evens, and finally laying 5 to 4 . So did his relative, Lord George Bentinck, win nearly the same amount over his mare Miss Elis, when she won the Stakes and Cup, at Goodwood, in 1849.

Mr. George Payne for many years was a consistent follower of Alec Taylor's stable, and at times plunged heavily. Of course, he won occasionally, but in the end, like everyone else, he had to his credit a great deal less money than he began with. Teddington, then the joint property of Sir Joseph Hawtey and Mr. Massey Stanley, won Mr. Payne a big stake over the Derby, but it was nothing to what he stood to win on Savernake in 1866, when he was beaten a short head by Lord Lyon, after one of the grandest races ever seen at Epsom. Mr. Payne sustained even a greater disappointment with "brother to Flurry," afterwards named Pell Mell, in the Leger of 1872, when that horse lost the race to Wenlock by an equally short shave, Payne and all the stable having plunged to win an enormous stake, but as they got on at very long odds the losses were not unusually great.

A Good "Systex."-Exemplifying what I state in the third paragraph at p. 338, the most any man should lay aside for backing horses is one-tenth of his income-same as what a prudent man allots for the rent of his house-and he should not risk more than one-tenth of that in any one bet, and when the lot is lost he should knock off till 
the next year. If that principle was to be adhered to no very great harm would accrue. But if betting debts were to be made recoverable by law, the same as any other debt, the measure would act deterrently upon backers, while it would also influence some of the layers.

\section{HYGIENIC PRINCIPLES.}

\section{CH.APTER XXI.}

Rheunatism axd Lombago.-For many years before, and up to the time I wrote about rheumatism as I did at p. 271, I was subject, as I have said, continually to terrible attacks of lumbago, but strange to say I have had only two or three "touches" of it since then. I can't account for this gocd turn of luck, for I never used any preventive other than those described, except it be that for the last couple of years I have returned to my old practice of using dumb-bells, and, as I did for many a year before I ever knew what rheumatism was, I work with them (14 lbs. each) for five minutes before I go to bed and after my bath in the morning. Whether that exercise has kept away lumbagn or not I don't know, but this I know, that I never was in better health than I have been since I began again the dumb-bells, and rightly or wrongly to that exercise I accredit the cause.

GOOD RECIPES. - To the receipt for making a mutton hash, which I give at p. 350, may be added the following for making a curry, and it will be found to be equally valuable. It was given to me recently by the lady whose portrait, with those of her sons, is given at page 1 . For about a pound and a half of meat, cut in small dice two large onions, a carrot and a turnip, and fry them in butter; cut up the meat to be used in dice, which add to the vegetables with one tablespoonful of curry powder and a little sweet chutney; add flour to thicken, with salt to taste, and simmer until cooked.

But what can beat a properly grilled British mutton chop, served without gravy or anything to give it relish except mustard, pepper, salt, and a crisped potato? Surely cutlets smothered in sauce are not more toothsome and certainly not so wholesome. Outside its own town we don't often find what is called a "Barnsley chop," which is the two centre chops cut out of the saddle, and served double. If the mutton be prime, sufficiently long hung, and properly cooked, in my opinion this homely Yorkshire dish, for taste and nourishment, takes a lot of beating.

Correction.-The printer added $7 \mathrm{lbs}$. to the weight I consider an average man should be ; therefore, in the fifth paragraph of $\mathrm{p} .353$, the weigkt should read " 12 st.," and not 12 st. 7 lbs. 
USBALDESTON, ¿̇C.

ChAPTER XXII.

OSBALDESTON's Hounds.-In connection with what I say at p. 357 I wish to refer to what Sir Reginald Graham contributed to The Field of May 26, 1894, in a most interesting letter alluding to Mr. Osbaldeston's pack. He states that his father, Mr. Bellingham Graham, purchased all Osbaldeston's hounds except 25 couple, when he took over the Quorn in 1821, but upon the Squire's return in 1823 be repurchased an equal lot from Mr. Graham at $£ 1,110$. Sir Reginald also states that Osbaldeston's most celebrated stallion-hounds were Furrier, Flourisher, Vaulter, Rasselas, Valentine, Hermit, and Rocket. Furrier, a black and white hound, by Saladin from Fallacy, was bred at Belvoir in 1821, and at one time there were $24 \frac{1}{2}$ couple by Furrier in the Squire's pack, and sometimes he made the whole of his pack for the day's hunting of hounds got by that famous sire. In conclusion, Sir Reginald plaintively asks, "Where are the descendants of this historic pack?"

Woodland Hunting. - Osbaldeston found out some eighty-five years ago a fact which many men of the present have not learned yet, which was that, if woodlands be constantly hunted, foxes will fly from them nearly as readily as they do from gorse or spinneys. He therefore dusted his big woods during cub hunting in rare style, and it is recorded of him by Mr. Blews, that when he took the Burton country he took his hounds to the great strong woodlands which then existed near Wragby, six days a week for five wesks on a stretch, until at last he made the foxes so anxious to get away, that they would fly at even the sound of his voice. This he proved one day, to decide a bet of a guinea, which he made with a friend on the subject. Having stationed him in a particular spot, and going into the wood, which is now nearly all cut down, the Squire began to cheer an imaginary pack of hounds, when a leash of foxes went away almost immediately, in full view of his friend. Naturally, however, woodlands were not the Squire's favourite coverts, for when he took the Pytchley country afterwards, which he continued to hunt till the end of his remarkable career, he considered that in it he had "at last found Paradise."

Osbaldeston's RACING Career.-Dealing with Osbaldeston only as regards the feats he actually performed himself, I make no mention of the stud of flat racehorses which he kept for years. Although he usually rode them himself, and could hold his own with the best professionals of the day, he was not nearly as successful on the flat as he was across country. In fact the gallant fellow lost heavily by the business, and it principally brought about his ruin.

\section{CAPTAIN BARCLAY-ALLARDICE. Cillpter XXII.}

The Track and Donicile in the Great Walk.-As stated at p. 372 I took my account of Captain Barclay's walk from what 
appeared in Bell's Life, in 1874, but I have ascertained since that one or two slight inaccuracies with regard to the domicile and the tracks used crept into that account, no doubt owing to the fact that Bell itself was not in existence at the time, nor for thirteen years afterwards, and as I ferreted out the particulars lately from perhaps the only person alive who knows them, I will correct some of what appears at pp. 376, 377. The track which was first selected began at Barton's Yard, on Mill Hill, and continued along the Exning road, past where the gas works are, for half a mile out and home. It is strange that this place should have been chosen at all for such a feat, as the first sixty or seventy yards was up the sharp rise of ground which we see there still. The house the Captain put up at was that of the father of Frank Buckle the jockey, and there it stands now exactly as it did in 1809-the second on the left in Barton's Yard. It is easy to understand why Barclay could not be made comfortable in such a pill-box of a place, nor could he continue to breast that hill $\epsilon$ very time he started. The change of quarters and course had therefore to be made on the sixteenth day, as described, and the new abode was a house which stood where Heath Cottage now is, near the Horse and Groom (not "Horse and Jockey" as given by Bell's Life), both the house and the inn belonging to a man named Parkinson, who was a stonemason and a great friend of the fighting men of the day who patronised the inn, and were backing Barclay through thick and thin. There remains this moment the identical doorway at which the new track began, and crossing the Norwich road it went straight to the corner of the Severals, where Judge Clarke's house now stands, and to make the half-mile, along the Ely road, to a little beyond where Tom Jennings lives, every yard of which was level as a table. The line could not have been "up the heath," as described by Bell's Life, for paddocks, enclosed by high hedges, then occupied the area on which Captain Machell's and Ryan's stables are now built. Parkinson's house was commodious, so Barclay was made as comfortable as he could be under the circumstances, and guarded by Gully, Gregson, and that lot, needless to say he was not allowed to be disturbed by the cruwd outside.

A Disgracefte Exhibitiox.-In contrast with Allardice's manly exploit I shall relate a disgraceful exhibition which is recorded in the "Records of the Racecourse." After having given little glimpses at the morals of King Charles II. and his Court at Newmarket, and their diversions, the author states that a certain nobleman (?), whose name he gives but, for the sake of his descendants, I shall not repeat, for a wager of $£ 50$ backed himself to walk, stark nakerl and barefooted, five miles on "Newmarket Common" in an hour. He lost the match by half a minute, but had the honour of good company, for the King, his concubines, and his nobles attended! On Newmarket Hearh have been seen many strange sights, but I question whether a stranger one was 
ever witnessed than that of this dirty old brute walking stark naked, amid the ribald jests and laughter of the King of England and the ladies and gentlemen (?) who constituted the Court of that "merry monarch" two hundred years ago.

\section{JOHN SCOTT.}

\section{Chapter XXIII.}

Mr. Bowes ANd Col. Anson.-Although Mr. Bowes was connected with John Scott's stable longer than any other patron, he took no part in the management, and seldom went to Whitewall, or even to see his horses run, after they left the Streatlam paddocks. Not so Colonel George Anson, who, from 1830 till he went to India in 1853, was the predominant ruler of Whitewall. That beau ideal of an accomplished and courteous gentleman had reposed in him, to an unlimited degree, the confidence of all the patrons of the great northern stable, and being a consummate judge of a racehorse, and of how, where, and when he should be raced, he "placed" the horses of that mighty stable, leaving to Scott their preparation. The other owners did not trouble themselves about their horses, and often did not know when or where they would be raced, relying entirely upon the sagacity of the ever popular Colonel, but when the proper time came to take advantage of a "good thing" down went the money for the stable all round, irrespective of whose horse it might be, and so the plan worked for three and twenty years in most perfect harmony, and without a single hitch or unpleasantness. I wonder how such a system would work at present!

West Australian's Leger day was the last day's racing Colonel Anson ever saw in England, for he sailed for India immediately after, and thus was lost to the Turf one of the brightest lights that ever shone over it, and a man whose example the best in the land even now might with advantage follow. Scott loved the Colonel devotedly, and despite the mighty "West's" achievement he ever reckoned that that day was the most sorrowful he ever experienced, and, as has been often recorded, the old trainer dared not trust himself to meet his good friend at the weigh room, after the race, to bid him farewell as was arranged.

Fourteenth EarL of Derby.-I am indebted to the Hon. Frank Lawley for some of the following particulars concerning Scott's stable, having taken them from one of that gentleman's interesting articles. Next to Mr. Bowes, the fourteenth Earl of Derby was perhaps Scott's principal patron during the Whitewall era. That great statesman was withal one of the leading turfites of the day, and while he could play the game of the ring his wit and joviality were the life and soul of the Jockey Club; and when among its members, or engaged in any other sport at Knowsley or elsewhere, he never permitted his recreation to be interfered with by political or 
State considerations, which, by natural instinct in him, stood secondary to sport. In about 1841 he sent his horses to Whitewall, where they continued for the remainder of his racing career, which practically ended in 1863, some six years before his death. During that time Lord Derby had under Scott's care a total of nearly 250 horses, and won in stakes nearly $£ 95,000$ - a big record then, but it would now be for the same races something like three times the amount. A lot of the Knowsley bred horses, and those Lord Derby purchased, were of little use, so that with the exception of one Oaks, one Two Thousand, one Doncaster Cup, two One Thousands, and two Goodwood Cups, the Knowsley "black jacket and white cap" fluttered in front in great races very seldom when compared with the "all black" of Streatlam. It was in two year old and minor races that Scott won for the "Rupert of Debate" the most of this stake-money.

MLEMoRable RACES.-A memorable race was the Leger of 1851, when Scott saddled Newminster to represent the North, and Alec Taylor, who died last winter, stripped Aphrodite, then the joint property of Sir Joseph Hawley and Mr. Massey Stanley, to do battle for the South. A great race it was between the two, for, coming away from the other fourteen starters, the future sire of Hermit beat the Fyfield crack, and thereby caused tens of thousands to be lodged in Yorkshire banks to the credit of the followers of Whitewall.

In the Derby of 1836, in a field of twenty-one, Scott ran second to Bay Middleton with Lord Wilton's Gladiator, his brother Bill riding and the next two horses were Venison and Slave. Referring to these four horses in their position in the Stud Book, Mr. Lawley, in one of his sporting reminiscences, says of this race that, "In the long and splendid history of England's greatest race no such four horses were ever placed for it as Bay Middleton, sire of The Flying Dutchman, Andover, and Aphrodite; Gladiator, sire of Sweetmeat and Miss Sarah; Venison, sire of Alarm, Miami, and Ugly Buck; and Slave, sire of Sting, Merry Monarch, and The Princess. It may also be remarked that each of the placed horses for the Derby of 1836 were the sires of animals that could stay for any distance-e.g., The Flying Dutchman, Sweetmeat, Alarm, and Subduer."

Bill Scott ANd JoHx's ChILDReN.-Writing of Bill Scott, at p. 388, I should have added that he won the Two Thousand in 1842, on Mr. Bowes' Meteor, and the next year also on that gentleman's Cotherstone, while in 1846 his own horse, Sir Tatton Sykes, carried him to victory

John Scott, by his first marriage, left a son and two daughters, but there was no issue by the second marriage.

MR. NAYLOR-Correction.-By a slip of the pen, or the print, a mistake has been made in the table at p. 392. It was Mr. R. C. Naylor, as is mentioned in the text, and not Mr. Bowes, who bought Stockwell. 


\section{MAT DAWSON. \\ CHAPTER XXIII.}

Much of what I have said with regard to Mr. Mathew Dawson's late years has been discounted during the process of delay in the publication of my book, so I must devote some pages to bringing the history of this Prime Minister of trainers up to date, but in doing so $I$ an enabled by information which he gave me lately to add much interesting matter to that which already appears in the above chapter, and at the same time I can correct a few slight inacouracies which occur.

Corrections, p. 394.-I find that it was at Bogside, for Lord Montgomery, that Mat's father trained horses over a century ago, and in 1815 he moved to training quarters at Gullane, and I am glad to know that only six out of the seventeen sons and daughters died young.

More Great Horses and Jockeys.--To the list of good horses which were trained by Mat, and given at p. 395, may be added Crowberry, Galore, Mowerina, Cannobie, Pericles, Silenus, Wild Oats, and Leonie; and the jockeys he employed most were Marlow, Whitehouse, Custance, Tom French, Fordham, Archer, and, of late years, perhaps Jack Watts and Tommy Loates. Mat also tells me that Lord Falmouth did not win any handicaps, because he would not allow his horses to run in that class of race, and he showed me a year ago how he had got the names of the horses put under their several portraits, as was so often suggested by me and others (p. 397).

His Marriage-Death of Mrs. Dawson.-When training for Lord Eglinton, at his seat in the North, Mat got married, on the 7th July, 1844, to Miss Mary Rose, the daughter of Mr. Alexander Rose, who had charge of the gardens and forests at Eglinton Castle; and that good woman, after being to her husband the best of wives for over fifty years, died on the 19th October, 1894, after a few days' illness.

A Marvellous Record.-Although in the first year of his training he prepared for the Derby Lord Kelburn's (afterwards Lord Glasgow) Pathfinder, and had won the Oaks with Catherine Hayes in 1853, it was not until 1856 that Mat went in regularly for the classic events, having previously confined his operations to the North; but since then a year has not passed without his having horses under preparation for them, and for some five-and-twenty years have his representatives started, giving him the following marvellous record:--He has had six Derby wins, with Thormanby 1860, Kingeraft '70, Silvio '77, Melton '85, Ladas '94, and Sir Visto '95; three seconds, with Dundee '61, The Baron '87, and Crowberry '88; nine thirds, with Cannobie '56, Buckstone '62, Scottish Chief '64, Speculum '68, Queen's Messenger '72, Atlantic '74, colt by Macaroni out of Repentance '75, Childeric '78, and Galliard '83. The Two Thousand he won with Atlantic, in 1874, and Camballo the year after, Charibert in '79, Galliard in '83, and Ladas in '94. The One Thousand was his share in 1873 with Cecilia, Spinaway in '75, Wheel of Fortune ' 79 , Busybody '84, Minthe '89, and 
Mimi '91. The Oaks came to his stable through the means of Catherine Hayes in 1853, Spinaway in '75, Jannette '78, Wheel of Fortune '79, and Mimi in '91, after which she won the Newmarket Stakes. He both won and ran second for the St. Leger, in $187 \pi$, with Silvio and Lady Golightly, and did the same the next year with Jannette and Childeric. He also won it with the rank outsider, Dutch Oven, in ' 82 , The Lambkin in '84, and with Melton the year following. His seconds for that race were The Reiver in ' 53 , Leolinus in ' 74 , with Trent running third, while Ladas lost by a flukey short halflength in 1894. Blanche of Middlebie and Julius were also third in 1858 and 1867.

Thus is seen that his classic double events were the Two Thousand and Derby with Ladas, who lost the triple event by little over a neck; Derby and Leger with Silvio and Melton; One Thousand and Oaks with Spinaway and Wheel of Fortune, two years running, also with Mimi ; while Busybody, who won the Oaks, was trained by Mat up to the day before she won the One Thousand, and Jannette credited him with the Oaks and Leger. Besides which he won the Grand Prix de Paris, with Trent, in '74, and Minting in ' 86 ; and was second with Primate in '66, The Baron in ' 87 , and Crowberry in ' 88.

HeAth Faru.-In 1893 he sold the lease of Heath Farm to Lord Marcus Beresford, and leased, from the Jockey Club, The Marsh, which adjoins Melton House, and there he now has his valuable stud of brood mares.

LADAS.-I now come to deal with Ladas, and considering what that colt has done for Lord Rosebery and the veteran trainer whose history I am now bringing up to date, it may be excused in me if I draw the attention of my readers to p. 399 for the record of what Mr. Dawson said of the handsome son of Hampton before a bridle had ever been put on his head, and what I wrote concerning the Illuminata colt nearly two years before illuminations in the little village of Exning celebrated the great Epsom triumph.

The Derby of 1894. - The history of Ladas is too fresh in the minds of everybody to warrant my referring to it further than to record a couple of incidents which I am not aware have hitherto been puolished. I must, however, chronicle in Thoughts upon Sport the reception Lord Rosebery got upon winning the Derby, for, if anything, that book is one of reference, and I think that what I wrote in September, 1893 (p. 399), further entitles me to do so. I therefore state, upon the consentient authority of every chronicler of the Press, and upon that of everyone who saw the Derby of 1894, that never in the annals of racing was there such a demonstration on a racecourse in favour of a win. Applause, deafening to a degree, rent the air as Ladas carrying Jack Watts in "the rose and primrose hoops" passed the post; but when the Prime Minister of England, in his ecstasy, rushed through the crowd, and as owner of the colt he himself had bred, seized the bridle and led 


\section{xliii}

in the winner like a.man, the "earthquake shout of victory" burst forth in volume till "the roar " resembled naught but thunder in the Alps, and to his dying day the longest liver of the multitudes who, on June 6, attended the Derby, will never, unless he gets softening of the brain, forget that scene. No doubt to Lord Rosebery as "the most popular owner in England," which I rightly described him to be, and at the time of victory being Her Majesty's Chief Counsellor, was accorded the greater share of that "explosion of applause," but I am very sure that "the veteran trainer," although he was unfortunately not able to be present, came in for his share, for Mat Dawson as a trainer is equally popular with Lord Rosebery as an owner.

I need not here enumerate them, but thase circumstances which surround the Derby of 1894 , especially the fact that for the first time it was won by a horse the properly of the Prime Minister, constitute it as the most memorable upon record, even though the winner, with four and a half to one on him, started the greatest favourite in the annals of the race. I must, however, allude to a feature which has at the present moment a peculiar significance. An ebullition of public feeling such as broke forth on that occasion, shared as it was by losers as well as political opponents of Lord Rosebery, while it shows how the nation admires a manly sportsman, demonstrated with emphatic evidence the contempt which the British public entertain for those who, with narrow-minded bigotry and impertinent interference, strive to injure the noble sport, and for that matter, all sport.

With the Woodcote Stakes, the Coventry Stakes, the Champagne Stakes, and the Middle Park Plate to his credit when a two-yearold; and the Two Thousand, the Newmarket Stakes, and the Derby in his three-year-old year, Ladas won for Lord Rosebery $£ 18,513$, and started for the Princess of Wales' Stakes at Newmarket, on the 5th July, an unbeaten colt. In both this race and the Eclipse Stakes, at Sandown, on the 20th of the same month, he was beaten by Isinglass, and again did the son of Hampton suffer defeat, this time at the hands of Throstle for the Leger on September 12th.

In threshing out the circumstances of these three races, columns of newspapers may be measured by the yard, while men more or less qualified to judge have talked on the subject almost ad nauseam. Now my humble opinion is this, that as far as Isinglass is concerned, he won the two races from Ladas through the assistance he got from a pace-maker rather than through his own merits, great, no doubt, though they be. Priestholm was started at five-furlong speed to serve the seasoned stayer and to run out the youngster, a plan of campaign which accomplished the result desired. If, however, Ladas and Isinglass were to be started in a match at weight for age, say the one mile and a quarter across the flat at Newmarket, with nothing else to make or mar the pace, assuredly I would back Ladas. 
THE LEGER OF 1894.-As regards the Leger, the facts are simply these. In his gallop on the morning of the race, Ladas ran away with Tommy Loates. Fearing therefore that he might do the same thing in the race, the riding of which was left entirely to his own discretion, the light weight jockey kept Ladas 100 yards in the rear until he had reacher the Red House, then having given him his head he got out of his hands and rushed to the front, which his marvellous turn of speed enabled him to gain before the leaders had reached the distance. This extraordinary but badly timed spurt, which his rider, except through lack of strength, was not to blame for-although it settled the chance of Matchbox, which was the only horse the Ladas party feared-enabled the erratic Throstle, whom Morny Cannon had kept pegging away, to get up on the post, and win by a neck and shoulders, the good Ladas being unable to come a second time. To talk of the Leger having been won on the merits of Throstle would be simply ridiculous, for even when she could be got to run straight and to give her running in her trials at Kingsclere she could never beat Matchbox, and over the Leger course, with a strong jockey on Ladas, and Throstle running with the best manners, the colt could, as far as I am a judge, give the filly 7 lbs. and a sound beating. Anyway, John Porter got his turn out of Mat Dawson, for with Throstle he did to Ladas what Mat did, in 1882, with Dutch Oven to the Kingsclere cracks, Geheimniss and Shotover, and in the annals of the "Sellinger" there were never as great "surprises," even by any of Scott's lot.

Among all the horses trained by Mat Dawson I don't think there could have been an animal possessed of more beautiful shapes than Ladas, whose head, neck, shoulders, middle piece, and hind legs are simple perfection; his quarters may not be equally grand, but they are better by far than most horses', while his style of galloping could never have been surpassed on the Heath of Newmarket. He has been likened to The Flying Dutchman, but if the portraits which I have seen of that horse be faithful, give me Ladas.

I have been informed that Lord Rosebery was offered $£ 20,000$ for his colt by a well-known American gentleman, but like a British sportsman possessing patriotic feeling he refused the offer, and I think it is highly likely that his lordship will keep the grand horse in the country, as the Duke of Portland has done St. Simon.

Mat's Illyess and Affliction.-Mr. Dawson had been suffering for over a year from suppressed gout, and most of the time, being unable to walk or ride, he had to perform his duties while seated in his carriage. To have been able to prepare Ladas, crippled as he was, and achieve such results, was a source of general satisfaction, for it assured the public at large, as it did the grand old fellow himself, that he was as good a man as ever.

This feeling of contentment was not allowed to him for long, for his wife, who had been his partner for over fifty of the fifty-four years of 
his public career, died, as already stated, in the autumn of 1894, whereby the poor fellow met with the greatest affliction that had ever befallen him.

Sir Visto AND Derby of 1895.-Endowed with that bull-dog courage which forbids the Anglo-Saxon ever to think he is beaten, Mat rallied, and with another colt of Lord Rosebery's set about to try to win the next Derby. This, as the world knows, he succeeded in doing with Sir Visto, who started at odds against him of from 7 to 10 to 1 . The race was in all respects the opposite to last year's. It was the most open that ever was known, and a few days before 10 to 1 could have been got against almost any of the remarkably bad lot that started. Sir Visto being in no way to be compared with Ladas in either shape, make, action, or ability, I have nothing more to say about him, except that I hope he will win the Leger, for which old Nat is at present preparing him specially.

Owing to his crippled state Mat Dawson was unable to go to either of these Derbys or even to the Leger, but has had to pay more than one visit to Bath during the past two years, the waters of which have done him great good, and when I saw him last Whitsuntide he was better on the pins than I had seen him since he was attacked by the gout in 1893, whon for the first time in his life he suffered from illness. He grew a moustache while laid up, but so little has it affected his jovial appearance that I did not notice the addition until he himself drew my attention to it.

This Mexorr.-Having now brought my history of Mr. Mathew Dawson up to date, July, 1895, my readers will find in this book a memoir more exhaustive than any other ever published of that gentleman, and with the assurance that the details are absolutely correct, even to the spelling of his christian name, I wind it up by supplying in a table the record of the classic races to which he is now entitled, and which is to be taken instead of what is given with the others at p. 407 , and I hope the chronicle will soon have to be further added to:-

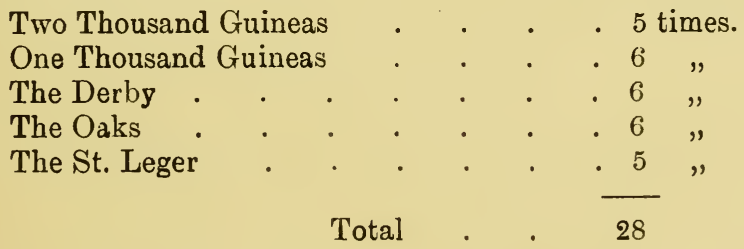

\section{WHOO WHOOP!}

\section{Chapter XXIV.}

The Sporting League.-The suggestion thrown out by me at pp. 411,412 , that a combination between sportsmen of all classes should 
be formed so as to defend ourselves from the attacks of our enemies, written by me as it was some time in 1892, was given effect to in the summer of 1894 by the starting of the Sporting League. I don't suppose that my observations would have had any effect, but at all events, what I wrote, and which was in print in the spring of 1894 , would have come to light a year before instead of a year after the Sporting League, had my original publishers paid even ordinary attention to the business I so foolishly entrusted them with.

The Agricultural Question.-The same remarks apply to what I say at p. 418, with regard to the agricultural question and the next election, for a resolution identical with what I suggested was passed at a meeting presided over by Lord Winchelsea, and held at Anderton's Hotel, London, on July 31, 1894, while letters appeared in The Field advocating the very same measure. The "next general election "is now a matter, of history, and there can be no doubt whatever that the result, giving the Conservatives the greatest majority that any party have had in the House of Commons for over sixty years, was brought about to a very great extent by the way sportsmen and farmers pulled together, and, in some places, the labourers. Now that they have the power it is to be hoped that measures beneficial to the farming interest may be adopted by our great party-and that without delay. 


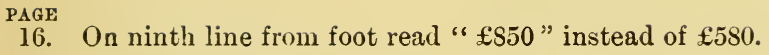

17. On eighth line read "Roister" for Royster.

20. The eighth line from foot should begin a paragraph.

33. On fifth line read "Patrick" for Tatrick, and on the ninth line read "Then" for Phen.

36. In second paragraph read "Kill " for Kiln.

39. On fifth line read " on" for of.

103. On second line read "mainly" before indebted.

106. On fifteenth line read " top" instead of point.

115. On eighth line read " but" for out.

130. In fifth paragraph read "Barkby" for Barkly.

148. On twelfth line transpose "to" and "two."

162. The brothers Beasley were born in rotation as follows: Thomas, John, 204. Harry, James, William-not as indicated in these pages.

173. On ninth line read "Hambleton" for Hamilton.

211 Eclipse was not an Irish horse.

252. On this and other pages, the word "let" might have been employed instead of "set."

28s. The Derby was won in 1787 by Sir Peter Teazle, the property of the twelfth Earl of Derby, the founder of that race.

353. In fifth paragraph read "12st." for 12st. 7lbs.

392. In the table read "R. C. Naylor" for Bowes.

394. There is only one " $t$ " in Mr. Dawson's Christian name. 



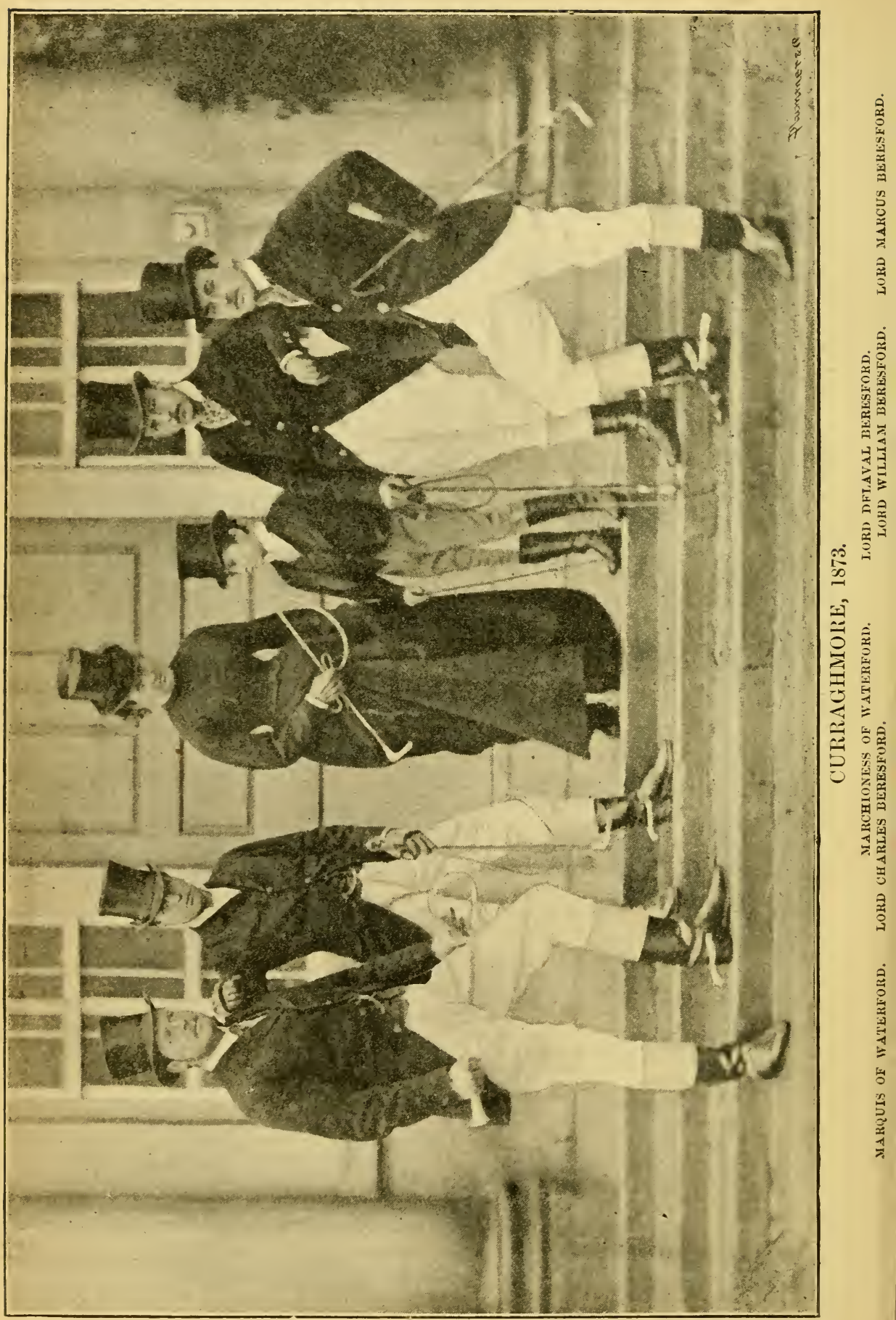




\title{
THOUGHTS UPON SPORT.
}

CHAPTER I.

\section{HISTORY OF THE CURRAGHMIORE HUNT.}

\author{
First Section.-Henry, Third Marouis of Waterford, Master, \\ 1844-59.
}

History of a First-rate Pack of Foxhounds - Previous to 1879-Why the Curraghmore is. selected by the Author-Henry Lord Waterford as a Rider to Hounds-He comes to Curraghmore-County Waterford Pack-The Grove Hounds-Captain Jacob-Mr. IVilliam Barton-Mr. Richard Burke-Lord Waterford taking Tipperary-Johnny Ryan-Rockwell-Drafts from England-Lord Waterford's Marriage-Lakefield-Mr. Vyner's Notitia I'enatica-Outrages reported-Stables burned-How explained-Lold Waterford's Popularity-Abaudonment of Tipperary-Mr. Millett-Lord Waterforl'a Liberality-No Hunting Record kept-Sport shown by Lord Water:urd-Dates given are correct--Lord Waterford starts Hunting from Curraghmore-The Waterford Pack - Mr. Briscoe's Pack-The Waterford Country-Fresh Territory-Sir John PowerLord Waterford, Rents part of Kilkenny-Adds to his Pack-Lord YVaterford's Foxhounds-Huntsman and Whips-New Coverts-Magnificent Sport-The Meets_Those who hunted-Now Alive-Now Dead-The Marquis as a Horseman-His Horses-His Coach-His Driving-Famous Runs-Knockbrack to Woodstock-Fate of the FoxWhere he is Now-A Greyhound Fox-A Fine Run-Lord Waterford Not Out-Some of his Hunters-His own Turn-out-His Servants' Turn-out-Rig-out of his FieldTheir Riding-1S48-The 85th Regiment-Their Hunters-Their Officers-Captain Peel - His Connection with Lord Waterford-Orlando-Peel's Early Days-As a RiderAnecdote-Famous Racehorses-Who Rode Them-Exploits-Captain Peel on Shinrone-Captain Little on Sir Arthur-Desperate Race-A Comparison by the AuthorWaterford in those Days-Peel as a Breeder of Thoroughbreds-Flying Column-Willie Beasley-Peel's Auecdotes-"A Real Old Irish Gentleman, one of the Olden Time"The Kilkenny Hunt-Sir John Power-Its Sporting and Social Standing-The Hunt Week-Long Description of this Festival-The Club House-The Fun-"Handicapping"-Mrs. Walshe- "The Marquis" leading the Fun-Ably assisted-His Assistants -The General Company-The then Marquis of Worcester-7th Hussars-Political Excitement 1846-48-Episodes-Harry Jephson and Larry Dobbyn-Teaching a Lesson -Good Results-Extraordinary Feat of a Foxhound-29th March, 1859-Death of Henry, third Marquis of Waterford-Minute and A uthentic Details-His Birth-His Age -Universal Regret-Daring Deeds-Generous Disposition-His Funeral-His Portrait -Sale of Lord Waterford's Horses-Exhaustive, but correct particulars-Great Prices -Gemma ie Vergi-An Unlucky Record-William Brophy's Sale in 1892-Singular coincidence with Lord Waterford's in 1859-Particulars-Comparison-Lord Water ford's Racing-Johnny Ryan his Jockey-Unparalleled Record-Some of the RacesAnd Racers.

Perhaps in years to come it may be of interest to know how a first-rate pack of foxhounds was kept up in Ireland, and to learn what sport it showed previous to the land agitation which began there in 1879 , and no doubt a description will not come amiss to the general reader of the present time. I shall, therefore, give a history and description of the sport of one in the hope that some copies of this book may be in existence at the time our sons' sons might like to read of such. 
In selecting the Curraghmore, I do so for three reasons, viz. :-

(a) I know all about it.

(b) It was the premier pack in Ireland at the time it was stopped by the Land League in October, 1881.

(c) Because it no longer exists.

In the year 1840, Henry, third Marquis of Waterford, gave up hunting in England, where he had made for himself a reputation as a rider to hounds second only to that of Thomas Assheton Smith, John Musters, and George Osbaldeston, as the annals of Leicestershire, Warwickshire, and Northamptonshire can testify. His lordship then came to reside at Curraghmore, there to live the life of an Irish nobleman upon his ancestral property as many of his forefathers had done.

The only foxhounds in the co. Waterford at that time were a small, badly-sustained pack, of which the late Mr. William Fitzgerald was Master, and these gave, in a rough-and-ready way, tolerably good sport. As they had been established for some years, and were popular with the gentry, Lord Waterford made no proposition at that time, that I ever heard of, to take over these hounds.

Captain Jacob of Mobarnane, in the co. Tipperary, then owned the Grove Hounds, which he had purchased some years previously from Mr. William Barton of Grove, near Fethard, and he hunted the "Tipperary country.*

Before making Curraghmore his fixed abode, Lord Waterford purchased this pack from Captain Jacob, and took over his country. With it came their huntsman, Johnny Ryan, whose father and grandfather had hunted them in Mr. Barton's time. They were an excellent lot, and very well bred; but he augmented the pack by a large importation from some of the then best kennels in England.

His lordship rented Rockwell, near Cashel, and from there he commenced to foxhunt Tipperary in the autumn of 1840 . This he did entirely at his own expense.

He married, in May, 1842, Lady Louisa, daughter of Lord Stewart de Rothesay, and after his marriage moved his hunting establishment to Lakefield, near Fethard, where he and Lady Waterford resided during the hunting season.

I regret to have to record, on the authority of Mr. R. T. Vyner in his Notitia Venatica, p. 9, that Lord Waterford was subjected to much annoyance during some of the years he hunted Tipperary, not alone by the receipt of several threatening letters, but upon two occasions demoniacal attempts were made to poison his hounds. The climax of this villainy was reached in the summer of 1844 , when the stables at Lakefield were set fire to, and it was with the greatest difficulty that the occupants were saved. This last outrage was attributed by some to a discharged servant, and by others to

* Mr. Richard Burke has lately come to live at Grove, and has his pack of foxhounds there, so that after a lapse of half a century the Tipperary country is again hunted from there. 
people with whom some of the other servants were on bad terms. Everyone agreed, however, that none of the offences were committed directly against his lordship, whose popularity among all classes was as universal in Tipperary as it was everywhere else.

This outrage led to his giving up the hunting; but with the magnanimity which characterised so many actions of "The Marquis," he presented a large portion of his pack and five horses to the Tipperary gentry, who then began hunting that country by subscription under the Mastership of Mr. Millett of St. Johnstown. The list of subscribers was headed by Lord Waterford with $£ 100$, which, I think, he continued annually until his death in March, 1859.

Unfortunately Henry Lord Waterford although a most particular man about having all other accounts written up with minute exactness, did not himself keep a hunting diary. There now remain alive but few of those who hunted with him in Tipperary. Most of these gentlemen I have applied to for particulars, but none can give them precisely; they all agree, however, in stating that the sport shown by him during his four years in that country was extraordinarily good, and he did things in regal fashion. I should like to be able to give some details of the sport and other matters which would be interesting, but, for the above reason, I am unable to do so. The dates, however, which I mention may be relied upon, for I have taken great pains to ascertain them, and they are recorded upon the consentient authority of several parties who remember perfectly the occurrences and can fix the time with accuracy.

Directly the outrage was perpetrated at Lakefield the Waterford gentry came forward and offered Lord Waterford their hounds and country. Mr. Henry Briscoe of Tinvane kept at that time a pack of foxhounds with which he and his father had been hunting a portion of the Kilkenny country in the Carrick and Piltown districts, and this was also offered to his lordship. Luckily he accepted them, and gave up bis idea of returning to England, as he had intended.

The County Waterford and Mr. Briscoe's packs, thus amalgamated with that which Lord Waterford brought from Lakefield, formed the nucleus of the afterwards famous Curraghmore Hounds.

His lordship at the same time acquired the hunting right to the country in the co. Waterford which has descended to the present Marquis, the boundary of which is from Gurteen to the Comeragh mountains, along them to Cloncoskoran, then in a line to Clonea Castle, with, of course, the sea and river Suir on the other sides, all within the county.

This extent was much too limited, so he entered into an arrangement with the then Sir John Power of Kilfane (great-grandfather of the present young baronet), who owned the Kilkenny Hounds and had the hunting right to the country, to take at a rent of $£ 50$ a year the southern portion of Kilkenny from the Slate Quarries to Woodstock, embracing Carrigtruss, Wynne's Gorse, Castlemorres, Killeen, and 
Kiltorcan, together with the Welch mountains and Bessborough country which Briscoe hunted.

Having acquired this fine tract, Lord Waterford was enabled to hunt three or four days a week, but the hounds he then had, even in their amalgamated state, were not sufficient, so he set to work and procured reinforcements from many of the crack kennels in England, and in a short time started a capital and well-bred pack at Curraghmore.

Thus in the autumn of 1844 foxhurting was established at Curraghmore. This was done under the title of "Lord Waterford's Foxhounds;" with Johnny Ryan huntsman, whipped into by Tom Clooney and George Woods.

The Waterford portion of the country was in a very neglected state, and required a deal of reformation, but the Master went about it with a will, and soon made all things straight. After a while he planted Ballydurn, Ballyneale, Rathgormack, and other gorse coverts, which ever after held foxes that afforded some of the best runs in those parts of the country.

It would be out of place here to refer to Lord Waterford's previous exploits at Melton in scarlet, or across Aylesbury Vale and other places in silk; it is sufficient now to state that as an M.F.H. he soon became equally famous in his own country. The sport he showed all through the Mastership of his own hounds was quite magnificent-so much so that men came from all parts of Ireland, and many came from England, to participate in it.

Lord Waterford's meets were very largely attended, and at them were found many hard and good men to hounds. Alas! nearly all these fine fellows have since gone to other hunting-grounds, but there still remain Sir Robert Paul, John T. Medlycott, George Malcomson, Wm. Madden Glascott, Sir James Langrishe, Captain Peel (late of the 85th Regiment), Robert Watson, (the veteran Master and huntsman of the Carlow and Island Hounds), Congreve Rogers, Wray Palliser, Lord James Butler, Maurice Knox, Harvey Montmorency, Lord Howth, George Gough, Joseph Strangman, and until last year that fine sportsman and great man to hounds, Horace Rochford, who, even in his old age, betook himself to polo, and was one of the best men of the day in Ireland at that grand game.

Among those who hunted with him, who are dead and gone, were the Coxs of Castletown, Johnny Power of Gurteen, Harry Jephson of Waterford, the two Sir John Powers of Kilfane, David and Fred Malcomson, George Bryan of Jenkinstown, William Quin of Loughloher, John Courtenay of Ballyedmond, Sir Nugent Humble, Lord Huntingdon (grandfather of the present Earl), Richard and Thomas Morris, John Power O'Shee, William Power of Seafield, the Lalors of Cregg, Henry Briscoe, John de Montmorency, John Jones of Mullinabro', Dan Osborn of Silverspring, William Bailey of Norelands, John Wade of St. Canice's, William Flood of Flood Hall, Rev. Nicholas Herbert and his brother Walter, Captain Pack Beresford, Tom and 
Hugh Gough of Clonmel, George Meara, Father Martin Flynn of Waterford, Edward Roberts, and his sons Sam, Arthur, and Richard. Of course there were scores of others whose names do not occur to me at present, but the foregoing not alone hunted regularly, but many of them were intimate friends of the Marquis.

He defrayed all the expenses, and did everything at Curraghmore in princely style. He turned out his men on the best mounts he could procure for them, while his own horses carried him brilliantly. $\mathrm{He}$ was always in the van, being, as the world knows, a brilliant horseman. Long ago as it is, and although but in my teens, I well remember how he sailed away on Peacock, Captain, and The Rock to the tail of his hounds, in his own quiet and finished style, without fuss or hurry. In fancy I see him this moment driving up to the meet in mail phaeton and pair, or drag and four greys, at a great pace, and with skill which the best professional coachman might equal, but could not surpass.

The records of his sport are extraordinary, but from personal experience I can speak only of his last season. Tradition has, however, handed down many famous foxhunts, a few of which I shall now give a brief account of.

Lord Waterford had four celebrated runs with the same fox from Knockbrack into Woodstock in the season 1848-49. I often heard them alluded to when I was a boy as being about the most brilliant of their time. That good fox was not killed by hounds. He never waited to be found, but broke before the hounds got up to the covert, and went as straight as a dart to Woodstock, where he always got to ground. His fame having got abroad, and Knockbrack being in Sir John Power's old hunting territory, a countryman thought it would please him to get hold of this good fox and let him go in some covert of the northern country which the Kilkenny hounds then hunted. Accordingly, when he got to ground after his last run, the man dug out the fox and arrived with him in a sack next morning at Kilfane. Upon telling Sir John what he had done, his recompense was as great a licking as ever man got. When the sack was opened the fox was found smothered in it. Sir John got him stuffed and presented him to Lord Waterford, and ever since he has lain in the library at Curraghmore. $\mathrm{He}$ is a splendid specimen of the mountain greyhound fox-the very best breed to show sport.

Another great run was had in the middle of March, 1859, which I had the good luck to participate in, and I could never recall having seen a finer one since. It was from Corbally, over Miltown Hill, through Killahy, through Killeen Gorse, on to Coolnahaw-an eight to nine mile point straight-then to the left by Kiltorcan through Kyleer Wood, across the railway at the Tank, and to Killeen again. Being headed at the covert, the fox ran though Carrigbannan, and an inside ring of the same line he took before, and got to ground under a sleeper of the railway near Ballyhale Station. He was left there after giving a run of 
twenty-two miles in exactly two hours and twenty minutes. Out of a very large field, only five rode it from find to finish, including the huntsman on Merryman and Billy Barry, the whip, on Magpie. Unfortunately, Lord Waterford did not see this great run, as he was away at Liverpool at the time, seeing his horse Ace of Hearts run in the Grand National.

Among the many good horses which carried him while he hunted from Curraghmore, perhaps the following were his favourites:- Sir Nick (called after his great friend, Rev. Nicholas Herbert), Killarney, The Celt, Conrad, Hackfall, Cardinal Puff, The Doctor, Welcome, The Rock, also Blueskin and Lord George, on whom he rode several steeplechases as well as hunts.

He turned out in the field differently from men of the present day. He never wore top boots or white breeches during the two seasons I hunted with him. His dress was a black velvet cap, red coat buttoned up to his chin, showing a blue silk necktie, brown cords, and black jackboots. I never saw him carry any whip other than the ordinary racing kind. His servants were, however, smartly turned out, and, as I said before, always splendidly mounted.

With few exceptions, the general rig-out of the men who hunted with him was by no means smart. Our boots and breeches were not of orthodox cut, but we followed our Master's fashion as regards whips, and never used the crop and lash; we also wore velvet caps. Most of the field were well mounted, and could hold their own with any other Hunt they went with; nor could any of the many English visitors of ten go before some of the Waterford men, in either a fast spin or through a long run.

In the autumn of 1848 there came to Waterford the 85th Regiment of Light Infantry. This was truly a sporting regiment, and had in it some sixteen officers who hunted regularly with Lord Waterford's and the Kilkenny packs. Among them they had nearly forty hunters. Many of these officers were first-rate men to hounds, notably Colonel Brook-Taylor, Lieutenant Bond, Lieutenant Thompson, and Major Blackburn (brother of the English Judge).

None, however, went better than did their brother officer, the present Captain Edward Peel, R.M. Inasmuch as he occupied a prominent position in the history of Curraghmore at the time I am writing of, was a very intimate friend of Lord Waterford, and is now one of the few living representatives of that companionship, I shall devote a short space to this fine sportsman. He is son of General Peel, who won with Orlando the nemorable Derby of 1844 . He joined the 85th Regiment when young-in 1845-and served in it till the Crimean War, when he was appointed D.A.Q.M. General in the Turkish contingent at Kertch during the war, and was afterwards Consul at Oran and Port Mahon, and then R.M. for thirty years in different parts of Ireland. Inheriting the love of sport from his celebrated father, he soon made his name as a rider to hounds, 
between the flags, and upon the flat. In the hunting-field he was a particularly good man on an untrained horse. In one of the runs from Knockbrack to Woodstock just alluded to, he got several falls, yet he contrived to see the run as well as anyone who rode it and was well up at the finish. Afterwards Sir Robert Paul was asked by some of the 85 th how Peel went, and replied, "Peel went very well, but his horse went very badly." He was for years the favourite Corinthian jockey of Lord Waterford and Lord Howth, but, to prevent the attention of the military authorities being drawn to his riding, rode under different names, as well as his own.

These were the days at Curraghmore of such horses as Sir John by Windfall, the Hero by Welcome, Lord George by Economist, Ducan-dhurras by Molyneux, and Sir Arthur by Arthur, all belonging to Lord Waterford. Upon these horses and many others Capt. Peel rode races in public and trials over the private course at Curraghmore. I'Anson, afterwards of Blink Bonny and Caller Ou celebrity, was then trainer to his lordship; Johnny Ryan was first jockey, with John and Denny Doyle apprentices-the latter is living now at the Curragh, but si dly crippled with rheumatism. Old Racing Calendars record the performances of all these horses, which were quite the best of their day--some being equally good over a country as on the flat. On Duc-an-dhurras, carrying 13st. 10lbs., Peel won the Corinthian at the Curragh in 1848 , the race being $1 \frac{1}{2}$ mile heats.

One of the severest steeplechases of its day was that between Capt. Peel's Shinrone, ridden by himself, and Lord Waterford's Sir Arthur, ridden by Capt. Little. It was over that terrible course, Whitefields, on Coppenagh Hill, near Thomastown in co. Kilkenny, a weight-for-age race, Sir Arthur, a four-year-old, receiving $10 \mathrm{lbs}$. For the last half-mile the horses raced head and head at a terrific pace, and Shinrone only just won by a head.

I will here remark that I am very sure there is not a stable in the kingdom at present which has in it four or five horses possessed of the shapes, with like powers of endurance and pace, which characterised the horses I have named (not to speak of the others referred to later on), all of which belonged at the same time to the same man.

I often heard Capt. Peel describe Waterford as being the best place the 85th was ever quartered in ; plenty of fun of all sorts, the best of foxhunting, good cheery fellows, and any amount of hospitality. The officers were constant visitors at Curraghmore, and theirs was considered by the Marquis about the most sporting regiment then in the service.

Peel retains the love of sport which characterised him all through life. He is passionately fond of breeding thoroughbred horses, and generally has a few good ones in training. His mare Flying Column, ridden by the late lamented and accomplished Willie Beasley, made most of the running in the last (1892) Liverpool Grand National, and finished fifth out of five-and-twenty starters. 
Although he loves racing, as he does all sport, he does not bet. There are few men now of my acquaintance with whom I enjoy an interview as much as I do with this gentleman. From him I hear anecdotes and reminiscences of the sporting past which are so deeply interesting to me, and, as they are given by one possessed of able practical experience, my enjoyment is increased many fold. Alas, his contemporaries are fast "returning the cap and jacket," but he is well and hearty as ever, and long may he remain so, and continue to be, if he will excuse me for using the metaphor, a connecting link of the chain between sportsmen of the past and the present-and "a real old Irish gentleman, one of the olden time."

Lord Waterford being closely allied to and identified with the Kilkenny Hunt, I shall give an outline of proceedings characteristic of the time. Its fame was about at its zenith in the era I am writing of. No hunt club in the kingdom stood higher in the category of sport, good fellowship, and social position of membership. Sir John Power, who established it, owned the hounds, and they were hunted from Kilfane. It was the custom to have what was called a "Hunt Week" in the city of Kilkenny once or twice during the season. Nany of the leading men in Ireland, often numbering one hundred, used, on these occasions, to visit the marble city, and each brought three or four horses at least. Lord Waterford and others brought a dozen. Every day during the carnival these gentlemen hunted. The head-quarters of the party were at Walshe's Hotel, the greater portion of which was used as the club house during the season. Here forty to fifty sat down to dinner every day during the "Hunt Week," and right merrily did they keep up the festivity.

All the bedrooms were, of course, engaged, but, truth to tell, very little for sleeping purposes. To dress for dinner in the evening and for hunting in the morning was about all most of them were required for. Although these hard-headed, firm-seated top-sawyers of old could sit up late and hunt all day, none of them ever thought of drinking in the day time. A man addicted to such a propensity would have been "black-balled "for any club of gentlemen he might be put up for. At the same time everyone was expected to drink his two or three bottles of wine after dinner, and the steadier he carried them the better he was thought of. These grand old fellows did not entertain a like opinion to that of Soapey Sponge when he came to the conclusion that "drinking and riding were two men's work"!

"Handicapping" was then also a favourite after-dinner amusement, and it was resorted to nightly at these festivals.

After indulging in this innocent, but not altogether innocuous, diversion during the hours which the party devoted to Bacchus, these sportsmen betook themselves to a quiet turn at the pasteboard and the ivory. These amusements were carried on mostly in the landady's boudoir. Mrs. Walshe was of a good old sort. Dearly did she 
love the rattle of the dice and the shuffle of the cards, and ofttimes would the old lady join in the game, and well able was she to hold her own.

Truly a hot shop was Kilkenny during these festivals. At no time was it found in its normal state except the few hours of day time devoted to hunting. During the evenings, nights, and mornings the quietude of the city of the cats was disturbed to a degree. Yes, this festive foxhunting fraternity made mirth and melody, fun and frivolity resound off the walls of Kilkenny's old city after days on which they had ridden hard across the paragon pastures of its favoured county.

Lord Waterford, of course, attended regularly these sporting reunions, and with him came many of his hunting men. As may be supposed, "The Marquis" was the leading spirit of all the fun, but he had those nearly as gay as himself in playing the game all round, among whom may be mentioned the late Lords How th and Clanricarde, Mr. Power of Gurteen, Sir Richard Cox, and that prince of good fellows Harry Jephson. In addition the following were usually to be found there : the then Lords Ormonde, Desart, and Clonmell, the present Lord James Butler and Sir Robert Paul, the then Sir John Power and his son John, George Bryan, Captain Ponsonby, John Wade, Henry Meredith, Henry Briscoe, Horace Rochford, John Jones, Ned Lalor and his son Tom, Tom Connolly of Castletown, Captain Pack Beresford, Captain Peel, and other officers of the 85th, cum multis aliis.

In 1848 the 7 th Hussars were quartered in Kilkenny, so the present Duke of Beaufort (then Marquis of Worcester), Lord Suffield (then Mr. Charles Harbord), General Fraser, Colonel Cooper of Markree, co. Sligo, and others of that crack regiment were generally to be found among the peep-of-day boys at the club house.

In the years 1846-48, there existed great political excitement in Ireland; the sports of the country were not, however, interfered with as they were in recent years, and foxhunting flourished in Waterford, Kilkenny, and all other parts of Ireland. Some country gentlemen were, no doubt, obnoxious to the peasantry for some reason or another, and upon more than one occasion Lord Waterford's and the Kilkenny Hunts were molested. A determined onslaught was made near Ballyhale upon a number of gentlemen when returning from hunting with the Kilkennys, and they had to ride for their lives across country. On another occasion, about the same time, the late Captain Harry Jephson and Mr. Larry Dobbyn of Waterford, with another gentleman, whose name I forget, were returning late at night from hunting with Lord Waterford, and were proceeding down the steep hill approaching Mullinavat from Hugginstown. Mr. Dobbyn was a considerable distance in front of the others and was walking beside his horse, when suddenly he found himself attacked by four men. Larry was a powerful and determined fellow, and, well 
knowing how to use his fists, in less than a minute two of the scoundrels were laid senseless on the road from well delivered "straight ones," and the others ran away up the hill in the direction of Jephson. Larry shouted to catch them, which was done, and a sound thrashing was administered. Thus were the four fellows accounted for, but in a way they little anticipated, for when they attacked Larry, although they thought he was alone, they did not recognise him in the dark nor did they imagine a man equally good with his fists was within a hundred yards in the person of "Sporting Harry." The report of that encounter, with its results, spread through the country, and there were no more attacks made upon the hunting men.

I give the following instance of a hound's extraordinary powers of finding his way home upon the authority of Johnny Ryan, under whose immediate knowledge the occurrence took place. In about the year 1850 Lord Waterford sent a draft of hounds from the Curraghmore kennels to a friend of his in the co. Clare ( $\mathrm{I}$ forget who). The hounds were sent in a van four miles from the kennels to Fiddown Station, thence in a horse-box over fifty miles by railway to Limerick, from there across the Shannon and several miles into the co. Clare to their destination. This journey of some seventy miles was thus made in covered conveyances. Within ten days one of the bitches found her way back to the kennels at Curraghmore, having made the journey on foot. How or where she crossed the river Shannon is unknown; but unless she did so by either of the bridges at Limerick or Castleconnell, which are some ten miles apart, she must have swum across, and at all parts the Shannon is wide and rapid.

Wherever "March 29, 1559," occurs in a sportsman's diary, it should be encircled with a mourning border, for on that day was killed one of the greatest foxhunters that ever lived, and one of the finest riders between the flags of his day or for many years after.

Yes, Henry, third Marquis of Waterford, known, as he always was and always will be, as "The Marquis," was killed on that day, at a small fence on to the road in the valley between Miltown and Corbally Hills, in the co. Kilkenny.

I was hunting with his lordship that day, and although so many years have passed since the appalling catastrophe, I remember vividly all the lamentable circumstances, so I shall give a few particulars, the accuracy of which may be thoroughly relied upon.

Lord Waterford's meet was at Castlemorres, the seat of his intimate friend, the late Mr. John de Montmorency. A fox was found in the demesne, which gave us a bad run to ground on the banks of the stream under Glenbower Wood, not far from Tom Shea's house at Mullinbeg. Lord Waterford then changed horses and trotted off to 
draw Corbally, in the hopes of finding the fox that had given the great run which I related at page 5. A fox was found there, but whether he was the one wanted or not no one can tell. However, he ran the same line exactly as that of the previous occasion as far as the top of Miltown Hill, but then wheeled sharp to the left, down the hill and up that of Corbally.

The hounds were hunting slowly, and had just recrossed the Kilmoganny road, on to which was a low rotten fence, with a narrow shallow grip on the landing or road side. It was when jumping this insignificant obstacle that Mayboy, the horse Lord Waterford was riding, pecked on landing, and threw him heavily on the top of his head on the hard road. He never moved nor uttered a sound after his fall.

Of course, all the field pulled up, with the exception of a few who happened to be in front at the time. Dr. O'Ryan was close to the poor Marquis, and got to his side in a minute, but life had already departed.

Many theories were given as to what caused death, among them apoplexy, but $I$ think there is no doubt whatever that he broke his neck, for the top of his hunting cap was bulged in, and there came a bluish mark across the back of his neck soon after death. However, the clearest explanation of the fall which I ever got was from Sir John Leslie, and that only within the last two years, when he informed me that this fine horseman was suffering from acute lumbago at the time, and was perfectly unable to sit a horse if he made any mistake. This accounts for the catastrophe beyond all manner of doubt, and scatters the theory of sudden apoplexy, which at all times appeared to me absurd.

Lord Waterford was born on the 26th April, 1811, therefore he had all but completed his forty-eighth year when he was killed.

His death, occurring as it did in the flower of his manhood, caused more sensation, and I am sure more universal regret, than did any other event for many a year before or after. His multitude of friends mourned him as a brother. All sportsmen recognised the fact that one of their greatest chiefs had been cut off, while the whole nation lamented over the untimely death of "The Marquis."

Yes, he was indeed a universal favourite. His daring deeds, his lively escapades, his fame as a foxhunter, and his brilliant horsemanship were known to everyone, while his generous disposition was ever put to practical illustration. Truly, he was a rare specimen of manliness, which, in addition to his deeds, his noble bearing and strikingly handsome face plainly portrayed.

I don't believe there ever was in Ireland a larger funeral. It took place on the 6th April, 1859. The number of those who attended could be computed only in hundreds, and all came for the sole purpose of doing reverence to the memory of their dead favourite.

Lord Waterford left no portrait or likeness after him except a miniature which the Marchioness had. That gifted lady, however, produced 
a very faithful likeness of him in bust portrait some time after his death, a copy of which, neatly framed, with coronet on top, her ladyship presented, with her compliments, to each member of the Hunt who had subscribed for and presented a pair of silver claret jugs to Lord Waterford in the year 1858 .

Capt. Richard Elwes, at that time quartered with his regiment in Waterford, and myself happened to be in front of the Marquis when he got his fall, and, knowing nothing of the catastrophe, we went on with the hounds. After a bad run over Corbally, by Templeorum, and through Mountain Grove, the fox was killed on the side of Dowling Hill. Elwes brought home the brush and gave it to Harry Jephson, who was perbaps the greatest friend the Marquis then had in Waterford. A few years after it came into my possession, where it remained until the end of 1888, when I gave it to Lord Marcus Beresford as a Christmas-box.

I have a catalogue of the sale of Lord Waterford's stud before me, from which I condense the following, as it will be interesting to some to compare the prices of that time with the present. It took place at Curraghmore on June 24 and 25, 1859.

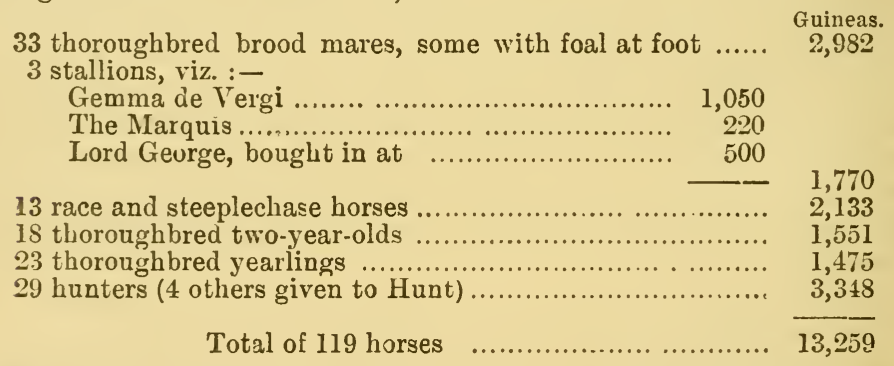

The residue of the pack, after Briscoe choosing the best 32 couple consisted of 29 couple, and they fetched 126 guineas.

The highest prices given for the hunters were :-

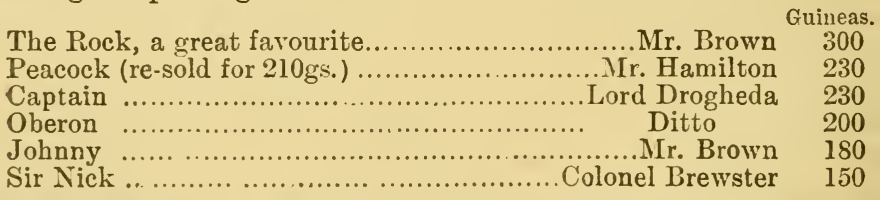

Oberon afterwards won many steeplechases, carrying poor Dan Meaney in the familiar "black and silver lace." Mayboy, the ewenecked, flat-ribbed, leggy brute that Lord Waterford was killed off, was sold to Mr. Sewell for 91gs. I shall never forget the moan of anguish given forth in hushed tone by the crowd when this cursed chestnut was led into the ring.

This sale was very largely attended. Men from all parts of the kingdom nd many from the Continent came either to buy or to see 
this great stud before it was broken up. The prices realised were considered to be very high at the time, but if such a stud was to be sold now it would fetch at least five times the amount.

There was a great row raised after the sale when it was found that the largest buyer, a Mr. Hamilton, was a madman unaccountable for his actions, so the several horses knocked down to him, including Gemma de Vergi, had to be re-sold soon after. They, however, fetched a total pretty nearly the same as at the Curraghmore sale.

Among the brood mares were: The Deformed, kought by Mr. George Bryan for 360gs.; Juanita Perez, Mr. Weatherby, 350gs.; Peri, Mr. Bryan, 280gs. (this mare went subsequently to the Royal Stud, where she produced Perinita and other good horses); Duchess de Guise, 210gs.; Ariadne, 195gs.; Queen Margaret, 100gs.; Ossifrage, 100gs.; Kick up the Dust, 105gs. ; Sarah Ellis, 100gs.; Mag on the Wing, Prism, Red Rose, Rosamond, Titania, Vesta, etc.

Among the race and steeplechase horses was found Bumble Bee, sold t3 Captain Pack Beresford for 550gs., one of the famous "Bee family" so well known at Ballymanus. Also Ace of Hearts, by Great Heart, bought by Mr. W. J. H. Powell of Measgwynn, in South Wales, for 315gs. Ace of Hearts was the last horse that carried the Marquis' blue jacket and black cap, which he did in the Grand National of 1859, a week before his owner was killed. This horse in February, 1862, for Mr. Powell achieved a record in steeplechase annals, when, with The Rug, owned by Captain McCraith, he ran two dead heats of four miles for the Carmarthenshire Steeplechase. Night coming on, the owners agreed to divide.

Gemma de Vergi seemed an evil genius during the earlier part of his career. He was bred by Cook at Rugeley. Cook was poisoned in 1856 by Palmer, then owner of Gemma. Palmer was hanged. Lord Waterford bought the horse at Palmer's sale; he was killed. The man who bought Gemma at the Curraghmore sale was a madman. Sudden death or something untoward befell someone connected with this horse at a subsequent sale, after which I lost sight of Gঃmma de Vergi.

I compiled the foregoing, as I did the remainder of the history, several months ago, but there has recently taken place an event which bears such interesting appropriateness to this portion that I must refer to it. Moreover doing so will show what a marvellous increase has taken place in the value of Irish thoroughbred horses since 1859.

At the Dublin Horse Show in August, 1892, which has just taken place, the stud of the late Mr. William Brophy of Herbertstown, consisting of thirteen lots, was sold by auction by Mr. Robert J. Goff. This sale was, perhaps, the most extraordinary that ever took place in Ireland. Apart from the prices realised, a record has been scored which is not only without parallel, but it is likely to remain so. A brood mare with foal at foot, her yearling, her two-year-old, and her 
three-year-old were sold at the same time, and fetched a total of 20,850 guineas. Here are the particulars :-

Chrysalis (1876) by Lecturer out of Winged Bee, by Artil. lery out of Queen Bee, by Harkaway out of Calcavella................................ Lord Marcus Bere-ford Her filly foal ty Philammon........................ James Daly

Her yearling colt by Kendal..................... Mr. W. Fulton Laodamia, her two year-old filly, also by Kendal ditto Chrystabel, her three-year-old filly by Lyric or Kendal ditto

Total price realised for Chrysalis and her four youngsters The other eight lots fetched

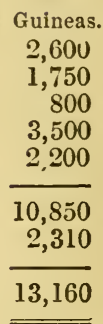

Total of thirteen lots 13,160

Bumble Bee, a three-year-old, referred to by me when treating of Lord Waterford's sale, was by Lord Henry out of Queen Bee, by Harkaway out of Calcavella. Thus we have the close consanguinity which exists on the maternal side between her and this wonderful brood mare Chrysalis, who, with her family, has just fetched the extraordinary sum I have quoted, the dam of Bumble Bee being the granddam of Chrysalis, with the famous Harkaway her sire. Needless to mention that Lord Marcus Beresford, to whom Chrysalis was knocked down, is nephew to Henry, third Marquis of Waterford.

If prices of thoroughbreds in 1859 were the same as they are in 1892 what an enormous amount would Lord Waterford's stud have then realised! His 119 horses, including 33 thoroughbred brood mares (some with foals at foot), 3 stallions, 13 racehorses and 41 thoroughbred yearlings and two-year-olds, not to speak of 29 hunters, fetched, in 1859, only 13,259 guineas. Mr. William Brophy's stud of thirteen all told fetched, in 1892, 13,160 guineas!!

Although this chapter purports to be a history of the Curraghmore Hunt, it will not be out of place at the present stage, particularly after treating of the Marquis' sale, to make reference to some of the racing and steeplechase records of that nobleman. In doing so I must needs make specific mention of his jockey, Johnny Ryan, who is now (1892) stud-groom to the present Marquis, and to whom I shall again allude when I come to treat of the last decade of the history He came from a racing stable at the Curragh, entered the service of Lord Waterford in 1842, and continued as first steeplechase and flat. race jockey, also as second horseman, until his lordship's death in 1859. During these seventeen years Ryan distinguished himself on the flat and between the flags in the "light blue and black cap" to quite an unparalleled degree. He rode a total of 130 races for Lord Waterford, of which he won no less than 112, was second in five, and third in three, the three third places being for the Liverpool Grand National. Thus showing a record which I should say was never approached by any other jockey, professional or otherwise, in the annals of racing or steeplechasing.

Among the best horses which Ryan rode for Lord Waterford were 
Lord George, The Marquis, Sir John, Warner, Henry, Duc-an-dhurras, Cheroot, Augustine, Postillion, and Firefly. His best races were, perhaps, the Autumn Steeplechase, at Liverpool, in 1849, which he won on Sir John, beating Vain Hope, The Doctor, and fourteen others ; the Metropolitan Steeplechase, at Epsom, in 1851, which he won on Lord George, beating Maria Day, British Yeoman, Rendsburg, Mullingar, Spectator, Springbuck, etc.; the Epsom Hurdle Race in 1851, winning on Lord George, with Vesta, Little Queen, Bedford, and four others behind him; the Rock Stakes at Cashel in 1852, on Warner, beating Old Rake, Billy-the-Darter, Crutches, Adieu, etc.; the Flat Race at Cashel-same meeting - on Augustine, beating Warner, the horse he won on the day before, Peg-the-Rake, Ranger, and Sphynx; the Hurdle Race at Howth in 1853, he won with The Marquis, beating Augustine, Venus, Carlow, Dearest May, and Venison. Ryan also won finely-ridden races on Cheroot at Tipperary, Postillion at Punchestown, Sir John at Cashel, and on Lord George at the Curragh.

As it may be tiresome to my readers to hear more than the tithe of this fine horseman's achievements under the "Beresford blue," I shall cease further reference; but what I have said is, I consider, quite worthy of recording in a chapter dealing with the sport of Curraghmore, while the record furnishes a connecting link between former and present racing and riders.

John Ryan, the jockey, was no relative to his namesake, the huntsman.

Second Section.-Henry W. Briscoe, Esq., Master, 1859-70.

Succession of John, fourth Marquis of Waterford-Meeting of the Hunt-His Handsome Offer Accepted-Committee Formed, Mr. Briscoe selected as Master, Mr. Medlycott Hon. Sec.-Hunt started as a Subscription Pack-Liberal Subscriptions-New Arrangemenis -Lord Bessborough-Briscoe chooses a Pack out of Lord Waterford's-The Brocklesby Lot-Hunter's selected-Title of Hunt changed-Monetary and other arrangementsCurraghmore Kennel Book-Villager-Extensively uscd-Good Results-VigilantHis Progeny-Splendid Strains in Curraghmore Blood-Kennels Bred from-ResultsMr. Briscoe as an M.F.H.-Briscoe's start-Huntsman and Whips-John Duke-Johnny Ryan as a Huntsman-Briscoe took the Horn-Dan Ryan-Wonderful Sport-Mr. Glascott's Pamphlet-Sport in 1861-62-Four Great Runs-"The Annefield Fox"GJascott's Concluding Remarks-A Contrast-Glascott as a JuGge of FoxhuntingMore good Runs-Particulars of Some-A Beautiful Pit of Hunting-Mr. Joseph Strangman, Secretary, vice Mr. Medlycott, resigned-Succession of the present Marquis to the Title-Hunted with Briscoe-Never expressed a wish to take the HoundsBriscoe's illness-Had to Resign Mastership-Testimonial to Briscoe-Banquet.

UpoN the death of Henry Lord Waterford his brother John succeeded to the title as fourth Marquis. He, however, being a clergyman, could not very well keep on the hounds as Master, so a meeting of the gentlemen interested in the hunting was held in the City of Waterford in the summer of 1859. At it the new Marquis offered to lend the county a pack of hounds to be selected from his brother's kennel; to make them a present of any four of the hunters they chose, and in addition to give a large yearly subscription. This generous proposal was accepted with acclamation by 
the meeting, and a committee was formed consisting of the late Lord Bessborough, Sir Robert Paul, the late Mr. Thomas Lalor, the late Mr. David Malcomson, Mr. Joseph Strangman, and a few others.

The late Mr. Henry Whitby Briscoe of Tinvane was unanimously elected as our new Master, and Mr. John T. Medlycott of Rocketts Castle kindly consented to undertake the duties of honorary secretary. A list of subscribers was then opened and most liberal sums promised by all present, Lords Waterford and Bessborough, with Messrs. Dav George and Fred Malcomson, heading it with princely amounts.

Each gentleman who owned a fox-covert offered it free to the new Master. Lord Bessborough had several in the Kilkenny country, which, by the arrangement with the late Lord Waterford, were subject to a rental of fifty pounds a year to the Kilkenny Hunt. Lord Bessborough, in addition to his subscription to the new fund, now undertook to pay this rent, so that our Hunt might retain them.

Soon after this meeting and previous to the auction at Curraghmore in June, Mr. Briscoe, as promised by Lord Waterford, selected his pick of the Curraghmore hounds and four of the hunters. This he did with the assistance of Johnny Ryan the huntsman, and chose thirty-two out of the sixty couple which constituted the pack. The first lot chosen by Briscoe was that of five couple and a half, a reduction of the Brocklesby pack, which had been sent by Lord Yarborough to Lord Waterford the very week he was killed, and which the poor Marquis never even saw. His selection of the hunters was Merryman, Sunshine, Cheasty, and Wall-horses suitable in every way for the work they were to be continued at. The title was then changed to that of "The Curraghmore Hunt," as Lord John, in his position of a clergyman, did not wish the pack to be called by his name.

Lord Henry had always given three or four days a week, but when the Hunt was changed to a subscription pack the money available did not enable Mrr. Briscoe to have more than two days. So great an extent of country not being now necessary, fresh arrangements were made with the Kilkenny men, and they took back a portion of the territory which had been lent to the late Marquis, including Wynne's Gorse, Kiltorcan, Castlemorres, and Killeen, all fine sporting coverts.

The sum agreed to be given Mr. Briscoe for hunting the country was $£ 580$ per annum, which, however, was subsequently raised to $£ 1,000$; the fund in addition provided for keeping in order the coverts, fowl and damage claims, and expended a lot of money in repairs of the kennels and stabling at Tinvane, and started the new Master with extra horses. The payment of field money which, of course, in Lord Waterford's time was unknown, was then introduced, and this also was given to Mr. Briscoe. Hounds and horses were then removed to Tinvane.

I have before me the "Curraghmore Kennel Book," commencing in 
1859 and continued down to end of 1881. It was compiled by the present Lord Waterford, and started with the thirty-two couple of hounds which Mr. Briscoe selected, including, of course, the Brocklesby lot. This, as I said, consisted of five couple and a half, and it was lucky for Briscoe it came at the time, for it gave him not alone several good working hounds, but brought to the Curraghmore pack the bluest foxhound blood in England. Among the lot was Villager, six years, by Mr. Foljambe's Royster, out of Lord Yarborough's Vanity, a wonderfully bred dog and of about the best strain they ever had at Brocklesby.

It is to this hound that the Curraghmore in the greatest degree owed their thorough-breeding, not alone when handed back by Mr. Briscoe to the present Marquis in 1870, but even up to the time when that nobleman was stopped hunting in Ireland in 1881. In fact, when his lordship sold the two packs there was hardly a hound in them which did not go back to Villager.

Briscoe bred a great deal from him, and also from a two-yearold hound of this lot called Vigilant, by Lord Yarborough's Pleader, out of his Violet. The descendants of Vigilant did not, however, turn out as well as Briscoe expected, for, after a generation or two, they became noisy. He got a splendid hound out of Mermaid called Mountebank, good looking and capital in his work. Briscoe bred also from Mountebank, but all the strain had eventually to be got rid of.

Vigilant and Villager were grandly shaped, and fit to show with any stallion hounds in England, and they were remarkably good at work. They were not, however, of a handsome colour, having a lot of black, little white, and no tan except one small patch with which Villager was adorned. Their progeny, however, were usually of the beautiful Belvoir tan.

After carefully examining the pages of the old Kennel Book as I have just done, I can't help admiring the splendid strains of blood which were continuously brought into that pack by Henry Lord Waterford, Mr. Briscoe, and the present Marquis during their several years of office. Scarcely a single hound whose pedigree does not relate to the following kennels:-Mr. Foljambe's, Lord Yarborough's, Lord Henry Bentinck's, Duke of Rutland's, Mr. Meynell's, Lord Leconfield's, Lord Portsmouth's, Mr. Lane-Fox's, Lord ('alway's, Mr. Watson's, The Milton, Lord Doneraile's, Duke of Grafton's, and The Oakley. If ever blue foxhound blood was to be found, where could a man look for it if not in the foregoing kennels, while judiciously crossing that of the one with the other should, as it did in this instance, produce a pack of foxhounds second to none other in breeding.

Under those circumstances it is not surprising that with three successive Masters of the calibre and capabilities of ours, the Curraghmore hounds should have shown a continuance of magnificent sport. 
The choice of Mr. Henry Briscoe as Master was most excellent, for no man knew the duties all round better than he. He had kept and hunted foxhounds of his own for several years previous to his selling them to Lord Waterford, and he always studied the working of hounds during the many years he continuously hunted with the Kilkenny, Tipperary, and Lord Waterford's packs. Briscoe rode to hunt, and did not hunt to ride. He was in a word both theoretically and practically qualified in every way for the duties of M.F.H., but as I shall devote a chapter entirely to that great foxhunter, I need now say no more about him except so far as directly concerns the subject of this chapter.

Briscoe started with Johnny Ryan as huntsman and Billy Barry as whipper-in, each of whom had served under Lord Waterford in their respective capacities. Barry was, however, soon parted with, and his place was filled by Harry Hardy, who in turn also changed and went to Mr. Filgate, then and ever since Master of the Louth Foxhounds, and with whom he has remained to the present day. Briscoe then imported John Duke from an English southern pack, and things worked most harmoniously for some years without further change; Ryan carrying the horn, with Duke whipping in to him.

Old Johnny was a capital huntsman, quick as lightning, but never in a hurry. He was a brilliant rider to hounds, with one of the neatest seats I ever saw and perfect hands; he seldom used his horn, and when he did he had but three blasts, each totally distinct from the other-one long single note to draw hounds from covert, one sharp quick touch to bring them to him when casting, and a rattling double-double-double to get them away on their fox and proclaim the end of a run. He had a melodious voice, but used it also sparingly. After some years he gave up his post and went to America.

Briscoe then took the horn himself and showed a continuance of quite as good sport as we had with Ryan; Duke whipped to Briscoe also, and soon became first-rate at his work, he was a very fine rider and had a powerful and capital voice. Dan Ryan, a son of the huntsman, was soon after made second whip, and a right good man he was; and for many years he whipped to Duke, when he succeeded to the horn.

The Curraghmore hounds, under Mr. Briscoe, showed exceptionally good sport. I don't think any other two-day-a-week pack in the kingdom showed better within the same period, and, from what I heard at the time, it quite equalled the magnificent sport shown by Henry Lord Waterford in the previous decade of the Hunt.

It would be tedious and uninteresting to the general reader to have to wade through accounts of foxhunts-no matter how brilliantwhich took place so many years ago, particularly when they had not taken part in them, so I shall not impose the task upon them, except so far as to prove to demonstration that the sport was of the character I say. 
The better to do so I shall quote from a pamphlet written by Mr. Glascott of Alderton, a man who constantly hunted with the third Marquis and also with Briscoe, although he lived in the co. Wexford and had the most inconvenient means for visiting us.

That gentleman took for his theme the sport of Mr. Briscoe's third season only, but I can assure my readers that we had several still better, and the one chosen is but a fair sample of the sport we had from 1859 to 1870 .

\section{Curraghiore Hunt, Season 1861-62.}

"Hounds were out sixty-eight days.

"Killed forty-one foxes and ran sixty-one to ground, thus accounting for one hundred and two foxes.

"They had twenty first-class runs of from thirty minutes upwards, with many good things of from ten to twenty minutes, at such a pace that only the light-weights and thoroughbreds could live in."

Mr. Glascott records the particulars of several of the above, which, though highly interesting to one like myself who had the good fortune to participate in most of them, would, as I said before, be tedious to the general reader; so I shall refer to only four, which were given by the same fox, and are of extraordinary celebrity. They were all from the Owning or Annetield portion of the Welch mountains, and over beautiful lines far away into the Kilkenny hunting grounds, passing through and far beyond those parts known as the Wynn's Gorse and Kilmoganny country, and in one instance on to Callan and Kells. This good fox, known as "The Annefield Fox," always beat the hounds; but I know in, at least, two of the runs he was relieved by a fresh one. Anyway, it was the same fox which was found on the four memorable occasions, and he gave us the cream of the cream before he shifted the pride of leadership on to another good one. What became of him I never could satisfactorily find out; but I heard he died in a wet drain, or was found dead near it, after the run of 11th April, 1862. Here are the particulars :-

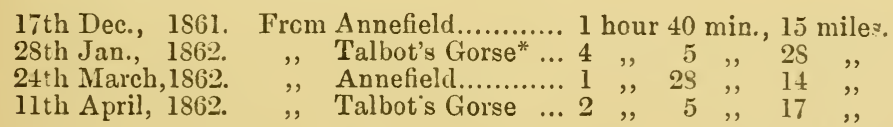

The record of such a season's sport with one pack of hounds, hunting only two days a week, as Mr. Glascott says, "deserves to be handed down to our sons' sons." He concludes with these remarks:-

"The hunting hounds consist generally of twenty-five to thirty couple, standing about $22 \frac{1}{2}$ inches, of great length, bone, and muscle, which on a near inspection surprises you, as looking at them sideways from a little distance as they step along to cover-brought out as they are in condition fit to go-they appear light, lengthy

*Talbot's Gorse was only a small patch of furze on Castletown hill, and not a regular covert. 
hounds. I cannot say what the kennel discipline is, but when brought out they appear to me as near perfection as it is possible to bring hounds. In the field, quietude and dependence upon themselves for hunting is the order of the day, and with a fair scent and once clear of the field they require little interference on the part of the huntsman. The club is, in every sense of the word, nobly supported, the country well stocked with game; harmony and good-feeling pervade all classes, from the popular nobleman of the club to the humble peasant."

This pamphlet of Mr. Gltscott's was published in 1862, and truly stated the happy relations which then and for many years after existed between the Curraghmore Hunt and the farmers. What a direful contrast with the state of things brought about by the Land League only a few years after!

I never knew a man better able to judge the results of an M.F.H.'s management than Mr. Glascott, although he never held that office; but he was a good man to hounds as ever I saw, and, having his eye always on them, and knowing what they were doing, he never did harm, hard though he rode. I make these observations to show how well qualified he was to judge of Mr. Briscoe's management, and entitled to put that opinion in print. I may add that he was past the meridian of life when he wrote the pamphlet, and had hunted regularly ever since he was a boy.

I did not keep a diary of my hunting, so I cannot fix the date of some of the runs I am about to record, but I vouch for the accuracy of the details.

December 30, 1862. From Glenbower, round Garryduff Hill, by Tom Shea's house of Mullinbeg into Carrigtruss ; across the covert without checking to near Boolyglass; to the right through Harristown, by Lismatique Castle to Moonruha; across the Harristown River, from which the fox went as straight as a ruler for five miles to Rochestown House, running the boundary headland of Killeen Gorse without touching the cover. He was headed at Rochestown, so wheeling to the left he crossed the Mullinavat River, and was going for Tory Hill, when he was turned over in the open by that beautiful bitch Barmaid, two miles from where he crossed the W. \& K. Railway. 14 miles-1 hour 25 minutes. This was one of the finest foxhunts I ever saw, and every hound was up-from Carrigtruss to the kill, about 40 minutes, was clinking-the country before that was roughfrom Slievenamona, through Rathanny, by Carrigeen, through Knockaderry, across the Dungarvan road at the Slate Quarries, up the distressing hill of Guilcagh, by the Five Roads, and killed just before getting into Baylough Woods. A magnificent run of some eleven miles. Time, exactly sixty minutes. Only two men out of a large field were within half a mile of the hounds when they killed their fox. Toiling up the steep of Baylough they viewed him with roached back and draggled brush gallantly striving to gain the 
woodland, and right valiantly did these two men endeavour to save the poor fellow, Master and huntsman being far away, but their efforts were fruitless, for, scrambling over the second last fence from the covert, he was pulled down.

From Curraghbaha to near Bonmahon, to the right, over a fine expanse of grass country (I forget the names of the townlands) crossing the Stradbally River, at the time very flooded, and killed within a field of Carrigmorna. About twelve miles. One hour ten minutes. Mrs. Dick Roberts went this fine run like a bird on her famous black horse, and was presented with the brush by Mr. Briscoe.

Met at Kilmacthomas ; found in Curraghbaha ; ran through Faha, by Grouse Lodge to within two fields of Woodhouse; bore to the right along the sea coast to near Clonea Castle, then wheeled inland to near Carrigmorna, to near Curraghbaha, through Faha again, through Seafield, and to ground at Ballylaneen village; hounds running their fox in view for the last three fields, and were not twenty yards from his brush when he got to ground. Fifteen miles in one hour and thirty minutes, over a fine grass, but stiffly-fenced, country. Duke, the huntsman, was the only man out of a large field who rode this great hunt from find to finish. Lord Clanricarde went well on a roan horse belonging to poor Dan Smithwick, and if these men were now alive they would remember well this run.

I was witness of a beautiful bit of hunting in Briscoe's time by a well-named bitch-Matchless-one of the hounds selected from Lord Waterford's pack. It was on Listrolin Hill, where irregular single walls built of loose stones abound. This bitch carried the line of her fox along the top of one of these for over a hundred yards, giving tongue all the time. The stones were laid singly on the top and were so small and loose that they toppled off under her feet, and it was with the greatest difficulty she maintained her footing; the body of the pack contented themselves with looking at her as they flourished along on both sides, knowing they need not on that occasion assist her along her perilous path, but they very quickly took up the line as soon as it left the wall.

Mr. Medlycott held the office of honorary secretary to the Hunt for two or three years until about 1862, when Mr. Joseph Strangman took over the duties, which he continued to perform to the end of the history of the Hunt. Further reference will be made later on to the great services rendered by that gentleman.

When the late Lord Huntingdon lived at Whitechurch and hunted that part of the co. Waterford, he brought large contingents to our meets at Gardenmorris, Kilmacthomas, and Newtown Chapel. In tiptop style he did so. As far as Dungarvan he brought them on his drag with his own team, then with four posters they came on to Briscoe-the Fitzgeralds, Odells, Humbles, Furlong, Smith of Headborough, Maxwell of Mcore Hill, Victor Roche, William and John Hunt, the Hudsons, cheery McDermot of the R.I.C., Dick and Mrs. 
Roberts, the Heljs, and many others. These were the gond times for the Kilmacthomas folk. What a roaring trade John Walshe did at the jolly little imn, and could we not get there the best of egg-flip and all things equally good? Ah's me !

The present Marquis of Waterford succeeded to the title on the death of his father in 1866. He was then serving in the 1st Life Guards, in which regiment he continued until 1869, when, as a captain, he sold out and came to reside at Curraghmore. Whatever may have been his wishes regarding the keeping of hounds, he never even indirectly intimated he would be inclined to follow in the footsteps of his uncle, and take on the Curraghmore country. On the contrary he was always an ardent and substantial supporter of Briscoe, for whom he entertained the highest regard and admiration both as a friend and sportsman, and he gladly hunted with him like any other member. Through an unlooked-for incident, however, a change in the Mastership became imperative, and then for the first time was it known that Lord Waterford would be willing to take upon himself the trouble and responsibilities attached to an M.F.H.

During the season of 1869-70, Mr. Briscoe got into a very bad state of health, so much so that at the time there seemed very little chance of the poor fellow's ultimate recovery, and both his medical advisers and friends strongly recommended him to give up the hounds, which necessarily entailed more work, care, and worry than he was then physically fit for. Poor Briscoe was naturally loath to relinquish a position he had so satisfactorily filled, and in which his heart delighted; it seemed to him like sinking suddenly into old age, and being put aside on the shelf. However, prudence prevailed, and he resigned, no doubt the more cheerfully from the knowledge that his beloved hounds were to pass to one who would in every way do them justice.

On retiring, Briscoe, who had somewhat recovered his health, was presented with a very valuable testimonial by the members of the Hunt and gentlemen who had partaken of his sport. The ceremony took place at a banquet in the City of Waterford, in the summer of 1870, at which the Marquis of Waterford presided.

\section{Third Section.-John Henry (present) Marquis of Waterford, Master 1870-81.}

Natural that Lord Waterford should be the Head of the Curraghmore Hunt-His taking office as M.F.H.-Got a Capital Start-Well-bred Pack-Good Workers-Imported more Hounds-His Lordship as Judge of Hounds-As Judge of a Horse-His weightBegan well-"Servants' Horses"-His Passion for Hunting-Apprenticeship-John Dnke-Increase of Territory-Hunting Days increased-Kilkenny Hunt-John Going -Boundary of the New Territories-Increase of Stud-Boundary of Lord Waterford's cuuntry-Owned and acquired-Great area-All Hunted fairly-Out-Stables-Description of Curroghn:ore country-Woodlands-New Gorse Coverts planted-Lord Waterford not yet satisfied-Acquires Lord Huntingdon's country-Gave it up-The Ross 
country-The Ballydurn country-Sport over them-Welch Hills-Pembrokestown, Knockaderry-Mount Neil-Clonassey-Roanmore-The Fences-The Going-Good Scent-The Cry of a Foxhound-Of the Curraghmore-Riot-Gorse Caverts-Carrigtruss-Knockbrack-Ballydurn-Rathgormack-Ballyneale-Duke's Fall-Johnny Ryan and Lord Waterford Hunt the Hounds-His Lordship Hunts both Packs-Duke recovers -Resumes the Horn-His Lordship takes it again-Holds it till the end-Great sport - His hard riding-His big weight-His good horses-Mr. Strangman as SecretaryDid great service-Testinonial to him-Good man to Hounds-Farmers supported Hunting-So did the Gentry-No Game Preservers-Sir Robert Paul-Mr. CongreveLord Bessborongh-Mr. Ned Briscoe-Mr. Henry Bowers-Especial assistance given by the two latter gentlemen-Hunting establishment at Curraghmore-Horses-Stud Groom and Servants-The Kennels-Huntsman-Whips-Horses out each Hunting Day-Going to the Meet-Lord Waterford's Favourite Hunters-His Exploit over Ragdale Bottom-His Expenditure on Ifunting-Author's opinion of the Curraghmore Hounds-From 1859 to 18S1-His Lordship's Hunt Servants-Ourselves-A Neet at Guilcagh Cross-Small Meets-All the better for Sport-Author's Remarks and Opinions -Corroboration-Ladies Hunting-The Dowager Marchioness-Mrs. Dick Roberts and others-Numbers greatly increased-Those who went best-The Dowager Lady Waterford's Hunting-Her First Run-Grey Mist-Her wonderful Powers of EuduranceHer Riding - Her Pluck - Kens sana in corpore sano - Her Pilot - Her Favourite Hunters-Lord Waterford's Marriage-Lady Waterford's love of Hunting-Her Lady" ship as a Judge of Hounds-Her Riding-In the Field-Her Ladyship as "Master"Author's Opinion-Her Favourite Horses-Always went well-Duke of Counaught's Visit to Curraghmore-Good Sport-Osborne's Picture of Curraghmore Hunt-As a Work of Art-Presented to Lord Waterford-A Sad Memento-Those who Hunted with Lord Waterford-A Long List-More Names-Another List-An Indiscretion-Author goes in for it-Best Men of the Welter Weights-Best of the Middle-Best of the Light -Best of them all-Mr. Tom Lalor-Captain Slacke-Officers-Good men from Tipperary - Kilkenny-Limerick - Wexford - Some names given - Permanent visitors "Little Melton"-Great benefit to tradesmen, etc. - Will Kawle-A good servant and plucky fellow - Trophies "Nose Boards" at Curraghmore Kennels - Digging not resorted to-Exceptional cases-Good Runs-Shown by Lord Waterford-Autlor in some-Interest likely to be shown-Halcyon days-Rhapsody--Astonishing fact-No blank days-No hunting diary-Some dates not given-Other details correct-Particulars of Kuns-Several pages-Running $v$. Hunting a Fox-Fiue Hunting Run-Run in a suowstorm - Exploit of Mr. Ton Lalor and the Author-- The Flying Graces"Damsou pie"-Difference in Packs of Hounds-Lethargy of some-Dash of the Curraghmores-Breaking up their Fox-Good Sport-Princely maguificence-Scattered right and left-Happy relationships-None now remain-Painful duty-Ungarnished truth - Unpleasant manifestations - Ontrages-Newtown Wood-Ruffianly mob-Lord Waterford stoned-Hounds stabbed-Result-Meeting of Hunt called-Proceedings as recorded by Irish Sportsman of the day-Lord Waterford gives up Hunting from Curraghmore.

IT seems natural that the Lords of Curraghmore, always famous for their sporting proclivities, should be at the head of the foxhounds of the country, and, owing to the circumstances I have just related, it happened that the present Marquis, in the early part of 1870, took that place. When taken over from Mr. Briscoe, the pack consisted of about twenty-five or thirty couple of exceptionally well-bred hounds ; they were first-class in their work, and gave Lord Waterford a capital start. He had naturally a quick and accurate eye for a hound, and spared no expense in procuring the best and most suitable blood in England. His opportunities for getting good sires, owing to his large circle of hunting friends, were greater than usually fall to the lot of any Irish M.F.H., and, as the result showed, he, in a few years, got together a pack of nearly sixty couple of hounds, capable as regards appearance, quality, and work of holding their own with the 
best kennels in England. Moreover, in an incredibly short time his reputation as a judge was established.

As a judge of a horse and of the horses required for himself and his servants he was equally successful. For a man riding seventeen to eighteen stone it is no easy task to get hunters, no matter what his means may be ; but Lord Waterford began well, and in a few years had collected a stud of well-bred heavy-weight horses which could not be surpassed. Some of them were really marvels over the country. He never believed in what is usually termed "servants" horses." For a huntsman to show sport he considered the best horses were necessary, consequently his men were as well mounted as himself, the only difference being in the size of the animals, During the many years it was my privilege to hunt with him I can safely say I never saw a wrongly shaped or badly behaved horse come from his stable, and where all the good ones were found was frequently a puzzle to me as it was to many others.

Passionately devoted as Lord Waterford was to hunting, he did not, on assuming the command, fall into the error, committed by so many young Masters, of fancying he was, without serving any apprenticeship, at once competent for the duties of huntsman-he knew he should study and learn. He began by appointing John Duke his huntsman ; a very wise selection, for Duke knew the country, and had been tutored by that fine old sportsman, Henry Briscoe; he also had all the qualities necessary for a huntsman, was an excellent horseman and quick, and had a good voice.

During his heyday, which lasted many seasons, he hunted the hounds in tip-top style, and showed first-rate sport. I never saw a man who could stick to hounds in the way he did; wherever they went he followed. He had very good hands, and did not meddle with his horse beyond keeping him straight; but he had not that graceful seat which characterised the two Ryans.

Lord Waterford hunted three days a week for a couple of seasons, but finding the old country too circumscribed for that number, and wishing to add another day a week, he came to a further arrangement with the Kilkenny gentlemen by which they lent him all the southern portion of their country-most of which is known as the Ross country -in addition to the portion Briscoe hunted. The Tipperary Hunt, then presided over by that good and genial sportsman the late Mr. John Going, at the same time lent Lord Waterford their portion lying north of Owning village as far as the river Anner with Slieve-na-mon. mountain, and the river Suir as its other limit; this we called the Carrick country.

The addition of these two fine tracts to his already extensive area gave Lord Waterford plenty of room to hunt the four days a week he had so long wished for, and he lost no time in availing himself of the opportunity, for having already increased his pack up to some fifty couple, he had only to buy more horses for himself and his men. 
The Curraghmore country thus enlarged covered a very large area. Taking as the four corners, say, Thorney Bridge on the river Anner, the river Nore from a point nearest to Brownstown Wood, Dunmore East, and Clonea Castle near Dungarvan, we have a point-to-point measurement as follows :-

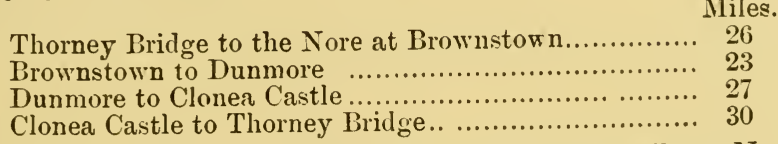

This gives an area of something like 725 square miles. Nor does. this survey take in adjacent outside parts, nor the undulation of the country, which necessarily adds considerably to the area.

Vast as was that extent of country it was all huntable, and Lord Waterford visited all parts fairly and with equal regularity. To enable him to do so, he had to establish out-stables at Mullinavat, where the horses were sent over night the days they hunted the far-off Ross country, the hounds being vanned to and fro on hunting days.

The country I have described was in all respects eminently suitable. for foxhunting. We had large tracts of woodland in Curraghmore, Baylough, Churchtown, Coolnamuck, and Gurteen, on the Waterford side of the Suir, with Bessborough, Carrig-a-tubrid, Dowling, Corbally, Owning, Kilcash, and, lastly, Newtown Wood, of disgraceful memory, on the Kilkenny and Tipperary side. These gave every facility for cubhunting, and afforded the tinest strongholds for foxes. Lord Waterford hunted the big woodlands on his by-days, which tended in no small degree to drive foxes to the surrounding gorses, few of which were ever drawn blank. Over the rest of the country there were, of course, numerous gorse and other coverts, but Lord Waterford had to plant several in addition, notably Weatherstown in the Ross district; Earlie's Gorse, between Carrick and Clonmelgiven by and called after that prince of good fellows and prime sportsman the late lamented Earl Clonmell-Ormonde's Gorse, situated between Snow Hill and Tory Hill, given by Lord Ormonde. Then in the county Waterford he planted Keily's Gorse in the Dunmore district, Lady Waterford's Gorse near Kilmacthomas, Carrig-a-nure between Ballyduff and Ballydurn, and the late Mr. Fred Malcomson planted Carrigeen near Gardenmorris.

Although he had this enormous territory, the love of foxhunting was so insatiable in Lord Waterford that, in addition, he actually took up the part west of Dungarvan which had been hitherto hunted by the late Earl of Huntingdon when he was Lord Hastings, but this accession not being satisfactory, he gave it up after hunting it and showing good sport there for a season or two.

The district known as the Ross country extended from Snow Hill, by Knockbrack, to Tullagher, round by the rivers Nore and Suir, and covered nearly (if not quite) seventy square miles. The Ross resembles the Ballydurn country, which is of much greater extent, 
and situated in the co. Waterford. These two were nearly all of grass, and old laid down; the fields are fairly, but not over, large, and are divided by big, sound, safe fences, every part of which is negotiable, allowing hounds to carry a head and race abreast over, while horses have equal likerty and the advantage of being able to keep on better terms with the hounds than if the fields were larger, fences smaller, and at times having but one or two jumpable places in them.

In my experience I never saw a country I would prefer to ride over to those of Ross and Ballydurn. Yes, over them we used to have the sport long ago! The foxes were plenty, stout and straight; the country wild and not over-peopled or cattled; and the coverts were far apart. The old grass land nearly always, particularly in the Ross country, carried a good scent; so with a pack like the Curraghmore, by Jove! it was not surprising we had sport the like of which was seldom equalled but never surpassed in any shire in England.

We had, however, some rough portions in the old country, notably along the Welch hills, and in parts of Pembrokestown and Knockaderry; but if they required a bit more careful riding and did at times knock up a horse, we could all the more appreciate the lovely open grass which we immediately got into after leaving those scrub-clad regions. Over these parts, by the way, hounds usually raced, the stunted bracken, furze, and heather rendering scent all the more powerful.

That about Mount Neil, which lies west of Kilmacow towards the river Suir, required, I think, more judicious riding to get over safely when hounds went hard than any other portion of Lord Waterford's country. The fences were very straight with narrow tops, and had no grips to guide a horse where to take off. Like all other parts it carried a capital scent. On the other hand, the Clonassey country, and all that lying along the incline to the Welch mountains as far as Carrigtruss, was enclosed with small single fences, mostly low walls, to get over which all one had to do with his horse was to "sit down in the saddle and keep his head straight."

The stiffest part in all Lord Waterford's region was that which lay between Lane-Fox's Covert (three miles from the city of Waterford) and the river Suir, round by Roanmore. It was, however, only of some six square miles area, but if a man was carried by a new purchase in safety over that little patch, he might place the most implicit confidence in him wherever else he went.

Taking the old Curraghmore country all in all, the good and the bad, I don't think there was a more sporting one to ride over in any part of the kingdom. We had every possible description of fence to negotiate except timber and water-the pastures were sound, and afforded the best of going ; there was very little plough, and when it was met with a hundred yards generally got us to its end; and if betimes we came to a portion of bog or otherwise awkward going it 
only afforded an opportunity for displaying the amount of "head" possessed by those who essayed to stick to the tail of the hounds.

I may here remark that Waterford and Kilkenny are proverbial for being scent-holding countries. In fact, I have heard men say, who hunted with many packs, that the Curraghmore country carried the best scent they ever experienced.

It has been said that the cry of hounds is the criterion of their pace, for as a rule they reduce their cry in accordance with the pace they go, and some run actually mute when going hard. Not so the old Curraghmore. Many a time has it been my good luck to see them for miles racing the line of their fox, but their warbling: music sounded and resounded in my ears, ay, when fields in their rear, and often was it my only guide to follow when that paragon pack had raced clean out of sight. A noisy hound was never kept, nor was one which when hunting did not throw his tongue.

They were also remarkable for their steadiness from riot. I have seen hares cross the line of their fox, and, although within fifty yards, not a hound would lift his head to them. It was the same in the deer parks of Curraghmore and Faithlegg, venison never tempted into riot those staunch and well-trained foxhounds.

We had some beautiful gorse coverts, and as they had been planted for generations, they had attained an appearance and grandeur absolutely natural. Could anything in the shape of a fox-covert surpass rugged Carrigtruss or charming Knockbrack, situated as both are-for they are there still-in the centre of a wild surrounding country? The then carefully tended gorse grew thick and close in parts, while ragged and stunted patches here and there permitted flashing views of Belvoir $\tan$ as hounds quickly passed the bare places to draw the thick. These two coverts were my especial favourites, for I could see the hounds work every bit of them, and the fox could always go away without being headed.

Ballydurn, Rathgormack, and Ballyneale were also lovely coverts, but did not afford the same facilities for seeing hounds draw as did Carrigtruss and Knockbrack.

In January, 1873, Duke got a very severe fall, which laid him up for the remainder of the season. Lord Waterford then requisitioned old Johnny Ryan, who had returned from America, to hunt temporarily one pack, while he himself hunted the other. The work was too hard for the old huntsman, and Duke, still suffering from the effects of his fall, was unable to resume the hunting in the following season. His lordship, therefore, took both packs in hand, and hunted them regularly four days a week all through the season 1874-75.

During the season 1875-76 the huntsman worked the bitch pack on Mondays and Thursdays, while the Master handled the dog pack on Tuesdays and Fridays, and this arrangement was continued through the following season of 1876-77.

Lord Waterford took up hunting both packs again in 1877-78, and 
continued till the end, Duke becoming kennel huntsman. His lordship showed very excellent sport during the seasons he carried his own horn, as is proven by the record further on, but, as I say, they are only very few indeed of the fine runs we had with him.

He always rode over seventeen stone, and for some years eighteen stone, but he was magnificently mounted, and his determined hard riding brought that disadvantage to a minimum. He was indeed "a rum one to follow and bad one to beat." He had the good sense to leave his hounds alone, and did not interfere with them by voice or horn until they had come completely to fault.

As I have already said, Mr. Joseph Strangman succeeded Mr. John Medlycott as hon. sec. to the Hunt in about the year 1862, and continued in office to the end of the annals of this great foxhunting era. No man could have discharged the duties of his onerous work with greater ability, tact, and energy than did $\mathbf{M r}$. Strangman, in recognition of which the gentlemen of the Hunt presented him with a valuable service of silver plate upon his marriage.

Besides being our hon. sec., he was for many years to be found at all the favourite meets, but when hounds had got away with a good scent on a straight fox, the usual place to find Strangman was close in their wake. Like many others, he did not hunt with the Curraghmore after his lordship was stopped at Newtown Wood in October, 1881.

The present Lord Waterford was, like his uncle and Mr. Briscoe, most fortunate in having all over his extensive territory a population imbued with true foxhunting proclivities. As in most counties, many of the gentry did not participate actively in the sport, but one and all preserved the foxes, and did their utmost to further the grand old sport; none more so than Mr. Congreve of Mount Congreve, Lord Bessborough, and Sir Robert Paul. There was not a single man in the country who reserved his coverts for shooting in preference to having them disturbed by the hounds drawing for a fox. The farmers all over the country were as aportloving as the gentry, and until they were demoralised by the evil teaching of the Land League no community furthered the sport of foxhunting more than did the peasantry residing over the Curraghmore hunting domain.

Lord Waterford had two able assistants in looking after his country in Kilkenny and Tipperary in Mr. Edward Briscoe of Harristown and Mr. Henry Bowers of Owning. Next to those immediately connected with the hounds we were indebted to those two gentlemen for a great deal of the sport we enjoyed for many years, owing to their knowledge and assiduity in looking after the foxes and coverts-not alone in the winter, but in the summer, when vixens and cubs require far more care and attention than they usually get. They were relatives of Mr. Briscoe, the M.F.H., and, no doubt, owe most of their education in foxlore to that able exponent. 
The hunting establishment at Curraghmore, in the venatic reign of the present Marquis, consisted, on an average, of thirteen hunters for his own riding. All were up to eighteen stone, full of quality, magnificent fencers, and able to carry him over any country to the tail of the hounds, and to stay with them, no matter how hard or far they ran. He had, as a rule, twenty-one for his huntsman and two whippers-in; while with those ridden by Lady Waterford, the carriage horses and young ones, eighty stalls in the Curraghmore stables were kept constantly occupied.

The stud-groom was Johnny Ryan (no relative, however, of the former huntsman), and he had under him between coachmen, second horsemen, and helpers about forty men directly connected with the stables. In the kennels were always from fifty to sixty couple of hounds, with Duke, two whippers-in, feeder, and assistant.

Lord Waterford hunted his country in regal fashion and at great expense, for no money was ever spared by him in doing a thing well if he did it at all. He had always two, sometimes three, horses out each day for his own riding. The huntsman and two whips had each two a day. In addition to these, Lady Waterford had her own two, and generally three or four more were sent for some of the visitors who might be short of mounts. Thus some fourteen or fifteen hunters were sent from Curraghmore every day his lordship hunted; not including, of course, the visitors' own horses. He usually drove the party to the meet in his coach and four, but many times extra traps had to be requisitioned. He always drove greys, the family colour. As with the hunters, the carriage horses and hacks were just the very best of their sort that money could buy or good judgment select.

Out of such a large stable of horses, where all were exceptionally good, it is difficult to name what might be considered the best, particularly when a period of eleven years has to be dealt with; but I should say the following were as near perfection as ever were horses capable of carrying eighteen stone to hounds:-Irishman, Arthur, Knockany, Heron, Mainspring, Callan, The Clown, a wonderful bay horse from Galway whose name I forget, Zinganee, and Poulaphouca. The latter horse, in January, 1885, jumped with Lord Waterford the Ragdale Bottom, in Leicestershire, covering twenty-six feet from where he took off to where he landed. Of course I remember a great many others which could gallop and stay under his lordship, but I forget their names.

A very short way would go the average cost of foxhunting a country in maintaining an establishment such as this.

As is shown in another chapter the annual cost is estimated at $£ 650$ for each day per week the hounds hunt. I am quite sure his hunting cost Lord Waterford $£ 1,000$ a day, and as he hunted regularly four days a week, with an occasional by-day, it would come to over $£ 4,000$ a year, and that exclusive of the expense of his own personal hunting and cost of horses for his own riding. 
I have seen a great many packs of foxhounds both in the field and on their flags, including some of those considered to be the best in England; but, without bias or partisanship, I must state that, as far as my humble opinion goes, I never saw the equal of the Curraghmore in a combination of breeding, shape, colour, and work.

As a great deal depended upon the young entry, of course some years the pack looked better than others, but taking the hounds, say, from when Mr. Briscoe got them in 1859 until the present Marquis sold them in 1881, I am quite safe in stating that there were few packs of foxhound, perhaps not one, which held so unbroken a record for breeding, shape, levelness, colour, work, and sport, as did the pack whose history I am striving to give.

Needless to say the Hunt servants were well turned out in the field, for a smarc Mlaster makes smart men. Our own hunting toggery was also improved even from what it was in Briscoe's time, for we got the real Melton cut from the residents and visitors at Curraghmore, substituting hats for caps, and we added thongs to our whips.

A meet say at Guilcagh Cross Roads, on a fine hunting day about Christmas time, when Curraghmore would be full of company, was indeed as perfect an exhibition of the sort as could be seen in any other part of the world. Of course, numerically, our meets were very small compared with some of those in the shires and other parts of England; as a rule sixty or eighty was about our number, but that was all the better for sport. A crowd, as everyone knows, increases the difficulties hounds and huntsmen have to contend with under the best of circumstances, while many a good man endeavouring to get away is blocked and shut out. Not so with us-everyone could have a fair start, and, except upon rare and exceptional occasions, it was his own or his horse's fault if a man did not get away and remain on good terms with the pack.

It may be considered that some of my remarks and opinions are extravagant, and that I am carried away by prejudice or inexperience; but to those who cavil at them I would only remark, ask anyone who has hunted regularly with the Curraghmore any time during the present Lord Waterford's Mastership, and who could ride a foxhunt, whether I am exaggerating or not.

The only lady I remember hunting in Henry Lord Waterford's time was Miss Smithwick of Kilkenny-now Mrs. Coghlan of Dromina-and she went beautifully; certainly none other rode to hounds then. In Briscoe's time, however, ladies began to come out, among the first being Mrs. Henry Lambert of Carnagh, co. Wexford, and her sister, Miss Williams, and these two ladies could show our best men the way across country, but none could do so better in later years than the Dowager Marchioness of Waterford, mother of the present Marquis, the late Mrs. Slacke, Mrs. Dick Roberts, Miss Nugent-Humble, and the late Ladies Selina and Louisa Hastings.

During the present Lord Waterford's time the number of ladies 
who patronised the Hunt greatly increased. Those hunting regularly and best over the country were the Marchioness of Waterford, the Dowager Marchioness, Mrs. Dick Roberts, Miss Humble, Mrs. Bookey of Clonmel, the late Mrs. Gandy, Miss Caroline Quin of Annerville, Mrs. Magee, Miss Power of Mount Richard, Miss Bloomtield, Mrs. Goff of Waterford. The Dowager Lady Waterford did not begin to ride across country for several years after she first came out with the hounds; but once she began she ever after went as straight as anyone, no matter how fast or how long the run might be. I saw her ladyship jump her first fence, which was not far from Wynne's Gorse, and from that to the end of a very good run into Castlemorres, she went in the first flight.

Her horses were, of course, perfect animals, and she knew well they could always go where any other horse went. She had wonderful pluck, and never required assistance. She, however, generally selected a good "lead" (Lord Waterford usually), but never anyone who was not in the very first flight. To her pilot Lady Waterford was never the least inconvenience, nor did he often know until after the run that he had been favoured with the distinction. The horses I think which carried her best were Luna, Red Herring, The Girl, Snuffy, Clear the Way; also her favourite grey The Mist, on which she rode her first hunt. She had the most wonderful powers of enduring fatigue $I$ ever saw in a woman. No day was too long for her, and no weather, except frost, kept her from hunting throughout the season. She has enjoyed a life-long continuance of good health, and never had even a headache. In the Dowager Marchioness we have indeed exemplified mens sana in corpore sano.

Lord Waterford married in 1874 Lady Blanche Somerset, only daughter of the Duke of Beaufort. With her ladyship's early training at Badminton it is easy to understand that her heart was in horses, hounds, and hunting. Not alone that, but she was an excellent judge of all three. No woman in the kingdom was a better judge of a foxhound, either of his points on the flags or of his work in the field, and few men could teach her. Her ladyship rode beautifully to hounds, and went as straight with the Curraghmore in her first season as she had previously done with the Badminton, although the former is very much more difficult to get over. She always took her own line, her sole pilot being the hounds. She knew every hound in the pack, and many times have I seen her turn them to Duke or to Lord Waterford when no whip was up to assist in the cast.

With due respect for her noble husband and for every other M.F.H. I hunted with, in all truth and without adulation I will say I never saw anyone manage a tield of foxhunters as well as did the present Marchioness of Waterford. Her ladyship understood hunting and the duties of M.F.H. a vast deal better than most of those who take that office, while of course a word or beckon from her had 
tenfold more influence upon the field than could any coming from a Master.

Her favourite horses were to be found, I think, among Anchor, Enid, Mrs. Riggs, and Zazelle, but I never saw her go much better upon one horse than another. She always went well.

In the early part of 1879 , and again in the winter following, H.R.H. the Duke of Connaught paid a visit to Lord and Lady Waterford at Curraghmore. During the next summer Mr. William Osborne, carrying out instructions received from Mr. Cranfield of Dublin, painted a meet at which the Duke of Connaught was present. It was in the Long Meadow part of Curraghmore Park, in front of the house on the mountain side, and he brought in portraits of most of the gentlemen who usually hunted with Lord Waterford.

The artist produced a very fine work; nearly all the likenesses are faithful, while he succeeded in grouping the lot without undue crowding and in their natural positions, and as Osborne is one of the best painters of a foxhound in the kingdom, the hounds form a remarkable feature in the picture, exceedingly good likenesses having been made of most of them.

Plates were struck off from the original painting and have been widely circulated, so there is no necessity for my further describing it.

The gentlemen of the Hunt purchased the picture from Mr. Cranfield and presented it to Lord Waterford in 1878. It has ever since hung in a conspicuous place in the principal hall at Curraghmore, and now presents a sad memento of what his great Hunt was in happier days.

From the "key" before me I give the names, in the order they there appear, as a list of those who usually hunted with Lord Waterford.

Frederick Power of Bellvue, Charles Gregory, Raymond de la Poer, Miss Bloomfield, Sir Robert Paul, Lord William Beresford, Nicholas A. Power of Bellvue, Richard Power of Tramore, William J. Paul, Harry R. Sargent, Harry Courtenay, F. G. Bloomfield, Mrs. Bookey, Earl of Bessborough, Patrick W. Power of Pembrokestown, Robert G. Paul, E. N. Power of Tramore, Dowager Marchioness of Waterford, Henry IV. Briscoe, L. G. Strangman, Lord Charles Beresford, Lord Marcus Beresford, Captain Slacke, Ambrose Lambert, Captain Cuffe, Captain Gandy, C. E. Denny, Wray B. Palliser, Earl of Donoughmore, Lord Delaval Beresford, Earl of Tyrone (a child on his donkey), Marchioness of Waterford, Marquis of Waterford, Joseph Strangman, Thomas Lalor, Captain Pennefather, Dr. O'Ryan, Joseph O'Neill Power of Snowhill, James Mandeville, John Bell, V.S., W. G. D. Goff, Samuel Perry, Patrick Walshe, Arnold de la Poer, Miss Villiers Stuart, Thomas W. Anderson, D. K. Cummins, John H. Power of Mount Richard, Octavian Mansfield, Benjamin Bunbury, John Pender, Mrs. Gandy, William B. Mulcahy, Surgeon-Major Keogh, with John Ryan (second horseman), John Duke (buntsman), Arthur Wilson (first whip), Henry Mathews (second whip), and of course the picture included H.R.H. the Duke of Connaught. 
The foregoing records the names of those who hunted regularly with Lord Waterford, but other gentlemen deserve to be chronicled, notably Ambrose Congreve of Mount Congreve, Edward Quin of Shanakill, Joseph Stephenson of Fairbrook, Captain Harry Dawson of Blenheim, John Medlycott of Rockett's Castle, Tatrick Mahon Power of Faithlegg, Henry Morris of Bell Lake, Thomas Hunt of Rockmount, Congreve Rogers of Tramore, John Maguire of Mount Congreve, sporting Tom Widger and his five hard-riding sons, all of co. Waterford. Phen in co. Kilkenny we had Dawson Milward of Tullagher, Thomas Spencer of Waterford, Pat. Henneberry of Ringville, John Jones of Mullinabrow, and his sons John, Willie, and Henry, Alec Anderson of Ballymountain, Edward Bowers of Clogga, Dan. Osborne of Silverspring, John Walshe of Fanningstown, David Coghlan of Cassawn, Pat Coghlan of South Lodge, the Quinlans of Manganstown, John Hyland of Ballyneale, as also the two gentlemen I have before alluded to, Henry Bowers and Ned Briscoe.

All the gentlemen whom I have in the last paragraph enumerated gave the most substantial support to our old Hunt. Some of them did not take active part in the field, but through their love of sport and by zealous preservation of foxes enabled others to do so. Mr. Osborne would have included the likeness of each in his picture, but they would neither give him a sitting nor send a photograph.

As a rule it is as indiscreet to refer in print to any man who may be considered better to hounds than his companions as it is to mention who had the best of certain runs. Men go out to hunt to enjoy themselves, and to ride according as it suits their individual tastes; it must, therefore, be very objectionable to some who may have gone a run well, and, at all events, to their own satisfaction, to see others cracked up in the papers because they went better. We have quite enough records of "competitive examination" without adding the hunting-field to the category. There are, however, exceptions to every rule, and, in the face of my foregoing statement, I shall name those who, in my opinion, were our best men.

Looking over the names of these gentlemen, some of whom I had the pleasure of meeting for many years in the hunting-field, and were dear friends of mine, and all of whom I have often seen going to hounds, I will say that among those riding fifteen stone and upwards none could touch the present Lord Waterford, or Wray Palliser, when the latter was in his heyday, which was in Lord Henry's and Mr Briscoe's time.

Among the middle-weight class riding about fourteen stone Sir Robert Paul was one of the best men to hounds in the third Lord Waterford's field, but he never hunted after Lady Paul's death in 1858. The late Henry Briscoe, Joseph Strangman, D. K. Cummins, Johnny Medlycott, and William Mulcahy were first-rate men to hounds, and were at all times able to keep the pace with the lightweights. 
Those riding under and up to, say, twelve stone we had: Lords Charles, William, and Marcus Beresford, Captain Slacke, Wm. J. Paul, Harry Courtenay, Robert and Charles Humble, the late Thomas Lalor, Samuel Perry, and Thomas W. Anderson, eleven men whom I would back to go to a pack of foxhounds against an equal number out of any other Hunt in the kingdom.

Good as those men undoubtedly were there are two whom I must select as being the best of all, and in naming the late Mr. Tom Lalor and the present Captain Slacke I don't think I can cause jealousy. And still narrowing the limit, I shall put Captain Slacke as the better man of the two, for he could go well on a strange and halftrained horse, while Mr. Lalor could not go on any except what he was accustomed to, and that was perfect and brilliant hunters, but when mounted on one of them even Slacke could seldom get before him.

I have alluded only to those gentlemen whose portraits are given in the Curraghmore picture, but we had many visitors, notably officers quartered at Cahir, Carrick, and Waterford, who invariably held their own with the Curraghmore, and among them I may chronicle Colonel Tate, then a captain in the 12th Lancers; Colonel Wardrop, when he was a captain in the 3 rd Dragoon Guards; Colonel Ward Bennett, then of the Inniskilling Dragoons ; that best of good fellows and deeply lamented, the late Capt. Clayton of the 9 th Lancers; Mr. Elmhirst of the Carabineers; Major Fred Amcotts of the 5th Dragoon Guards, and others. Then from co. Tipperary we had Captain Billie Quin, Hugh Baker, James Dobbyn, Willie Riall, George and Tom Gough, Godfrey Philips, and others. Co. Limerick sent us at times the Rev. William Gubbins and John Gubbins. From Kilkenny came Sir James Langrishe, the Smithwicks, Ralph Bunbury, Sir Richard Power, Major Connellan, Jerry Nolan, Colonel Izod, and many others when the meet was at their side of the Suir. Years ago strong contingents used to come from Wexford, William Glascott and his son "Jim," Maurice Knox, Henry Lambert, and Wat Breen. Latterly, however, few came from there except when the meet was in the Ross country, and then they were well represented by James Maconchy and the Deanes of Stokestown. All those visitors whom I have named were nailing good men to hounds.

Visitors rented quarters and stabling in Waterford, P.iltown, Portlaw, but principally in Carrick-on-Suir, which latter was quite a little Melton in the hunting season. From these gentlemen it is needless to say a great deal of lucrative employment was derived by the poorer classes, and a vast deal of money was expended amcng the car proprietors and tradespeople of the above towns.

The last first-whip I recollect at Curraghmore was that most excellent and thoroughly reliable servant, Will Rawle, whose father was Master of the Berkhamsted Staghounds for years. When 
Mr. Springfield was Master, Rawle hunted and showed good sport, but above all he proved himself to be a determined plucky fellow upon many ocrasions during that troublous time.

The trophies of foxhunting are by no means a reliable record of the sport shown by a pack of hounds, but there are still to be seen at the kennels of Curraghmore boards on which are nailed the noses of foxes killed during many seasons of the present Marquis's time. What the number is does not signify, but I will say that they were all killed in sportsmanlike style, for neither in the present Lord Waterford's time, nor in that of his uncle's or Mr. Briscoe's, was "digging" ever resorted to unless under most exceptional and thoroughly reasonable circumstances. When a fox had beaten the Curraghmore Hounds to ground, he was left to do so again. Needless to say a terrier was never seen in the ranks of that pack.

It will, I think, astonish not a few of my readers to hear that I cannot recall to mind our having more than three blank days during Briscoe's time, and I swear there were not six! The Curraghmore Hounds had only one blank day during the eleven years Lord Waterford was Master, and that was when he was not out, but it was so wet the hounds went home at one o'clock without drawing a covert where they would have been certain to find.

I shall now proceed to give short particulars of a few of the many great runs we had while the present Marquis was Master, the greater number of which were shown by himself while he carried his own horn and hunted his own hounds. Happy I am to add that I saw a good many of them, though not all. I venture to hope some interest will be taken in hearing of what was done within comparatively a few years, particularly as the account may probably be read by those who partook of the sport we had in the halcyon. days of Curraghmore and who can bear me out in stating that the few accounts of foxhunts which follow these remarks but poorly describe the average doings of the Curraghmore previous to the sport being stopped in 1881 . Yes the fine, ay brilliant, runs we had in those days can be counted by the dozen.

Like his uncle, the present Lord Waterford neglected to keep a diary of his hunting. This seems extraordinary, for, again like him, he is most particular in having accounts and records kept in minute detail. I kept one for a few years, but it recorded only the sport which took place on the days I was out, and unfortunately I did not keep it regularly, and discontinued it many years ago. From these facts I am unable, as I was with some of Briscoe's, to fix some of the dates, but the other details are critically correct.

We had a run in January, 18i1, from Knockbrack almost straight to Brownstown without a check, although the hounds ran through the little gorse of Busherstown, a point to point of some six miles, distance run fully eight miles, all grass and stiff fencing; time, forty minutes. 
No doubt this was a very brilliant gallop, and lacked only a kill in the open to classify it as a perfect foxhunt; but a well-known gentleman who was on a visit at Curraghmore at the time, and who for years had hunted as a rule five and six days a week with some of the crack packs of the English shires, told me the day after that he never saw so fine a foxhunt in his life, nor had he heard of its equal in England for a long time. And when I told him as a matter of fact that we had had two or three runs that season just as fine as the one under discussion, and that we expected to have even better before the end, I don't think he credited me, but he might have done so.

November 11, 1873 : Carrigeen, two miles straight for Knockaderry, to the right through Carrigphilip, Ballytobin, and Shanaclune to within half a mile of Dunhill Castle, then to the right through Ballynageera and Savagetown, across the Waterford and Kiln road at the old police barracks, and straight up to Carrigeen again, through the little gorse without a check and straight for Slievenamoona, the hounds running into their fox in the middle of the field next Rathanny covert. Distance by six-inch Ordnance map, eleven miles ; time, fifty-seven minutes. This good fox ran until he died, for he dropped dead before the hounds ran into him.

February 24, 1871 : Gardenmorris, through Carrigeen, by Carrigphilip bog, through Knockaderry and across what is now the middle of the reservoir, by Mr. Christmas' school-house, through Pembrokestown and Butlerstown, and killed in the open at Old Court. Eighteen miles ; one hour forty minutes. A point to point of nine miles.

It occurred to me at the time that I never before saw so many out of a small field ride so fairly all through as fine a run as this was. Tp to Butlerstown, within a mile of the finish, ten or twelve men continued well with the hounds, and at least six or seven saw the fox killed. A few days after I found an explanation of this. It was at that time a habit of mine, when I had the chance, to walk, as soon after as possible, the line of any exceptionally fine run that I might have ridden. Accordingly, I walked the one in question. Strange, but true, along it all I did not find a fence which could stop any man who had the slightest inclination to ride until I arrived at Butlerstown. After that I found some big ones, particularly after crossing the Dungarran road. Several men that day took for a time the "pride of place," but I don't think anyone held it as long as the late and deeply lamented Captain William Quin of Loughloher on his grey Chasseur d'Afrique, but the horse never recovered the effects. Father William Gubbins of Kilmallock also went well.

Soon after the Old Court run, we had one from Knockbrack to near Mullinahone, then a wide sweep towards Carrig-a-Nurragh, by Cat's liock, to the base of Tory Hill. Leaving it on the right, the fox went two miles as if for Clonassey, then wheeled down to near Dunkit. Here, I think, he lost his bearings, for although well ahead he never tried any of the many places he might have got to ground in about 
the quarries, but headed for Bishop's Hall, beside the ruins of which, in a grass field, he was pulled down. Sixteen miles; one hour thirty minutes. Miss Stubber (now Lady Stalbridge) went brilliantly through this fine but trying run. She was alone up at the kill, having fairly pounded the few then with the hounds at the big fence into Bishop's Hall. Ungallant, no doubt, but so chagrined did I feel at having been planted by a lady, I went off home without looking at the fox being broken up, although he was killed within twenty yards of me!

Perhaps the best run which the Curraghmore had in the present Marquis's time was that had on the 9 th December, 1873, when they met at Tullagher in the Ross country. Found in Brownstown, ran to Weatherstown, to within two fields of Knockbrack; on towards Tory Hill, leaving it on the right, to Cat's Rock. Here the fox was seen dead-beat, toiling up the side of that steep gorge, but he gained Galway's Covert, where he got safely to ground. Distance, twenty-two miles ; point to point, eleven miles ; time, two hours twenty minutes. The only men who rode this fine run from end to end were Lord Waterford on Irishman, Captain Slacke on Crocus, Duke on Quinine, and Mr. Arbuthnot, a visitor at Curraghmore, on a horse of Lord Waterford's called The Cure.

Not, perhaps, as fine as that just referred to, but a wonderful and magnificent run was had from Mount Neil to Tory Hill, when Lord Waterford carried the horn. Point to point the distance is eight miles; line run over, eleven to twelve miles; time, one hour and ten minutes. 'There was only one check. Tory Hill being so far a way from where a fox was likely to run that day the earths were not stopped, so he got to ground.

We had exceptionally good sport under circumstances very adverse as well as favourable.

Any hounds possessed of ordinary nose power, if they have fairly good shoulders and feet, can run a fox when there happens to be a good scent, but give me the pack of hounds that can hunt their fox upon a bad scenting day, and he a long way ahead, over an extent of rough and poor scenting country intersected by numerous cart-tracks and pathways along which the fox runs and suddenly turns or doubles out of, getting thereby still farther ahead, but by steady and determined hunting the pack sticks to its fox and accounts for him in sporting style after a long and arduous chase.

I think the finest exhibition of that class of hunting which I ever saw was towards the end of Briscoe's or begi nning of the presen Marquis's time, when the Curraghmore found their fox in Clonassey and hunted him without ever changing on to another along the line of the Welch mountains till they ran him to ground in a rock near Birchwood, running as they did over Listrolin, Milltown, and Garryduff Hills, and through the coverts of Carrig-a-tubrid, Corbally, Glenbower, Owning, and Birchwood. This was a splendid 
hunting run, but to be appreciated only by those who rode to hunt, for the country was rough and hilly, though the pace was fair. It was, however, rather too much of a good thing-about two hours and thirty minutes-and very distressing to the few horses that went it. Point to point over eight miles, hills and line making up fully sixteen miles.

Early in Briscoe's time, about Christmas, ' 61 , a fox took us from Carrigtruss as straight as he could go into Castlemorres, with a blazing scent and in the teeth of a snowstorm-about tive miles. I forget the time, but it was as fast a run as ever I saw. The snow began to fall just as the fox went away, but so heavy did it come down that the country was white when we got to the end of this short but splendid spin. Hounds could not hunt a yard after getting into Castlemorres woodlands.

Again I remember a curious, but very different, sort of run, which we had in, I think, 1869. Three hounds got away close to their fox out of Ballydurn, while the body of the pack was hunting in covert. Mr. Briscoe shouted to the late Mr. Tom Lalor and myself to stop them. This we manfully essayed to do, but to accomplish which we should have had to get to their heads. This, after going as hard as our horses could carry us for fully a mile, we found to be an utter impossibility, for they were simply racing. When we found we could not get to their heads, poor Lalor and I thought we might as well try to stick to their tails, so ding-dong we clapped after the flying Graces. They raced their fox to the fence of Duckett's Wood, but so pressed was he that he had to change his point, which was evidently Curraghmore, and wheeled sharp to the left, going through Whitestown, leaving Clonea Tillage to the right, and slap up to the foot of the Comera.ghs, where, not a hundred yards in front of these three matchless bitches, he got to ground under Crotty's Rock. The distance this couple and a half ran their fox was between seven and eight miles, and at a pace which I don't think could have been exceeded in speed by hounds, but I did not take the time. There was not the slightest hesitation, for they ran the whole time as if they were in view. These beauties were two fields ahead of Lalor for the last two miles, and I was a field behind him.

From our lofty position on the side of the mountain we could see the body of the pack and its followers hunting our line. When they came up to us in process of time, by Jove ! we caught it hot and heavy for having gone away with three hounds before the body had got up! I am very sure Lord Waterford remembers the incident well, for although he left the administration of "damson pie" to Briscoe, who was then Master, I have a notion his lordship would have liked to have added a little juice to the aftercourse, but he considerately restrained himself! That was all mighty fine, but I am very sure that there were not two men out, including both his lordship and Briscoe, who would not have done precisely what Lalor and I were abused for if they had been in our places that same day! 
We see at times a great difference in the way packs of foxhounds carry themselves and the dash they go with; not alone that, but there is often a marked difference in the way packs break up a fox.

I have seen some show lethargy even when apparently in good health and condition, and of a good scenting day; others when thrown into covert, particularly if it were of gorse, would not half draw it, hourds following each other in straggling order along the pathways; then, when the fox had gone away, they would run or hunt the line without that dash and fling which is so essential to the foxhound, many of the pack relying entirely upon a few of their fellows to do the work. I have also been up at a kill with certain packs, and was surprised at the want of fire shown at what should have been to them an exciting time, several hounds not caring whether they partook or not of the feast:

Not so the old Curraghmore during any time of its three Masters. Even on a bad scenting day, close and relaxing, they always evinced fire and dash as they jauntingly jogged along in their thoroughly-disciplined throng. No matter how thick, strong, or tangled a gorse covert might be, as soon as these hounds entered it they all spread, every one taking his own part. Then to see how this paragon pack would fling out of covert in a body, crashing as they did through or over the fence like the first rush of a mountain torrent. Along the line of their fox, possessed of equal pace, each hound strove for leadership, so that the head this pack almost invariably carried was the admiration of all who hunted with them. Perhaps the best time to see their courage and spirit was when they had pulled down their fox. The blood of the victim seemed to raise that of the hounds to such a pitch that to take the fox from them was a danger of the highest degree for anyone other than the Hunt servants. If, however, the carcase was not recovered within a minute or two, there would be nothing left for trophies beyond the mangled head. How they had accounted for their fux would, however, be seen clearly from every hound, for, with hackles up, each invariably took good care that he got his share of what he had so ably assisted in bringing to hand.

The greatest calamity that ever befel the Curraghmore Hunt was of course the death, in March, 1859, of Henry Lord Waterford; but the second, and happily only other, was that which I have now the unpleasant duty of recording, and I do so in plain ungarnished truth, so that it may be handed down to posterity.

During the season 1880-81 unpleasant manifestations began to bs shown in many ways against the hunting by certain sections of the farmers in different districts of the Hunt, and it soon became apparent that hunting would not be as pleasant in the near future as it had been for so long in the past. The season 1880-81, however, pulled 
through, but not without outrages more or less malignant. It was not until the following season was about to commence that matters reached the climax.

On the 6th October, 1881, while cubhunting in Newtown Wood, not far from Slievenamon Mountain, Lord Waterford, with his hounds, servants, and the few gentlemen, including the late Mr. Thomas Lalor, the owner of the covert, were attacked by a mob numbering over two hundred, and absolutely stoned out of it, while some of the hounds were run through with pitchforks.

The ruffians who composed this mob were not residents in the locality, nor had they any interest or claim to the land. They were all strangers, and came from afar; but they must have had accomplices among the local peasantry, for bells rang out in various quarters as Lord Waterford and his hounds were seen approaching, such being the means commonly adopted at the time in Ireland for summoning crowds for disorderly action.

This determined, cowardly, and atrocious outrage of course brought the consideration of future hunting in the Curraghmore country to an issue. Lord Waterford immediately called a meeting of the supporters of the Hunt, and it was held in the City of Waterford a few days afterwards.

At this meeting the late Earl of Bessborough presided, and to it Lord Waterford related what had occurred.

The Irish Sportsman had a special reporter present, and in its next issue that paper gave an exhaustive account of the proceedings. In years to come, as well as at present, that report will be interesting, and as the speeches were taken in shorthand there is no doubt as to their correctness. I shall therefore reproduce it to show hereafter how the evil advice of self-interested, self-elected, but well-paid, agitators stirred up our people to wage war against a nobleman who spent lavishly his money in the country, drove him from it, destroyed our sport, and ruined half the people in the neighbourhood.

In thus handing down to posterity this infamous record I wish it to be understood that I do so entirely from a sporting point of view and in no way political. If people have grievances they can have them adjusted by constitutional means in other places besides the hunting field.

LORD WATERFORD AND THE CURRAGHMORE HOUNDS STOPPED HUNTING!

Importaxt Meeting of Members of the Hunt.

From Irish Sportsinan of 15 th Octoler, 1881.

"In consequence of Lord Waterford and his field baving been stopped hunting at Newtown on the 6th inst., and of the outrage committed upon them, his lordship called a meeting of the members of 
the Hunt, which assembled at the Imperial Hotel, Waterford, on the 11th inst. It was largely attended by the gentry and nobility of the county and neighbourhood, a few of whose names we append, as also a detailed account of the proceedings, with a verbatim report of the speeches taken in shorthand by our special correspondent. Elsewhere we refer to the lamentable occurrence, but here we merely report the proceedings of this never-to-be-forgotten meeting. Among those who responded to his lordship's circular were [Here followed the names of nearly eighty gentlemen, representing, as they did, all creeds and politics, nearly all of whom have already been mentioned.-AUTHOR].

"Lord Bessborough having taken the chair, after being duly voted to it, the Secretary (Mr. J. Strangman) read several letters of apology from members and others expressing their regret for not being within reach of Waterford to attend the meeting in time.

"The Chairman said: My Lord Waterford and Gentlemen,-As it is your wish that I should take the chair, I do so with deep regret that it should be necessary, and with sorrow that such an event should have happened in this country as has led to this meeting being called by Lord Waterford. (Hear, hear.) I will say no more just now, but will give way to Lord Waterford, who will now address the meeting. (Applause.)

"Lord Waterford, who on rising was received with the most enthusiastic applause, said : My Lord Bessborough and Gentlemen,I have asked you to meet me here to-day to take into consideration the continuance of foxhunting in this country during the present winter. Up to this unfortunate year-a year which, I think, is the blackest that has ever passed over this unfortunate country-(hear, hear)-I believe that all Irishmen, irrespective of creed, class, politics, or anything else, were joined together and united on one subject at any rate, and that was the sport afforded therein by foxhunting. (Hear, hear.) I am sorry to say that, owing to the teachings. of the Land League, who have engendered such a terribly bad feeling in this country, certain branches have passed resolutions to put down foxhunting in this country, and have been able to carry out. this resolution in certain parts of the neighbourhood. On Thursday last we met at Newtown Wood on the property of my friend Mr. Lalor. We had a couple of hours' good hunting there; but after some time we heard the chapel bells begin to ring, horns were blown on the surrounding hills, and an assemblage of people collected. They gathered round the wood and made a tremendous noise by yelling and hooting. I was able to continue the hunt, however, for a short time, and then the crowd entered upon Mr. Lalor's property and pelted, not only myself, but, I am sorry to say, other gentlemen of the Hunt. (Shame.) Some of the hounds were seriously injured by stabs from pitchforks. I then thought it was better to blow the hounds out of covert, which I did, and went home. Along our way the fields were lined with people who hooted and pelted us, but at 
the same time kept us at a safe distance. We then proceeded home, and I thought it best to do so, as I perceived that hunting under such circumstances had become impossible. (Hear, hear.) I next considered it my duty to call this meeting, and to return to you the trust you placed in my hands, now over eleven years ago, of hunting this country. I have held the position of Master of the Hounds here during that time, and endeavoured to give you sport, and to keep up that splendid old sport of foxhunting in this neighbourhood. (Hear, hear, and applause.) I took it up shortly after the death of my father, and continued it till the death of our dear old friend Henry Briscoe, whose funeral we attended with so much sorrow yesterday, who had shown us such sport in this country; and, long after this generation has passed away, his name will be remembered and kept alive as that of a fine old Irish sportsman. (Hear, and applause.) It is a singularly curious thing that he should have passed away on the very day after the death-knell of his favourite sport that he loved so well had been sounded in the country. (Hear, hear.) Passing from that I will now say a word on what stares me plainly in the face, but which I must meet much against my will, and that is to give over hunting. I do so with deep regret and with strong reluctance, not, I assure you, so much on my own account as on account of the many poor people that will be thrown out of employment, and for the sake of those many and dear friends that have shared with me for so many years the pleasures of the chase, and from whom I have received so much kindness and support. For myself I feel it the more on account of the many ties it will sever, and also for the fact that it will put down the splendid old system that was so long maintained-the splendid old sport of foxhunting-in this part of the country; a sport which I may say has been the mainspring of social life amongst us. (Hear, hear.) I say this is my chief sorrow, because I consider that hunting would be, from the present state of the country, anything but pleasant occupation during this winter, and, so far as I can see, for some time to time; for it is impossible to carry on the sport of foxhunting except you be supported by the united efforts and consent of every class in the country. (Hear, hear)

"Gentlemen, I can only say I shall carry away with me many recollections of the happy meetings we have had, and in the words of the Kilkenny hunting song,

Good sport I have had,

Good fellows I've met.

(Applause.) I now beg to say that with regard to the hounds, I shall not be able to sell them till the spring of the year, and I shall be happy-if you think there will be any possibility of continuing the sport from time to time among yourselves-I shall be most happy to hand you over a pack of hounds, and give you every support in my power. I return you, again and again, my most sincere thanks for the kindness and support you have bestowed on me, and now beg to tender you my resignation. (Applause.) 
"Sir Robert Paul, Bart., then came forward amid applause to address the meeting. He said : My Lord Bessborough, my Lord Waterford, and Gentlemen,-I have got, I may say, a sad task to perform, and that is to propose this resolution: "That this meeting of the members of the Curraghmore Hunt, called together by the Marquis of Waterford, having heard the statement now made to them by his lordship, desire to express to him in the strongest manner their great sorrow at the unexpected and unhappy event described in his speech, and their indignation at the ungenerous and cowardly treatment to which he and his friends and his hounds have been subjected.' This, my lord, is the resolution which I have the sad task of proposing. On looking round upon this meeting the first feeling that strikes me is that there is no other object, no other business, no other matter of any kind whatever, that would bring together so many men of different lines of thought, so many men of different classes, as the object for which we are assembled. (Hear, hear.) If it were a meeting of landlords and their friends, we should have a few of that class. If it were a meeting of tenant farmers, we should have a number of that class. If it were a meeting of merchants, we should have a few of that class. But when it is the members and friends of a Hunt of which Lord Waterford was the Master, we find a gathering of men of different classes, creeds, and opinions, who on no other business could be found so numerous. (Hear, and applause.) My lord, I have always said that hunting, ufter all, was only an amusement, but, after all, it goes a great length. Hunting brings together people in the prime of life and in youth, people of different sets of principles, of different religions, of different lines of thought. They meet together, and feel for each other a mutual kindness and affection. (Hear, hear.) And although their old fathers may be at home taking different lines of politics and different sides on various subjects, their sons are brought together on the hunting field in that class of fellowship which will make them good friends and kindly neighbours. (Hear, and applause.) Now this is the sort of thing which has existed in this courtry for a long time. (Hear, hear.) I recollect, for I am an old member, although I have giren up the present pursuit, but I have it in my heart-(cheers)-I remember, my lord, your uncle, the late Henry Marquis of Waterford-(cheers)-when the hounds were given up to him by the gentlemen of the committee-(cheers)-and for nuany a long day he presided at the meetings of the Curraghmore Foxhounds. I have descendants of my own who feel as I do, but I do not look forward to them for the same happiness, the same pleasant times that I have enjoyed myself in connection with the chase. This is the first time, my lord, at which a general break up has become so very apparent. (Hear, hear.) And now, my lord, there is one phase of this matter which demands your very serious recognition. About this time twelvemonth-not much longer-this thing began with the 
sin of a most outrageous murder. From that time the system has gone on; outrage after outrage has been perpetrated, and I fear it is not even now culminated. This movement, in short, is most un-Irish and most contrary to the nature of every true Irishman. We know every man has his good nature and his bad nature, and we know that the promoters of this wicked agitation know the bad parts of men and they know their good ones too; but it is only the bad parts that this agitation is working upon and developing. (Hear, hear.) They know all their weaknesses and all their failings, and to make their weaknesses and their failings the more apparent is what they are trying to do. (Hear, hear.) They think it was a great victory for them to be able to draw out the minimum of their vice, to make them attack the poor unfortunate and unoffending hounds, and to make them insult the man who had done more good for them and shown more kindness towards them than any other in this country. (Applause.) We deeply regret, my lord, the decision to which you have come-(hear, hear)-but I for one must admit you have judged rightly. But so far as hunting is concerned, and much as I love the hunt, there is another consideration which we regret far more than the breaking up of it, and which will be far more lamented with a great number of men, and, my lord, I would appeal to you to consider that there is another and far greater honour, a far higher duty for you than even to be Master of the Curraghmore Hounds. Hitherto, as the representative of a noble house, and as Lord of Curraghmore, you have done your duty well-(hear, hear, and loud applause)-and I would not, for any insult of the kind that has been offered, for any obstruction such as this, or for two, or three, or four events of the kind, be driven from the grand position you have taken. (Applause.) Consider, my lord, that your being in Curraghmore and fulfilling your duty there as you have done, has been a great obstruction to the system of agrarian outrage that is now passing over the country. (Hear, hear.) My lord, it is to get you out of it that they have done all this. (Hear, hear.) I beg of you and again beg of you, not to do otherwise than remain where you are. (Loud applause.) Go to hunt where you like, but return sometimes to Curraghmore. (Hear, and applause.) To encourage those among whom you have always been recognised as the leader and mainstay of the Constitutional party with which you have been allied is your first duty. (Cheers.) I beg now to move this resolution.

"Mr. Bloomfield seconded the resolution. He denounced in strong terms the gross and cowardly insult that had been offered to Lord Waterford, and the attack which had been made on his hounds on Thursday last. Sir Robert Paul had well said it would be a triumph to the party to see the man who had been every man's neighbour and every man's best friend driven out of this country. He sincerely trusted, with Sir Robert Paul, that his lordship would not allow any such proceeding to drive him from the country. He had lived long 
among them and tried to do his duty well, and he had pleasure in being present to see this great and influential meeting, and to add his mite to the general expression of good feeling by seconding the resolution.

"The Chairman said in putting this resolution: I should like to say a few words. You are all aware I cannot make a speech or speak as a foxhunter; but I should say from my old recollection, and from my knowledge of foxhunting men, I should be exceedingly sorry to see it abolished in this county; and from the part I have taken in such sports in days gone by, I can fully understand and appreciate the feeling that has arisen, and will arise, toward those who have been the cause of, and those who have taken part in, this outrage. But I do not believe, I cannot believe, that the people of the country generally would like to see such a proceeding repeated as that which took place on Thursday last. (Hear, hear.) As to the political events which are going on in the country, I believe they had little to do with that outrage. I believe it must have been instigated by others who brought the men who took part in it from a distance to perpetrate the outrage. I do not think Lord Waterford is wrong in the course he has decided upon. After such an insult as was offered to him, I do not think he could continue to hunt this country, and therefore I think the members of the Hunt should accept his resignation. You are a body of hunting gentlemen, and you know what course to take, I think it would be a matter of deep regret to see the Hunt permanently broken up; but for one occasion the effect must be good instead of bad; it will open the eyes of the people to the loss that would ensue upon the abolition of foxhunting in the country. The farmer will feel it by the drop he will experience in prices, and the horse-breeder will feel it in his business. I have taken some part in hunting-a very small part-I have taken part in it in this way, I have gone to see the chase, and took up a stand at some point from which I could see a great deal of what was going on ; I have been among the crowds, and have heard nothing but good feeling towards the hunt and towards those that took part in it, and I think it strange that all this good feeling should have changed, and that it should have changed in a single year. (Hear, hear.) I do not think it is the people of this neighbourhood that have done all this ; but, if the people of the neighbourhood do not exert themseives to prevent it, it must be taken for granted that they are parties to it. (Hear, hear.) I shall now put the resolution.

"The resolution was carried amid acclamation.

"Mr. Lalor proposed the next resolution as follows: "That whilst submitting to the justice of Lord Waterford's decision as to the impossibility of carrying on at present the hunting of the country, this meeting sincerely trusts that his lordship will not in any other way sever his connection with their county, but will still continue at this crisis to reside at Curraghmore.' My lord, it is my painful duty 
to propose this second resolution, and I never got up to speak with greater regret than on the present occasion. (Hear, hear.) I remember how these hounds were handed over by the father of the present Lord Waterford to the present committee. (Hear.) He also handed over to us four hunters, a noble subscription, and the right to the use of all his coverts, and from that day to the present his noble son has done everything he could to promote the sport in the county. (Hear, and applause.) But, my lord, the sport itself was a small thing in comparison with the good feeling that these hounds promoted amongst all classes, all creeds, and men of all principles. (Hear, hear) No matter whether the partaker in the sport was a peasant or a peer, a Tory or a Radical, a Protestant or a Catholic, it was the sport of the many. If a man fell at a fence, it was never asked who he is or what he is, but every man galloped to raise him up and to enquire if he was hurt. Some men fear the Land League will follow this up. I regret exceedingly that all that we loved so much should in so short a time be broken through. It was an outrage I did not think possible. In this part of the country it was not thought possible that anything of the kind could occur. There was no cause whatever for it. (Hear, hear.) The hounds hunted in the wood. No man followed them over any field of any man who did not want his field trampled on. What annoyed me more than anything else was that I could not recognise any man in the crowd, that no people were there whom we knew. There was a few belonging to the neighbourhood, but they kept out of the way of people who would know them. But there was no doubt an outrage was committed on that day. I believe the people who committed it came from seven or eight miles distance. They knew they were not known, and hence they conducted themselves in a very outrageous manner. They did injure some of the hounds. Not alone that, but they threw stones. I don't believe they wanted to seriously hurt any man, but it was a demonstration that could not be mistaken, for it was indeed the death-knell of hunting in this country. Lord Waterford, like his uncle, has lived all his life in Curraghmore, he has spent his money here-(hear, hear)-he has offered to come to see us, to give us as fine a pack of hounds as are in the world, to give us a handsome subscription, and to encourage us in every way, if we can see our way to hunt the county. (Cheers.) But I speak for myself, and I think I may answer for every man in this room, that none of us will go out to hunt in this county without his lordship. (Great cheering, and "Certainly not.") I love sport as well as any man-(hear, hear)but I do say that I would rather never see a hunt again than to see it without him. (Applause.) Therefore I would say that we cannot accept his lordship's generous offer, and therefore beg leave to propose this resolution. But before I conclude I have to say one word, and I will say it. I do say that that demonstration on Thursday last was not personal to his lordship any more than to any other man in 
the field. (Hear, hear.) I do say the people of the county feel well towards Lord Waterford, and every man in this room should take the insult as much to himself as Lord Waterford. (Hear, hear.)

"Mr. A. Denny, in seconding the resolution, said he was somewhat out of place amongst a number of hunting gentlemen, but that was no matter. The question came to this, would Lord Waterford reside among us or not? It became a very serious question to every citizen and every country gentleman to take into his consideration. $\mathrm{He}$ heartily concurred in the resolution proposed by Mr. Lalor. No doubt Lord Waterford had formed a right resolution with regard to hunting, but he hoped he would not allow what had happened to drive him from his home, or from among his many fast friends. (Cheers.) They all deplored and denounced the conduct complained of, but he hoped it would not have the effect of driving his lordship from among us, and thereby weakening our small garrison that has stood so firm, and which he did so much to uphold and encourage in this country. (Applause)

"Mr. Wray Palliser proposed the third resolution, as follows: 'That this meeting also desires to express their cieep gratitude to Lord Waterford for having for the last eleven jears carried on the hur.ting of this country at his own, and a great expense, and for having during that time shown such excellent sport, and they hope that there will be soon again among all classes a good feeling both in their business and amusements.'

"Mr. Spencer seconded the resolution, which was passed with much enthusiasm.

"Lord Waterford said : My Lord Bessborough and Gentlemen,I have heard the three resolutions which have just been proposed and passed, and I thank you most sincerely for the way in which you have passed them, and to the gentlemen who spoke for the terms in which they have moved and seconded them. With regard to the last one, I must say it has ever been to me a source of the very greatest plea. sure to hunt this country, and I only wish we could continue to do so. With regard to the other two, I may say I have no intention that any organization whatever should drive me out of the country permanently. (Cheers.) I may go to England to hunt during the winter, but I mean to carry on Curraghmore much the same as it has been carried on hei'etofore. (Cheers.) I am determined too that I, for one, will not turn my back on the enemy; and I am quite certain that, along with you, gentlemen, we shall soon see better times dawn on this unfortunate country. With regard to one remark made by Lord Bessborough, that I had resigned the Hunt because I was insulted on Thursday last, that was a slight mistake on the part of my friend Lord Bessborough. I should not resign it on that account, or for many insults-I hold your interests and your pleasures too dearly at heart for that-but I resign because I feel convinced it could not be carried on. I recognised the significance of the organised mob 
that met lin Newtown Wood. I met that organised mob on the Friday before, which I believe was got up by a Land Leaguer at my gate (by name Peter Wall), but he spent his time in hiding himself behind a hedge. (Laughter.) My reason for giving up hunting this county is, that I find it impossible to carry it on. With regard to the remarks of Mr. Lalor, I hope you will consider your decision, and if it be possible to carry on the hunting you should consid rr not only yourselves, but your friends. You should look forward to the fact that thousands are interested in its being kept together, and that others who come after us will be served as well as ourselves, and should look forward to the fact that my son should have some sport in the county where he will reside. (Hear, hear.) I think you should get up subscriptions and keep up foxhunting in the county; and, no matter whether I am there or not, I can only repeat again my deep and sincere thanks to you for your great kindness to me on this and on every occasion. (Loud applause.)

"Sir Robert Paul, Bart., having been called to the second chair,

"Lord Waterford proposed a vote of thanks, in a speech of some length, to Mr. Josh. Strangman, D.L., the Secretary of the Curraghmore Hunt, who had acted in that capacity for twenty yenrs, and to Mr. Edward Briscoe and Mr. Henry Bowers for the great kindness and assistance he had uniformly experienced at their hands in looking after the country. To Mr. Harry Sargent's able management of the annual Hunt Steeplechase Lord Waterford also bore emphatic testimony.

"Mr. Medlycott seconded the resolution, which was passed amidst applause.

"Mr. Strangman thanked his lordship, and said he would rather act as Secretary for twenty years more than to see such an unhappy termination to his labours. He was only sorry the Hunt was not to continue.

"Mr. Henry Bowers and Mr. Briscoe briefly responded, as did also Mr. Sargent.

"A vote of thanks to the noble Chairman for attending and presiding concluded the proceedings.

"A private meeting of the Stewards of the Curraghmore Hunt Races was afterwards held, and it was decided not to hold the races next year."

The present Marquis of Waterford's Mastership thus ended at the beginning of the season 1881-82. By a curious coincidence, his reign of office was for just eleven years-the same period as that of his predecessor, Mr. Briscoe. 
Fodrth Section.-I'homas O. Springfield, Esq., Master, 1882-84. Concluding with additional matter and Opinions given by the Author.

Lord Waterford to Hunt in England-Hunted from Badminton-Curraghmore closedServants discharged-No Hunting-Bitch Pack retained-Dog Pack sold-Lord Lonsdale-- Another Hunt Meeting-What happened-Munificent offer by Lord WaterfordDifferent opinions-Sporting Speech by his Lordship-Result-Mr. Springfield chosen Master-Tinvane-Will Rawle-Kennett-The Curraghmore again a Subscription Pack -Lamentable contrast-Opposition resumed-Gaultier $v$. other places-MIr. Patrick Wall of Credan-His Father-Malignant Obstructionists-Worse and worse-Insults to Ladies-Hunt attacked-Armed mobs-On the Fences-Howling and yelling-Mobs charged-Fences taken-Cowardly gangs-Poisoning the Hounds-Contrast-Another curious fact-Lowest classes-Ballinaboola-Great escape of the Pack from total annihilation-Another Hunt Meeting-All further idea of Hunting relinquished-Hounds to be returned to Lord Waterford-Last day the Curraghmore Hounds drew a Covert-Mr. Springfield as Master-Will Rawle as Huntsman-His courage and determinationUnparalleled opposition-Banquet to Springfield-A sorrowful company-Sale of the Dog Pack-Full particulars-Ditto Bitch Pack-Remarks on both Packs-Table of Masters of the Curraghmore-Table of Huntsmen-Notable Whippers-in-Long Reference to.

Author makes further Reference-Lorl and Lady Waterford Hunting in England-Where they Hunted-Lord Waterford's accident-The House of Lords-Master of the Buckhounds-Authentic details of the accident-Its results-From beginning to present time-Lord Waterford and Racing-Curraghmore Hunt Steeplechases institutedBallydurn-Williamstown-Their duration-The Stakes-Modestv of the AuthorFirst Red Coat Race-An Event in it-The Greatest Event in the Annals of the Ieeting_-" The Brothers' Race"-Detailed Particulars-From Start to Finish-The Scene on the Course-John Ryan, Stud Groom-His Services-Lord Waterford a resident Irish nobleman-Paradoxical working-The Land League-Its greatest stumbling block -The Lords of WVaterfora and their Tenantry-Sedition-Agitation-Foxhunting, why assailed-Lord Waterford, why selected-Deplorable result-Particulars thereof-Establishing a Pack of Foxhounds v. Stud of Hunters-Author's long dialogue thereon-Few Thoroughbred Packs-Indifferently-bred Packs-They show sport-And should be supported-What we want is Sport-The Irish Tenant Farmers -Author's long acquaintance with-Love of sport home-spun in them-Demoralised solely by evil teaching-By the lowest scum of society-Gaultier a noble exampleMr. Patrick Wall again-" At the same time"-Why Author denounces the Land League in these pages-Land League brought Politics into the Hunting Field-Sport knows no politics - The curtain drops-Accuracy of dates and data vouched for by the Author-Those published by others incorrect-Personal and peculiar advantages of the Author-Feelings of Author while compiling this long History.

Immediately after the meeting just alluded to Lord Waterford made arrangements to hunt in England for the future. He and Lady Waterford remained at Curraghmore, and did not hunt until after Christmas, 1881; they then went to Badminton and finished the season with the Duke of Beaufort.

Of course Curraghmore was shut up, and the servants, with many: of the stablemen, were discharged.

The hounds did not hunt at all in the season 1881-82, after the atrocity in Newtown Wood.

Lord Waterford sold the dog pack immediately after the outrage, but cherishing a hope that perhaps the agitation against country gen l men which was rampant in Ireland at the time might quiet down, kept on the bitches, on the chance of hunting being resumed the following season. Lord Lonsdale was at that time Master of the 
North Pytchley, and Lord Waterford lent them to him for the remainder of the season, and first-rate sport they showed the Englishmen.

In the summer of 1882 a meeting was held in Waterford to consider the advisability of resuming hunting. At it everyone expressed the wish that Lord Waterford should remain at Curraghmore and continue as heretofore, but this his lordship steadfastly refused to do, but offered to lend the gentry his pack of bitches, which had been returned, and to give $£ 500$ a year towards the hunting if the gentry would undertake it.

There were different opinions expressed by those present as to resuming unless Lord Waterford partook in the sport as of old. Many said that they would not hunt in Waterford again as long as his lordship was prevented, but that they would subscribe to the Hunt for the sake of sport; others said they would neither hunt nor subscribe, as doing so meant disrespect to the nobleman who had so long and magnificently maintained the sport, and who had received disgraceful treatment; others were willing to try what could be done, at all events for a time.

Lord Waterford, in a fine sporting speech, impressed upon all present that it was his particular wish that another attempt to hunt should at all events be made, and that while he appreciated the fine feeling which actuated those present in their expressions regarding the resumption of the sport, he would personally wish to see the hunting go on, even though he would not partake in it.

After a very lengthened discussion it was finally agreed to begin hunting again, but this decision was arrived at only after Lord Waterford's emphatic request that the attempt should be made.

Mr. Thomas Springfield was chosen Master, it being deemed more politic to elect a gentleman unconnected with the country than one of long residence therein.

The stables and kennels at Tinvane were then put into repair, and the hounds and horses were moved thereto from Curraghmore.

Will Rawle, who had been first whip to Lord Waterford for some of the last seasons, was appointed huntsman, with Charles Kennett and Charles Fleming to whip in to him.

Thus did the Curraghmore again lapse into a subscription pack with "field-money." Their hunting days were reduced from four and five to two a week.

IIr. Springfield turned out his servants smartly, and mounted them well. His meets were, however, a lamentable contrast in point of numbers to those we were accustomed to in Lord Waterford's time. Those gentlemen who at the meeting expressed their determination never to hunt except with Lord Waterford adhered thereto, and nany others followed their example.

Directly hunting recommenced, so did opposition thereto manifest itself. 
To few parts except the Gaultier country could Mr. Springfield bring the hounds without experiencing unpleasantness of one sort or another, while to Rathgormack, Kilmacthomas, and Ballydurn he dared not go at all.

With the exception of Mr. Patrick Francis Wall of Credan, the farmers in Gaultier remained loyal to the sport all through. That man and his father, Mr. Peter Wall, who held a farm from Lord Taterford, just alongside Curraghmore demesne, were among the most malignant obstructionists in the country throughout these troublous times.

Things got worse and worse, and hunting with the Curraghmore became, from a service of sport and pleasure, that of difficulty and absolute danger.

Crowds numbering from fifty to two hundred would assemble at some of the meets, jeering, hooting, and insulting alike both ladies and gentlemen.

These scoundrels attacked our Hunt even upon the public road, and many times did so when the hounds were in the act of drawing coverts lelonging to Lord Waterford, the farms surrounding which were in the hands of men who had no oljection whatever to our riding over their land.

Ofttimes did the mob, each member of which was armed with stick, pitchfork, or other weapon, range themselves three and four deep on top of some wide bank adjoining the covert where hounds were drawing, and by howling, yelling, blowing horns, and every means in their power strive to prevent the sport being carried on.

On several occasions hounds got away with their fox, leaving the garrisoned rampart between them and the field, so that to follow we were obliged to charge and take the fence by storm. This was done many times, but when the cowardly rascals saw five or six men coming full gallop at them with clubbed crops, a gap in the ranks was precipitately opened and over we went, not, however, without, as a rule, being able to administer a "back cut" en passant.

Gentlemen returning singly or in small parties from hunting were often set upon by these gangs, and they had to fly or fight for their lives.

Strange to say, the opposition and obstruction was not experienced universally all over the country. Some coverts could be drawn quietly enough, to wit, Ballyneale, while, two miles off, Rathgormack and Kilmacthomas dare not be approached. Neither could Ballydurn be drawn, although it was Lord Waterford's own property.

Another curious fact remains, that the opposition to the hunting was not as a rule carried on by those farmers who owned the land surrounding the coverts, nor even by those whose land had to be ridden over in a run. It came principally from those of the very lowest class, and, generally speaking, the mobs were composed of parties living far away from the scene of their outrages. 
Although that was not the sort of amusement men went to hunt for, I don't think the gentlemen of the Curraghmore would have allowed these hirelings to stop their hunting if they had confined their outrages to themselves alone. This they did not do, but upon many occasions attempts were made to poison the hounds. Mr. Springfield was ever vigilant, and took measures to get information beforehand, so with the use of stratagems he was enabled, as a rule, to frustrate these base attempts. Several times, however, hounds picked up poisoned meat along the roads and in covert. Springfield and his men always came out well supplied with emetics; so directly a hound showed symptoms, one was given him on the spot. By this means many were saved, but from the effects of the poison they did not recover for months, and several lost all their hair.

The pack had a great escape one evening-Fiddown Bridge, a quarter of a mile in length, had strewn all along it poisoned meat. Hurrying out of a heavy storm which was raging, the hounds were trotted very fast across the bridge and had not time to get their heads down. Thus they escaped.

The most determined and serious attempt of all was made on the 25th of March, 1884, when the total annihilation of the pack was prevented only by the merest chance and another piece of good luck. Ballinaboola, a low-lying covert of about ten acres, had over 100 pieces of poisoned meat put into it when everyone knew it would be drawn. Mr. Springfield had actually brought the hounds to within a few fields on his way to draw it when he found the country so submerged in water owing to a heavy rainfall, that he changed his mind, and went off elsewhere. He became informed of the escape he had, and immediately laid the case before his Committee.

Accordingly a general meeting of the Hunt was called, and the outrage at Ballinaboola having been explained, it was there and then determined that no further attempts to hunt should be made, and that the hounds should be returned to Lord Waterford. For the Curraghmore gentlemen would not again risk the destruction of such a valuable rack, knowing that sooner or later the ruffianly object of its destruction would be attained, despite all measures of prevention.

Thus the 25th of March, 1884, was the last day a covert was drawn by the Curraghmore.

Mr. Thomas Springfield was a keen and ardent sportsman, and showed exceedingly good sport during his two seasons' Mastershipseasons unparalleled in the annals of foxhunting for difficulty and opposition. He strove manfully against all, and showed indomitable pluck throughout. Will Rawle did his work well, and showed equal courage and determination. He was always as foremost in charging the mobs of miscreants as he was in riding to his hounds.

The season 1882-83 was very bad for scent, and the weather was terribly broken, so, with the troubles caused by the Land League, Springfield's sport was not good. 
The season 1883-81 was an exceptionally brilliant one, and this despite all opposition. Scent was good, but the month of January was very wild, and upon two occasions Mr. Springfield was driven home by bad weather. In seventy-five days twenty-one and a half brace of foxes were killed and thirty brace run to ground, all accounted for in fair and sportsmanlike manner.

On the 8th February, 1884, was a run which takes its position among the best the Curraghmore ever had. It was from Coolnamuck, over that fine tract of country, leaving Mothel Village close on the right, straight to the Racecourse by the Carrick Gate, where the fox was headed. He then turned and ran back to Coolnamuck, and was killed in Mill Vale. Time, one hour, without the slightest check whatever. When taken from the hounds the fox was so stiff that Rawle set him on his legs, and he stood like a block of wood.

The Hunt entertained Mr. Springfield at dinner in Waterford soon after the hunting was given up. Lord Waterford presided, and although everything was supplied of the best, and the company was composed of the cheeriest fellows, who occasionally enlivened the proceedings with song and story, never was there a dinner where real enjoyment was less felt than at this, the last of our old Hunt.

The hounds having been returned to Lord Waterford, he sent them at once to England for safety preparatory to selling them.

The Curraghmore dog pack was brought to the hammer in Tattersall's yard at Rugby in November, 1881.

The entered hounds numbered twenty-five and a half couple, and were put up in lots of one couple, one and a half couple, and two couple, and fetched from $10 \mathrm{gs}$. to $150 \mathrm{gs}$. a lot; the amount totalling $755 \mathrm{gs}$. There were eighteen and a half couple of unentered puppies, which were put up in one and a half and two couple lots. One and a half couple were given to Lord Guilford by Lord TWaterford, and the remaining seventeen were knocked down at from $5 \mathrm{gs}$. to $30 \mathrm{gs}$. a lot, making $160 \mathrm{gs}$. for the unentered hounds, or a total of $915 \mathrm{gs}$. for the whole forty-four couple.

The highest price was obtained for lot 8, consisting of one and a half couple, which were knocked down to Mr. Russell, after a spirited competition, at 150gs. They were Samson, 5 years, by Lord Coventry's Rummager, by his Vampire, dam Speedy, by Milton Seaman, by Milton Forester; Villager, 3 years, by Gallant, by Bramham Dreadnought, by Mr. Chaplin's Damper, dam Vanquish, by Bramham Guider, by their Gamer; Regent, 2 years, by Milton Rifleman, by their Sultan, dam Redwing, by Lord Coventry's Rummager, by his Vampire.

The bitch pack was sold by auction also at liugby, and the sale took place on the 16th May, 1885. The entire pack, old and unentered, and a few dog puppies, was offered for sale in twenty-five lots of one and a half and two couple each ; they comprised thirtyeight and a half couple, and realised the sum of $90 \mathrm{tgs}$. One lotGraceful, by Milton Richmond; Rosebud, by Brocklesby Glider; and 
Wary, by Milton Messmate-before the hammer fell, reaclied $135 \mathrm{gs}$. The other lots ranged from $10 \mathrm{gs}$. to $70 \mathrm{gs}$. each.

\section{TABLE of the Two SALEs.}

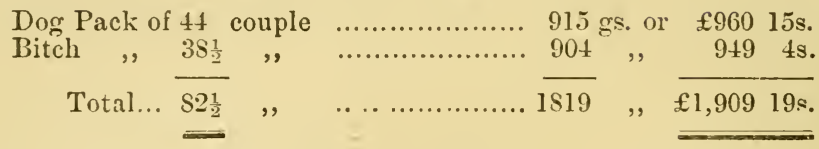

Thus were the famous Curraghmore hounds scattered all orerEngland just when they had attained the zenith of their fame and excellence. And through following the doctrines preached by the myrmidons of the Land League the evil-disposed portion of the people of Lord Waterford's country annihilated there, perhaps for ever, the noble sport of foxhunting!

No doubt above was a great price, and ranks, with few exceptions, alongside the highest foxhounds ever sold for; but it must be borne. in mind that these were two packs of perfectly pure-bred foxhounds, all well trained and excellent workers, not a faulty hound among. them, all level, and all of the Belvoir tan. I therefore do not think Lord Waterford's hounds fetched as much as they were worth.

It may be convenient here to hare a table of the names of those who hunted the Curraghmore hounds from their establishment in. 1844 till the Hunt was broken up exactly forty years afterwards.

Chronological Table of Masters of the Corraghmore Hunt.

\begin{tabular}{|c|c|c|}
\hline $\begin{array}{l}\text { Term of } \\
\text { Oflice. }\end{array}$ & Master. & Title of the Hunt. \\
\hline $1844-59$ & $\begin{array}{l}\text { Henry, third Marquis of Water- } \\
\text { ford. }\end{array}$ & Lord Waterford's Foxhounds. \\
\hline $\begin{array}{l}1559-70 . \\
1870-81\end{array}$ & $\begin{array}{l}\text { Henry Briscoe. } \\
\text { John Henry, fifth Marquis of } \\
\text { Waterford. }\end{array}$ & $\begin{array}{l}\text { The Curraghmore Hunt. } \\
\text { The Curraghmore. }\end{array}$ \\
\hline $\begin{array}{l}18 \$ 1-82 . \\
1882.84 .\end{array}$ & $\begin{array}{l}\text { No hunting. } \\
\text { Thomas Springfielu. }\end{array}$ & Dr. \\
\hline
\end{tabular}

Chronological Table of Hoxtsaren.

\begin{tabular}{|c|c|c|}
\hline Years. & Days a Week. & Huntsman. \\
\hline $\begin{array}{l}\text { 1844-64. } \\
1864-69 . \\
1869 \text { to Jan., } 1873 . \\
\text { Jan., } 1573, \text { to end } \\
\text { of Season. } \\
1873-74 . \\
1874-76 . \\
1576-77 . \\
1877-81 . \\
1881.82 . \\
1582-84 .\end{array}$ & 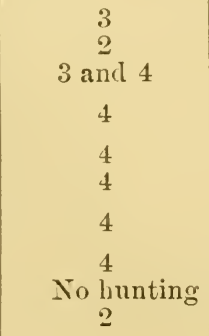 & $\begin{array}{l}\text { John Ryan. } \\
\text { Henry Briscoe. } \\
\text { John Duke. } \\
\text { Lord Waterford. Dog Pack. } \\
\text { John Pyan. Bitch Pack. } \\
\text { Lord Waterford. Both Packs. } \\
\text { John Duke. Do. } \\
\text { Lord Waterford. Dog Pack. } \\
\text { John Dnke. Bitch Pack. } \\
\text { Lord Waterford. Both Packs. } \\
\text { this season. } \\
\text { Will Piawle. }\end{array}$ \\
\hline
\end{tabular}


Of course there were many whippers-in whose names can't be remembered, but among the best who whipped in to Johnny Ryan, in the third Marquis's time, were Tom Clancey, Ned Bolger, Tom Ryan (father of Tom and William, the famous steeplechase jockeys in the "seventies" and "eighties"), and, lastly, Billy Barry, whom I remember well. He was a capital rider and cheery fellow, with a most magnificent musical voice, but he much preferred to be close to the body of the pack when running their fox, than to wait to get on tail hourds.

Dickey Cooney did second whip for a few years in Briscoe's time, and was very smart in his work, but he got too heavy. Duke, imported by Briscoe from England in 1860, was the best whipper-in I ever saw. He got tail hounds out of covert so quickly, generally without leaving one behind, that he had them clapped on to the body, directly at the first check, if he did not nick them in beforehand. A good whipper-in does not always make a good huntsman, but Duke was an exception - he was both. Dan Ryan, son of Johnny the huntsman, whipped-in during the last year or two of Briscoe's time. $\mathrm{He}$ and Billy Quinn whipped to Duke in the present Lord Waterford's first few years, and they were both exceptionally good men, Quinn promising, at one time, to graduate into an accomplished huntsman. Next to Duke I think Arthur Wilson was the best whip I ever saw with the Curraghmore. He was taken out of the stables on an emergency to fill the place of a whip who was summarily discharged. Wilson soon showed aptitude for the duties, and quickly rose from second to first whip, and, as such, served Lord Waterford for three seasons. He subsequently left Curraghmore, and, after being with the Fife, under Mr. Anstruther Thompson, and with the Belvoir, under Frank Gillard, he became huntsman to the York and Ainsty, and is now huntsman to the Atherstone. Will Rawle was the last first whip of the Curraghmore in the present Lord Waterford's time, and, from his ability, but more so from his staunch reliability, he was promoted to the horn when Mr. Springfield took the Mastership in 1882, and, as I have elsewhere shown, he acquitted himself well. He married one of the youngest of Mr. Henry Briscoe's daughters, and is now huntsman of Lord Fitzhardinge's pack, the Berkeley. Charles Kennett, Charles Fleming, and George Southwell whipped to Rawle in Springfield's time; the latter succeeded Fleming in the last season.

Thus we see what was the sport had with the old Curraghmore but a few years ago. Thus have I recorded the princely magnificence with which Lord Waterford hunted his country. Thus is shown what an amount of money was scattered right and left out of the pockets of the rich men into those of the poorer classes. Thus is recorded the happy - oh, how happy !-relationship which for generations existed among all classes in our peaceful sport-loving community.

All that state of things has been changed, and nothing now remains but its history! 
Having traced the record proper, I shall now make reference to erents and circumstances which, although not exactly a portion of it, relate directly to the Curraghmore Hunt.

After finishing the season 1881-82 with the Badminton, Lord and Lady Waterford for the succeeding three seasons hunted respectively in Lincolnshire, Cheshire, and Leicestershire.

For that of 1882-83 they rented Little Brocklesby, which is situated quite close to Lord Yarborough's kennels, and therefrom had hunting five and six days a week.

In Cheshire, for the season 1883-84, they hunted from Hampton, near Malpas, a capital centre from which they could get the North and South Cheshire, Sir Watkin Wynn's, and the North Staffordshire Hounds.

Next season they went to Leicestershire, to Quenby Hall, close to Billesden Coplow, a house, curiously enough, situated within two miles of Lowesby Hall, Sir Frederick Fowke's place, which was rented by Henry Lord Waterford when he hunted in Leicestershire in the "thirties." It was in the dining-room of Lowesby that he jumped a five-barred gate on Don Juan, in front of a blazing tire, for a wager, after dinner. The dining-room is still just as it was at the time of this exploit, and the actual gate is still kept in the coachhouse by Sir Frederick Fowke.

Towards the close of the season 1884-85, while hunting with the Cottesmore, Lord Waterford met with a most serious accident, the results of which have been melancholy and disastrous in the extreme. For orer seven years has that great foxhunter been prostrated, during most of which period he has suffered intense pain. This accident was the more unfortunate as he was making his mark in the House of Lords and fast rising in rank as a statesman. Enfeebled as he was, he has been able on many occasions during his illness to take active part in the debates, and in doing so he has always been permitted to address the House seated.

He is looked upon as a great authority on all Irish questions, and if it had not been for his accident he would certainly have held an important office in Lord Salisbury's Government. He was Master of the Buckhounds in 1885-86, but the cluties had to be performed by his brother, Lord Charles Beresford.

An account of this acciclent has not hitherto been laid before the public in full and true form. I shall therefore relate the circumstances minutely, which I am enabled to do, having been favoured by Lord Waterford with the particulars.

The Cottesmore hounds had found in Ouston Wood and got away with a good fox. Lord Waterford, on a horse he was trying belonging to Mr. Henry Chaplin, rather a hard puller, got a capital start. After going some distance a gateway appeared in front, the gate having been propped open with a forked stick. The hounds were running very hard at the time, and the pace of his lordship was proportional. 
He was riding for the gateway intending to gallop through, $b_{\mathbf{u}} t$ unfortunately, just as he came within fifteen or twenty yards of it, a frightened sheep hit the gate with its horns and knocked the prop away, and, beautifully hung as most Leicestershire gates are, it began at once to close. He knew that it was impossible to pull up within the distance, but, although the gate was too high to be jumped, he was in hopes that the tremendous pace at which he was going would have carried him bang through it. Unfortunately it did not close sufficiently quick, and it caught the horse on the shoulder in front of Lord Waterford's knee, shutting the horse in and sending him with his chest against the post with such force that, although as thick as a man's body, it was snapped off short at the ground. His lordship, to prevent his legs being broken against the pust, threw his feet out of the stirrups ; there was therefore nothing to lessen the force of the collision, which was simply tremendous. In addition, he caught his foot in the gate and was pulled off, but, strange to say, he did not at the time feel much hurt, and he was able to finish the run.

He rode back to Tilton, and that evening made a long speech at a political meeting for Lord John Manners, the present Duke of Rutland, who then represented that constituency. The fall took place upon a Tuesday. Lord Waterford hunted with the Belvoir on Wednesday, and with Sir Bache Cunard's Hounds on Thursday, and it was not until that evening, when returning from a very good day's sport, that he suddenly found his legs, from his waist down, had lost nearly all sensation. It was an exceedingly cold evening, so he believed he had got a chill, but he did not for a moment dream that his back was injured. He went out again upon Friday, with the Quorn and never rode better in his life. He had perfect power in his legs, but he had no sensation in them. On Saturday morning he saw his medical man, who arrived when his lordship was half dressed to go out hunting again. The doctor at once said that by reason of the terrific shock he had received three days before he had sustained seyere concussion of the spine and injured the sensory nerves of his spinal cord.

From that injury Lord Waterford has ever since suffered. He was six months confined to bed, and to the sofa for four years. During that long period he at frequent intervals suffered great pain, sometimes for a fortnight or three weeks together, and, in the early stage, much longer. The treatment which has done him most good is that of the actual cautery. This has been applied down the spine some thirty or forty times. In other words, thus often has he been fired with a red-hot iron exactly as a horse is.

Of late he has been making a gradual improvement, and he is now able to drive himself about and to walk at a time 300 or 400 yards; this, until now (the summer of 1892), he has never been able to do since he met with the accident. He now enjoys excellent health, and better still it is to know that a total recovery is looked forward to with confidence by his medical attendants. 
It is strange that with such an uncle and such brothers Lord Waterford never cared for racing, but on the contrary he hates it. However, in 18\% 0 , the first year of his Mastership, he instituted the Curraghmore Hunt Steeplechases, purely to give a day or two's. sport to the farmers of his hunting country. They were held at. Ballydurn for that and the next year. That fixture was, however, inconvenient, and a more suitable course was selected in 1872 , at. Williamstown, near the City of Waterford, and over it our annual. festival was held until the hunting was stopped.

The Stakes ranged from $£ 50$ to $£ 300$ and for some years the Meeting was a two days affair. As it was I who had the practical management under Lord Waterford's direction, it is not for me to. speak much of it, but its success and popularity a:e well known in history. Suffice it now to say that it afforded sport and amusement, while it caused annually a circulation of money in the City of Waterford and its neighbourhood of thousands upon thousands of pounds.

As I say in my chapter on Hunting, it was the Curraghmore that revived red-coat racing in Ireland, and it was on the 1st May, 1873 , we had our first scivey in pink between the flags at Williamstown. Oh, what sport it was! How well do I remember the brilliant way old Mainsail carried me over our beautiful natural course, and how he would have won, only for Captain Slacke on Crocus and Jimmy Dobbyn on J.P. going before us at the finish! The good old horse had the wrong man up that day, and no mistake.

This chapter and my allusion to the Curraghmore meetings would: indeed be incomplete were I to omit the particulars of a race which caused more interest in our county than ever did another before or since, and'which will be remembered during the existence of everyone who was alive at the time within fifty miles of Waterford.

This was "The Brothers' Race," and it took place on the 30th April, 1874, at the annual meeting of the Curraghmore Hunt Steeplechases.

Lords Charles, William, and Marcus Beresford had a sweepstakes of 100 sovs. each, p.p., three miles, over the Williamstown Course, twelve stone each, owners up. Lord Charles rode Nightwalker, a black thoroughbred horse, and bred by Billy Power, the sporting tenant of the course; Lord William rode Woodlark, a grey mare ; and Lord Marcus was on a bay gelding called The Weasel. They ea h wore the Beresford Blue, Lord Charles with the ancestral black cap, while the others had white and blue caps as distinguishing enblems.

No racecourse in Ireland, except Punchestown and Fairyhouse, ever had more people on it than Williamstown had on that, the most memorable day in its annals. Old men and women who had never before seen a race came fifty miles to see the Brothers' Race. Not a person, except the too aged and incapacitated, was in a farmhouse within ten miles of the course, while the city was as deserted as if plague-stricken-all, all flocked to Williamstown. Excitement rose to boiling pitch as the three brothers filed out of the enclosure and 
did the preliminary. I fancy now I see them jogging side by side to the starting post, where poor Tom Waters awaited them, ready with ensign in hand to send them on their journey. The only delay was while he delivered a short but sporting speech to these grand lads, when away they went, boot to boot. The pace was a cracker from the start, but none made the running more than another, for all three were girth to girth most of the journey, and at no time did two lengths divide the first and last till just before the finish. Yes, every post they made a winning-post ; and ding-dong did they go at each other, though, of course, riding like sportsmen. Fence after fence was charged and cleared by them locked together, and it was not till Nightwalker was beaten, just before the last fence, they separated. A determined struggle between Woodlark and The Weasel then ensued ; and, after a desperate finish, old Judge Hunter gave the verdict to the former "by a short head."

Never was seen a better race of its class, nor was any ever ridden more determinedly for victory. The scene of excitement on Williamstown Course during and after it beggars description. Not a mouth was shut or a voice lower than its highest pitch.

The Meeting held on the 5th May, 1881, ended the Curraghmore Hunt Steeplechases.

Among all his servants I don't suppose Lord Waterford ever had a better one than "Johnny Ryan the Jock." We had to designate him by that term to distinguish him from his namesake the huntsman. Ryan was steeplechase jockey and second horseman to the third Marquis, then he became groom to the fourth Marquis, and was afterwards for some years second horseman to the present Lord Waterford, and for the last five or six years of his lordship's hunting he held the onerous and responsible position of stud-groom. Whether it was over the Curraghmore country, in Leicester, Lincoln, or Chester shires, Johnny Ryan sent his horses to the meet so fit and well, that, with his own determined hard riding, Lord Waterford was always to the front, whether the run was fast, or long, or both. Yes, he was the very hest stud-groom his lordship ever had, and the fact of his being continuously in the service of the Curraghmore family for over half a century speaks volumes for his integrity. He was a very fine horseman, with one of the neatest seats I ever saw, and particularly good at teaching a young hunter his business.

Curraghmore, his hounds, horses, and hunting had such attractions for Lord Waterford that he spent nine or ten months out of the year in his ancestral abode, while the Marchioness preferred her home and its attendant pursuits and vocations to any place of pleasure she was ever in. As a consequence, Curraghmore was nearly always full of guests, so that upon hunting, employment of labour, and entertainment the Marquis expended a very large sum of money annually in the county during the time he was allowed to remain there.

By a somewhat paradoxical working out of a means by which an 
injury may be done personally to a man, the Land League has prevented his lordship spending that money annualiy for over ten years (in perpetuity, for that matter), with the result that he is now a richer man by a very considerable amount!

The greatest stumbling-block the Land League had in formulating its scheme for despoiling the landlords of Ireland was a good landlord, while, of course, their greatest stand-by was the bad. Now it is a matter of history, and we have only to go to the tenant farmers who held land under them to prove it, that the Poers and Beresfords of Curraghmore were always paragon landlords. Their land was let at a fair rent, which enabled the tenant to live and thrive out of it to such an extent that contentment supreme reigned over the Curraghmore estates down to the time the tenants got demoralised by the Land League. It is a fact that evictions were unknown there until, in 1881, demoralisation had taken such firm hold of the property that it became absolutely necessary for the landlord to assert his rights in a few cases.

With this state existing, there was the most cordial relationship between the various Lords of Curraghmore and their tenantry, and with no one of his predecessors was this more observable than with the present Marquis.

But sedition began to be sown all over Ireland in 1879, which, budding into agitation in 1880, and springing into full bloom in 1881, enabled the prime movers to decide who were first to be made examples of from their point of view.

Foxhunting, they knew, was one of the great attractions Irish country gentlemen had to their homes, and the object of the Land League being banishment of the landlords, they attacked that sport. They fixed upon Lord Waterford as the first victim, chiefly on account of his high social position in the country; secondly, because of his being a good landlord, and as such impeding their progress of spoliation; and thirdly, his was the premier pack of hounds in Ireland. It being maintained and hunted by himself, its disruption the Land League considered would most strongly exhibit the power of their organisation, and at the same time emphasise their malignity more than in the case of a subscription pack.

Yes, the Land League worked out their wicked will with a vengeance, but with what a deplorable result-not alone to the sport we all enjoyed, and which many of the very members of its branches often joined in and were always welcome to, but to the poorer classes, and to local traders generally!!

Furthermore, not one penny of rent was reduced thereby!!

Waterford, from being one of the most flourishing and social cities in Ireland, has since the time I allude to retrograded in the most deplorable degree.

There is no hunting and no estublishment at Curraghmore now; no racing at Williamstown; no visitors coming to the small towns, 
and none of the expenditure among the gentry which took place long ago consequent upon the hunting. What that monetary loss is to the Waterford community it is impossible to estimate, but I put it down some years ago, when the figures were fresh in my mind, at something like sixty thousand a year!

The races brought about an enormous circulation of money. Between $£ 2,000$ and $£ 3,000$ a year was disbursed by myself alone, and I was enabled to fix the amount paid in fares to carmen for driving visitors to and from the course at over $£ 200$ a day-the distance being a mile.

It is a great mistake to think that a pack of foxhounds, well bred and good workers, can be got together as easily as a stud of hunters. It takes a man a long lifetime to bring to perfection one pack, not to speak of two, if he has to start with drafts from ordinary kennels, and neither money, sagacity, nor assistance will hurry the process.

That fact should be borne in mind before any old-established pack of foxhounds is given up.

Although perhaps only in a suggestive manner pertaining to this chapter, I may be permitted to give a few reasons for what I have just stated, and show how difficult it is to get together a pack even of moderate pretensions, while it is a simple impossibility to get one like the Curraghmore except under circumstances similar to Lord Waterford's.

It may astonish not a few to know that out of the many packs of foxhounds which are in England and Ireland, the kennels from which an M.F.H. such as Lord Waterford or Henry Briscoe would breed could be counted almost upon a man's fingers.

No doubt many indifferently-bred packs show capital sport-even packs badly shaped and uneven do so oftentimes-and if a man wants to keep hounds it is a vast cleal better for him to have such than not to have any at all. If the packs which are indifferently bred and shaped were to be done away with in England it would, indeed, be a bad day for the nation.

Ingenuous youth, and all ye who aspire to have the decoration of "M.F.H." after your names, don't for one moment be carried away with the idea that, even possessed as you may be of a great command of money, you will get together a pack of foxhounds, even of the most ordinary excellence, in a hurry, and to suit the country you want them to hunt.

If a man wants to establish a pack of foxhounds where none have already been, he has of necessity to do so by purchase or by begging. By neither process will he get anything from another man's kennel except the refuse, for no man in his born senses would think of giving even his own brother the best, or even moderately, good hounds. Well, then, after expending a very considerable amount upon buying or otherwise getting together his pack-say forty couple-all entered, and from one to four years old, I am well within the mark when 
I state that there will not be found five couple out of the forty that will be reasonably satisfactory, and out of that five I am very sure there won't be one couple perfect as regards points, work, and breeding.

No, the only way to get a pack of foxhounds together with any degree of satisfaction and within a reasonable time is to buy one ready-made. But then, where is such to be found? and, if found, will the hounds suit the country they are required for?

Of course it is best to breed hounds as highly as opportunity offers, to train them properly, to draft carefully, so that the pack may be level and run together. But a badly-bred lot-unsteady, uneven in height, and unequal in pace-if they can run and hunt a fox, assuredly they have a right to be supported, and the man who keeps such in preference to keeping none deserves all praise. A scratch and badlymanaged pack will at times, if they have good luck, show better sport than the best bred and best managed pack in England will without good luck.

IIy readers will kindly observe that I have been dealing in this chapter with a pack of hounds which was of the highest class; and while I have described it with enthusiasm I am in no way prejudiced against packs which are not as fortunate as the Curraghmore was.

What we want is Sport, and we should strive to have it by any and all honourable means.

I have known the tenant-farmer classes over many parts of Ireland ever since I was a boy (particularly those residing in the hunting country of the Curraghmore), and I had, up to within the last few years, frequent opportunities of friendly intercourse with them while hunting, shooting, and fishing. With that experience it is with pleasure I record the fact that I never met a man in all my expeditions who ever expressed the slightest antipathy to hunting or any other branch of sport; on the contrary, one and all appeared to be innate sportsmen, inheriting the title from their forefathers, in what I may call "home-spun" fashion. I furthermore record as my firm conviction that our fine body of Irish peasantry would never have turned against foxhunting had they not been contaminated by the doctrines of the Land League, promulgated as those doctrines were by a few individuals here and there who by nature were ill-disposed to everything that was good, and who, through their own idleness and bad conduct, had lost any property they might ever have possessed. These derelicts of society, as is the case in all revolutions, seized the opportunity of agitation to create a rupture, knowing that nothing could make them worse off than they were while, perhaps, some change might make them a trifle better.

I am, therefore, quite confiaent that the opposition shown to hunting, not alone over Lord Waterford's country, but over all others where it appeared in Ireland, was the result of bad teaching, and enforced by coercion, but was never the spontaneous outcome of the farmers' feelings. It was therefore monstrous that those poor people should have been led astray and thus demoralised. 
In proof of what I state I again refer to the conduct pursued by the tenant-farmers residing in Gaultier. This was a large section of Lord Waterford's country, and therein he possessed an estate held by well-contented tenants, yet no obstruction whatever was given to hunting. The farmers therein were left to themselves, and were nut contaminated by Land League agents. Mr. Patrick Wall of Credan, to whom I referred before, was not a tenant of Lord Waterford, and although he strove to feed disaffection in that district, he miserably failed. Well would it have been for our country at large if the other tenant-farmers had acted like those of Gaultier.

At the same time I must state that as the opposition to our hunting was first instituted by only a few individuals, well known to be but the malcontents of the neighbourhood, the majority should have dealt summarily with them, and in the most forcible fashion shown them that the sport-loving community was not to be coerced into doing what was repugnant to their feelings. More especially was it their duty to have done so from the fact that to sustain the hunting and other sports was the only way they had of showing gratitude to the gentry from whom they had received great and substantial kindness, and that at times when such was much needed by many of them.

In denouncing as I have clone the Land League, I do so only as regards its action in molesting the prime sport of our nation. That body has as much right to its political opinions as I and others who differ from it toto celo. This is a free country, and every man may hold and support whatever principles he chooses-political, religious, or other-so long as he does not interfere with the privileges of his neighbour. Spert knows no politics, no religion, no party. The field of sport is open to all. The hunting card invites everyone, and to its meets everyone is welcome, no matter who or what he is. Nothing is required of him when he comes out to hunt, except that he will behave himself like a sportsman.

I. now bring my history of Lord Waterford's Hunt to its final close.

In laying before the public the Annals of the Four Masters, I do so with the assurance that all the details are absolutely correct. I might have alluded to other events, but being unable to do so with critical accuracy as to dates and details, I eliminated them altogether.

I have seen in print from time to time records of this Hunt, but many of the dates and some of the details are lamentably incorrect, This may be excusable in the compilers from the fact that they were not pussessed of the personal knowledge, with other peculiar advantages and facilities which I have had.

In the compilation I derived pleasure, tempered at times by sad recollections of the periods ending with the "seventies"-while dealing with later years sorrowful alone have been my feelings. 


\section{CHAPTER II.}

\section{HUNTING.}

Times Changed-Opposition to Hunting in Ireland-Farmers' Sufferance-Mufti v. Foxhunting Uniform-M.F.H.'s and Colonels of Regiments' Duty thereon-Horses and Fodder 'from, Stallions for, the Farmers-Damage Claims-Puppy Show, Dinner, and Dance-Men hunt to enjoy themselves-Masters too hard at times-M.F.H.'s Memorandum to his Field-Hunt Sec.'s Memo. : Rate of Subscriptions-Few come out to hunt-Master's boiler bursts-Good Books on Hunting-Decrease in Irish, Increase in English, Hunting-Galloping Snobs-Farmers' Forbearance-Red-coat Races-Curraghnore Hurt Red-coat Race-Result of Red-coat Races in Ireland-Loss to WaterfordWestmeath and Co. Down Red-coat Races-North of Ireland Sportsmen-Ward Hunt Lawyers-Mr. Nathaniel Morton-Mr. Hanway's System of Training Horses-Longshanked Spurs-Late Mr. William Quin's Idea-Lord Marcus Beresford and his SpursHarrieıs as a School for Venery-All can hunt who wish it-Author's Egotistical Anecdotes-Ugly Visions-Advice.

LET it not be imagined I am about to enter into the details of the science of hunting, either generally or in particular, for if I did, perhaps I should be found lamentably ignorant of the glorious subject. I shall merely state my notions of how the finest sport under the sun might be made even more universally popular than it is-how to perpetuate the sport, and, in a special chapter, as its importance deserves, will show what national superiority hunting has over every other institution of the kingdom excepting religion and education.

Tempora mutantur nos et mutamur in illis. But though times have changed since I hunted, time has not changed my love of hunting (or for any kind of sport, for that matter), and although I can no longer participate in its enjoyment, I feel as deep an interest in it now as I did years ago, when that interest was second to few men's in the world.

Deprive him of horses and hounds if you will, A foxhunter once is a foxhunter still.

With these egotistical remarks by way of excuse I shall strive to deal with our national pastime. In cloing so $I$ fear I can add little or nothing to what has already been written scores of times by far abler pens than mine, but as these essays came from, of course, the best authorities in the world, I can do no harm if I repeat some of them, while giving ideas of my own, particularly in times like the present, when new ideas are being put forth everywhere, and when "change and decay in [nearly] all around I see."

The lesson we have learned in Ireland during the past few years should show us how easy it is to put an end to hunting, and stimulate us all the more to popularise and sustain it. This is my reason for making the remarks I do in this chapter. Every true Irishman is a sportsman, and it would be as difficult for him to change his love for 
hunting as it would be for woman to change her love for her firstborn. The opposition shown to hunting in Ireland during the past few years was the result of bad advice, but was never the spontaneous outcome of the farmers' feelings; and I have reason to know that it is the general, almost universal, regret of every farmer residing in places where it was stopped that the sport was ever interfered with.

Thus far rhapsody, now for reason. There is no concealing the fact that hunting can be carried on only under sufferance from the farmers ; and when we consider the amount of damage and inconvenience sustained by them, through the following of the king of sports, every consideration should be shown them, and everything possible done to compensate them; not necessarily altogether with money, for there are other and, in many instances, far more effective means. This, I fear, is not at all times nor in all hunts done as much as it should be, nor is the noble sport popularised in the eyes of the non-hunting community to the extent it might be.

I think it is a grave mistake for men to hunt in mufti. Nothing tended more in old times to make hunting popular than the sight of a red coat and well turned-out breeches and top-boots. The labourer in the field, the housemaid at the window, the schoolboy at his desk, the child with his toys, and everyone else, looked up from their work to see a man so equipped pass by. Is it to be supposed that a man clad in a drab covert coat with tweed breeches and leggings commands the same curiosity or admiration? No, indeed, he does not, and, of course, the pursuit he is following suffers accordingly in estimation. It is all very well for a certain class to affect nonchalance, and to say they can, as no doubt they do, ride as hard and as straight in the garb of a groom as they could in the orthodox uniform worn by their fathers; but there is a very prodigious and highly important class of the community who would come out to hunt if they could sport the bright colours, without which, the immortal Jorrocks says, there would not be many foxhunters (speaking, of course, of tifty years ago). These men like to be in the fashion, but seeing that mufti is adopted for the hunting-field, they stay at home, not having in them as deep-seated a love of the sport as the leaders of the fashion.

It is decidedly my firm conviction that it is the duty of all Masters of Foxhounds to intimate to those who hunt with them that they should adopt the uniform of a foxhunter. Furthermore, colonels of regiments should enforce the same upon their officers. Why is the uniform of a soldier made so showingly becoming? Simply to popularise the service of arms. The red coat of the foxhunter has precisely the same effect upon foxhunting.

Masters of Hounds, and those who hunt with them, should make it a general rule to buy their horses and the requisite fodder, etc., direct from the farmer, in preference to buying them from dealers; yes, and pay even more for them.

Thoroughbred stallions should be kept in all hunting countries for 
the free service of mares belonging to the farmers of the district those most likely to beget weight-carrying hunters, of course, being selected. Let the gentry pay if they use them, but let the farmers have their service gratis.

Compensation for the loss of poultry and damage done to crops and fences is, we all know, requisite; but it is seldom meted out sufficiently nor with the promptitude advisable. Bis dat qui cito dat. The money, too, should be sent to the recipients, instead of requiring them to come for it, at further cost, inconvenience, and loss of time. Of this many Hunts are neglectful.

Great imposition, however, at times is practised by claimants for compensation, and, no matter what vigilance may be used, equal distribution cannot at all times be made. It has been suggested by experienced authorities upon the subject that if claims were leftmore to the farmers themselves for settlement they would be the more readily adjusted, and at less expense to the Hunt, but on this I offer no opinion. No doubt it would work well among the higher class and best-off, but it might not work so well among the poorer and less fastidious as to the rights of meum and tuum. However, be that as it may, there is no duty of a Hunt so difficult, troublesome, and unpleasant as adjusting "damage claims"; it should therefore be left to the committee, and not imposed on the Master.

I think a great deal could be avoided if M.F.H.'s were to have an annual puppy show just before cubhunting. To it should be invited the heads of each family of farmers within the limits of the country hunted over by the pack. The puppies lately in from walk should be judged by competent parties unconnected with the country, and prizes given for the three best dogs and three best bitches. After the adjudication, all should be invited to a good, substantial dinner presided over by the Master, and supported by some of the leading and most popular members of the Hunt. To it should also be invited the Hunt servants, as well as the ganekeepers and earthstoppers of the country. In the evening the female members of the farmers' families, with their brothers, should be invited to a dance, winding up with a supper to all.

No doubt this would cost a considerable sum of money, but I am convinced a good deal of it would be got back by many claims for poultry and damages being either waived altogether or more easily dealt with. Beyond doubt, however, such an entertainment annually would popularise the Hunt among the peasantry and farmers in a manner no other means could excel. It has been a habit with several Hunts in England for years, and Mr. Burke has instituted the practice into the Tipperary country. Others, both in Ireland and England, should follow the example.

Damage done to the fences and property of small farmers should be repaired, as soon and as often as it occurs, by a staff of labourers under a trustworthy overseer employed by the Hunt specially for 
the purpose. It is always better thus to remove causes of complaint than to wait until complaints are made. At the same time, wherever existing systems work harmoniously, by no manner of means should they be changed.

Wire-that ogre of the foxhunter-will have to be dealt with, and in my opinion the only effectual way is to come to an arrangement with the farmers by which the gentlemen, at their own expense, will be permitted in the autumn to take down every strand of the villainous impediment, substitute wooden paling during the winter, and replace the wire in the spring.

What is required, if we want to perpetuate hunting, is to prevent friction with the farmers; and that can always be done best by courteous off-handedness on the part of those adjusting claims, who, if they are popular and have tact, can accomplish their ends with satisfaction to all parties.

The days for haughty overbearance are over, and different tactics from the past must be adopted in the future both as regards hunting and everything else. There is no use talking of the expense. If foxhunting is to be had it must be paid for, and as the late Mr. Sam Reynell used to say long ago, "foxhunting can only be sustained upon the sufferance of the farmers."

Men go out to hunt to enjoy themselves according to their own ideas of enjoyment, and as long as they do not interfere with the sport of the day, or do unnecessary damage, they should be allowed to enjoy themselves in their own fashion, whether they be swells or sweeps, peers or peasants. There are times, however, when Masters of Hounds are too hard upon some of their field, and blame them for doing things which, from his point of view, are very bad, but which have been very often, nearly always, done through ignorance.

Not long ago I saw recorded what struck me as an excellent idea; it was this:-Let the Master have printed instructions and requests as to hunting circulated through his country, to be hung up in hotels, livery stables, \&c., so that all who go out with his hounds may have a rudimentary idea at all events of what was expected and the reason why. Now as these pages will circulate among men who hunt, some of whom may be a bit verdant as regards venatic law and principles, no matter how ardent their love may be for the sport, I venture to compile a notification such as I allude to, and, to employ some of the amusing phraseology of dear old Jorrocks, "if by so doing I shall spread the great light of sporting knowledge among ingenuous youth, then will this day henceforth remain red-lettered in the mental calendar of my existence!"

"The Hon. Horner Hunter, M.F.H., with best compliments of the season, invites the attention of all who hunt with the Gorse Covert Foxhounds to the following memoranda, which he has drawn up for their guidance and instruction, and without their observance of hich he cannot succeed in showing them the sport he is desirous of doing.

"Huntsman's Hall, Christmas, 1893." 
1. Utmost civility and courtesy to farmers are particularly enjoined upon all occasions.

2. Horses and all their requirements for food should be bought from the farmers whenever practicable, instead of from the dealers, even if at a higher price.

3. Exceptional damage done while hunting, no matter how unintentional, (1) assistance rendered by the farming or labouring class, should be promptly and liberally paid for.

4. Do not ride over new grass, or seeds, or jump fences unnecessarily. Headlands are always the soundest going, and generally nearest the line of the fox, while the corners of the fields have often the easiest fencing, except where there happens to be a cattle pond.

5. Gentlemen are requested to come out in scarlet or black coats, with orthodox breeches and top-boots, and not in drab coats, breeches and leggings. The former is the uniform of a foxhunter, and what has materially aided in making the pursuit the most popular of all British sports, while the substitution of the latter is certain to injure it.

6. Meets are arranged by the Master for the general convenience of the members and the hunting of the country; it is therefore expected that the meets will be the rendezvous, and that no one, for his own individual convenience, will go to coverts which are likely to be drawn first. Such a practice attracts foot-people, creates noise, and results in foxes being disturbed, whereby good runs are often lost. If it be persisted in, the Master will drave elsewhere when he finds it has taken place.

7. There is ample time for gossiping on the road to and from huniing, at the meet, and going from covert to covert, but directly the hounds approach a covert, and until the run is over, nothing should occupy a sportsman's attention but the sport in which he is engaged, and that generally requires all his "doing" and never requires his talking.

8. While the covert is being drawn the field should stay together, in whatever position pointed out by the Master, and should avoid moving about, as well as talking.

9. When a fox goes away, do not make the least noise till he has gone so far as you can in the time "count twenty" (as Mr. Jorrocks tells us). Then gallop to where he has broken, and give a loud, clear "Gone away." This instruction is particularly for young foxhunters (though many an old one transgresses on such occasions), for they imagine that whenever they see a fox they should shout; just as the young Irishman of fifty years ago, going to his first fair, following his father's advice, should, wherever he saw a head, hit it! A fox is essentially a nervous, stealthy, crafty animal, and likes to get away unknown and unseen, and if he thinks he has done so he will gain courage and go away; but if he knows he is seen, he loses heart, and in all probability turns back to covert, and the run is spoiled.

10. Apropos to the last paragraph, if you happen to be close to where a fox is breaking covert or crossing a ride in covert, do not stir a muscle of your body; and if you are to leeward of him, ten to one he will not mind you if you are not unduly exposed to view, or, if he thinks you do not see him, he will go his way; but the least motion will attract his keen and always ready eye, or, if you are to windward of him, his equally sensitive nose will betray your presence, and back he goes. 
11. Bear in mind that when it is necessary for you to halloa a fox away you should do so from the spot he broke covert, and whenever you have to tally one in or out of covert, do so from where he was when you last suw him. The huntsman then brings his hounds to the right place without delay, whereas, if you shout from where you were stancling ot the timeperhaps half a mile away-an obvious and at times most disastrous delay is occasioned. It is to the fox and not to you the hounds are to be brought.

12. If more than one fox is afoot, do not tally or halloa any but the hunted one, and, if you are not perfectly certcin, do not shout at all, more particularly after the fox has been hunted for some time. Nothing is more baneful to hunting than changing from the hunted to a fresh fox.

13. Let hounds get well away with their fox from covert and settle to the scent before you follow them. If the scent be bad, do not go within a hundred yards of them; they need all the room they can get to work the line out, and they cannot get away from you. When scent is gool and they are racing on good terms with their fox over a good line and his point several miles distant, then

\footnotetext{
If your horse be well bred and in blooming condition, Both up to the country and up to your weight, $\mathrm{Oh}$, then give the reins to your youthful ambition, Sit down in your saddle and keep his head straight!
}

Remember also that there is a vast difference betwe $n$ hounds getting well a say with a fox and getting away well with him.

14. Do not interfere with hoünds at a check, unless requested to do so by the Master or huntsman. If asked to turn a hound, get beyond him, so as to get him between you and the huntsman, before you try to do so. Never gallop after him till you liave got beyond him, or he will gallop away from you.

15. Do not crowd a huntsman when he is making a cast or interfere with him by making suggestions; doing so, unless you have actually seen the fox, distracts his attention from what he is much better able to form an opinion on than you are, gets the hounds' heads up, and the smell of your horse's sweat spoils the scent.

16. Do not hurry hounds running along a lane. A fox likes running a lonesone lane, but often makes a sharp turn out of it, and of course hounds, if pressed, will overrun the scent, and a good run is often spoiled thereby.

17. Do not jump into a road unless hounds have carried the scent up, down, or across it, or until they have done so. Foxes often resort to dodges when they come to a road, and hounds then must be left to themselves, more almost than when in any other difficulty.

18. Do not bring your horse near the pack when breaking up a fox. The smell of the blood will often make the quietest horse kick a hound, and if he does it is sure to be a good one, if not the best in the pack!

19. Last, but not least, never buy a fox. Nothing encourages stealing like having a market for the stolen, and foxes offered for sale are nearly always stolen from some country, and generally from the very country in which they are afterwards offered for sale. It is much better to tell the fellow who brings you a fox to buy to knock his brains out than to give him even sixpence for it. 
Then, if the Hunt happens to be a subscription pack, might be added the following notice from the Committee; for the Master should have nothing to do with the collection of subscriptions; that should be left to the Committee, Seeretary, or Treasurer :-

The Committee of the Gorse Covert Foxhounds begs to inpress upon those who hunt with the pack that it cannot be maintained without heavy expenditure; therefore it is expected that each lady and gentleman will subscribe liberally to the fund, and pay the subscription to the Treasurer punctually every first of September, when contracts for the coming season have to be entered upon.

It should also be borne in mind that even if through any cause residents in the country may be temporarily prevented from hunting, they should continue their subscription, for they must remember the same expenditure has to be kept up, whether they hunt or not.

\section{By Order of the Con. Gorse Covert Foxhounds.}

Thomas Tally-ho, Hon. Sec.

Now if the foregoing simple rules and observations, with the explanations, were to be fully dinned into the heads of the hunting community, I am convinced they would be generally followed, and would thus make the duties of M.F.H. and huntsman comparatively easy, while the followers of the chase would enjoy all the more sport, and, best of all, the "pastime of princes" would perhaps never cease to be the "glory of youth, consolation of age, sublimest of ecstacies under the sun."

Most Hunts, I think, can boast of having some followers, more or less, who like to hunt but don't like to subscribe to the fund, and what is worse, indulge those propensities. Now, to those gentlemen I should convey the information-and that, too, without any meal in my mouth-that if they hunt they must subscribe. Of course, there are scores of cases in which exceptions should be madegood sportsmen who can only barely afford to keep a horse or two, and such like, and men who in other ways aid and assist the sport; and on no account whatever should a farner be allowed to subscribe, for he gives enough without having to give money.

Of course, it has to be left optional to a man what he subscribes, but I think it might very well be calculated at $£ 5$ for each day per week he hunts; i.e., a one-day-a-week-man should subscribe $£ 5$ a year, a two-day-a week $£ 10$, and so on. Should he favour more Hunts than one with his presence he should subscribe proportionately to them all.

Of course, landed proprietors and those with other standing and position in the county should subscribe much more largely, and that, too, whether they hunt or not, are residents or absentees. Everyone of means, whether he be county or city man, should feel proud of his county Hunt, and show that pride by sustaining it with his money. When I shall have shown in a following chapter what a prodigious national advantage hunting is to our kingdom, it should 
need little more to convince men without even any sporting proclivities that they should support hunting by every means in their power.

As I said before, there are many and diverse reasons that induce men to take the field-I cannot say to hunt-and to quote from Jorrocks (p. 244 of "Handley Cross"), "how warious are the motive that draw men to the kiver-side. Some come to see, others to be seen; some for the ride out, others for the ride 'ome; some for happetites, some for 'ealth; some to get away from their wives, and a few to hunt."

Yes, truly, only a few to hunt! Only a few out of a large field, perhaps two hundred to five hundred, who know anything about what they are engaged in, with all the rest caring little or knowing nothing about it. Is it therefore to be wondered at that the boiler of the Master's temper at times bursts with tremendous force, scattering scalding steam right and left among the offending and unruly crowd? No, indeed, it is not; and every allowance should be macle for such explosions, for he, being "one pure concentrated essence of hunting," with nervous anxiety for the safety of his hounds, and his sole object in view being to show a good day's sport, would be more than human if he could, or even would, put up with the aggravation he is so continuously subjected to by a host of ignoramuses mad with excitement!

However excusable it may be at times for a Master of Hounds to use strong language, it would, of course, be better that he should not do so, and there are many Masters who, no matter what the provocation, never resort to it. To prevent the effect we must remove the cause, and that is most readily done by initiating possible offenders into the mysteries of liunting usage and science by means of some such practical lessons and explanations as I have endeavoured to give. This is all the more necessary in these days of reformation, and when the company in the hunting-field, like many other institutions, is of a different character to that of years gone by.

Men need a course of instruction in hunting quite as much as they do upon any other subject-a great deal more than upon many. But they seldom or ever get such instruction, hence most of the harm they do arises from ignorance; but they get blown-up by the Master all the same, and, like the whipper-in of old, get damned if they do this, and damned if they do that, until at last they are damned if they know what to do!

How many men who hunt continually, and who think they are fond of it, ever read a hook like Beckford's "Thoughts upon Huntiriñ," or Delmé Radcliffe's "Noble Science," with the view of learning theory? They may read "Jorrocks" or "Soapy Sponge," but do so simply because these books are written in an amusing strain; but they are quite oblivious of the fact that almost every chapter, and sometimes every page of the chapter, gives sound practical advice 
and information-the former book as to hunting, and the latter as to riding to hounds, for the author, the late Mr. Robert Smith Surtees, of Hamsterley Hall, Durham, was a houndsman, a horseman, and a sportsman, but he was not a hard rider.

I have already said enough about the deplorable events which have occurred within the past few years in many of our Irish hunting. countries, events which have had the effect of reducing some of the Hunts from first-class to mediocrity, and of quite annihilating others; but the lamentable fact remains that hunting in Ireland is now not nearly what it was before the insane agitation arose against it. Not so in merry England, and to English hunting the following remarks chiefly apply.

By the statistics I shall quote presently it will be seen that within the past nine years the packs of hounds in England have greatly increased, which shows that hunting is more popular in that country now than it has been, perhaps, since Beckford's time. From this very popularity, I fear, arises the danger threatening our national sport. I am not by any means singular in so thinking. The late Col. Bromley-Dayenport, one of the finest all-round sportsmen England ever prnduced, put his fears on the subject plainly in his charminglywritten book "Sport," and very many others coincide with him.

I allude to the numbers of men who come long distances by rail from non-hunting districts to hunt with some of the crack packs. Many of them, no doubt, are keen sportsmen, and do as little harm individually as is possible for any man riding to hounds; but there are a great many who are not sportsmen, who know nothing about hunting, and who, as the author of "Sport" puts it, are "unable to distinguish seeds from switch, or turnips from tares," who, through ignorance or ill-manners, do damage to fences and newly laid-down fields, and as compensation they give insolence and insult to the farmers and labourers; for they never subscribe either to damage or Hunt funds, and, being total strangers, "arrive by train and so depart, leaving broken fences and damaged crops as the only trace of their visit. These are the evils which may lead to the decadence of foxhunting."

Farmers show extraordinary forbearance, and their toleration is beyond all praise, but continuance of that forbearance cannot be expected in the face of such wanton mischief done by strangers, particularly in times like these, when their farming accounts show loss oftener than profit. It therefore behoves all Masters of Hounds and genuine sportsmen, including the good men who come from a distance, to put a stop to these inroads of galloping snobs before it be too late. Most assuredly, were I Master of the Hunt they came to, I would ride up to each and all of them and order them out of the field, and if they did not obey me I would take the hounds home.

The hunting season in every district should, I think, wind up with 
red-coat point-to-point races, such as was introduced, in 1873 , by the Curraghmore, and which have since been the fashion with the Kildares, and I am happy to see they are becoming the custom with most packs in Ireland. These races should be jealously restricted to the members of the Hunt and gentlemen hunting with it, with absolute exclusion of the regular racehorse, professional racegoer, and bookmaker.

To effect this, I do not think a much better programme could be adopted than one on the lines of our own old Curraghmore Redcoat Race, which was a race within a race. The system was somewhat as follows :-A sweepstake of $£ 5$ each, p.p., for horses the bon $\hat{a}$ fide property of subscribers to the covert fund and regularly hunted with the Curraghmore Hounds during the past season and up to within a fortnight of the meeting, and that had never won a steeplechase value $£ 30$ or started for one of $£ 100$; to be ridden by those qualitied to enter a horse, provided he never rode the winner of a steeplechase value $£ 100$; weights, 13st. and 11st. 7lb.; four miles, over a sporting country; to be ridden in full foxhunting costume, with tall hats and red coats; the riders of 11 st. $71 \mathrm{~b}$. to wear a wide white band round the left arm. Conditions: If the race be won by a horse carrying 13st., he takes all the stakes ; if by a horse carrying 11st. 7lb., the stakes to be divided between him and the first 13st. horse; at least five horses in each class the property of different owners to start, or the conditions will be changed or race declared void at the discretion of the stewards.

The principle was to confine the race to absolute hunters, regularly kept at work through the season, and not thrown by for the purpose of the race, to be ridden by novices between the flags; and as each man mounted himself according to his weight for the purpose of going straight to hounds, the weights were chosen as being about the average of the light and heavy men. Of course, if the entries admit of it, there could be separate races for the light and welters.

In addition there should be, at least, two races for farmers of the country, for their own bona fide horses, to be ridden by themselves or sons, or by members of the Hunt qualified for the red-coat race, but not by professionals.

No doubt the professional racing man looks upon that sort of thing as a farce, and takes no interest in it; but that genus seeks for gain, not glory, on the racecourse, and if red-coat races be kept unpopular according to the professional turfite's ideas, and they be not favoured even with his presence, so much the better for all parties.

I wish to see point-to-point races popular all over the country. The peasantry attend them in large numbers, and come long distances to do so, reminding one of "auld lang syne," and undoubtedly beneficial results to the hunting of their respective countries must ensue.

Lady friends sometimes object to young fellows riding steeple- 
chases, and are quite nervous at the idea of their donning a silk jacket; but they have no such feelings as regards a hunt, and when they get up in a red coat for the point-to-point race no objection is made, as it is looked at it in the light of a hunt.

As we get old we get prosy, and like to talk of ourselves; so I beg the reader to excuse my egotism in stating that it was I who drew out the first article for a red-coat race which appeared in any programme in Ireland in recent years. It was for our Curraghmore Meeting advertised for February, 1873, but, a severe frost setting in, the meeting had to be postponed to the following May. In the meantime the Ward Hunt adopted our idea, and it was at Fairyhouse, in the spring of 1873 , that the first was run; but had it not been for the frost the Curraghmore would have taken the lead, as it most assuredly did in publishing the article. In fact, I proposed the same race to Lord Waterford and the other stewards two years before, but it was not adopted.

Since then these races have become every year more popular, and they are now the wind-up of the season with several Hunts.

Ah, me! many a man in my own old city of Waterford, ay, and for twenty miles around, regrets the loss of his annual outing over old Williamstown, of which he was robbed by those who stopped the Curraghmore Hounds.

What a joily little meeting was that of Westmeath in the spring of 1890, re-establishing as it did old Newbrook, where the popular Lord Greville and other members of his Hunt dispensed hospitality right and left, and showed a good day's sport to the hunting farmers. The only fault was the artificial course. This could be remedied in future by having the red-coat races run outside the artiticial track, taking in the old natural fences.

Earlier in that season I had the luck to be in the North of Ireland, where I attended such another meeting held near Bangor, co. Down. Sporting Lord Londonderry got it up, and it was restricted to the gentlemen and farmers who hunted with the Down Staghounds and Harriers. He gave a silver cup each for the light-weight and heavyweights, and cash prizes were given for the farmers' races. There was neither entrance fee nor stakes. Unlike Newbrook the course was perfectly natural, and formed a circle nearer five than four miles, with turns that required a man to use his head, for there were but few flags, while the fences demanded both a good horse and a good man to negotiate them. Nearly twenty started for each of the redcoat races, and while we saw in neither horse nor jockey aspirants to Grand National laurels, every man did his best to win, which we do not always see even in the Grand National.

Now this Northern sporting event deserves more than passing description. In all parts of Ireland, except Ulster, we have foxhounds and harriers, not forgetting, of course, the world-renowned Ward Union Staghounds; therefore it is but natural that through 
Munster, Leinster, and Connaught we should find hundreds of sportsmen only too anxious, after their hunting season has ended, to make their début between the flags or from point-to-point. But, let me ask, what Hunt is there south of the Boyne-ay, or any two of themwhich will send forty horses on the same day to compete in a scurry for two cups? Yet, as I have said, the co. Down sportsmen did so.

With very few packs of hounds in the North, or other inducements for sport, I met many a sportsman there, and found them even keener than the Southerner. Lots of good fellows from the Bann Water and other places emigrate southwards in the winter, like the swallows, and skim over the broad plains of Meath and Kildare at the tail of the hounds, with very few (and at times no one) before them.

The Ward Hunt, however, can beat all creation in producing sporting lawyers. While in most countries the limbs of the law are generally innocent of sporting proclivities, our Dublin barristers and attorneys come in force to swell the meets of the Ward when within twenty miles of the metropolis, and nearly always when an unusually fine run is being had over the broad acres of that terribly stiff country, the leading men are niembers of the bar or solicitors. As a wind up of the season it is quite usual to have a point-to-point race between the two representatives of litigation, where wig-and-gown, and "all that and those" ride hard at each other. God preserve me from law, but if I had to engage in it, give me sporting advocates such as the Dublin lawyers.

At Ballymena, Mr. Nathaniel Morton has a stud of hunters which, for quality, action, manners, and breeding, I seldom see excelled. He is a gentleman horsedealer, in addition to being an eminent merchant in Antrim, and a sportsman besides. He shows his horses loose, either in a large yard or under a long covered ride, well tanned, and where they are put, or rather put themselves, for they are not ridden, over a gorse hurdle, which is raised over five feet for some, and which they clear with a good six inches to spare. I was greatly interested in this performance, and feel convinced that the way to see a horse use himself to perfection is to let him do so without a rider, whether it be in any of his paces or over fences. Mr. Morton, however, gives every trial of his horses, and an intending buyer can see them ridden by a groom, or he can ride them himseli.

Mr. William Hanway, a large farmer in the county Kildare, trains his racehorses by letting them loose in a big field, and setting collie dogs after them to make them gallop, a performance both horses and dogs enjoy so much that they get plenty of it. By this means he does away with the strain on their legs consequent upon carrying a rider, and has them so fit that for years they have either won or got placed in the Farmers' Race at Punchestown, and with his horse John Kane similarly trained, he won the Conyngham Cup in 1885.

Writing about horses being let loose and to themselves reminds me of what I consider a very dangerous fashion which has crept into 
the hunting-field of late years-that of wearing long-shanked spurs, ome being straight, making the danger still more pronounced. Now, to my ideas, no new innovation upon our old fashions is more objectionable and dangerous. Men throw horses very much oftener than horses throw men. Nine out of ten falls may be assigned to the rider's hands and heels. That good authority, old Mr. William Quin of Loughloher, told me once, "When you jump into a field, fix upon the place you will jump out of it, and go straight for it ; steady your horse when within a few strides of the fence, to get his hind legs under him, and then leave the rest to his own honour!" Yes, if you want to get safely over a country the less you meddle with your horse while fencing the better ; it is therefore manifest that the shorter your spurs are the less likelihood there is of touching him unintentionally, and no matter how short they are, a man will do so at times when he gets a shake, even though he be an accomplished rider. A man with a bad seat actually excoriates the shoulders of his horse with long-shanked spurs even when galloping. For my part I always wore spurs with which I could touch my horse only with grea+ difficulty. In his advice to "ingenuous youths," that renowned and practical workman, Mr. Jorrocks, says of spurs, "the less they use them the better."

I remember once extricating Lord Marcus Beresford from an awkward and dangerous predicament into which he got, owing to one of these infernal spurs. The horse he was riding gave him a fall, and he got hung up by the leg in a complicated entanglement of boot, girth, and stirrup-iron, which were all kept skewered together by his longshanked spur. But for the docility of old Red Herring the results might have been very serious to Lord Marcus, for he could not have liberated himself.

Though I said in the opening lines of this chapter that I did not mean to enter into the scientific mysteries of hunting, I will just giva a hint. Nothing can teach a man the real science of hunting better than carefully watching a pack of beagles or harriers hunting a hare if they be left entirely to themselves. With foxhounds many things distract a man's attention, and as there are times when all his energy and faculties must be centered in himself and his horse, he cannot learn very much, but with the "thistle-whippers" it is different. When a man takes his Bachelor degree with harriers he soon qualifies as Master of Arts with foxhounds, if not as a Senior Fellow.

I go with my friend Jorrocks, whose sound, sensible sayings I quote so very often, where he says that "all men who wish to do so can hunt," even upon very limited incomes, but they must deprive themselves of other enjoyment, and be content to ride a screw, and turn out less smartly than others. The privilege of riding in breeches and leggings should be allowed to the poor but sporting fellows who elect to adopt this laudable method. With that garb, however, I think a pot hat should be worn, but it must suit the man. By the 
way, how characteristic of a man is his hat, and the way he wears it; it is nearly as indicative of his character as his eye.

In fact a man, if he has the will, can do most things he has a taste for. I remember, when I was a boy in London, learning the business of wine merchant, my father allowed me very liberal pocket money, out of which, however, I had to pay for my mid-day dinner in the city. After a while, I found these dinners made sad inroads upon my allowance, and that, after paying tailors' and other bills, I had very little "to carry over" for amusement; and, as my great ambition was to learn to box and to drive tandem, I had to devise some modus operandi, for I would not trespass further upon my good father's liberality. My plan was this : I ate a tremendous breakfast at eight a.m., and an equally substantial supper at ten p.m. at the house of a good old aunt, where I lived; but instead of spending $2 \mathrm{~s}$. or 2s. 6d. on my dinner, at "Baker's," in Change Alley, or "Joe's," in Finch Lane, I dined off twopennyworth of bread-and-cheese and a pennyworth of beer at an eating-house. I must confess, however, that the capital dinner my aunt gave every Sunday, and any to which I was invited during the week, suffered severe punishment from my healthy appetite. Now this deprivation (a very mal à propos term, by the way, when comparing grub with sport at the age of eighteen) enabled me to save some 12s. or 14s. a week, which additional surplus left me quite enough to enter into arrangements with Nat Langham and a swell jobmaster in Piccadilly-I forget his name now-the one to teach me "the noble art of self-defence," and the other how to drive one horse before the other. By steady attendance upon "old Nat" from six to eight nightly, I soon became tolerably handy with the gloves; and as I spent every Saturday afternoon and any odd hours I could get away during the week with the head lad of the stables, it was not very long before I was equally handy with the ribbons, so that after about six months I was honoured by Nat's introducing me to a distinguished audience at the Mitre Tavern, as "a new Corinthian novice," and right proud I was on the occasion! My other mentor was equally good; in fact, as regards my pocket, very much better, for he often gave me a tandem gratis to show them off in the Park on a summer's Saturday afternoon. Reader, forgive this egotistic digression, but the pen refuses to leave unrecorded what memory recalls with such mingled feelings of pleasure and regret. $\mathrm{Ay}$, and I now remember that by doing without dinners I had an odd day now and again with the Surrey Staghounds and West Kent Foxhounds. What pleasure would it give me now to remember dinners I ate over thirty years ago! But I have a great deal of pleasure in thinking of the "rounds" at Old Nat's, and the rounds of the Park in those heedless, happy days.

I agree entirely with Colonel Davenport's concluding remarks in the chapter on foxhunting in his splendid book entitled "Sport," and "ugly visions sometimes haunt me" too-visions of a time coming 
when not only our national sports, but many other British institutions, may be supplanted, or possibly be upronted altogether, through fanatical ideas of "humanitarian n!orality" and advanced opinions culminating in socialism and communistic disposal of all men's property.

Those days may be far off, and as we cannot "pierce the veil of the future "we should be ever vigilant and take preventive measures. This book treats solely with sport, so to those alone who, from mistaken notions of humanity, or other more or less righteous motives, strive to interfere with our national sports, I would say that without hunting the whole breed of foxes would, within a few years, be ruthlessly swept off the face of the three kingdoms by poison or other means, and none of the money shortly to be alluded to would be spent in this country, for men would then go abroad for amusement. While, as it is, foxes are well cared for during the whole course of their lives, except during the very short time they are being hunted; and when they are killed, the means are infinitely more merciful than those of trap or poison. Shooting and fishing, too, afford an easier death to birds and fishes than that dealt them by their natural enemies or the net.

If the ultra-righteous people to whom I address these remarks were to wage war against those who practise the diabolical cruelty of cock and dog fighting, badger-baiting, rabbit-coursing and trappigeon shooting, etc., or engage in the pernicious habits of gambling. or tippling, they would undertake a better work. But let them leave the national sports of our country to sportsmen.

It is all very well for these good people to say that the money which is spent upon sport should be devoted to the relief of those people in the country who have none of the luxuries and few of the necessaries of life. Very righteous remark. But does not every shilling spent on sport go into the pockets of people, many hundreds of whom would be without the necessaries of life if sport was giver up in Britain?

I now leave this phase of my subject with the hope that what I have written may be of some utility, and that no one, not even the young men who come from a distance to hunt, will take offence at my remarks. In the next chapter I shall endeavour to show how important hunting, as an institution, is to the nation from a monetary point of view, as distinguishable from its sporting aspect. 


\section{CHAPTER III.}

\section{WHAT HUNTING IS TO THE NATION.}

Author's Letter in 1875-Accurate Calculations-Author's Letter of 1881-Criticism CourtedRefutation Defied-Cost of Hunting-Table of Same-Cost of Keeping HuntersHunting Establishments, Value of-Annual Cost-Table of Same-Stupendous Amount -Author's Dogmatism-His Defiance Repeated-But Explanation Given-Cost of Feeding Hounds-Farmers' Co-operation-English and Irish Farmers and Yeomen-Innate Sportsmen-Farmers Get the Money-The Little Red Rover-Poetical Advice to Farmers-Result of Stoppage of Hunting-Importance of these Facts and FiguresLeading Periodical's Opinion in 1881-Table of Packs, 1881-1890-England $v$. IrelandWhy ?-A Mistake in the Press.

As far back as November, 1875, I published a letter on this subject in the Irish Sportsman. The calculations I made were reproduced in many other sporting and daily papers at the time, and though they have been quoted very often since, I have never heard their accuracy questioned. The calculations could not, however, be upset, for they were based upon the accurately-kept accounts of several first and second class hunting establishments-fox, hare, and stag houndswhich I was allowed to inspect, and also upon what I know myself on the subject.

I reproduced the calculation in the second edition of my "Recipes" early in 1881, but when the agitation against hunting began in Ireland towards the end of that year I went much deeper into the subject, and published letters, signed "The Fox," in the Freeman's Journal and other papers, which received vastly more attention than the others. The first letter dealt only with first and second class establishments, but that of the autumn, 1881, included many smaller packs, and in consequence the estimated average cost was reduced considerably.

It is necessary to give this explanation in order to explain the alteration in some of my figures, and I want to be as explicit as possible.

The following calculation is based upon proper and economical management, without providing for waste or extravagance. Stupendous though the figures undoubtedly are, and although they can be approximate only, I confidently lay them before the public as being under rather than over the mark. I court criticism and defy refutation, and do so without apprehension.

Previous to 1860 the yearly cost of keeping foxhounds was calculated at a little under $£ 500$ for each day they hunted in the week; that is, a pack which hunted two days a week would cost a little under $£ 1,000$ a year. From 1860 to 1870 this sum amounted to ove 
$£ 600$, and now I am quite certain $£ 650$ a day does not cover all the expenses of foxhunting a country. Staghounds can be kept for £5550 a day, as they have fewer incidental expenses, though the deer cost a great deal. Harriers can be kept for $£ 200$ a day. Hunts in the field three or five days a week are proportionately more expensive than those hunting four or six days.

To foxhunt a country in the style Lord Waterford did the Curraghmore, or as his father-in-law, the Duke of Beaufort, does the Badminton, would cost annually, at the least, a thousand pounds a day for each day a week they hunt.

According to the returns given for 1890, the packs of hounds and the number of days per week they hunt are as stated in the following

Table showing the Cost of Hunting the various Countries ix the United Kingdom, including that of the Master.

\begin{tabular}{|c|c|c|c|c|c|}
\hline Description. & $\begin{array}{l}\text { Num- } \\
\text { ber of } \\
\text { Packs. }\end{array}$ & $\begin{array}{c}\text { Couple } \\
\text { of } \\
\text { Hounds. }\end{array}$ & 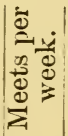 & 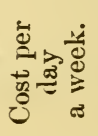 & $\begin{array}{l}\text { Yearly } \\
\text { Cost. }\end{array}$ \\
\hline Staghounds- & & & & $£$ & $£$ \\
\hline English ...... & 13 & 319 & 26 & 553 & 14,300 \\
\hline Irish ......... & 3 & 85 & 8 & , & 4,400 \\
\hline Foxhounds- & & & & & \\
\hline English and Scotch & 162 & 6,120 & 473 & 650 & 307,450 \\
\hline Irish $\ldots . . . . . . . . . . . .$. & 16 & 532 & 42 & ," & 27,300 \\
\hline Harriers- & & & & & \\
\hline English and Scotch & 103 & 1,694 & 215 & 200 & 43,000 \\
\hline 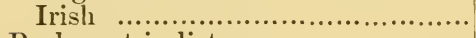 & 25 & 417 & 52 & & 10,400 \\
\hline Packs not in list, say .................... & 10 & 300 & 20 & 400 & 8,000 \\
\hline Total.. & 332 & 9,467 & 836 & - & 414,850 \\
\hline
\end{tabular}

This makes the annual cost of 332 Hunts to be $£ 414,850$. Let us call them in round numbers 330 packs. Each Hunt has an average field of, say, 100 hunting men, each of whom has, say, three horses in his stable. That gives us 99,000 hunters. These cost fifteen shillings a week per annum to keep, which amounts to a total of $£ 3,861,000$. We can, therefore, put down the bare cost of maintaining the Hunts and keeping the hunters of the United Kingdom at over four millions and a quarter per annum; and this prodigious sum includes none of the "extras" contingent upon hunting, such as mansions and houses taken for the hunting season, entertaining friends, covert hacks, and carriage horses, travelling expenses, red coats, top-boots and breeches, or the many gratuities which render the generosity of hunting men proverbial.

To make a correct valuation of hunting establishments is a task 
even greater than that of attempting to arrive at the annual cost of hunting a country or the keep of the hunters ; but let me essay it.

Put the 99,000 private hunters down at $£ 100$ apiece (a very low average, in view of the fact that many are worth from $£ 200$ to $£ 500$ each, and few are of less value than $£ 70$ ), and we have $£ 9,900,000$ as their value. The 330 Hunts have from twenty to eighty couple of hounds in their kennels, so if we value each pack at, say, $£ 700$ all round (also a low tigure ; Lord Waterford's kennel sold for $£ 1,910$ a few years ago), we have $£ 231,000$ as the value of the hounds. Each Hunt has, on the average, say, ten servants' horses (a ridiculously low average, considering some Hunts have thirty horses for the men), worth, say, $£ 50$ apiece, that is $£ 165,000$, or $£ 396,000$ as the valuc of the hounds and servants' horses belonging to the 330 packs.

The foregoing shows that we have 33,000 private hunting stables, and 330 stables for the Hunts; so, placing the value of saddlery, horse-clothing, stable furniture, eto., at the low estimate of $£ 25$ all round, we have $£ 833,250$ as the aggregate. The cost of renewing, repairs, etc., is included in the other estimates.

For convenience, and as a companion to the former table, I append the following, which shows

The Value of Hunting Establishuents of the United Kingdon and their Arvual Cost of Maintenance.

\begin{tabular}{|c|c|c|c|c|}
\hline- & $\frac{\dot{0}}{\stackrel{\Xi}{\Xi}}$ & 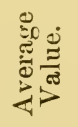 & $\begin{array}{c}\text { Total } \\
\text { Value. }\end{array}$ & $\begin{array}{l}\text { Anmual } \\
\text { Cost of } \\
\text { Main- } \\
\text { tenance. }\end{array}$ \\
\hline Private liunters. & 99,000 & $\begin{array}{c}£ \\
100\end{array}$ & $\stackrel{\mathfrak{f}}{\underset{1}{4}, 000,000}$ & $\stackrel{\mathfrak{E}}{3,861,000}$ \\
\hline Hunt servants' ditto & 3,300 & 50 & 165,000 & $141+850$ \\
\hline Packs of hounds $(9,467$ couple $)$ & 330 & 700 & 231,000 & 414,550 \\
\hline Saddlery, clothing, etc., in stables ...... & 33,330 & 25 & $\$ 33,250$ & $\begin{array}{c}\text { Includerl } \\
\text { above. }\end{array}$ \\
\hline Total, 102,300 hunters, 330 packs & $\ldots$ & ... & $11,129,250$ & $4,275,850$ \\
\hline
\end{tabular}

Now this result shows us that the hunting establishments of the United Kingdom are of a marketable value of nearly eleven millions one hundred and thirty thousand pounds sterling, while their maintenance, as I have said before, requires an annual expenditure of a good deal over four millions and a quarter!

Was I wrong in styling the figures stupendous? or in stating that hunting did more for the nation than any other institution, bar religion and education? No, I was not. Neither am I wrong in firmly asserting that, astounding as the amounts appear, they are very far short of the absolutely correct amount spent on hunting in the British Isles. 
Some people may, perhaps, accept the return as incorrect, but. again I defy anyone to prove one single item to be over the mark. Howerer, as I want this subject to be thoroughly understood, and my readers and the public to have confidence in the correctness of the returns, I will give a simple example, the accuracy of which anyone can test, and by consulting a Master of Hounds or Hunt secretary it is very easy to find out whether I am correct or not in my other figures.

All dogs the size of a foxhound, if kept in kennel and properly fed for hard work, will cost about 1s. 6d. a week to feed (I don't allude to one or two dogs, which may be fed very well and conditioned on the refuse of the kitchen, which but for them would be given away or thrown into the manure pit). Now, 9,467 couple means 18,934 hounds-say 18,900 for the sake of simplicity; these, at 1s. $6 \mathrm{~d}$. each, cost just $£ 1,417$ a week to feed. Nearly $£ 73,700$ a year for only feeding our hounds! Again, the man who keeps an account of all his hunting expenses knows that each day he goes out with the hounds costs him about $£ 3$, and to keep the cost at that figure he must hunt each liorse he has pretty nearly three days a fortnight. If he has to go long clistances by train, that sum must be increased proportionately. I know I am prolix on this subject, but I want to. impress these important facts upon the public.

We are able to invest this rast amount of money in hunting, and to keep the annual cost in steady circulation; and we shall be able to do so for generations to come if the farmers will continue to us their permission to hunt over their lands, their forbearance in respect to damage done, their assistance in preserving foxes and hares, anda requisite as important as any-if they will give up the use of wire on their fences, and as palings.

The farmers and yeomen of England are as tine specimens of manhood as can be found in any land, and so are the farmers of Ireland if let alone. Farmers are nearly all born sportsmen, not with an outward veneering like many of those who think themselves higher up in the social scale, but with true, innate, and deep-seated lore of sport.

Of course there are some without that inheritance, who, from selfish motives or warped conceptions of what is for the general good, do not approve of hunting or of any sport ; but, thank heaven, they are in the very, very small minority. But eren they must admit the fact that of the colossal sums I have quoted nearly every shilling finds its way, directly or indirectly, into the pockets of the farming class; and that upon the little red rover of the hazel eye and russetbrown brush they must look as the sole representative of more sport than all the other wild beasts, birds, and fishes of the world put together. Yes, it is the fox, with the assistance of the hare and the deer, that calls forth all this vast yearly expenditure of money. 
Attend, ye farmers, to my tale, And, as ye mend the broken rail, Reflect with pleasure on the sport

That lures your landlord from the court

To live and spend his rents among'

The country-folk from whom they sprung.

And should his horse, with trampling feet,

Do damage to your tender wheat,

By you, perhaps, that horse was bred,

And yours the oats on which he's fed;

Ah! then restrain your rising ire,

Nor rashly damn the hunting squire.

If hunting were stopped, there would follow from the rural districts of England an exodus that would inflict upon its yeomen the loss not only of all the money spent on hunting, but of a vast proportion of the other outlays of country gentlemen.

I hope my readers share my opinion of the importance of the matters with which I have dealt in this chapter. The facts and figures I have given possess a significance the recognition of which will do more for hunting than all the rhapsody or reason put forth in a dozen books.

A leading periodical, when reproducing the estimate $I$ gave in 1881, adds: "These figures, which no sophistry can dispute and no method of statement darken, show with marked evidence the value hunting is to the kingdom, when we know this vast amount of money finds its way into the pockets of the farmers and tradesmen without leaving any profit, but, on the contrary, an unremunerative outlay to the sportsman," etc.

We engage in commercial, agricultural, and other undertakings, and though we thus spend large sums on labour, etc., we do so with the direct and sole purpose of making money. But a sportsman faces endless expenditure for no return whatever save a scurry across country; this is a fact to be borne in mind by the detractors of sport.

In conclusion I give a comparative table of the packs of hounds in the United Kingdom in 1881 and in 1890, taken from the same authority as the former tables :-

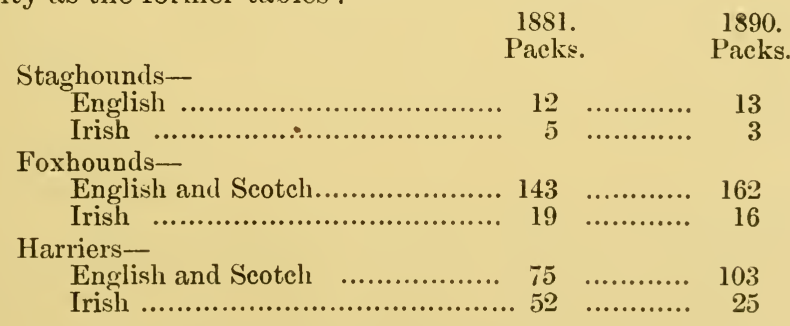

This shows that England and Scotland have increased their hunting establishments within the past nine years by one pack of 
staghounds, nineteen packs of foxhounds, and twenty-eight packs of harriers; while Ireland, within the same suggestive period, has decreased hers by two packs of staghounds, three packs of foxhounds, and twenty-seven packs of harriers. Not alone that, but some of the packs still hunting in Ireland are but shadows of what they once were. Why? Echo answers, "Why?"

P.S.-The foregoing chapter appeared as an article from me in the columns of Land and Water in February, 1892. At the Brocklesby Puppy Show, held in the following summer, Lord Yarborough did me the honour of quoting my figures, but although his lordship stated distinctly the source from which he took them, the papers all over the country gave to Lord Yarborough the credit of compiling them. 


\section{CHAPTER IV.}

\section{FOXES.}

Hen houses-Lambs-Natural Food-What to feed Foxes on-Worms-Vermifuge-Little trouble preserving Foxes-Vixen teaching Cubs-Vixen's care of Cubs-Vixens' breeding places-Country Gentlemen's duty towards Foxes-Relief to M.F.H.-Mr. Ned Briscoe and Mr. Henry Bowers-Activity and Shapes of a Fox-His Foot $v$. a Dog's-His endurance $v$. a Foxhound's-Buying Foxes-M.F.H. buying FoxesMountain Dog Foxes-Crossing Breeds-Greyhound Fox-"Long, Limber, and Grey" -Author's Admiration of the Fox-A Vexed Question-Docking Foxes-An Anecdote.

VERY little is known of the nature of foxes ; and still less is it known how easy it is to prevent their doing damage.

If the door posts or windows of the hen house be occasionally rubbed with tar, no fox will go near it; or better still, burn a little assafœetida therein, and a fox will not go within a mile of it, even if he is starving. The smell made by this process is objectionable; but it is a capital way of preventing a fox going to ground in a dangerous earth or one that cannot be easily stopped.

If a piece of tape be tied round the neck of a lamb no fox will go near it. In no case will he take a lamb unless it be a poor, weakly one, and unprotected by the ewe, as it is too troublesome and heavy to be carried off ; and if the mother were there she would drive him away. Ninety-nine out of a hundred of the lambs which are laid to the foxes' charge are really killed by cur dogs.

The food a fox likes most is of the plainest kind-such as rabbits, rats, mice, frogs, beetles, crows, blackberries, hurts, also fish; and the more decayed the meat and fish the better he likes it; rotten fish, however, gives them the mange, as we learn from the number of mangy foxes found at times near the seaside.

Now, if foxes are regularly fed with rabbits, crows, rats, and mice, which at all times are easily procured, they will seldom, if ever, attack game or poultry, and, in fact, will do little or no damage. Care must be taken, however, not to make them too comfortable at home, for if they be they will not travel, and therefore can't gain that knowledge of the country which is so essential to good runs. A fox is naturally a lazy fellow, and seldom travels far except in search of food and in the clicketing season.

We seldom hear of a fox having worms, which is attributable to the fact of his living so much upon animals which have furry skins; and for this reason I recommend the skin of a rabbit to be mixed occasionally in dogs' food to act as about the very best vermifuge.

When it is remembered that the fox provides the attraction which induces gentlemen to stay in the country and spend on hunting the millions of money I have already referred to, we should zealously 
protect and preserve him; particularly when by taking the little trouble I have mentioned we can make him as inoffensive as a kitten, and more so than a cat.

Nothing is more interesting in its way than the sight of a vixen tending her cubs. On a fine day she brings them out of the earth and plays with them as a bitch does with her puppies; but at the least sign of danger she and the youngsters disappear. As they grow older and hardier she teaches them to tear up their food, and will bring home a half-killed crow or rabbit to furnish an object lesson, and see then how the little fellows growl and fight over the prey! Finally she brings them out at night, and shows them all the earths and places in the vicinity where they can go to ground in moments of danger. As soon as the cubs can take care of themselves she leaves them to do so.

A litter was once brought out near my house. I took great delight in watching the cubs morning and evening, and repeatedly saw the vixen, after a game of romps, hunt in the young ones before going off herself on a foray ; but no sooner were they driven in than they would reappear and try to follow her. Then she would regularly cuff them with her paw, and even bite them, and, having sent them back to bed, would remain about the earth till she saw they were not likely to come out again.

Vixens, though such cunning animals, often lay up their cubs in most exposed and dangerous places. I have known one to breed three years in succession in the old flue of a greenhouse. When a litter is found to be in a dangerous place it should be carefully disturbed, and the mother will then move her family to safer quarters. Sometimes a vixen will have two nurseries, which she will use alternately, and, seeing the marks at both, a keeper often calculates upon having two litters instead of one. If cubs be laid up near to a dwellinghouse, the vixen very often becomes extremely vicious, and will attack women and children even without being molested by them. But, strange to say, she will not take poultry from that place, nor will she allow the cubs when they get hardy to do similar damage. Another of the many instances of the craftiness of the species.

A great many people think that there is little or nothing to be done about hunting from the "last day of the season" till the following cubhunting. They are very wrong in such ideas. The day after the last of the season is the first of the next with the Master and Hunt servants, and so it should be with country gentlemen owning or living near fos coverts.

Vixens lay up generally between early March and May, during which time, and until the cubs get hardy, they require careful looking after, both to prevent their being worried and to have them well fed. If a vixen finds plenty of food laid for her near where she has her cubs she will not visit hen roosts or do damage, neither will she have occasion to leave the cubs in search of food, but can stay at home and 
protect them. It should be the pleasure of men living in the country to personally look after these matters, and not expect the M.F.H. to do so; besides, when going through the country they have grand opportunities for friendly chats with the farmers and their families.

The two best men I ever knew for looking after a foxhunting country were Mr. Ned Briscoe of Harristown and Mr. Henry Bower's of Owning, in the county Kilkenny. Neither hunted, but the delight of each was to look after the earth-stopping and coverts in the winter, and the vixens and cubs in the summer, and to these two sjortsmen was the Curraghmore Hunt deeply indebted for a great deal of the good sport it had during the eleven years of JIr. Henry Briscoe's Mastership, and the like period of Lord Waterford's. In fact, next to the Master and huntsman, I always looked upon them as the most useful men we had in the whole Curraghmore Hunt. Besides knowing what to do and how to do it, they liked doing it, and did it.

I think the fox is of all animals the most active and supple of body. Unarmed though he be with the claws on which the cat so largely depends for her agile movements, he can jump and climb nearly as well; while he can turn and twist himself in the smallest space and into any shape short of a knot. It is curious, howerer, that the shape of his foot differs so essentially from what we recognise as the shape best calculated to fit a dog for the endurance of long and hard work. A fox's foot is flat and down-at-the-toes, while a dog's should be quite the reverse. Still, that grand and game little animal is often able to beat for miles over a country the best pack of hounds, handicapped as he often is with a belly full of food, eaten, perhaps, only a few hours before he is found, and never in what is called "condition." Oh, what a shame it is (except under very few and exceptional conditions) to dig a fox out and give him to the hounds when the gallant little fellow has got to ground after beating his forty pursuers fairly and squarely above it! To me it was always the most Cockney, hair-clresser and grocer sort of business to see a terrier as an adjunct to a pack of foxhounds.

Apart from the sport he gives, and money he keeps in circulation, I really think the fox is the most to be admired of all wild animals. His perfect symmetry of shape, lovely colour, and bewitchingly roguish eye always charmed me; while activity, inherent courage, sagacity, and endurance are the highest attributes of eren the human race.

Buying foxes is, as I said elsewhere, a very wrong thing for any man to do. The chances are the fox brought to be sold has been stolen in the very country wherein he is offered for sale; if not, he has been stolen from some other country. In either case, he should not be bought.

Masters of Foxhounds have, of course, at times to buy foxes to re-stock portions of their country; but when this is necessary they 
should see that their importations come from a bona fide non-hunting country. It will not do that the foxes are taken from parts of a country which are not hunted, for we in Ireland all know that foxes bred and living in wild, rocky mountains come down to the lowlands to forage, and in the spring travel far into the interior; and when old mountain dog foxes are then and there found they give runs as straight as a ruler to their rocky fastnesses; generally speaking, the very best of the season.

No one should buy a fox except the M.F.H., and he only after he has used every precaution to ensure its having been taken from some place which is at least thirty miles from where a foxhound draws.

The breed of foxes, like that of all animals, needs to be crossed, and it is highly desirable that imported vixens and dogs should be turned down at times throughout a country. The straightest running and stoutest breed is "the greyhound"-generally, if not always, got in wild mountain districts ; but he is, I fear, a bit mischievous at times. Thick-set, short-necked, foxes are bad, and so are foreigners. "Long, limber, and grey" is the sort to give good runs. And everyone knows that the early spring is the best time to turn down foxes in a strange country.

As to foxes being alike to dog:s under certain similar circumstances there is great difference of opinion. The relation of two incidents which came directly under my own notice may enable my readers to form their own judgment. For my own part I infer therefrom that the pairs were overtaken under conditions which made separation or flight impossible to them.

The Curraghmore Hounds, in the spring of the year, about 1865, had hunted a fox for some miles over the Bessborough country, and finally ran him into Gortrush. They carried the scent to the middle of the wood, and there they killed two foxes in the same spot. I saw the dead bodies at the time. One was a dog, the other a vixen, and both were quite clean, and with no appearance of having been hunted. About the year 1884, again in the early spring time, the Dungarvan train, in daylight, ran over and killed two foxes in the same spot, near Kilmeadan. Their mangled bodies were brought to Waterford, where I saw them next day, and there was sufficient evidence to show that they also were of different gender.

Men who pay attention to hunting know that a fox, when he runs through a heavy country, gathers in his brush a lot of wet and mudthe weight of this handicaps him terribly, and tends, at times more than the hounds, to pull him down. It therefore often occurred to me that it might not be a bad plan to "dock" a fox whenever the chance offered. No doubt to lose what Nature gave for a good and specitic purpose would cause him, at least, inconvenience, particularly when he had to make a quick turn or exert unusual activity. True, also, a fox deprived of his brush would not alone look awfully bad, 
but lots of times, when at a distance, he would be taken for a hare. Worst of all he would have taken from him that which has been the ilex inimitable during the annals of foxhunting as the trophy of prowess. Nevertheless a hob-tailed fox will take a deal more killing than the fellow with a brush.

I remember in 1858 Lord Waterford's hounds ran a fox to ground near Killeen. The earth-stopper, Tommy Knockmore, took him out, cut off half his brush and then let him go. (A week after he gave me the piece docked off, and I have it still.) For five or six seasons after did that fox give us capital runs, and, resorting to Killeen, he became, by reason of the "finds," a regular annuity to old Tom. Many a time I saw him going away with his stump stuck straight up in the most grotesque style. He was the bane of Briscoe and Johnny Ryan, for there was no killing him, and I think he must have died of old age. We called him Bobbie. 


\section{CHAPTER V. HORSE-BREEDING.}

Clippings from Author's Scrap-book-Horses of the Ancients-Early Horse-breedingCurious Act of Parliament-Stallions 150 years ago-Origin of the Thoroughbred-. Author's Interest in the Subject-His Experience-Theoretical rather than PracticalIrish Horses-Government Stallions-Local Horse Shows-Ball's Bridge ShowInverse Ratio-Mares-Dams of Great Horses-"Nicking"-La Flêche-Steeplechasers and Hunters-"Jumping Blood"-Author's Experieuce of Thoroughbred Hunters-Suitability of Mare to Horse-Physiology-Suggestions-In-and-out Ruuning-Malpractice-Breeder to Blame-Not the Trainer or Jockey-Ciceroues-Disorganisation of System-A Code for the Farmer-Ould Plan of Training-Grumblingold Fairs-Dublin Horse Show-Clonmel and Moy Fairs-Magnificent Hunters in Plenty-Irish Dealers-Stud Farms-Good Mares-Mr. Hutton-Increase of Thoroughbred Sires-How to Improve the Jares-List of Stud Farms-All First-class-Fees for Service-Knockany and Bruree-Mr. John Gubbins-A Great Establishment-Captain Stamer Gubbins-L'ncas--Xenophon-Victor-Umpire-Solon-Ireland better off than ever-Lackaday:-Exportatlon of Good Horses and Mares-Positive Insanity-Free Trade-Protective Measures-Our Horses and the Foreigners-Our Colonies-Stockwell-Other Good Results from Stud Farms-A Tribute to great Sportsmen-Thei: names-A Stud of Horses and a Kennel of Foxhounds - A Bad Example-Strange Notions of an Owner-Everything Bad-Points of a Brood Mare-Author's OpinionWatercress and La Flêche-Royal Dublin Society-Dublin Horse Show-A Short History-Great Irish Institution-Leading Spirits-Samuel Ussher Roberts-Jamez Talbot Power-James O'Reilly-The Society and the Show Non-Political-The Section which Supports them-Real Patriots-Dear Old Ireland !

Frow my scrap-book I take some of the following particulars of the ancient history of our horses.

The earliest allusion to the horse is where Anak, about 1590 B.C., found mules in the wilderness, the progeny of the horse and the ass. About 1500 B.c. horses were used in warfare. Early in the Christian era we find that Julius Cæesar, when he invaded Britain, was opposed by "immense bodies of horsemen," and later on that Boadicea harangued her army from her war chariot, and in it led her famous charge against the Roman General Suetonius. Unfortunately for my purpose there was no Weatherby in those days, so what breed the horses were or what they were like I can't conveniently state. Doubtless they were good, and answered well their purpose.

In the reign of Henry VIII. it would appear that horses were beginning to deteriorate in siza and strength, owing probably to incestuous breeding, for it was enacted ( 32 Henry VIII., c. 13) "that no person shall put on any forest, chase, moor, heath, common, or waste any stoned horse above the age of two year not being fifteen hands bigh."

It was not until the year 1616 that improvement in the breed of horses began to be systematically pursued in Great Britain. We read that James I. then gave 500gs. to Mr. Markham for a stallion he had imported from Arabia, but a prejudice set in against the horse because he was not a success as a racer, and he was not much 
bred from. In Queen Anne's reign we find the "Darley Arabian," a horse bred on the desert of Palmyra, and imported from Aleppo by Mr. Darley. His progeny are described as being "unequalled for beauty, speed, and strength." From this horse first sprung our thoroughbreds. Next we have the Godolphin, but he was said to be a Barb and not an Arabian. He lived to be twenty-nine years old and died in 1753.

In 1752 there were sixty thoroughbred stallions standing in various parts of England. The fees were then very moderate compared to now. Cronootes headed the list at $28 \mathrm{gs}$. Bolton Starling was next at $8 \mathrm{gs}$., while others varied from 1 to $3 \mathrm{gs}$. Eight of these were imported Arabians, and it is owing to them and well-selected Barbarys that Great Britain now reigns supreme in the production of the best breed of horses in the world.

Although I bred many a setter and pointer, as well as other dogs, I never bred a horse in my life. Nevertheless, I took the deepest interest in horse-breeding, but more in the hunter than the thoroughbred class. Any ideas I may have formed are, therefore, so theoretical I am not going to put many of them into print.

Of course, I have been shown over many breeding establishments, English as well as Irish ; and at our Dublin Horse Show I see hundreds of hunters with lords and ladies of the harem which are considered worthy representatives of their classes, while at Newmarket, the Curragh, and other head-quarters of the thoroughbred I have seen racehorses innumerable from the yearling upwards.

At all these places I listen to what is said about breeding by others who, from long practical experience, ought to know what they are talking about. The theories put forward by some are, however, so at variance with those laid down by others that I am fain to try to form an opinion of my own.

Lacking, therefore, as I do all practical experience, and possessing only this thin veneering of theoretical knowledge on the subject, I am not going to try and teach practical breeders their business; but I will venture upon some remarks which I trust won't be taken as altogether puerile.

We in Ireland are justly famous for our horses, but I think by taking a little more trouble we might become much more so. Our climate is suitable for rearing horses hardy. Our soil is to a great extent of a limestone nature, which is the best for producing bone. We feed our young ones well, but do not pamper them, leaving them out in the air and to the elements more than do the English breeders, whereby they grow up all the more healthy, and we train them to perfection.

Of late years our breed of horses has been greatly improved by the introduction all over the country of those thoroughbred stallions provided by Government, and whose service can be obtained by farmers at a nominal figure.

Local shows have also done an immensity of good, while that held at Ball's Bridge is quite the greatest and best exhibition of the sort in 
the whole world. The finest specimens of every class, except the cart horse, are there exhibited.

I don't think we pay as much attention as we ought to the breeding and conformation of our mares. As long as some of us can breed a foal got by a thoroughbred horse, we don't much care what the mare is like. This is a subject which should occupy the consideration of the Royal Dublin Society, and doubtless it will do so.

For my part, I think it would be a better plan to produce foals from fine, big, roomy thoroughbred mares, well-shaped and tempered, and got by half-bred stallions, than is the present and more popular idea of proceeding by quite the reverse method.

I think it is decidedly a bad plan to breed from a mare that has been worked unduly hard when she was young. So also is it to breed from either horse or mare that is not well-shaped, no matter what might be their pedigree or even performance.

I am not well versed in the pedigrees of horses, and I have not time to search them up, but it strikes me from memory that mares which have been first-class on the Turf do not, as a rule, throw progeny of equal merit, and that it is mares either unknown to fame or of little value that have dropped most of our great horses.

Who knows but the hard work which good mares must endure in early training produces bad effects on their offspring ? Anyway I think the great thing is to get strains that will "nick," and when a man finds a sire to which his mare has foaled a good horse, it seems very foolish to change her to another, except by way of experiment. Yet such is constantly done.

We all wish good luck at the stud to the beautiful and clinking La Flêche; but it will be interesting to watch if she will throw anything nearly as good as herself even if mated to Orme.

If a man goes in for breeding steeplechasers or hunters, undoubtedly his best plan is to select sires and mares which possess jumping blood, just as a "milking bull" is looked for by the proprietor of a dairy.

The breeding we want in hunters is one parent thoroughbred, the other half-bred, but both to be stout-hearted.

Except for racing purposes, to maintain horses in perfectly pure blood is not necessary. In steeplechases a horse with a stain in his. pedigree will win as often as the thoroughbred, while we all know a half-bred hunter is a customer more cut-and-come-again than the pure bred, and he makes a much better hack.

I had only three thoroughbred hunters in my life, and they were the most unsatisfactory horses I ever owned. One, by Giraldus, was a lovely conveyance to hounds for three or four miles, but that was the length of his tether. Another, by Charles XII., I could rever get to the end of, and by himself he was a grand performer, but in company he was a lunatic, and gave me some terrible falls. The third was a very good horse, and a picture to look at, but he was a delicate brute, and could come out only once a fortnight, yet he was got by Bird- 
catcher, of whom he was the image, even to the grey hairs. The Charles XII. horse could trot fifteen miles an hoụr, but he was a tremendous puller and most unpleasant hack. The other two were about the best to stumble on a road I ever saw.

No doubt the majority of our farmers take trouble to properly mate their mares, but there are many who trust everything to good luck. No matter what the mare may be, she will be sent by some of them to the nearest horse whose service can be had at the lowest price, totally regardless of whether he is suitable or not. While both one and other are generally in an overworked state.

We all know that the main principles of the physiological law apply to animals of the lower order equally as they do to mankind, and that sound offspring is more likely to come from robust and healthy parents than from delicate ones.

Physiology, however, has taught us more, and for many a long year has established the fact that the state of the system existing in the parents at the precise time of conception has a most material effect upon the progeny ; and that even in the case of those naturally and habitually sound, if, at that time, they suffer from disarrangement of system, or of temper, the offspring will most likely be affected thereby. It is also well known regarding multiparous animals, such as the dog, that the first conception in the female has an influence upon those subsequent; in short, that the female is likely, in all future conceptions, to "throw back" to the first impregnation. The same rule applies to uniparous animals, but necessarily the effect is not so frequently discerned.

These are facts proved by science, and are therefore incontrovertible. Unfortunately, they are not generally known, and those who are aware of them give little heed thereto. Among ordinary horse-breeders not one in a thousand ever even heard of these great principles of Nature, which are the very foundation of their calling. It is therefore highly important they should enlighten themselves upon the subject, for unless their system be based upon the observance of the principles by which Nature governs procreation, success can't be relied on, nor will it ensue except by mere chance and good luck.

It is manifest, therefore, that breeders of thoroughbred horses should use very great judgment and discrimination in the selection of the first sire they put their mares to. Furthermore, a man should satisfy himself that the mare he breeds from was rot stinted in the first instance to any other than a horse of desirable breed. For my own part if I were in the business I would not give a £5 note for a thoroughbred mare for breeding purposes that had her first foal by a cart or common-bred sire.

In racing we hear a deal about what is called in-and-out running, and at times very strong comments are made. No doubt it is caused occasionally by malpractice, but I am convinced a lot of it is caused by disease, the result of non-observance of Nature's laws by those who bred either the horse himself or some of his immediate progenitors. 
Suffering from these inherent disorders, a horse can never be relied upon to run systematically in the same form. Generally the disease is latent and can't be discerned, much less traced; but all of a sudden, and without apparent reason, he will go amiss. It is therefore wrong to blame a trainer or jockey for a horse running in-and-out, unless there is direct evidence of dishonesty.

It is also well for the public to know, especially those critics and would-be cicerones who at times air themselves in the press, that a horse is not a barrel-organ, which as long as it be ground will repeat the same tunes. They should remember if they ever knew, or learn if they don't know, that horses are in their constitution like men, and equally liable to sudden disorganisation of system by indigestion, loss of sleep, nervousness, change of habitation, diet, and even change of water. That being the case with all horses, no matter how sound they may be by nature, it is manifest that those unfortunates which suffer from organic troubles born in them are all the less to be depended upon. Is it, therefore, more difficult to understand a horse being fit one day and unfit the next, or unfit one month and fit the next, than a man being so?

To the experienced and extensive horse-breeder I don't presume to suggest anything, but to the ordinary tenant-farmer who goes in for breeding a weight-carrying hunter or other good class of horse I would submit the following code: $(a)$ Don't let your mare be stinted in the first instance by any other than a well-bred horse. (b) Never breed from a mare that has had her first foal by a common bred horse. (c) Breed only from well-bred, useful, sound, and well-shaped mares, that have not been overworked as a two or three year old, or kept long in training, and bear in mind that height does not always imply size. (d) Select for your mare a horse which from breeding, conformation, temper, etc., etc., she is most suitable for. (e) Don't put her to him when she is in a state of lassitude, bad temper, or suffering from disease, even though of a temporary nature. $(f)$ The horse should at the time of service be equally free from such. $(g)$ Never breed from either mare or horse which is afflicted with roaring, or other hereditary disease. (h) While carrying her foal give your mare plenty of exercise but no hard work, and feed her well. (i) Feed well also the foal from the time he is able to eat, remembering the old saying that "the best of a horse goes in at his mouth."

If these rules, so simple and so easily carried out, were to be observed systematically by our farmers, I am very sure the best possible results would follow.

As to training their young horses, all the Irish farmers have to do is to stick to the ould plan, and if the English were to adopt it they would not find it a bad one.

We are at times too fond of grumbling, and the habit usually tends to lead us into the idea that certain thirgs are not existing in as good state as they were formerly. This is exemplified in horse-breeding. 
Many entertain the idea that neither the quality nor the number of horses bred in Ireland at present is up to the standard of, say, thirty years ago. I do not coincide with that opinion. I think we have, on the whole, as good class of hunter as ever we had ; certainly he is better bred, and I think we breed as many as ever we did.

No doubt the once great fairs of Rossallagh, Castledermot, Cahirmee, Spansill Hill, Limerick, Ballinasloe, etc., are not now what they were; but that is eaused by the growth of the Dublin Horse Show. Ball's Bridge has become a gigantic horse fair as well as show; and men prefer holding over for it valuable animals rather than sending them to the country fairs. On the other hand, while the old annual fairs have retrograded, Clomnel in the south, instituted years ago by my friend Mr. John Bell, as a monthly horse fair, is, I believe, as great as ever it was; while Moy in the north, for three days in every month, is a gigantic market. At the latter are found of ten over a thousand horses, but I can't say they are of high-class or likely to make good hunters. The north of Ireland men do not go in for that class of horse nearly as much as the southern. I daresay, however, within the next few years we shall see in that respect a great improvement in Ulster through means of the Government stallions.

Seeing the magnificent hunters which are picked up in large quantities in Ireland by dealers like Messrs. Daly, Widger, Morton, McDonald, O'Brien, Donovan, D'Arcy, and several others, it is ridiculous to say we have not still as fine hunters in abundance as ever we had. That we have-and the prices realised are far higher than they were when I was a boy, while the following facts prove that our horses all round are much better bred now than they were then.

In old times the only place the Irish hunter was to be found was among the farmers. To a great extent such is still the case, and long may it be so. But of late years stud farms have sprung up in many parts of Ireland, and although the primary object of their proprietors is to produce thoroughbred racehorses, in many of them are now found tip-top hunters, half-bred, thoroughbred, or with only a stain in their pedigree. By means of these centres great good has accrued, inasmuch as care is there taken that the mares bred from are the right sort.

Mr. Hutton and his brother, of Ligamaddy, county Down, think nothing of giving $1,000 \mathrm{gs}$. for the brood mare they wish to breed from, nor will any fee stop them from mating her with the sire they deem most suitable.

Forty years ago a thoroughbred stallion let to farmers' mares to pro. duce hunters was practically unknown in Ireland. It was only since then they have become plentiful, and I think I am safe in saying Mr. Briscoe of Tinvane was one of the first men who introduced the system. Now we have more than three hundred thoroughbred sires scattered over the country, a great proportion of which are sound and free from hereditary disease, while the most of them are fully qualified to beget aseful progeny, and the fees for service are moderate. 
Manifestly it would be to their own advantage, as well as to the public, if the owners of these stallions used supervision over the mares they allow to their horses, for the reputation of the sire cannot be either made or maintained if the mares be of a bad class, while, if unsuitable mares could not get sorved by well-bred sires, they as a class would soon bə relegated. Most of our stallions are the property of gentlemen of means, who have the interest of our horse-breeding at heart, and it is from them the example should come, the following of which would develop more generally the improvement which I maintain has of late years come over Irish horse-breeding.

I have no list by me, so I can jot down only as they occur to me the proprietors of our Irish Stud Farms, and of necessity I must omit some. However, here follows a gnodly number:-

Mr. William Pallin of Athgarvan, Mr. James Daly of Clonsilla, Mrs. Anderson of Ballymoney, Mr. John Gubbins of Knockany, Mr. John Hutton of Ligamaddy, Mr. N. J. Corbally of Rathbeal, Mr. Hillier of Castleknock, Mr. Charles Blake of Heath House, Mr. William Brophy of Herbertstown, Mr. Mat Maher of Ballinkeele, Mr. R. N. Talbot of Grennan, Mr. J. C. Murphy of Oberstown, Capt. Greer of Crotanstown, Lord Greville of Clonhugh, Sir Charles Coote of Ballyfinn, Mr. John Reese of Civility Farm, Mr. B. B. Trench of Loughton, Mr. J. O'C. Murphy of Breemount, Mr. William Dunne of Ballymanus, Messrs. Widger of Waterford, Mr. Davies of Kilcock, Mr. R. C. Dawson of Cloughran, and Mr. Edmond Smithwick of Kilcreene.

With the exception of the establishments of Messrs. Dunne, Gubbins, Maher, and Brophy, I don't think any of the above were in existence twenty years ago; while many of them can't count ten anniversaries. They nearly all rank as first class, and many of them have no superior in England. In them are from five or six to a score or more brood mares, some half, but mostly thoroughbred, and all possessing every essential for dropping stout foals.

Mr. Gubbins, at Knockany, co. Limerick, has Kendal, by Bend Or, standing at 200gs. a mare. Mr. Pallin for the service of Favo and Mr. Murphy fos Boulevard get 50gs., while Mr. Gordon for Ben Battle gets $30 \mathrm{gs}$. The other sires in these various studs are let out to thorough and half bred mares at from $5 \mathrm{gs}$. to $20 \mathrm{gs}$. Then we have the Government thoroughbred sires standing at $£ 1$ a mare to farmers, and distributed all over the country, together with those other stud farms which I can't call to memory. Of course there are also many men who, although their establishments may not be very extensive, have several useful mares and also thoroughbred stallions. This speaks volumes for the facility which Irish breeders now have for getting at good blood. When, therefore, they flourished so well in the past, what must not be expected of them in the future?

The stud farms at Knockany and Bruree owned by my friend $\mathrm{Mr}$. John Gubbins are the most extensive in Ireland, and few are more so in England. The Knockany Stud was established in 1866 by his elder 
brother, the late Captain Stamer Gubbins. Some fifteen years after the present owner enlarged the establishment at Knockany, as well as that of Bruree, and started a pack of staghounds at the latter place, where he then resided. He laid out an enormous sum of money upon both, the one as a stud farm, the other as a hunting establishment, and intended to live permanently at his native place. Owing, however, to the outrageous conduct of the Land League he was obliged to leave the country, and has since then lived in England, Bruree being turned into an extra stud farm.

The Irish Sportsman gives an exhaustive account of these establishments, from which I see that no less than six thoroughbred stallions are located there for stud purposes, viz., Kendal, May Boy, Lentulus, Ashplant, Ambergate, and Butterscotch. The brood mares number twenty-two and are sired by Solon, Springfield, Petrarch, Rosicrucian, Uncas, Barcaldine, Xenophon, Hermit, Galopin, Ben Battle, Coltness, Hampton, May Boy, Philammon, Victor, and Lord Gough-all out of thoroughbred dams. It would, I think, be hard to find such a collection of matrons in any one establishment.

I remember some five-and-twenty years ago, when Captain Gubbins had at Knockany Uncas, by Stockwell, and Xenophon, by Canary, the fees charged for their service were to gentlemen $£ 10$, to farmers half that sum ; yet these stallions were about the most useful we have had in Ireland within my memory. Their fame would have been even greater had they been let to no mare other than of good class, but their popular owner was so generous and noble-hearted he could refuse nothing, so every mare sent was served whether she was bad or good.

After the death of their owner Uncas and Xenophon were sold to go to England, whereupon their fees were raised to $25 \mathrm{gs}$., and subsequently still higher.

In those days we had other great sires in Victor, Umpire, and Solon, owned respectively by Mr. Harris of Kilmallock, Mr. Ryan of the Curragh, and Mr. Cashman of Donadea; but they stood at 15g. and $20 \mathrm{gs}$. I don't think any other five stallions did more good to Irish breeding during the past forty years. From them descended alike flat-racers, steeplechasers, and hunters of the very first merit. Luskily their blood is still plentiful in Ireland.

With all these facts before us I cannot see how any man can think Ireland is not infinitely better off as a horse-breeding country than ever it was.

Lackaday ! we are not as rich as the Saxons, and cannot afford to refuse selling to them most of our good horses. Were it otherwise we would have in Ireland to-day Ilex, Why Not, Cloister, Barcaldine, Bendigo, Roy Neil, Tibbie Sheils, Roman Oak, Philammon, Kilwarlin, and a dozen more which, as Irish horses have been for the whole century, are mines of wealth in the mother country.

Worst of all is selling out of Ireland the good brood mares. Even to England they should not be sent. As to selling them or first-class 
stallions to go abroad, the law should prohibit, from all parts of the kingdom, such positive insanity !

To allow the practice is to permit an outrage against the common weal surpassed in enormity only by that of allowing our great agricultural community to be ruined by admitting to this country, free of duty, foreign meat and bread stuff. The farmer is the backbone of our nation, and the wily foreigner covets greedily our good horses. It behoves, therefore, both Lords and Commons to adopt protective measures before the one gets broken or the cupidity of the other be gratified.

As the system exists at present, England is for the foreigners not alone the nursery, but the school from which they can choose their horses. John Bull expends, yearly, a prodigious amount of money, subsidised as it is by large grants from Government, upon breeding horses. He takes all the trouble and incurs all the risks. Then when we have produced horses or mares of phenomenal excellence, which, having passed through the dangerous part of their career, are sound and ready-made for stud purposes, over comes some continental gentleman and takes out of the country the very animals we should be the most desirous ourselves to retain! No doubt very large sums are paid for them, but prices equally good can be obtained from our own countrymen, and by selling to them we get the eggs and keep the goose.

To our colonies some of our good horses and mares should be sold, but to the foreigner, most assuredly, I would give nothing except of third or fourth rate class. Elsewhere I allude to the fact that the great Stockwell escaped from transportation only by a fluke.

I look to these stud farms for other good results besides improvement in our horse-breeding. Steeplechases over a natural country, by reason of red-coat point-to-point races, are becoming popular again, and as the proprietors of these farms are all sportsmen, with good position and ample means, they, by their influence and with plenty of horses at command, may, in time, bring back to the old style our grand sport.

When dealing with Steeplechase Reform, in reply to a letter of Lord Howth's in April, 1891, I gave as one of the reasons for the decadence in the sport that we had no men now in Ireland who bred, reared, trained, and raced their horses from their own stables, such as we had in my younger days, and I then gave the names of those I remember doing so-all of whom were contemporaries in racing. In tribute to the memory of those fine sportsmen I reproduce the list, and I trust that before many years we shall have a number quite as great, following the good old example. Here it is :- "Lords Howth, St. Lawrence, Clanricarde, Waterford, Rossmore, and Drogheda ; the Courtenays, Quins, McCraiths, De Burghos, Russells, Gubbins, Aylmers, Sadliers, Bryans, Forsters, Ainslies, Bernards, Moores, Manserghs, Masseys, Magranes, Crokers, Prestons, Westenras, Hoeys, Gartlanes, Goughs, Longs, Harpers, Dunnes, Powers, Studdarts, Persses, Naughtons, Stackpools, and O'Ryans; while 
racing tenant-farmers were to be found over almost every county in Ir Whelans, Ivers, and scores of others."

To go carefully over a stud of good horses or a kennel of first-rate foxhounds, where everything is done properly, is to me a source of great enjoyment, and I never lose an opportunity.

I have visited many such establishments, and, as I said before, I strive at each to gain information. Some, of course, are kept in much better style than others, and naturally a uniformity of quality is not found in the animals. However, with only one exception, I found the stud farms, both in England and Ireland, all that could be reasonably desired. As an example of how things should not be done, and to show what opinions are held by some horse-breeders, I shall describe the place I take exception to. I was shown over it by the proprietor, and it was very extensive.

As I always do, I asked the owner's opinion as to breeding, shape, crosses, etc. He told me that, of course, all depended upon luck (what does not?) ; that horses of every shape won races, and for his part he did not care what a mare's shape was, he would breed from her if she came from a lucky or "fashionable" strain; her yearling, if got by a favourite stallion, would sell weli at Newmarket or Doncaster, even though deficient in shape. Like that famous parrot, I said nothing, though I was thinking a lot, as I went regularly through some twenty boxes, containing brood mares, or mares and foals, and looked over nearly as many yearlings in the paddocks.

Everything I saw was bad. Old tumble-down stabling, dirt and untidiness everywhere; the mares and foals were housed in badly ventilated, overcrowded stalls or sheds. The hay in the rick which supplied the racks was most inferior in quality, and quite musty, while the bedding was of furze, ferns, and rushes in such a beastly state of dirt that it seemed in proper condition for top-dressing a field.

This practical breeder seemed to consider that the bone and condition of his animals should be easily seen, and certainly I give him credit for carrying out the idea with uniformity, for in every one of the forty odd animals, the one was high and the other low.

No doubt they were purely bred, and all are in the Stud-book, but, as I have said, they were badly cared for, and from their looks were badly fed, nor was one of them what could be called a really trueshaped animal, not even the two stallions he had.

I trust there is no other such establishment in the kingdom, for I do not think it could be possible to rear any horse, much less a thoroughbred, sound and healthy, at such a place. Yet it and its owner are wellknown, and the prices got at Tattersall's sales for yearlings sent therefrom show at times a very good average.

Astonished at the bad shapes of some of the brood mares, I asked the pedigree of one with a miserable foal at foot. This turned out to be one of the purest strains of the fashionable blood this breeder so 
much appreciated, and he had bred from her for three or four seasons. Pretending to be struck by the particularly high tint of cerulean blue which circulated through this mare's blood, I took out my pocketbook as if to copy it, but in reality to take down what I thought of her shapes. Here is the entry: "Big head, ewe neck, straight shoulders over long cannon-bone legs, pretty good ribs and centre piece, narrow across the loins, her propelling power being from hind quarters short from hip to hock, and long from hock to heel. Though ten years old, her feet are some of the smallest I ever saw, and very shelly. She looks half starved." I was told this mare won great races in good company, and I took it for granted she did.

I need not say that I did not hold the opinion of this breeder in any way. I am very sure that an ill-shaped yearling would command only a poor price at either private or public sale, no matter how full of running blood its pedigree might be. No doubt the matron described had won good races, and I am aware that leggy horses are often the speediest, and that length from hip to hock is not necessary over short cuts. Racehorses that are moulded on hunter lines, which stand on short legs, are sometimes slow, but nine good racehorses out of ten are certainly good-looking, though what is known as a "three-cornered devil" will occasionally win races.

This breeder would have been correct if he had said that in no breed of horses is there to be found so much bone in proportion to flesh as in the English or Irish thoroughbred, and that horses of every class and size won races. Look at Watercress, a great raking horse nearly seventeen hands high, and likely to grow into an animal capable of carrying any weight; he is able to win a five-furlong sprint in the best company, and can get away from the slips as fast as can his tiny but tidy stable-companion, the gazelle-like $\mathrm{La}$ Flêche, the best mare we have seen in England for many a year.

To the Royal Dublin Society are we indebted for the Dublin Horse Show held annually, in August, at Ball's Bridge. I shall, therefore, give a short history of the Institution. The better to effect my purpose I reproduce from the Irish Times some of what it says when dealing with the Show held on the 22nd to 25th August, 1893 :-

The Royal Dublin Society is the oldest institntion of its kind in the world, having been established as far back as 1731, in which year fourteen citizens of Dublin met in the rooms of the Philosophical Society, Trinity College, to consider in what way they could " best promote improvements of all kinds." Those who attended at the meeting were Judge Ward, Sir Thomas Molyneux, Thomas Upton, John Prall, Richard Warburton, Rer. Dr. Whitcomb, Dr. Stephens, Dr. Magnaten, Dr. Madden, Dr. Lehunte, Thomas Prior, Arthur Dobls, William Maple, and William Walton, and on June 25th, 1731, which was the date of their meeting, it was agreed to form a Society, to be called "The Dublin Society for improving husbandry, manufactures, and other useful arts and sciences." To trace the history of the Royal Dublin Society from its inception down to the present day, 
uring which period it has effected a wonlerful amount of good, would ccupy more space than could be given in the columns of a newspaper. Nor is it necessary in this instance except as relates to the Horse Show. We may state, however, that Arthur Young in his "Tour in Ireland," published in 1780, says :-- "Great honour is due to Ireland for having given birth to the Dublin Society, which has the undisputed merit of being the father of all the similar societies now existing in Europe." Towards the end of 1867 or early in 1868 the project of holding a horse show on an extensive scale was mooted, for long before was seen that horse-breeding was one of the great industries and resources of the country, and the upshot of the movement was that a committee of the Royal Agricultural Society, which had been formed for the purpose of holding a "National Horse Show," obtained permission from the Royal Dublin Society to hold the Show on the premises. of the latter in Kildare-street, and there and then the Royal Dublin Society undertook an annual horse exhibition, and appointed a committee consisting of twenty-five members to carry out the project. Without money nothing can be done. Money was the obstacle in this case. It was forthcoming in the shape of a public subscription, which appeal met with a liberal response. In addition the Council voted $£ 100$ to the fund. The first Show was held in Kildare-street on July 28, 29, and 30, 1868, when the entries numbered 368. At the time the promoters deemed this a huge success. And so it was for an initial attempt, yet how diminutive do the figures read compared with yesterday's totals. The payments for admission amounted to $£ 583$, which affords proof of the fact that from the outset the idea of a National Horse Show caught on with, at first, the Irish people, and subsequently with those resident in distant parts-even in foreign parts. There are, no doubt, some who will, after glancing over these remarks, say, "Ol, we knew all this before; tell us something we don't know." On the other hand there are thousands-strangers to our city-who are not acquainted with the history of Ball's Bridge Shows, who are ignorant of the importance of Irish horse-breeding, and the benefits that follow not merely Ball's Bridge, but provincial shows. Well, the gate money taken at the first venture was $£ 583$, and since then it has grown and developed so rapidly that it is now not a head or a neck, but a Sackville-street in front of any other similar institution in the world. There is only one horse show in the world-Ball's Bridge. None other can with it compare. In the inaugural year, that is in 1868 , the value of the prizes given was no less than $£ 470$. We have here evidence of liberal treatment from the outset. Large as that sum appeared at the time it was small as contrasted with the $£ 1,729$ to be doled out on the present occasion, exclusive of numerous valuable cups. The last show was held at Kildare-street in 1880, and in that year the entries numbered exactly 600 . The growth of the show was so great that its promoters were compelled to look for new grounds, which were found at Ball's Bridge, fifteen acres of land having been purchased from Lord Pembroke, but even this was found insufficient, and ten additional acres were purchased. Still the requirements of the show grew on so steadily and rapidly that in 1891 a further extension of space was found necessaly, and additional ground was purchased from Lord Pembroke, making a total area of thirty-eight acres, the buildings on which cover five acres, and represent an expenditure of $£ 50,000$. The permanent halls and stables at Ball's Bridge now provide comfortable accommodation in the way of stalls and 
loose boxes for 1,350 horses, and now a branch of railway has been run on . to the front of the premises. This, we need not say, is a great boon to exhibitors, as it saves then the risk and bother of getting valuable young horses full of exuberant spirits throngh the crowded streets of the metropolis. In the first show held at Ball's Bridge there were only 589 competitors in the varions classes, while the attendance-ascertained for the first timewas 17,736 . Then, in 1982 there were 694 entries, with an attendance of 14,973 ; in 1853 there were 733 entries, and 19,980 visitors; in 1854 the entries numbered 806 , while 26,558 persons paid for admission, and the latter attendance was not reached again until 1857 , when the entries stood at 950 , and the attendance reached 26,244. In $188 s$ the entries totaller 1,051 , while the attendance reached 32,534 ; in 1859 the figures were-entries 1,075 , attendance 36,711 ; in 1890 - entries 1,324 , attendance 43,438 ; in 1891-entries 1,322, attendance 46,083; in 1892-entries 1,304, attendance 53,547 , or nearly four times larger than it was eleren years ago. These figares prove the yearly increasing popularity of the Show, which has become quite an international gathering so far as the visitors are concerned. The entries this year are 1,200, or about a hundred less than last year. The trivial faliing off can be accounted for in this way. Numbers of provincial shows have been held throughout Ireland during the past few months, and the dealers purchased scores of high-class horses which would otherwise come to Ball's Bridge. Again, owners of middling or rubbishy horses must have learned by this time that Dublin is the wrong place to bring them to at very considerable cost. Some years ago it was nothing unusual to see a lot of moderate horses in a big class, but this is certainly becoming a thing of the past. There is no gainsaying the fact that as well as "licking creation," as our friends across the Atlantic would say-as regards our great equine gathering we can defy all competitors so far as the production of weight-carrying hunters-a fairly large number of which we saw and almired yesterday-is concerned. There are a number of causes to account for this. In the first place we are blessed with an even temperature in our climate, as there are no sulden transitions from heat to cold or vice versa. The soil is for the greater part a limestone one, and it is a well-known fact that on no other soil will young horses develop so much bone. Undoubtedly, the Royal Dublin Society has effected a great deal of good in its laudable efforts to improve the breeding of hunters in this country, and it is evident that if it received adequate financial aid from the Government, it could do a lot more in the way of improving the breeds of huuters, remounts, and useful horses. Another great good effected by the Society was that it has educated the people into the importance of breeding from sound stallions.

With every member of the executive committee doirg his best to promote the interests of this great Irish institution, and bringing our Horse Show to the proud position it holds, and where among the members perfect harmony has always prevailed, to make mention of one more than another, perhaps, may not be fair. But, as in all bodies consisting of so many members, some few must, of necessity, take the lead, I don't think I can be found fault with when I name among the formost my old friend and townsman Mr. Samuel Ussher Roberts 
with Messrs. James Talbot Power and James O'Reilly. To these gentlemen is the nation at large, and Ireland in particular, indebted for the success which has attended the Dublin Horse Show. It was by reason of their ability, sound practical judgment, and thorough knowledge of the requirements that the principal improvements were brought about. While in carrying out the details of the working their powers, both administrative and executive, never tired.

The Royal Dublin Society has ever been non-political and nonsectarian, and, needless to say, nothing pertaining to "party" is associated with the Dublin Horse Show. Withal, it is a curious fact, and one suggestive to an eminent degree, that throughout the long history of the Society and the comparatively short history of the Show, both one and other have been supported solely by that section of Irishmen which all along represented wealth, social position, and adherence to constitutional principle.

Patriots, in the only real and true meaning, have the members of that section always proved themselves to be, and may dawn never open the day on which they will be supplanted in my own dear old country! 


\section{CHAPTER VI.}

\section{THE BUYING AND CARE OF A HUNTER.}

Theoretical Instruction Useless-"An Eye"-A Verse-Buy from a Dealer-But better Buy from the Farmers-Buy when you see what suits you-Horses go well in all shapes-Author's Horse, The Squire-Well "balanced" Horse-Minting-Head and Neck-Hint to Verdant Green-Would-be Sporting Artists-Wine and Horses-Judges of Horses-Medium Class-Long Tails-High Class-Daly, Darcey, Widger,McDonaldJudges of Wine-An Extract-Care of a Hunter-Only for Owners of Small StudsJorrocks-Construction of Stable-Clothing-Clean Litter-Feeding-Buying Oats, etc. -Buy from Farmers clirect-Storing Oats-Watering Horses-Staling-Drink during a Run and after Work-Jogging Home-Stable Preparation for Horse Hunting-Treatment after Hunting-Doing him up-How to Feed him-Horse's TemperamentsNatural $v$. Artificial State-Long Fasting-Wash his Yard-Exercise-PhysickingFiring, Blistering, etc.-Sea Sand, Turf Mould, etc.-Summer Treatment-Preparing for Hunting-Beans-Condition-Ages of Grand National Winners-Aged HuntersComparative Age of Horse and Man-Clipping-Shoeing-Different Sorts of HoofsThe Frogs-Contraction-Corns-Pressure on Soles or Bars-Removing a ShoeIgnorant Smith's v. Nature's Law-Cats, Goats, and Dogs in Stable-Hard Pullers -Bits-Ladies' "Hands"-The Groom-A Tip on Lunging-Readers' v. Author's Experience-A few Useful Recipes.

How to choose a horse is a matter upon which no man can instruct another unless the pupil has naturally an eye for form; if he has not, he need not expect ever to be able to buy on his own judgment, except by chance, a horse that will please him, or turn out well. No one can be taught on paper how to judge or choose a horse, it would be as easy to teach him on paper to ride or drive. Nor will experience much help a man who has not the natural "eye." I have known men, though having dealings with horses all their lives-ay, Masters of Hounds, too-who knew very little about their points (or those of a hound either).

Everyone knows a horse should have sloping shoulders, good legs, back, and loins, quarters well let down and be well topped-in fact, everything good; but let me see the man who can teach in a book what these essentials are. Fancy a lexicographical definition of "wellribbed-up"!

A head like a snake, and a skin like a mouse,

An eye like a woman, bright, gentle and brown;

With loins and a back that would carry a house,

And quarters to lift him smack over a town!

Unless a man is a good judge and has plenty of money I am of opinion he will suit himself better, more cheaply, and with far less trouble by entrusting the purchase to a respectable horsedealer than he will by trying to pick up what he wants (or thinks he wants) himself. Let him go to his dealer and tell him what he requires, and the price he is prepared to pay; then depend upon it he will not long remain unsuited. 
A dealer knows every horse in the country, and, being a good and practised judge, will not buy anything but a "useful one," which he can do 20 per cent. cheaper than the tyro, or even the gentleman who knows a horse. This leaves the dealer a profit sufficient to enable him to sell to his customer at or under the price the latter would have had to pay the original owner. Then, again the buyer has only to go to the dealer's yard to suit himself, instead of going about the country or to a lot of fairs ; and if he does not like his purchase the dealer will, as a rule, exchange it until he is suited. A man buying his horse in this way obtains the benefit of the matured judgment of the professional, plus whatever gumption he himself may possess.

At the same time, a man who is a good judge and knows what he wants should, as a return for the sport he allows so many to enjoy, buy his horses direct from the farmer whenever he can, and, as I said in a former chapter, pay liberally. Moreover, he will have a better chance of ascertaining correctly the breeding, for the chances are the farmer has bred the horse.

When a regular hunting man, with good means, sees a horse that suits him he should buy him, even though he may not actually want him. He may not be able to get one when he does, and it takes a long time, sometimes, to get off selling condition and get on that required for hunting.

Horses go well in nearly all shapes. The best I ever had was apparently very deficient in some points. He had beautiful shoulders, and trotted from them with grand even knee action, but he was a trifle calf-kneed. He had great depth of heart, but ran slack behind the girth, which gave him a "tucked-up" appearance when in hunting condition; and his back was only fairly good. His quarters were not equal to his shoulders, but they were well let down, and he had grand ragged hips. His hind action was decidedly not good in trotting, but like many another good one his hosks nearly touched each other in that gait, but when he galloped the hindlegs came well to the front, giving powerful impetus, and when changing on our big Irish doubles he kept them wide apart, which gave a fulcrum equally powerful. He was wonderfully game, with a grand constitution, and he loved his work. No matter how hard was the day before, he would come out of his stable the next morning prancing and neighing. He was got by Full-cry, a thoroughbred horse by old Harkaway, and out of a mare by Priam, winner of either the Derby or St. Leger, a pedigree which, perhaps, made up for his deficiency of shape. He carried me for seventeen seasons, I paid only $£ 45$ for him, and he was called The Squire.

We have all had in our time our "favourite hunter," but, like other favourites, he to a great many does harm. If a man through preferential riding gets unduly accustomed to one horse, he often finds it difficult to go as well upon others, and in many instances loses his nerve altogether when put on a strange mount, although he may go like a bird on the horse he is accustomed to. I would therefore 
advise men having small studs to change them frequently, and those with large ones to ride each horse in his turn.

A horse should be what is called well "balanced"-i.e., his middlepiece, hind and fore quarters should all be as nearly as possible of same dimensions. I have heard that Landseer made three equal orals on his canvas before drawing a horse, and then filled in. I have a notion that a horse so proportioned, with his shoulders sloping and his quarters well let down, would be just about as safe a conveyance orer a country, or returning home tired along a rough road on a dark night, as most men need wish to possess-provided, of course, that he had good manners.

If I were to name a horse the most perfect in shape which I have ever seen I should name Mr. Vyner's Minting. In that great horse is depicted what true shape and perfect "balance" is. If he were to be dissected from the point of the shoulder to the elbow, and from the point of the hip to the stifle, there would be left the three portions of his body as equal in weight as perhaps are those of any other horse at present in the kingdom. He stands 16 hands lin., measures $9 \frac{1}{2} \mathrm{in}$. under the knee, and girths $6 \mathrm{ft}$. $4 \mathrm{in}$. He is up to $17 \mathrm{st}$. with hounds and his weight arerages $11 \mathrm{cwt}$. 2 qrs. From his breeding and his own prowess he is, of course, eminently calculated to beget racehorses of the first water, provided the mares put to him be of the right sort, and from his conformation no horse which I ever saw appeared to me more fitted to beget weight-carrying hunters.

I like a horse with plenty of room in the gullet and a head loosely seton, sufficiently to allow the fore and middle fingers to be run down between the jawbone and neck. At the same time, this sort of head must not be set on a neck unduly long in the windpipe, for, if it is, the chances of roaring and ultimate broken-wind are greatly increased.

Without attempting to describe the good points of a horse, let me advise "ingenuous youth" to keep clear of a horse with a light mouth, ewe neck, and straight shoulders, particularly if he possess strong propelling power, has white in his eye, and is, say, a chestnut. The verdant sportsman is not, however, to take it that a heavy mouth, ram neck, and crooked shoulders are desirable simply because they are the opposite of those points against which I caution him !

No matter how clever an artist may be with brush or pencil, he cannot make a proper portrait of a horse unless he be a good judge of his points; neither can he paint or draw any sporting subject without a practical knowledge of it, as many of the ghastly productions of the day so eloquently prove. How can a man draw a coach and four without knowing how the horses should be tackled? And if he puts a man on the box, how can he represent him unless he can drive himself? If possible, the cloven foot is shown more strikingly when a landlubber attempts a sailing scene or a Frenchman a fox-hunt. The man who at present is about the very best painter of a hound in the kingdom owes his reputation to having been taught the true formation of a foxhound 
by one of the best judges of hounds in England upon the flags of his own kennels in Yorkshire.

There exists a somewhat curious similitude of principle observable in the buying of a horse and buying of a man's wine. Most men think they know all about horses and wine, whereas a really good judge of either, much less of both, is seldom met with. There are many classes of horse and kinds of wine, with various qualities in each sort, the price for the higher being run up at times far beyond their value. Men, although they may not be good judges all round, generally know pretty well what wine and what horse will suit them in the class they generally use, but to do so they must have a correct palate for the one and a correct eye for the other.

A Master of Hounds, used to buying ready-made 15st. hunters, to carry himself, at from $£ 100$ to $£ 200$, and 12 st. horses to carry his men, at half the money, will acquire an eye for those two particular stamps, and be able to pick out very accurately what he wants; but ask him to choose the best colt out of a drove of "long tails," or the one which will make the best weight-carrier out of a number of half trained, out-of-condition four-year-olds, and he may be quite at sea. The same man may be quite as much out of his element among a lot of really very high class hunters. He will be lost in admiration of their symmetrical shapes, their even action and perfect manners; while, if he sees them schooled, he can at once pick out the best performer. But let him price these horses for the market. How can he tell, when they are all so apparently perfect, which is the one worth $£ 250$ and the one worth, maybe, £500? But ask Mr. James Daly, Mr. Giles Darcey, Mr. John Widger, or Mr. Edward MrcDonald to look at them, and they will very soon classify them, simply because their natural eye for form has been trained by long experience of this class of horse. So it is with dealers who buy the yearlings and the youngsters; no matter how unkempt and untrimmed, they can pick the best. And, perhaps, the man who buys the finished hunter, fit for Rugby or Leicester, may "put his foot in it" when he goes among the soft ones.

So precisely it is with wine : the man who is accustomed to a certain class will, if he has a correct palate, tell correctly enough which among the lot is the best value; but if put out of the class to which he is accustomed, he will be in just the same fog as the man among the horses. Still we often hear men accustomed only to beer and whisky pass judgment upon high-class claret and champagne. Even a merchant accustomed only to select wines in their crude state can know nothing about the fine old matured stuff, unless he is in the habit of using it at his own dinner table.

Since writing the foregoing I read in The Horsebreeder a practical and sensible article upon choosing a horse, so I reproduce it.

\section{HiNTS ON HoRses.}

Some men are said to be born with an eye for a loorse, some to have an instinctive idea of shape, but this is the exception, and, as a rule, study is 
necessary to all in order to acquire sufficient judgment to be relied on. Experience is too often bought by loss and disappointment.

When you meet a horse that at first sight appears suitable to your purpose, showing the general character and qualifications, and having ascertained his price, made conditions as to soundness, and tested his movements in the manner I advise, you may proceed to

\section{THE LOOK ALL OVER.}

Here I will introduce one of my most important golden rules, which buyers should commit to memory :-

A horse's power and value must be measured by his weakest points.

A well-known writer reminds us that "the strength of a chain depends upon its weakest link," and this is truly applicable to the horse, whose worth must be estimated by his weakest point. No matter what a lorse's performances, appearances, or merits may otherwise be, you must reject him for one bad fault. Horses are usually selected for their good points, prominently brought forward by the seller. This is the mistake, and the trap into which the best judges, being carried away by a horse's superior merits, too often fall. Then, in looking at a horse with the eye of a purchaser, you must seek first for his defects, not perfections, which, though unusual, is the safest course to pursue.

A horse takes two looks. The first or general look, by which you take in at a glance his outline and character, clirects the centre of vision about the top of the shoulder or withers; symmetry and good conformation, economy of power, and harmony in his component parts, being what you should look for. This first look should give you a fair impression of the horse's height, power, bone, breeding, and quality, as also his length and breadth, the first being essential to speed, the latter to endurance. A horse should be well proportioned, with an equal balance of power all round. If a horse has a long, powerful, or ponderous forehand, he requires correspondingly powerful hind quarters, which if light, the propelling engine not being equal to its work, the machine soon breaks down. On the other hand, if the fore legs are weak, they will soon give way under the excessive propulsion of powerful hind quarters. The duty of the fore quarters is simply to support the equilibrium of the machine. As is often the case, a horse may have good fore and hind quarters, yet have a defective or light "middle piece" or boiler which supplies the steam that cannot be got up without a good firebox to hold the fuel, and a horse with a light carcase is generally a bad feeder, and cannot stand work. The utility, then, of the equus caballus depends upon his symmetry and wellbalancerl conformation.

A horse should stand well, and much of the character of his movements may be judged even while he is at rest. As he stands he walks, and as he walks he gallops. The weight of the body should be evenly distributed over the limbs, and the forelegs so placerl that a perpendicular line erected at the point of the toe should touch the point of the shoulder. The hind legs ought to be well under the body, but not too far in or over-weighted, impering their freedom of action. As it is so important to observe if a horse stands well and firmly on his legs, he should be placed for this purpose on level ground and allowed to stand naturally, not as they are 
usually shown with the fore legs in an elevated position, and made to stretch. Dealers, grooms, and showmen in sale yards invariably adopt this show pose, not always to a horse's advantage, particularly when he is "calf-kneed" and his hind legs are naturally "too far away from him." It is a mole of disguising such defects as straight fore legs, being "bakerkneed," or standing over, and hooked hocks, etc. This position is deceptively complimentary to a horse naturally low before, giving him better carriage and forehand, making him appear to cover more ground, taking from his leight if leggy, lowering the hips, and thus raising the loins, levelling the back, and making the shoulders look more oblique. A horse can in this way be got to measure at least an inch under his true height, an imposition sometimes recoursed to in selling horses to match, etc. You must therefore insist upon a horse being allowed to stand naturally, when his very attitude and the position of his legs may betray his weakness, and point at once to well-known diseases and malformations that will render further inspection unnecessary.

I now come to describe how to take care of a hunter, a matter much easier dealt with than choosing him.

My observations on this subject are only intended for the information of owners of small studs, such as I once had myself. I would not presume to make suggestions to a swell with a large stud, and still less to that greater swell-his stud.groom!

Jorrocks tells us it was either Walter Scott or little Bartley the bootmaker who said that "there was no young man wot would not rather have a himputation on his morality than on his 'ossmanship," and goes on to remark, " and yet how few there are wot really know anything about the matter. Oh, but if hignorance be bliss'ow'appy must they be!"

While allowing the grand old fellow his own rate of discount for exaggeration, we can, of course, knock off from the above assertion a large percentage, but even then we shall have a big balance. I don't assume to know as much as other people about horses or how to take care of them better, but not being quite as big a dunce as the friends of Jorrocks appear to have been, I may be permitted to say a few words about care of hunters, and as I had two or more at a time for nearly five-and-twenty years, was always my own stud-groom, had them well and fit, and seldom employed a veterinary surgeon, my methods of treatment could not have been bad.

I always kept my horses in roomy boxes, about $14 \mathrm{ft}$. square and as many high (if $20 \mathrm{ft}$. high so much the better, as they cannot have too much air and ventilation). Box stalls of greater are than $14 \mathrm{ft}$. square are dangerous, for they give room for gambolling, in which a horse, when fresh, indulges, and so often slips up. Be careful to avoid draughts, and equally so to supply a constant current of fresh air. Have your stable floor so constructed that the urine will flow off at once. Don't overclothe horses, but, of course, have them warmly clothed in winter after clipping, while exercising the same care to ensure plenty of good, dry, clean litter. 
Feed regularly-rarenous horses three times a day, the delicate four times. Give each as much good sweet old oats as he will eat, and when doing strong work a large handful of crushed two-year-old beans in each feed. A mash of bran, potatoes, or turnips should be given twice a week to keep their bowels right; very little hay, and that of the best. Don't give more at a feed than the horse will eat and finish with a relish. Try to make each horse, when in hard work, eat on an average at least 14lbs. of oats a day. Give every day one or two raw carrots whole, not chopped.

Salt, to assist digestion, is as requisite to animals as it is to mankind, hence they should be supplied with it ; therefore keep always a piece of rock-salt in the manger for your horse to lick.

I think well-saved hay of the previous summer may be given after Christmas, as old dried-up stuff has no nourishment in it. Oats should always be from six to eighteen months old, and should be quite sweet. The former season's oats may be given in April. If you have to buy from dealers, lay in your supply about June or July, before the new corn comes to market, or you run the risk of getting the new mixed with the old. Be sure it is fresh threshed, and not kiln-dried, and let it be turned well from one end of the loft to the other, at least once a week, and always have plenty of fresh air about it. It should not be heaped more than six inches deep, or it will get musty. But the best plan if you do not grow it yourself is to buy the oats from the farmer, and let him send it to you fresh threshed from the stack as you want it.

I seldom see hay what I call properly saved-that is, before it has lost all its greenness, and while the sap is in it. Farmers are fearful of its "heating" after having been ricked, and, therefore, they leare it until it has got quite dried up before bringing it to the haggard; whereas, if proper care and trouble were taken to have the meadows cut only in hot weather, and then save the hay quickly, our horses would have it nice and sweet even when it would be two years old.

Let a horse have water always in his stable to drink when he likes. Nothing is so unnatural, and consequently bad, as to let him get ravenously thirsty, and then suddenly charge his stomach to excess. Let him take what he desires before leaving the stable when going to hunt. This will be perhaps nine or ten o'clock, and as he will not have a run much before twelve, or maybe one or two o'clock, it will be all absorbed long before then. Let him take a few "go downs" of water during the day, or during a long run, just to refresh him. Let him stale as often as he likes while out, and if he does not do so bring him under cover and spread straw under him, or otherwise induce him, for many horses will not stale out of doors.

When the day's hunting is over, if you have a long ride home, go to a farmhouse and make your horse a good big drink of flour or ground oatmeal and water. If he is very beat slip half a glass of whisky into it while he is drinking. If you put it in beforehand and he smells it he 
will not take it. Do not give him whole oatmeal, for if not steeped beforehand it is likely to give colic. Then jog him home at five miles an hour. Nothing is worse than walking him slowly or trotting him fast after a long, hard day, unless it be to leave him shivering in the cold while you go into a friend's house to regale yourself.

Before twelve o'clock on a hunting day let your man put a quart of good old oatenmeal into a bucket, and on it pour as much boiling water as it will take up; put a cover over the bucket and leave it beside a fire till the horse comes home. Let the man also put a feed of oats into another bucket, with as much boiling water as it will take up, cover over the oats with dry bran about four or five inches deep, and leave it also beside the fire till the horse returns.

Directly the horse comes home have cold water put to the bucket of oatenmeal, and let him take a good drink of strong gruel, not lukewarm, as some people give it, which is as little refreshing to a thirsty horse as it is to a thirsty man, but with the chill only taken off. When the man goes for the gruel he should take advantage of the opportunity to mix up the bran and oats well together, and let them soak till the horse is ready for them. Then, leaving his saddle on, let him be washed down from head to foot as quickly as possible. Scrape the heavy wet off immediately and put on his clothing and bandages, but don't wisp or further clean him till next day. Let him eat hay during this proceeding. In fifteen or twenty minutes he will be quite dry; then let the clothes be removed and dry ones put on, but do not take off the saddle till the perspiration has completely dried up.

All this should be done in a spare stall. When finished, bring the horse into his box-stall well and deeply littered with fresh clean wheaten straw, let him roll if he will, and drink from the bucket in the stall as much water as he chooses, and then give him the scalded oats and bran. Put on dry bandages, and, if late, leave him to rest for the night. It is a bad thing to overload a horse's stomach after a long day's fast, therefore, unless he comes home early, I would give him only the one meal at night. He will feed all the better next day.

A smart groom will, by adopting this method, have his horse comfortably done up for the night half an hour after he comes in, unless he is a fretful beast that "breaks out."

If a horse does not eat the scalded oats readily, give him a mash of boiled potatoes, which he is sure to eat. When fatigued, and after long fasting, he will not eat hard dry oats with nearly the same relish, nor will he digest it so well as the nice warm soft preparation which I describe. If he has endured cold or wet, flaxseed well steeped for four or five hours, and mixed with his mash, is a capital preventive against coughs.

There are, of course, horses of such peculiar temperament and fastidious taste that the foregoing treatment may not exactly suit, but they are the exception.

Though a horse can drink a great deal at a time when very thirsty 
and absorbs the water rapidly into his system, his stomach is very small, and cannot contain much food, but this he digests very quickly also. In his natural state he would be constantly feeding, but in the artificial or unnatural state of training or hunting condition, we have to act as best we can to lessen the evils attendant thereon. Anyway the more he eats the more work he will do. I think the fasting consequent upon a long day's hunting much more frequently knocks up a horse than the actual work he does.

A horse's yard should be drawn, and it, with the sheath, washed with soft soap and warm water once a fortnight. Allowing this part to accumulate dirt often impedes free discharge of urine, and consequently causes kidney derangement.

Physicking is old-fashioned, and often much overdone. If a horse's feeding and exercise be properly attended to, very little physic, as a rule, is necessary. Of course, at times it is required; for instance, if an accident suddenly throws him out of work, and his usual routine is upset, or if he gets surfeited in any way, he probably will require a light purgative. When it becomes necessary to physic, the horse should be carefully "prepared "with bran or other mashes, and he should not get the purgative ball until his dung has lecome soft, when a much smaller dose of aloes produces a better effect, with less injury.

As soon as the hunting season is over, look to your horse's legs, with a view to firing, blistering, or charging where such is required, but don't follow the old plan of blistering and charging when it is not required. If you fire a horse he should have at least three months' rest from any severe work, to give him a fair chance of coming round again. Those not fired or blistered should have their regular long walking exercise in the cool early mornings.

Sea sand, or dry turf-mould, is very good for a horse to stand on in the day time in summer, as it serves the feet. Some people recommend the bare pavement, but I never tried it.

Give from 7 to $10 \mathrm{lbs}$. of oats a day; 10 or $12 \mathrm{lbs}$. of hay and some nice fresh clover or grass as soon as it can be got. They may get this up to the end of July. A hunter should never le let out of condition. I don't think he can be got back under two years, if once allowed to fall completely off. He is unlike a dog, which can be got into the best and hardest condition in a few months. For that reason it is obvious a hunter should never be turned out on grass.

Light harness work in a four-wheeled trap, where the weight won't come on his fore-legs, will do a sound-legged hunter good in summer; and gentle ploughing or harrowing in light ground will serve "dickey" legs. No carting or two-wheeled work. Towards the end of July knock off the grass, reduce the daily allowance of hay, and increase the oats and exercise. Long walking, and trotting up hill in deep ground, with an occasional pipe-opener in clothing-but little galloping is required-will get him fit and well by the first week in November. Don't give your hunter long days before Christmas, but try to have him 
back in his stable by three or four o'clock, thus getting him into his work by degrees. A severe run or long, fatiguing day before a horse is quite fit does more harm than five such when he $i$ s fit.

Don't give beans till he begins regular hunting, as they are very stimulating and heating; they should be given crushed and never be less than two years old.

Of all the requisites for getting through a long and severe run with hounds, there is nothing more essential to the horse than condition. It takes a long time to get him thoroughly fit, hence it is that as a rule horses under five years old are seldom found at the end of a severe run, simply because those younger have not had sufficient time to get into tip-top condition; they crack up when the pinch comes, no matter how game, clever, or well-bred they may be, or despite how artistically they may be ridden. The Grand National, since it was established in 1839, has never been won by a four-year-old, was won only four times by a five-year-old, and twelve times by a six-year-old. How foolish, therefore, is a man when he thinks he can have satisfaction with a horse, not to speak of a stud, which he buys just before the hunting season-unless he happens to buy out of a stable of oldseasoned horses, which, obviously, he seldom gets the chance of.

There are a great many, and first-flight men too, who don't care about riding seasoned hunters, but my experience has shown me that it is after he has become "aged" that a horse attains his prime. It is then he has taken his degree with hounds, and it is then, after years of good hard feeding, he has acquired the condition requisite to carry him through a trying run and sustain a long day's fasting.

I think the age of a horse may, like a man's, be divided into seven stages, and I compare the two as follows :-

Foals and 4-year-olds to children and schoolboys

Horses of 4 to 5 years old to youths of 18 to 20

$\begin{array}{crrrr}, & 5 \text { to } 6 & ,, & \text { to men of } 20 \text { to } 25 \\ ,, & 6 \text { to } 7 & ,, & ,, & 25 \text { to } 30 \\ , & 7 \text { to } 11 & ,, & ,, & 30 \text { to } 40 \\ , & 11 \text { to } 15 & ,, & ,, & 40 \text { to } 60 \\ , & 15 \text { to } 20 & ,, & ,, & 60 \text { to } 50\end{array}$

A man for hard work is in his prime between the age of 30 and 40, a horse from 7 to 11, providea that each have had fair play in their youth.

Of course hunters must be clipped, but the hair to above the knees and hocks should be left on to protect the legs from injury. So should the part under the saddle. Then if the saddle fits; is properly stuffed, and a leather-cloth used, the danger of sore backs is reduced to a minimum, provided the saddle be not removed till the perspiration has completely dried up.

Shoeing is a source of great trouble at times, and there is nothing to which a man should pay more attention, for there is not one 
farrier in twenty who knows anything about the proper principle of horse-shoeing.

On no account must a smith be allowed to pare the frog or cut out the angles between it and the bars. This they are always fond of doing, for the purpose, as they say, of "opening the heels," and so prevent contraction! Nothing causes contraction so much as this very operation. Neither should they be permitted to apply a rasp to the outside of the hoof, and with still greater care must the sole be saved from their villainous knife. Nature provides horn for the protection of the foot against accidents, hence the stronger and thicker it grows the better, and the frog is there to lessen concussion; thus if a clumsy, ignorant smith cuts and pares them away to make his job look neat and clean, of course he weakens what Nature means to be strong, and thereby does great injury. Depend upon it, contraction, corns, and disease in the foot are almost invariably caused by shoeing.

Horses' hoofs, as everyone knows, vary greatly in shape and in subtance, but, with the exception of the shelly and brittle hoof, I think one may be just as sound and good as another, provided it is as Nature, not shoeing, has given it to the horse. The brittle, shelly hoof must be made tough and strong by such applications as Clark's Hoplemuroma, or it will be a fruitful source of trouble and annoyance, by reason of casting shoes and so making bad worse. The "muley" foot is said to be the most liable to concussion, to generate navicular and other disease, and is most susceptible of contraction; therefore plenty of room must be given at the heel so that the frog, by ability to perform its natural function, will be enabled to counterbalance the effects of the natural deformity (so to speak) of the "muley foot." The flat, splay foot should be guarded against pressure of the shoe on the sole, by carefully bevelling the shoe. The large, round, tough, strong hoof, which is neither flat nor "muley," is the most easily managed, and nothing but gross ignorance or negligence will bring about corns or disease, or render it liable to cast shoes.

To sum up:-Never allow the smith to touch either sole or frog with a knife, except merely to pare off jagged pieces and to remove grit; let him fit the shoe to the foot, not the foot to the shoe ; don't let him allow the shoe to rest on or press any part of the sole or bars, but bear on the outside crust only, and let the frog come nearly to the ground. When removing a shoe have the clenches of the old nails carefully cut off, and let the shoe be gently drawn-not wrenched-off.

Horses used for heavy draught or fast driving should have shoes to come only three-quarters along the hoof, leaving the growth of the frogs perfectly uncontrolled. The result will be the horses will seldom fall, and can travel in absolute safety over ice ; particularly going down hill, as the frog can then act to best advantage. Hunters during the summer should be shod in like manner.

Horses hate to be alone, and as they are very fond of cats keep a few always about the stables, but never let dogs or goats there, for the 
smell of either is most injurious to a horse. It is an awfully bad plars to have kennels near stables, yet we often find them there.

Many a horse pulls hard and is nearly uncontrollable in a curb, whereas in a plain or twisted snaffle a child might ride him. However, few horse 3 will pull if they are not pulled. No saying is truer about this noble, but oft-abused animal than that "every horse has his own bridle"; experience should, therefore, soon teach in which he goes best; out I would, be very careful how I let servants ride a tender-mouthed horse in a curb. They can do less harm to his mouth with a plain snaffle than any other bit, so let such be used at exercise. A net sold for the purpose to put over the nose is an excellent check on a hard-pulling horse, so is a bit made of leather rolled to resemble a snaffle. It is, however, men's hands, as a rule, that make horses pull. They seldom pull with ladies, who have hands so much lighter than men.

I must add a word or two relative to the ultra desideratum of a hunting stable - that is, the Groom. No matter how vigilant the master may be, he will never have his horses well cared or turned out as he would wish them to be unless he has a thoroughly reliable and conscientious man to look after them. In small hunting stables, where the master superintends things himself and understands the details, it is not absolutely necessary that the groom should be a master of arts, but it is highly requisite that he should be trustworthy in all things and carry out his master's instructions. Neither is it necessary that he should be a good horseman. On the contrary, all that is required of an ordinary groom, in the riding line, is to have light hands and to be able to prevent a horse kicking him off at exercise. The less he likes or knows about riding over a country the better ; that is his master's prerogative. Do not bother, either, about your groom being a teetotaler, for scarcely any are such, and a servant requires, and is as much entitled to, his beer and grog in moderation as his master. Be satisfied if you find he is abstemious in liquor, is not easily affected by drink, and never gets drunk on duty. Of course he must be intelligent, smart, fond of his horses, and take a pride in bringing them out fit and well. He should always keep his eyes and ears wide open and his mouth close shut, and he must do what he is told. When a master of moderate means gets hold of a man like this to look after his hunters, he should appreciate and treat him properly, so that, apart from higher considerations, he may retain his services; for servants nowadays are not found with righteous propensities, or who take an interest in their employers, as easily as they were some two or three decades ago.

I will here give a tip as to lunging a stubborn horse over fences. It is not generally known in this country, but it is in Australia. Put on a saddle and bridle with a plain snaffl ${ }_{3}$; put the roins under the stirrup leathers ; fasten the irons in their place by passing a strap through each and under the belly; get a strong but light rope, about twenty-five yards long, double it in two, an $t$ in the middle make a loop sufficiently 
large to pass over the horse's tail and form a crupper; around the loop serve cloth or leather, to prevent chafing. Make a knot in the doubled rope so as to meet the back of the saddle; pass the rope ends through each stirrup-iron and the rings of the snaffle; then go in front of the horse with the two ends of the rope in your hand. By very little manipulation you will see what power you have over him, and that in no way can his mouth be interfered with, while he must keep his head straight and follow you wherever you wish to pull him. A man behind with a long whip forms a useful auxiliary. I give a rough illustration of what I describe. The dotted lines show the tackle.

No doubt many of my readers know far more about horses and their management than I do, but experience has taught me that, consistently with the unnatural state in which, of necessity, we have to keep them, the more closely we follow the laws of Nature the better. The more air we give them, the more attention we pay to their food, exercise, and shoeing, and the less pampering they get, the more work we shall get out of them. If we feed and care for them properly, we can work them hard.

To the hunting man accidents are the bane of his season. Remedies simple in their compound are ofttimes more effective than those made of ingredients which require a Latin dictionary to translate, and the veterinary Encyclopcedia IKedica to explain the nature of. I shall therefore conclude this chapter by giving a few recipes which, although simple and easily made up, I can vouch, after many years' experience, possess extraordinary curative properties.

For Wounds, be they incised or lacerated, and no matter how deep or dangerous-unless the tendons be cut across-the following lotion will cure them :-Blue-stone, $\frac{1}{2}$ oz. ; sugar of lead, $\frac{1}{4}$ oz. ; well ground together and mixed in a quarter of a pint of vinegar with a pint of rainwater. First cleanse the cut thoroughly, and then apply the above two or three times a day, shaking it beforehand and letting it well into the wound. A bandage is not to be applied, as the wound will heal from the bottom, finally closing in, and will leave little, if any, mark. A bottle of this stuff should be kept constantly in every stable, for in the kingdom there is not a better cure for cuts.

For Mod Fever, Cracked Heels, and Thrush :-A tablespoonful of sugar of lead mixed well in a mortar with a tumblerful of glycerine. Apply well with a sponge; in twelve hours wash it off with soft soap. If necessary, in a day or two, apply again. This for CHILblaINs is also an excellent recipe.

For Spraiss of the joints or Straiss of the sinews :-First rub well with spirits of turpentine, as soon after the injury as possible, then apply as a poultice, hot, a strong curd, produced from boiling milk poured upon finely powdered alum-first straining off the whey. To be renewed night and morning. This is alike good for man and horse. Clark's "Neurasthenipponskelesteriso" for strains of the back sinews or "breaks down" is marvellous, and should also be 


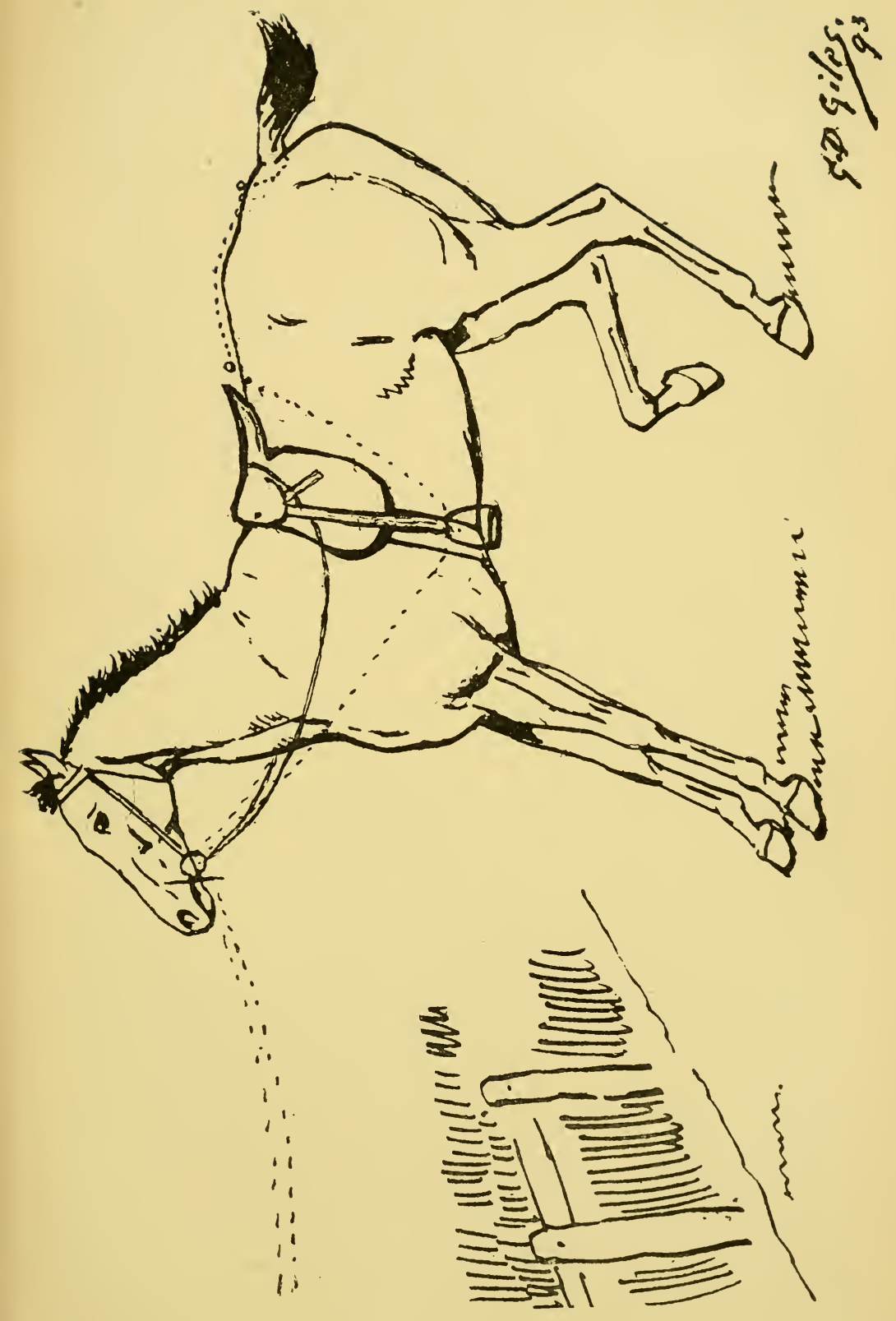



kept ready in all hunting and racing stables. To avoid spelling out the awful Greek, "Neuras." is sufficient to write for.

For an ordinary CovGH give ten drops of tincture of belladonna in half a pint of water at night, and ten drops of tincture of bryonia in half a pint of water in the moraing - both times fasting. Be careful in measuring, as they are poisons. Let the horse drink water in which lime has been dissolved. Hay should not be given to a horse while he is coughing, but he should get his regular walking exercise and not be cooped up.

For a BREast or BACK SCalded by the collar or saddle :-Sugar of lead, one tablespoonful, mixed with half a pint of vinegar and a pint of water. Bathe often, and leave constantly on the part a piece of linen saturated in the lotion.

For WARBLES either of the following applied same as the latter recipe :-Tincture of arnica, $\frac{1}{2}$ oz. ; mixed in half a pint of warm water. Or, sal almonia, 2oz. ; vinegar, one pint ; spirits of turpentine, half a wineglassful ; sweet oil, quarter of a wineglassful.

For BuRNS or SCALDS whether for man or animal :-Rub or pour spirits of turpentine over the part immediately after the accident. Instead of smarting, as most people would imagine, it gives instantaneous relief, and renders further remedies the more effective.

For BRittle FeEt, as I said before, Clark's "Hoplemuroma."

To prevent CRIB-BITING remove the crib and all else the horse can lay hold of. Feed him out of a bucket, to be taken away when he has finished.

To Stop BleEding wash well with either spirits of turpentine or whisky. If they can't be got, plaster the cut over with pig dung, and bind it on with a handkerchief.

For WARTS :-White arsenic, $1 \frac{1}{2}$ oz. ; yellow arsenic, $1 \frac{1}{2} \mathrm{Oz}$. ; cream of tartar, 1oz. ; hog's lard, 2ozs. ; made into an ointment and applied twice a day.

For CAPped Hocks, Big KneEs, etc. :-Equal parts of strong spirits of ammonia, turpentine, and sweet oil, rubbed in like a blister.

To renovate a covert coat or make WATERPROOF ANY CLOTH:-Sugar of lead, $\frac{1}{2}$ lb. ; powdered alum, $\frac{1}{2} l b$. ; dissolved in a bucket of soft water. Stir well up and leave it to get clear, then pour into another bucket; put the coat in and let it steep for twenty-four hours. Allow it to dry without wringing.

To make Waterproof AND KeEP Soft Top Boots, or any other boots, have them well rubbed over with common castor oil once a month. The application does not interfere with the subsequent polishing.

To take Stains out of a RED CoAt :- Half an ounce of oxalic acid dissolved in a pint of water. First sponge the stains out, then add another half pint of water and sponge the coat all over. Don't make the solution stronger or it will burn out the stains.

If a man gets A B.ID FALL he should take a hot bath directly he gets home, after which, if bruised or stiff, he should rub spirits of turpentine 
well into the part while the pores are open. When going to bed take two blue pills and a purgative early next morning.

For Rhedmatisn, Lumbago, etc., also Godt, see Shooting chapter. As a substitute for Sticking Plaster the inside skin of a raw egg will answer all the purposes, while for a Borl, where it can be readily applied, there is no application more soothing or beneficial than the skin of an egg.

The foregoing remedies nere included with others in a little pamphlet entitled "A Few Recipes Useful to Country Gentlemen," which I published some years ago, and which ran into two editions. 


\section{THE LATE HENRY W. BRISCOE, ESQ., D.L., M.F.H.}

Reference to Briscoe in the Curraghmore History-The Author's Mentor-His BirthTinvane-His Father-His Crest-T.C.D.-His Marriage-His Father's Harriers-His Foxhunting the Welch Mountains-His Right to that Country-How Hunted-Good Sport-Sale of his Pack to Lord Waterford-The Kilkenny Hunt-Mr. Briscoe as a Rider to Hounds-As a Judge of Hunting-Briscoe's Recovery to Health in 1870Chosen Master of the Kilkennys-Dissensions in that Hunt-How he Healed them-As Master of the Kilkennys-Sport shown-Errors corrected by Author-Briscoe as M.F.H. -Particulars of his various Qualifications-Long reference-Briscoe in Society-How Appreciated by the Ladies-Among his Own Family-D.L. and J.P.-As a Country Gentleman-His Sound Judgment-He first Imported Thoroughbred Stallions-Their Names-Their Success-Not fond of Racing-As a Shot-His Breed of Pointers-His Faults-No Vices-Never Drank at Night-Never Gambled-His Jealousy-Hatred of Smoking-Great Friencl of the Author-Author's Mode of Humouring him-How he got Information-Where got-When got-Results-Author's enjoyment at TinvaneSunday-school-Foxhound Kennels-Author's notion upon them in general-The Tinvane Kennels-Compared with Swell Kennels-Construction of Kennels-Briscoe's Popularity-His Good Health-His last Illness-His Death-His Age-His Funeral- IIelancholy Coincidence-Briscoe and Foxhunting in Waterford died together-Too True-A Verse to his Memory-Peace to his Manes !

I HAVE had necessarily to make reference to Mr. Henry Briscoe in my history of the Curraghmore Hunt, I shall, however, devote a chapter of my book to further mention of the man from whom I learned the little $I$ know of the rudiments of the noble science of foxhunting, and under whom, while Master of the Curraghmore, I enjoyed such magnificent sport during the eleven best years of my life. Besides, he was for many years, and up to his death, one of my most intimate friends. However, what will be a better reason to my readers for giving this biography is that, to the foxhunting community of his time, he was a brilliant light, and weli known as an M.F.H.

Henry Whitby Briscoe, D.L. and J.P., was born on September 29, 1809. He came from a good old stock (as we say in Ireland), who for generations owned the Tinvane estates, and resided at the old hall which is situated about a mile and a half from Carrick-on-Suir, on the immediate confines between counties Tipperary and Kilkenny. His father was a great sportsman of the old school, and loved coursing to a degree, while his breed of greyhounds was quite famous. I refer to the fact to bring in the curious coincidence that the crest of the family is a greyhound running with a hare in his mouth.

The subject of my chapter as Fellow Commoner took his degree with honours in Trinity College, Dublin. He succeeded to the property upon the death of his father in about 1832, and soon afterwards married Deborah, eldest daughter of Mr. Shaw of Annefield.

From his boyhood he was passionately fond of field sports. His father kept a pack of harriers, which were taken in hand by young 
Henry almost as soon as he was able to sit on a horse, but hares were not his ambition, and he soon bred the harriers into foxhounds, and took to the more exalted degree of venery. He hunted the Welch mountains and their neighbourhood for several years, but I don't know whether he had the prescriptive right in himself, or got leave to hunt it from the first Sir John Power of Kilfane. Probably the latter, for Sir John then owned the Kilkenny Hounds, and had the foxhunting right to the country, inasmuch as he had established the pack early in the present century ; moreover, Sir John was a contemporary of Briscoe's father.

Anyway, Briscoe hunted the parts I have named. He had no enclosed coverts, but along the tops and sides of the hills were wild, natural patches of gorse and heather, in which foxes in abundance took shelter. Briscoe hunted early in the mornings, so his hounds generally struck the drag which they had to hunt to his lair before they actually found their fox, and there is no doubt that from these natural fastnesses he showed great sport. Owing to the limited extent of his country and the skill with which he handled his hounds, together with their own good qualities, foxes after a time became scarce along the Welch mountains, and Briscoe was glad at times to let them have a shy at a hare when one was started.

Soon after Henry Lord Waterford commenced hunting from Curraghmore, he bought Mr. Briscoe's pack, and took up his country. From that time forward Briscoe was a constant follower of Lord Waterford's and the Kilkenny Hounds, and he became a leading member of the Kilkenny Club.

As I said in the Curraghmore chapter, he rode to hunt, and his whole soul was in the hounds and their working. He simply used his horse as a means to an end, but so effectually that he was always with the hounds, whether they went a splitter of fifteen minutes or worked through a long run. The consequence was, he soon became as good an authority on hunting as was the second Sir John Power, who had then succeeded his father, and was considered the best gentleman huntsman of the day.

To avoid repetition I must refer my readers to the second section of my chapter on the Curraghmore Hunt for the portion of Mr. Briscoe's history from 1859 to 1870 , during which period he was Master of that pack, but had to resign in consequence of ill-health.

It so happened that in 1870 the Kilkenny Hounds were without a Master, and for some few years there existed unpleasant circumstances connected with that Hunt, owing to social and other dissensions among some of the leading members.

Directly it was known that Briscoe had given up the Curraghmore, the Kilkenny gentlemen invited him to take office with them. They one and all recognised the fact that no man could be found more likely to bring about a reunion between the dissentient parties, for he was alike popular with botb, and had not espoused either side in the 
quarrel ; moreover, they knew how well qualified he was to fill the rôle of M.F.H.

Briscoe, having made a wonderful, and entirely unexpected, recovery of his health, accepted ihe invitation, and became Master of the Kilkennys in the summer of 1870. In doing so, he undertook both a delicate and a most difficult duty, for not alone existed the strife I have alluded to, but the horses, hounds, and country were in a very bad way. However, from his thorough knowledge of the duties, he soon reformed the stud, pack, and country, and by adopting judicious measures and applying them with tact and discretion he soon healed all social sores. The consequence was that within a very few seasons he brought back the Kilkenny Hunt to as grand a standard of unity, sociability, and sport as it had ever attained in its halcyon days under the Powers of Kilfane.

I can't give many particulars of his reign in Kilkenny as I was not as nearly connected with that Hunt as I was with the Curraghmore; but I can say that the sport shown by him was quite as good as what he showed in our country.

I wish here to correct an error I saw some time ago in print, where it was stated that Mr. Briscoe had John Duke with him in the Kilkennys. He never had. He brought Duke to the Curraghmores from England in 1860, and he never left them. John Tydd was the Kilkenny huntsman, and a very good one too.

Briscoe held office in Kilkenny until his death in 1881, a period of eleven years, exactly the same as he held the Curraghmore.

In some of the duties pertaining to the qualification for M.F.H. many men have been superior to Briscoe. There have been gentlemen who could hunt a pack of foxhounds with greater ability, others were better judges of hounds, others were finer riders and could select a hunter with better judgment. And there were masters who had a better knack of managing an unruly field. But taking in globo the duties, it may with safety be said that few men have ever been found who, all-round, were as highly qualified for a Master of Foxhounds as was Henry Briscoe.

Without being facile princeps in any one detail, he was admittedly first class in them all. He was an excellent judge of hounds, particularly those best adapted for stud purposes. These he mated upon such scientific and calculative principles that his crosses, as a rule, so nicked that the progeny gonerally turned out superior in shape and work to their parents. He used only the best strains from the best bred packs in England. A well-shaped hound, no matter how good in his work, unless he possessed undeniably good blood, would not be bred from at Tinvane. The puppies were always selected with good judgment, while no man could train a young entry better.

As a huntsman, Briscoe could handle hounds as well as most professionals, and it was accorded by those qualified to judge that with few exceptions he was the best gentleman huntsman of either his day or before it. Assuredly from 1860 until his death no gentleman that I 
ever saw, except Mr. Robert Watson, could hunt hounds like him. Impatient as he was in many things, he never was so while carrying the horn. Carefully would he draw his coverts, and never would leave a fox behind him; but directly the fox had gone away then would he have the hounds got out with all expedition.

During a run he never interfered with them until they had shown themselves in absolute need of assistance. He would then take them in hand, and with a judicious cast, quickly made, would generally set them right. With a bad scent Briscoe was remarkable for the perseverance with which he followed up his fox; never would he leave off until completely run out of scent or darkness came on. The consequence was his hounds were self-reliant and hard-working, and accounted for nearly every fox they found. When a fox had beaten them fairly to ground he was left there; no spade or terrier would be resorted to except under peculiar circumstances, his hounds getting plenty of blood by fair sportsmanlike means. That he fed and conditioned his hounds to perfection was in evidence daily, for they returned to their kennels at all times with their sterns up. No fox was too good for them, no day too long.

Briscoe was an excellent judge of a hunter, whether he required him for his own use or that of his servants, or with a view to turning an honest penny upon him, while his stable management was quite on a par with that of his kennel.

In none of the foregoing qualifications, for an M.F.H., did he shine brighter than at the meet, or jogging from cover to cover. His hearty, genial manner made everyone happy. He was always in good humour and ready with a story appropriate to the subject discussed, while quick repartee was a special phase of his jovial conversation. At the same time, when necessity required it, he could give a fellow "a dressing" that he would not readily forget, for he was-as all masters of hounds should be-a strict disciplinarian, and insisted upon men behaving themselves, and not interfering with the sport which they and others had come to enjoy.

Amongst the peasantry, also, his cordiality made him the greatest favourite, and they would do more for him for nothing than they would do for, perhaps, any other man in the country for money. Around the festive board the dear old fellow was ever the nucleus of the merriest portion of the party, and when we got him to sing The Cruiskeen Lawn, and after that, in the drawing-room, to dance The Foxhunters' Jig, he was, indeed, the personification of a real old Irish gentleman. Jolly as he was in the dining-room, and appreciated there by the men, he was still more so in the drawing-room, and proportionately more appreciated by the ladies. "Laugh and be fat, hunt and be happy," was his motto.

Unlike other public favourites, he was as pleasing in his manners and conversation in his own house, amidst his large family, as he was everywhere else. I don't think I ever admired him more than upon the 
frequent occasions of my joining the early Sunday dinner at Tinvane, with good Mrs. Briscoe presiding. In that house in these good old days was to be seen indeed a united and happy family.

Like most popular and well-known men, the Squire of Tinvane was seldom dubbed "Mister." Everyone, high and low, called him "Henry Briscoe."

He was a Deputy-Lieutenant, and, for more than one county, a Justice of the Peace. He was a most useful country gentleman, a painstaking, impartial magistrate, and at our local Horse Shows he always took a leading part. In fact, he was in a continued series of useful rural work, which his sound judgment and experience eminently qualified hirn to undertake and carry out.

No man of his means in his day-and few with greater means-did as much towards the improvement of the breed of Irish horses. He was the first in his part of the country who imported thoroughbred stallions likely to beget hunters. These he let to farmers' mares at a nominal sum, buying the produce whenever a suitable or likely young one offered-a course it would be well if many II.F.H.s of the present day followed. As I have already said in another chapter, Greatheart, Red Hart, Legatee, Confessor, Hospodar, Glenmasson, Umpire, and others were of his importation. They all got good cattle, while some of the produce, under both silk and scarlet, turned out quite celebrated. The strains, particularly those of Greatheart and Confessor, are still looked for.

Briscoe was not fond of racing. He attended all local meetings, just as he would any gathering or party got up for amusement, but more for the sake of meeting his friends than to see the sport. When a young man he rode a few steeplechases, but only where the riders were confined to men of his own social standing.

He was a good, steady shot, and he had for many years a breed of pointers of rare quality, the strain of which was at Tinvane for nearly half a century.

He was neither a fisherman or exponent of any other branch of sport.

He was always a temperate man. During the "hunt week" in Kilkenny, described elsewhere, instead of sitting up with his companions over their wine, or spending the night in gambling, he would slip off to bed long before midnight. He habitually kept early hours. Nine to ten o'clock was usually his hour for bed, while daylight in winter and shortly after in summer saw him in his stables or kennel. He never betted, much less gambled. I don't think he knew a game with cards, and certainly he could not play billiards, and he hated smoking with intensity.

Briscoe had his fads and his faults, like other people ; but, unlike others, he had no vices. He was not fond of imparting his knowledge to others, being very jealous of it, nor could he brook contradiction or opposition on subjects upon which he considered he was better informed 
than others. In fact, he was dictatorial in debate and determined in baving his opinions adopted by others, and seldom would he adopt theirs. This propensity rendered him, as he certainly was, imperious in manner, although courteous and affable, but second fiddle he could play to no man.

Although many years my senior, we were always the greatest friends, and he told me a lot more about hunting than I think he ever did to anyone else. I had, however, to humour him, and at times to employ stratagems to get out of him what I wanted. No plan succeeded better than to make what I knew was a palpably wrong remark. Immediately my poor soul would be consigned to Avernus, and my body likened to a sanguinary donkey's, but I cared not for body or soul so long as I drew from old Henry the shapes which constituted the perfect foxhound or the weight-carrying hunter. This, through the means of my idiotic remarks, I generally did, either by descriptive dialogue, or, better still, by practical illustration on the flags of the kennels and in the stables.

For many years my Sundays were generally spent with him. When church was over I accompanied the family to Tinvane, and after an early dinner the remainder of the evening was spent among the hounds and horses. Under the apple-trees in the old orchard, "and the bustling pack at my feet," many a lesson was given me by him, and from such a mentor it was not difficult to learn something about the shapes of a foxhound and the theory of working him.

Never did I enjoy interriews with anyone more than I did those with my dear and genial friend, nor shall I ever do so again.

Since the now long-past period of these, my Sunday-school visits to Tinvane, I have seen a great many kennels, and a great many packs of foxhounds. I shall, therefore, put on paper what has occurred to me with regard to the construction of kennels in general and those for foxhounds in particular.

It strikes me that a lot of unnecessary trouble and expense is at times gone to in building kennels. Of course, as with most things, it is nicer to have them fitted smartly than otherwise; but I am pretty certain that expensive adornments are not necessary adjuncts to the well-being of a pack of hounds. Take, for instance, the old kennels at Tinvane. In them hounds enjoye $\lambda$ the very best of good health, and from them showed the very best of sport. Yet every detail, though perfect in its principle, was of the simplest description, and, like the Irishman's cabin, "with not a single thing for show." I know many others fitted up with all sorts of grandeur and even luxury for the hounds, but lamentably deficient in the all-important principle-sanitary arrangements-with the result that in them kennel lameness and other disorders are constantly to be found, while in the field the work of the occupants is by no means first-rate nor is good sport shown.

The great thing for kennels is to have them built upon stiff clay or rock, with a southern or south-western aspect, good drainage, with 
large and lofty lodging rooms. Ground damp must be prevented. Water should ke carefully looked to, for some sorts engender disease in hounds, and all sorts will cause rheumatism if conveyed any distance through leaden pipes. The flags must be of a quick-drying description.

I leave for the last the most important item of all-ventilation. That should be provided for upon the recognised principle of letting in the fresh air from the bottom, and the foul escape at the top. In doing so every precaution must be taken against draughts from the influx, while the outlet should be close up to the ceiling or to the ridge, according as the lodging rooms be ceiled or open to the roof.

Unless hounds are housed in pure air, manifestly their sense of smell must get impaired, with a result obvious to everyone. Men, except those grossly ignorant, must know what I say is correct with regard to the ventilation of kennels, but the fact remains that seldom is the principle carried out.

If kennels be contrived on the principle I have named, the get-up may be plain and unpretending ; but if they are not, all the painting and plastering in England won't make them healthy.

I have been shown over kennels the lodging-houses of which had the walls covered with porcelain and the floors with tiling equal to marble, but the stench from want of ventilation was unbearable. In one place-and very swell, too-the only means for letting in the fresh air and out the foul was through one great hole in the wall bored halfu'ay between the floor and the ceiling, and the feeder tcld me that in cold weather he stuffed it up with a wisp of straw !

Except the illness he suffered from which occasioned his giving up the Curraghmore Hounds, Briscoe enjoyed singularly good health until just a few months before his death.

As he was starting to attend the Curraghmore Hunt Steeplechases in the spring of 1881 he was seized with a heavy cold. This he could not get rid of, and he passed into rapid consumption, which carried him off at Tinvane on the Tth of October following, when he had just completed his seventy-second year. As may be supposed his funeral was largely attended by all classes. The cortige of cars and carriages extended in unbroken line for over a mile, while many followed on foot and on horseback. It was attended numerously by farmers, a fact which testified emphatically to Briscoe's popularity, for he died at a time when the peasant population of the country was in a state of agitation against the gentry, perhaps greater than at any other period of that troublous era. Albeit hundreds of the peasantry who desired to attend the funeral, were deterred by reason of their fear of the Land League!

By a strange and melancholy coincidence, this fine old Irish sportsman died exactly on the day following that upon which the Curraghmore hounds were stopped hunting in Newtown Wood, about four miles from Tinvane, by the villainous mob, as minutely described in the Curraghmore chapter. 
I made the remark, while standing at his graveside in Fiddown Churchyard, that "Henry Briscos and our foxhunting died and were buried at the same time." Alas, too true has that remark proved!

Had this great foxhunter lived to see what was in store for the sport he loved so well, and in particular for the Hunt he had done so much for and was so proud of, I verily believe the sight would in itself have killed the grand old fellow. Happily he was spared the ordeal.

By altering a line I can apply one of Warburton's poems to my friend :-

Oh dear Henry Briscoe-how cheery

To ride by your side in a run ;

Whether midnight or morn, never weary

Of revel, and frolic, and fun.

When we laid this good fellow the tomb in

His grave was not mocked with a bust,

But his favourite evergreen blooming,

Shall spring and o'ershadow his dust.

Peace bə to his manes, and may the sods for ever lie lightly o'er the grave of Henry Briscoe! 


\section{CHAPTER VIIJ.}

\section{STEEPLECHASING.}

The Birthplace of Steeplechasing-Pounding Matches-Ancient History-Curious RecordsOld English-Ross and Douglas-Clinker and Radical-The Grand National-Irish Winners-Author's Love of Steeplechasing-His Experience-Old Times-CashelTipperary-Newcastle-Stand-houses-Dressing-The Courses-How Kept-Results -Selection of Courses-Riders' Costume-Farmers' Colours-Our Dress-FestivityBetting-Mullins and his Wife-Roulette and Hazard-"The Hells"-_ Old Bones""Handicapping" - Those who Attended-Ladies-Farmers-Enthusiasm-TentsDrink-Shocking Scenes-The Plates-Honour and Glory-The Limerick Drag Hunt -Gentlemen Jockeys-Captain Tempest and Dan Meaney-The Pace Then and NowPresent Arrangements-Compared in Detail with the Past-Is Steeplechasing Better off ?-Lord Howth's Letter-Author's Reply-A Means to an End-Inferior Purposes -Irish Steeplechasers OIden and Nowadays - "Mr. Armstrong "-Schooling-"Patent Safety"-A Query-“A Qualified Hunter"-Hunters' Flat Races-Old Rulers and . Mentors-Hurdle Racing-Author's Opinion-Who is Who now ?-What the Farmers Like-Natural Courses, not Artificial-Curraghmore-Tramore-Mr. Martin MurphyMr. Thomas G. Waters-His Kindheartedness-His Motives-A Good SportsmanMonuments to his Memory-I.N.H.S. Committee-Takes Action-A Pity-Cork Park"Regulation Fence"-Increase of Meetings- "GateMoney" Meetings-Author'sNotions - Sport the Pole star-Author gets Tired at Last-Blurts ont-“"Hunters," Bless the Mark!-Present System-I.N.H.S. Committee Again-Should be Supported-Corinthian Columns-Censors and Reformers-More to be Done-Our Rulers-A Suggestion -Our Authorities must be Supported-What to Do-In a Nutshell-Pleasanter Topics -Author Runs Riot-The Better to get off a Rough Line-A Horse's Stride-15 feet of Water-20 feet-How Jumped-Painters and Pictures-Galloping-How to be Convinced-Funny Illustrations-Nose and Feet-Landseer-The Forge-A Drake Quacks!-"Hark back!"-Punchestown and Fairyhouse-Aintree and SandownThey should be Copied-The Regulation Fence-How to Make One-To Lay out a Course-The Punchestown Double-An Artificial Double-A Natural One-Do Horses go as Fast now as Formerly?-The Question carefully dealt with-Woodbrook's Grand National-Subject entered into fully-Grand National from 1843 to 1889Tables of Comparison-Argued out-Real Steeplechase Courses-Not Billiard Tables -No comparison-A Grand National Winner-The Press in Old Times-The Irish Sportsman-Mr. William Dunbar-Manfully Maintained Sport-Now what do we see? -Daily Sporting Papers-Good old Bell's Life-A Record in Telegraphy-Mr. Charles Barrington and Malahide-Lord Manners and Seaman. Postscript-Cloister's Grand National of 1893.

TнAт Ireland is the birthplace of steeplechasing there can be no doubt ; in fact, the right of title has never been questioned. Tradition hands down, and is backed up by family records, that the sport existed in some parts of Ireland, and absolutely flourished in Connaught, long before the beginning of the present century. I have heard men relate what their fathers told them they saw at steeplechases in Clare, Galway, and Roscommon "twinty years afore the rebellion of '98." *

Steeplechases seem to have sprung from "pounding matches," a sport much in vogue among Irish gentry early in the last century, and continued to be until long after the beginning of the present. I often

* The Irish peasants, even up to quite recently, took their dates from some great historic event. 
heard them described when I was a boy. The diversion consisted in two men riding a match against each other over some terribly stiff country until one was brought to a standstill. The rules were simple. One man was to follow the other wherever he went. Lots were drawn to decide which was to take the lead at starting. This the rider retained until his horse fell or baulked. In case of a fall the other man was bound to follow in the same place, but when a baulk gave him the lead, it was optional for him to go at another place. Thus the match continued until one pounded the other. Large sums usually changed hands over these matches, and as the most difficult country was chosen, terrible accidents often occurred. Matches of this sort were known to have decided which of two rivals was to claim the hand of the lady they were in love with-the fair one agreeing to abide the result and take for better or worse the winner!

Necessarily this pounding business was done at a very slow pace and without any line of country being laid out. Eventually the idea was conceived, in the middle of the last century, to ride at best pace across country from one point to another, the winning post being near to some tower or steeple which could be seen from the start, perhaps five or six miles away, and no other guide or beacon was allowed, hence was derived the name steeplechase.

There appeared in an English magazine not long ago an article giving interesting records of Irish steeplechasing when in its infancy, and from it I learn that the oldest record which is authentic is a IIS. in the possession of the O'Briens of Dromoland, County Limerick, which gives particulars of a match in 1752 , between Mr. O'Callaghan and Mr. Edmund Blake, over four and a half miles of country. The course was from the Church of Buttevant, with the spire of St. Leger Church for a winning-post.

Perhaps the earliest reference found in print is in the first volume of the old Sporting Magazine, where it records an appeal made to the Turf Club to determine a dispute upon a race at Ballyshannon, held on January 3, 1793. The report runs thus: "Four horses started for one hundred guineas, twenty-five guineas a side; one of the horses was to carry a featherweight-that is, the lightest weight procurableand was ridden by a small boy. In the race each was to leap a wall six feet high. The first from the post was the horse carrying the featherweight. When he came to the wall he was stopped by the boy, who, with great dexterity, alighted, turned the horse over, climbed the wall himself to the other side, mounted again, and came in first to the winning post. Another horse and his rider got over clear, but the other two baulked the wall. On it being contended that the boy lost because he dismounted at the wall, it was decided that as the horse which he rode had only to carry featherweight, the saddle was sufficient, and the race was awarded to him."

It appears also to have been the practice about this time in "all hunters' plates run for in Ireland to have a four-foot fence, with a 
four-foot drain to cross twice in each heat." Another old letter relates how the writer "had seen two Irish horses in a race leap a river which measured twenty-two feet clear."

One hundred years ago, unless the owner entered his horse in person, it was necessary in Ireland to swear an affidavit to prove the qualification of a hunter. This is copy of a form used: "I, Walter Butler, of Cregg, Gent., maketh Oath, and sayeth that a bay gelded horse, called Rasper, which deponent [by his servant] now offers to enter, and run for the hunter's Plate, at Galway, never started for either Match or Plate [but a fair hunter's Plate], and has been actually used as a hunter, at the last season, and not only to get the name, but really as a hunter; nor has he been in sweats with an intention to run, but only from Lady Day last." They were more particular then about the qualification of hunters than we are now.

The first regular steeplechase in Ireland was got up in 1803, but no authentic record has been kept of it.

A six days' meeting used to take place over the Annagh course at Westport in the early years of the century. The stewards were the Marquis of Sligo and Mr. Martin Blake, while the late Mr. Hunter's father was judge. The late Marquis of Sligo was a great sportsman. It was he who bred the famous Waxy, Langar, and other horses, and it was he who presented to our Turf Club the Sligo Whip. The present Earl of Sligo has lived out of Ireland for several years, and his splendid castle, on the borüers of Clew Bay, is tenanted by a caretaker.

On St. Patrick's Day, 1813, a memorable meeting took place at Rathcrogan, in the county Roscommon. "The distance was six miles, over six walls, five feet high, and several yawning ditches. It was weight for age, the stakes being one hundred guineas. The runners were: Mr. G. Harkans' Young Blacklegs, 4 years ; Mr. W. French's mare by Swordsman, 5 years; Mr. J. French's Peter Finnerty, 6 years ; Mr. Plunkett's Baronyboy, 6 years ; Mr. B. Blake's Merryman, 5 years ; and Mr. J. French's Wellington, 5 years. The latter was favourite at starting, and there was an excellent race between him and Young Blacklegs for the first five miles, when Wellington refused, and Young Blacklegs won easily; the mare by Swordsman was second."

About 1815 the all-important question of weight seems to have come up for consideration, for in a four mile 'chase at Dungarvan, for a plate of fifty guineas, we find the horses carried twelve stone each. Another contest at Lismore is described as "a regular tumble-down race." The winner, Mr. Foley's Brown Bess, fell four times, while the horse which came in third had been down no less than six times. "In all," the report says, "there were twelve falls, but no one was killed. Betting even at starting that there would be six falle."

Galway, ever since the time the Eastern men were driven into Connaught by Cromwell, has furnished hard riders. In all parts of the country are still to be seen places where Burkes, Blakes, Bodkins, and Martins rode over, either for a wager, in a pounding match, or steeple- 
chase, and surely some of them are appalling. John Dennis on Alhambra did marvels, and so did the famous Giles Eyre, who first started the "Galway Blazers."

These and others of "The Tribes," together with the Marquis of Clanricarde, were the men at the head of Irish steeplechasing up till the forties, when Henry Lord Waterford came to Curraghmore and taking the lead of everyone, brought the sport under a proper system. Lord Clanricarde, like Lord Sligo, is, miserabile dictu, succeeded by an absentee, and Portumna Castle is also tenantless!

After making this short reference to the infant days of steeplechasing, and before dealing with the sport as it has existed during my own time, I must say something about the English.

In 1819 the sport was in full swing in England, and was described in a magazine of the day as " a sort of racing for which the Paddies are particularly famous, and in which, unless the rider has pluck and his nag goodness, they cannot expect to get home."

Another Englishman of that period writes that "steeplechasing, a system of horsemanship dangerous in the extreme, has become a favourite amusement with the young fox-hunters of the day."

At the Derby of 1825 Lord Kennedy betted Captain Horatio Ross $£ 1,000$ level that he would find a man in Scotland who would beat him in a steeplechase. Horses were not named at all! Subsequently his lordship laid Ross $£ 2,000$ to $£ 1,000$ on the event, which bets were vastly added to as the day approached. The match came off on 30th March, 1826. The course was from Barkly Holt to Billesden Coplow, in the Quorn country, just four miles. Terms : Not to go more than a hundred yards on a road or through a gateway. Captain Douglas was the man Lord Kennedy selected, and his lordship went to enormous expense in purchasing horses for the match. At last he fixed upon Radical, a famous hunter, belonging to Mr. Thomas Assheton Smith, for which he paid 400gs. Captain Ross had no horse of his own sufficiently good, but he was so popular that every stud in Melton was placed at his disposal to choose from. He selected Clinker, a thoroughbred by Clinker, dam by Clasher out of Lily of the Valley, by Eclipse (I can't resist the temptation of showing that he had Irish blood in his veins!), and he belonged to Mr. Francis Holyoake. Clinker won the match by half a mile, and did the journey, as taken by stop-watch, in $11 \frac{1}{4}$ minutes-a great performance, as the country was very hilly.

Before the race Lord Kennedy proposed to Captain Ross that, "as such an enormous sum was pending on the match, both between themselves and others, he thought it advisable that they should start with as few openings for a wrangle as possible; that in a flat-race crossing or jostling was not allowed, but that in this match he thought it would be best that the riders should do just as they pleased." To this Ross replied, "In short, I understand that we may ride over each other and kill each other if we can." "Just so," responded his lordship. 
I shall now give verbatim Captain Ross's account of the match, as he wrote it to a friend many years after. "Odd enough the first jump was a five-barred gate. I lay with Clinker's head about opposite to Douglas' knee. When within forty or fifty jards of the gate I saw clearly that Radical meant to refuse, so, recollecting the bargain, I held Clinker well in hand. Radical, as I expected, when close to the gate turned right across Clinker. I stuck the spurs in, knocked Douglas over the gate, and sent Radical heels over head but lying on this side of it. Douglas did not lose his horse, for the rein was fastened to his wrist, and he was soon mounted again, but it finished the match effectually. I turned round, jumped the corner of the fence, and gained such a lead that he never caught me again. I suppose, in these days, killing a man in that way would be brought in as 'wilful murder'; not so in 1826 : the verdict then would have been 'justifiable homicide." "

This match created a great deal of interest at the time, as it was the first race across country which people had seen, and many came to it from all parts of the kingdom.

Clinker was one of the most brilliant hunters in England, and after the match was bought by Captain Ross from Mr. Holyoake for $600 \mathrm{gs}$. He was carried gloriously over Leicestershire for several seasons by that famous horse, and had but one fall with him.

Irish horses, although accustomed to a very different country, have throughout history made fame over English steeplechase courses.

The Liverpool Grand National was first started in 1839, but I am not able to record how the initial attempt was supported by my countrymen. In 1840 thirteen horses started for that race, of which no less than six were Irish, Mr. Barry's Arthur, ridden by Mr. William Macdonagh, and Mr. John Power's Valentine, ridden by himself, running second and third. It was from the last-named horse the far-famed brook took its name. A solid built wall five feet high then stood where the water-jump now is. This Mr. Power backed himself heavily to be first over. He won his wager, but thereby lost the race. Such a cracker did he lead them that ten out of the thirteen fell at it.

Since then there have been but few Grand Nationals in which Irishmen did not take part, while it was won by horses bred in Ireland as follows :-

Matthew, the property of Mr. John Courtenay, of Ballyedmond, was the first to win it, and this he did in 1847, beating a field of twentyeight. Abd-el-Kader won consecutively in 1850 and '51, the first year beating thirty-two, the largest field that ever started for the race. Wanderer won in 1855, and so did Anatis in 1860. Huntsman in 1862 won in the shortest time resorded, $9 \mathrm{~min}$. 30sec. In this race poor Joe Wynne, riding O'Connell, was killed at the fence before the water-jump, the same which proved fatal a few years after to one of the finest gentleman riders of the day, Mr. George Ede ("Mr. Edwards").

We had then a spell of bad luck, and no Irish horse caught the 
judge's eye until Cortolvin, bred by Mr. Michael Dunne of Ballymanus, did so with 11st. 13lb. in 1867. This is the highest weight ever carried first past the post in the National up to and including 1892. The little Lamb won the next year, and again in 1871. After that for eight years our horses could do no better than run into places, but then came their turn, and for four years in succession we carried away the blue ribbon: The Liberator in 1879, Empress 1880, Woodbrook 1881, and Seaman in 1882.

By the way, what grand Irish parentage The Liberator had, and what a rattling ring there is in it-by Daniel O Connell out of Mary O'Toole! He was owned and ridden by that fine horseman, my friend Mr. Garrett Moore.

We had then to wait for five years until Gamecock in 1887 brought us again to the front. After that, from 1889 to ' 91 , we won off the reel with Frigate, Ilex, and Comeaway.

Thus out of fifty-three races have the Irish horses a record of seventeen wins, while they ran into places no end of times. *

Thus far for ancient history, now for the modern.

I never owned a racehorse, and am not likely to do so; but I truly love racing, and, like most Irishmen, I love steeplechasing still more. But the change has been so marrellous since I was a boy I feel constrained to describe it.

Having been a regular race-going man for over thirty years, I have attended nearly every meeting of importance in Ireland, and have seen a great number in England. I never missed a Punchestown since its re-formation in 1861, and for the twelve years of its exis'ence I managed our old Curraghmore meeting. I make these remarks to show that I may fairly claim to know something about the subject I am now going to tackle.

In old times our meetings in Ireland were got up and carried out in very rough-and-ready style. Those long established, like Cashel, Tipperary, and Newcastle, had permanent stone stand-houses, but of the most primitive construction, resembling lime kilns, and not much larger. Indeed, I think the big hill overlooking Newcastle did duty for its grand stand. They had no dressing-rooms ; the jockeys dressed in a tent or the open air, and were weighed in the latter without a particle of shelter.

Piiders generally came to the meeting wearing their jackets, boots, and breeches under their ordinary clothes, so that they had only to pull off the latter to be ready to weigh out. I remember dressing-or rather undressing-for a steeplechase under the lee side of a fence, in a storm of wind and rain, while a friend held an umbrella over me!

The courses were laid out over a perfectly natural country; not a single sod or stone would be removed nor a fence trimmed, and there was no levelling of places where the going was bad. In fact, with the

* See postscript for Cloister's win in 1893. 
exception of the three meetings named, courses would be laid out a few days beforehand, and nothing further done but put up the flags on the morning of the races. In many places the courses were "out and home;" i.e., after going half the distance the horses were turned round a post and raced back over the same line.

As a means for keeping the fences between the flags clear for the horses to jump, each had to be guarded by half a dozen men armed with sticks, and as badges of authority they sported hatbands of coloured calico. The run-home was protected only by ropes fastened loosely to rickety posts, and although the stewards and hunt servants, mounted and with long-lasned whips, strove manfully to keep it clear, the spectators crowded the course, and only when the horses were upon them divided, leaving a narrow lane to the winning post.

Needless to say that, having to deal with a multitude of country folk, some of whom at times were a bit unruly, and others more or less under the influence of bad drink, keeping either the fences or the run. home as clear as they should be was an impossibility. As soon as the leading horses passed everyone closed in, unmindful of those behind, which had either to charge the crowd or be pulled up. I saw many a man ridden over, nearly all were hurt, while some were killed outright. Collisions between the racing horsez and those ridden by the stewards and servants, causing terrible disasters, were also of frequent occurrence.

Previous to the seventies the get-up of our gentlemen-riders could not well be called smart. Riding between flags was so little their custom they did not consider racing boots and breeches necessary adjuncts to their wardrobes, so when they donned the silk, those used for hunting, topped with the velvet cap, constituted their rig-out. We all hunted in caps in those days, and when requisitioned for a race they were sometimes covered by a lady of the family with red, white, or blue silk, and sometimes the whole tricolour. This rig certainly looked very "chalk," and widely different from the Newmarket cut of our present Corinthian jockeys. In farmers' races it was 6 to 4 on "green jacket and black cap," being the colours of the riders. Now green is the exception, and the jockeys in these races are equipped very much smarter than they used to be.

In those days we dressed going to races in our worst clothes. The only man who went in Ascot style was the late Captain Billy Quin, and we used to laugh at him ! It was not until the ladies patronised racing that we donned broadcloth and "toppers."

Somehow in olden times we made races an occasion for festivity, and the licence very often exceeded proper limits. No doubt it was because we had so few meetings, for nowadays, when racing can be had every week in the year, and often every day in the week, no one ever thinks of indulging in the "pleasures of the table" more on those occasions than any other. The Race Ordinary, invariably held at the best hotel in the town, presided over by the leading steward, and patronised by 
his fellows, is now unheard of. Directly the last race is over away home everyone hurries.

Betting was not carried on to any extent on Irish courses five-and thirty years ago-in fact, I can remember only one bookmaker at our Southern meetings. He was named Mullins, and was often assisted by his wife; and even they had not sufficient betting to occupy all their time, so they worked a roulette-table as well.

Although betting was not much in vogue, except among the gentry, roulette and hazard were immensely popular. These games were played openly in the enclosure and also at the hotels every night as long as the meeting lasted. Very large sums were lost and won, but only by the upper classes of society. The keepers of the "hells," as the gaming-places were very appropriately called, found their vocation so lucrative that they paid high fees to the race executive and hotel proprietors for the privilege of playing. $£ 100$ was a common sum at a small country meeting, while $£ 500$ was for many a year the annual stipend paid by "Old Bones" to the Punchestown fund.

Another fashionable game, was that called "handicapping." A rum old game it was. What a mart it created for the exchange of every conceivable commodity a man might, or might not, be possessed of ! A fellow's horse or his house, his watch or his wardrobe might be "challenged," but, by the unique principle of the game he might, if he had sufficient acumen, attain double the value of the article by judicious appreciation of "the award," and at the same time retain his property in the end! What various degrees of satisfaction were felt by men in the morning consequent upon the result of their "opening" or "sporting," "holding " or "not holding," the night before! Truly, this intellectual game conduced eminently towards sharpening up the wits of a youngster and improving his powers of rapid mental calculation. I could not refrain from some allusion to this extraordinary game of the bygone era, but I must return to my subject.

The people who attended these old-fashioned race-meetings were of a class quite different from that of the present day. The stand-houses and enclosures were all very small, and the sum paid for admission never exceeded 5s. The accommodation, however, was quite sufficient, as no one went to the stand-houses except the local gentry and those who came from a distance. Ladies were never seen inside them. The few who did attend always drove in their carriages, from which they never stirred. On the other hand country people attended in their thousands. The run-home was lined with a solid mass of spectators, while every fence and vantage ground was thronged with frieze-coated farmers, their sons, and labourers. Within a ten-mile radius of the course not one of them could be found at home, except those too ill or too old. Wherever was a fence more formidable than the others there would congregate the crowd in greatest numbers. Every man evinced the keenest interest in the sport, which was intensified when a neighbour's horse ran, and if he won the excitement culminated in frenzy. 
There were tents, as there are now, but in much greater numbers, and in them was very bad drink sold-liquor so adulterated and pernicious that those who partook of it were rendered simply mad. Shocking scenes resulted and terrible fights took place. At times when faction met faction a regular battle was fought, particularly at races in the counties Limerick and Tipperary, within which, by the way, most of the Southern meetings were held.

Long ago a $£ 50$ plate was considered a biggish affair, and for it we had often fifteen or twenty of the best horses in Ireland competingay, and journeying 100 miles by road for the purpose. No horse-boxes on railways then. Except the Tradesmen's at Newcastle, the Rock Stakes at Cashel, and the Barronstown Plate at Tipperary, which were the most important events in Ireland, there were then very few worth $£ 100$. Neither had we flat or hurdle races at our steeplechase meetings.

Men who raced in those days did so for sport, for honour and for glory. As a rule they were well-to-do, and did not seek to supplement their incomes by either the stakes or gambling on the Turf.

I well remember the Limerick Drag Hunt, run April 23, 1860, when thirty-seven of us, on bonâ fide hunters, started for fifty sovereigns, five miles, over the beautiful country of Fedamore and Boherard in that county, in full fox-hunting costume, 12 stone each. Some of us came over one hundred miles for the gallop, and we considered ourselves well repaid, for it was a clinker and no mistake! By some means the line to be run over became known to some of the local people, and they having horses entered, and there being no other as suitable, the stewards considered it fairest to show it to all of us. As this was a "line," indeed, just five miles, straight as a ruler from start to finish, we were shown over it backwards, from the winning to the starting post. We got permission that, should the hounds check, or not go fast enough before us, we were to make the best of our way to the winning-post; therefore, I need not say the unlucky hounds were overridden in the first half-mile (I remember my horse landing over a high stone wall on one-he never moved after!), and we made a downright steeplechase of it to the finish. Almost all our gentlemen riders took part in this scurry; and racing men like Captains Shaw, Trocke, and M'Craith, with Sir Richard de Burgho and sporting Pat Russell, rode steeplechasers, but they carried penalties. I, in the name of "Mr. Thomas," rode a very good horse, called the Blind Vet, belonging to poor Larry Dobbyn, V.S., of Waterford, and he had only three before him when Mr. Ivers won on The Knight. Happy, and yet sad, recollection! Egotistical though it be, I can't help relating the event.

There were very few races for gentlemen in the days I speak of. Occasionally we had one, usually called the Corinthian Cup, but no horse except a regular hunter was qualified, and he was, as often as not, ridden by his owner. We had only some five or six "gentlemen jockeys" in Ireland then-I mean those who rode regular races-but it was customary for them to pay a professional for standing down when 
they got up, and if this was not done habitually things were made unpleasant for the amateur during the running. Poor Captain Shaw found this to his cost in many a race, till finally and fatally he found it at Youghal.

I think it was Captain Tempest who I saw give Dan Meaney $£ 10$ for the mount on Blind Harper, at Cashel, for the Rock Stakes, and, as well as I can remember, the plucky and popular officer won. $\mathrm{He}$, and perhaps three or four more, were the only soldiers who could ride a steeplechase at the time I refer to.

Notwithstanding the stiff fences which were in every Irish steeplechase course twenty or thirty years ago, I maintain, no doubt against the better opinion of many others, that the pace was as good then as it is now. Anyway, the horses went as hard as they could lay legs to ground, being, of course, steadied to a certain extent at the formidable fortifications they had to face; and as the horses of olden time were as good as, if not a vast deal better than those of to-day, what I say cannot be far wrong.

Now, let us contrast the state of former steeplechase affairs, as I have endeavoured to describe them, with what they are at present.

Our stand-houses are excellently constructed, fitted with every convenience, and many are luxuriously so. Well-constructed palings keep the run-home as clear as at Epsom for the Derby; nicely trimmed, pretty little hedgerows made of privet, furze, or laurel, so as not to hurt the horses' legs if they gallop through instead of over them, are the fences we often see, and galloping through is invited by the method of planting. These are in some courses diversified by diminutive mounds of clay, with a narrow shallow dry ditch on the landing side, so that horses may clear them from field to field without increasing the length of their galloping stride, or rising more than a foot and a half. To be sure, we have the conventional "gallery" jump in front of the grand stand in the shape of a brook so graphically described by Bromley-Davenport as a

Shallow-dug pan, with a hurdle to screen it,

That cock-tail imposture, the steeplechase brook !

Gentlemen jockeys come now, in some instances attended by valets, bringing portmanteaus stuffed with as many changes of clothes as would suffice a man for a tour. They dress in comfortable rooms, and come forth adorned for the fray, smart as the Newmarket professionals.

Our stand-houses and enclosures cover twenty times more ground than the old ones, and they are not one whit too big for the multitudes at $10 \mathrm{~s}$. to $15 \mathrm{~s}$. a head. We have scores of betting men at every meeting, and they have hundreds to bet with them ; but we have neither roulette nor hazard-at least, not to be seen.

Within the enclosures we have crowds of all classes, from the appren tice and junior clerk to the principals of every business under the sun. These, together with the gentry, nearly all bet upon every race, and a great many of them heavily. Ladies come in numbers little short of the 
men, and many of them also indulge in betting, and at times to large amounts.

Outside the enclosures is a contrast just as great. Scarcely one small farmer or labourer is to be seen, and this refers to big steeplechase meetings (bar the two I am going to name) as well as to the small provincials. Many attribute this to the decrease in the peasant population, but though that may have something to do with it, the true cause is discoverable elsewhere, as I shall endeavour to explain. Anyway it gets rid of the tents to a great degree; and, as far as they are concerned, a very good job.

Punchestown and Fairy House attract a very fair contingent of the farming class, but let me inform my readers these are the only steeplechase meetings in Ireland where the courses are natural, and where they are practically the same as they were in the days of Brunette, Blueskin, and New Broom.

Excepting them, at nearly all our steeplechase meetings are flat and hurdle races. Stakes are given of from $£ 100$ to $£ 500$, and Leopardstown has added one of $£ 1,000$; but the fields of horses for them are not nearly as large as we had for the old $£ 50$ and $£ 60$ plates, nor are they of as good a class. Men run horses now for gain and not for glory. They don't patronise the Turf to support it with their incomes, but only to make incomes out of it. A fifty sovereign stake would not now bring forty horses from long distances to compete in a friendly scurry over five miles of a natural sporting country.

Now we have far-and-away more "gentlemen" than professional jockeys, and consequently more races confined to gentlemen riders, while the amateur can ride in any race-handicap or other-without let or hindrance. This brings about the fact that our present gentlemen jocks are as good as any, and better than most, professionals, while a great many of the best are officers in the army. Moreover, there are five times as many race meetings in Ireland now as there were before the seventies.

Having stated both sides of the question as regards past and present steeplechasing as fairly and correctly as I can, let me, for information sake, ask the question, Is steeplechasing in Ireland on a better or worse footing than it was, say, thirty years ago? As I cannot argue out the subject with my readers, I must have recourse to a sort of desultory dialogue, mixed up with suggestive questions and my own opinion. I shall however deal with the subject straight, and as fairly as I can.

Of course, it goes without saying that the not only desirable, but absolutely requisite improvements in stand-house and course-keeping arrangements, are as much an advance upon the old, as are railway upon past coaching arrangements. To these improvements, too, let us not forget we owe the presence of the ladies at our race meetings. But that is not the question, however close it might lie to it. We have to consider steeplechasing pure and simple.

A great deal has been written within the last few years upon the 
sport in all its moods and tenses, and nearly all the scribes took a fling at what they call the "open grave."

The Earl of Howth contributed an article in Baily's Magazine of February, 1891, under the heading of "Steeplechase Reform," in which he dealt with the subject in a form of question and answer. Thinking his lordship was too hard upon our Irish National Hunt Steeplechase Committee, and not being in accord with some of his ideas, I ventured a reply in the following issue of Baily. My article in that magazine was very condensed, but I replied at much greater length in the Irish Sportsman of March 28, 1891.

The letters are too long to reproduce in these pages, but I shall give in substance, my reply to his lordship.

Steeplechasing was once considered to be a means to an end; viz., to stimulate men to improve the breed and stamina of hunters. That end has long since been attained, for we have had for many years as perfect hunters, well bred, and up to weight as I conceive it is possible to breed or make them. While this happy result may not be attributable entirely to steeplechasing, no one can gainsay that it has had a vast deal to do with it. I am of opinion, however, that having gained its primary object, the grand old institution, like many others, has been turned to very different and vastly inferior purposes.

Thirty to forty years ago most Irish steeplechase horses were up to at least 13st. with hounds; and though the weights in handicaps were, I think, lower than at present, the weights for age were often higher, while the courses were seldom under three miles, and often longer. Now we see wretched weeds not up to 10st. with harriers, and good for nothing but what they are used for, running in some of our principal steeplechases. These, by judicious "placing" and an occasional mount given to "Mr. Armstrong," bring grist to their owner's mill, but seldom do they "improve the breed or stamina of the horse," or exhibit the latter quality in themselves. But if we go a bit farther back, to the time when races were decided by the barbaric custom of heats, the comparison between past and present 'chasing simply ends.

The big natural courses of old days required careful and continued schooling, and until a horse was a perfect fencer he dared not face the old steeplechase course with any idea of getting safely over it. This schooling, if a horse had an easy temper and was properly handled, often qualified him as a "patent safety" with hounds.

May I ask if the schooling requisite for many of our present steeplechasers to safely negotiate what I have, perhaps profanely, described as "pretty little hedgerows," qualifies them as perfect hunters?

In my young days no horse was considered qualified for a hunters' race till he carried his owner regularly and safely to hounds for at least the greater part of one season, and of course we never rode horses till they were over four years old, and seldom till they were five off. Now a horse if seen a few times at a meet can get a certificate to run as "a hunter"! 
To an old fogey like myself it does seem difficult to understand what useful result can be produced by allowing hunters to run against each other on the flat. Except the Brighton Downs, I know no country over which we can follow hounds without fencing. Oh! were our old rulers and mentors of chase and 'chasing to look up and see what is now going on, methinks they would go back and contentedly remain where they are !

I always looked upon hurdle-racing as an iniquitous institution. What practical use is it or can it be? It is hybrid and serves no good purpose, and affords only an opportunity for gambling additional to the many which exist, and that over a lot of devils which are as worthless for flat-racing as they are for steeplechasing.

Most of the multitudes who now attend races don't care a jot for the sport; they come only to bet and for the outing. They would rather stay at home at their desk or counter and back some "tip" than go without having a bet on him, to see that horse run. Take from the stands at Punchestown and Leopardstown the ladies and the commercial element, the one coming to see and to be seen, the other to gamble, and a very sparse attendance will be left, but among it will be found the sportsmen.

The farmers, as a rule, have not as yet succumbed to the infatuation of betting, and still like to see a good steeplechase over a natural country ; but they would not give a pin to see one over the cock-pit courses of modern days, with their abominable abortions of fences. Therefore they stay away, even if living within a few miles of these artificial hippodromes. On the other hand, they always go to the point-to-point races, to Fairyhouse, and to Punchestown, where, with good sport, they see racing over natural fences. This proves that, notwithstanding a great reduction in the peasant population, there are many in the country still who could go to races if they cared; and that the falling-off in their attendance at country meetings is not wholly attributable to emigration, although many people contend it is.

I speak about this from personal experience. To our old Curraghmore meeting, held annually over the almost natural course at Williamstown, every farmer, with his wife, daughters, sons, and labourers, crowden, lining the fences and every vantage ground in their thousands, same as was done thirty years before at Cashel and Barronstown, ay, and they would come many a mile by rail and road for the purpose. Not so to a neighbouring meeting, quite as well carried out in its way, but with an artificial course ; to that few of the farmers would go, dismissing the bare suggestion, as scores of them have done to myself, with the observation, "I would not be bothered looking at the like"!

Tramore is the meeting I allude to. Since then Mr. Martin Murphy has done everything to make it first class, except to provide a natural country, which is impossible, and it is now among the racing community and townspeople one of the most fashionable meetings in Ireland; but the farmers don't attend, even though they have now no Williamstown. 
I am well aware it was the late Mr. Thomas G. Waters who laid out these new courses and remodelled the old. In doing so he was actuated by the purest motive-viz., a wish to prevent the accidents which, just about that time, were of unusual frequency. Mr. Waters was a man of peculiarly tender heart, and could never bear to see anything hurt, much less the horse, of which he was so fond, or the Irish steeplechase rider, of whom he was so proud. He was therefore, the more easily convinced in his own mind that our old courses were too stiff. He was partly right in this, for some of them werenotably Newcastle, where that famous mare Kate Fisher, and, I think, three other horses were killed at one meeting alone, a series of disasters which brought about an outburst of abuse of Irish 'chasing in the English Press. It would have been better, however, had he adopted less drastic measures; and had he foreseen the effects his wholesale cutting-down was destined to have upon our steeplechasing, he would have been more sparing with the spade and pickaxe, while equally merciful to horse and jockey, for never was there a better sportsman in Ireland than my old friend Tom Waters.

It is, however, fair to his memory to state that the sporting press of Ireland were silent during the remodelling of the courses; nor did we hear a word of complaint from owners, trainers, or jockeys. On the contrary, the last-named three, as a rule, approved of the reformation. I should also mention that heavy betting began just at the time Mr. Waters commenced work, and who knows but there might have been some who were very glad to look on and see courses made the easier? To bring off "a good thing" over the old natural courses was very uncertain; perhaps therefore, they thought it the best policy not to express the opinions they really held on the subject as regards sport.

Although Waters cut the fences down, it was he who built up the stand-houses and introduced all the improvements we now enjoy; for which ladies, jockeys, owners, pressmen, and all others connected with racing owe him a debt of gratitude.

Righit glad am I to see that our Irish National Hunt Steeplechase Committee has at last taken action in the matter, and has issued mandates that the size of the jumps must be increased. It is a pity such a step was not taken long ago. It is a greater pity that it did not veto the wholesale cutting-down system directly they saw Cork Park-which was the first circus of the kind-and forbid laying out courses on such lines.

In their recent action I think a mistake was made in laying down a hard-and-fast rule for all steeplechase courses. I am thoroughly in accord with their idea of having one somewhat formidable jump, such as the so-called "regulation fence," in every two miles, but I would have the formation of every course dictated by the natural lie of the country, utilising every safe fence, thus giving diversity of jumps with artificials as few as possible. The position for the regulation fence should be 
adapted to the course, and left to the discretion of the official inspector, and not to rule and measurement.

We have now a great many more steeplechase meetings in Ireland than we used to have, but most of them are small affairs. Whether that increase has proved beneficial or otherwise I can't well say. But as regards those meetings which have sprung up and are carried on as commercial affairs, I certainly am not in favour of. The principle is so at variance with that on which meetings in my day were promoted, probably I don't understand it sufficiently. Those such as Baldoyle, Leopardstown, and Cork Park, being near to large cities, may do well enough, but to have the "gate money" business extended to the country I think would do a great deal of harm.

I feel that our farmers and country traders should be afforded the opportunity of seeing a steeplechase as often as possible, and thus keep alive in them the love of the old sport. For that reason assuredly I would not allow any more courses to be enclosed, but would give people free access same as of yore.

Our Trish National Steeplechase Committee, like other corporations. who have to frame rules which will be alike effective and popular, have a hard task at times. Sport, however, is the only star they should steer for. To assist a number of people to make money by means of starting a race meeting on limited liability, or other such principle, should not for one moment occupy their consideration, unless it be clearly shown that good results to sport will follow.

When dealing with Lord Howth's letter already alluded to, I referred to matters which, in my opinion, caused a great deal of the injury which steeplechasing has in late years sustained, notably where I stated that we have not now men in Ireland to support steeplechasing of the same calibre as the old.

Even when I was a young man, not to speak of for many years previously, we had all over Ireland noblemen and gentry of good means, who not alone bred and reared steeplechase horses, but trained and raced them from their own stables, and rarely were any sent to a public trainer. As well as my memory serves me, Mr. John Hubert Moore, when residing at Jockey Hall on the Curragh, was the first man to whom horses were sent to be trained for cross-country work, and one of his first patrons was Captain John F. Montgomery, familiarly called "Rufus." Whether it was that the young men, being less well-off, were less sporting than the old, or that they considered their horses could be done more justice to in a public stable than their own, certain it is that since early in the sixties men have given up by degrees home-training. It is not for me to say which was the best plan, but of this I am positive that we had better sport with better horses under the old system.

In some of our big crack training stables we have some few good steeplechasers owned by a few good sportsmen; but, with all due respect to owners, I would submit that, while there is no doubt about 
the high standing of some, the ability of others, and the general rectitude of the whole, there is a lamentable falling off in the body as compared with that of former days.

At page 98 I made mention of the men who supported steeplechasing thirty and forty years ago, and, in drawing a comparison, I feel assured that the present men will not feel aggrieved, but, on the contrary, will accept as a fact what must be as palpable to themselves as it is to me.

This is the more to be regretted when it is equally evident that Irish trainers, as a class, are now very much better than they used to be.

The names I gave were those who, in my own time, bred, reared, trained, and raced their own horses from their own stables. Not alone that, but nearly the whole lot were racing at the same time and for many years in Ireland, and they were all independent men.

There may be others, but the only man whom I can call to mind that now races on the lines of the men I named, is my old friend Mr. Mat. Maher, of Ballinkeel, whom I have already mentioned as an example to follow. That gentleman, assisted by his brother, Captain George Maher, can not only breed and rear a racehorse, but can train him and bring him out fit to win in the best company, alike over a flat or flagged course. This he has many times proved, but never more emphatically than in the case of the gallant Frigate, who, trained by the brothers, ran into second place for the Grand National no less than three times, and eventually won it by beating nineteen others in 1889 . She carried 11st. 4 lbs., and doing the journey in $10 \mathrm{~min} .1 \mathrm{sec}$, she beat the average weight and time of that race by exactly 5lbs. and 31 seconds. Good old Frigate was born at Ballinkeel, from Gunboat and Fair Maid of Kent, both of whom were also bred by Mr. Maher.

That is a record which very few owners of the present day can lay claim to, but lots of the old fellows could, at least to equally great.

Nany ovations have I seen given to winners of races, but never aught like that given to Frigate when she won the National. The old mare had run for it no less than five times; once she was knocked down, and her performance upon the other occasions is recorded above. Running so continually in such consistently good form made her a favourite with everyone, down to the very newsboys in Liverpool and bargemen at Aintree. She ran subsequently, but was again knocked down.

When the old pillars of our sport died or ceased racing, orders went forth to Mr. Waters for the pick and spade, the bill-hook and scalping shears to hack and to hew the natural courses, which were sacred from harm in the old men's days. Then came into fashion the artificial courses, which are the great and leading light to the destruction of steeplechasing, and with them the extinction of the old and useful "half-bred"-so called because he had a stain in his pedigree, and could not be traced in direct line to Flying Childers.

Of course we all admit the great advantages of thorough-breeding, but I can't help thinking that for steeplechasing and hunting, the relegation of the "half-bred" is a mistake. 
Again, while I admit that public trainers, as a rule, bring horses to the post in better condition than do the private men, I am of the most decided opinion that the sport would be better sustained and maintained by having our horses for steeplechasing trained at home. Thereby would be created sporting emulation and rivalry among owners other than that which they have on a racecourse.

Our gentry now are not nearly so well off as they used to be, and they can't do things they once did, nor can they do almost anything in the same style.

Deplorable, also, is the fact that they don't now look upon steeplechasing, as a branch of sport, in the same light as did their forefathers.

To bring back to our gentry their old incomes is an impossibility, but to regenerate in them the love of steeplechasing is by no means impossible; on the contrary all that is needed is to bring back to steeplechasing its original system.

I am now tired of this dissertation, and so I am sure will be my readers, so I shall not bother myself or them with further remarks or comparisons, but will blurt out that I am firmly of opinion that, as far as steeplechasing is concerned, the love of sport is fast giving way to the love of gain. Owners don't care a fig now for winning a race, except in so far as they gain by it; and they would rather lose a race and thereby make money, than win the race and get nothing. Horses are used now as machines for gambling, and not, as of old, as winners of glory to their owners; nor is steeplechasing any longer an institution for improving the breed and stamina of the hunter; on the contrary "hunters"-bless the mark!-are now expected to improve steeplechasing.

How long the present system will last time alone can tell, but my opinion is the grand old sport is fast going down hill. It is not, however, too late to put on the skid, and if the authorities would do so without any more delay perhaps the upset of the coach may be prevented.

I need not say I hold our I.N.H.S. Committee in the greatest esteem, and would, in every way in my power, support them. It is, therefore, painful to me to hear that body spoken of in the disrespectful manner some sections of the press and public at times adopt. It is a body of gentlemen in whom everyone should place confidence, and to whose decisions all should bow. Without such a body to regulate our steeplechasing, constituted as it must be with absolute power, the sport would soon fall to the ground, precisely as did the prize-ring of England when the Corinthian columns were taken from under it. Censors and wouldbe reformers should bear this in mind.

During the past few years our Steeplechase Committee have effected some great improvements, both in their legislature and the way meetings are conducted, but there remains a lot more for them to doluckily, however, not as much as have the Turf and Jockey Clubs.

We in Ireland are fortunate in having as rulers of our racing and steeplechasing a body of men, young and practical in their ideas. 
They graduated under predecessors remarkable for sound judgment, to which they gave effect with energy and foresight, grappling as well as they could with every difficulty that lay in their way. With that example before them, and being now possessed of the experience which the others had to acquire, our present rulers are in a better way to bring about reform than were those who went before them. They, however, have been brought up in the old school, and no matter how practical men may be, after being engaged at the same business for a certain time they are prone to get into the one groove and can only see out of their own glasses. Nowadays that won't do. Men, while preserving intact their righteous principles, must go with the times, and to keep their place they must import new blood.

I think, therefore, that both our Turf and Steeplechase Clubs would do well to admit as members, representatives from the training and riding fraternity.

I have thus given an account of how steeplechasing was conducted long ago, and how it now goes on. My own opinions I have also stated plainly, and now I put together in a nutshell what I think ought to be done, with the courage of their convictions, by both the English and Irish National Hunt Steeplechase Committees. Of course, a great many good judges will disagree with me, and I admit that some of my proposals are fraught with difficulty and may perhaps be now impracticable, but I flatter myself that others of them are reasonable and should be adopted, even though apparently difficult to tackle.

If, however, our authorities are to take action and perhaps have to adopt drastic measures, they will have to be silpported by the general public, for there is no doubt that great opposition will at first be given by parties who think alone of their own interest and care naught for sport. After a time that would all subside, and the fine sport of steeplechasing might possibly regain the position it held in olden time.

Make the fences stiff but safe. Have no steeplechase under two and a half miles. Encourage three and four miles by making the longer the race the bigger the stake. Have no flat or hurdle races for hunters. Have hunters' steeplechases for hunters only. Encourage point-topoint steeplechases over a perfectly natural country for regular chasers as well as hunters. Don't allow any horse to start for a hunters' steeplechase until he is five years old. Give liberal allowance to home-trained horses. Peduce the present number of meetings. Allow no addition to "gate money" meetings, and, whenever the chance comes, shut up those existing. Encourage natural and oppose artificial courses. Last, but not least, bring influence upon employers to veto betting among those they employ.

I now leave this section of my chapter and proceed to others more pleasant to deal with.

A horse of average size will clear, in his stride at full gallop, about twenty-two feet, but put before him fifteen feet of water, level with the banks, without a guard, and then see how difficult it will be to 
make him take it in stroke, and when he does take it, see what a catapult effort he makes to clear it. If the water be twenty feet wide, and he lands clear without baulk or fall, it will be a feat to be talked of for a whole season, yet the distance is less than what he covers in his ordinary stride. This phenomenon is caused, of course, by the fact that when approaching a jump at a gallop a horse will always shorten his stride, and collecting his hind legs well under him will spring when all four are close together, and thus is produced the jerk we feel. It is even betting that a seasoned hunter, although well able for twenty-four feet, will not jump twelve feet of water without in some way disturbing it. A young one, full of impetuosity, will, but the old one won't.

The position in which horses and dogs are drawn, when galloping, is perfectly unnatural, and one it is absolutely impossible for them, even for the hundredth part of a second, to be in. Never can both fore legs and both hind legs be extended at the same time; one foot must: always be on the ground, except when the animal is travelling through the air in the act of jumping, and even then the legs can never be spreadeagled as they are usually represented in a picture. When, however, an artist draws a horse in position at all resembling the properwith legs doubled up and crossing each other-what a horrible effect it has, simply because we are not accustomed to that style, nor is the real position as discernible in the object as is the imaginary elongation. To become convinced on the subject one has only to observe attentively how a horse's legs move when be is in a slow canter-they go through precisely the same action when galloping, only, of course, quicker.

Artists, like poets, seem to take a licence; anyway, they sometimes produce funny illustrations. As a rule, when painting or drawing a horse galloping, they will show his fore-feet a long way in front of his nose, oblivious of the fact that his nose is always foremost, and the feet can never extend beyond it.

Even the great Landseer occasionally used his brush upside down. In his picture of the forge, which has been copied oftener than perhapg. any other, the horse is placed with his head to the light, which necessitates the poor smith to do his work in the dark! In other pictures, where he shows wild forl, we see the mallard with his mouth open evidently in the act of quacking, and the ducks with theirs shut. Surely every old woman knows that a drake never quacks, while a duck is continually doing so. These sort of mistakes are unpardonable, and spoil the whole picture in the eye of the man who knows what is what, even though he be no judge of the picture as a work of art. and unable himself to draw a line on canvas.

I find I have run riot and got altogether off the line of my chapter. Perhaps all the better for getting my readers off the very rough linethey have followed me over previous pages. However, I must hark back to the proper scent.

As I said before, Punchestown and Fairyhouse are the only real steeplechase courses we now have in Ireland, for the fences are all natural, and the tracks have almost every description of fence. They 
therefore require both jumping and riding, for none but a horse thoroughly schooled can get over them in safety.

In England there are Aintree, Sandown, and other courses with fences stiff enough to test the best horse and man, and we have Leopardstown modelled on the lines of Sandown, though not as stiff as Aintree. The fences in all these courses are artificial, and lack the zest of the old naturals, but they sufficiently answer the purpose for which steeplechasing was originally and properly intended; and if the old sport is to be saved from perdition, both the English and Irish head-quarters should forthwith command that all other courses shall be constructed equally stiff.

Our Irish horses run so often now at English meetings, it was good and wise of the Leopardstown executive to construct a course upon the English lines; and it was equally so of our I.N.H.S.C. to institute the regulation fence, which, if made with the hedge, is precisely like some of the Aintree and other English fences. It was considerate, however, of them to leave it optional with executives to have this fence either a bank or hedge ; for to most Irish horses the former is the easier, a hedge with wide grip and rail in front being very uncommon in Ireland.

But what an amount of talking and writing there was against this same regulation fence when it was first introduced; principally by people who were as capable of forming a correct opinion on the subject as they were of riding over the fence itself. That has now, naturally, all subsided, and men have schooled their horses so that the "ghastly grave," when made and located properly, is negotiated as safely as any other fence in the race.

By the way, does it appear to those who have to construct a regulation fence of the "bank" character that it is simply a single bank, with a grip of $6 \mathrm{ft}$. wide and $4 \mathrm{ft}$. deep in front, and that any ordinary double can be utilised by filling up the off-side in a slant from outside the grip to the top of the fence? There was not much trouble in converting the up-fence at the top turn past the stand at Punchestown into a regulation fence-just half an hour's work for a man with a spade to widen the grip to $6 \mathrm{ft}$. This had to be done to conform with the rule that a fence $3 \mathrm{ft}$. high, with a $6 \mathrm{ft}$. grip in front, should bə in every two miles of a course-the natural doubles doing the duty over the remainder of grand old Punchestown.

It is not everybody who can lay out a steeplechase course to be raced over with reasonable safety. Few indeed can do so, and a most extraordinary fact is that very often the best rider over the course when laid out is the worst man tolayit out. This has been demonstrated many times.

About the very best, gentleman jockey of the present day, in reply to a question I asked him lately as to the height of the double into the Herd's Garden at Punchestown, and which he had ridden over at least one hundred times, said it was five feet high, and would have bet me a tenner on it had I allowed him. Now, the fact is, the actual height of that fence from the edge of the grip on the take-off to where the horses land on top is about $2 \mathrm{ft}$. 9in., certainly under $3 \mathrm{ft}$. This 


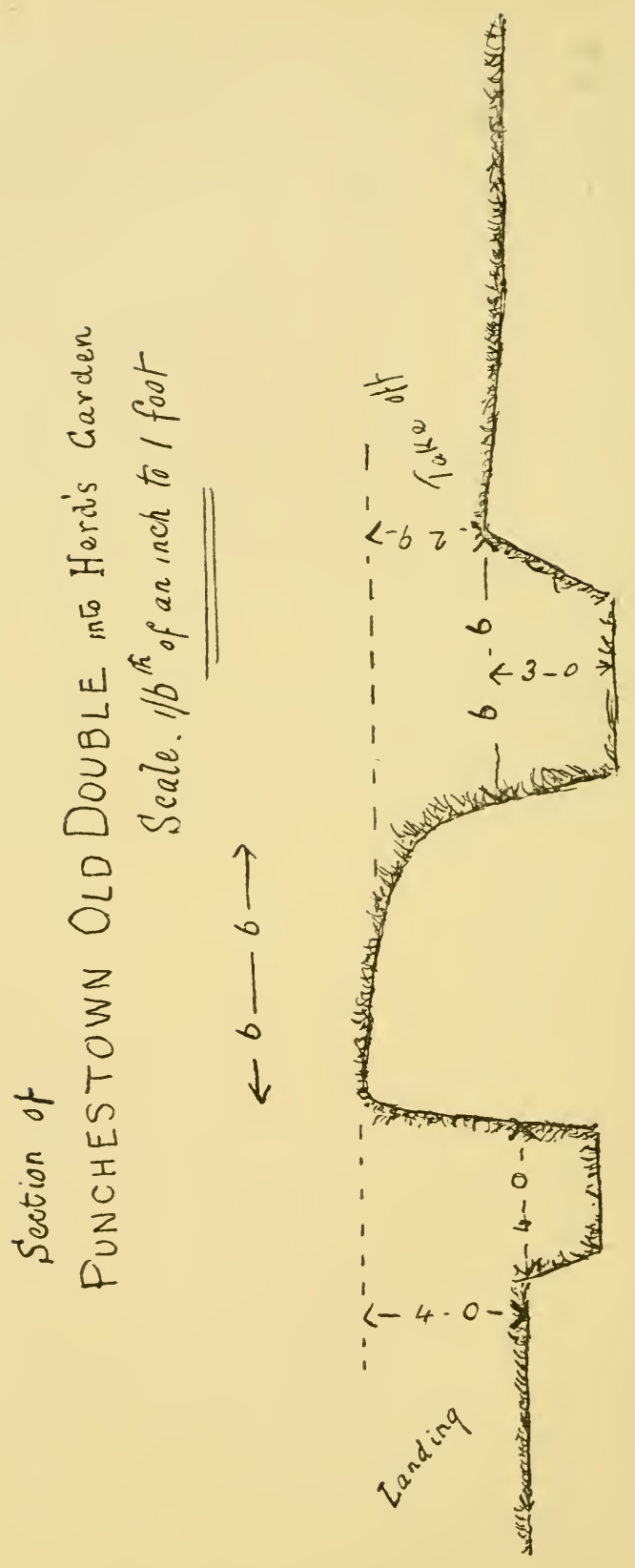


statement will astonish many, and few will credit it ; but let them go and measure the fence-meanwhile don't bet I am wrong.

I mention this to show how little is known about a steeplechase course, even by those who would be expected to know. I need not say my object is not to depreciate "the double" at Punchestown for testing a horse's capability for jumping or a man's capability for riding, for we all know it is fully equal to the task. Its dimensions are as nearly as possible :-Grip on take-off, $6 \mathrm{ft}$. $6 \mathrm{in}$. wide, $3 \mathrm{ft}$. deep. Height of fence from take-off, $2 \mathrm{ft}$. 9in. Width on top, 6ft. 6in. Drop, $4 \mathrm{ft}$. Grip on landing side, $4 \mathrm{ft}$. wide. This I show more clearly by the annexed section.

I have asked many people what the height was, and no one ever said it was under four feet, while some said it was over six feet. The fact is, an optical illusion is occasioned by men's eyes catching the bottom of the grip as they approach the fence, and then taking the height from that depth as they stand on the edge, oblivious of the fact that the horses don't jump from out of the grip-at all events, until they have first fallen into it.

The fence is now precisely as it has been for the past twenty years. In about 1870 it was lowered 3in. or 4 in., as may still be seen by the cutting on the top.

An artificial double should never be allowed on a steeplechase track, for the simple reason that not one man in a thousand knows how to construct it properly.

In a natural double the great thing is to have the top slanting upwards, so that a horse can see the width, and that he has to put his feet on it. There should be a somewhat sharp incline for $4 \mathrm{ft}$. or $5 \mathrm{ft}$. up to the edge of the taking off grip, so as to give the horse a better purchase with his hind hoofs ; in fact, to enable him the readier to get his hind legs under him. The width of the grip should never be less than $6 \mathrm{ft}$. to $6 \mathrm{ft}$. $6 \mathrm{in}$.; while the top should be the same. Nothing like making a horse take off well away from an up-jump when going fast. If a double be less than $6 \mathrm{ft}$. wide on top, horses will try to fly it, which generally creates an awkward complication of them and their riders in the next field. If the grips of the Punchestown doubles were only $3 \mathrm{ft}$. or $4 \mathrm{ft}$. wide, half the men and horses would be killed over them. About the best fence of the sort I ever saw was on the old Fethard course in co. Tipperary. It was fully $7 \mathrm{ft}$. wide on top, with a grip before it of over $6 \mathrm{ft}$., but it was not $2 \mathrm{ft}$. high. Horses must change on a fence like that, and then there is seldom a mistake made.

It is only a matter of opinion whether horses go faster or slower over a steeplechase course now than they did in former years; for no man can make a positive statement in the matter. I was always of opinion they went as fast long ago as they do now. They were ridden as fast as they could go then, and they are ridden as fasi as they can go now, while no one can deny that steep'echase horses were bett $r$ as a class in former days than they are at present.

To strengthen this argument I tabulated from the official returns a statement in 1881, soon after the Grand National, and it appeared at 
the time in a letter of mine comparing present and past steeplechasingIt dealt only with the fourteen horses which won that race carrying 11st. and over up to 1851, compared with that year's winner, Woodbrook, carrying 11 st. $31 \mathrm{bs}$.

I reproduced the table in Land and Water, in the spring of 1892 , and it showed plainly that Woodbrook's was the worst performance of the lot. Some of the others would have won almost before he had got to the racecourse the second time; while Bourton in 1854, carrying $91 \mathrm{bs}$. more and doing the course in $1 \mathrm{~min}$. $51 \mathrm{sec}$. shorter time, would have galloped out of his sight altogether. Again, Woodbrook, ridden out to the last pound, beat a field of only thirteen horses, the smallest, except to, up two 1881, the average being twenty-one. No doubt he won in a storm of wind and rain, but it is highly probable that some of the others won the race in weather quite as bad. In Woodbrook's. year the fences were, I think, trimmed lower than usual.

I shall now enter further into this interesting question of the relative pace of our steeplechasers past and present. For that purpose I shall deal with the Liverpool Grand National up to 18.90, from the time it became a handicap, nearly half a century back, and to show that the course has been practically always the same I shall first describe it.

The race was first run in 1839, and the line of the course was never altered until about ' 89 , when the run-home was changed from the five-furlong post, but the distance, four miles and a half, was never altered. A few years before, some of the original fences were cleared away and artificial ones, quite as stiff, put in better places. It is the habit with some people to state that the fences at Aintree were in old times much stiffer than they now are. They could not have been, for if they were they would have been simply unjumpable. A stream intersected the course and formed Becher's and Valentine's Brooks, but although that is no longer in existence, and the brooks are dry, these fences are as formidable as ever. The dreadful stone wall opposite the Stand was removed a great many years ago, and the water jump substituted.

In selecting the Grand National for my data I consider I am dealing with the best cross-country horses of their respective times.

AVERAGE WEIGHT AND TIJIE OF THE WINNERS OF THE LIVERPOOL GraNd National FROM 1843 TO 1889 (INCLUSIVE), TAKEN IN DECADEs, from the detailed record given in "The Sporting Chronicle Annual " for 1892 :-

\begin{tabular}{|c|c|c|c|c|c|c|c|c|c|}
\hline \multirow[b]{2}{*}{ 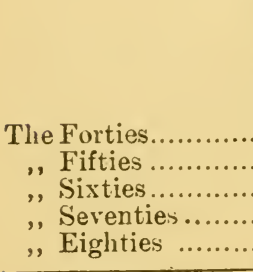 } & \multicolumn{3}{|c|}{$\begin{array}{c}\text { Winners carrying } \\
\text { less than list. }\end{array}$} & \multicolumn{3}{|c|}{$\begin{array}{l}\text { Winners carrying } \\
11 \text { st. and upwards. }\end{array}$} & \multicolumn{3}{|c|}{$\begin{array}{c}\text { Average of the } \\
\text { Decade. }\end{array}$} \\
\hline & $\begin{array}{c}\text { No. } \\
2 \\
9 \\
7 \\
5 \\
4\end{array}$ & $\begin{array}{|cc|}\begin{array}{c}\text { Weight. } \\
\text { st. }\end{array} & 1 \mathrm{~b} . \\
10 & 9 \\
10 & 0 \\
10 & 4 \frac{1}{2} \\
10 & 8 \frac{1}{2} \\
10 & 7\end{array}$ & \begin{tabular}{|c} 
Time. \\
min sec \\
$1219 \frac{1}{2}$ \\
$1014 \frac{1}{2}$ \\
1050 \\
1016 \\
1015
\end{tabular} & $\begin{array}{c}\text { Yo. } \\
5 \\
1 \\
3 \\
5 \\
6\end{array}$ & $\begin{array}{rr}\text { Weight. } \\
\text { st. } & 1 \mathrm{~b} . \\
11 & 8 \\
11 & 12 \\
11 & 6 \\
11 & 7 \\
11 & 2\end{array}$ & \begin{tabular}{rr}
\multicolumn{2}{|c}{ Time. } \\
nin sec \\
11 & 4 \\
9 & 59 \\
10 & 29 \\
10 & 19 \\
10 & 45
\end{tabular} & & $\left|\begin{array}{cc}\text { Weight. } \\
\text { st. } & \text { 1b. } \\
11 & 1 \frac{1}{2} \\
10 & 13 \\
10 & 12 \\
11 & 1 \\
10 & 11 \frac{1}{2}\end{array}\right|$ & \begin{tabular}{|rr}
\multicolumn{2}{|c|}{ Time. } \\
min sec \\
11 & 42 \\
10 & 7 \\
10 & 40 \\
10 & 17 \\
10 & 30
\end{tabular} \\
\hline $\begin{array}{l}\text { Average of the } 47 \\
\text { years }\end{array}$ & {$[27$} & 106 & 10 & [20] & 117 & 1031 & {$[47]$} & . & 1039 \\
\hline
\end{tabular}


In order of merit I would place the performances as follows :-

\begin{tabular}{|c|c|c|c|c|c|c|}
\hline \multirow{6}{*}{$\begin{array}{l}\text { Best } \ldots . . . . \\
\text { Second } \ldots . . \\
\text { Third ........ } \\
\text { Fourth ..... } \\
\text { Fifth ........ }\end{array}$} & \multicolumn{3}{|c|}{$\begin{array}{c}\text { Winners carrying less than } \\
\text { llst. }\end{array}$} & \multicolumn{3}{|c|}{$\begin{array}{l}\text { Winners carrying 11st. and } \\
\text { over. }\end{array}$} \\
\hline & The Seventies & 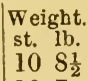 & \begin{tabular}{|c|} 
Time. \\
min sec \\
1016
\end{tabular} & The Fifties & $\begin{array}{ll}\text { Weight. } \\
\text { st. } & 1 \mathrm{~b} . \\
11 & 12\end{array}$ & $\begin{array}{l}\text { Time. } \\
\text { min sec } \\
959\end{array}$ \\
\hline & ,, Eighties & 107 & 101 & ,, Seventies & 117 & 1018 \\
\hline & ,, Sixties & $104 \frac{1}{2}$ & 105 & , Sixties & 116 & 1029 \\
\hline & ,, Fifties & 100 & 10 & , Forties & & 11 \\
\hline & ,, Forties & 109 & & ,, Eighties & 11 & 10 \\
\hline
\end{tabular}

I admit the light weights do not sustain my argument, for by further comparison we find the Forties are much below the average, for, although with the highest weight, the time is a long way the slowest. However, the average is entirely spoiled by the exceptionally bad time of Discount in 1844, viz., 14min. Probably there is a mistake, for it is $2 \mathrm{~min}$. 10sec. longer than any other ever recorded. If it be incorrect,' and putting it at, say, $11 \mathrm{~min}$. (i.e., 13sec. over the average of the light-weight lot), we would have the Forties, with 10st. 9lbs., $10 \mathrm{~min}$. 50sec., which would beat the average well, and be nearly as good as the Seventies and Eighties. The Fifties are also below the average, considering the light weight; the Sixties are a fair average ; the Seventies beat the average well; and so do the Eighties.

The high-weight class gives strong support to my theory, as is shown thus : the Forties are somewhat below the average; the Fifties beat into fits all record up to 1891 ; the Sixties are a good average; the Seventies beat the average; the Eighties are a long way below the average.

No doubt there was only one horse, Bourton, who won in the Fifties carrying 11st. or nver. But his was a record and no mistake, for, with 11st. 12lbs. (within 1lb. of Cortolvin, who carried the highest winning welght in Grand National history), he won the race of 1854 in $9 \mathrm{~min}$. 59sec.

Comeaway's win in 1891, meritorious as it was, equals only that of Bourton in 1854-just forty years ago. Both horses carried 11st. $12 \mathrm{lbs}$. and did the journey in $9 \mathrm{~min}$. 59sec., which gives them alike the best winning records of the Grand National.

I have gone into those abstruse, and perhaps to some people uninteresting, calculations for the purpose of confronting the many who, with dogmatic assurance, denounce the pace of steeplechasers of old in comparison with that of the present day.

Of course we all know that time calculation is unreliable. The only way to find out the relative merit of horses is to try them against each other. An authentic time-record is, however, very much more to be depended upon than any man's opinion, particularly when based only upon memory. Making, therefore, all due allowance for whatever defect there may be in a system such as the above, and in the absence of any other more reliable, I think my table, showing a record of halfa-century's racing, fairly proves my assertion that horses, able to carry weight, went as fast long ago over a long steeplechase as they do now. 
Be it well understood 1 speak only of real steeplechase courses, such as Aintree, Punchestown, Fairyhouse, Leopardstown, and Sandown ; I certainly do not allude to billiard-table courses, like Cork Park, which have been introduced of late years with their two-mile races, for such, in my opinion, are not steeplechases at all. Anyhow we cannot compare them, for horses long ago were never raced over such places.

Assuredly the steeplechasers of the present day lack the stamina and staying powers of the old ones, and if they go as fast it is because they have light, smooth, and level courses. A sorry time would they have over the old heavy and uneven fields where speed and endurance were maintained. Speed over flat, artificial ground, but without endurance, is the usual order of to-day.

No doubt there are some few exceptions; for instance, Royal Meath, Cloister, and Comeaway. They are quite capable of stretching the neck of any horse that ever went a steeplechase. But are they not all. Irishmen?

Some short time ago I cut from a newspaper a notice which I intended to reproduce in these pages, for it appeared to me to be about the best an the subject I ever read. It was a description of the sort of horse best calculated to win a Grand National. Unfortunately I mislaid the cutting and I forget what paper it came from. However, in substance it was as follows: The horse we want for a long steeplechase like the Grand National is one that can keep going on after he is beaten. The pace at which that race is run and the severity of the course causes the unsound and unfit horses to crack up, even if they don't fall, before half the journey is gone. It is only then that the real struggle legins. By degrees others drop off beaten. One horse, however, has been going great guns and bang in front all the way until within a mile of home. $\mathrm{He}$ is well bred, well "balanced," in perfect condition, gallops with freedom, jumps without undue loss of power, and he is well ridden. However, when coming along the canal he feels the pinch, and at the racecourse he shows clear evidence of being beaten. His place is taken by another horse full of running, and who then appears to have the race at his mercy. Nevertheless the other keeps pegging away after him. The leader, equally well ridden, has not the same high credentials as the other, and before the last hurdle is reached he, too, gets beaten, and through some loose screw, shuts up within the next hundred yards hopelessly so. Then comes on our struggling friend and gamely wins his race, although he was beaten half a mile before the other horse.

When making comparisons between past and present steeplechase arrangements, I overlooked one item, possibly from the fact that a comparison could not be drawn. I speak of the reporter for the Press.

Thirty years ago the proprietor of an Irish newspaper never dreaint of sending a representative to our meetings, and when reference was given it was in very skeleton style. In like manner were all branches of sport neglected by the Press. Needless to remark we had no journal devoted solely to sport, while in England there were only The Field 
and Bell's Life. The English Press, outside these papers, and a few magazines, gave as little heed to the sports of our country as did the Irish.

My friend the late Mr. William Dunbar of Dublin saw the want in Ireland, and in the year 1869 started, as a weekly paper, the Irish Sportsman.

The publication of this paper was a great boon, and its issue on Saturday was looked for with eagerness. Mr. Dunbar was a man of good social position, an eminent scholar, a gentleman, and a sportsman, and under his management the paper flourished for many years until his death. It was always well edited, and dealt with sport in style as brilliant as any journal started since or before it. Through troublous times, and when to uphold anything in which our gentry took interest was a hazardous undertaking, it fearlessly stuck to its principles and manfully sustained our sport in all its branches. It is still to the fore, and long mas it so continue.

Editors of the daily papers of Dublin took the cue from the Irish Sportsman, and soon after its appearance they sent reporters to our meetings, and began to record the proceedings in their columns.

Now what do we see? Every paper, not alone in Ireland but all over the kingdom, devotes columns to sport in every morning's issue. Several papers devoted solely to the subject are now issued daily. Some of them deal with the various branches of their calling in much more extensive fashion than did many of the dailies long ago with political, social, foreign, home, and all other events put together.

Men at present can't wait a day, not to speak of nearly a week, to hear of current sporting topics, and at times they must have evening editions, as well as the morning. No, they would not await the issue of even Bell's Life, but chucked up that reliable and most interesting journal, and took on to the dailies, in consequence of which good old "Nunquam Dormio" had to strike its colours.

The result of every race is now known all over the kingdom within an hour, and that of the important events is flashed to the Antipodes in the same space of time.

Perhaps a greater record in telegraphy was never made than that of Mr. James Gordon Bennett with regard to the Derby of 1890 . By his ingenuity the result was known in New York in ninety seconds after Sainfoin had won!

Before concluding my chapter I shall refer to a couple of feats which, in my opinion, "make history," and deserve to be called not alone famous and celebrated, but plucky in the extreme. I allude to the winning of two events of similar kind and under similar circumstances within recent years by two sportsmen, neither of whom were high up in the art of jockeyship. Each man backed himself to buy a horse and on him win an approaching great steeplechase-neither having a horse fit for the feat or knowing where to find one at the time they made the wagers.

Mr. Charles Barrington of Dublin backed himself early in 1879 to 
ride the winner of the Ward Hunt Cup at Fairybouse on the following Easter Monday upon a horse not then in his possession. This sporting wager he won on Malahide, beating nine others in a canter by three lengths, after having led them from start to finish. The fact that Mr. Barrington had not ridden at all for years previously, and had never any experience between the flags, made this feat all the pluckier and more sportsmanlike.

Three years afterwards Lord Manners, under similar circumstances, entered into the same sort of engagement with regard to the Grand National of 1882, which he won on Seaman, beating a field of eleven.

A word also about these two good horses. Malahide was by JocoMiss Fisher, by Kingfisher, and was bred by my friend Mr. James Dobbyn of Tipperary, who hunted him for two seasons. Mr. William Jameson (the owner of Comeaway) bought him from Mr. Dobbyn and called him Malahide, and Mr. Barrington bought him from Mr. Jameson for the purpose of the race.

Seaman was by Xenophon-Lena Rivers, and was bred by the late Captain Stamer Gubbins, but being a miserable yearling he was not shown with the Bruree horses when they were sold after the owner's death. I don't think I ever saw a horse go over our Conyngham Cup course in such brilliant style as did Seaman in ${ }^{\circ} 1881$, when, carrying 11st. Tlbs., and ridden by Mr. Harry Beasley, he won from a large field of good horses. He laid only one hind leg on the double into the new country and landed a yard clear of the off grip! No other horse ever jumped that fence in such a fashion. He was rather a small horse. with very bad legs, but luckily he did not require much galloping. $\mathrm{He}$ was scarified with the irons from knees to knuckles and from hocks to heels; nevertheless, Captain Machell bought him for nearly $£ 2,000$ from Mr. Linde for Lord Manners, as being the horse most likely to win for him his plucky sporting bet. In selling Seamain Mr. Linde sold a rod to whip himself, for the son of Xenophon, in winning his race, beat by a head Cyrus out of the Eyrefield stable, with the crack Mr. Tommy Beasley riding.

P.S.-Since I put together the list of Irish horses which won the Grand National, that good horse Cloister has added to our laurels by winning in 1893. He carried 12st. 7 lbs., and thus broke all previous record. The race was timed at $9 \mathrm{~min}$. $32 \mathrm{sec}$, but this I think must be a mistake. I saw the race and paid my utmost attention to Cloister, He went the same pace all through, which by no means struck me as being fast, for at no time was he fully extended, and he won by forty lengths. If, therefore, carrying $12 \mathrm{st} .7 \mathrm{lbs}$. he did the course in $9 \mathrm{~min}$. $32 \mathrm{sec}$., he is the very best horse that was ever saddled for the Grand National. I always held for Cloister the highest opinion, but I certainly would not give him that record. 


\section{CHAPTER IX. PUNCHESTOWN.}

Early History-Arrangements-Meeting of 1854-A Comparison-Angelo Hayes' PictureMeeting of 1861-National Hunt Steeplechase-Biggest Stake in Ireland-The Winner and Placed Horses-Meeting of 1862-Lords Drogheda and St. Lawrence-Thomas G. Waters-What they did-"Princely Punchestown"-Wisdom and Foresight of Lord Drogheda-Late Lord Clonmell-Lord Drogheda again-Doctrines against Hunting - The Land League-Kildare Hunt opposed-Outrages-Hounds Puisoned-Burning Coverts-Interferences with Hunting in 1881-82-Programme for 1882-Meeting Withdrawn-Results-Great Loss to Tradesmen and others-Wholesome LessonResults-Punchestown continued in 1883-Lord Drogheda's Capital Idea-The Courses-A Flat Race !-The old Pilot-Mr. Perey La Touche takes the Tiller-His qualifications-What he has done-Foxhunters' Plate Course-National Hunt Steeplechase in 1862-Late Marquis of Downshire-Late Marquis of Conyngham-The Downshire and Conyngham Cups-The Courses at Punchestown-Conyngham Cup Course-Author's Rhapsody-Liberality to Owners-Punchestown Double-The Ladies' Lawn-The Ladies-Meeting of 1890-A Comparison-The Stand-houses-Reserved Stand-Ladies' Stand-Charges-Another Comparison-Special Advantages of Punchestown-Conyngham Cup Course again-The Farmers' Race-Its Peculiarities -The Present Earl Clonmell-Lord Otho Fitzgerald-Liberality of Kildare Hunt to Farmers - Author's Sad Recollections-His Advice-His Personal Experiences -His First "Leg-up"-National Hunt Steeplechase, 18ว2-Captain McCraith-"Mr. Thomas"-Mr. Apjohn-The Race-Author's feelings After-To Clear the DoubleHorses who did so-Capt. Johnny Bates-Terrible Accident in 1864-Capt. McCraith and Mr. George Knox-Results-Another Dreadful Occurrence-Panic on the StandResults-A Welsher-Royal Visits - A Loyal Comparison - The Prince of WalesA Sore Subject-Meeting of 1886-A Narrative of Loyalty and Pluck-"Does anyone else wish to hiss the Prince of Wales?"-Accidents-Poor Willie Beasley !-His death - Major Trocke and Countess-The Kildare Hunt Plate of 1892-Who was who thirty years ago.

Punchestown as a race-meeting dates from 1847, if not a year or two farther back.

About that time the sporting Kildare Hunt established a small annual meeting over some portion of what is now called the "Old Course," restricted to the members of the Hunt and its farmers, with one or two small races for regular steeplechasers. The arrangements were as primitive as those at any other meeting of the period, and it was not until 1854 that the first stand-house was erected, somewhere near the spot occupied by the present one, but it was only a small wooden structure.

The meeting in 1854 was the most important of any previously held, and I think it was then for the first time that two days were given. Even so the total of all the stakes did not nearly amount to what we now have for the Conyngham Cup.

From the fact that Mr. Angelo Hayes has handed down to posterity in the shape of his magnificent picture "The Corinthian Cup " at Punchestown in 1854, it would appear that that race was the important feature of the meeting. 
In this picture are strikingly good likenesses of some of the leading: steeplechase notorieties of Ireland in that day. The scene is laid at the wall with the Furry Hill as background. The portraits include those of Lords Waterford, Drogheda, Conyngham, Howth, St. Lawrence, Clonmell, and Cloncurry ; Messrs. John Preston, Sam Reynell, Fleetwood Rynd, William Kennedy (then Master of the Kildare Hounds), Colonel Campbell, Major Dickson, and Sir Philip Crampton. Those in silk mounted to start are Captain William Hely-Hutchinson on Torrent, who won the race, Captains Barnard, Warburton, Severne, Wombwell, Chichester, Barclay, and Hutton, also Messrs. Wilkin, Boyce and Price. Out of that group there now remain alive, as far as I know, only three or four.

In the year 1860 the Kildare gentlemen conceived the idea of reconstructing the old system upon new lines, and, headed by the Marquis of Drogheda and Lord St. Lawrence (the present Earl of Howth), published an article for 1861, under the title "The Kildare and National Hunt Steeplechases." There were seven races for $£ 770$ added moneyfour of which had an additional sweepstakes of $£ 5$ each-and there was the Kildare Hunt Cup, value $£ 50$, for members only.

The above inaugurated the National Hunt Steeplechase, which was for $£ 300$, added to a $£ 5$ sweep, three and a half miles. This was far and away the biggest stake hitherto offered for a race in Ireland. Of the many horses entered, 35 accepted and 27 started, and the race resulted as follows :-

Captain McCraith's The Rug ..Owner Mr. Thomas Harper's Tickle Toby .............................. Knox 2 Mr. William McGrane's Ben Bolt..................... aptain 'T'ownley 3

So eminently successful did this meeting prove, that for 1862 the Stewards gave $£ 900$ for eight races, five of which had sweepstakes. added of from $£ 3$ to $£ 5$. In addition the 4th Dragoons had their private challenge cup and the Kildare Hunt had theirs.

Lords Drogheda and St. Lawrence continued to be the leading spirits of Punchestown for some years. After a time, however, the latter nobleman gave up taking active part, and the whole management. devolved upon Lord Drogheda, and to his able and fostering care are we indebtea for the steady progress made up to the present time, when Punchestown stands, as it has stood for many years, unrivalled by any steeplechase meeting under the sun.

Lord Drogheda had a zealous and able lieutenant in the late Mr. Thomas G. Waters, who threw his whole soul into the work, and carried out with determined energy all the improvements which give Punchestown its place. The improvements were judiciously begun in a small way, but gradually they were increased, until now, for convenience and extent, the stand, enclosure, and course arrangements rival any in the kingdom, and surpass most. Yes, to Lord Drogheda and the late Mr. Waters we owe Punchestown, which, since the first visit of the 
Prince of Wales in 1868, has been dubbed "Princely," as Ascot and Goodwood are designated "Royal " and "Glorious."

His lordship, with wisdom and foresight, created a race fund by soliciting subscriptions beforehand for the meeting of 1861, and continued to do so for some years after. These came from each Hunt in Ireland, and from many sportsmen who wished to help the good work. His appeal was met with such liberal response, a nice capital and sinking fund was soon created; and as the receipts from stand, course, and entries were very considerable, he was enabled not alone to carry out all his plans, but to vastly increase the stakes, until in this year, 1892 , they aggregate $£ 2,760$ in cash, with cups value $£ 250$ for a two days' meeting of twelve races.

The late lamented Earl of Clonmell for many years added $£ 25$ to the Farmers' Race. Alas! that genuine sportsman and prince of good fellows joined the majority in June, 1891, and nowhere will his loss be more deeply felt than at Punchestown, where for over twenty meetings he dispensed lavish hospitality, and welcomed alike both friends and strangers with that jovial heartiness which at all times characterised the genial lord of Bishopscourt.*

Lord Drogheda's conservative opinions were, as in many other instances, evidenced in his control of Punchestown. He preserved in their natural state its classic courses, and all hail to him for doing so. At the same time he went with the times as regards stand-house requirements, while his thorough knowledge of steeplechasing was ever and anon in evidence by the alterations and additions he made in the annual programme, which invariably bore advantageous result.

Atrocious doctrines against hunting, and all else pertaining to Irish gentlemen, began to be preached by the leaders of the Land League towards the end of the seventies. As stated elsewhere these foul precepts bore fruit eventually, and for several seasons great opposition to hunting was shown all over Ireland.

The Kildare Hunt, like the Curraghmore, was singled out for especial malignity in consequence of its being so eminently supported and represented by the Irish aristocracy and gentry.

Outrages of the most horrible description-similar to those described in the Curraghmore chapter-were committed, including poisoning of poor inoffensive hounds and foxes, burning some of the best coverts in the county, prevention of hunting by organised mobs surrounding coverts, shouting, hooting, blowing horns, and ringing bells, not to speak of insulting ladies and gentlemen in the most scandalous manner. In a word, the Kildare Hounds were unable to hunt with any degree of pleasure to their followers during the season 1881-82.

The programme for Panchestown is always issued early in January, and in 1882 it came ont with the suggestive proviso that the Stewards reserved to themselves the right to withdraw the meeting if they deemed

* Since writing this chapter Lord Drogheda has also died.-AUTHOR. 
such a proceeding advisable. They did consider themselves so justified, and in 1882 there was no Punchestown.

This proper action of the executive brought the agitators against hunting in Kildare to their senses.

Consequent upon a gigantic race-meeting like Punchestown thousands upon thousands of pounds are circulated. Shopkeepers and tradesmen, hotel proprietors and car-owners, as well as many of the peasantry, all make money, while numbers of the small traders reckon upon paying their rent, if not a great deal more, out of the profits of the race week.

All that good fortune was taken from the Kildare folk in 1882, so, although many of the losers were sympathisers with the Land League, drastic measures were taken by them to prevent further interference with hunting, with such result that Punchestown was again a meeting in 1883 , and so it has continued.

I may say, however, that for some years after a proviso, admonitory and suggestive, was inserted in the programme.

Lord Drogheda obtained a capital idea during his visit to Australia a few years ago. He took it, I think, from the Melbourne Race Executive, and established it at Punchestown. The rule is to supply each rider at the scales with a white saddle-cloth, in the hind corners of which is a large red number corresponding with that of the horse on the card. Exhibiting this is of the greatest convenience for ready reference, and I wonder the excellent example is not universally followed.

The only mistake ever made at Punchestown was some ten years ago, when a flat race was published in the programme. Fancy, a fat race at Punchestown! Happily, it did not fill, so it was never started. I devoutly hope Punchestown will never be anything but what it is-the premier steeplechase meeting of the world.

It is not likely to be anything else, for although the old pilot gave up the tiller in 1886, he handed it to Mr. Percy La Touche; and while he holds it Punchestown will keep to windward of all other meetings. Mr. La Touche is eminently qualified for the task, for he is a practical sportsman, understands steeplechasing thoroughly, not alone theoretically, but practically, for he rode many a race in the grand arena, and has been for years one of the best men with hounds across Kildare. $\mathrm{He}$ is also well endowed with both administrative and executive ability, while no man in Ireland is more popular. All who attend our meetings, whether on business or for pleasure, know what attention they receive from that courteous and painstaking gentleman whenever he is called upon.

Since he took office Mr. La Touch 0 has expended over $£ 4,000$ enlarging and improving the stands and enclosures. The work has been executed by Messrs. Musgrave of Belfast, under the superintendence of Mr. Robert Waters, who succeeded his father as manager.

Mr. La Touche has also laid out the Foxhunters' Plate Course, where it turns to the right before reaching the first brook, and rejoins the old course at the back of the double in the Herd's Garden, thus leaving 
. 


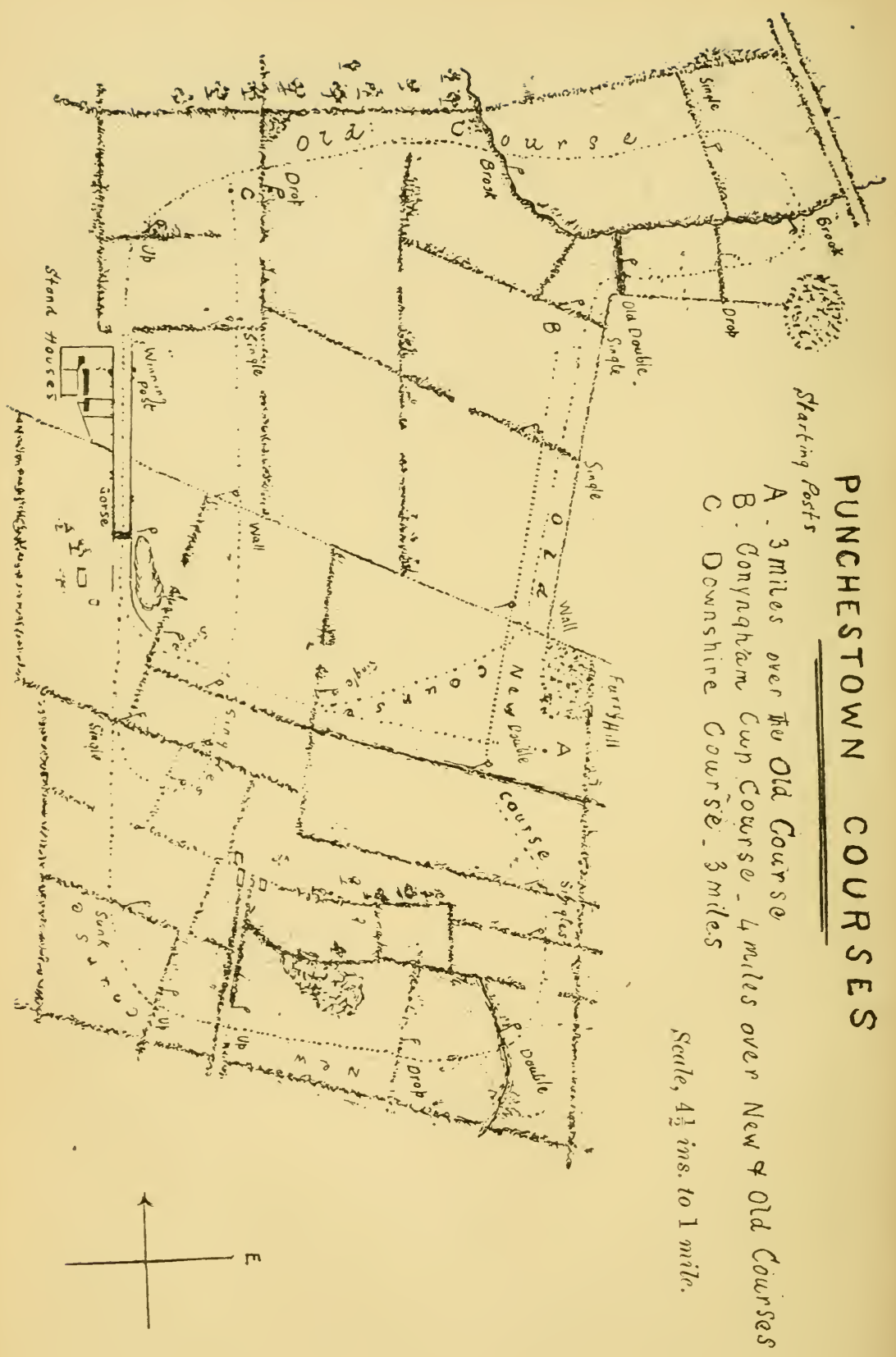


out the far-off and extreme left portion of the Old Course. This was done to obviate the necessity of finishing over the Conyngham in races of less than four miles, for the big fences in that course were considered. dangerous to finish over, as was proved by the severe falls got by Major Burke and Captain Orr-Ewing a few years ago.

The courses at Punchestown are quite natural, as, with few exceptions, are the fences, and a little trimming is all that distinguishes the exceptions. I have heard people assert that the fences were greatly cut down within the past twenty years. They never were. The run-home was altered and greatly improved some years ago at considerable expense ; the nasty dip near the pond was then filled up, and the run-in, for nearly quarter of a mile before the winning-post, was made straight and level.

The first race for the Conyngham Cup was run in 1865, and was won by General Election. The line was then over the Old Course.

The track now known as the Conyngham Cup Course was opened for the first time in 1862, when the National Hunt Steeplechase was run over it, but there was so much grief in that race it was not again used till about ten years ago, when the race from which it now takes its name was run over it. Since then it has been utilised annually for that particular event and for several others.

The late Marquis of Downshire gave, in 1863, a silver cup, and continued that generosity annually for some years. I think the late Marquis of Conyngham gave one also; anyhow the races respectively called after these grand old sportsmen have invariably been about the most interesting items in the two days' sport.

The Downshire has always been a welter race, and has had for its. second fence the formidable $4 \frac{1}{2} \mathrm{ft}$. stone wall. For a few years portion of its course lay at the back of the stand, but that was wisely altered long ago.

The tracks of the various courses at Punchestown have been selected and laid out with skill in such matters more consummate than any I ever saw displayed elsewhere.

The magnificent track of the Conyngham is three miles in circuit, i.e.s the Old and New Courses, and so well is it laid out that, although the distance is four miles, the only fences that have to be jumped a second time are the single before the wall, the wall, and the gorse hurdle. The Old Course is two and a quarter miles in circuit, and for threemile races only two fences and the gorse have to be jumped twice, while in the Downshire, of three miles, the only fence jumped twice is the gorse. The National Hunt Cup is run over the Foxhunters', Conyngham and Old Courses, distance being four miles and a quarter, yet only two fences have to be jumped twice.

Think of that, ye executives of hippodromes, a mile or mile and a half round, with their three-mile courses!

From the stand at Punchestown the horses in each race can be seen in their stride every yard from start to finish, except when racing towards you from the far brook to the old double, and from the turn for 
home in the Conyngham-in all about half a mile. Many is the course where you see horses broadside on only for that distance, the rest of the journey being run directly to or from you, so that no one can tell what a horse is doing, or what his rider may be doing either. Oh, truly, truly has it been said if a man wants to see a steeplechase he must come to Punchestown!*

The executive makes racing there as cheap as possible to owners of horses ; the entrances for the various plates seldom exceed 2 per cent., and never 3 per cent., of the value of the prizes.

Another great feature is that one gate payment gives access to all parts of the grand stand and enclosures, and visitors are not pestered by janitors and extra charges, as at so many meetings in England. The charge is only 15s. for the first day, 10s. for the second day, or 20s. for both days. A complimentary ticket from Mr. David Mahony admits to the Ladies' Stand free, while one from Mr. La Touche admits to the Reserved Stand, on the top of the Ladies' Stand, on payment of a sovereign for both days.

The Reserved Stand is the most convenient and best-managed of any I know. No one can ever get on it without a ticket issued direct from Mr. La Touche, and no more people will get tickets than the stand will easily accommodate. This allows the privileged holders plenty of time to look over the horses in the paddock, or transact their business at their ease, to obtain a near view of the preliminary gallop, and then go up to their stand, whence they can see the horses' hoofs over every yard of the different courses, except just behind Moll Dunne's Hill, which, in the Conyngham Cup Course, hides about two hundred yards equally from all.

Managers of other meetings who charge twice as much and don't give half the value, should take note of these arrangements characteristic only of this premier meeting.

I have been to many places where women most do congregate, but commend me to the Ladies' Lawn on a fine afternoon for a display of beauty and elegance which I have never seen equalled, much less excelled. Neither Royal Ascot nor Glorious Goodwood can produce lovelier specimens.

The meeting of 1890 was attended by about the greatest number of ladies I ever saw there, while the receipts of the public stand showed that considerably more people attended in 1890 than ever did previously. The horses, too, which ran that year were of a much better stamp generally than I had seen for a long time.

If we had the same class of patrons now as we had twenty years ago, and same class of horses, would not Punchestown, with its present arrangements, be as near perfection as it is possible for humanity to make anything?

But one thing is to be regretted at Punchestown, and that is the

* See page 147 for a description of the old double. 
lamentable display we nearly always see in the Farmers' Race. Twenty to thirty horses often start, but before two fields have been travelled there is a long tail, and before the leaders pass the stand there are not more than a third of the lot in the race; and when it is won perhaps not more than half a dozen have gone the course.

Objections are invariably lodged, which result generally in the disqualification of the horse which came in first and often of the three placed. In 1891 the race had to be declared "null and void," because the first four horses were disqualified for one reason or other. Oddly enough it was the best Farmers' Race I ever saw at Punchestown; horses went like racers and were ridden by men like jockeys.

So uncertain is it that the horse which comes in first will be eventually declared the winner that the bookmakers stipulate specially for this race, that they pay only on "first past the post."

To reduce these difficulties an extra race of a more open character was introduced in 1892.

The present Earl of Clonmell follows his brother's good example and gives a large contribution to the stakes to be run for by the farmers. Lord Otho Fitzgerald, late M.P. for Kildare, presented the Challenge Cup, value $£ 50$, some years ago, and with the addition of a hundred guineas from the fund the Kildare farmers are dealt liberally with and owe a debt of gratitude to their County Hunt.

I am continually in the habit of bragging that I never missed a Punchestown since 1861, and every year when leaving after the last race on the second day I ask myself, will I ever see the historic spot again?

Alas, it makes an old habitué like myself bitterly sad to think of all the fine men and dear friends he has seen and met within that enclosure who are now gone for ever. If a man has friends in the world he meets them at Punchestown, but then comes the time when they are missed! Such sad, and too-oft repeated experiences, make my visits of late years very different indeed in enjoyment from what they were long ago, and were it not that I should look upon missing Punchestown as something approaching a personal calamity, I don't think I would go there again.

If some of those who have never been there will come, no matter how experienced they may be in steeplechasing elsewhere, they will go away with an opinion of the meeting similar to mine. To appreciate this to the full, they should go early and walk the courses, and perhaps during the day, go down to the Herd's Garden or Furry Hill to see how our Irish horses can jump a double.

With such an experience of Punchestown as I have had I can recall incidents of various nature, so 1 may as well relate a few. I will begin with one personal to myself.

At no time of my life do I think I felt such pride and satisfaction as I had when I got the leg-up on The Baron for the National Hunt Steeplechase of 1862 . I was smartly turned out in orthodox racing toggery, which, as I mentioned in a former chapter, was not common 
among Irish Corinthian riders thirty years ago, and my mount was a right good-looking horse ; moreover, this was my first try between the flags. Five-and-twenty went to the post, and on the way I well remember poor Tom McCraith calling to "Mr. Thomas" to look at the stringof silks and satins, asking him if he could see such a sight in England!

Of course every one of the twenty-five thought he was going to win. I know I had visionary notions to that effect, but still I asked McCraith what was best for me to do. His answer was to this effect:- "The race, bar accidents, is between Tom Pickernel and me, unless Apjohn beats us ; so get away in front as soon as the flag falls, for if you stay in the ruck you will be knocked down, and may be your first will be your last steeplechase."

Accordingly, to the front I went when Clancey dropped his flag, and, alongside the two gentlemen named, jumped the big double into the present Conyngham Cup Course, the first time a silk jacket faced it.

Poor McCraith's tip as to the result of our race was amazingly correct, for it was won by Ben Bolt with Mr. Pickernel ("Mr. Thomas") up, while Kate Fisher and Valentine, ridden respectively by Mr. Tommy Apjohn and Captain Mcl'raith, were second and third. My satisfaction after the race was not quite as great as before it, for I was a long way astern of those three-and others besides-at the finish! Never mind; the gallop gave me huge delight all the same, and it is pleasurable even now to recall it to memory.

To clear from field to field the old double in the Herd's Garden although the height, as I have said, is under $3 \mathrm{ft}$., requires a horse to cover at least $20 \mathrm{ft}$. in an arc at least $26 \mathrm{ft}$. This tas been attempted by many horses, but very few have accomplished the feat without a fall, and some have killed themselves in the attempt. The only horses I remember to have landed in safety without laying an iron on it are Redman, Lord George (an English horse), and Charity Boy; but others, no doubt, may have done so.

I need not say that when these aerial eccentricities were performed it was not usually with the consent of the jockeys ; there was, however, an exception in the person of Captain Johnny Bates of the 4th Dragoon Guards. That gentleman's great ambition was to ride a horse from field to field over the double, and he invariably tried to gratify it on the many mounts he had some years ago at Punchestown, but I don't think he ever succeeded.

I was witness in 1864 of a very terrible accident, perhaps the most fearful I ever saw on a steeplechase course. It was in the Welter Stakes. Captain McCraith on Forager and Mr. George Knox on Hard Times had come away from their field, and were going head and head for their race, but after crossing the last fence they got entangled in the ropes and posts which were supposed to mark the line of the run-in. Most awful falls were the result to both. McCraith and Knox, together with their horses, lay in a heap senseless. One unfortunate rustic was killed on the spot, and injuries of very severe nature were sustained by several 
others, for the two horses turned somersaults into the midst of some fifty people closely packed. An investigation was held to ascertain who was to blame for this appalling catastrophe, particulars of which the narrative does not require.

I was witness of another very dreadful occurrence at Punchestown some twenty years ago. The Grand Stand was packed full of people just before one of the races, when a cry was raised by some scoundrel in the ring that it was falling. This created an immediate panic, and there was a general stampede from off the stand. In the frantic struggle several people fell and were trampled on Two or three had limbs broken and many were otherwise severely injured. Luckily no one was killed. If the fellow who raised the cry which caused this disaster could have been recognised and captured, I should have liked to have seen him treated as I once did a welsher in the same enclosure. He was stripped to the skin, flogged unmercifully, daubed over with paint, and then kicked out on the course with nothing whatsoever upon him except one boot and stocking.

I, with many thousands of my countrymen, regret that members of our Royal family do not visit Ireland oftener than they do. We fail to see why Scotland should be favoured yearly by visits from Royalty, any one of which is of longer duration than all the visits put together, which our gracious Majesty and her family have vouchsafed to Ireland since her reign began!

This is all the more inexplicable when it is known that in no part of the kingdom and upon no one occasion did our Queen or any member of the Royal family receive more heartfelt loyal greeting than they did upon the few occasions of their coming to Ireland.

The Prince of Wales knows well what a welcome he got upon the two visits he paid Punchestown, and I am very sure H.R.H. cannot recall their like upon any other he ever paid to a racecourse.

Having said thus much upon a subject we Irish feel very sorely about, I shall relate what I was an eye-witness to the last time the Prince of Wales came to Ireland. It was at the wet and windy Punchestown of 1886.

At that time the country was very much disturbed by the Land agitation. Nevertheless the welcome given H.R.H. was of the heartiest description, and almost universal. Upon the Royal party leaving the Reserved Stand, and while enthusiastic cheers rent the air, there came a hiss from a young man standing quite close to where I was in the Public Enclosure. Within a few paces of the individual there also stood a dapper little man wearing a covert coat and billycock hat. No sooner did the hiss reach the ears of this little chap than off came the hat and the coat, and straight from the shoulder he let drive, right between the eyes of the Nationalist, a sock-dolloger which for beauty and effect I scarcely ever saw beaten. Heels over head the fellow went. After picking himself out of the mud I never shall forget how the little man danced round him, asking would he like to hiss the Prince of Wales 
again! This the cur replied to by sneaking off with his companions as fast as he could. Whereupon the little man, still hopping about with fists in position, lustily sang out with suggestive inquisitiveness, "Does anyone else wish to hiss the Prince of Wales? Does anyone else wish to hiss the Prince of Wales?"

I never could find out who this gentleman was, but he could use his fists, and that too with marked effect upon a man several inches taller, and more than a stone heavier, than himself.

There are thousands in Ireland who would do just the same thing under similar provocation, and I only relate the occurrence as an example of Irish loyalty.

Accidents with calamitous results have, of course, befallen many a good man and horse over Punchestown, but they were not more numerous than those over other steeplechase courses of less formidable character. Never, however, was one so universally regretted as that which befell Mr. William Beasley at the meeting of 1892 .

He was riding Mr. J. H. Peard's All's Well in the Kildare Hunt Plate, on the second day (April 27), when the horse, with another, came down at the double, and poor Willie got a kick in the head. Consciousness never fully returned to him, and he died on May 9.

He was the third brother of that famous family of gentlemen riders. Although he had not attained the high honours between the flags which his two elder brothers, Tom and Harry, had won, he was a top-sawyer in his profession. He was a genial gentleman, popular alike in private and in public, and long will it be before his untimely death will cease to be regretted.*

This unfortunate Kildare Hunt Plate of 1892 was gallantly won by Major Trocke on his mare Countess, carrying top weight, 12st. 7lbs, having won the Drogheda stakes the year before on the same mare. Loud and continuous were the cheers from the stand-houses as our veteran Corinthian passed the winning-post; and seldom, if ever, has there been a more popular win at Punchestown.

We little knew that while we cheered the gallant Trocke poor Willie Beasley was lying crushed at the double!

Major Trocke of Hillbrook, in the King's County, may indeed lay claim to the adjective "famous" which I expound on in the chapter on Racing $\mathrm{He}$ has been to my certain knowledge riding steeplechases for nearly forty years, and never passed a year without winning at least once. $\mathrm{He}$ has bred, reared, and trained many race-horses, some of which were of very high class, and many a winner in the best company has he piloted, while his reputation on the Turf has never been tarnished even by suspicion.

Before bringing to a close my memoir of good old Punchestown, I shall make mention of a few of those who, early in the sixties, held

* Reference to the brothers Beasley will be found in the chapter on the Curragh. 
prominent place among Irish sportsmen, and by their influence gave Lord Drogheda effective support in making Punchestown what it isI jot down the names just as they occur to me, beginning with those who were masters of our foxhounds, according to their countries, and it will be seen our patrons represented all parts of Ireland :-Captain Rye of the Muskerry, Lord Shannon of the United, Lord Doneraile of the Duhallow, Sir David Roche of the Limerick, John Going of the Tipperary, Henry Briscoe of the Curraghmore, Sir Nugent Humble of his own pack, Henry Meredith of the Kilkenny, David Beatty of the Wexford, Robert Watson of the Carlow and Island, Captain Cosby of the Queen's County, Burton Persse of the Galway, Baron de Robeck of the Kildares, Captain Coote of the West Meath, Sam Reynell of the Meath, Captain Filgate of the Louth; with the masters of our two packs of staghounds, those fine sportsmen Leonard Morrogh of the Wards and Captain Balfe of the Roscommon. Then we had the Marquises of Conyngham, Clanricarde, and Downshire, Lords Howth and St. Lawrence, Colonel Bernard of Kinnitty, his brother Captain Richard, one of our then few good Corinthian jockeys, Richard Stackpoole of Eden Vale, John Harold Barry of Ballyvonare, Captain Studdert of Cahermoyer, Thomas Naghten of Thomastown, Sir Richard de Burgho of Castleconnell, WVilliam Quin of Loughloher, Captain Pack-Beresford of Fenagh, Judge Gough of Rathronan, John Preston of Bellinter, Captain Mervyn Archdale of Castle Archdale, John White of Nantenan, Michael Betagh of Clonsilla, James Cassidy of Monasterevan, Colonel Frank Forster, John Hubert Moore, Thomas Harper of Naptown, P. M. V. Saurin of Duleek, Michael Dunne of Ballymanus, Sir John Power of Kilfane, and his son Richard, Colonel Carden, who for mary years was master of the Queen's County Hounds, Colonel John White, of the 7th Hussars, a notable all-round sportsman, and a comrade-in-arms of the Duke of Beaufort and the late Lord Dunsandle, with whom he was great friends; Colonel the Hon. Charles White of the Co. Clare, Captain Archibald Peel, who lived near Ashbourne, and now lives in Sir Watkin Wynn's country; George Bryan of Jenkinstown, the Hon. H. Fitzwilliam, who rode Redman when he flew the double; Colonel Ainslie, who commanded the Royals, the owner of Juryman, Wild Fox, etc.; Colonel Harford, who rode many a winner at Punchestown ; William Nagrane of Dublin, J. D'Arcy Hoey of Newry, who bred Comeaway; James Gartlan of Carrickmacross, Robert Long of Mayfield, Lord James Butler, who won the famous eighteen stone steeplechase at Whitefields nearly forty years ago ; Joseph Tuite of Sonna, Lord Bectire, now Marquis of Headfort, Sir Walter Nugent of Clonave, etc.

In Kildare were found Lords Naas, Cloncurry; Clonmell, and Milltown, the Baron de Robeck of Gowran Grange, Thomas Conolly of Castletown, Richard Moore of Killashee, John Wakefield, the "best man" then with the Kildares, Sir Edward Kennedy, J. P. Tynte and his son Fortescue, Edmund Mansfield, the right-hand of the Kildare Hunt, Major Barton, Cristopher Rynd, David Mahony, who habitually smoked 
cigarettes twenty years before they became the fashion, Right Hon. W. H. F. Cogan, MI.P., Captain Charles Warburton, Charles Roberts of Sallymount, Michael Aylmer of Courtown, and Charles Hoffman of Mullaghboden, posssibly the only living participant in the celebrated Laragh run. This run was had with the 1861, when Lord Naas was Master, and it ranks among the finest foxhunts we ever had in Ireland. The fox was found in Laragh, a gorse covert between Sallins and Maynooth, and he was killed at Bellinter Park wall, near Kilmessan Station, in co. Meath, an eighteen-mile point, all over the finest grass country. Stephen Goodall, the huntsman, Mr. Hoffmann, Mr. Johnnie Wakefield, and a groom of Mr. Tuthill's were about all who got to the end.

Towards the end of the sixties there came to the front men equally useful to the Turf. Among them I may mention the late Lord Clonmell, Captains John F. Montgomery, Kirkwood, and Stamer Gubbins, Pat. Russell, Harry Croker, John Gubbins, Major Burrows, Percy La Touche, William Blacker, Mat Maher, C. J. Blake, H. E. Linde, William Dunne, Edmond Smithwick, Captain Peel, P.M., Captain Trocke, James Chaine, etc., etc.

The foregoing chronicles only men who stood prominent in the steeplechase world, between, say, 1860 and ' 75 . Owing to insufficiency of memory I have no doubt omitted some who are equally entitled to reference, and I hope to be forgiven for doing so.

Well do I remember all the fine fellows I have mentioned. With most of them I was well acquainted, and some were very dear friends of mine. Alas ! few remain alive-far too few ! 


\section{CHAPTER X.}

\section{THE MARQUIS OF DROGHEDA, K.P.}

IIis Death - Sloock Caused - Its Suddenness - Particulars - Concurrent CircumstancesContinental Trip-Curragh June Meeting-News Received There-Meeting of the Turf Club-Resolution of Condolence-As a Racing Man-Moore Abbey-His Early Life-Hunting-Shooting-Game and Foxes-His Yachts-Coursing-BoherbawnPunchestown-The Curragh-Head of Irish Turf-No one his Equal-Appreciated During Life-A Lycurgus-His Lordship's Characteristics-Born to Govern-Physique -Hauteur-His Eye-His Supervision-Impartiality-Ranger of the CurraghResults-His Tenantry-Lord Drogheda as a Public Man-His Politics-His Habits"The Black and Silver"-His Steeplechase Horses-His Racers-His Jockeys-His Breeding Establishment-Philammon-His Produce-Satanella and other Brood Mares-Lord Drogheda a "famous" owner-Moneypenny-His Long Service-A Characteristic Narrative-A Comparison-Lord George Bentinck and Lord Drogheda -Lord Waterford-Their Deaths-Funerals of the two latter-Author's personal Experience of Lord Drogheda-His successor.

EABLY in the morning of the $2 y$ th June, 1892, at his residence in St. James' Place, London, died suddenly, of heart disease, Henry Francis Seymour Moore, third Marquis of Drogheda. Aged 66 years.

Such briefly was the direful news conveyed to the public in the morning papers of the 30th June, 1892.

The tidings came as a shock to everyone, while his friends and associates heard them with the deepest regret. The shock was the more severe from the fact that Lord Drogheda appeared to be in his usual bealth and spirits for some time past. He attended in his place in the House of Lords on the day of his death, and was at the Carlton Club up to midnight. He then went home, and was heard going up to his room at about 12.30 a.m. In the morning at 7.30 , when his valet went to call him, he found his lordship lying dead upon the floor, and apparently in the act of undressing.

As is too frequently the case in sudden visitations of death, the sadness of this event was increased by surrounding and concurrent circumstances. It was the intention of the Marquis, accompanied by the Marchioness, to have started for a continental trip on the following morning. Yet another melancholy episode. The June meeting at the Curragh was being held when the terrible news reached Ireland, and it happened to be perhaps the largest ever held there. Just as the thousands had assembled for a day's sport, came upon them like a thundercrash the news of the death of the head of all Irish racing, and at the scene of where his far-sighted judgment was so continually and emphatically displayed.

It was of course only fitting that the Turf Club should be the first to express their sense of the great loss which the death of the Marquis 
of Drogheda occasioned, and accordingly a special meeting of the members was immediately held at the Grand Stand. At it were present :-Mr. C. J. Blake (in the chair); Mr. W. Dunne, Lord Carlow, Mr. M. A. Maher, Colonel Thompson, Captain Dewhurst, Captain Richardson, Captain Stubber, Mr. M. J. Corbally, Captain Maher, Captain Greer, Mr. W. H. West, Mrr. Mr. Betagh, and Mr. J. G. Blake.

IIr. C. J. Blake said-" As now senior steward of the Turf Club, it devolves on me to-day - a day which I cannot but designate as a dark day for the Irish Turf-to convey to the Marchioness of Drogheda our expression of sincere sympathy and condolence with her ladyship in her great affliction, and to give expression to the deep feeling of sorrow and dismay which the intelligence of the sudden death of Lord Drogheda has occasioned, not only to the members of the Turf Club, but to every Irishman in any way connected with the interest and welfare of Irish racing. Distingushed in life as the late Marquis of Drogheda was in every respect, in person, in position, and, above all, in the nobility of his character, we, who have for so many years regarded him as the head and mainstay of Irish racing, cannot now dwell on the loss which his lamented death will occasion to his country at large, as well as to his personal friends, however much we might desire to do so. In the midst of surroundings which cannot but recall forcibly to our minds the energy and untiring care, of him who has departed, and feeling, as I do, personally almost overwhelmed by the greatness of our loss, it would be vain for me to attempt further to give adequate expression to our great sense of sorrow. The hearts of all those acquainted with Lord Drogheda will tell them what no words could tell so well, and long after every vestige of his mortality shall have disappeared will be found in our Club, and in what I may designate as our national institution, the memory and the mark of a noble life, devoted not merely to promote the material interest of racing, but to establish and maintain among racing men the honour and the integrity which so distinguished his own life."

The resolution was passed unanimously, and a copy was forwarded to the Marchioness of Drogheda, and also furnished to the members of the Press.

Were it not that this book may in years to come be read by those who are not yet born, it would not be necessary for me now to state in a few pages what the late Lord Drogheda was as a resident Irish nobleman, and what he was to our Irish racing, for the simple reason that anyone conversant with our sport or knowing anything of our gentry for the past forty years knows all that I have to tell.

In 1817 Lord Drogheda took the mastership of the old EmoFoxhounds, and, with William Nevard as huntsman, he held office for three seasons. As M.F.H., or rider to hounds, he did not attain the laurels which on the Turf, as an owner of racehorses, were most justly his. He was, however, all his life a staunch supporter of foxhunting, and, for many years, a pretty regular attendant at the meets of the Kildare Hounds. 
He was fond of shooting, and was a good shot, and had at Moore Abbey battues once or twice a year. But while requiring his keepers to show good sport for the guns, he took care that they always had foxes when the hounds drew his coverts.

For many years he spent the summers yachting, but he preferred the practical to the racing part. He was a member of the Royal Yacht Squadron, and for many years was Commodore of our St. George's Club. He owned the Fancy, 120 tons, the Cecile, 190 tons, and the Ferida, 180 tons, all fore and aft schooners.

Lord Drogheda was also fond of coursing, and in former days owned good greyhounds. The Leinster Coursing Club always enjoyed his permission to hold its meetings over the meadows of Boherbawn, and except Lord Lurgan's in the North, no Irish coursing club of its day held higher position.

I have already in my chapter on Punchestown related what his lordship did for steeplechasing. I now state that he did quite as much for flat-racing in general and the Curragh meetings in particular.

He was our head and leading light of both branches for the past thirty years. Others he had working with him in the formation of our chasing and racing laws, in the reformation of them according as such became advisable, and in their administration, but not one of his colleagues ever did nearly as good work.

It is not always that a man's worth is estimated at its full value during his lifetime, but every man in Ireland who knew even the first rudiments of our sport, has for many a year looked upon Lord Drogheda as the Lycurgus of Irish racing whether across country or on the flat.

He was pre-eminently fitted by nature to govern-no man could have five minutes' conversation with him without being impressed with that fact, while his eye, peculiarly penetrating as it was, evidenced the determination which lay within.

Although tall, his physique did not portray that "presence" which perhaps a heavier frame might have done, but he had that unimpassionable hauteur, combined with the bearing of an aristocrat and the courtesy of a gentleman, which intuitively calls for and is invariably accorded respect.

In addition to assuming the leading part in the legislation of the Irish Turf, he took a front place in watching over some of those for whom that legislation was framed.

Malpractice could seldom be carried out at any race meeting which he attended without his detecting it. His eagle sight, assisted by the powerfully strong race-glasses which he was wont to carry, readily discerned untrue running, and whenever a delinquency was proved against a man, be he owner, trainer, or rider, Lord Drogheda visited him with punishment fully commensurate with the offence.

The consequence of this strict supervision and stern administration of justice was, that upon the Irish Turf within the past thirty years malpractices have been comparatively few. Scandals there were 
none. Upon the passing of the Curragh Act about 1861 he was appointed to the Rangership.

As an Irish landlord he was an example to many. His almost constant residence was at Moore Abbey. He employed labour to a large extent, far more than many possessing larger demesnes. $\mathrm{He}$ furthered with purse, precept, and personal attendance our useful rural institutions, while Horse and Agricultural Shows received his special attention. Residing and spending his income among his tenants, he was a good and indulgent landlord to all those he found deserving; at the same time he asserted his rights from those who were not so. He was a staunch Conservative in politics, but whenever he became convinced that a change was desirable he always supported it. He was singularly abstemious in all his habits.

To state that Lord Drogheda's character was unsullied by even the slightest insinuation is but to mention what the world knows and what history must always record.

During the sixties and seventies his colours were constantly seen at our important race and steeplechase meetings. None were more welcome than the "black and silver," for apart from the popularity of their owner, the public knew full well that the horse which carried them was run to win.

I may mention some of his best horses which I remember, and I begin with the steeplechasers. Oberon, a brown gelding, which he bought for $£ 200$ from among the hunters at Lord Waterford's sale in June, 1859. This horse, with Dan Meany up, I saw win several good races. Westmeath, with Captain Warburton in the saddle, won the Kildare Hunt Cup at Punchestown four times in five years. Other good horses were Templemore, Robin Hood, Satanella, and Tambourine.

Among the flat-racers I remember Philammon, Spahi, Minette, Culrerine, Miriam, Aspasia, Commodore Trunnion, Francis Joseph, Sisyphus, Mons Meg, Hypatia, King Rene, Swivel, La Rose, Allen-adale, and Pelagia, who was an own sister to Philammon. This fine mare, together with Tambourine, were burned to death in a fire which accidentally occurred at Moore Abbey stables.

His favourite jockeys were Dan Meany, Johnny Whelan, John Connolly, Denny and Frank Wynne, also the English jockey Macdonald. His gentlemen riders were Captain Charles Warburton, Captain Arthur Smith, and Mr. George Knox. I heard him say that he considered Dan Meany one of the best steeplechase riders he ever saw.

Although he did not go in for breeding upon extensive lines, preferring to do a little well to doing much imperfectly, Lord Drogheda bred several good horses. The best were, I think, Fhilammon, Spahi, and Miriam.

Philammon, foaled in 1874, by Solon out of Satanella, was a very good horse. He ran second to Fashion for the Chester Cup in 1880, and was second to Prestonpans for the Liverpool Autumn Cup same year. In 1881, when seven years old, he won the Liverpool Spring 
Cup carrying 8st. 12lbs., also the Esher Stakes with 9st. 12lbs. He ran well but unplaced in a field of thirty-two for the Cambridgeshire in 1831 with 8st. 12lbs. on him. Lord Drogheda refused several good offers for Philammon, preferring to retain him for a time in Ireland, so as to let our breeders have a chance of the service of his good horse. He was rewarded for the philanthropy, for the produce of Philammon turned out, as a rule, high-class. From him came Philomel, Philtre, Giraffe, Pet Fox, May Moon, Miss Pitt, also Philistine and Pitman, who, as two-year-olds, ran a dead heat for the Patriotic Stakes at Baldoyle in 1886. Philammon was afterwards sent to England for stud purposes, and there he sired other good horses, among them being Phil, Gloaming, Punster, Phyllida, Castleknock, Dainty Davie, Stanton, Philadelphian, Dewdrop, etc.

The brood mares which did best for the Moore Abbey stud were Satanella, Qui-va-la, Miriam, and Minette.

Lord Drogheda as an owner of horses came under the category which, in my chapter on Racing, I describe as being most entitled to the qualification "famous." In addition to racing them, he bred, reared, and trained his race-horses at home.

In Michael Moneypenny, who came to Moore Abbey as stud-groom in 1848 , he had a faithful servant. Subsequently he became trainer, and looked after the breeding establishment until his death, which occurred in 1891. A record creditable alike to master and man.

The following action of our late chieftain, occurring as it did many years ago, is not generally known, so I shall relate it as being a sample of the rectitude which characterised him during his fairly long life.

Soon after his appointment to the Rangership of the Curragh, Lord Drogheda attended the first race-meeting held there. He had a horse running in one of the races, and he went down to see the start. His horse won, and thereby landed him a good sum in bets besides the stake. Hurrying back to the stand-house, he lodged an objection to the race as being null and void. This he proved by stating that it was started a few minutes before time.

Of course I never saw Lord George Bentinck, and I know him only by what history records, but it always struck me that Lord Drogheda and he had characteristics in common. In fact, I have before now styled the subject of this memoir "our Lord George Bentinck." As the world knows, the latter was, up to the time of his death, the ruling spirit of the English Turf, and occupied the highest position among its patrons of unsullied renown.

These two great pillars of our sport differed essentially, however, upon some points. Although they both betted, Lord George did so in gigantic sums for the love of gambling, and thereby nearly ruined himself. Lord Drogheda indulged in betting purely for amusement, and in such sums as could in no way injuriously affect his income.

Over English racing Lord George Bentinck usurped absolute dictatorship. In Ireland Lord Drogheda was elected to leadership. 
Within my own time our sport has lost many of its chief patrons, but to my mind Ireland never lost the like of Lord Drogheda since Henry Lord Waterford was killed in 1859.

By a curious and melancholy fatality these three great sportsmenLord George Bentinck in 1848, Lord Waterford in 1859, and Lord Drogheda in 1892-met with untimely and sudden deaths.

I attended the funeral of Henry, third Marquis of Waterford, on 6th April, 1853, and I was also present at the funeral of Henry, third Marquis of Drogheda, on 6th July, 1892, upon which occasions I saw interred the remains of two of the greatest sportsmen and most useful Irish noblemen that were ever buried in Ireland.

Lord Drogheda was born on August 14, 1826; he was therefore within six weeks of being sixty-seven years old.

Although a visitor to our Irish race-courses only as an humble sightseer, I was honoured by the late nobleman for many years with correspondence and conversation upon racing matters, and he has done me the favour of giving effect to suggestions of mine upon more than one occasion. I have also had interviews with him upon other matters, and I can say that I never found a man possessed of more practical ideas, or one more agreeable to transact business with. I never knew him to be a week without replying to a letter, no matter how trivial might be the subject of it.

Now that Lord Drogheda is gone, another mentor must be sought for to preside over Irish racing, but where will such as he be found? 


\section{CHAPTER YI.}

\section{RACING.}

Ancient History of the Turf-Interesting Dates and Events-Author's Notions-They will be Ridiculed and not Adopted-Suggested Changes-A Table-Manifest effect-A. Flutter-The Derby of 1892-How to produce Weight-carrying ThoroughbredsTraining Stables-Two-year-olds-Effect of a Severe Race-Celebrated OwnersAbsurdity-"Lucky" $v$. "Celebrated"-Trainer and Jockey more entitled-Mr. Mat Malier-Major Trocke-Author's Rhapsody-Mr. Blundell Maple-Mr. R. VynerPatriots-Ages of Horses Raced in Ireland since 1850-Number and value of races same time-Author's remarks thereon-Sagacity of Irish Owners-Ages of English Horses Raced in 1891-English $v$. Irish Horses in number-Result one $v$. the other-Reasoll why-Supposition of the Author-Many particulars-Irish $v$. English Trainers-And Training--And Rearing-Englislı Polish-Handicapping-A Paradox-Argued OutA Suggestion from the Author-Injustice-Iniquitous Rule-Letter from the AuthorQueen's Plates-Their Object-Their Failure-Author's Suggestion as to their Reformation-A Formula for Adoption-What it would result in-A Premium not a StakeThe Government-Increase of Value of Queen's Plates-Good opportunity-Conservative Rulers and Radical changes-A Hint to the Jockey and Turf Clubs-Love of Sport $v$. Money Making-Examples-A 5sov. Sweep-A Trial at KingsclereLord Falmouth - Baron de Hirsch - Newmarket - Suburban Meetings - Ascot and Goodwood-The Leger-Grand National and Punchestown $-5,000$ and 10,000 Guineas Stakes-Not really Popular-Result-Cost of Racing in Ireland-Irish Racing Calendar of 1891-Particulars of Expenditure covering several pages-Dealing with various items-In various ways-With Result Extraordinary-Table of SameBoys employed in Irish Stables-Cost of Racing in Ingland-Particulars of Expenditure still more Extraordinary-Weatherby's Calendars - More pages of wonderful matter -Winding up with Tables showing Stupendous Result-Boys employed in English Stables-More than Ten Regiments-Estimat s taken at Low Rate-Newmarket Racing Stables-Palatial-Where the Money Goes-Racing $v$. Hunting-Various Comparisons-Growth of Popularity unprecedented-Cause thereof-No doubt of its continuance-A Gloomy Foreboding-The Zenith-The Descent-A Calamity-Our Nobility and Gentry-Pilots and Helmsmen-Buttress of Racing-Advice to Radicals Author's visits to Newmarket-Mat Dawson-His Pictures-His Betting-Other parties' ignorance-"An Honest Man"-Whitewall-The Scotts-Highfield-The I'Ansons-Old $v$. New Race Stabling-Trainers' Houses-Jockeys' Incomes-Two Interesting Cuttings-One not to Author's wishes---The other to them.

IN some of the earliest history we find horse-racing recorded among the greatest sports of the time. If we dived into researches of "grey antiquity" we would find that Greek raced Trojan across the "windy plains of Troy," and where Cæsar tells us that Cassevelaunus kept 4,000 racing chariots. Happily, for my purpose, to search up the Racing Calendars of those days is not necessary.

I shall, however, make reference to a few items of interest recorded in the early annals of our English racing. The particulars I condense from long cuttings which I find in my old scrap-book-a little volume which has many times done me good service while compiling this book.

The exact place where racing began in England, nor yet the date, cannot be fixed reliably. One authority says that the Romans held meetings at York and Doncaster A.D. 204, but how he finds that out I don't know. Others claim for Cheshire the pride of place; anybow Chester Races can be traced back to 1511 . 
In the time of Henry II. there used to be races in Smithfield; but only for the purpose of finding out which was the best horse to buy at the fairs held there. It was not until the reign of James I. that horseracing, as a public sport, was introduced; but the races were purely for amusement. Croydon in the South and Garterly in the North seem to have been the only important meetings.

Charles II. was a warm supporter of the Turf, and we find him attending meetings at Hyde Park, where he dispensed Royal bounty, and at one time gave a 100-guinea silver bowl to be run for. It was this monarch who, in 1667, started racing on Newmarket Heath. The sport began to increase in favour at this time, and meetings were held in many places during Easter; but towards the end of the seventeenth century these were prohibited as being "contrary to the holiness of the season."

Races were first started at Epsom in about 1717, Ascot followed in 1727. In 1719 George I. gave at Newmarket a "Royal Cup" value 100 guineas, for five-year-old mares, 10st. each; four miles. Racing at that time was confined, generally, to matches, which were run over courses varying from four to twelve miles!

In 1740, racing had become so prevalent throughout the country, a law was passed to restrain it, and it was enacted that after the 24th June, 1740 , no plate should be run for of less value than $£ 50$, under penalty of $£ 200$. Parliament further settled the weights to be carried, which were as follows:-Five-year-old, 10st.; six-year-old, 11st.; sevenyear-old and aged, 12st.

The St. Leger was first run for in 1776. It was called after the best known and most popular man of the day, "handsome Jack St. Leger." 'Then followed the Oaks in 1779. Mr. Richard Tattersall, in 1782, started at Hyde Park Corner "Tattersall's," but that establishment was moved in 1865 to its present site at Albert Gate. The Duke of Richmond, in 1802, established races in his Park at Goodwood. Long before the Derby was brought to Epsom in 1780 Lord Derby had it run for many years at Wallasey in Cheshire, near to where the golf links are.

Racing calendars go back to the early part of the seventeenth century, when we find Ie Nerv-Markitt Kalendar. In 1709 another was published in York by Reginald Heber, who ran it until 1768. In 1729 John Cheny started one entitled "An Historical List of all Horse Matches Run," and continued it till 1750. It was then taken up by a man named Pond under the title of the Sporting Kalena'ar, but that work seems to have ceased in 1754, leaving Heber sole chronicler till 1768. Thomas Falconer then carried it on until 1773 , when Mr. James Weatherby took it up, and from then till now the Racing Calendar has been published by the Weatherbys.

The Jockey Club was started about 1750 , but it was not until Mr. James Weatherby was appointed keeper of the Match Book at Newmarket in $17 i 3$ that racing came under ship-shape régime. He soon 
after became Registrar $\checkmark$ the Jockey Club, and started an office in Oxenden Street, Haym ,rket, where he continued until 1843, and then moved to the present premises in Old Burlington Street.

Through the courtesy of Mr. Weatherby I was enabled to look over some of these old Calendars, and truly they are interesting. By them I see that races were started on the Knavesmire at York in 1710, where they have been continued annually almost ever since. There were races at Clifton in Yorkshire in 1709, but they don't seem to have been continued. Black Hamilton started races in 1715, and carried on for over forty years, while in 1747 Malton came to the front.

I had not time to work up any more of these records.

After this short reference to old times I shall proceed to treat with flat-racing as it is at present carried on. I fear, however, there is very little use in my writing much upon the subject, for the simple reason I know my views are so at variance with the popular notions that there is not the remotest chance of their being adopted. Nevertheless, the same views are held by thousands, and there is scarcely a man connected with the Turf who has the good of the horse at heart who does not entertain them. But reformation seems repugnant to our turfites, actuated, as some of them are, by motives more or less selfish.

However, the following are my opinions on the laws governing our flat-racing, and let me hear what is to be said against them, except by those who have interests to serve other than those of the noblest animal going upon four legs.

Racing should be a means for improving the stamina of the thoroughbred horse, just as steeplechasing should be a means of improving that (as well as the breed) of the hunter ; for this reason it is manifest that young racehorses should be allowed time to develop fully their strength. Surely that is not permitted by our present Jockey Club laws. I think, however, the adoption of regulations on lines somewhat like the following would very soon attain the desired end. But let me preface my suggestions by stating that they will not be adopted, and will only bə ridiculed.

1. AGE.--

To date from April 1.

2. Youngsters. -

Not to be galloped beyond half-pace until they are two years old, or to be raced before July 1.

Scale of distance and weight.

Not to exceed

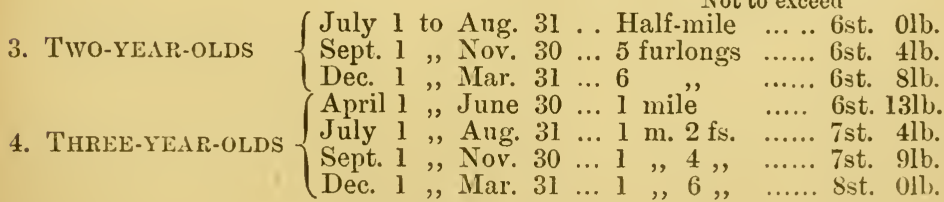

Handicaps in accordance. 
5. FOUR-YEAR OLDS.-

All classic races, such as Two Thousand, One Thousand, Derby, Oaks, and St. Leger, to be for four-year-olds only, same date and distances to be fired as at present, but the value of the stakes should be at least double what they now are.

6. Five-YEAR-OLDS, SiX-YEAR-OLDS, AND AGED.-

Races for all distances up to four miles, and for the most valuable stakes which the Jockey Club and all other race executives can aflord to give.

\section{STAKES.-}

For two-year-olds none higher than $£ 300$.

For three-year-olds none higher than $£ 500$.

For four-year-olds and upwards as valuable as they can be made.

To alter the date for age to April 1 would be a decided change for the better to breeders generally, especially those with limited incomes. Foals would be dropped in genial weather when milk is plentiful, instead of in the depth of winter when it is scarce. The date for age formerly was May 1.

The adoption of rules in accord with the foregoing would manifestly give our thoroughbreds a better chance of growing into useful horses and racing up to a longer period than does the present code of the Jockey Club. Our youngsters could not be put into anything like hard work till they were well over two years old, or carry heavy weight till the back-end of their three-year-old year, while they would be brought into their fouryear-old year with gradual and systematic increase of light work, and until they had attained that age no very valuable stake would exist to excite the greed of their owners.

I consider it a shame to put 8st., not to speak of 9 st $7 \mathrm{lbs}$, on two-yearolds, or to ask a three-year-old to rane for a mile and three-quarters.

If rules like mine, particularly with regard to four-year-olds, were to be adopted, what a rint would be created all over England! Fancy changing the Guineas, Derby, Oaks, and Leger from three-year-olds to four-year-olds! Well, my conservative friends, and all who look for early returns from your two-year-olds, much as you may be horrified, the idea is good and sound in the real interest of racing. Deny it if you can! Deny also that to encourage four, five, and aged racing by giving the largest stakes for those ages, will tend to make our racehorse a vastly more useful animal than he is at present !

We had for the Derby of 1892 265 entries, with one exception the largest on record. How many of them will ever start for any race? How many will start for the Derby itself, and how many of these will, perhaps, ever start again? Then of the original entry whose carcases have escaped despatch to the nearest kennels and have attained their four-year-old year, how many will be seen in a racing stable or anywhere else, except as very light-weight hunters, or between the shafts of a hansom? Change the present system for one which it is acknowledged would be beneficial to our racehorse, something like what I have formu-

* This article was written by me early in 1891. The reader is referred to the Racing calendar for the record of the Derby of 1892, and what has become of the great entry it received.-THE AUTHOR. 
lated, and see if we shall not have good sound weight-carriers running up to their fifth, sixth, and aged years. Then would we see improvement in the steeplechaser; hunting stables and cavalry regiments could be easily supplied with weight-carrying thoroughbreds, while stallions and mares would go to the stud sound, with plenty of bone and up to welter weight. Early training of horses, like the early schooling of children, is baneful to a degree. The legs of the one and the brains of the other are too soft for hard work, and if they get it, they break down.

No doubt our training establishments are very much better looked after now than they were in years gone by ; but at times, even now, we find nervous young horses illtreated by their attendarits, either in the stable or on the exercise ground, before they have learned what is expected of them. Then, again, see what raw two-year-olds suffer in a severely-contested race, flogged and spurred, as they often are, while doing their utmost. Some of them never forget it, and it is such treatment that makes many of them the rogues, cowards, and savages they often become.

Now for some more of my funny notions upon other racing matters.

It appears to me strange that owners should be considered famous simply because they happened to possess some great horses. Of course, if men bred horses and afterwards raced them with such success that they became celebrated, the owners would have some claim to fame, and no doubt we have many such men, both in history and at present. But a man who, solely by possession of ample means, acquires a horse, good when purchased, or which turns out good in the trainer's hands after purchase, does not deserve the laudation sometimes given to him. I make no personal allusions, but everyone can call to mind examples of the class of lucky owners I mean. Yes, "lucky" rather than "famous" would, I should say, be the more appropriate adjective. It is the trainers and jockeys of great horses who should be held famous, for it was their ability, and not the owner's money, that made the horses great. Moreover, it was in all probability the trainer or other such qualified cicerone that selected the horses in the first instance for this rich man's stable. No doubt the owner sometimes (not always by any means !) gets the bulk of the gains, and his name appears among the list of winners at the end of the season-perhaps at the head of themwhile he is congratulated all round-he who, in all probability, has had nothing whatsoever to do with the work which has won him his so-called celebrity!

No, the owner who I think deserves to be called famous in the annals of the Turf is a man like Mr. Mat Maher of Ballinkeel, who breeds and trains his own horses, and in addition, if he rides them, as does our veteran Major Trocke, he is all the more famous. But to talk of men, rich or not, aristocrats or otherwise, being celebrated because they owned horses that ran well without, perhaps, their owners even seeing them during their preparation, much less taking any part in it-Pshaw ! Lord Waterford, the Days, John Osborne, Tom and Joe Cannon, Major 
Trocke, Tom McCraith, the Beasleys, the Cullens, and scores of others of old and present time who bred, reared, trained, and rode their own horses to victory. Hurrah for those fellows!

The foregoing rhapsody must not be interpreted to mean that I am oblivious of the fact that owners, possessing great wealth, are not essential to our sport, for surely they are, and for so many reasons, palpable to everyone, I need not explain them. I only wish we had more workmen among them.

A man like Mr. Blundell Maple, who, to prevent his being sold out of the country, has given $£ 15,000$ for Common, a horse whose greatness at present exists principally in having the mixed blood of Isonomy and Thistle in his veins, and Mr. Robert Vyner, who has refused to sell Minting for $£ 21,000$, which was offered privately for him by a foreigner quite recently, are also the sort of men who are not alone celebrities of our Turf, but are absolutely patriots.

In the Irish Racing Calendar for 1891 (Vol. 102), which Mr. Thomas Brindley has brought out in a most careful and comprehensive style, is given a tabular return of horses which ran in Ireland for the last forty-two years; and also a table showing the number of races and their value within same period. From these I have compiled the following analysis :-

Table Showing Ages of Horses which have been Raced in IRELAND SINCE 1850.

\begin{tabular}{|c|c|c|c|c|c|}
\hline & 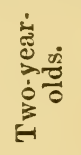 & 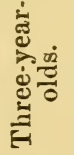 & 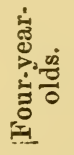 & 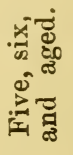 & 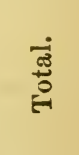 \\
\hline 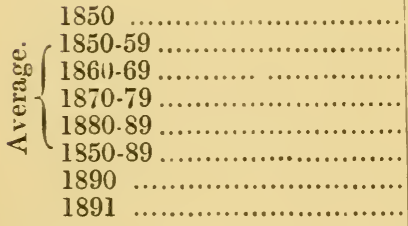 & $\begin{array}{l}63 \\
93 \frac{1}{2} \\
79 \\
58 \\
55 \frac{1}{2} \\
71 \frac{1}{2} \\
64 \\
79\end{array}$ & $\begin{array}{l}77 \\
84 \\
68 \\
74 \frac{1}{2} \\
55 \\
70 \\
62 \\
61\end{array}$ & $\begin{array}{l}49 \\
83 \frac{1}{2} \\
93 \frac{1}{2} \\
171 \\
204 \\
138 \\
219 \\
199\end{array}$ & $\begin{array}{l}332 \\
296 \\
406 \frac{1}{2} \\
598 \\
674 \\
493 \\
760 \\
756\end{array}$ & $\begin{array}{r}521 \\
557 \\
647 \\
901 \\
988 \\
773 \\
1,105 \\
1,095\end{array}$ \\
\hline
\end{tabular}

Number and Value of Races run in Ireland since 1850.

\begin{tabular}{|c|c|c|c|c|}
\hline \multirow{3}{*}{1850} & \multicolumn{3}{|c|}{ No. of Races. } & Value. \\
\hline & & 273 & ....... & $£ 15,537$ \\
\hline & $\ldots$ & 318 & ....... & 18,739 \\
\hline $1860-69$ & 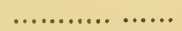 & 330 & ……........... & 20,008 \\
\hline 0.79 & & 434 & & 30,666 \\
\hline $1880-89$ & ...... & 491 & $\ldots$ & $28,042 \dagger$ \\
\hline$-1850-89$ & ….......... & 393 & ..... & 24,364 \\
\hline 189 & & 63 & .......... & 39,524 \\
\hline & & & & 39,144 \\
\hline
\end{tabular}

* When Mr. Vyner refused this sum, he was asked to name the price he would take for his horse, but he declined.-THE AUTHOr.

+ Punchestown stopped in 1882. 
Now this exhibits what I consider direct evidence of a satisfactory state of racing affairs in Ireland. It proves that the number of horses we had running in Ireland in 1891 was more than double that in 1850, while the number of races in 1891 much more than doubled those in 1850 , and the value of the stakes was greater by more than 150 per cent. Still more satisfactory is it to see that while the total of each decade shows a steady increase in the number of horses, that increase is entirely due to the four, five, six, and aged, for the two and threeyear-olds in 1891 about maintain the average of the period between 1850 and 1889.

This shows that our Irish breeders and owners recognise the fact that racing two and three-year-olds is the bad game I have already striven to prove it.

Ruff's Guide for 1891 gives a table of horses which ran in England for as many, or more, years back as our Irish Calendar, but it is restricted to flat races only, not even including hunters' flat races for some years, so by it is seen that a very great predominance is in the two and three-year-olds, which is, of course, comprehensible. By this table we see that the

Horses Which RAN oN THE Flat in 1891 iN ENGLANi WERE:Two-year-olds. Three years. Fuur years. Five, six, and aged. Total. 1,062 641 293 310

2,306

The Irish table included all races.

Almost every autumn 1,000 yearlings are sent to the Newmarket training stables alone, a number practically equal to that of all the horses we have in training in Ireland. What the total number of horses in training or running in England is I know not; but it is far and away beyond what we have. For all that, we are able to send some from the Curragh and other places to compete in many of the great English events, and very often win them, while some of the best horses ever owned by Englishmen were bred in Ireland.

How is this accounted for? I certainly cannot tell. Our horses, although bred in Ireland, are all from English strains, if they are not from parents directly and perhaps recently imported from England. The secret of our success in producing good horses must not therefore be sought in the breeding alone. It lies in the climate, the soil, or our methods of rearing and training. The Irish winter is not nearly as severe as that of England; while our summers, I think, are just as sunny as the English. Neither have we more rain, although many people say we have. In Ireland there is a great deal of fine rich land, which produces the best and sweetest grass, a large proportion of which is from a limestone substratum. Grain, grass, and roots grown on that sort of land are notoriously the best for producing bone. Tipperary, Cork, and Limerick are all limestone countries, and from them come the greater number of the horses bred and reared in Ireland, and often the best.

Irish mares are kept in regular, steady work on the farm all the time 
they are carrying their foals, which keeps them in good health and natural condition, which is so essential to the well-being of their progeny.

As regards rearing our youngsters, be they half or thoroughbred, we never pamper them. Our foals, yearlings, and two-year-olds are, in most instances, well fed and tended, but in all cases they are, more or less, inured to a certain degree of hardship by being left exposed to vicissitudes of weather. This the English thoroughbred is never allowed to experience.

I was lately at a select but small breeding establishment in Wales. The weather had been fine for some time, but a shower happened to fall during my visit. Never did I see more energy exhibited than by the stud-groom hurrying off a number of stable-boys to get the yearlings under cover! If these pampered pets had been in Ireland they would have been left where they were, even if snow, instead of rain, had been falling on their precious bodies.

I am not for a moment going to suggest that our trainers are more sagacious than the English; but it is a fact that when they send horses to England to run, they nearly always give a good account of themselves, more particularly at jump-race meetings.

As I said before, explain I cannot the superiority of our Irish bred and eared horses to those of practically the same strains bred and reared in England-it is an undeniable fact. Perbaps it is that we rear ours hardier, upon a better soil, and in a better climate; or, perhaps, our trainers do know a bit more about making the best out of their few horses than do our neighbours out of the great number they have. Again, perhaps the hardy rearing to which we subject our youngsters kills off the weakly ones, leaving none but the sound and strong. Just as the children seen running about the slums in a half-naked state, living in filth and half-starved, nearly always appear to be healthy, hardy, and happy, simply because all the delicate ones have died.

One thing we certainly do not do, and that is we do not bring our horses to the post with that beautiful po ish on their coats which the English horses generally have. At the same time ours are just as fit to go.

I do know, however, that the class of race and steeplechase horse we had in Ireland twenty years ago was better and, as a rule, up to more weight than what we have now, even though the number be greater. Of course we can name only comparatively few, because the whole lot was few. But those were toppers, and with some of our ald Racing Calendars before me, I can pick out scores of horses of the highest class which ran in Ireland in the forties, fifties, sixties, and seventies. But to give a list of them might not be interesting, nor would it prove my case.

What a paradox is handicapping, and how unjust is the idea! We strive to produce good horses, and as soon as one has proved himself to be better than another, weight is put upon him to bring hin back 
to the inferior animal. Worse it is that there seems to be no other means of bringing the good, bad,_and indifferent together so as to give each an equal chance of winning. If we could but thrash the bad and middle class into running up with the good ones, all would be well, but we can't, at least the operation generally proves abortive.

I think, however, our racing executives might at times lessen the injustice by having races restricted to horses of the same class onlythat is to say, of first, second, and third class form, those of each lot being brought together by handicapping. Weight will, of course, bring the best back to the worst; but what we should like to do is to raise the worst to the level of the best. Alas! that can't be done, so we must penalise the good horses, which, to my mind at all events, is a paradoxical mode of proceeding, and subversive of justice.

A most iniquitous rule was in force up to even a very few years ago. That of giving allowance to half-bred horses-in other words, or rather by other means, penalising by inverse ratio our thoroughbreds, penalising the very object we want to attain as soon as we have attained it! I wrote a very strong letter some seven or eight years ago against this allowance to half-breds, and although I am sure my letter had no influence upon our racing powers, I am glad to say there is now no rule of such a stultifying nature.

King's and Queen's Plates are a very ancient institution. They are given annually by the Government to be run for in long-distance races by three-year-olds and over.

Now the object of these plates is a most laudable one, and what I aimed at when formulating my code of rules at the beginning of this chapter; i.e., to encourage men to breed horses with stamina and staying powers. It is quite clear that object has not, by one cause or another, been attained, and Queen's Plates, with their hundred guineas and two to four mile courses, are no more productive of their object than are five-furlong sprints, and very few horses start for them.

What burlesques some of them are! I have seen horses start in a walk, then jog or canter till within a mile or mile and a half of home, and then only begin to race, just reducing the distance to whatever the jockeys chose to make it.

My idea is that these Queen's Plates should be raised to $£ 200$, with a free entry, that they should be three miles distance, and for fouryear-olds only, 9st. each; that, in the case of Ireland, there should be three plates given annually to each of the four provinces. Let these be restricted to horses bred in their respective province. Have the first run for as early in the year as possible, and over the most suitable course in the province. Let the winner of the first be excluded from the second race. Have the second plate run in two or three months after the first. Then, as soon after as convenient, start the two winners against each other. By that time we should have four out-and-out winners from the four Irish provinces. They would have won $£ 400$ each, while those which ran in the ties would have 
won their $£ 200$ apiece. I would then start the four winners at the Curragh October meeting for, say, $£ 300$ to the winner, $£ 100$ to the second, $£ 70$ to the third, and $£ 30$ to the fourth and last.

By some such method as this there would be $(a)$ a distinct incentive to bring out horses fit to stay a long distance on the flat; $(b)$ a fair distribution of the money over Ireland, and thereby encourage thorough breeding; $(c)$ running the winners off in ties would bring out the best four-year-old in Ireland, and that at a season when he would be far advanced; $(d)$ there would be no monopoly of Queen's Plates as has been in so many cases already historic ; $(e)$ finally and financially the prize would be worth looking for, as the winner all out would have got $£ 700$, the second $£ 500$, the third $£ 470$, and the fourth (or last in the final race) $£ 430$, while the other four winners, although beaten in their first ties, would have got their $£ 200$ apiece.

No doubt, at times, these races would have little interest to the public, as the issue would often be a foregone conclusion. Never mind. The object of Queen's Plates is not to provide races necessarily interesting to the public, but to encourage the breeding of stout thoroughbreds. The money takes the form of a premium rather than a stake, therefore let these races be fought out annually on the rerits of our four-year-olds at equal weights. Let the public look elsewhere for races which will give them excitement.

In these days of huge stakes men don't value a $£ 100$, therefore Queen's Plates should be made up to a sum that would be valued. The Government of a great nation like England would not grudge a few thousands a year of extra expenditure upon the most popular sport of the people, not to speak of improvement of the most profitable animal we have in the kingdom. Fifteen Queen's Plates, totalling $£ 1,530$, are given annually in Ireland, productive, as I say, of no good result. Let there be now given $£ 2,900$, allocated somewhat upon the lines I have suggested, and then see what result it will bring about.

A change to something like what I have described would apply at present with especial adaptability. Our Conservative Government has of late years introduced into Ireland thoroughbred horses, which are distributed fairly over the four provinces. These serve farmers' mares at the low charge of one sovereign. Their produce will soon be plentiful all over the country, and if they had Queen's Plates to run for such as I have described, it would undoubtedly prove a still further inducement to our farmers to breed strong thoroughbred horses.

What will our rulers say to all these radical changes which I have proposed in our racing? Of course they will say that I am an enthusiast, or perhaps something worse. I don't care what they say about me. I have the good of our racing and our racehorses as much at heart as any of them, and I see many things which require adjustment. I think therefore it would be a good plan if the Turf and Jockey Clubs were to follow the example set by the National Hunt Clubs and 
begin making improvements in flat-racing in the same way as their collaborators have done in steeplechasing.

They might begin by cancelling their rule which relates to nominations becoming void by reason of the death of the nominator. A rule so fraught with absurdity comment upon it is unnecessary.

Then, after having put the more important matters right, they might make it compulsory upon trainers to have exhibited on their horse's clothing in the paddock, and on the saddle cloth when going to start, a large red number corresponding with the horse's number on the card. Such would be of the greatest convenience to the public, and would save stable-boys having to reply a hundred times a day to the question, "What horse is that?"

As I said more than once, love of sport pure and simple is not the chief inducement nowadays to attend race-meetings. Racing men look upon the Turf the same as every commercial man does upon his business-simply to make money out of, while the general public go for the purpose of betting. We could find few people who would care to see a race between, say, five horses of real good class ding-dong from post to post won by half a head, with heads separating the others, if the race was only for a sweepstake of 5sovs. each. Still fewer are found who care to look on at a trial. If Mr. John Porter was to send an invitation to one hundred of his friends to come and witness a trial between the cracks at present in the Kingsclere stables, including Orme and La Flêche, I venture to say very few would avail themselves of it for any purpose other than to spot the best to back in the future.

In old times there were a great many men in England who raced purely for the love of the sport. No doubt most of them betted, but lots of them did not. In recent years we had Lord Falmouth, and now we have Baron de Hirsch, imbued with the same ideas; neither betted, while the latter gives the stakes he wins to various charities. We must remember, however, they were very rich men; moreover, they won large amounts in stakes. If such were not the case, the question arises, would they be satisfied with honour and glory alone?

Newmarket, with all its historic associations, and where between the best horses of the year magnificent sport is to be witnessed, never attracts large crowds except on the days of the Two Thousand, the Cesarewitch, and the Cambridgeshire. Why? Because to get there is very troublesome, and except upon those three races there is no very heavy betting.

At all suburban meetings, where racing is not nearly as interesting as at Newmarket, but where there are greater facilities of access, huge stakes, and prodigious betting, people assemble in thousands. Multitudes flock to Ascot and Goodwood, because to attend them is "the fashion" and the "right thing," but they care not for the sport. Many do not even look at the racing; they go simply to be seen by and to see others.

Not so to Doncaster for the St. Leger, Aintree for the Grand 
National, and to old Punchestown. To these meetings pour thousands of men and women solely from pure love of sport, being, as they decidedly are, the most popular in the kingdom.

The newly-instituted stakes of 5,000 and 10,000 guineas are not nearly as popular among sportsmen as the races $I$ have just named. No doubt they bring the "gallery," but that is not a true criterion of popularity. Doubtless many will disagree with me, but I am very confident that what brings the crowd is the big betting, for, although good horses at times run, small fields and bad sport are often the result of these monster stakes.

$\mathrm{Be}$ the inducement to attend races what it may, the noble sport causes an enormous expenditure of money. In no other branch of sport have we such a medium, while the circulation is general among all classes.

I never heard of any calculation being made of what racing costs and causes to be spent; I shall therefore enter upon the subject.

I shall begin with Ireland, but I must take in flat-racing and steeplechasing combined, inasmuch as the table given in our Irish Racing Calendar for 1891 does not separate them, and it is from that interesting and valuable volume I take the figures upon which I base my calculation.

Pages 185-6 of that book tell us that, in 1891, 1,095 horses ran in Ireland for 603 races of the aggregate value of $£ 39,144$. It also gives ninety-five as the number of race and chase meetings held there in that year.

These 1,095 racehorses must be worth, on a low average, $£ 150$ apiece, but even at that figure they would total £164,250.

They cost, on an average, 30s. a week each to keep and train. Those kept in their owners' stables cost less; those in training stables more. That would total $£ 1,64210$ s. a week, or $£ 85,410$ a year.

These 1,095 horses have each gone to, say, only two meetings in 1891. Taking long and short, each journey for horse and man would cost the owner a five-pound note. That would tot up to $£ 10,950$, say $£ 11,000$, for the travelling expenses of the horses to the meetings they ran at.

The entrance stakes and forfeits would be at least £2 for each race they were entered for. Say each horse was entered for only five races, that would also come to $£ 10,950$, or say again $£ 11,000$.

Let us suppose that these horses are owned by 220 men (i.e., giving five to each, which is, I think, too many on an average for Irish owners), and that they go to see their horses run at the two meetings they are sent to. A man cannot go by train and stay at an hotel for a night or two without it costing him, at the very lowest calculation, a fiver. At that very moderate allowance, our owners will have paid in personal expenses just $£ 2,200$.

I find that about 1,630 is the number of mounts professional jockeys had in Ireland in 1891. Bulking the fees for winning and losing mounts in both steeplechases and flat races, and adding a trifle for travelling, 
which has to be paid by either the jockeys or their employers, we may put each mount down at $£ 6$. That gives us, say, for round numbers, $£ 9,800$ as the sum paid to and for professional riders, and is calculated only at the statutable fees.

It is to be observed that the foregoing figures deal only with horses which have actually raced. There has been nothing said about those which did not race, but which have had to be fed and cared for all the same, and in many instances trained. Neither have I dealt with the foals or yearlings. To treat with either the non-starters or the youngsters in a calculation such as this is a very difficult undertaking, because there is no basis to start from in the shape of a return. Any calculation that can be made must, therefore, be approximate even to a greater degree than if the numbers were given.

I shall, however, despite the difficulties, attempt the task.

To begin:-The number of racehorses, including those from twoyear-old upwards, which did not start in Ireland in 1891, I can't be far wrong in putting down at half that of the horses which did start. That gives us just 550. Many of them were two-year-olds; and others which, having to be laid by, would not cost as much to keep as if they were older or in training. On the other hand there were many which were kept in training, but from one cause or other were not started for a race. Taking them all round, let us put the 550 non-starters at 20 s. a week to keep ; that would be to $£ 550$ a week, or $£ 28,600$ for the year.

Considering the fact that seventy-nine horses started as two-yearolds, we may reasonably conclude that at least treble that number of foals bad to bo bred-i.e., that one out of three foals bred for racing start as two-year-olds. (I don't think one in six do so; but uever mind.) That would give us, say, for round numbers, 250 foals reared in 1889. Say half of them dien or were useless before they were fit to be trained, that would leave 125 to go into a trainer's hands at, say, eighteen months old. These 125 youngsters would have cost, including service of the dam, at least $£ 50$ apiece up to that time. 'This totals $£ 6,250$ as the cost of our two-year-olds before they had begun the rudiments of their education. Thus we had, in 1891, 675 horses which did not start-costing to keep $£ 34,850$.

We shall dive still deeper into the mysteries of racing, and see what further good the grand old sport does by reason of the circulation of money.

In Mr. Brindley's little "white book" I see chronicled ninety-five different race-meetings as having taken place in 1891. Some few of these were comparatively small local affairs of one day. On the other hand a great many were important meetings with two days, while we have Cork, Baldoyle, Fairyhouse, Leopardstown, and old Punchestown, not to speak of the Curragh, of very first class importance.

Now what was the amount of money spent by the public attending these race reunions, totally irrespective of the cost of racing the 
horses? To answer that question requires a tidy bit of consideration and figuring up. We must take into account railway fares, hotel bills, ear hire, admission to stand-house, luncheon, then comes the inevitable trifle spent upon drink to counteract the effects of heat in summer, cold in winter, or, in the absence of both, for the sake of conviviality. An odd bet or two we shan't include, but surely we must not eliminate the sum which has to be spent upon " ourselves' new coats, our wives' new gowns."

Now bulking all the above items of expenditure, which for any ordinary individual are simply unavoidable, in a greater or less degree, if he attends a race-meeting, we cannot come at a lower estimate by way of average than that of $£ 5,000$ for each of these meetings. $£ 5,000$ multiplied by 95 gives $£ 475,000$, and is the sum which, at the lowest possible calculation, people spent in Ireland in 1891 for the purpose of attending our race-meetings.

That large amount has to be increased by whatever may be spent by local gentry in entertainment of whatever visitors they may have with them for the races, also by whatever has been laid out upon erection of stand-houses, keeping them in repair, men employed in the enclosures and on the course, together with scores of other incidental but necessary items of expenditure too numerous to particularise much less calculate the cost of.

I shall now give a table of the foregoing figures which will show at a glance

THE VALUE OF OUR IRISH RACEHORSES, WHAT WAS SPENT BY OWNERS TO RACE THEM, AND WHAT WAS SPENT BY THE PUBLIC TO SEE THEM RACE IN 1891.

Value in money of 603 flat races and steeplechases run for

Value of 1,095 horses which started, at $£ 150 \ldots . . . . . . . . . . £ 164,250$

Value of 675 horses which did not start, at $£ 150 \ldots \ldots \ldots \ldots . . . \ldots 10.250$

Total value of 1,770 horses

$£ 39,144$

..................

Keep and training of alove starters ............... £85, 410

Keep and training of above non-starters...............34,850

Total keep and training of 1,770 horses 120,260

Travelling expenses of horses to meetings ................ 11,000

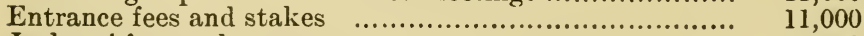

Jockeys' fees and expenses ..................................... $\quad 9,800$

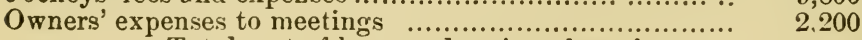

Total cost of keep and racing above horses __....... 154,260

Amount spent by public attending Irish meetings in 1891

Total expenditure

$\frac{475,000}{£ 629,260}$

The sums paid by owners in purchasing horses I cannot estimate; the amount is considerable, but it has to be left out of the estimate.

In Ireland each boy in a training stable has to look after two horseswe have some 1,800 racehorses, therefore we have over 900 boys employed, not to speak of head lads and trainers. 
Far more difficult is it to arrive at an approximation of the expenses of racing in England, but I must try to do so.

According to the Racing Calendar we find that for steeplechases and hurdle-races there started in 1891 about 3,200 horses; for flat-racing, about 2,320-totalling 5,520. These include the horses which raced in Ireland; we must therefore deduct their total of 1,095 , which leaves 4,425 starters for races of all sorts in England in 1891. We shall call it 4,420. The number of steeplechase meetings was 268 , and that for flat-racing 110. These total 378, and do not include Irish meetings.

The value in money of stakes given for flat-racing amounted to $£ 448,695$. Unfortunately there is no return of what was given for steeplechasing or hurdle-racing in the English Calendar. I therefore have to take a shot at the figure, and I put it at about $£ 500$ a meeting, or, say, $£ 130,000$. Neither has Weatherby a return of the number of races run. Of course by counting the races from the pages of the Calendar and adding up their value to the winner we could arrive at the amounts, but that would be a very troublesome job and would take longer time than I at present have to spare for such purposes.

(Perhaps Messrs. Weatherby might see their way to have these two yearly totals given in future editions of their excellent and accurate Calendars.)

Now, the expenses all round of racing in England are a great deal more than double those in Ireland. Men have much longer journeys to go to see their horses run. The bills of English trainers are higher than ours, but they are, not twice as high. Subscriptions to their races are four-fold higher than to Irish, for not alone is the entry fee high, but for nearly all English events there are sweepstakes of from $£ 5$ to $£ 50$ with a proportional amount of forfeits. In Ireland such embargoes are practically unknown. The expenses of the Newmarket jockeys to Ascot and Epsom, not to speak of Goodwood and other far-off meetings, are, it is needless to remark, vastly more than are ours to Cork and Baldoyle, while the special retainer fees to some of the crack professionals equal quite the sum total paid to all our jockeys.

In fairness it may therefore be accepted as a fact that racing is much more than twice as expensive in England. But I shall put it down at only double and calculate the English expenses upon the same lines as I did the Irish.

Assuming that there is a like proportion of non-starters to starters, we would have in round numbers 2,700 horses, which in 1891 did not start for a race. They, like the Irish, had to be kept, and many of them trained. Adding these 2,700 non-starters to the 4,420 starters, we come at a total of 7,120 .

The arithmetic at last becomes somewhat simple, viz. :-

If the expenses of racing and keeping for racing 1,770 horses be $£ 154,260$, what would be the like expenses of 7,120 horses? The answer is $£ 620,526$. Double that is $£ 1,241,052$.

Let us turn the last two figures into noughts so as to make the sum 
handy, and we have the very lowest amount that can be, by any mode of calculation, put upon the expenditure of owners to see their horses race in England in 1891.

To continue working out this problem I shall put the value of English racehorses down at $£ 500$ apiece all round. This, in the face of the returns we see of sales, and that a horse which is not worth $£ 200$ is not kept a week in a crack English racing stable, must be considered a very inadequate sum. That figures up $£ 3,560,000$.

Bearing in mind the gigantic proportions, as compared with Irish meetings, of such as Epsom, Ascot, Goodwood, Doncaster, Liverpool, Manchester, and Sandown, and that the crowds which congregate at nearly all the other meetings held in England are vastly greater than those which are found at ours, and that an Englishman has a ten-pound note to spend where an Irishman has often only a one-pound note, I may, I think, with every degree of propriety, put down that $£ 20,000$ is spent, one way or another, by the general public-outside the owners -upon attending the various meetings in England, against the $£ 5,000$ that is spent in Ireland. Mr. Weatherby tells us there were 378 meetings-race and steeplechase-held in England in 1891. We have, therefore, only to multiply $£ 20,000$ by 378 to arrive at what the British public spent upon going to see our sport that year. Here is the product : - £7,560,000.

As a companion to the table I gave of our Irish racing, I now give one showing the

VALUE OF OUR ENGLish RACEHORSES, WHAT WAS SPENT BY OWNERS TO RACE THEM, AND WHAT WAS SPENT BY THE PUBLIC TO SEE THEM RACE IN 1891.

Value in money of stakes for flat racing ............. $£ 448,695$

Value in money of stakes for steeplechases, say...... 130,000

Value of 7,120 racehorses at $£ 500$

Total amount of stakes .......................

Cost of keep and racing these horses.....

Amount spent by the public attending English meetings ........................................................

Total amount expended upon racing in England in 1891

130,000
$1,241,000$
$7,560,000$

$£ 578,695$

$3,560,000$

TOTALS OF BOTH TABLES:-

Value of stakes in Ireland.

Value of stakes in England

Value of 1,770 Irish racehorses

Total amount of stakes

Value of 7,120 English racehorses

Total value of 8,890 racehorses .........

Cost of racing 1,770 horses in Irelaud

Cost of racing 7,120 horses in England

Total cost of racing 8,890 horses ...........

Amount spent by public on Irish meetings .............

Amount spent by public on English meetings..........

Total cost attending race-meetings ......

Grand total of expenditure consequent upon racing
$£ 39,144$

578,695

265,500

$3,560,000$

154,260

$1,241,000$

475,000

$7,560,000$

$8,801,000$

$£ 617,839$

$3,825,500$

$1,395,260$

$£ 9,430,260$
$8,035,000$

in 1891 
In English racing establishments each horse has, as a rule, a boy to himself, therefore there are some 7,100 boys employed in the racing stables in England, besides the head lads. This added to the 900 employed similarly in Ireland shows that we have some 8,000 young men employed in the racing stables of the kingdom-a number equal to that of more than ten regiments of the line! And they have a better time and are much better treated than the soldiers.

To go into a calculation of the annual cost of the requisites for our racing stables is not necessary, as it is provided for in the "keep" of the horses. The amount for that item alone runs into a great many thousands of pounds per annum, as all saddlers right well know.

When we come to consider what has been spent upon the stables at Newmarket and other places, with dwellings attached, which for style and comfort quite equal those provided for Royalty, the amount becomes absolutely appalling! The sum has to be counted in thousands and it runs into many millions.

As in hunting so it is in racing-all the money spent upon the sport goes through countless channels from the richer to the poorer man. Thousands of men who at one time were in a very low monetary condition have become well off directly through this gigantic circulating medium.

Unlike hunting, however, racing is a business. Nor is it carried on under the sufferance of any one or any thing. It is self-supported and self-sustained. Racing, too, sends money flowing into a great many reservoirs. The money spent upon hunting has practically but one-the pocket of the farmer.

Racing has enjoyed a growth of popularity within the past few years perhaps unprecedented in the annals of any other institution in the kingdom. No doubt that popularity is mainly to be attributed to the inborn love we as a nation have for the sport, pure and simple. At the same time, a vast deal is to be attributed to a cause far away inferior. I allude to the propensity for betting which has taken root in the public within the past thirty years. Racing in its own innocent sport-productive vocation unfortunately affords a ready means for indulging the pernicious vice of gambling. A fact very sad and deplorable.

There is no manner of doubt but that racing will continue for many years to be the most popular of all British sports. How long this will continue to exist no one can predict. The zenith must, however, be attained at last, and when there remains no further means for ascent -what then? The descent must be made. The period of that calamity is probably far away in the future. No one now alive may perhaps see it, but come it will. As long $s$ we have nobility and gentry possessed of integrity and of great wealth, as we have at present, and as long as that community embarks in the ship the same love of sport which they do at present, and as long as they select from 
their own ranks pilots and helmsmen skilful to con and to steer, all will go on as it has gone with racing.

Should, however, our sport at any time be left without the nobility and gentry as a buttress, down it will crumble just as surely as did the Olympic games of old and, as I said before, the Prize Ring of latter days, when these once great institutions lost the support of the self-same class.

Give heed, all Radicals, to this assertion!

My visits to Newmarket are always of the pleasantest nature. I value more highly chats with some of the celebrated trainers there than I should interviews with the heads of almost any other branch of art and science. I always spend some time with the Prime Minister, Mr. Mat Dawson, when, in his sitting-room or strolling about, I enjoy the conversation of that great man. Yes, great he has proved himself to be, and neither envy nor jealousy, nor yet emulation, can detract from him one iota of the qualifications which have placed him at the head of his profession. Good he also is, for never has he wilfully done wrong during his public life.

What a collection of equine portraits he has at Melton Houserepresenting animals made celebrated through his own skill and sagacity. In the hall hang the tails of Julius, Thormanby, and the white Chanticleer. Around the dining-room are paintings by first masters of Thormanby, Kingcraft, Wheel of Fortune, Jannette, Dutch Oven, Silvio, Minting, St. Simon, Melton, Newminster, Julius, Alice Hawthorne, Sterling, Ormonde, Catherine Hayes, Tristan, and Barcaldine. A bronze statuette of St. Simon is there also, and as it was produced from a life-sized statue executed by Sir Edgar Boehm for the Duke of Portland, the likeness is a perfect one. The figure shows the horse's grand formation and perfect symmetry, and it is easy to understand what his trainer states as a fact, that St. Simon was the best horse he ever saw.

Mr. Dawson told me that, except upon a few occasions, he never backed horses heavily, and, moreover, added that if he had done so he would probably be a poor man now. He has often not a penny on many of the great races. A modest fiver or tenner-perhaps a pony, if he had something very good-was the usual sum he put on his horses, when he backed them at all. When a man like Mat Dawson, with all his knowledge and opportunities for gaining "information," sees the folly of backing horses and refrains therefrom, is it not lamentable, ay, criminal, for those possessing neither to persist in doing so?

$\mathrm{He}$ is about to retire from public training, but is still hale and hearty, and long may he remain so, to be a living example of what an "honest man" is.

Besides Newmarket and other training quarters, I visited classic Whitewall, where still exist in pristine simplicity the single stalls in which John Scott stabled his racehorses, and from which the great 
Wizard of the North did such marvels. I had as cicerone old Jim Perrin, who for forty years was head lad at Whitewall. He told me yarns most interesting, and showed me the stalls wherein stood West Australian and many another horse rendered famous through means of Scott's training.

The home of Caller $\mathrm{Oa}$ and Blink Bonny at Spring Cottage I have also visited, and at Highfield met Mr. William I'Anson, the genial representative of the owner and trainer of these great mares. Highfield, like Whitewall, is another establishment of the good old times. I confess I like to see these historic places preserved in their original state and style, rather than have the classic old walls and stalls pulled down as they have been at Newmarket and elsewhere.

It is the habit of some people to assert positively that a certain horse was the best that ever started. They may do so, but to prove it is simply impossible in the absence of an actual trial. Mr. George Dawson could, if he chose, tell to the ounce the difference between Ayrshire and Donovan, simply because he had at the same time these two Derby winners under his own charge, but he could not state as a fact what either of them were, as compared with Ormonde or Melton. Even the jockeys who have ridden the horses are, except as a matter of opinion, unable to draw the line accurately between some of the cracks.

At times, however, facts can be stated with regard to certain horses which would give people good reason to suppose that someone in particular had a legitimate claim to the title.

Upon perhaps the best authorities on racing at present alive, I shall refer to two. They are St. Simon and Barcaldine.

Owing to the death of Prince Batthyany the nominations for St. Simon for the classic races became void, and as a two-year-old in 1883 he was purchased for 1,600 guineas by Mat Dawson for the Duke of Portland and Lord Charles Beresford. Although at the time having shares with the Duke in other horses, Lord Charles unluckily gave up St. Simon. He ran eight or nine times and was never beaten, and if required could have won every race by a hundred yards. Collaterally, he was two stone better than Harvester. Mat Dawson thus found in the colt the makings of a horse quite phenomenal ; accordingly, he put him in training to win the long distance autumn races, knowing that no horse then in England could get near him at any reasonable adjustment of weight. Unfortunately he showed symptoms of not being able to stand the work, so the Duke, like a sportsman, rather than have his horse put to the stud otherwise than sound as a bell, stopped his training. No one therefore knows except Mat Dawson what a marvel was St. Simon, and he has often told me that he was not alone the best horse he ever trained, but the very best he ever saw.

Barcaldine, bred in 1878 by Mr. Geo. Low, of the County Kildare, was, next St. Simon, perhaps the best horse seen under silk in modern 
history. He, too, was never shown to the public in his best form, as he could never be made more than half fit. Yet were seen his great performances over all distances and under all weights. If he could have been wound up to concert pitch, and his powers developed to the full, some of the best judges, including his owner and trainer, Mr. Robert Peck, hold that the son of Solon and Ballyroe could have given age, weight, and a beating to any horse that had ever run previously.

What a deplorable circumstance is in connection with that great horse! I don't mean to refer to it further than to state that there are many men of integrity and honour who consider that his then owner was not as fairly treated as he might have been, nor were circumstances taken into account which not alone might have been explanatory, but considered extenuating or, perhaps, have excused the hasty and idiotic action which brought about the enquiry. No doubt, from what was stated in the papers at the time, the sentence appeared to have been deserved, and therefore justifiable, but many people know facts connected with the lamentable case which were not recorded. Possibly they were not put in evidence on the part of the accused, but that such an oversight should have occurred would appear to be improbable.

Instead of doing as he did, had the owner of Barcaldine contented himself by simply scratching him for the Northumberland Plate when he found he could not get his money on through being forestalled by the public, he would have done what he was entitled to, and have taught a salutary lesson to the British backer, at the same time leaving free, to make a record and a fortune, the best horse that was ever bred in Ireland, bar, perhaps, Harkaway.

- Marvellous as have been the changes which have come over racing within the past few years, none surpasses that which relates to the position of the trainer and the jockey.

Trainers have built for themselves houses which are simply baronial. In them are boudoirs, billiard rooms, and banquet halls, which, for elegance, are not surpassed in the houses of their employers. As to the prudence of this undertaking opinions differ, but my notion is that men who, like our Newmarket and other trainers, have plenty of money it is highly desirable that they should freely spend it; and when their bent is upon building the more taste they display and the more substantial the work, the better it is for themselves, their friends, and their tradesmen. Moreover, in this particular instance, we have another illustration which shows what practical advantage the sport of racing is to the public community. The houses and stabling built at New market within the present decade have caused a circulation of money among tradesmen and labourers which can be estimated only in hundreds of thousands.

The establishment of Mr. Richard Marsh at Egerton House, Newmarket, is the most magnificent of thr kind in the whole world.

ln the case of jockeys a change has taken place which was never 
dreamt of fifteen or twenty years ago. A boy, out of neither his teens nor his apprenticeship, and without education, may now earn, if he be skilful in the saddle, a better income than a bishop, while some of the leading jockeys get, in retainer and ordinary fees, more than is paid to the Lord Chancellor of England! Of a truth that of jockey is now about the very best profession there is in the kingdom. What a pity it is that some of those who follow it and jump suddenly into such brilliant financial circumstances do not realise their position, and, through honest performance of their duties, retain it. No doubt, before long, old prejudices will be overcome, and boys of good social position and well educated will, instead of to college, be sent to our leading training stables there to take their degree in riding. It is to be hoped these young gentlemen will always go straight and never in "rings."

Just as I am about sending the MS. of my book to the printers I find in a sporting paper two returns from different sources which are interesting, so I reproduce them.

Messrs. Weatherby in their annual volume of "Races Past" give table showing the number of races of different distances in Great Britain and Ireland in the undermentioned years, and is as follows :-

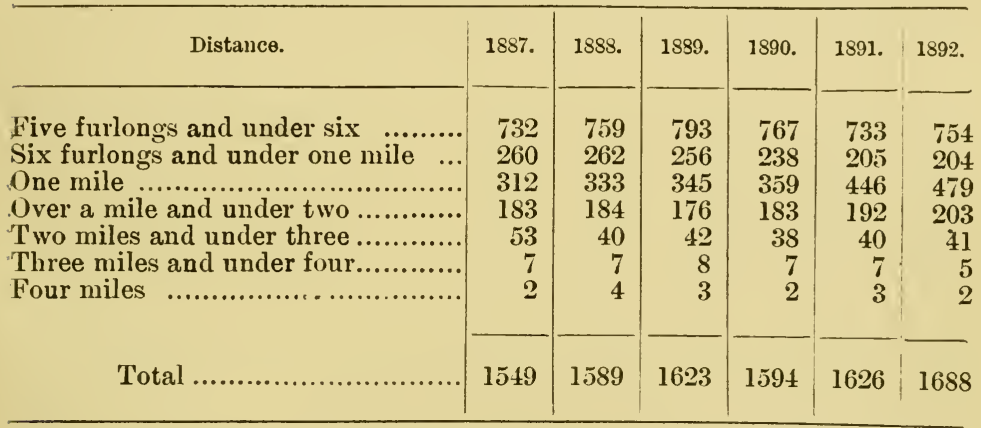

The above statistics are in precisely the inverse ratio to what I should wish to see them.

The next shows a return in every way conducive to my satisfaction :-

The latest racing statistics published show a distinct falling off in the value of the leviathan sweepstakes and a distinct increase in the financial aggregates of the old-fashioned stakes raced for at the open meetings. True it is that the Eclipse Stakes, won this year by Orme, maintains its position as the richest race run in England; and the Lancashire Plate, won by La Flêche, is second ; but still the value of these races has a tendency to travel down hill. The Eclipse Stakes figures read as follows:-1889, £11,165; $1891, £ 11,075$; 1892, £9,405. Those for the Lancashire Plate show a still greater drop. Thus in 1889 it was worth $£ 9,000$; in $1890, £ 9,091$; in 1891 , $£ 8,971$; and in $1892, £ 7,930$. I next turn to the Leicestershire Royal Handicap, and what a terrible falling off is there. This race was unjustly 
advertised as a $£ 16,000$ stake, but it has not caught on with the public, like most of the events that are advertised to be raced for at Oadby. Rusticus

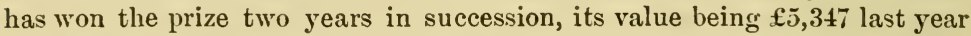
and $£ 4,205$ last September. Compare these big stakes to the Derby, Oaks, and St. Leger, and we find that the "old timers," as they are now remodelled, are steadily improving. Thus the Derby in 1899 was only worth $£ 4,050$; in 1890 it rose to $£ 5,930$; in 1891 to $£ 5,510$; and in 1892 to $£ 6,960$. Good old Derby! The St. Leger has also gone up, being worth but $£ 4,800$ in $1589, £ 5,125$ in $1890, £ 4,300$ in 1891 , and $£ 5,270$ in 1892 . The Oaks in 1889

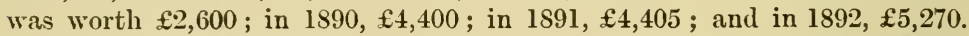
Take these figures as they stand above, and they show a tremendous balance in favour of the old-fashioned races over the modern "Frankensteins." 


\section{CHAPTER XII. \\ THE CURRAGH.}

Its Early History-Compared with English Downs--Effect on Horses-What can be Carried on Simultaneously-Its Area-Its Herbage-Its Hares-Traioing Establishments-A Trip on a Jarvey-Mountjoy Lodge and Dan Broderick-French House aud Michael Dennebey-Conyngham Lodge and Captain Joy-Turf Lodge and the HuntersLark Lodge and William Disney-French Furze, Paddy Gavin, and the KeegansBrownstown and the Knoxs-Normanby Lodge, Dick Sadlier and Colonel Thompson Jockey Hall and the Wattses-Mr. John Hubert Moore-Mr. T'. G. Gordon -Athgarvan Lodge and Mr. Pallin-Mr. Bowes Daly-Eyrefield Lodge and Mr. Linde-Eyrefield House and the Beasleys-Something about this Extraordinary Family-Donnelly's Hollow-Crotanstown-The Author gets Upset-The Racecourse-Waterford LodgeDavy Canavan-Hamilton Lodge-The Fox Covert-Rathbride Cottage and Mr. W. P. Cullen-Rathbride Manor and Mr. Meredith-Rossmore Lodge and Mr. F. F. CullenMilletta Lodge and "Mr. St. James"-Curragh View-End of Our Drive-Olden Times on the Curragh-Its Highwaymen-Homes of Great Horses-Sir HerculesBirdcatcher - Faugh-a-ballagh - Brunette - Guiccioli-Connaught Ranger-RollerFreney-Birdcatcher again-Bob Booty-Chanticleer-Ierne-Hollyhock-PleiadIldegarda-Thump - Wheel -- Bagot-Mr. Robert Hamilton-Master Bagot-Mr. Edwards - Tom Tug-Commodore - Cornet - Sweet William - Smallhopes - Irish Escape-The Highflyer Mare-Milesius-The Baron-Stockwell - Stockwell might never have been heard of-Russborough-Harkaway and Tom Ferguson. Postscript: Death of Mr. William Beasley-Marriage of Mr. Thomas Beasley.

ExCEPT that the first race run there was in April, 1741, I know nothing about the ancient history of the Curragh, so I can give my readers only a sketch of what the noble plain is like at present, and refer to events of comparatively recent date. I can, however, assure them that many a long year has passed since grass first grew on it, and that nothing else has ever grown there except a few furze bushes.

From off none of the downs or wolds of England have I ever felt such invigorating air as I do off the plains of our own Curragh. Bo it morn, midday, or night, and whether in any of our four seasons, there comes from it a bracing ozone not to be found on Epsom Downs, Langton Wold, or Salisbury Plain. It quite equals, if it does not surpass, the air we find on the west coast of Ir el ind, blown in from the mighty Atlantic.

Who knows but this health-giving property may not have a vast deal to do with the hardihood of our Irish racehorse referred to in other pages of this book?

I don't know how many acres there are in the Curragh, but it would take a great many of the downs in England to make the same extent. In the centre we have a military camp which is in itself a large village, around it, and in the closest proximity, several regiments of artillery, cavalry, and infantry can, in simultaneous review, fight their miniature Waterloos, while within a mile there is a range long enough to spend the force of bullets from our farthest shooting rifles. Nor do the extensive operations which daily take place in and about the 
camp in the least interfere with the exercising of the various strings of horses belonging to the surrourding training establishments. Mr. Pallin can also have a hunt in far-off portions of the plain, his hare giving the hounds a four-mile point without leaving the Curragh or nearing either military or trainers' strings.

Then have we not the world-renowned racecourse, where a four-mile course is laid out within its circumference, upon which the timehonoured Anglesey, Peel, Waterford, Howth, Red, and Sligo posts have stood for generations? On the further sde of the railway we have the Curragh Gorse-a covert of the Kildares from which many a rattling fox was run.

Now, my readers, $I$ in no way exaggerate when I state that, if so minded, we could have all the following events taking place at the same time on this noble plain, and that, too, with perhaps little or no interference with each other :-

All the troops in Ireland under review.

All the R.I.C. in the County Kildare ball practising at the rifle-butts.

All the trainers' strings at exercise.

The Curragh October Meeting.

The Kildare Hounds drawing the gorse for a fox.

Mr. Pallin's Harriers drawing furze brakes for a hare.

A coursing meeting if there were hares, which there are not.

Now what do you think of that, all ye who boast of the greatness of England? Where is the place in all your land that could give space for such vast and varied exhibitions of military and sporting events to take place at the same time? And if a man had a front seat in a balloon he could have a bird's-eye view of the whole panorama! I repeat, there is no exaggeration in what $I$ have stated.

The Curragh is, as the crow flies, fully six miles long and three miles across, with hill and dale adding considerably to the extent. It does not run out into inland peninsulas, but is practically a parallelogram in shape.

The herbage, too, although never having been desecrated with a plough, is far away richer and better in quality than that grown upon any plain I ever saw in England. The grass grows short, thick, and sweet, and is particularly good for sheep, while the hares which once lived there in plenty were of the stoutest and best running breed to be found in the three kingdoms. The late Mr. James Galway, the breeder of Master McGrath, told me he often saw a Curragh hare run clean away, without their having given her a single turn, from the best brace of greyhounds in Ireland. Coursing meetings of importance used to be held on the Curragh long ago, and there was a park near where the camp is into which the hares could run for safety, holes being in the walls at convenient places for them. A portion of this old hare park still remains, but the hares have long since been annihilated. 
Our various training establishments are all situated around, or close to, the verge of the Curragh, and are, like those near Malton, pretty nearly in their primitive state. The dwelling-houses are mostly of the cottage style, only a few are two-storied-a style no doubt adopted by the old folk as being that least likely to feel the effects of the storms which too often sweep our plain. The stabling which adjoin the lodges are all of the good old-fashioned substantial style, lacking nothing in anything pertaining to the comfort and well-being of the horses which occupy them, but all in simple, useful fashion. None of the ornamentation, decoration, and so forth which distinguish the gorgeous establishments of Newmarket are to be found in these abodes. Our Irish trainers know and do their work quite as well in their homely, snug little shanties, with their barn-like rows of stabling adjoining, as any of the Englishmen in their regal residences surrounded with villages of stately stabling, while our humble boxes contain as healthy horses and turn out more winners in proportion than come from the superbly decorated stalls of England.

While scribbling these notes my thoughts naturally run to the principal establishments around and near the Curragh; for the information, therefore, of those of my readers who are not as fortunate as the others who know them, I shall pay an imaginary visit to each. To do so I shall figuratively hire a jarvey in Kildare and take with me three Newmarket trainers who, strange to say, have never visited the Curragh, nor have they been to Ireland. They are Messrs. Joseph Cannon, Arthur Sadler, and George Dawson.

Before starting from the ancient town of Kildare we shall look in at the old Club House. Oh, what tales these walls could tell! Around this very table the great men of old feasted and made merry upon the nights of the Curragh meetings. Many were the magnums of port and claret drank over that mahogany. See here are the marks of the dice-boxes which in vehemence were dashed down while high play was indulged in. Now the place is deserted and has been for years since the time of the Charlemonts, Howths, Waterfords, Clanricardes and Sligos, the Disneys, Westenras, Dalys, Powers, Courtenays, St. George's, Archdales, and Irvines !

Down the old and narrow road our jarvey rattles us for a little over a mile, when we arrive at the Curragh verge. The first training establishment we shall visit is Mountjoy Lodge. Here the veteran Dan Broderick still resides. For some years before his lamented death, sporting Captain Stamer Gubbins had here his training establishment with Dan as trainer, whence to victory were sent Fairyland, Juggler, Sailor, and many other great horses.

Next we come to the home for many years of straightfoward Michael Dennehey. A man who puts his money on a horse sent to the post by the owner of French House has, at all times, an honest run for it and often wins. To train a horse for the flat or over a country, Mr. Dennehey can hold his own with any man, while 
there is not a trainer on the Turf who holds an escutcheon more untarnished.

Now we arrive at an establishment larger than some of those about the Curragh. It is Conyngham Lodge, built many years ago by the late Marquis of Conyngham. The celebrated brothers Murphy lived and trained here for a long time after they moved from Pope Lodge, which is farther on. Since they died various tenants have held it, none of whom dwelt there as long as did that best of good fellows Captain George Joy. To that gentleman's judgment and sagacity are our friends in England indebted for the possession of some of the best horses of modern times-Bendigo, for example. He died at Conyngham Lodge in February, 1891, regretted by everyone who knew him.

Turf Lodge is next en route. Here Mr. Richard Newcomen has resided for years, and at times owns a good horse and trains others. In former days Turf Lodge was the home of the Hunters, and there were stabled the famous Roller, and, as dam of Birdcatcher, the still more famous Guiccioli.

Lark Lodge, once the residence of that great pillar of Irish racing Mr. William Disney, comes next. Here we are shown the sods which cover the bones of Birdcatcher.

At French Furze House we meet Paddy Gavin, who has under his care a promising lot of youngsters. Many a good race have I seen him ride with Tom and William Ryan, Davy and William Canavan, Tom Kelly, and other good cross-country jockeys of twenty years ago. The Keegans lived here for many years, and were, in long bygone days, celebrated alike for training and riding. I remember Larry, who at the age of eighty died here in 1881. In his day he was one of our finest steeplechase riders, but he had a very ugly seat. Paddy Gavin married his daughter, and has lived at French Furze for several years.

Brownstown, the home for generations of the Knoxs, is our next visit. This is the birthplace of Birdcatcher, and here lived, until his death a short time ago, that once great cross-country rider Mr. George Knox. Many of his last years were spent under the affliction of total blindness, the result of a fall in a steeplechase.

A little way off the Curragh we come to Normanby Lodge, called after, perhaps, the most popular Lord-Lieutenant we ever had, who kept his racehorses here in the thirties. When I was a youngster the late Mr. Richard Sadlier held court at Normanby, and that in regal style. From it the hospitable Tipperary man sallied the day on which he won the famous Welter Private Match at Punchestown on his wonderful brown horse, Bismarck, beating Mr. Alan Macdonagh on Humming Bird and Mr. Henry Linde on Nereid. A northern sportsman now resides here, in the person of Colonel Thompson, a member of our Turf Club, and who has in training there several useful horses of his own. 
Now we see clustered among trees of ancient planting, through which the Gothic windows look out upon the Curragh, a place of historic fame. It was the home of the Watts', and it is Jockey Hall. Here was stabled Echidna, when she dropped The Baron. Here, too, the latter as a sire held court, and out of Pocahontas begat Stockwell. At Jockey Hall Mr. John Hubert Moore for several years resided in the sixties and seventies. During his time the best horses in Ireland, bar none, were trained at The Hall. Among them were Scots Grey, Curragh Ranger, Furley, Rufus, Albert, Revenge, Revoke, and many others whose names I can't at the moment recall to mind. Over the private course at the back his father taught Garrett Moore how to ride a steeplechase.

Another North of Ireland gentleman, Mr. T. G. Gordon, resides now at Jockey Hall. He, like the former occupiers, has a large string of first-class horses under his charge, and as a sire he has at present the renowned Ben Battle. Mr. Gordon, as a member of our I.N.H.S. Conmittee, does good service to our sport. We see that within the past couple of years he has put the place in thorough repair and wrought great improvements in the house and stables, which from old age and hard usage they truly were in need of.

Leaving Jockey Hall we wheel sharp to the left and travel along the eastern end of the Curragh. In doing so we pass the rifle butts, and cross the line of fire. After about two miles we turn up to the right and arrive, by a short cut and the back entrance, at another establishment, as famous and as ancient as any about the "Short grass." This is Athgarvan Lodge, the seat of my friend Mr. William Pallin.

We have now had some three hours on the Curragh, and travelled nearly seven miles. At all of the houses, with profuse hospitality, we were offered refreshment, and at some we certainly partook thereof. Now, however, comes the hour for luncheon, and with the effects of the Curragh air in our systems, we have a keen desire for it. This feeling is the more intensified by the hearty welcome which we receive, and forthwith we sit down to a sumptuous repast presided over by the genial host.

Athgarvan Lodge of the present day is very different from what it was when George IV. visited Mr. Bowes Daly there in 1821. Then mains of cocks were often fought on the green plot opposite the drawing-room windows, which is now the tennis ground, and here in the dining-room, during the night's carouse, was many a battle brought off upon the mahogany. Habits and fashions were very different then from now, and if these walls could speak they might tell queer tales! Cock-fighting and hard-drinking were, however, in olden times, practised at the Curragh in many other places besides Athgarvan Lodge.

Mr. Pallin is a man of very refined taste. He has a collection of rare oak furniture and equally antique silver. Everywhere we see, in choice selections, which betoken the instincts of the man, trophies of the race, the chase, and foreign travel. 
On the sideboard is the Grand Military Hunt Cup of 1878. To win this cup Mr. Pallin had set his mind directly he joined the 20th Hussars in 1871 , and upon former occasions he ran third and fourth for it, but in 1878 he won it with Theseus, ridden by Captain Lee Barber, Pallin not being able to get the weight. It was for hunters that had never won a race of $£ 20$, the property of officers of the Army and Navy, and Mr. Pallin showed his judgment in producing the best of his year in an animal he bought for $40 \mathrm{gs}$. at Tattersall's. He has willed it that when his third and youngest son, now a boy of six, can challenge for it, the three brothers are to ride for this cup upon maiden hunters, hunted solely by themselves, 12 stone each, three miles over Punchestown. In the event of only cne competing, he is to ride over the course for it. May we be there to see the father lead back the winner after a good race between his three boys.

The walls of Athgarvan Lodge are hung with racehorse portraits executed in high art, conspicuous among them being originals of Birdcatcher by Harry Hall, and The Baron by Herring, while many are the work of the owner's own brush.

Within the past two years the old dwelling has been repaired and a lot added to it. The stables were previously remodelled and spacious yards laid out whereon formerly stood useless outhouses. In a word, from an old tumble-down concern, whicl it was but a few years ago when Mr. Alan Macdonagh lived there, Mr. Pallin has made the house about the very best at or near the Curragh, while the out-offices are all that can be desired for the purpose of life which he has laid out to follow-that of breeding thoroughbreds. Not one of the many stud arms which I have visited in England surpasses in excellence of design or management those of Athgarvan Lodge.

Since he betook himself to the calling few men in Ireland have done more, or perhaps as much, as he has towards the furtherance of breeding thoroughbred stock. At present there stands at Athgarvan Favo, by Favonius, out of Adrastia. He was a good racehorse at all weights and distances, having won fourteen and was placed thirty-five times. $\mathrm{He}$ is, as we see, a magnificent specimen of a weight-carrying thoroughbred stallion, and is sound as a bell, while his breeding shows a grand combination of the best blood in the Studbook. On his sire's side he has that of Sweetmeat and Harkaway through King Tom, while his dam gives him the mixed blood of Stockwell and Newminster. No horse of late years has done Irish breeders so much good as Favo. He has begat a prodigious number of winners, and for four years has stood at the top of our list as a sire of winning horses.

Master Ned is also there, descended as he is from the best line of Irish blood now available, a direct union of Birdcatcher and Harkaway. Astrologer we also see--a son of Hermit, out of Stella-whose greatgrandsire was Melbourne.

So well known are the Athgarvan yearlings that at Doncaster during the St. Leger week they fetch a high average price. 
It has taken us nearly two hours to go over this model stud farm, visiting as we did the stables, stallion yard, paddocks, brood mares and foals, yearlings, and last, but not least, the kennels, wherein Mr. Pallin has some fifteen couple of as nict-looking harriers as are to be seen in Ireland. We must, therefore, bid adieu and good luck to the genial master.

While our trap goes round by the road I take my friends a short cut across a few fields which brings us to Eyrefield Lodge. This, I need not say, is the residence of him who I think I may call our Irish Mat Dawson. In fact, Mr. Henry Eyre Linde takes higher honours than the English champion, for, in addition to the flat-racer, he can, as the world knows, train a steeplechaser, which the latter cannot do. Unlike other gentlemen trainers, Mr. Linde resides in the home of his ancestors, where he was born, and as far back as $180 \mathrm{~T}$ the place is marked on the map of The Curragh as the residence of Eyre Linde, Esq. He has within the past few years enlarged his stabling to a very great extent, and in a style which brings it more like that of Newmarket than any other near the Curragh. The stalls are loose boxes, capable of accommodating in all fifty to sixty horses. At the farther end from the house is the farmyard, and there are found cattle, sheep, pigs, and poultry of as good and useful breeding as are the horses in the stables. Huge stacks of the primest oats, with gigantic ricks of hay and straw, flank the lot and shelter all from the Curragh gales. In addition to his own household, Mr. Linde has of necessity a very extensive establishment comprising over a score of men and boys; but the Master of Eyrefield is, from his own farmyard and garden, able nearly throughout the year to provision the lot, great as the commissariat undertaking undoubtedly is.

Two fields at the back of the stables is the private steeplechase course. It was the first of the kind ever laid out in Ireland. In its track, which is a mile and a quarter, is found every description of fence to be met with on either English or Irish courses, and of dimensions which require both riding and fencing to be executed in the highest degree of excellence. This explains how Linde's horses can always jump, and his men can always ride.

After tramping round the track and returning to the house, we feel inclined for further refreshment. This we partake of in the cosy dining-room, the walls of which are decorated with portraits of Messrs. Tommy and Harry Beasley on Empress, Woodbrook, Mohican, Whisper Low, Too Good, Gamebird, and other steeplechase celebrities, which bore away the palm of victory from Aintree, Paris, and from all parts of Ireland.

For many years Mr. Linde has had, as first lieutenant, Mr. Tommy Beasley, and until lately his brother Harry assisted; while as head lad Dan McNally-"Eyrefield Dan" as he is called--has been a valuable servant ever since Linde began his profession.

To recount the marvellous achievements of this gentleman trainer 
with racehorses during the past quarter of a century would be impossible for me. But have they not been chronicled over and over again? I will merely say that no man of modern, nor perhaps of former, days has gained such celebrity over steeplechase courses. For years past he has furnished more favourites for the Grand National than any other two owners or trainers put together, and I doubt if the same number can total among them as many of their horses having won, been placed, and ran forward in that race as he can. I have no Calendar by me, but from memory I know within the last fifteen years he has prepared for the Grand National two winners in Empress and Woodbrook, while Martha and Cyrus lost in their respective years by short heads only. Fair Wind, Too Good, and Mohican in other years ran into third place. Other horses from his stable may have been placed, but I am safe in stating that every Eyrefield horse which started for the Grand National, except the one or two which fell, had many more after than before him at the finish. The Sefton Steeplechase at the Liverpool Autumn Meeting has been won by his representatives more frequently than by those of any other man in the kingdom, steered as they were nearly always by Mr. Harry Beasley.

No one stards more prominently in the winning records at Chantilly than Mr. Linde, Too Good, Whisper Low, Mohican, and Seaman alone establishing for him that position. Over our own famed Punchestown for the past twenty years no stable has at all come near that of Eyrefield. For years the Prince of Wales' Plate and Conyngham Cups have gone to it, while all the other races, bar of course the Farmers' and perhaps the Kildare Hunt Cup, have often from time to time been won by horses under his care, while the records of Cork, Baldoyle, old Curraghmore, Leopardstown, and every other meeting in Ireland, including the Curragh, return scores of winners supplied by him.

What I don't think any one of his profession can say, he owes to no man his acquirements. He taught himself. Starting life in quite a different sphere, he soon gave up the calling and betook himself to that which he innately was so pre-eminently gifted for. Nor was that until he had got well into the fourth decade of his age.

To the master of Eyrefield the training of a flat-racer is as easy to superintend as is that of the chaser. A five-furlong sprint, a Queen's Plate, or a two-mile timber-topping are all alike to him. At the same time he likes best the cross-country work, and of that I know he very much prefers the natural to the artificial business. To lead back a winner over Punchestown or Aintree is to my friend his greatest pride and satisfaction.

In another particular the subject of my notice differs greatly from other gentlemen trainers. He knows how to mate judiciously and scientifically thoroughbred mares and stallions. This is evident to anyone looking over the foals, yearlings, or other thoroughbred youngsters at Eyrefield. 
Unlike as he is to other trainers of the first class, he is similar to many of them in the one great golden rule-Linde has always run his horses straight. I have known him ever since I saw him leading in as winner at Fairyhouse, in 1873, Highland Mary, with Mr. Tommy Beasley up, then but a boy. From that day to this never has there been one word, or even a hint, against the way in which the one man ran and the other rode horses.

Highland Mary, bred in 1869, was the first really good animal Linde owned, and although she cost him only $£ 25$, the achievements of this mare laid the foundation of his fortune. She was by Solon out of Scotia. She bred only one foal, the first Eyrefield by Uncas; but he as a four-year-old, and not fifteen hands, won the Prince of Wales' Plate at Punchestown in 1881, and the Germans bought him for $£ 1000$. Since then Linde prepared all the following horses, and, except a few, for every race they ran : Empress, Woodbrook, Seaman, Cyrus, Martha, Usna, Lord Tara, Turco, Gamebird, Mohican, Whisper Low, Fairwind, Carmelite, Too Good, Mayboy, the two Eyrefields, Primrose League, Niblick, Alexander, Chancery, Spahi, and quite a host of other clinkers whose names I forget. Lord Tara and Gamebird did wonders for him, yet all he paid for them was respectively $£ 5$ and $£ 65$.

Although he takes charge of horses for his friends, he won't take anything but good ones, and always holds a share in their ownership.

Upon the conclusion of the racing on the second day at Punchestown some five or six years ago, when he had won well-nigh every race of the meeting, I heard him bidding good-bye to Lord Drogheda, and winding up with, "I am sorry, my lord, Punchestown does not continue for a few days longer, so that I might win some more of your races"!

He has been surnamed The Farmer-I think by the late Captain Joy-by reason of "farming"-i.e., winning-so many races. By that title he is often styled by his friends.

In Mrs. Linde her husband has found a partner in every way congenial. Of racing she is a capital judge, and takes as much interest in it as he does. She is a brilliant rider to hounds, and hunts regularly with the Kildares. They are alike generous and good, and dispense charity right and left.

At Eyrefield, as at Athgarvan, we have been for a long time, and as time presses we must leave the hospitable abode where the jovial master has entertained us the entire time with his amusing anecdotes and unbounded heartiness.

Within a couple of fields of Eyrefield Lodge, but farther away from the Curragh towards Athgarvan village, stands Eyrefield House, where three of the brothers Beasley superintend the training of a most extensive and highly select lot of racehorses. This ancient edifice is two-storied, and has at the back a most convenient and excellent range of stabling, all kept in the most scrupulously tidy style.

I must now say a few words about this celobrated family of 
gentlemen jockeys. First, they come of a good old Irish family, which for many years resided in the County Kildare. The brothers under notice are Thomas, Harry, William, John, and James. I may say, without fear of cavil or contradiction, that never in racing history has there been a record of so many of the one family possessed of such excellence in horsemanship. I know these young men well, but even so I beg they will excuse my calling them in this book by the names they are universally known by, for fear that some of my readers might not quite know who were "Mr. Thomas Beasley" or "Mr. Henry Beasley," whereas Tommy and Harry Beasley are known all over the civilised globe.

Well, anticipating the forgiveness of these fine fellows, I begin with the eldest, Tommy. He was brought up at the feet of that great master of steeplechasing, the late Mr. Alan Macdonagh, than whom, with his brother William, there were no cross-country jockeys superior in olden time. After getting his first lessons from that mentor he came under the banner of Mr. Linde, where for many years past he has remained. To give a full account of this fine horseman's achievements I shall not attempt. A few, however, may be mentioned. He won three Liverpool Grand Nationals on Empress, Woodbrook, and Frigate; Croydon Steeplechase of four miles on Pride of Kildare; Paris Steeplechase on Whisper Low, and Birmingham Grand Annual Steeplechase on Abdullah. At Punchestown some of his principal wins were Prince of Wales' Plate on Eyrefield (the first four-year-old that ever won it); two Conyngham Cups on Cork and Christmas Gift, and at the meeting of 1892 the Kildare Hunt Cup on Nap, showing that his right hand still retains its cunning. His win on Christmas Gift in the Conyngham of 1876, when quite a youngster, was very meritorious, for he beat by a neck, after a desperate race, the crack Mr. Garry Moore on Scots Grey.

$\mathrm{He}$ holds a record in the Grand National quite unparalleled. Out of twelve rides he won three times, as stated above, was second twice on Martha and Cyrus, who each lost the race by half-heads, was third on Martha, and fourth twice on Sultana and Cruiser. Spahi fell with him at the tirst fence in 1887 ; and Frigate, in 1890, when going well, and with a good chance of scoring her second win, although carrying 12st. 7lb., was knocked down by the French horse Fetische. He rode Zitella in 1883 and 1884 , but I forget whether she stood up or not. Anyway, out of the twelve mounts he gave a good account of himself in eight, and it is certain that two, at least, of the others fell. He won twice in succession, in 1880 and 1881, and lost it by only a short head the year after.

On the flat Mr. Tommy Beasley is as good as between the flags. At the Curragh he won its Derby on Pet Fox, Tragedy, and Narraghmore, several Queen's Plates with Spahi, Carmelite, Red Prince, Chatterbox, May Boy, etc. He also with two-year-olds won many of the Waterfords and Angleseys. With Spahi he beat Fred Archer for 
the Welter a short time before the untimely death of that jockey. The Baldoyle Derby he won with Primrose League and Grecian Bend. At Liverpool he won two Welters on Primrose League and Wordsworth.

I don't think his brothers will object to my doing so, or perhaps disagree with me, when I state as my opinion Tommy is the most finished jockey of the family. He can ride a five-furlong race as skilfully as any professional, while Tom Oliver in his best day could not give him 3lb. in a Grand National. It is well known that he rode for the latter with as cool a head as he would in a spin for a tenner.

Like his friend Mr. Garret Moore, he has been singularly lucky in escaping bad falls. The only one I remember his suffering from was that given him many years ago by Alhambra at the Curraghmore meeting, while his worst fall was when he broke his leg riding from the post-office across the Curragh. No doubt both he and Mr. Moore rode as a rule only well-schooled horses, but had it not been for that cool, steady nerve, which was the peculiar characteristic of these two gentlemen, a very different result would have been the case.

Besides his brilliancy as a horseman with the silk on, Tommy Beasley is a tip-top man in scarlet, a combination very rarely met with. Moreover, he is a crack shot and a skilful fisherman.

The second brother is Harry, and while I doubt that he could ride a short race on the flat or finish up the straight after a long steeple chase in the same style as his elder brother, on a rough mount he certainly is the better man; in fact, I never saw anyone who could handle an awkward horse in a steeplechase in such style as Harry Beasley. It may be said of him as truly as it was some years ago of Mr. Tom Pickernel, that "he can ride any horse at any fence at any pace."

He has ridden more in public than his elder brother, and consequently has won more races. Over Punchestown he won oftener than any man recorded in its annals. I forget how many Conyngham Cups are to his credit, but on Seaman, Frigate, and on Comeaway twice were some of the wins. The Sefton Steeplechase at Liverpool he has won oftener than any other jockey, carrying it off in 1879, '80, '81, '83, and '85. He won the Grand National in 1891 on Comeaway, and was second three times and third once out of thirteen mounts, so his record is little short of Tom's. At Paris he won the Grand Hurdle Race in 1881 on Seaman, and was second for it on Turco and Mohican the year before and year after. For the Grand Steeplechase he was third on Mohican in 1882, when his brother won with Whisper Low, and he won that race in ' 83 with Too Good, and again in 1890 with Royal Meath. Other important events all over the kingdom he is bracketed with.

$\mathrm{He}$ also is a good shot and a fine fisherman. He owes his start in life as a gentleman rider to $\mathrm{Mr}$. Linde, but for whom he might never have been heard of except in commercial circles. 
Willie is the third, and with his brothers, Harry and Johnny, conducts the Eyrefield House establishment. He, too, is a beautiful and highly-finished horseman. He graduated under Mr. John Hubert Moore, than whom few more accomplished gentlemen trainers ever led in a winner. Naturally he has not as brilliant a record as his elder brothers, but he has scored many times, among them the Conyngham at Punchestown in 1891 on Sarah Bernhardt. He was second on Frigate for the Grand National in 1888; on Flying Column in ' 92 he made nearly all the running, finishing fourth out of a field of five-and-twenty ; and when Harry won the Steeplechase at Paris on Royal Meath, Willie was handy, ready, in case of accident, to do the trick on Bayleaf. He has the same style as Tommy, and I am of opinion he only wants time to become quite as finished.

Johnny and Jimmy Beasley, I think, also got their early tuition from Mr. Moore, and they likewise do him credit. If they had not such extraordinary brothers, these two youngsters would be quite at the top of the tree. Johnny rides in the style of Harry, and fears a rough mount just as little. Jimmy has been connected with a foreign stable for some years, and he is now in India, doing well.

The first mount these brothers had for the Grand National was in 1877, when Tommy rode Sultana, and since then (up to 1892) that race has never been started without some of them. In 1880, '84, '87, and '89 three rode, while in '79 they all rode except Jimmy, who was abroad. It is unfortunate, however, that at no time did more than one get a place.

Here is a family record unparalleled, and likely to remain so :-

Mounts of the Brothers Beasley in the Grand National. Sixteen Years, 1877-92.

\begin{tabular}{|c|c|c|c|c|c|}
\hline & Won. & Second. & Third. & Not Placed. & Total. \\
\hline $\begin{array}{l}\text { Tommy } \quad \ldots \ldots \ldots \ldots \ldots \\
\text { Harry } \ldots \ldots \ldots \ldots \ldots \ldots \\
\text { Willie } \ldots \ldots \ldots \ldots \ldots \ldots \ldots \\
\text { Johnny } . . . \ldots \ldots \ldots \ldots \ldots\end{array}$ & $\begin{array}{l}3 \\
1 \\
0 \\
0\end{array}$ & $\begin{array}{l}2 \\
3 \\
1 \\
0\end{array}$ & $\begin{array}{l}1 \\
1 \\
0 \\
0\end{array}$ & $\begin{array}{l}6 \\
8 \\
5 \\
3\end{array}$ & $\begin{array}{r}12 \\
13 \\
6 \\
3\end{array}$ \\
\hline Total & 4 & 6 & 2 & 22 & 34 \\
\hline
\end{tabular}

Jimmy never rode in the Grand National.

What a sensation would have been caused at Aintree in 1889, had not Usna broken down at the far-off turn, before coming to Valentine's Brook. Bar any other accident, there is no manner of doubt he would have won with 12st. 7lb., and thereby have broken the record, while Frigate was going second best. The two brothers, Harry on Usna and Willie on Frigate, coming away from their field, and finishing a good race, which no doubt they could have managed 
to do, would indeed have brought down the stands, or rather sent up the cheers of those on them.

It is equally certain that if Frigate had not been carried out of the course by Usna when he broke down, and had to be pulled up to avoid going into the canal, she would have won by twenty lengths, giving Willie a blue ribbon.

As I said elsewhere, I don't accord to ordinary owners of racehorses much credit simply because they happen to possess great horses. The one who, in my opinion, deserves laudation is the man, like Harry Beasley, who can train a horse as he did Comeaway, and on him carry off the Grand National, that win being, in point of weight and time, the best on record except Bourton's in 1854.*

These five brothers are quite as popular as they are skilful.

Come, come, we must be off, for we have been nearly as long with these three gallant young fellows as we were at Athgarvan and Eyrefield, so, driver, hurry on, for we have no other place to stop at till we come near the Stand House, which is nearly four miles off.

Hullo, pull up! Get down, my friends, till I show you our famous Donnelly's Hollow. Yes, here it was that on the memorable 13th December, 1815, Dan Donnelly the Irishman beat George Cooper the Gipsy. Was there ever selected a better site for a prize fight? Upon this sward, level as a billiard table, the twenty-four foot ring was pitched. Around it ample space was afforded within their inner circle for the upper ten, while the high sloping banks which surmount three sides of the plateau sheltered from the wind the gladiators, at the same time affording the occupants of the outer ring a full view of the battle, standing, as they could do in this natural amphitheatre, in rows one above the other. I don't suppose a spot more naturally adapted to the purpose of a fight could bo found anywhere.

In 1888 this monument was erected by public subscription to mark the site of the great battle, and to commemorate the skill and endurance of a brave Irishman. See how the pretty little erection with its neat railing has been defaced by thoughtless people, who with Goth and Vandal notions break off pieces to carry away as mementoes !

From Donnelly's Hollow to the Stand House, on the north side of the Curragh, we have no racing stables, although in days gone by at Crotanstown were housed good horses.

There is the road to Newbridge, and here at this corner is the place where I got the upset which you saw the illustration of at Linde's. Yes, returning to Newbridge about four years ago, after spending a festive night at Eyrefield Lodge, I and two others got here about as complete a capsize off a jarvey as ever men got. The driver, entertained no doubt by "Dan" with the hospitality proverbial at that house, would not be restrained from driving full speed along the road we have just travelled, although the night was dark as Erebus. You

* Since I wrote the above Cloister has won carrying 12st. 7lb. ; and poor Willie Beasley has been killed. 
see there are no fences and nothing dividing it from the grass but drains over a foot deep and two feet wide, with banks of mud thrown off the road on the inside. Sweeping round this turn at the Soldiers' Home, going ten miles an hour, the near wheel, over which I was sitting, ran up on the bank. In the twinkling of an eye the car was sent flying upside down, and the driver in a tangent from his seat; the other two fellows went sprawling all fours, while I described. from the near to the off side, a back somersault so complete that I landed on the road in the sitting position which a second before I was in on the car. The sensible old horse luckily stood stock still, and when we picked ourselves up we found no one had sustained the least injury. Not so our habiliments. In a pretty pickle our evening clothes were with mud, for in the darkness down was coming the rain in torrents. Neither was injury done the car beyond having the iron rail of the driving-seat bulged in. This, they said, was caused by the weightiest part of my body coming in collision with it in my aerial transit!

We now arrive at the Stand House. See now before you, my friends, our historic Curragh racecourse. Yonder to the left is the four-mile post, used only for the Queen's Plates. Starting there is seen, in their stride, the horses coming along that wide stretch at foot of yon slope. Sweeping round the post, near the chains they pass the stand outside the rails, going far away to the left by the starting post, and finishing up the straight from the chains ; thus doing their four miles without travelling twice over the same ground, except for about two furlongs. Can you beat that at Newmarket, or have you in all your courses a better run-home?

Here, at back of the stand, is Waterford Lodge, called, as you know, after "The Marquis." Close by lived for years old Davy Canavan, who sixty years ago trained at Gurteen for Mr. John Power. It was he who trained Valentine, Tidy, and other celebrated horses, the property of the popular, but unfortunate, Squire of Gurteen. Canavan was a good horseman of the old school, and his sons William and David were equally so of a more modern era.

Old Davy was sent to Leicestershire in charge of a horse to a gentleman who had bought him from Mr. Power. The horse was bred near Tramore and was a famous hunter, but necessarily unaccustomed to water, of which we have very little in Ireland. The new owner was well pleased with the appearance of the horse, and amongst other questions asked if he was good at water, to which Davy replied, "Arragh! why wouldn't he? Wasn't he bred in sight o' the say!"

Hamilton Lodge, close by the Stand House, is where James Dunne trains a few horses. He, too, is of the good old school, and was an accomplished horeman in his day. At this lodge, nigh a hundred years ago, dwelt Mr. Robert Hamilton, a benefactor to Irish racing, of whom more anon.

Passing under the Railway bridge we see half a mile off the Curragh 
Gorse, and shortly afterwards arrive at Rathbride Cottage, where that fine horseman, Mr. William P. Cullen, has lately come to resicle, and has several useful animals under his charge.

Historic Rathbride Manor is close by, and was for years the abode of the St. Georges and the Irvines. Here in old times were stabled many famous racehorses, including Faugh-a-ballagh and Mickey Free. The bones of the latter rest here. Within the past few months, Mr. Rice Meredith has come to live at the manor. Perhaps no young trainer of present times, excepting my figurative companion George Dawson, has achieved in so short a time more successful results for his patrons than Mr. Meredith. Not alone in Ireland, but in England, and for many most important races, has he led back winners within the four years he has undertaken the duties of public trainer. From this gentleman and his father before him, Punchestown course has been rented ever since races were established there. In Mrs. Meredith he has a wife who looks after her husband's business as carefully and efficiently as himself. Kind for her, for is she not the daughter of Tom Waters, and great-granddaughter of Watts, who bred and owned The Baron?

A mile farther on we arrive at Rossmore Lodge, called after the nobleman who, with many others of the same class, was a column of our Irish racing half a century ago. The eccentric Tom Ferguson lived here in the thirties and trained the famous Harkaway. For many years Joe French, a quondam trainer from Newmarket, lived there, and cared his horses with consummate ability. It was he who turned out Bendigo when he won the Cambridgeshire in 1883. Strange that with all his sagacity he should have lost most of his earnings upon backing horses, resulting in his having to live for the last of his years upon a small annuity. He died at Newmarket in 1890. During recent years Mr. Frederick F. Cullen has sojourned at Rossmore Lodge. He with his brother William are, like Mr. Meredith, young trainers, and also have been most successful for their patrons. Unlike most others, they are their own "first jockeys," and whether it be on the flat or over a country few men can give weight to either of these gentlemen.

Milletta Lodge we pass by, as no one has lived there for some years. Poor Reggie Greville had it for a time. You remember he was called The Limb, and rode as Mr. St. James. He was a capital horseman, and connected with the Jockey Hall stable, for which he won many steeplechases, principally over Punchestown, where he was almost invincible. The poor little fellow was killed at Sandown, dying, as he always wished to, with a silk jacket on.

Curragh View is next reached. It has just been vacated for Rathbride by Mr. Meredith, and is a cosy little place for a small string. Here a trainer of no mean sagacity sojourned for many years-Tom Connolly. This ends our visits and brings us to within a mile or two of Kildare, from which we started many hours ago. 
Thus have we made a circuit of the famous Curragh and visited nearly, if not quite, all its training stables. My three companions agree with me that a more enjoyable drive, or a round of calls more pleasant to make, would indeed be difficult to find, while no more hospitable or agreeable hosts could be found anywhere than the trainers residing on the Curragh of Kildare.

Our lots are cast in pleasanter times than those of the old folk. $\mathrm{My}$ old grandmother used to relate thrilling accounts of dark deeds committed on the Curragh, when the high road from the south of Ireland to Dublin lay across it between the towns of Kildare and Newbridge. The bleak and dreary waste was then the scene of many a robbery committed by Redmond O'Hanlon, Freney, and other notorious highwaymen. When journeying from Monresfort to Dublin, as my grandparents did annually to spend the winter in the metropolis over a hundred years ago, they always broke the journey at Carlow, so that their old carriage might rumble across the Curragh in daylight. Upon one occasion they were more than a fortnight on the road, having been snowed up, and such-like delays were often experienced by travellers in those days.

As I said before, the stablings at the Curragh are, in many instances, precisely as they stood nearly a century ago. Of course, therefore, there are now to be seen the veritable stalls in which our great horses were located during their running period, and where they stood while transmitting to posterity the very best and stoutest blood that is to be found in the Stud-book of to-day.

Reverencing as I do everything that has history attached to it, particularly if it pertains to sport, I visit with infinite pleasure those old places whenever I get the chance. Thinking, perhaps, that my readers might like to hear something of these great racehorse progenitors and where they were located, I shall tell of a few, but I shan't weary them with lengthened pedigrees or performances which have been so often published, and which can, with some trouble, be traced in our old Racing Calendars.

Sir Hercules, by Whalebone, out of Peri, was foaled in the north of Ireland, in 1826, and was, as everyone knows, the sire of Irish Birdcatcher and Faugh-a-ballagh, also of the great steeplechase mare Brunette. I am not sure, but I think he was called after the celebrated wit of his day, Sir Hercules Langrishe of Knocktopher Abbey. At all events, early in the thirties he was the property of Lord Langford, and stood at Summerhill, co. Meath, and I think he stood for a time somewhere at the Curragh.

; Guiccioli, in about 1828, was bought by Mr. Robert J. Hunter, and was stabled for some years at Turf Lodge, but it was at Brownstown, when the property of Mr. George Knox, that she became the dam of Birdcatcher in 1833, of Faugh-a-ballagh in 1841, and of Connaught Ranger in 1342, the latter being by Harkaway and the others by Sir Hercules. Guiccioli, by Bob Booty, out of Flight, was bred in about 1823 by either Mr. Martin Joseph Blake of Galway, or 
by Mr. Joseph Miles Macdonnell of Dhu Castle, co. Mayo. The former was known as "the man for Galway," and the latter as "Joe More" (Anglice, Big Joe). At an ordinary during a race-meeting at Kilkenny, Mr. Hunter asked, would anyone buy for $£ 30$ Guiccioli, then in foal to Roller, and the late Mr. John H. Jones of Mullinabro', near Waterford, would have done so had he not been dissuaded by his friend Sir Richard Cox, who said to him, "Why do you want to buy such a cat of a thing? She'll never breed hunters for you."

Mr. Jones, who was a great friend of mine, told me years ago the narrative. He was all through his long life very fond of breeding horses. The last he bred was Paddy, by Skylark, out of Mavourneen, who won the Manchester November Handicap in 1892. He also bred Bacchus, by Uncas, out of Nelly, a horse which in his racing career carried a great deal of money.

Guiccioli was put to Roller twice, but the produce was not remarkable, except perhaps in George. The best of this mare's progeny undoubtedly were Birdcatcher, Faugh-a-ballagh, and Connaught Ranger.

Roller, by Quiz, was one of the greatest horses of his day, and was also the property of Mr. Hunter, but he was imported from England. He raced from, and stood at, Turf Lodge, where Mr. Hunter resided before he became our racing judge, which he did some forty years ago. Roller won twenty-nine races, mostly of four miles. He got a great many good horses, including Colonel Westenra's Freney.

Birdcatcher was bred in 1833, and, as I have stated, by Mr. Knox at Brownstown House, but Mr. William Disney purchased him afterwards, and it was at Lark Lodge he stood as a stallion. His greatest race was for the Peel Cup at the Curragh October meeting in 1836, which he won by more than a distance, beating Freney and others; nor could he be pulled up till he had run into Newbridge, nearly two miles from the winning post. For racing purposes he never recovered that performance. He was put to the stud in 1838, and covered until 1859, during which long period he was about the most successful sire this kingdom has ever had, his grandson, Stock well, perhaps alone excepted. He covered, off and on, in England and Ireland-about half his time in each country. He died in $186^{\circ}$, and his head was given to the Dublin Royal Veterinary Co lege, while his body lies buried at Lark Lodge.

Bob Booty was another of our great Irish horses. He was bred in 1804 by Mr. Denis Bowes Daly, then and for many years residing at Athgarvan Lodge, the present home of $\mathrm{Mr}$. William Pallin. He was by the imported Chanticleer, but out of Ierne, bred at the Curragh in 1790 by Mr. Robert Hamilton. Practically, therefore, Bob Booty was an Irish horse. He did not start for his first race till he was four years old, but he won that, it being a King's Plate of four miles at the Curragh. Mr. Daly then brought him to England, where he won some trying races, and beat first-rate horses. He was then sent back to the Curragh, where in 1809 he won the Kildare Stakes-a 
great trial race in those days-and also a King's Plate of four mile. heats, beating the famous Hollyhock and several others. He ran till he was six years old, and was then put to the stud hy Mr. Daly at Athgarvan Lodge, where he begat many winners. His name is most famous as being the sire of Guiccioli, Pleiad, and Ildegarda. Pleiad was the dam of Maria, by Sir Hercules, while Ildegarda foaled Colonel Westenra's Thump to Humphry Clinker and Mr. William Quin's Wheel to Camel. These were some of the best horses of their day.

Bagot, foaled towards the close of last century, was not a success on the Turf, but he was so well bred Mr. Hamilton bought him and located him at his lodge near the Stand House, where he got many good winners, including Master Bagot out of Harmony, by Eclipse, who was the best horse in Ireland at the time, and perhaps as gond as any in Fngland. He was sire of Hollyhock and many other wonderful horses. Mr. Hamilton was an astute breeder of the thoroughbred, and from Hamilton Lodge sent many good horses, but I need not particularise them.

Mr. Edwards, who was a Yorkshireman, was also a great Irish henefactor in the early part of this and latter part of last century, but I dou't know exactly where he resided on the Curragh. He imported Tom Tug, previously called Rover, from England in about 1782, and he became the most popular sire of his time in Ireland; from him sprang Commodore, Cornet, and Sweet William. Commodore, bred in 1794 also by Mr. Edwards, was out of that good mare Smallhopes, by Scaramouch. He also bred Irish Escape, by Commodore out of the Highflyer mare, bred by Mr. Tattersall at Highflyer Hall in 1791. To enumerate Irish Escape's victories would fill many puges, I therefore only say he was one of the very best horses that ever ran on the Curragh; but he got nothing of much note except the clinking Milesius and Flight, the dam of Guiccioli.

The Baron, by Birdcatcher, out of Echidna, was bred in 1842 at Jockey Hall by Mr. Watts; and, it is needless to say, the famous Stockwell, foaled in 1849, was got by The Baron out of Pocahontas (1837), and was, bar his grandsire Birdcatcher, the very greatest sire England ever possessed.

Riussborough of more recent years was another good horse. He was by Tearaway out of Cruiskeen. He belonged to Lord Milltown, and was called after his seat in Kildare. When marching across the Curragh with his regiment in the spring of 1850, Captain Peel (alluded to in the history of the Curraghmore Hunt) was told by a shepherd that a good horse was located in Murphy's stable at Pope Lodge. This was Russborough. At the following Curragh June Meeting Captain Peel brought Iord Waterford to Murphy's to try and buy the horse, but he wolld not he sold, and Murphy was exceedingly surprised at their knowing anything about him. Three months afterwards he ran a dead heat with Voltigeur for the Leger. Russborough did nothing at the siud. 
I shall now leave this portion of my subject, for although it has treated of only a very few of our greatest Irish horses, and those of olden time, pedigrees and such particulars are not palatable to some of the present generation, but it is well to let them know what we Irish have done for the English Turf from its earliest history down to this day. I have made allusion only to horses which stood at the Curragh, leaving out scores and scores which stood in the country many of them being quite as famous as some of those I have mentioned. Eclipse, of course, as everyone knows, was an Irish horse, and belonged to Colonel O'Kelly, a forefather of the Kildare family, but I don't know if he was ever located at the Curragh.

Like other institutions, and mortals as well, the British Turf has to thank luck for some of its greatness. It is to pure good fortune that we are indebted for the great Stockwell, for if we had not escaped three distinct disasters, that horse and his strain would never have been heard of. Here they are :-

No. 1. Had Guiccioli been bought from Mr. Hunter by Mr. Jones, she in all probability would never have been put to Sir Hercules, or bred Birdcatcher-ergo, no Stockwell!

No. 2. Birdcatcher was very nearly being lost, for when a yearling he got a severe attack of inflammation of the lungs, and was, at Brownstown, actually turned out to die!

No. 3. Echidna was the property of Mr. Watts of Jockey Hall, but she was no use for racing purposes. Her owner offered her in 1840 to a priest near the Curragh for $£ 20$, but his reverence would give only $£ 10$. This was refused, and as Birdcatcher was standing close by at Brownstown, Watts put the mare to him in 1841, and she foaled The Baron.

Were there ever more miraculous escapes?

It is certain that Harkaway during most of his racing career was trained at Rossmore Lodge, but I can't say if he was located at the Curragh while at the stud. I must, however, before ending this chapter, refer to the horse which was not alone the best ever bred in Ireland, but was perhaps the best that ever carried a saddle. At the same time I shall allude to his owner, who was as extraordinary as the horse.

Thomas Ferguson was an Ulster man, and resided for many years at Barkston Lodge, near Newry, but I don't know whether he wis born there or not. He began life in a linen faciory, but having the love of sport, particularly racing, deeply ingrafied in hin, it was not long before he gave up the calico and took to silk.

Coming south, and being an accomplished horseman, a good sportsman, and genial companion, he soon made for himself a name, and became a general favourite among racing men, so much so that after a time he was elected memher of the Coffe Room. He owned severa! good horses, among them Teetotum, Beagle, Peacemaker, Barkston, and Rust. This was the time when Alan and William Macdonagh were in their prime as gentlemen steeplechase jockeys, but neither the brothers, 
John Dennis, nor anyone else in Ireland could do much better across country than Tom Ferguson.

In process of time he became possessed of an unnamed chestnut mare, by Nabocklish out of Miss Tooley, bred by Lord Cremorne. He put her to Economist, and in 1834 she dropped Harkaway. He was a late foal, but grew into an oversized and ungainly colt. He was not paid much attention to at first, nor was he started for a race until Ssptember, 1836, when, not half fit, he was beaten in the Angleseys at the Curragh.

After this he was beaten three times and won twice, but it was not until June, 1837, he showed his true form, when in the Kirwans he proved himself one of the most extraordinary horses of the day. In that race, carrying 7 st. 13lb., he beat with the greatest ease such cracks as Birdcatcher, Freney, Langford, Blackfoot, Mercury, and six others. From that time forward Harkaway got little rest. He was run at every Curragh meeting for a year after, and was beaten only in the Kirwans of June, 1838, carrying off as he did in 1837 three King's Plates, the Northumberland Handicap, the Wellingtons, the Kirwans (again in October), the Challenge for same and the Royal Whip. In 1838 he won the Rossmore Handicap, the Wellingtons, the Kirwans, and no less than four Queen's Plates. Altogether, from September, 1836, till June, '38, he ran twenty-three races at the Curragh, and won eighteen of them, beating easily, after giving them lumps of weight, some of the best horses ever bred in Ireland.

During the same period we find the great chestnut at many of the English meetings. His first appearance in England was at the Liverpool July meeting of 1838 , in the Tradesmen's Cup, for which he started favourite, although carrying top weight and only recently arrived from Ireland after a two days' voyage in a schooner. He ran splendidly, but was beaten half a length by St. Bennett, to whom he gave 15lb., while amongst the eleven behind him were such celebrities as Melbourne, Cardinal Puff, and Cruiskeen. He pulled up very lame, but his irrational and headstrong owner insisted upon running him next day. He won the first heat easily, but was beaten in the second, and had to be withdrawn.

Ferguson's ability had then to be taxed to the utmost to get his horse fit for the Goodwood Cup, which followed in less than a fortnight. To southern Hampshire from Liverpool the good horse had to be caravanned, and when he arrived, naturally he was anything but fit, or even fresb. Nevertheless be won the race without an effort from a large field of horses, amongst them being Dormouse, D'Egville, and Miss Adrien, to all of whom he conceded great weight.

At Cheltenham, in 1839, he beat another lot, including Caravan and Grey Momus, the latter having previously won for Lord George B ntinck the Two Thousand and the Leger, the Ascot Gold Cup, the Grand Duke Michael and the Drawing Room Stakes, besides other great races. This was a huge triumph for Ferguson, who hated with intensity Lord George, with whom he was continually at variance. 
Harkaway's greatest performance was perhaps that of winning the Goodwood Cup of 1839 (second year in succession). The distance was two miles and three-quarters, and this, carrying 9st. 4lb., he did under five minutes, and beat with the greatest ease eight of the best horses in England, to all of which he gave a lot of weight, except the clinking Epirus of the same age, who carried equal weight, but was beaten a distance.

It would be tedious to particularise auy more performances of this marvellous horse, so I shall sum up in a nutshell his career : He began as a two-year-old at the Curragh in September, 1836, between which and October, 1841, he ran there 29 times, and won 19. In England he ran 15 races, and won eight of them, making 27 wins out of 44 starts. His last race was at the Curragh October meeting of 1841, when for Her Majesty's Plate he was beaten.

The annals of the Turf accord to Harkaway praise equal to any horse, while the press of the day is unanimous in declaring he was the best that ever started; and many men, even up to now, allege that his superior has never since appeared.

He was equally good over all courses, from one to four miles, while big weight made no difference to him, and carrying it he beat the best horses in England and Ireland.

From the records of the Turf we learn with regret that by reason of malpractice of his owner the running of Harkaway was greatly interfered with, and there remains no doubt whatever that he could have won many more races than he did, perhaps every one he started for.

Ferguson, while naturally a very good-hearted, amiable man, was afflicted with a violent, and at times ungovernable, temper, which could not brook opposition, much less what he considered injustice, and when he met with such he would give way to paroxysins of rage unrestrained in violence. This infirmity made him many enemies, and brought him constantly into trouble, for he cared not for class or person. In fact, the more exalted in station the man might be who provoked him, the more terrible was Tom's scathing vituperation.

Towards the end of 1838, after winning the Chesterfield Stakes, he had a terrible row with the Jockey Club, owing to Lord George Bentinck having forestalled him in backing Harkaway, and in characteristically forcible fashion delivered himself of the following announcement: "I've got the Chesterfield Stakes, and I will get more, but, by $\mathrm{G}$-, the public must understand that Harkaway is my horse, to win money for me, and not for any $d-d$ fellow, either a lord or a lord by courtesy and a thief by the curse of God!"

Lord George Bentinck offered a great price for Harkaway, and several others wanted to buy him, but no money would tempt his owner. To one man, who wrote to ask the price and what condition the horse was in, "Choleric Tom" laconically replied, "His price is 6,000 guineas, and I hunt him twice a week"! 
During the Harkaway era Ferguson suffered a great deal from gout which tended to make him all the more violent, and may, perhaps, to some extent account for the outrageous manner he behaved and ran his borse.

Harkaway was at times treated very unjustiy in weights, and this immensely riled his owner, but knowing how great were his horse's powers he felt on nearly all occasions disposed to back him. If, however, he found himself forestalled, he would bet against him, and then either scratch him or have him pulled. This he made no secret of but warned the public both by stentorian voice in the ring, and through the press, that Harkaway's running did not depend upon the horse's condition nearly as much as upon the condition of his owner's book. Nor were these tactics confined to England At the Curragh and other places in Ireland Ferguson ran Harkaway and other horses in a most scardalous manner. On one occasion on Blackrock Strand, not many miles from his own home, when everyone in Newry, then a town of more importance than Belfast, bad backed his horse Barkston, he rode him into the sea, having laid heavily against him !

That Ferguson should have in the end of his career acted as he did is the more to be regretted by reason of his being possessed of many estimable qualities, and having started as a Turfite under such favourahle auspices. It is in the interest of this extraordinary horse that I relate the malpractice of his owner, which, however, is simple history.

From an old cutting I copy a description given of Harkaway when he was at the stud. In colour he was a dark chestnut of beauteous and unc smmon brilliancy, indicative of the highest breeding. He was very highly topped, and had a large lean head, broad forehead, listening ears, full, good-tempered and soft eye, a blazed face and very large nostril, the more remarkable as being bald on the near side. His lips were very thin and firm, his crest was peacocky with a long and powerful neck, which even in training could never be got lean. He had grand shoulders thrown well into the back, exceptionally high wither, great but long back, giant forearm, capital rib, bringing in an altogether splendid forehand to a hindquarters equally so. The quarters were deep, with broad ragged hips, tail set high, from a great dock carried out in a way that implied vigour; remarkably sunken anus, close sheath, powerful gaskins, hocks a trifle "cow-fashioned," which brought them closer together than the hoofs, great flat swordy legs, pasterns rather long, with good sound large feet. His girth measurement was extraordinary, but he always stood a little over his forelegs. Though his tail was set high, he was a trifle goose-rumped; and, standing nearly 16.2, he was not in the least split up. He was longer from his hip to his stifle and from his hip to his hock than any ordinary horse, and measured more from the point of the shoulder to the rump than any horse of the day. The formation of his hocks, as with many other clinkers, gave him wide spreading action in his gallop.

This description coincides entirely with what was told me of Hark- 
away quite recently by a well-known Newmarket trainer who remembers him well. From it can be seen that while possessed of magnificent points his general conformation must have been ungainly, and his appearance would not warrant his wonderful performances.

Ferguson had not many horses of merit after Harkaway went to the stud, and, retiring from the Turf, he died in a few years. Harkaway was then sold to Mr. David Robertson, at whose place, Ladykirk, in Berwickshire, " the great Irish chestnut" died in February, 1859.

Like many other horses whose performances were of the highest order Harkaway was not very successful at the stud. At the same time he got several useful animals in Peep o' Day Boy, Horn of Chase, Ballinafad, Chaseaway, Wild Huntsman, Blucher, Idle Boy, while Tom King, out of Pocahontas, must keep for ever in memory the great Harkaway. His daughters were more useful than the sons, and among them we find the dams of celebrated horses-notably Irish Queen, dam of Sweetsauce ; Golden Horn, of Wild Oats ; Thorn, of Sprig of Shillelagh; Lizzie, of Leprechaun; while from Queen Bee has come the celebrated "Bee family," so identified with the good sportsmen, the Dunnes of Ballymanus.

Since I wrote the foregoing chapter there happened at the Curragh one of the most melancholy events which was ever recorded in its annals. I allude to the untimely death of Mr. William Beasley, to which I make further reference in my chapter on Punchestown.

At the time of his brother's death Mr. Tommy Beasley was going to be married. The wedding had, of course, to be postponed for some months, but it has since been celebrated. To illustrate how universally popular is that gentleman, I may mention that over five hundred of his friends joined in the purchase of a testimonial in the shape of plate and jewellery, which was presented to him and Mrs. Beasley. The subscription was fixed at a sovereign, and there. fore the sum reached only a little over $£ 500$, otherwise it would have come up to a very large amount. 


\section{CHAPTER XIII.}

\section{DRIVING.}

A Horseman-A Coachman-An Irish Turn-out-Funerals-An Irish Serrant's Hat-Whip -Boots and Breeches-Dubliners v, Yorkshiremen-"The Tantivy"-English TrapsIrish Jarreys-Irish Drivers-London v. Dublin-Fun in the Streets - Wilson's Posting Establishment-Ten miles an Hour-Not Driving-Larry Doolan-Irish Wit-Fairy House and Baldoyle $v$. Epsom and Sandown-Exceptions-Dublin Horse ShowDundalk Traps-English Hackney Traps-Taste v. Money-A Money-macle Turn-out -Taste-To Fit-ToBalance-A Description-Tuition-The Old Waterford TrapsWilson's of Liverpool-An Object Lessnn-Driving at Dublin Horse Show-Wilson's Turns-out-Hodgson's Driving-Great Improvement-Table of Driving Prizes-Pull and Put Ourselves Together-Good Irish Drivers-Sailing a Boat $v$. Driving HorsesJohn Bates-Dungarvan Coach Horses-A Runaway-Diving-Nerve and PluckA Comparison-Author's Experience of a Queer Lot-Selby's Drive-Two Good Reproductions.

UNE glance at a man getting into his saddle, sitting down in it, and taking hold of his horse's mouth will generally show whether he is a horseman or not. Half a glance, however, is sufficient to show, by the way he gets into a trap, settles himself, and takes up his reins and whip, whether a man is a coachman or not.

All the world knowis that we Irish can breed a horse, train him, and ride him as well as any other men under the sun; in fact, we are born horsemen. To Irish-bred horses England owes the best strains in the Stud-book, and Irish-trained racers, everyone knows, have beaten the best that England could pull out against them over nearly every course, long or short, flat or flagged. Nor can England produce any man who can beat our good men to a pack of hounds, even over his own country; no more can she produce better finished gentlemen jockeys than we can.

It is altogether another part of speech when we come to a trap and driving it. In turning it out properly, and driving it in workmanlike style, we are not in it with the Saxon.

If we have a well-matched pair of horses-and seldom we have-either the harness or the trap they are tackled to is unsuitable; or if by chance there happens to be a fairly harmonious combination, all will be spoiled by the coachman's want of skill, bad seat on his box, or ill-fitting livery.

Any man who understands the subject may easily satisfy himself of the truth of this by standing for a short time in any fashionable street of Dublin or in our provincial towns. A really perfectly put together turn-out, properly driven by a smart-looking and smartly got-up coachman, will not be seen in a week in Ireland. Something is sure to be wrong, 
and anyone who knows how the thing should be done must agree with me.

Even our funerals we can't do properly. The stately Belgian, whose slow high-kneed action, arched crest, appropriate colour, with long flowing mane and tail, so eminently adapt him for the mournful duty, is conspicuous by his absence as the motive power of our hearses and mourning carriages. In Dublin as well as other towns in Ireland the grotesque appearance of the hearse, horses, and driver is at times provocative of feelings other than those suitable to a funeral. Not so in England, where that sort of business is carritd out on a system alike sombre, sedate, and lachrymose. I venture to say that the body of a humble artisan in Liverpool is, at the cost of some $£ 7$ or $£ 8$ to his representatives, sent to the grave in style more appropriately smart than perhaps would be one of the members of an Irish Town Council at five times the money.

What bothers an Irish servant more almost than anything else is his hat. Not five in fifty can put it on right, while four out of the five will have it wrong in five minutes after. His whip, too, is a source of continued inconvenience to the ordinary Hibernian. Jehu ; he seldom, if ever, holds or uses it in orthodox style.

And, oh! ye descendants of Barclay and Tautz, take pattern from the boots and breeches of an average Irish coachman. No matter how well off his master may be, see how the poor fellow is rigged out-his clothes suggest, indeed, that they were cut by a carpenter and sewn by a sailmaker. Also take a look at the polish and pipeclay. Hawkes of Piccadilly might at the same time see the effect of utilising a livery box or body coat originally built for a thirteen stone man on his successor in service weighing ten or eleven stone, and two or three inches shorter in stature.

As a matter of fact it would be well if some of our Irish gentry, particularly the Dubliners, were to follow the example of their English brethren-in Yorkshire, for instance-in the way they turn out, not only their horses and traps, but their men, for of course it is the masters alone who are to blame. Fancy a servant with a big bushy beard, colour, say, carrotty, driving a carriage in Hyde Park!

Mr. Thompson's coach, "The Tantivy," which he trots from the Shelbourne to Bray, etc., and back daily in summer, is as well put together and workmanlike a turn-out as any which leaves the White Horse Cellars. The horses are well matched, and with good action step together; they are harnessed "brilliant in brass and in leather," and tackled to as good a cut of a coach as any bowling up Piccadilly. Mr. Thompson, too, is up to the work of which he is so passionately fond, for he is a thoroughly good coachman; but-and this plucks "The Tantivy" of first honours-he scarcely possesses that easy grace on the box which "Nimrod" describes, and he holds his hands too high.

Look at the thousands of private traps of all sorts we see in London and in England generally; how few there are in which a fault can be 
found as regards smartness. Nearly all are tooled by men who are innate drivers and turned out as smartly as Melton men at Kirby Gate on the first Monday in November.

Irish drivers, be they jarveys, servants, or gentlemen, as a rule drive entirely for themselves; they do not care a jot for their neighbours and never think of giving them a chance. Our streets, where with comparatively little traffic blocks and collisions constantly occur, give ample proof of this. In England a man drives quite as much for his neighbour as for himself, and each knows exactly where the other will go; this, with ten times the crowd and traffic met with in Ireland, enables them to steer their traps clear through, with at times little more than an inch to spare between the wheels. Thus it is that driving in London with all its crowd is easy and safe, while in Dublin, notwithstanding its wider streets and little traffic, it is difficult and dangerous, for one man seldom knows where the other will go to.

Our Sackville-street is, I believe, the finest and widest street of its length in Europe. I am sorry to say it has not nearly the thoroughfare its dimensions would accommodate. There, at times, you see what bad driving is, particularly at the Carlisle Bridge end, where the cross-traffic of the quays intersects that of the bridge and street. You also see some fun occasionally in Dame and Grafton streets, but everything goes on jovially enough. No one gives quarter, and no one expects it. Carts cross carriages, while cars go for cabs, running at or into one another just as opportunity affords. Notwithstanding the confusion, you hear none of the slanging, barging, or bad language from Dublin drivers you hear from Londiners when a block occurs. No, with us that sort of thing is taken as a matter of course, and in the best of humour.

At times we find on the stand a really excellent "outside," smart in appearance and well driven by a man properly got up, but it is the exception and you see scarcely any in whose get-up .or method faults cannot be found; while the great majority, as regards horse, harness, car, and man, are badly turned out, and the driving is infamous.

Dear old Dublin has been described as the "car-drivingest city in the world," and so it is. To see the jarveys rattling along Essex and other narrow quays of our city at ten miles an hour every evening from the Cork Express at King's Bridge is a caution! Still more is it on a Curragh evening, and tenfold more when returning rom Punchestown. But that is not driving.

Our Irish "car-driver" is one of the last of our old institutions, and far be it from me to say or do anything to injure him. I write as I do with the earnest wish to induce him to smarten himself and his turn-out. $\mathrm{He}$ is civil and honest to a degree, and always contented with a just fare, the assessment of which he generally leaves "to your own honour." No other man in his humble sphere of life possesses such a fund of interesting anecdote, nor is Irish wit brought to the front more prominently than by Larry Doolan.

Notwithstanding all I have said, we have cars in Dublin which can 
bowl you along to Fairy House or Baldoyle, ay, even to Punchestown, more merrily than any hansom will to Sandown or Epsom ; while the wit and jocularity of the driver are unknown quantities in the Saxon.

In fact the genus London cab and 'bus driver is in my opinion about the least amusing person in the world. All the information he seems capable of imparting is on the state of the weather, which, from ocular demonstration, you know all about yourself. At the same time these men are all first-rate whips.

The jarvey trials at our Dublin Horse Show must convince all that the trappers are first-class and are well driven, while no traps can be turned out mıore smartly. Let us hope these trials will stimulate the jarveys as a class to general improvement.

The north of Ireland hack cars are much better appointed and horsed than those of the south, and the drivers know their business much better. Dundalk, I think, "takes the cake" in this respect from all Ireland. In no place have I ever seen so many well turned-out traps for hire as in that rising and prosperous little town.

Old Ireland is not the only place where we find badly turned-out hackney traps; every town in England provides them, but as a rule they are all well driven.

A trap, no matter of what sort, can be turned out smartly at very little expense if a man knows how to go about it, but unless he does and has taste, money will be of very little assistance to him.

It is easy to recognise what is turned out by money alone. The horses may be well bred, but they are nearly always long in the back and long in the leg, their action in front is uneven, and very bad behind; the harness is bound to be brand new, with flowing foreheadband rosettes. Wherever a spare inch is to be found the owner's crest is stuck on, just as if the various pieces were going to be run away with if they were not so stamped. The carriage will be painted in lively colour and picked out in that still more so, while it, too, will be adorned conspicuously with the owner's heraldic bearings. All that costs a lot of money, and, as a rule, the turn-out is not what a gentleman's should be.

Now a man with taste and knowing what he is about can put together in the acme of style, a trap for himself or a carriage for his wife, at half the money which it has cost the other to make a mess of it. The taste for such, however, must be born in a man; it may be improved by experience, but assuredly it cannot be bought.

A trap, whether it be a cab or a car, a cart or a coach, a barouche or a brougham, to look well must have everything to correspond-to fit-to balance. One item out of place spoils the whole. A little man driving a coach spoils the effect, be it in other respects the smartest at a meet of the Four-in-Hand, while a big heavy man upsets the cut of a polocart, however good its own equipoise.

No matter how well shaped they may be, if the horses do not match each other in action, pace, and pull, and don't lift their hind legs, they 
cannot set off to advantage the trap that is behind them. The harsess has to be regulated in style to match the horses as well as the vehicle. A rakish tandem set cannot be adapted to a brougham, nor can a barouche follow a set of $\tan$.

The trap, no matter of what description, must be huilt on lines graceful and evenly proportioned, and unless it be tackled to the pony, the horse, pair, or team it is suitable for, the effect of the whole will be spoiled. Then comes the last, but far from being the least, requisitethe coachman. That functionary must sit behind his horses in position such as will make it appear he can drive, and when he sets his horses going he must prove it, and unless he does the whole turn-out is bereft of interest to the man of taste.

The coachman, be he gentleman, professional, or servant, should be dressed in accord ; one should not ape the other.

As with the points of a horse or a hound so it is with a trap. No one can put it together properly on paper. Neither can driving be taught with a pen. The only way a man can learn to drive is to get instructions, with a pair of horses before him, from a man who can. A practical example or a good pattern is what is required to teach him how to put together a trap. I shall therefore refer to a few traps which I bear in mind as having been, what I call, properly turnedout and driven. They are a!l well remenubered by many others besides me, for they came from in or near Waterford, where I spent most of my life.

The Misses Barron, of Newtown, had a brougham very perfectly turned-out with a pair of bay horses, which went a good pace. The brougham and open carriage of Mrs. Roberts, of Weston, with her stately grey horse, moved slowly, but in orthodox style. Thirty years ago Mr. William Fitzgerald had a very smart jaunting car, under which be drove a big roan horse that ten miles an hour was nothing to. He was one of the very finest and best carriage horses I ever saw, and a team of such would be cheap at a thousand guineas.

Mr. John Snow had the smartest of "outsides." Horse, harness, and car, with the owner driving, was indeed a sporting turn-out.

Sir Robert Paul did all things well, but nothing better than in the way he had his carriages sent from Ballyglan. He had a pair of bay thoroughbred mares for many years. Then he had two big chestnuts for a long time. Each pair was a perfect match, but both were of a totally different stamp. They could and did go the pace, and that with scarcely changing a leg; so perfect and even was their action. Mr. Dawson Milward's double dog-cart was workmanlike and had a real sporting ring about it. His well-matched greys rattled along the quay of Waterford without a turned hair, although they had come fifteen miles from Tullagher under an hour and a half. Mr. Ambrose Congreve, unlike the other gentlemen I have mentioned, seldom drove his own trap; but he knew as well as they how things should be done, with the result that the Mount Congreve carriages were sent into Waterford in a style that would be admired in Hyde Park. 
Perfect as was the turn-out of each of these equipages, and well driven as they invariably were, with the servants smart-looking and properly dressed, there was no item in them which cost much money.

- They include nearly all the classes which are most in use in Ireland. and if men would take pattern from them there would be no cause to find fault with the traps or the driving we see in Ireland.

These examples can, however, be of use only to those who may remember them. I shail therefore give one of more general utility.

I allude to the equipages let for hire by Mr. John Wilson, of Sefton Mews, Liverpool. His establishment for construction and convenience $I$ am sure cannot be excelled, and I readily accept as a fact what $I$ hear, that its equal is not in England. Here are let out for hire every class of trap, from the polo-cart to the coach, numbering some eighty vehicles. In the stalls are fifty horses, with thirty stablemen and drivers. Each of the latter has supplied him for his own use top coat, hat, and gloves, while for special occasions they don livery. Be it to take a man to the railway station with a lot of luggage, to go to the Grand National with a large party, or convey a lady through a round of visits, a smarter turn-out or one better driven cannot be found than in the yard I am alluding to. Except the few cabs, none of the traps have an appearance of being hired. The men are tailored better by far than most of the private coachmen in Dublin, while the equipages, their horses, and harness betoken the carriage of a gentleman much more than many of those coming from the stables of Merrion and Fitzwilliam squares.

My advice to those of my countrymen who sport a conveyance, other than a cycle, is to come and see how Wilson turns out a trap, and take pattern therefrom, and if they make their visit on a Sunday afternoon, when the horses are in their stalls and everything burnished and bright, they will see how a driving-horse stable is kept in the acme of smartness.

The only department that can be found the least fault with is the harness room, which is altogether too small. Wilson has over one hundred sets of harness, fit to put on any gentleman's horse, with half as many more not quite so stylish. If he had a room where these could be displayed singly along the walls, it would be a sight of its sort nowhere else to be seen.

Then if a man wants to be suited with a trapper or two, let him visit his sale establishment in Hope-street, and there in the season he can have his pick from some forty horses, many of them Irish bred, but all with English manners.

The competitions at the Dublin Horse Show have for the past five or six years proved to demonstration how we Irish can be made to improve in our driving. I don't remember much about them previous to 1886 , but in that year there was not an Irish entry of much merit. Surgeon Croly's pair, Timekeeper and Strongbow, was the only Irish tandem worthy of exhibition; but though 
each of his horses was good, they were not matches in any way. From England was sent several very perfect exhibits by Mr. John Wilson, whose stables I have just alluded to. They were driven by his head man, Hodgson. I don't think so perfect a tandem was ever before seen in Ireland as his, and the style in which it was handled was equally unknown to us. Hodgson's figure-driving in the jumpingground fairly astonished everybody. Trap, horses, and man appeared part and parcel of one machinery working in most perfect harmony. The horses were sold for $750 \mathrm{gs}$. to go to America.

Of course nearly all the prizes that year went to England.

There was a great improvement all round in our driving exhibits in 1887 , but we were again beaten.

In 1888 we made most meritorious display, and were it not for the extraordinary animals which were sent from England, the Irish would have been decorated; but Wilson that year regularly swept the board. His three horses, Eclipse, Water Lily, and Surprise, sold for 1,050gs., consequent upon their performance at Ball's Bridge.

To make a long story short, we have made such improvement we can now hold our own and beat the English in all classes. This speaks volumes, for nothing is sent by them but the best of their best. We seem still to do badly in siugle-horse driving, but we do very well with pairs, while our tandems in 1891 and 1892 would take prizes in any show. In 1891 we won the two first prizes and one second.

Notwithstanding this improvement we are still a long way behind, as is seen by the following table which I compiled from the catalogues of the Dublin Horse Show from 1888 to 1892 inclusive :-

Total Driving Prizes for Five Years endisg 1892.

\begin{tabular}{|c|c|c|c|c|c|c|c|c|c|c|c|c|}
\hline \multirow{4}{*}{$\begin{array}{l}\text { English } . . . \ldots \ldots \ldots \ldots \\
\text { Irish ................. }\end{array}$} & \multicolumn{3}{|c|}{$\begin{array}{l}\text { Single } \\
\text { Harness. }\end{array}$} & \multicolumn{3}{|c|}{$\begin{array}{l}\text { Double } \\
\text { Harness. }\end{array}$} & \multicolumn{3}{|c|}{ Tandem. } & \multicolumn{3}{|c|}{ Total. } \\
\hline & Ist. & 2 nd. & $3 \mathrm{rd}$. & 1st. & 2 nur. & $3 \mathrm{rd}$. & Ist. & 2 nd. & วิrd. & lst. & 2 nd. & $3 \mathrm{rd}$. \\
\hline & 26 & 22 & 12 & 12 & 6 & 0 & 6 & 5 & 0 & 44 & 33 & 12 \\
\hline & 3 & 7 & 10 & 7 & 11 & 0 & 3 & 4 & 0 & 13 & 22 & 10 \\
\hline
\end{tabular}

Credit to where credit is due. Were it not for these object lessons which we have had from the English since 1886, the chances are that our turns-out and our driving at Ball's Bridge-particularly in the tandem class-would be as bad now as ever they were.

It is therefore manifest that nothing exists to prevent us Irishmen turning out our traps smartly and driving them properly. We have just as good taste as Englishmen, we can get as good harness and vehicles in Ireland as can be got in England, while the world knows we are not wanting in the horse line. Let us therefore pull ourselves 
together, and put ourselves together properly turned-out vehicles, and have them driven properly both by ourselves and by our servants, for although we have always been horsemen, we certainly are still a long way from being coachmen.

I don't want to offend any of my countrymen by drawing comparisons, but I would say that in my opinion the Irishmen to take pattern from in driving are such as Messrs. James Talbot Power and his brother Thomas, John Thompson, James O'Reilly, Nathaniel Morton, and John Hickey. Undoubtedly we have many othèr good whips, but these are the men who caught my eje in the arena at Ball's Bridge and elsewhere.

I shall now cease making comparisons and finding fault, and by way of atonement for what I have said, shall give a tip to those who at times have to make long journeys by road, and it is particularly useful to my old friends the jarveys, who, with our gentlemen and servant coachmen, I have been abusing so hard.

Put a quart or less of oaten meal into a tin can, and pour in as much boiling water as the meal will soak up, covering over with a tightfitting lid. Place the tin in a convenient corner of the trap, wrapped in a rug or cloth. When the time comes, pull up at a house (or side of any stream if a bucket be carried) and make your horses a nice drink of meal and water. After the soaking the meal will come out in a thick gruel, and, being still hot, will take the chill off the water and afford a much more nourishing drink than freshly-mixed meal ; besides, the latter is very liable to give gripes. This is a straight tip, and useful alike to drivers of public and private traps.

Another good plan is: If a horse or horses run away and become uncontrollable, the best thing to be done is for someone to get behind the driver and encircle his body across the chest with his arms, and in this position pull with all his might; adding to the exertion all his weight by taking somewhere a good purchase with his feet, but he must take care not to interfere with the reins, and the heavier he is the better.

As with sailing a boat so it is with driving horses. As long as everything goes smoothly, to handle properly the one and the other is comparatively an easy job. It is not, however, until a man is caught in a hobble with either the tiller or tapes and has to get himself out of it that he can show whether or not he has real skill and nerve. To drive properly a well trained pair or team of horses along a rozd, around a show-yard, or even in crowded streets, no doubt requires a certain amount of skill, but I don't think it requires a great deal of nerve. Give me, however, the fellow like John Bates, who drove the Waterford and Dungarvan coach some twenty-five to thirty years ago. He seldom had what could be called a handy team, while some of the changes along his daily route were as unruly as were ever given into the hands of man to drive a coach with. Often I saw Bates during that dreary thirty miles getting together these pull-devil-pull- 
baker brutes, and sending them along in perfect style, making each do his own share of the work. Often, too, have I seen him in an awkward fix ; but that was the time to see the man. Cool as if he was driving a pony that had shied at an old woman, would he handle these jibbers and bolters, and get them into their collars again. Yet he was not what is termed a fancy or fashionable coachman.

Never will I forget the run away we had down Cushgam Hill with a heavily top-laden coach. When within fifty yards of the bridge at the bottom, where exists a sharpish turn to the left, the coach was rolling to an extent that, if not steadied, no power on earth could prevent an upset at the turn. Yet, this man, by cool and skilful manipulation of his horses, although apparently not under control, brought his coach to a balance and rounded the turn in safety.

That is what I call driving, and that is what I call nerve and pluck. Perhaps some of the mighty fine fellows we see tooling a coach to admiration, and cutting figures with a tandem in a show-yard, if caught in a dilemma of the sort, might feel inclined to jump clean off the box, or if they stuck to it would lose their head and capsize the coach.

In those days I ofttimes had occasion to visit Dungarvan, and I always took the box-seat. Bates, when he had a fairly handy team, gave them to me for the stage, and from him I learned lessons in driving four horses which, I am sorry to say, I was never afterwards in a position to put to much practice.

Starting from Dungarvan one morning at daylight, with no one on the coach but ourselves, he gave me the reins, saying, "Now, sir, let me see how you can handle one of the queer lots." The near-wheeler was a well-known devil, but her vagaries were minimised by cunninglydevised straps and gags, so she started right enough. Not so the others. Directly their heads were let go the off-wheeler tried to stand on his head, while one leader danced on his hind legs, the other trying to bolt for the stables. Then, as if suddenly possessed of the information that a duffer was to drive them, and not wishing to take undue advantage, away the four plunged into a gallop. Round the corner of the square, and the still more dangerous turn at the bridge, these incarnate devils tore, I steering them as well as I could. Down with their heads, and away they went for over two miles before I could get a pull at them. How old Bates enjoyed the joke, and the funk that I was in, but anon he cheered me with, "Don't be afeard, sir; only keep them in the middle of the road." The latter part of his advice I had not much trouble in following, for the road was straight and level, but I confess to having had some difficulty with the first part!

The annals of British coaching do not, I think, record a greater feat with four horses than was that performed by the late James Selby, I shall therefore give a few particulars of it.

At the Ascot meeting of 1888 , a bet of $£ 1,000$ to $£ 500$ was booked 
against Selby driving from the White Horse Cellars in Piccadilly to the Old Ship in Brighton and back in eight hours; distance being 104 miles. The event came off on the 18th July following. With five gentlemen on the coach and the guard, Selby started with the "Old Times " from Hatchett's at 10 a.m. to the minute, and reached the Old Ship at 1.56 .10 p.m. Here he turned round and started on the return journey without further delay. He arrived at the White Horse Cellars at 5.50, welcomed with thundering cheers by a large concourse of people. Thus he won the bet, with ten minutes to spare, and did the 104 miles in just $7 \mathrm{~h}$. 50min. There were thirteen changes, which together occupied $14 \mathrm{~min}$. 25sec., the plate being greased upon two of the occasions. The coach was stopped specially to grease it a third time, and again to allow the party to get down, which they did only once. Each of the special pull-ups took a minute, therefore $16 \mathrm{~min}$. 25sec. was all that was lost in the fifteen stoppages. At Streatham and Patcham on the down journey, the smart lads in changing his horses detained Selby only forty-seven seconds. Deducting the time taken for stoppages, an average of just fourteen miles an hour was kept up; i.e., $4 \mathrm{~min}$. 4sec. to the mile. Between Earlswood and Horley, on the down journey, the pace was twenty miles an hour!

Selby for years had driven the "Old Times" between London and Brighton, and was not alone well known along the road, but, being the cheeriest and most obliging of men, was intensely popular with all classes. The day fixed for the great drive was, of course, well known, and the hour at which he would pass each place was accurately calculated so with that love for sport and fair play inherent to Englishmen, all parts of the road were, at the time, kept clear for him on both his out and homeward journey. And this applied to the London streets through which he passed.

Just as the coach at full gallop was approaching the railway crossing at Crawley, a train appeared. To signal one or other of the drivers to stop was imperative on the part of the gate-keeper, but, like a sportsman, he selected him of the locomotive, and hoisting his danger flag brought the train to a stand, which enabled Selby, without a check, to flash by in front.

As an example of the keenness with which the London police perform their duty, Selby was served with a summons for "furious driving" a day or two after the event; but the Beak before whom he was arraigned, like a sensible man, let him off with a caution !

Needless to say, the hero was fêted in fashion usual with Englishmen upon all occasions where nerve and skill in anything pertaining to sport are exhibited to a degree such as was done in this great drive. But the poor fellow did not long live to enjoy his reputation, for in the following winter he caught cold and died of inflammation of the lungs.

Since I wrote the foregoing I have come across an article upon driving which appeared some time ago in the Live Stock Journal over the 
initials "W. A. C. B." I consider it so excellent I reproduce it as follows :-

A well-matched, well-put-together, and let us certainly add a well-driven pair of horses, is one of those things which, if not exactly a joy for ever, is at least pleasing to the eye until the spectator sees something he likes better. A stepping harness horse is a beautiful thing to look at, but is an expensive luxury. It is not merely costly to buy, but it is also costly to keep up. Two horses at least must be kept to perform the work of one, for they must never experience the sensation of fatigue.

A very common phrase of stable Anglo-Saxon is that a man is driving two horses, but not a pair. Colour is a mere matter of taste; some like them to match ; others prefer a contrast-a chestnut and a roan, a bay and a grey, or a black and some light colour. But in action and shape they must match. Nothing looks worse than to see one horse stepping up to his nose while his companion strides along like a match trotter. A squarely built Norfolk horse alongside a lighter blood-like companion is a very bad combination, while a short-necked horse and a long-necked one not only look ugly together but are uncomfortable to drive into the bargain. And how much of one's comfort on the box depends upon proper harnessing! It is timehonoured advice that the coachman should, before mounting to his seat, look round to see that the harness is all right, and the practice is to be recommended, as if you start from hotel yards on a busy day you may find that in the rush and hurry one or both of the coupling reins have been left unfastened, a throat lash is perhaps hanging down, or possibly the pole pieces or pole chains have been overlooked. In the matter of putting things right, the beginner must leave himself in the hands of some experienced person. It is positively annoying to see how some horses in the Park are bitted together. Heads fastened up by a tight gag bearing rein; the driving rein is on the bottom bar; pole pieees are swinging about so loosely as to let the horses come dangerously near the carriage when they have to hold back, or else are pulled so tight as to deprive the wretched animals of all liberty. Coupling reins are often wrong, and then, of course, the task of driving becomes needlessly difficult.

Too much attention cannot be paid to the bitting of horses; and now that the Queen has directed bearing reins to be dispensed with in her own stables, that piece of harness may be regarded as virtually out of fashion; and when it is given up increased attention will have to be paid to bitting and coupling, because when a horse's movements are no longer crippled by a too tight bearing rein it will be of paramount importance that the bit be of that pattern in which the horse will go most kindly ; that the curb chain be not tight enough to make the horse fight, nor so loose as to be useless.

In the streets of London, as well as on country roads, one sees a vast amount of bad driving; and, to begin at the beginning, great mistakes are constantly made in the manner in which horses are started. At the funeral of the late Mr. Braidwood, the head of the London Fire Brigade, who was killed at the disastrous Tooley-street fire, the horses which drew the engine which served as a hearse were with the greatest difficulty induced to travel at a slow pace. In the course of their work they were so accustomed to starting almost before the men were on the engine, and to begin at once at their best pace, that they could not understand being made 
to walk. A good many owners and their coachmen spoil dozens of horses every year through hurrying at starting. The coachman may be late in dressing; he jumps to his seat, starts his horse at once, and hurries round to the front door; and when his master drives, he, if of an impatient turn of mind, frequently jumps up and starts at score ; and it only requires a week or two of this sort of thing to turn quiet horses into impetuous starters as soon as they hear the coachman mounting, or feel him gathering up his reins.

\section{Elsewhere the same writer says :-}

When the Badminton book on Driving was given to the world, no little criticism was expended on the Duke of Beaufort's protest against twohanded driving. A good many people appear to have understood the Duke's directions as though he intended to say that the right hand should never touch the reins, and that the coachman of one horse or of four should drive down Piccadilly with the reins in the left hand alone. It is needless to say that the Duke of Beaufort never intended to say anything so foolish. What he protested against was the practice of drawing the right rein out of the left hand and then keeping the hands several inches apart, and no fault is more common than this. The coachman has then, to all intents and purposes, a rein in each hand, or, as the Irishman said, "a rein in each hand and the whip in the other." In this position the right hand cannot be removed without allowing the right rein to become slack, consequently the horses at once shoot round to the left, should the coachman take his hand off the reins to use his whip. To fiddle away at a horse while the whip hand is at the same time holding a rein is uncoachmanlike in the extreme. The right hand may come to the assistance of the left as often as is required, but in no circumstance should the reins ever be of unequal length in the left. hand, and the young coachman cannot be too particular on this point. To use the whip well, said an old coachman, use it as little as possible, and no better advice can be given. To see a horse hit unnecessarily is annoying to a good coachman, and the London coachman's theory of "hit and hold 'em" is sometimes carried to a foolish extent. A lazy horse must, of course, be kept up to his work, for one that will not go into his bridle can no more be guided with safety through the traffic than a boat can be steered that has no way on her. The whip, besides being a weapon for punishment, when punishment is needed, is also a valuable aid. Horses that are constantly driven along the same road get very cunning at the corners, which they will sometimes cut very fine unless the coachman be on his guard. On such occasions a touch down the shoulder of the inside horse will keep him from coming round too quickly; or if his companion does not turn quickly enough, a touch of the whip on his outside shoulder will help to send him in the required direction. The novice at driving may also be warned against indulging in that pernicious habit of "chirruping" to his horses. If one is freer than the other, it is the freer one only that takes any notice of the noise, and this is exactly what the coachman does not want-he means to encourage the other.

Position in driving, though, of course, not everything, is yet a good deal. By adopting a wrong position the coachman loses power. The feet should be kept to the front, but in driving a brake or a coach the toes must not project beyond the footboard. In the old coaching days there was a "fine 
agin it," as Mr. Verdant Green's scout told me when he walked on the grass in the quad of Brazenface. A bent body is not graceful, nor should the hand be thrust out in front of the body, in which position the arm will soon tire. Self-taught drivers are very common, but no one who desires to drive well ought to trust to practice alone. There is a right and a wrong way of doing most things, and the self-taught man usually selects the wrong one. There are in London several good coachmen who give lessons, and from one of them more will be learned in a week than can be picked up in a year of unaided practice.

The writer of the foregoing omitted to refer to the hind action of a harness horse, I will therefore supplement his excellent article by stating that a horse cannot either look well or go well in harness unless he has hind action equally good with the fore. Good hind action is looked for in hacks and hunters, but doubly is it desirable in the harness horse. Yet, how seldom do we see it! We continually see good and sometimes perfect shoulder and knee action with bad hock and hip action. 


\section{CHAPTER NIV. \\ FISHING.}

Anthor not an Izaak Walton-Bosh about Fishing and Fisl-Flies-Rods-And TackleAuthor's Ideas-Light Lines-Heavy Lines-Striking a Fish-Scores of Flies-Four Kinds-Their Names-Author's Peculiarities-Skull-dragging-Westmeath-Galway -The Shannon-A Fishing Trip to Killarney-How to Go-Good Sport-An Adventure on Lord Landnothing's Water-Diplomacy-Day's Basket-Boys will be Boys-Sport and Devilment-The Steep Places-The Runs-Fair Play-Fine PlayMountain Scenery-Grouse-Grandeur-Land and Water-The Author a Poacher-Criticism-Explanation-Escutcheon of a Sportsman-Au Invitation to Mr. "Rose Price"-and Others-Loch Leven-What Fishing Costs.

I NEVER was much of a fisherman, though I took a turn at the "gentle art " whenever I could. I am, however, of opinion that, like many other things in the world, there is a lot of bosh talked and written upon both fish and fishing.

Fish are odd creatures, and very little is really known about them.

Of course we all know one fly will kill one day, and another the day after, and, perhaps, no other pattern will be looked at on these particular days; moreover, we know the nearer the artificial is in colour and shape to the natural fly "on the take," the better chance there is of its killing. Again, we have all seen a good fisherman, with the most approved rod, tackle, and flies, unable to rise a fish, while a boy with a rod like a flail and flies tied in a wisp is filling his basket.

I am no authority on this branch of sport, but my notion is that the colour is what attracts the fish, and not the fly itself or its tying, for with its keen sight a fish must see the hook, and so cannot mistake the artificial for the natural. Everyone knows how readily the line startles a fish, and that the finer it is the better chance we have of inducing him to take the fly. But, then, is this correct? The line for salmon is necessarily strong and coarse, and therefore can be seen by that fish, who has just as quick an eye as the nimble trout. Who knows but when fish are on the feed they are so greedy they will go at anything that appears to suit their taste, regardless of the caution that under other circumstances would prevent their doing so ?

What is called "striking" I also have my doubts about, and my reasoning is this: If a fish wants to take a fly he will naturally shut his mouth on it, but directly he finds what he has caught he will try to spit it out; while doing either one or other he will generally hook himself, provided the fisherman has his line straight. If, therefore, a man "strikes" when he sees the rise I think he is just as likely to jerk the fly away from the fish as to hook him.

"Missing" fish is nearly always the fault of the man through having 
a slack line. The angler who throws straight hits his fish just as often as the straight shooter hits his birds.

I never could throw a long line, so I contented myself with a short one, and when I could not cover a pool with a line thrown straight I left it alone rather than try to do so with a line bellied, and that is, I think, what all bad fishermen should do.

I am also sceptical about the necessity of having some scores of different pattern flies in one's book, for the simple reason that about the very best fisherman I ever met used only four different sorts during the whole season, and he seldom went out without landing a lot. $\mathrm{He}$ always used the finest of casting lines, and had the flies tied on to even finer gut. Under his advice I always used the same patterns, and with them I killed trout in most months of the season, whether I tried brooks, rivers, or lakes, and I did so in England, Scotland, and Ireland. The flies were Steward's pattern of hare's ear, dun, black, and grey spiders. I had them very small, medium-sized, and large for lake and evening fishing, and I always used the finest of tackle. Whenever there was the least deviation from the pattern, there was a corresponding diminution in the quantity of fish I caught. Men holding opinions that fish in certain rivers will take only certain flies, will laugh to scorn my notion of trout having universal taste. They may do so and welcome.

I never could endure fishing out of a boat either on sea or lake, neither coula I see much fun in bait-fishing even for trout, while that for roach, perch, or eels I considered fit only for boys. I also looked upon the salmon-fishing off Galway Quay as a very one-horse affair, and fit only for Cockneys. Salmon-fishing, however, I know absolutely nothing about.

I often wished I was an expert fly-fisherman, for next to hunting and shooting there was no sport I liked better than playing a lively pound trout in his native mountain stream with a light rod and fine tackle, and where skill, time, and patience were required to land the beauty. You will see fellows take enjoyment in skull-dragging them out without a minute's play, using great heavy rods and tackle, but I never saw any fun in that sort of fishing.

Long ago I went for some years with my very dear, but now, alas! dead, friend, George Baker, for short trips to the Westmeath Lakes, Galway, and the Shannon. We generally had good sport, but I did not care much for dapping out of a boat on Belvidere, bobbing with a shrimp off Galway Quay, or cross-lining on Lough Derg. What I liked was wild mountain river-fishing, where hard exercise and charming scenery would be combined with sport; but the latter should be good, for I never had much patience in anything, and whipping away for hours without getting a rise I considered horribly monotonous.

I had good fishing often, but only once to perfection, and that was many years ago when I was a boy. Accompanied by a companion, we hired a car in Cork to take us on a fishing excursion to Killarney, through Googawnbarragh, Inchageela, Glengariff, and Kenmare. 
By way of parenthesis, the best way for seeing that charming country is to go from Cork to Killarney, and not from Killarney to Cork. By the former you have the scenery before you, and increasing in magnificence all the way; the other is the reverse in every sense.

We started fully equipped, intending to take our time along the route and to fish any likely-looking stream we could get leave on, or which was not preserved. In a wild place like Kerry an opportunity of asking for leave was then not always available, so once or twice, I fear, we boys were not as particular as we should have been, and took chance with a good river of its not being preserved. Anyway, in those days, most of them were free.

That ten days or so was the longest continuance of really good troutfishing I ever experienced. Every day we came across a goodlooking water, and we got rare sport on all we tried.

One day a keeper came up to me while an unusually good rise was on and almost every cast a fish was hooked, and I was landing them fairly well ; all beauties in the best condition, and from herring-size to over $1 \mathrm{lb}$. weight. In a determined and impudent tone he demanded my authority for fishing Lord Landnothing's water, which he had rented from Mr. Castingline of Cork. Without ceasing fishing, I assured him that we had been told the river was not preserved, but in any case he could see for himself it was overstocked, and that if he would only wait awhile, abate his anger, and allow me to go on as I was, I would materially benefit both the tenant and the landlord by the same means; a performance, by the way, not usual at that time in Ireland, no more than it has been since. During the parley, which took much longer than I do relating it, I was landing fish as fast as I could hook and play them, and my friend, not far off, was doing the same. The keeper was, of course, fond of a bit of sport, and certainly, after a while, was less vehement in his protestations, and, having given him my sandwich case and a flask containing some ten-year-old John Jameson, he allowed us to have what proved about the very best evening's fishing we ever had in our lives. As well as I remember, we killed between us about five dozen trout, weighing nearly, if not over, as many pounds. These we gave between the keeper and the landlord of our hotel.

Boys will be boys, so this exploit of ours may be forgiven, if not excused or even justified under the circumstances. A boy who has not love for sport and is innocent of devilment is in my opinion not much of a chap. The river was full of trout, and had not been fished for years nor was it likely to be for some time, so, as he said himself, the keeper did good service to his employer rather than otherwise by letting us have our sport.

The river we fished that day was rough and rapid, and in some places fell in cataracts several feet into pools which were encircled by high, almost perpendicular, rocks. In these we had the right sport. The 
sides were so high and the pools in many places so small we could not cast, and had simply to drop the tail fly in the water, and when taken by a trout, we got sport and no mistake, for the water was deep, with, of course, another fall or steep rocky outlet, which if the fish got over, or into, he was lost; and it was in such places we generally met the heaviest. Of course, we lost several, and would have lost many more but for the assistance the keeper gave us with the landing-net.

In other places along this stream we met rapid runs and eddying pools, studded plentifully with huge boulders rising high out of the water, while the bottom was rugged with rocks and stones carried down by winter floods. In this sporting river the fish had plenty of fair play, while we had fine play, for our rods and tackle were light. The whole was surrounded by mountains clad with blooming heather and evergreen gorse, with patches of granite rockwork here and there. Grouse apparently were plentiful in the neighbourhood, for on several occasions we heard the old cock crowing the evening-meal call to his pack. The scenery was that of the mountains overlooking Bantry Bay, than which there is nothing grander in the kingdom.

The greater portion of this chapter appeared as an article from me in Land and Water in September, 1892. Unfortunately, I omitted in the MS. to state that my companion and I were little more than schoolboys when we made this excursion into Kerry, and that we asked leave whenever we could do so. Moreover, that it occurred over thirty years ago. Without this qualification and explanation, of course my article showed me to have been guilty of most unsportsman. like conduct in having fished places for which we had not leave. The consequence was severe criticism was passed upon my conduct by correspondents in Land and Water. But, as I said in a subsequent letter of explanation to that paper, I do not think that the escutcheon of a sportsman is in the least degree tarnished by having done what we two lads did in Kerry, particularly under such peculiar circumstances.

Knowing as little as I do about fishing, I would not have alluded to that branch of sport in my book but for these correspondents. I do so to afford myself an opportunity of repeating the story of my exploit in Kerry, to show how little ashamed I am of it, and of conveying to my critics a word or two, which I do as follows:-

Someone signing himself "Rose Price," but giving no address, wrote most offensively, and wound up with the suggestion that if ever I again went to Kerry, some landlord of that county shoul.l duck me in a boghole. I beg to state that I am not at all unknown in Kerry, and have the pleasure of being acquainted with some of the leading gentry in that sporting county; none of whom, I flatter myself think me deserving of that treatment.

If, therefore, this Rose Price be what is called gentleman, and wishes to take upon himself the execution of the sentence which he 
deputed to others, I shall be pleased to hear from him on the subject at the address he will find at the foot of the Preface of this book.

The others who denounced me were not nearly so offensive; but they wrote over initials or other disguise. Even so, should they be disposed to teach me by any such method how to conduct myself as a sportsman, they also are at perfect liberty to communicate with me.

This is the first opportunity I have had of sending to these gentlemen this intimation; for, needless to say, it would not have been conveyed by the Editor of Land and Water, nor would he give the information which alone could enable me to write to them severally and collectively. I trust, therefore, all those who wrote about me in Land and Water on the 10th and 17th September, 1892, will see this page of my book, or be informed of the invitation it contains.

The three best salmon killed with rod and fly in Scotland during the autumn season of 1892 have been given as one of 56lb. on the Eden, one of 50lb. on the Spey, and one of 50lb. on the Tweed. The first was $47 \frac{1}{2}$ in. in length and 29in. in girth. The Spey fish was caught on the Duke of Richmond and Gordon's water at Fochabers, by the Earl of Winterton, and measured 49in. in length and 28in. in girth. The Tweed fish was caught on the Earl of Home's Birgham lower water, by Colonel the Hon. William Home, and measured 48in. in length and 28in. in girth.

Loch Leven is perhaps about the most wonderful lake in the world for trout. It is a comparatively small sheet of water, being only about nine miles in extent, but the number of fish taken out of it annually is something marvellous. Records have been carefully kept for the past forty years, and, despite the continual fishing, Loch Leven seems to be a veritable widow's cruse. Some of the best years on this historic loch were 1879,1880 , and 1888 . In the first-mentioned year 21,045 trout, weighing 16,192 lbs., were taken ; in ' 80 , 19,405, weighing 18,552 lbs. ; and in ' 88 , 23,516 fish, scaling 21,074 lbs. Last year-1892-was a very fair season, as the 12,735 trout taken made $16,058 \mathrm{lbs}$. The fish in Loch Leven are fine fellows, and some record baskets have been made on it. For instance, in 1891, in four days, Mr. and Mrs. Laird of London killed 156 trout, weighing 134lbs. A Mr. Nisbet in the same number of days got 124 trout, weighing close upon 100lbs. The fish are of a fine size, but heavy ones are the exception. A fivepounder, killed by Major Barton, was the heaviest taken since 1879. It is said, however, that in the olden days trout of eight and ten pounds have been caught, and there is a legend of an 18-pounder.

Rent is not charged in Scotland for troutfishing, but the sport entails a vast expenditure of money.

In the following chapter on Shooting will be found the calculat I made of what is spent annually upon Fishing. 


\section{CHAPTER XV. SHOO'IING.}

Author's Experience-Dogs-Driving-Advantages from Driving-Author as a ShotWounding-Best Method for-Killing a Cripple-Butts and Hot Corners-Shooting over Dogs-Autumn Shooting-Pigeon Shooting-Paraphernalia-Golden RulesHow to Carry a Gun-How to Choose a Gun-Jump and Recoil-Controversial Scribes-Author gives his Opinion-His Old Gun-How he made it Hit-Advice"A Tip"-A Shooting Excursion-Mr. Frederick Malcomson-Eleven Dogs-They all Set and Back same time-Game Fare-Good Liquor-Surfeited-Cooking a Grouse -Shooting a Sheep-Satisfactory Result-Good Cooking-How to Cook SnipePlenty of Snipe-10s. Gun Licences-Game Dealers' Licences-Destruction of Game -When to Turn down Hares-Selling Game-Old and New Practice-Presents of Game-Not sufficiently practised-Territorial Landlords-Tenants Preserve Live Game -Presents of Game to Fox Preservers-Game for the Market-The Prince of WalesBig Shcots-Extraordinary Records-Marvellous Feats-David Beatty-Edmond Power-Patrick Power-John Brady-The Author's Bags!-Tables of Great Shooti -A Confession-Cost of Shooting-Fishing included-Analysis of Scotch ShootingTable of Wages-The Guests-Small IIen-The Dogs-The Shepherds-Salmon Fishing-Analysis of Scotch Fishing-A Wonderful Result-English ShootingA long Explanatory Preamble-Resulting in a Stupendous Record-Nearly a Million and Three-quarters yearly to Poor People-Cartridges-Guns-Heavy RentalsCounty Rentals-Deer Forests-Cost of a Grouse, Pheasant, Stag, and SalmonLand Agitators-A Word to Them-Former Crofters-Sheep Grazing $\boldsymbol{v}$. Grouse Shooting-Keepers and Gillies $v$. Crofters and Cottiers-Results of Highland Farming -Rents-Expenditure-Bonnie Scotland-Territorial Magnates-Highland LassiesHer Majesty the Queen-Poor Old Ireland:-Shooting Tenants-A Reproduction from Land and Water-The Daily Telegraph-A most Interesting Extraction-"The Twelfth"-Deer Forest Commission-A Sportsman's Diary-Charming Record Rheumatism-The Gout-The Season of 1893-Great Record.

I HAD a fair amount of shooting during many of the best years of my life, but it was always over dogs. I never had a day's "driving," and have been present at very few "battues," therefore anything I could write upon shooting would be of little interest to the present generation, which, as a rule, knows little of the delight of watching two or three dogs doing their business properly on the side of a mountain, through the turnips, or over the stubbles. Young men of the present day care more for the "hot corner," the "butts," or walking up birds in places where they can bag twenty to fifty brace in a few hours, and with little exertion.

That skill with the gun is brought under much more severe test in driving than in shooting over dogs there is no manner of doubt. A man that can kill five out of ten birds he fires at, coming towards or across him at the rate of 150 miles an hour, and which have to be taken at every possible angle, is a much better shot than the man who can kill eight out of ten which get up slowly in front, and fly off in a straight line, as is the case when shooting over dogs.

To shoot grouse or partridge at all in some places, driving them to the guns must be resorted to. Upon low-lying flat moors where the heather is short, such as are found in parts of Yorkshire, grouse will 
not stand to a dog after the first couple of days. Neither will partridge lie close upon fields off which the corn has been shaved within an inch of the roots, as is the case where reaping machines are used. From such like places both grouse and partridge fly in scores the moment a man or a dog appears within ten shots of them.

Besides enabling men to shoot these places, driving, we all know, has been most beneficial in its results of killing off a greater number of old birds than can be done by any other kind of shooting. Cripples too are unknown, for the force of the fall alone kills the bird.

In spite of all these advantages obtained from the drive, give me the shooting which I have been accustomed to. Apart from my liking to see dogs work, and exercising my own legs and sagacity to find birds, perhaps the fact of my not being a very good shot may induce me to prefer the easy to the difficult work.

I was never a reliable shot. One day I might shoot as well as most men, and the next, perhaps, just as badly. Hitting birds without killing them I always hated myself for, but instead of seeking fresh shooting I searched for the wounded. To leave a crippled bird a moment longer than necessary without putting it out of pain is most inhuman; whether search for it interferes with the shooting or not, the bird should be caught and killed.

It is horrible to see a heartless keeper holding by the legs two or three wounded birds flapping their broken wings, before he gives them the coup de grace. When this is given it is often in a most cruel manner by crushing the back of the head with the thumb nail, or striking the bird's head against something-both painful and oftentimes slow pro cesses. The best, quickest, and easiest death to a bird is to place him on his back on the doubled palms of the hands and press the breastbone firmly, but not suddenly, with both thumbs. A second or two's pressure over the heart in this manner inflicts the easiest death a bird can possibly suffer.

As I said before, I had no experience of driving and little of battue shooting, but I think it is not much fun and less sport to be put in a hot corner at the end of a covert, or into a butt on the side of a mountain, and there blaze away until a succession of guns get almost red hot in your hands. The sport affords neither the exercise nor venatic skill attendant upon hunting a mountain or lowland with a brace of good dogs, where a man's knowledge of the haunts and habits of the birds must be equal to his skill in working his dogs to enable him to bring home a fair bag.

I never cared to have coveys of partridge marked for me, unless they were very scarce, and my time was limited; and until fairly beaten I seldom took advice from or accepted the guidance of keepers or watchers. A bag of five to ten brace of grouse or partridge, killed over a brace or two of good dogs (particularly if trained by myself), after seven or eight hours' hard walking, and unaided by anyone except my dogs, would give me infinitely more satisfaction than making the "best record" of a big shoot behind sod embrasures, or from hot 
corners, although I might leave off with thirty or forty brace to my credit. Moreover, I liked to bring my birds home with their plumage as little disturbed as possible, and see them spread out on the kitchen or larder table clean and well shot; and if, as was sometimes the case, a bird happened to get unduly riddled, or mouthed by one of the dogs (a rare occurrence with mine) I would throw it a way rather than bring it home. To prevent the disarrangement of plumage by rain I always had my game baskets and bags secured against such. In big shoots these particulars cannot be attended to, and birds are thrown into the creels in heaps, and often taken therefrom in a disgustingly crushed condition.

Again, compare driving birds to butts or corners with a day's roughshooting in the late autumn, when a man brings home his mixed bag of snipe and woodcock, with an odd brace or two of grouse, partridge, and wild duck - the grouse being then so wild that only long and quick shots can be had at them, and twice as fine, both in condition and plumage, as they are in August. I am an antiquated old fogey, and in point of downright genuine sport can't see any comparison at all between the two systems.

Of the practice of shooting pigeons let loose from traps I have a very poor opinion. It is not manly, it is cruel and unfair. No doubt it is shooting and is a fine medium for betting, but assuredly it is not sport. To shoot wild "blue rocks," flying like rockets from their native cliffs, or wood quests, flashing from ash trees, is sport and no mistake.

In these days of breechloaders the present generation knows little of the paraphernalia requisite in the old muzzle-loading days, the roll of which we had to call over before starting. It was :-Gun, powder-horn, shot-pouch, wads and caps, whip, whistle, and game-bag, sandwich-case, flask, pipe, baccy, and fusees. And on! what an amount of work we used to have cleaning the old muzzlers-half-an-hour's at least-which had to be undertaken after each day's work.

There are three golden rules, observance of which will banish the possibility of accidents while out shooting :-

a. Never carry your gun with the muzzle pointed towards anything it is not intended to kill.

$b$. Remove the cartridges directly you cease shooting.

c. Be as careful with a loaded gun as you would be with an open razor.

Even where the party consists only of steady and experienced men there must of necessity be some danger attendant upon big shoots; but when the young or excitable are included, the risk of being peppered is very great indeed. Luckily, I have not been upon any of those dangerous expeditions. I shot only in company with another, but until $I$ ascertained that he knew how to handle his gun and was a steady shot, I took very good care to keep on his right, unless he was left-handed, when I kept to his left. I never carried my gun except under my arm or over my shoulder with the hammers next 
the shoulder, and when expecting a shot the muzzle always pointed skywards and never horizontally. As a boy I was so taught, and following the instructions, even when shooting alone, I got into the habit and could not with ease to myself carry a gun in any other position. In every detail I was cautious and careful with firearms, and had a safety-guard to my gun which prevented it going off at full cock, except when the guard was pressed and trigger pulled at the same time. I don't think any gun should be made without such, and still the simple appendage is seldom seen. I never could endure a hammerless gun; one never knows whether it is cocked or not; besides, cropped of the hammers, a gun has the appearance of a horse without ears.

Treatises in the sporting press upon choosing guns and shooting straight may be measured by the yard, but I am quite content to think that to enable him to kill birds with it, a gun must "fit" a man accurately and be properly charged. To find out if it does is simply as follows:-See that it comes up to the shoulder handily, and well clear of the armpit. Fix your eyes on some small object at any distance between fifteen and fifty yards, bring the gun up quickly to the shoulder, and then shut the left eye. If the object is covered in a direct line from breech to muzzle, the gun suits (or "fits") and you can kill with it; but if you can see along the barrel, though the muzzle may be right on the mark, or that the breech may be on the mark and the muzzle under it, then the gun does not fit, and you will shoot over or under, as the case may be.

There are, of course, men who see with one eye better than the other, and others whose peculiarities of vision require specific modes of measurement for a gun. Luckily I know nothing of these infirmities, therefore I can't suggest provision for their individual treatment.

In Land and Water we had early in 1892 some letters upon the subject of "jump and recoil." As is generally the way with people engaging in a written controversy, they resort to animadversion upon each other because there exists a difference of opinion, so it was with some of those gentlemen who entered the lists upon this subject.

Peace to your manes, dear old Jorrocks! You, indeed, gave a true exposition of the general run of controversial scribes in your lecture at Handley Cross, when you referred to how writers of books upon the horse abused each other. Yes, true it is that after having read treatises by different parties upon the same subject, "one arrives at the grand climax of hignorance instead of gleaning wisdom as one went"!

I owned only three guns in my life, and I don't think I shot out of more than half a dozen others. I am, therefore, a very indifferent authority upon the subject of jump and recoil ; nevertheless I will say a few words about it. I have no doubt many guns jump and others recoil, while some do both the one and the other. I am however of opinion that if a man buys a first-class gun, and charges it with a properly proportioned quantity of powder and shot confined in a well- 
made cartridge, he can kill most birds he fires at which are within range, made and provided he fires straight after them if they are flying from him, or sufficiently before them if they are coming towards or crossing him.

I have a gun which I bought twenty years ago from Messrs. J. and W. Rigby, and I have shot with it ever since. It is of their then very best make, is of the celebrated old "Damascus twist," and is a pinfire, with old-fashioned hammers, and;12-bore. The gun "fitted" me when I bought it and has continued to do so, but when I began to use it, as Soapey Sponge said to Joggleberry, although I made good shooting, I made bad hitting. Guessing that the charge was wrong, I practised at a target, $6 \mathrm{in}$. long by $3 \mathrm{in}$. wide, made of sheets of brown paper. I fired just as I would at a bird; i.e., looking at it, putting up the gun quickly, and firing the moment it touched my shoulder, keeping both eyes open. I found I generally missed, just as I had done the birds.

I don't know whether it was my own fault for not having shot straight, or the gun's for having jumped or recoiled or done both. Anyhow, I changed the charge, and with marked effect, for I began to hit the target. I continued altering both powder and shot until at last I found myself "on the spot" every time. The sheets of paper pierced showed me that the strength was sufficient to bring down a wild goose at the distance, so I left off satisfied with my gun and $\mathrm{m} J$ hitting, and so I have remained ever since.

I should mention that the distances I practised at were twenty-five, forty and fifty yards, and I experimentalised with No. 8, 6, and 4 shot. The charge which I find suits my gun and myself is 3 dr. coarse grain "Battle Powder" with $1 \frac{1}{3}$ oz. of shot-a thick felt wad over the powder and a thin one over the shot, the former rammed tight, the latter not.

Perhaps some young gentlemen whom I have seen out shooting, and a few old ones too, might put more birds into the bag than they do if they tried similar experiments with their fire-irons, instead of reading scientific discourses on the subject, which at times tend more to muddle than to clear their vision.

However, unless a man has an eye naturally adapted to shooting straight, neither the gun or its charge, nor yet instruction or practice, will make him a good shot.

I will now give a "tip," and it is not a bad one. As everyone knows, the more a man drinks, even though it be water, during exercise the more he perspires, the more he wants to drink, and if he continues to drink he becomes incapable of hard work. At times, however, a man must assuage his thirst and then his best plan is to wash his face and hands in a stream or well, then rinse out his mouth, and finally dip his face in and take a great gulp, which, however, he must stop before it gets past the uvula. This answers all the purposes of a big drink, is manifestly cool and refreshing, and in no way will it impede the walking powers. 
About the year 1874 my friend, the late Mr. Frederick Malcomson, and I rented a mountain in the west of Ireland, and brought with us for a month's shoot three setters and eight pointers. This number was, of course, over that required, but I always loved seeing dogs work more than I did the shooting, and for that reason I generally worked more at a time (particularly on a mountain) than most people.

One day I took out the whole crowd, and gave them a run together for a couple of hours. Oh, such sport as that was! for all my dogs knew their business, and so did those poor Fred brought. On several occasions two packs, or odd birds, would be found at the same time by different dogs, with some of the others backing them as they set, while the remainder were ranging far away, or doing work which drew their attention from the others. Fred would go to one lot while I went to the other.

On one occasion three dogs set the same pack of grouse, and every one of the others backed them. So perfect a sight I never saw with dogs before, nor shall I ever see again. Those eleven dogs setting and backing were in every conceivable position, some sitting on their haunches, others half turned round towards the dogs with the birds, while these would ever and anon turn their heads cautiously to see why we were delaying, for, truth to say, Fred and I were transfixed with the exhibition, and stood for many minutes admiring its perfection.

However, it would not do to continue that sort of work if we wanted to shoot grouse; for a few repetitions, needless to remark, would have made the birds so wild they would never let us near them. In spite of this I think I should have continued it, but Fred would not have it, so afterwards we took out the dogs only in orthodox fashion.

Our shooting was in about the wildest place I ever visited; it was forty miles from the nearest railway station, ten from a post-office and the place where we could buy fresh meat. We put up at a farmer's house on the banks of the river Moy, but it was harvest time, and no one could be spared to go to market for us.

We brought some fresh meat with us, of course, but it was not long before our supply was demolished, or succumbed to the hot weather, so that we had none except what we shot. For the first ten days we had for dinner soup made with the essence of hare and grouse, trout and salmon caught in the river within twenty yards of the house, while grouse, hares, snipe and plover were our relevés. We came well supplied with Ayala, 1868, not to speak of "John Jameson," so with tea and delicious mountain cream, butter, eggs, and griddle-bread, we were well "done." Although we cooked the hares and birds in every imaginable manner (and well, too, albeit I was the chef), we got tired of roast, jugged, and hashed hare, roast, baked, and broiled grouse, and longed for beef or mutton. Poultry we got from the farmer's wife, but had a surfeit of it also, as we had to make breakfast and luncheon, of course, off the same fare as the dinners.

By-the-by, we found no way better for cooking a grouse than, after having him drawn, and a large piece of butter put inside, plastering 
him-feathers and all-over with mud, and baking him in the ashes of a good turf fire. After about fifteen minutes or so we took the bird up, and the hardened mud, falling off in one mass, exhibited our grouse without the trace of a feather, and cooked in the superlative degree of excellence.

This continuance of game fare became at last so intolerable that only the capital sport we were having, even though the birds were beginning to get very wild, prevented our returning into civilised regions. One day, however, a happy thought struck me : to wit that, perhaps, I might, by stalking or driving, manage to shoot one of the wild mountain sheep we occasionally saw, but which never allowed us within a mile of them. Accordingly, without telling Fred of my intention, I got up one morning before daylight, and trudged up the mountain to a sort of defile, towards or through which I had seen the sheep sometimes go when disturbed. I confided my plan to a couple of the farmer's boys, and gave them instructions that as soon as they thought I had gained my cache they were to try to drive some of the sheep to me. They succeeded capitally, and no long time elapsed before I saw a flock of about a dozen wending their way right up to me, and following each other slowly along a pathway they had no doubt often travelled. Fortunately I was down wind of them, and the morning being bright and clear I was able to pick out the fellow I considered would make the best mutton. This was a game-looking little chap with black face and crooked horns. The path I saw led right up to within about fifteen yards of me, when it bore to the right, which would afford me a full broadside shot; so I waited my opportunity and let drive both barrels almost instantaneously at the little wether, aiming just behind his left shoulder. To my intense disgust, away he went with the rest as hard as he could split, and disappeared behind a ridge. I knew I could not have missed him, and on examining the path I found a lot of blood; so I hurried on and soon discovered the poor little fellow in his last throes. Waving my hat. to the boys, and giving a loud Whoo-whoop! they were soon at the spot We bled and gralloched him in true Highland fashion, just as. if he had been a Blair Athol royal, and the boys bore the carcase between them to the house.

Never was meat sweeter to men than was this mountain mutton to Fred and me, and though it was rather tough for a day or two, and had precious little fat, we devoured it with ravenous gusto, after such a long course of fur and feathers.

That was, indeed, a jolly sporting trip, and many a time afterwards. we talked it over and agreed that we never tasted such ripping good and well-cooked game as we had in that lonely but lovely place; yet Fred had a chef to whom he paid $£ 100$ a year.

This, however, was not my first turn at cooking game of my own shooting, and for my own subsistence. Years before that, another fellow and I had to live upon snipe for nearly a week under somewhat similar circumstances. We put up in a rather rough-and-tumble old shooting 
lodge, and though it had a good kitchen, there was no range and only a bad grate; hence we had to do the best we could in the diningroom. We cooked our snipe thus, and I will back the method against any other that circulates in the cranium of any cook in Christendom: I drove six nails into the wooden chimney-piece in the dining-room, to each of which I attached a short piece of twine, and underneath I put a saucer with a piece of butter in it. To each of the strings I hung a snipe, tied by the bill, regulated to let him hang just opposite a hot, clear fire. I then twisted the strings, so that the birds revolved round and round, and I basted them well with the pure butter well melted. As soon as the trails began to drop they were taken off, and replaced by another lot, which were cooked in like manner, while we discussed the others in the perfection of hot juiciness. We each ate for dinner six or seven snipe, with wild duck or teal to follow.

The time I refer to was when our daily bag ran from twenty to thirty brace of snipe, with several duck, teal, and widgeon. Times are changed, however, and so are laws since then. Over the same ground the best shot in the kingdom would not now get a quarter the number.

If the iniquitous 10s. gun certificate and game-dealer's licence had never been heard of, we should still have good shooting in many places in Ireland. The first day we held the races over Williamstown Course hares were so plentiful that six were killed by the crowd, and on the same farm I had no difficulty in often getting my two or three brace of partridge before going to my office at $9.30 \mathrm{a} . \mathrm{m}$. Now you might as well look there for hyenas or ostriches as for hares or partridges. I got fifty hares once to stock the same place for coursing, and let them all go myself, every one being as strong and healthy as it was the day before, when caught. I marked each by clipping off the top of the left ear. Within a week nearly half of them were sold to licensed gamedealers in Waterford! The same story can be told of hundreds of other places in Ireland.

I may here remark that hares should never be turned down on strange ground in the evening, for if they be, they will travel all through the night in the direction of their old home whence they were taken. Hares feed in the evening and early in the morning, and roam about at night, never stirring from their forms in the daytime unless disturbed. Therefore, the time to put them out is from an hour after daylight to noon, and then in the vicinity of good covert and feeding ground. If this be done they will take refuge in the former immediately, and come out to the latter in the evening for food, for which they will then be ravenous. There, if they are not disturbed and fincl the place comfortable and the feeding good, they may remain; but turned-down hares seldom stay where they are put if the place be unenclosed.

In my younger days selling game by the proprietors of preserves was never thought of in Ireland nor was it practised much in England; in fact to do so would have been considered outré to a degree by the great majority. Now that is all changed, and game is sold by the lords of the manor as universally as are their sheep and cattle. A 
man may be on a shooting visit with a friend for a week, and be the means of having more birds put into the creels than any of the party, yet very likely he will not be given more than a few brace for himself or to send his friends when he is taking his departure. All is sold that is not actually required for the table of the host, or for a few presents.

In some places in England after a big shoot a brace of pheasants and a hare or two are sent to some tenants of the estate, and during the partridge-shooting a few birds are given to those over whose farms they were shot. No doubt these little compliments and attentions are duly appreciated, but I take the liberty of stating that the practice should be much more usual than it is among our shooting magnates, and, moreover, that there should be a still more liberal distribution by some of those who already adopt the proceeding.

In fact, I don't think I am going too far when I say that, instead of selling their game, the proprietors rould serve the interests of sport very much better if they distributed the greater portion, after supplying themselves and their friends, among those who preserved it and the fores. Of course some game should be sent to market for the use of those who neither shoot nor preserve, but there is no need whatever for such quantities as are sent at present. Besides, those uho sustain the sports of our country are more deserving of consideration in this matter than are the townspeople and others.

In the case of a man, or number of men, who pay a high rent for a shooting, perhaps only for the one season or where they may have no connection with the take other than the shooting, it is quite a different matter. They have every right to sell the game so as, to some extent, recoup themselves their great expenditure of money.

Large territorial landlords have no such excuse. Their incomes do not require to be supplemented by money got for their game, which is, as a rule, preselved for them by their own tenant farmers. A great deal of damage is done to crops by game, as recompense for which, and as a reward for the preservation as well as to encourage it in future, the greater part of the dead game should be distributed among the farmers.

Again, most of our great landowners are foxhunters. With the assistance of the farmers in preserving foxes, and with their permission to ride orer their grounds, foxhunting can alome be carried on. Therefore, to the farmers every recompense, ever'y indulgence, and every compliment should be paid. To send as a present to their wives all over a foxhunting country two or three times a year a basket containing a few brace of birds and some hares, with their landlord's compliments, would, I am sure, have a most marked and beneficial effect upon our foxhunting.

Of course, the general public must have a chance of buying a bit of game during the season. That can be afforded them in abundance by what is sold off the rented moors and manors, supplemented as it no doubt would be by that taken unlawfully, and for the sole purpose of sale.

H.R.H. the Prince of Wales, than whom there is not a better sports- 
man in Great Britain, takes this view of the subject and gives away, mostly to his tenantry, all the game which is shot in his preserves except what is used in the Royal household.

To interest fellows like myself who have never had anything like first-class shooting, I shall in the next few pages give records which will open their eyes. I take them from Sportascrapiana, the Badminton Library, and my old scrap-book, which contains a curious collection of sporting mems collected by me during the past thirty years. The records are therefore thoroughly reliable.

I begin with some of the shooting in olden time, and I may state that up to about 1840 flint guns only were used, and in about 1870 breechloaders took the place of the muzzle-loading detonator.

It appears from White's Natural History of Selborne, that partridge were unusually plentiful in the years of 1740-41, and that "parties of unreasonable sportsmen killed twenty, and sometimes thirty, brace in a day."

At Holkham-Lord Leicester's seat in Norfolk-I find the amount of game shot in the following years to have been :-

\begin{tabular}{c|c|c|c|c|c}
\hline Year. & Partrilges. & Pheasants. & Woodcock. & Hares. & Tctal. \\
\cline { 5 - 6 } & & & & & \\
\cline { 5 - 6 } 1793 & 1,349 & 262 & 114 & 358 & 2,083 \\
1800 & 3,865 & 355 & 127 & 854 & 5,201 \\
1818 & 1,711 & 1,227 & 181 & 3,176 & 6,295 \\
\hline
\end{tabular}

This shows that where pheasants and hares increase partridge will decrease.

Hares seem to have been wonderfully abundant in those times, for in 1806, on a complaint being made by the farmers of their being too numerous on Sir Thomas Gooch's estate in Suffolk, no less than 6,012 were killed over it in six weeks.

As encouragement to Suffolk gamekeepers to increase their stock of hares, pheasants, and partridges, a prize was offcred, in 1811, to the keeper who could show the best record, as regards quantity shot and quality of the shooting, in any six clays between 8th October and 8th December. The prize was awarded for the following, which was shot by thres guns over 4,000 acres :-

\begin{tabular}{|c|c|c|}
\hline & Killed. & Missed. \\
\hline 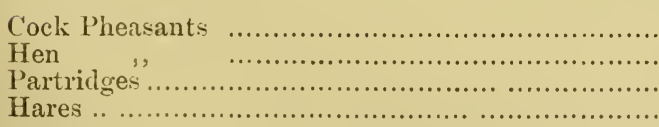 & $\begin{array}{r}378 \\
51 \\
506 \\
17 \%\end{array}$ & $\begin{array}{r}199 \\
39 \\
391 \\
94\end{array}$ \\
\hline Totals..................... & 1,112 & 633 \\
\hline
\end{tabular}


A capital killing average, and shows how the old fellows with their now-despised flint guns could shoot.

Termin in those days seem to have swarmed in some parts, for over this estate, in the same year, were killed by the keeper and two assistants, 9 martins, 31 pole-cats, 416 stoats, 120 magpies, 167 hawks, 310 fieldrats, 19 brown owls, 7 cats, and-which shows there was no hunting in the locality-22 foxes.

In the game-book at Riddlesworth for 1809, six guns are stated to have shot in January, 1 duck, 93 pheasants, 2 snipe, 19 hares, and 10 rabbits, total, 125 head, to which is appended a note in Mr. Thornhill's handwriting: "Have not heard so many was ever killed before." It was not long until he found the score beaten, for in the next year his return, in one day, was better by 150 head, standing as it did at 110 pheasants, 96 hares, and 63 rabbits, with ten guns. And again in November, 1813, with eight guns 143 pheasants formed part of the Riddlesworth bag of 232 head.

The following is a delightful record, and, as the Badminton volume says, "the carefully kept table must be one of the most interesting shooting records in existence." I have more pleasure in relating the performance than I have with any other in this chapter :-

"The late Lord Malmesbury kept a journal of his sporting life even to the quantity of powder and shot he used, the game he killed each day, the time he was out, the distance he walked, and the weather."

Here are the totals of the game which fell to his own gun over the Heron Court Manors, his property in Hants, in forty seasons from 1798 to $1840:-$

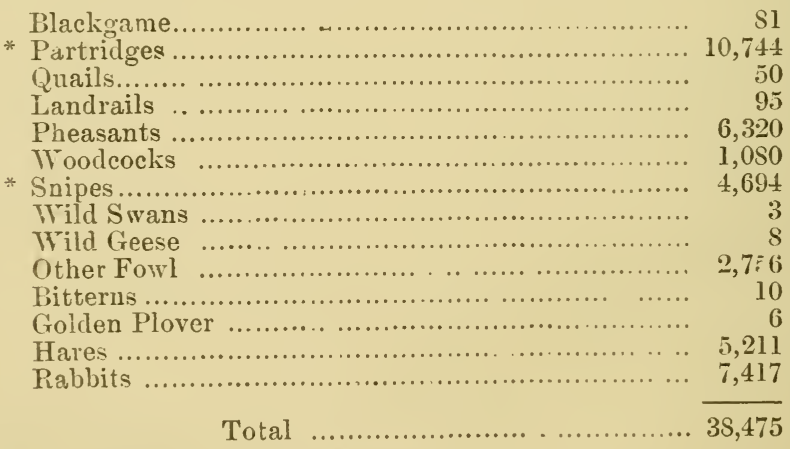

To shoot the above Lord Malmesbury was out 3,645 days, walked 36,200 miles (about once and a half round the world), missed 16,766 shots, and fired away about 750 pounds weight of powder and four tons of shot!

His daily average bag was only about eleven head, but he got them in fifteen shots, a marvellous record over so many years. And that was

* Rendering plural the words snipe and partrides by adding a final s gives words the sound of which has always been horrible to me. We never hear of grouses. 
done with the old flint gun, and of course either over dogs, stalking, or walking up the game. During the whole time this sportsman, noble in every sense of the word, was never confined to bed for one day by sickness or accident.

In the present day, when birds in thousands are driven to a turf bank, which they fearlessly fly for, and from there are shot in hundreds by a man with two or thrse oreechloaders supplied him in rapid succession by attendants, of course the daily average just given is only tive minutes' work. I shouid like, however, to know if some of the present-day shooters could, starting level and at even weights, beat the record of this great and grand old sportsman.

One of the first instances, if not the first, in which a thousand pheasants were shot in a day was in 1845 , when a party of nine guns shot something over that number on Lord Ashburton's estate at Bucken. ham in Norfolk.

Mr. J. Sidney Tharp, of Chippenham Park, Cambridgeshire, in October, 1826, with one gun, one dog, and one attendant, bagged ninety-nine partridge between 8 a.m. and 3 p.m. He was thers so knocked up that he was unable to go on to kill one bird more and so make up the huudred. He picked up all the birds and shot quite fair, not killing more than one at a shot. Moreover, the birds were very wild.

At Orwell Park, near Ioswich, the property of Mr. Tomlins, in about 1830, five guns in four days bagged 1,348 partridge.

In January, 1858, in four days, General Hall and seven friends at Weston Colville bagged 2,155 partridge. Only one day was fine, high wind on the others, with a hurricane on the first day.

The largest bags of partridge made by walking in line were in 1858 and 1859 o L Lord Ashburton's estate in Norfolk, when 314 brace and 332 brace were shot by eight guns, some of whom were not first-class shots.

In Staffordshire, over Lord Stamford's property, in January, 1869, eleven guns in one day's driving shot 551 partridges, and in another 615 .

In January, 1861, one of the largest bags of game on record was made at Bradgate Parl, the seat of Lord Stanford, in Leicestershire. In four days were shot by thirteen guns for three days, and fourteen guns for one day, 4,045 pheasants, 3,902 rabbits, 860 hares, 59 woodcock, which, with 4 partridge, 2 snipe, and 28 various, totalled to 8,900 head, showing an average of 2,225 head a day.

At Six Mile Bottom, Cambridgeshire, duriog the last week of the season of 1869, nine guns in four days shot, driving, 1,940 partridges ; a daily average of $242 \frac{1}{2}$ brace, or 22 brace to each gun.

At the same place in December, 1861, three bags were made in one week which are worthy of record. First day with thirteen guns, 193 hares, 267 rabbits, 736 pheasants, 7 woodcocks, 3 various, total 1,206. Second day with fourteen guns, 173 hares, 190 rabbits, 1,605 pheasants, 26 woodcocks, and 3 rarious, total 1,997. Third day thirteen guns shot 3,333 rabbits, beside 26 head of other game. A three days' shoot by, say thirteen guns of 6,56 ? head. 
The heaviest bag of grouse made by a party in a day was in the extraordinaly good season of 1872, when Mr. Kennington Wilson and his friends shot 1,313 brace. In the same year 1,006 brace of grouse were killed in a day on Lord Ripon's mocrs in Yorkshire.

Coming to recent years I find that in 1885 a party of ten guns in four consecutive days in December shot at Holkham 3,392 partridge, being 848 a day with 85 birds to each gun. Mr. Gurney Buxton headed this enormous score on each day with 172, 112, 95, and 96.

On the property of Mr. J. Price, at Rhiwlas, North Wales, two weighty bags of rabbits were masie in 1883 and 1885 , when, with nine guns in one day, they respectively amounted to 3,684 and 5,086. Of the latter Earl de Grey shot no less than 920, but he is one of the best allround shots ever known.

Sir Victor Brooke, Bart., is referred to as being one of our best rabbit shots, and that in his own park at Colebrook, Ireland, he in the year 1885 killed to his own gun in one day 740 rabbits out of exactly 1,000 shots. Moreover that one half of the day he shot from the right shoulder and the other half from the left.

The largest bag of grouse shot over dogs made by one man in one day was made at Grantully, Perthshire, on 12th August, 1871, by the Maharajah Duleep Singh, who killed 220 brace. He also made the largest bag of partridges on record, killing 390 brace on 8 th September, 18:6, on Hall Farm, Norfolk.

Elveden in Suffolk, once the estate of this Indian prince, is about the best for partridge in England. Over that property, in 1876, four guns killed in four days in October 2,531 partridge. In 1878801 birds fell to three guns in a single day. In 1885 that record was beaten by three others shooting in one day the extraordinary number of 856 partridge. The Elveden game books show another great shoot in September of the same year when, in fifteen days, the same three guns shot no less than 6,509 birds, giving an average of 72 brace per day to each gun!

Those great bags can only be made in the Eastern counties. Forty brace of partridge to six guns, walking up the birds, is a fair day's sport in the north, south, and west of England, or in Scotland. In the north of England there is no partridge-shooting to compare to Lord Londesborough's in Yorksaire. Over it in 1884 a party averaging six guns in four days killed, driving, 1,540 birds, one day's bag being 557 .

The quantity of game killed in the season of 1880 on the Duke of Sutherland's property in Scotland was wonderful : Stags 284, hinds 32 , roedeel 104, hares 5,940, rabbits 12,543 , grouse 52,613 , ptarmigan 142 , blackgame 1,997 , pheasants 170 , partridge 920, woodcock 713 , snipe 661, plover 36 , ducks 220 , various 99 -total 76,474 head. This did not include the game and rabbits killed by keepers.

In the year 1872, famous for abundance of grouse, Sir Frederick Milbank and his party, averaging six guns, in six days shot, orer the Wemmergill moors in Yorkshire, $3,983 \frac{1}{2}$ brace of grouse, of which Sir Frederick killed 1,099 $\frac{1}{2}$ brace. One day in eight drives he shot 
364 brace, in one of which he knocked down in 23 minutes 93 braze, or over eight birds a minute. He had three guns and two men loading for him.

The great bag of the season 1882-83 was made at Croxteth, Lord Sefton's seat in Lancashire, where six guns killed $7,67 \pm$ head in five days, averaging 1,279 a gun. Of the lot 5,543 were pheasants, 1,250 hares, 440 wild ducks, besides snipe, rabbits, etc. ; of woodcocks only eight were shot in the five days.

1,313 brace of grouse were shot in one day by a party at Bromhead. 1,100 brace were bagged by another party in a single day on the Wemmergill grouse moor; and 1,000 brace in one day by a shooting party at Studley Royal. Unfortunately I have not the date or further particulars of these shoots.

On his Blubberhouse moor, in Yorkshire, on August 30, 1888, Lord Walsingham made the largest bag of grouse ever made in a day to one gun. It totalled 1,058 birds, and was made between 5.15 a.m. and 7.30 p.m. He had twenty drives, which occupied seven hours and twenty-nine minutes, the rest of the time being spent in waiting for the drivers or in picking up the birds. From 7 to 7.30 was spent in walking home, during which fourteen birds were shot. Deducting these, and the half-hour occupied in shooting them, 1,044 birds were shot in 449 minutes' actual shooting-i.e., for seven hours and a halfan average of one bird in every twenty-five seconds! Four guns were used, and two loaders employed. Not a shot was fired by anyone but Lord Walsingham.

I find that " 70,000 partridges and 125,000 pheasants are the approximate estimate of the number of these bircls annually sent to London markets, coming mainly from Norfolk and Suffolk, and these numbers have probably been exceeded during the last few years."

It is also stated that "in 1884 the number of pheasants killed every season in the United Kingdom was estimated at 335,000, but this calculation is probably much below the mark."

I next find "figures taken from the accounts kept on an estate of 10,000 acres of preserved land in Norfolk which will give some idea of the rate of increase in the number of pheasants rluring the present century, and of the substantial advantage to the proprietor and his friends as well as to the community in general." I quote the years only in decades as nearly as they appear. Doubtless the rate of increase has been maintained to the present time, but the return ends in 1881 .

\begin{tabular}{c|c||c|c}
\hline Year. & Pheasants lilled. & Year. & Pheasants killed. \\
\hline 1821 & 39 & & \\
1830 & 119 & 1860 & 2,256 \\
1840 & 778 & 1869 & 2,697 \\
1850 & 1,716 & 1581 & 5,363 \\
\hline
\end{tabular}


When we read in Mr. Tegetmeier's excellent book on pheasants that "one pheasant had in its crop 726 wire worms and another 440 grubs of the crane fly," it is easy to understand that where pheasants are numerous insects destructive to crops are scarce.

That big bags are still made is in strong evidence, for in December, 1892, we find recorded in the Field that at Sudbourne Hall, Suffolk, in three days with eight guns were shot: 3,567 pheasants, 103 partridges, 464 hares, 473 rabbits, 37 woodcock, and 19 various-total 4,663 head, that is an average daily bag of 1,555 head, with 194 to each gun.

In the same month at Bishop's Wood, Herefordshire, in two days with seven guns were bagged: 2,725 pheasants and 81 other headtotal 2,806 , or an average of 1,403 a day and 200 to each gun.

A pleasing record is also given in that paper, where it states at Trewern, Oswestry, a country foxes are preserved in, five guns in November, 189?, in one day, and within an area of 35 acres of corerts, shot 353 head, consisting of 328 pheasants, 4 partridges, 9 hares, 9 rabbits, 1 woodcock, and 2 various - an instance among hundreds which shows that pheasants and foxes can be preserved in the same coverts.

A wonderful shot at wildfowl is reported to have been made in Scotland during the hard weather of Christmas, 1892. Sir Charles Ross's puntsman seeing a great congregation of birds on the ice, got within sixty yards of them and then fired, killing in the one shot 147 birds of different sorts, principally plover; the charge used was 4ozs. powder and 140zs. No. 3 shot.

A gentleman of my acquaintance, who does not wish his name mentioned, and a friend of his, towards the close of 1892, shot in the Highlands in five days' stalking and driving twenty-two hinds. This is, I think, the best record of such shooting.

As a specimen of what can be done with a gun by crack shots, two marvellous incidents may be given. The sportsmen on both occasions were the same, and notably the two best marksmen in England. Both (noblemen whose names I know, but am clebarred from mentioning them also) were standing side by side at the end of a cover expecting pheasants, instead of which a covey of eight partridge swept overhead, and, seeing the shooters, scattered in all directions Each man got four shots, and with them brought down singly the eight birds, which were picked up on the spot! Another day, shooting pheasants at Studley in Yorkshire, the birds crossing high over their heads at tremendous pace, these sportsmen by agreement tools alternate birds, and to their right or left as they chanced to come. They killed and picked up 98 pheasants, shooting bird for bird between them, and missing only one shot apiece!

The late Mr. David Beatty of Borodale, who was for over forty years master of the Wexford Foxhounds, was a wonderfully good shot. In about the year 1846 or 1817 he backed himself to shoot thirty snipe with thirty charges of shot. The shot was carefully measured, and the shooting began. He killed every bird up to nearly the end, when 
he missed one; he then lessened the charges, and won his match without another miss. He continued shooting and added largely to the bag with proportionately good work.

The late Mr. Edmond Power of Clonmel and the present Mr. Patrick Power of Faithlegg, near Waterford, were quite our De Greys and Walsinghams. Rarely would these men miss anything they fired at, and they shot regularly throughout the season. The first-named gentleman on the 12th August, about twenty years ago, in Scotland, bagged in single shots, without a miss, 58 grouse and a hare. This would have been recorded as the best shooting of that year's "twelfth" had not the late Captain Horatio Ross of Rossie accounted for 86 grouse out of 89 shots, and to him was accorded the palm of merit.

Although having a stiff leg, which occasioned him to walk lame, and being somewhat corpulent, Mr. Edmond Power was un extraordinary good walker, particularly on a mountain. He had a wonderful breed of pointers, and they knew their business as well as any dogs in the kingdom. Upon one occasion when on a visit in Scotland for shooting, he overheard his host and the keeper arranging the beats for the first day. After assigning the best to some of the other visitors, a flat, easy-walking outside beat was laid off for the laird and "the lame gentleman from Ireland." In the evening Power, after having walked his host to a stand, was less fatigued than any of the party, shot, without missing a bird, more than anyone else, and for his brace of dogs he refused tifty guineas. Needless to state thenceforward he was given good beats.

Mr. Power of Faithlegg had a dropper bitch which was gifted with extraordinary sagacity. She would never leave heel until she came to a field in which there were birds, but directly she came into one with birds, she would go straight to where they were and set them. Thus without beating a yard she would find five times more birds than all the other dogs put together. But for having often witnessed this wonderful manifestation, I would not believe such power could exist.

The best man I ever shot in company with was John Brady, a servant of my brother's. It was from him I learned my A.B.C. of Sport, and were it not for that man I might never have ridden a hunt, shot a bird, or trained a dog. In gratitude for what he taught me, and in tribute to the memory of an honest man, I record the fact that during the many days I was out with him, both as a small boy before I carried a gun and later on when we shot together, extending altogether over twenty years, I could never recall to memory his having missed anything he fired at. No doubt the number of shots got daily were not very many, but everything Brady fired at he killed, ofttimes while smoking his pipe. He was a wonderfully good walker, and first rate to train dogs and hunters, while no man could ride better to hounds. He tied flies beautifully and could fish well. He was a capital groom, and knew more about farriery than many veterinary surgeons. With all these outdoor accomplishments, he was a good indoor servant, and served our family for forty years. 
Many year's ago Brady and I were after grouse over old Blackstairs and, smoking at the time, an old cock unexpectedly got up. My pipe was in the right side of my mouth, so the gun sent it flying, splintering two of my teeth, and I missed the grouse, while Brady wiped my eye ! Never since, although always a heavy smoker, have I smoked a pipe from that side of my mouth.

To schedule the marvellous feats of shooting which $I$ have recorded is but right and proper. I therefore give a table of

Notable Bags of Gaje made ix Old and Recent Thues.

\begin{tabular}{|c|c|c|c|c|}
\hline Iear. & Head. & Days. & Guns. & Remarks. \\
\hline $\begin{array}{c}\text { PARTRIDGE- } \\
1740 \\
1858 \\
\text { 1959 } \\
1569 \\
, " \\
1976 \\
1855 \\
1854 \\
1855 \\
,, \\
.,\end{array}$ & $\begin{array}{r} \pm 0 \text { to } \\
2,155 \\
628 \\
664 \\
551 \\
615 \\
1,940 \\
2,531 \\
501 \\
1,5 \pm 0 \\
556 \\
6,509 \\
3,392\end{array}$ & $\begin{array}{l}4 \\
1 \\
1 \\
1 \\
1 \\
4 \\
1 \\
1 \\
4 \\
1 \\
15 \\
4\end{array}$ & $\begin{array}{r}1 \\
5 \\
8 \\
8 \\
11 \\
11 \\
9 \\
4 \\
3 \\
6 \\
3 \\
3 \\
10\end{array}$ & $\begin{array}{l}\text { Over dogs. } \\
\text { Driving. } \\
\text { Walking in line. } \\
\text { Driving or walking } \\
\text { in line. }\end{array}$ \\
\hline $\begin{array}{c}\text { GrotsE- } \\
1872 \\
, " \\
\text { Not giren. } \\
\text {," }\end{array}$ & $\begin{array}{l}7,967 \\
2,626 \\
2,012 \\
2,626 \\
2,200 \\
2,000\end{array}$ & $\begin{array}{l}6 \\
1 \\
1 \\
1 \\
1 \\
1\end{array}$ & $\begin{array}{c}{ }^{6} \\
\text { Not given. } \\
,, \\
,, \\
,,\end{array}$ & Driving. \\
\hline $\begin{array}{c}\text { R.IBBITS- } \\
1893 \\
,,\end{array}$ & $\begin{array}{l}3.654 \\
5,056\end{array}$ & $\begin{array}{l}1 \\
1\end{array}$ & $\begin{array}{l}9 \\
9\end{array}$ & = \\
\hline $\begin{array}{r}\text { HARES- } \\
1 S 06\end{array}$ & 6,012 & 6 weeks & & On the one estate. \\
\hline $\begin{array}{c}\text { Pheasalits- } \\
1821 \\
1830 \\
1840 \\
1850 \\
1860 \\
1869 \\
1881\end{array}$ & $\begin{array}{r}39 \\
119 \\
778 \\
1,716 \\
2,256 \\
2,697 \\
5,363\end{array}$ & & & $\begin{array}{l}\text { Totals shot in each } \\
\text { season over an estate } \\
\text { in Norfolk of } 10,000 \\
\text { acres, showing the } \\
\text { steady increase which } \\
\text { has taken place. }\end{array}$ \\
\hline
\end{tabular}


MIXED BaGS-

\begin{tabular}{|c|c|c|c|c|c|c|c|c|}
\hline Year. & Partridge. & Pheasants. & Hares. & Rabbits. & Various. & Days. & Guns. & Total. \\
\hline 1793 & 1,349 & 262 & 358 & 一 & - & season & - & 1,969 \\
\hline 1800 & 3,865 & 355 & $85 \check{4}$ & - & - & season & - & 5,074 \\
\hline 1809 & - & 93 & 19 & 10 & 3 & 1 & 6 & 125 卜 \\
\hline 1810 & - & 110 & 96 & 63 & 6 & 1 & 10 & 275 \\
\hline 1811 & 506 & 429 & 177 & - & - & 6 & 3 & 1,112 \\
\hline 1818 & 1,711 & 1,227 & 3,176 & - & - & season & - & 6,114 \\
\hline 1861 & - & 2,341 & 366 & 457 & 39 & 2 & $13 \frac{1}{2}$ & 3,203 \\
\hline 1864 & - & 4,045 & 860 & 3,902 & 93 & 4 & $13^{2}$ & $\mathrm{~S}, 900$ \\
\hline 1850 & & See page & $246 \mathrm{for}$ & particul & lars. & & & $76, \pm 74$ \\
\hline 1882 & - & 5,543 & 1,250 & - & $881^{*}$ & 5 & 6 & 7,674 \\
\hline 1892 & 103 & 3,567 & 464 & 473 & 56 & 3 & 8 & 4,663 \\
\hline ," & - & 2,725 & - & - & 81 & 2 & 7 & 2,806 \\
\hline
\end{tabular}

* Ircluding 440 wild duck.

t Best one day's record up to then.

\section{INDIVIDUAL SHOOTING.}

$\left.\begin{array}{c}1798 \\ \text { to }\end{array}\right\}$ Lord Malmesbury $\ldots \ldots$... $\ldots . \quad \ldots 38,475$ various game.

1826. Mr. J. Sidney Tharp $\quad \ldots \quad \ldots \quad \ldots$... 99 partridge, with 1 gun

1871. Maharajah Duleep Singh $\quad \ldots \quad \ldots \quad 440$ grouse in 1 day.

1872. Sir F. Mfilbank ... $\ldots . \quad \ldots \quad \ldots \quad \ldots 2,199$ grouse in 6 days.

1876. Maharajah Duleep Singh $\quad \ldots \quad \ldots \quad 780$ partridge in 1 day.

1885. Mr. Gurney Buxton... $\quad \ldots \quad \ldots . . . .4 .475$ partridge in 4 days.

„, Sir Victor Brooke, Bart. $\quad$... ... 740 rabbits in 1 day.

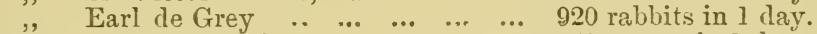

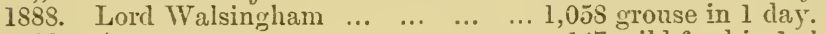

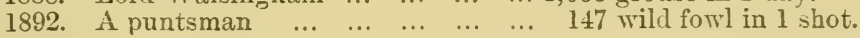

From what I have recorded of myself as a fisherman and shooter, it is plain I have not had experierce in big fishings or with extensive shootings. Moreover, shooting has so changed in its system since I engaged to any extent in it, I confess $I$ do not feel as confident in dealing with it as $I$ do with hunting, racing and other sports. Of course there are hundreds of men who have seen a vast deal more of hunting and racing than I have, but I think for a considerable number of years I saw in both as high-class sport as most men; I was therefore able, uvassisted, to deal with them. Entering, as I am now about to do, upon a treatise on big shootings, and calculating what is spent upon them and upon fishing, I have had to get some assistance from others.

The gentlemen who helped me bave had a life-long experience of the very best deer-stalking, game-shooting of all sorts, and salmon-fishing, they therefore know all about them, and having taken a great deal of pains to put mo right, I may fearlessly lay the following statement before the public. The undertaking is infinitely more difficult and complicated than the others, but I shall follow my precedent and keep figures below rather than above tie correct amount. 
I take for my basis the tables which are given by Mr. Watson Lyall in his Sportsman's Guide for October, 1892, and shall proceed systematically and deal with matters in detail.

Mr. Lyall treats only with the shooting and fishing in Scotland, but does so in very comprehensive style. In his tables he sets forth the name of the shooting and fishing, proprietors, tenants or occupiers, and the rent.

In a compilation such as his it would be quite impossible to obtain complete information, doubtless this is the reason why so many blanks are left in the rent column, although in nearly every instance the name of the tenant or occupier is given. We may also take it for granted there are some shootings and fishings of which no return has been made, and therefore they are not mentioned. The print used in the book is very small and in two or three instances a figure has been "dropped." Making, however, all due allowances, the following will be found to be a pretty accurate analysis :-

\section{TABLE of Scotch SHootiNGS.}

\begin{tabular}{|c|c|c|}
\hline \multirow[b]{2}{*}{ 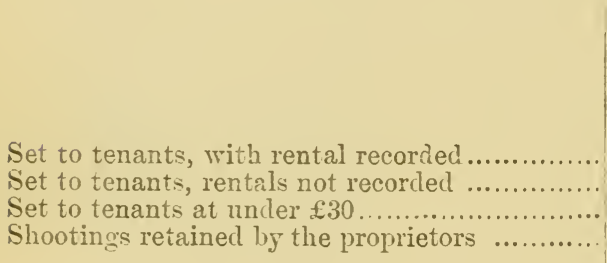 } & $\begin{array}{l}\text { Number of } \\
\text { Shootings. }\end{array}$ & Rental. \\
\hline & $\begin{array}{l}1,450 \\
698 \\
1,000^{*} \\
1,129\end{array}$ & $\begin{array}{c}£ 492,500 \\
237,300 \dagger \\
20,300 \\
\text { Not estimated. }\end{array}$ \\
\hline Total ................ & 4,27 & $£ 750,100$ \\
\hline $\begin{array}{l}\text { Ior round numbers, and for what may not have } \\
\text { been returned, we will call them .............. }\end{array}$ & 4,300 & $£ 757,000$ \\
\hline
\end{tabular}

In their proprietor.' occupation are 1,129 shootings-say they, on an average, are of the sam extent as are those let to tecants, consequently they require the sam? outlay. If I were to charge these with rent at same rate the amount would exceed $£ 334,000$, and they would not be parted with for half a million.

Unlike Irish shootings small shootings in Scotland do not, as a rule, require keepers or watchers-the shepherds do all that is needful. Upon extensive deer-forests several men have to be permanently employed for various duties, particularly to feed the deer in hard weather; likewise on large moors men must be kept to kill vermin, attend the dogs, prevent poaching, etc., etc. Leaving out the 1,000 small shootings and taking the larger, one with the other, we may allocate to each one keeper and two assistants, with wages respectively 
of $20 \mathrm{~s}$. and 15s. a week. During the first six weeks of the shooting, and at other times during the season, additional gillies have to be employed, their wages being 25s. to $30 \mathrm{~s}$. a week. I average their number at two.

Thus we would have for the

Annual Expenditure in Wages,

3,300 keepers, at 20 s. a week........................... $£ 171,600$

6,600 assistants, at 15s. , , ........................ 257,400

6,600 gillies for six weeks, at 25s. a week ............. 49,500

Total, 16,500 men ................... $\overline{£ 478,500}$

To the 3,300 shootings which are either let to tenants or are in the occupstion of the proprietors, there would be invited during the first six weeks a great number of guests. Of necessity they come in relays. Say three at a time are invited, and that there are four relays, we would then have twelve individual guests to each shooting. That would give us a total of 39,600 , most of whom have to travel long distances to the houses of their hosts. Put down to each $£ 10$ as his expenses of travelling, ammunition, and gratuities, we would arrive at $£ 396,000$ as the sum laid out by the guests, and this does not include the expenses of wives and daughters who are often invited.

We now come to deal with the "Shootings under £30." As seen in the table I have given, they total about $£ 20,300$, which I divide into 1,000 shootings. To each of these two friends go for a fortnight's shoot. They, almost to a man, have to put up at an hotel, the nearest to their shooting. From the time they leave home until they return these young fellows will each have had to pay daily at least 25s. to cover travelling, hotel-bills, ammunition, gratuities, and other expenses. Therefore, from gentlemen who take the small shootings we have, in a fortnight, an expenditure of $£ 35,000$. Their rents are included in the gøneral rental already given.

Dogs are used in great numbers over nearly all the moors in Scotland. It is only on very few where they are not a necessity early in the season. I shall, however, allot only six dogs to each of the large shootings, and two to exch of those under £30. That gives us 21,800 dogs. They are attended to by the assistants, but to foed during, say, four weeks, they will cost $1 \mathrm{~s}$. $6 \mathrm{u}$. each per week. That comes to, say, $£ 6,500$. Of course, nearly all the dogs come from England and return there for the autumn and winter shooting.

The shepherds are a very important factor in the maintenance of a grouse moor. Lucky it is that as a class the Scotch shepherds are exceedingly loyal, well-disposed men, for in their power lies a great deal towards rendering a season good or bad. Constantly on the moors attending their flocks, they without extra trouble do good service to the owner or lessee, and for this they get gratuities in some shape or other. There are no shepherds on the deer forests, but upon some of the extensive grouse-shootings there are many. I shall therefore put down three shepherds to each of the large and one to the small shootings, and that they get in donations 20 s. per annum. That totals up rc, say, $£ 11,000$ for the shepherds. 
A lot of money is spent upon the hire of ponies to convey men to the shooting, carry the game, luncheon, etc. These are supplied generally by the gillies, and they get about 3s. a day for each pony. I estimate the sum at $£ 10,000$, and include it in the expenses of the guests.

I now come to treat with the salmon fishing of Scotland.

From the same source as I took my statistics of shootings I compile the following

Table of Scotch Salmon Fishings.

Set to tenants, with rentals recorded .............

Set to tenants, rentals not recorded

Fishings retained by the proprietors

Number of

Fishings.

\begin{tabular}{|c|c}
\hline 276 & $£ 21,510$ \\
210 & $16,380^{*}$ \\
196 & Not estinated. \\
\hline 692 & $£ 37,890$ \\
\hline 690 & $£ 38,500$ \\
\hline
\end{tabular}

For round numbers, and for what may not have been returned, we will call them ......

* Calculated at sane average as the recorded rentals, say £ૉs.

Retained by the proprietors are 196 fishings. They, we must likewise suppose, are on an average of the same extent as those let to tenants, thus requiring the same annual care and expense. If I charged them with rent it would come to $£ 15,300$ a year, and they would not be given for $£ 20,000$.

To "Net Fishings" Mr. Watson Lyall gives a rental of some $£ 45,780$, but as catching salmon in a net cannot be included in the category of Sport, I eliminate altogether that item.

No doubt some tenants of the grouse moors and deer forests rent, in addition, some of the salmon fisheries. If the shooting and fishing be handy, the latter may be worked upon somewhat cheapor ratio than if it were taken alone. I don't think, however, anything appreciable is sared thereby.

The open time for rods on Scotch fishings varies between January 10 and November 1, but for many reasons, well known and not necessary to mention, some waters are not fished continuously. We may, however, with safety put down six months as the average duration of the season, and that one gillie employed on each water for that time at 15s. a week. That figures up to, say, £13,500. Each of these men will get in tips from guests at least $5 \mathrm{~s}$. a week, or $£ 4,500$, but, like the ponies, that item is included in the expenses.

For salmon fishing alone guests are not invited in numbers at all like those for the shooting; still, a good many come, and they stay longer. Let me put down the very moderate 1 as the number invited at a time to each of the 690 fishings, and that each remains for a month; 
that represents 4,140 visitors to Scotland for the fishing. Their expenditure may be proportionately less than the shooting guests', so I will put it at $£ 20$ each for the month, against $£ 10$ allocated to the shooters for a week or ten days. We then arrive at $£ 82,800$ as the sum spent by the Waltonians.

In round numbers the expenses of the lessee for a season's shooting or fishing in Scotland are equal to the rent he pays.

I shall now, as I did with Hunting and Racing, for the convenience of my readers, tabulate together the

\section{Cost of Shooting and Fishixg ix Scotland.}

\section{Shootixa.}

\begin{tabular}{llllr} 
Rentals of tenants recorded and estirnated & $\ldots$ & $£ 757,000$ \\
Wages of keepers and gillies $\ldots$ & $\ldots$ & $\ldots$ & 478,500 \\
Gratuities to shepherds ... & $\ldots$ & $\ldots$ & $\ldots$ & 11,000 \\
Keep of dogs for four weeks & $\ldots$ & $\ldots$ & $\ldots$ & 6,500 \\
Expenses of guests & $\ldots$ & $\ldots$ & $\ldots$ & 396,000 \\
Do. tenants of small shootings & $\ldots$ & 35,000 \\
\hline
\end{tabular}

Total cost of Shooting in Scotland ... FISHIxG.

Rentals of tenants recorded and estimated ... $£ 38,500$ $\begin{array}{lllllll}\text { Wages of gillies } & \ldots & \ldots & \ldots & \ldots & . . & 13,500\end{array}$ $\begin{array}{llllll}\text { Expenses of guests } & \ldots & \ldots & \ldots & \ldots & 82,800\end{array}$
Total cost of Fishing in Scotland
Grand total cost of Shooting and Fishing in

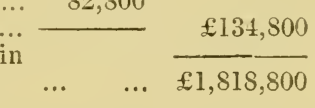
Scotland

This table refers only to Scotch grouse and mixed shooting, deerstalking, and salmon fishing; but it does not include quite all the lowland sport. Neither is trout fishivg included, on which a vast amount is spent in Scotland, but ro rent is charged.

It is to be observed that I have taken my basis from the returns given only by Mr. Watson Lyall. He is but one of a great many agents for the letting of moors and forests, and may have given only the properties on his own books. If, therefore, he has not included all the shootings and fishings in Scotland, of course my estimates are the more under the mark. I think, however, he gives practically them all.

What may be the amount spent all over England, Ireland, and Wales upon grouse, partridge, and pheasant shooting, salmon and trout fishing, not to speak of rabbit, cock, duck, and snipe shooting, I have not so ready a means of calculating as I have had from the statistics giren in the Sportsman's Guide.

However, to carry out my programme I shall cross the border, but I must give an explanatory introduction.

I don't know if the rentals of shootings and fishings outside Scotland figure as much as those paid in Scotland. Perhaps they do not. Partridge-shooting is not as costly sport as grouse-shooting. At the same time enormous rents are paid in Norfolk, Cambridge, and other crack counties; some run up to $5 \mathrm{~s}$. and 6 . an acre. On the other hand very good partridge-shooting can be got elsewhere for $1 \mathrm{~s}$. an acre or less. In Ireland long ago I had ground for next to nothing 
over which ten to fifteen brace in a clay could be bagged easily by an ordinary shot.

Grouse moors in Derbyshire or Yorkshire yield a bird an acre, while those in Scotland do not give more than a bird per ten acres on an average. Then, on a 2,000-acre Yorkshire moor, twenty or thirty men have to be employed on a drive. On a 10,000-acre moor in Scotland only about six gillies are needed. The English drivers would only be employed about six times a year with the grouse, but partriclge-shooting then absorbs them, and after that the covert shooting. In England I have heard it calculated that every 1,500 acres of moor or farm land employs one gamekeeper all the year round. In Scotland 15,000 acres in some places employs only one keeper with one or two assistants permanently. I think, therefore, there can't be much difference between cost in England and cost in Scotland of grouse moors alone.

Twenty thousand acres of good grouse-shooting can at times bo got in Scotland for $£ 500$; however, 10,000 acres for $£ 350$ would be about the average of good Scotch moors.

In England 10,000 acres of good partridge ground would cost at least $£ 500$.

Pheasants are, I think, quite as numerous as grouse; but pheasant shooting is not so generally let to tenants. Home-bred pheasants cost a lot of money, and those bought fully grown to be turned down for a shout cost much more. Grouse cost nothing to rear but only to shoot. Pheasants cost quite as much to shoot as do grouse.

Scotland is only about one-fourth the extent of the whole kingdom, but it is nearly all shooting or fishing ground. The shootivg season lasts there practically for only six or eight weeks, during which the sport is carried on everywhere every day. Over the remainder of the kingdom, although shooting of one sort or other is followed up from August 12 till the end of February, the area is not as generally covered with game preserves as is Scotland, neither is the sport continued so universally. At the same time shooting in England necessitates a vast amount of travelling, and the tips to keepers and carriers are higher than in Scotland.

Shooting nowadays is vastly more expensive than it was formerly. To provide for the big shoots pheasants and partridge have to be homebred and reared in enormous numbers, and to prevent poaching keepers have to be employed wherever game is required. If not strictly preserved every head would be killed, as is the case in freland. When I was a boy we had partridge, quail, hares, and snipe in plenty where not one is to be found now. Snipe, however, have been driven away principally by the drainage of the bogs.

A friend bas lent me for a day or two the Shooting volume of the Badminton Library, and from it I extract the following, which gives further explanation on the subject I am dealing with :-

"It may be said that in England at the present time (1886) fifty to seventy brace of grouse to five or six guns shooting over dogs is an excellent day's sport, and over a hundred brace the exception. In 
England a hundred brace of grouse obtained by driving is a moderate bag, a hundred and fifty to two hundred brace a fair day's sport on a large and well-stocked moor, two hundred and fifty to three hundred and fifty brace a good day, and anything over this very good indeed. It is only in Yorkshire that such large totals as five to seven hundred brace, the result of one day's grouse-driving, are obtained, and the moors on which such sport can be found may almost be counted on the fingers of one hand.

"In Scotland driving is little practised, as the birds are far less numerous and not nearly so strong and wild as in England. Grouse in Scotland lie to dogs long after August 12. In England they certainly will not do so. In the former country from thirty to forty brace of grouse in a day to one or more guns is considered average sport; any. thing approaching a hundred brace unusual.

"In North Wales good bags are made over dogs, especially in the neighbourhood of Bala.

"In Ireland twenty brace is a very successful day, forty brace uncommon, and as far as our experience goes fifty to sixty brace phenomenal, if not, indeed, unheard of.

"Partridge-shooting is in some respects akin to grouse-shooting, and the bags made of these birds are generally very similar in number to those of grouse. But partridges are nowadays hand-reared in many parts."

So far for the shooting. The fishing luckily requires less explanation.

In no part of the kingdom can you find such abundance of good rod salmon-fishing as is to be had in Scotland, although in some parts of England and Wales very good sport is to be had, while at Castleconnel, Ballinahinch, and one or two other places in Ireland, as good salmon-fishing is to be found as in any part of Scotland. It is, however, to the trout we must look to bring up the figures for the estimate of English and Irish fishing. No doubt it totals a very large amount, but I can't fix it. Even so, I doubt if the fishing can hold its own outside Scotland, as does the shooting.

After all this explanatory preamble, and dealing only with the items alluded to, I think I may be considered safe and well within the mark when I estimate the annual expense over all parts of the kingdom outside Scotland during, say, six months' shooting and six months' fishing, at double the amount of their cost in Scotland during its season,

England, in addition, has to be charged with the cost of the dogs. less the sum spent on them in Scotland; and, as will be seen, it comes to a very nice little sum.

As I said, nearly all the dogs used in Scotland are brought from England and return for the other shooting, but there are a vast number which are never brought to Scotland, certainly double. That would make in the kingdom a total for pointers, setters, and retrievers of something like 65,500. As they are laid by for half the year, they can be fed for one shilling a week. To keep up the kennels a tremendous lot of puppies 
have to be bred yearly, and they cost more than the old dogs. But putting the old and young down at the same figure, we come to $£ 340,600$ as the enormous amount spent annually upon the keep of dogs used for shooting. From that, for the purpose of this calculation, has to be deducted the $£ 6,500$ for the keep in Scotland, leaving, say, $£ 334,000$ to be charged to England.

To this has to be added what is called dog tax. In Irelınd we pay only 2 s. $6 \mathrm{~d}$. a dog ; over the rest of the kingdom 7.. $6 \mathrm{~d}$. is paid. Giving to Ireland, say, one-tenth of the dogs, the tax will come to $£ 22,900$.

Putting a value of $£ 2$ on each trained dog all round, the lot would be worth $£ 131,000$, throwing the puppies into the bargain.

Not yet have we nearly accounted for the money which these two grand old sports czuse to be expended. We have still to deal with such trifles as licences, guns, rods, clothing, etc., articles which, of course, must be put to the general account, and before focussing the totals in table form I shall, in further explanation, deal shortly with these items.

As we have 44,870 men, including guests, proprietors, and lessees, going to shoot in Scotland, we may take it that, all over the kingdom, at the very least 150,000 men shoot game. Each must take out a licence ; say, 100,000 at $£ 3,25,000$ at $£ 2$, and 25,000 at $£ 1$. That figures up to $£ 375,000$. I can't form any idea of the number of gamekeepers for whom certificates are taken out. Anyway they will bring the amount up to $£ 400,000$.

Now about the guns. Considering that hundreds of men are possessed of three or four, each of which cost from twenty guineas upwards, and that very few shoot with a gun for which they paid less than $£ 10$, and that every fellow must have one, we may allow a gun and a half to each of the 150,000 shooters, and assess the cost price all round at $£ 13$ a gun; that with the rifles will figure three millions of money, which at 10 per cent. per annum for renewals means $£ 300,000$ a year.

A tidy sum also is spent annually, and permanently invested, in such articles as game bags, baskets, and creels, together with belts, boxes, and bags for the cartridges, "et cetera ceterorum," as Jorrocks says. Say each man has $£ 2$ invested in such like, it totals $£ 300,000$, with $£ 30,000$ for yearly renewals.

We may with all reason put down that 75,000 men fish for salmon. Lots of them bave most expensive rods, with valuable assortments of flies and other minor tackle. Allowing that each, together with his trout gear, has invested $£ 5$ in that stock, we come upon $£ 375,000$ with $£ 37,500$ a year for repairs and renewals. Rod licences will come to about $£ 30,000$, although no licence is required in Scotland to kill salmon with rod and lice.

Shooting and fishing necessitate getting from our tailors, hosiers, and bootmakers a rig specially adapted to the work. Luckily fashion does not require us to dress for the mountain or river in style so costly 
as the covert side, and old clothes being rnore comfortable to walk in than new, a rig for shooting or fishing lasts a long time. Give to each man $£ 10$ worth of these clothes we tally up $£ 1,500,000$, which for wear and tear will cost $£ 225,000$ a year. Of this I shall charge one-fourth to Fishing.

Now to bring all these calculations into a concise form I set forth, in accordance with the foregoing exemplification,

The Totals of the Cost of Shooting and Fishing in the UNITED KingDOM.

\begin{tabular}{|c|c|c|c|}
\hline & Shooting. & Fishing. & Total. \\
\hline Scotland ............. & $\begin{array}{c}£ \\
1,684,000\end{array}$ & $\stackrel{£}{£} 134,800$ & $\begin{array}{c}\mathfrak{f} \\
1,818,800\end{array}$ \\
\hline $\begin{array}{rr}\text { England, Ireland, and Wales. } \\
\text { Shooting ......... } £ 3,368,000 \\
\text { Keep of Dogs... } \\
\text { Dog tax } . . . . . . . & 334,000 \\
22,900\end{array}$ & & & 3004500 \\
\hline $\begin{array}{l}\text { Licences } \ldots \ldots \ldots \ldots \ldots \ldots \ldots \ldots . . . . \\
{ }^{*} \text { Guns, Rods, and Requisites. } \\
{ }^{*} \text { Clothing ........................ }\end{array}$ & $\begin{array}{r}400,000 \\
330,000 \\
168,750\end{array}$ & $\begin{array}{l}30,000 \\
37,500 \\
56,250\end{array}$ & $\begin{array}{l}430,000 \\
367,500 \\
225,000\end{array}$ \\
\hline Grand totals ... & $6,307,650$ & 528,150 & $6,835,800$ \\
\hline
\end{tabular}

Thus do these two great branches of Sport nobly fill their places in the roll of money-circulating mediums.

As hunting is to the farmers, and as racing is to the townsfolk, so are shooting and fishing to the cotter and the labourer. Into the pockets of these poor and hard-worked people over one million and a half of the money spent upon shooting and fishing finds its way. While, bar rents and rail fares, the tradesmen and their workmen get the balance.

To many of those employed the wages and perquisites they receive for caring the preserves and attending sportsmen are their sole support, while to them all, the pay is a very material addition to whatever other means they may have of livelihood.

In addition to their regular wages and monetary gratuities, the gillies and the crofters in Scotland get as perquisites every year nearly all the hinds. These are shot a little before Christmas, and number from 4,500 to 5,000 . Needless to say, this great quantity of good wholesome meat contributes largely to the sustenance of these poor people during the winter.

During the process of making out these abstruse calculations and apportioning the expenditure, I came across some details which I daresay will interest some of my readers; I shall therefore relate them.

* Interest on money invested to provide for repairs, wear and tear.

Ufficial returns of some of the above are made annually, but I had not an opportunity of consulting any of them.-THE AUTHOR. 
The licences and dog-tax total to $£ 453,000$, which, going to the Revenue, relieves the country of so much taxation.

In the item of cartridges there is a marvellous outlay. Giving to each of the 44,800 men who shoot in Scotland, say, only 200 shots in their few days' visit, we gather up 8,960,000 empty cartridge-cases. These when full cost $1 \frac{1}{8} d$. each, so the little item of cartridges shot off in Scotland costs annually $£ 42,000$. Double that for the shooting outside Scotland, plus what may be fired by keepers, schoolboys, and by those who, beyond ammunition, incur no other expense, we can reasonably assess the cost of cartridges used in shooting game at an annual amount of some $£ 130,000$.

In Mr. Lyall's book I find those paying the heaviest rents recorded as follows : Mr. Hamar Bass, for Achnashellach, $£ 4,500$; Lord Hindlip, for Invermark, $£ 3,500$; Baron Schroder, for Glenfeshie, $£ 3,300$; Lord Burton, for Glenquoich, $£ 3,022$. Then come many tenants with rentals of from $£ 1,000$ to $£ 2,500$, and scores of men paying from $£ 500$ to $£ 1,000$ a year for their sport of a month or two. He does not record the rental paid by the American, Mr. Winans, who, for the past seven or eight years, has rented at some $£ 10,000$ a year enormous ranges of moor and forest which he neither shoots himself nor allows anyone else.

From the Sportsman's Giuide I also extract the following information: "The largest shooting rental of any county in Scotland is Inverness-shire, with over $£ 90,000$. Perthshire follows with about $£ 75,000$, then Ross-shire with nearly $£ 60,000$, Argyllshire with about $£ 35,000$, and Aberdeenshire with over $£ 30,000$. The other counties figure at smaller sums.

According to the figures given in the recent report of the Crofter Commission, "there are 109 deer forests in Scotland, having an area of $1,975,000$ acres. The yield of stags from these forests may be fairly taken at about 4,500 each season, and the rental at about $£ 30$ per stag, or $£ 135,000$." That shows a rent per acre of just sixteenpence halfpenny!

From another authority I learn that the average size of the deer forests of Scotland is something under 20,000 acres each. The Duke of Fife's Forest of Mar, in Aberdeenshire, is the largest, extending to over 80,000 acres. Next comes the Black Mount Forest, in Argyllshire, the property of the Marquis of Breadalbane, which is very nearly the same size. The largest holder of afforested land in Scotland is the Duke of Sutherland, who owns 212,658 acres, yielding the comparatively small rental of $£ 6,845$, or $7 \frac{1}{2} d$. per acre !

In proportion to the rent of a moor, the grouse shot cost about twenty shillings a brace. When all other expenses are calculated, each bird will cost the lessee twenty shillings. Pheasants cost quite as much. Likewise with regard to a deer forest. Each stag shot has to be paid for in rent something like $£ 30$, while the other expenditure brings him up to from $£ 50$ to $£ 60$. Every salmon caught in Scotland with rod and line costs the lessee at least $£ 5$. When sent to market 
this excellent food, supplied alone through the means of Sport, does not fetch one-eighth of what it cost to kill, therefore the British public can buy it as cheap as any other fish, flesh, or fowl.

Emanating from land agitators we hear constantly outcries against tracts of land being set apart to grouse moors and deer forests to the exclusion of cotter and crofter tenants. Does it occur to those onesided soothsayers that, with the exception of a very limited area, the land devoted to the grouse and the deer is totally unsuited to cultivation? Except after years of the hardest and most unremunerative labour these wild districts will grow nothing but their own ferns, rushes, and heather. Then, if the same labour be not continued, the land will, in a couple of seasons, revert to its original and natural herbage.

Portions of some of the deer forests might, in the spring and summer, be grazed by sheep and cattle; but would the same rents be paid for the grazing as are paid for the shooting?

Again, we know that, except when wonderfully well cooked, the meat of a wild red deer is often not very good eating. If therefore, deer cannot grow fat and become sweet venison on their highlands, sheep assuredly could not there become good mutton.

This was demonstrated forty or fifty years ago, when there was a general exodus from the Highlands of the cotter and crofter tenantry. Such became a necessity, for there was no other alternative for them but starvation, even if the low rents they paid were to be reduced to nothing. The ground occupied by these poor people had then to be let run into grouse moors and deer forests. Since then it has many hundreds of times been the experience of the landlord to have an extensive sheep-grazing thrown upon his hands by the tenant, and by the rule in Scotland, he had to take over the sheep at the market value of the day. Say the landlord paid $£ 500$ for the sheep, to get interest for his money, and the rent he was paid by the tenant, he should make some $£ 50$ a year out of his sheep-farming, an occupation, with all its worry, he would be very unlikely to undertake. As a grouse moor for this sheep-walk he would get at least $£ 100$ a year rent without any trouble to himself, besides being able to sell off the sheep at the price he paid for them.

Is it therefore to be wondered at that Scotch lairds prefer to see on their properties grouse and deer to sheep and cattle?

The keepers and gillies now employed on the moors and forests are worthy descendants of the old crofters and cottagers, but they are much better off by their weekly wage and are better housed than were their fathers when tenanting the place.

Experience has taught us and history relates that to make money on Highland moors or forests, by either grazing or tillage, is an impossibility, and when such was the case in the past, there is no chance of success in the future.

There are many reasons for this, among them being the following :Most of the deer forests and much of the grouse ground lie over 
mountains, which are from 1,000 to 4,000 feet high, a great deal of which are rocky or heather-clad, and in winter these regions for many months are covered with snow. They are proverbial for thunderstorms, and the consequential rainfalls cause torrents to tear down the steeps and flood the glens. Where the valleys are sheltered and not flooded the snow lies deep, and of ten does not disappear till late in the spring. These wild regions are far removed from populous parts, and connected thereto only by the very worst of roads.

Moreover, while the lowland Scotchman is about the best agriculturist in the world, and prides himself in the vocation, a Highlander hates farming or any work requiring hard labour, and being an inborn sportsman much prefers to earn his livelihood out of shooting and fishing.

No doubt large tracts of land can be found among the shootings which are of a quality excellent for tillage, while here and there are patches varying in small extent which, in olden times, were cultivated. Hills covered with good grass and extending over thousands of acres are sometimes seen which would, under favourable circumstances, afford a profitable undertaking through grazing of sheep and cattle. They, too, were let to tenants for the pasturage, but although the rent charged for the arable land ranged from only 5s. to 15s. an acre, and the grazing sixpence to a shilling an acre, a dead loss was sustained to both farmer and grazier. That being so it is manifest if crofters had the land for nothing nowadays they could not even live out of it.

The rent now paid for deer forests, including of course all the bad as well as the good land, is about 1s. $6 \mathrm{~d}$. an acre, and by reason of employment thereon and the grouse moors the Highlanders are not alone far away better off than they could possibly be by farming, but derive their money from a vocation they much prefer. To substitute farming for shooting would, of course, change for the bad this happy state of affairs, and would raise the rates to double or treble what they are at present, while, of course, the incomes of the landlords would be reduced to a quarter of what they are.

No man with capital, if in his senses, would think of embarking it in farming among the Highland shootings; therefore, to populate these tracts with crofters the Government would have to find the capital, and when found it would, in a few years, be entirely lost. This is in evidence from the miserable state in which the small farmers live in the Highlands who have not steady employment on the shootings and fishings.

Over some of the Highland properties a great deal of employment is given by the proprietors. In making roads, fences, planting trees, and drainage, thousands upon thousands of pounds are expended every year. Some of the territorial owners have individually, within the past twenty years, expended in labour, consequent upon these improvements, amounts varying from $£ 10,000$ to nearly $£ 100,000$.

This vast expenditure was nearly all occasioned by reason of the 
shooting, and were it not that deer and grouse are preserved, and extensive manors reserved for them, the proprietors would have required to lay out tens instead of thousands of puunds among the poor people.

Through the means of the shooting and fishing the rate of wages in the Highlands, during the past twenty or thirty years, has risen 50 to 100 per cent.

To your moors, your mountains, your rivers, and your lakes are you, bonnie Scotland, indebted in a very much greater degree than I have shown in this chapter. Your shootings and your fishings, located as they are amidst the grandest and most beauteous scenery, cause to be spent in the land of heather thousands upon thousands of pounds per annum more than I have figured up.

The sports of the Highlands induce your wealthy lairds and landlords to dwell for many months of the spring, summer, and autumn, in their ancestral homes, and there mix among the tenantry. What these territorial magnates expend within that time, particularly during the grouse-shooting, must be counted only by thousands-a no small item of which is the employment as cooks and housemaids hundreds of your Highland lassies, for, with the exception of ladies' and children's maids, female servants are not usually brought with the familits from England. Besides all this, to her Highland home in favoured Scotland goes our gracious Queen oftener than she does to any of her many residences, and spends thereat more time.

To poor old Ireland our Queen has come but twice during the fiftyfive years of her reign, and upon each visit spent less than a week there! Perhaps her Majesty would have come oftener had we Irish been as peaceable and law-abiding as are the canny Scotch! Albeit, had our Queen paid regular visits to Ireland she would have received there as loyal receptions as have been accorded her in either Scotland or England; and who knows but her gracious presence would have had a soothing influence upon the sympathetic and impressionable Irish?

An article appeared in Land and Water on December 24, 1892, which seems so excellent in principle and detail, moreover it is written upon the lines I have adopted for this book-i.e., the perpetuation of our sports by adjustment of abuses-I shall therefore reproduce it.

"The shooting tenant has become such a recognised institution both in Ingland and Scotland that it is as well that his position should be clearly defined. Everyone who can, and many of those who cannot, afford it, rent shootings not merely for the sport of shcoting, but because it is the right thing to do, and as a rule these persons are equally ignorant of the usages between country gentlemen and their tenants, and of the legal rights of the shooting and farming tenant. It is, we think, one of the most difficult situations a man can be placed in to become the shooting tenant on a large estate; nowhere will his tact and temper suffer greater trials. Unless he gets on with the occupier of the land, his sport will certainly suffer, and if he does get on with 
the occupier, it is often because of the sacrifice of his own sport. The usual thing, we are afraid, is that the shooting tenant does not get on with the farmers. There are, of course, shooting tenants and shooting tenants, but we think that in the majority of cases the farmer is in the right-certainly legally, and often morally as well. Leaving out of sight the few shooting tenants who are real good fellows and true sportsmen, who act on the idea of living and letting live, and who would get on with any farmer, the modern shooting tenants may be divided into two great classes : the one who takes shooting in order to kill a big head of game, and the other who takes shooting hoping to make the place pay, if not wholly, at least to a great extent. Both these classes are undesirable; we hardly know which is the most so, but feel inclined to say, 'A plague on both your houses!' The one is sometimes a snob, the other always a screw, and there is not much to choose in sporting matters between two such persons. It may be that a series of game farms is the most profitable use that land can be put to in these bad times, but then it must be by the occupier of the land, not by a person who has merely a right to sport over it. A Scotch case, bearing on the question of the rights of a sporting tenant to keep an excessive stock of winged game, has just been decided, with the result that such tenant has had to pay damages. There are a number of English cases to the same effect, the question always being one of facthas an excessive stock of game been kept up or not? This often is a difficult question to answer, as the term excessive has different meanings to different minds. Before the Ground Game Act was passed, we have heard occupiers cry out if there were half a dozen rabbits. Now as they have an equal right to the rabbits and hares, the complaint is as to winged game. No one will pretend that in some places an excessive quantity of winged game is not kept up, and it often happens that a tenant looks in a very different light on the head of game his landlord keeps and the head of game the shooting tenant keeps. There can be no doubt of the liability of a man who keeps up such a stock of game, whatever kind it may be, that does damage. It may be that now an action would not lie for the damages done by ground game at the suit of the occupier, as it would be said you have the remedy in your own hands. You could have killed down the hares and rabbits if you pleased, and as you did not do so, you cannot make anyone else liable for your own neglect. But this does not apply to winged game; here the occupier of the land has no right to kill a head of game. If he does he is guilty of an offence, and, therefore, in return for the protection the law has placed round the game, it has made the owner of the game liable for the damage it does. As a rule, this question as to damage arises solely in the case of pheasants. We have never yet heard of an action where it was sought to recover damages for partridges or grouse, but pheasants are a very different matter, and no one who has seen a field of corn near a cover where a number of pheasants are kept but will agree that they both can, and do, do very substantial damage. It 
is exactly the same as turning out a lot of fowls, and the rules as to liability for damage are precisely the same in each case, only the person who kills the fowls would not be guilty of a criminal offence; but the person would be who killed the pheasants. Apart from this distinction, the cases are identical, and as the owner of fowls who injures a neighbour's crops is liable to be sued for the damage his fowls do, or have done, so is the owner of pheasants liable to be sued for whatever injury his birds do or have done the farmer. We do not think that shooting tenants fully recognise this fact or their position. They often think, or act as if they seemed to believe, that the old times had returned; that, as in France before the Revolution, a seigneur was legally entitled to keep what number of pigeons he pleased to eat his tenant's crops, so now the shooting tenant can keep what number of pheasants he pleases, and so he can, with the trifling difference that the seigneur had not to pay for the damage the pigeons did; the shooting tenant has to pay, if the tenant requires it, for the damage done by the pheasants. We do not think that farmers as a rule-of course, there are churls everywhere-are inclined to grumble at a moderate supply of pheasants. We never heard any objection to the birds that. are naturally bred on the place, however numerous they might be, being considered as excessive. Nor do we hear very much grumbling at a moderate supply of handreared birds. What causes the complaint is the modern habit of excessive breeding on one or two fields, from whence the birds stray in a body to the nearest cornfield. The reasons are obvious when we read that an exalted personage is going to honour Lord A. by shooting with him. The guns are carefully picked so that only the best and most reliable shots should be present, so that the bag may be as large as possible; a bad shot is not tolerated however great his rank.

"We confess we have little sympathy with the man, whether the great landowner or the rich sporting tenant, who, to enable him to swagger as to having had the largest bag of the season at his shoots, gets up an abnormal head of pheasants; and we are not sorry to see that the farmers are making a stand. Times are too bad ior the farmer to allow any part of his crop to suffer. If a man will swagger, he mus pay for his swaggering, and we cannot say that the fact of his having do so causes us any regret. We were never among those who ran down covert-shooting, but covert-shooting is one thing, excessive breeding is another ; even to turn out pheasants in moderation is not objectionable if they can fly, and have not been kept for weeks in wire netting; but it is the indiscriminate turning out to kill a big bag that we feel to be so very objectionable, because it is so very unsportsmanlike. The case of the tenant who goes in for making shooting pay is rather different from that of the swaggerer. He will never turn down pheasants unless it pays to do so, and the dread of having to pay for compensation to the farmer will usually deter him. The cost of the pheasants alive is so out of proportion to the value when dead, that the stingy 
man is not likely to make himself liable to much compensation to the farmer. He rather tries to breed as much as possible on the ground, so as to be able to kill off or sell off as large a quantity as he can. But he often makes himself liable to the farmers for acts of sheer meanness. If he can save a sixpence in food, even although thereby his birds do harm to his neighbour, he will do it. If he can by not keeping up his fences, or in any other way, obtain an advantage, he has no regard to the interest of his neighbour. It is not to be feared that he will cause very much complaint, except, perhaps, in this, that he will be unwilling to pay for the damage his servants and friends, or even himself, may do in the pursuit of game. He may be permitted to take care of himself without causing very much harm. But the rich snob is a different and more dangerous person. He seems to increase, and to be likely to increase. So long as it is fashionable to kill a large bag, so long shall we have him with us, and so long as he is patronised by great people, year by year we shall hear more of him. Pheasants are all very well, but if a man wants them he should feed them on his own land at his own cost, and not at the cost of his neighbours."

More than a year after putting together the MS. of this chapter, and while it was in the printers' hands, there appeared in the Daily Telegraph (August 8 and 12, 1893) two articles which I, with great pleasure, reproduce.

The year 1893 was phenomenal for sunshine and little rainfall. Game of all sorts were never more plentiful and seldom as forward as they are now, the near approach of the glorious "Twelfth." In years to come it may therefore be interesting to read what was said in that paper about the prospects of sport and other matters relating to Scotch shootings, which happen to be germane to this chapter :-

The approach of grouse-shooting has been causing the tenants of Scottish sporting domains to troop northward for the past fortnight. The traveller down the Highland line during these days has found his progress impeded at every stage by trains of portentous length, conveying sportsmen to their respective quarters. The time has been, not so very long ago, when, on this same Highland line, business was so slack that the engine-driver has been known to pull-up in order to give a lift to the stray shepherd and his dog whom he might overtake in climbing the slopes of Drumuachdar, or rounding the end of Monadhliath ; but in these days of continuous brakes and corridor carriages, the traveller to the Highland capital finds himself whirled along as swiftly and as comfortably as if he were on his way to the metropolis itself. Not even on the eve of the Twelfth, however, when every station-master and porter is working his hardest to cope with the demands, is the dislocation of traffic so serious as was quite common in these parts a few years ago. The only fear, from the visitors' point of view, is that they may be getting the tag-end of the best season on record. Never, in the memory of the oldest inhabitant, has there been such summer weather in the North. It is not in the least degree paradoxical to say that the summer this year commenced in the middle of spring, and until three weeks ago the weather had shown one unbroken record of sunshine. It has 
been such weather as has pleased everybody except the Highlaud hotelkeeper, who looks upon the Sassenach as a fair subject for spoliation, and who got his house early in order in hopes of making the inust of him. But the visitor did not come any the earlier on that accuunt. Hence the grumbles.

One effect of the unprecedented weather has been that the season is everywhere six weeks earlier than last year. The hills on which you look to have the heather in full bloom in the beginning of September, have been ablaze with purple since the beginning of July. The sportsman has every right to expect a good time.

There is only one thing which may have the effect of chastening his hopes. A party of respectable and worthy gentlemen, headed by a sheriff and two M.P.'s, and called Deer Forest Commissioners, have been going about the northern counties for the last three months, and there are some ardent people who foresee in their proceciings the early extinction of wild sport in the north highlands. They have been commissioned to inquire "whether any, and if so, what lands" appropriated to grazing or sporting purposes in the highlands are capable of being "advantageously occupied by crofters or other small tenants," and in the sweltering heat of June and July, arrayed ofttimes in outlandish costume befitting a Wild West show, they have tramped the heather in search of such land, while startled hinds and whirring grouse have fled in terror at their approach. Whatever the Deer Forest Commissioners may have to recommend, or the Government who appointed them are prepared to carry out, the sportsman may find a grain of consolation in the fact that of the two and a half millions of acres devoted to sporting purposes in the crofter counties the Commission, in the better part of a working year, have not been able to overtake a fourth part, so that he may lay his plans with assurance for some years to come.

In discussing the sporting prospects in the North a sharp distinction must be drawn between the areas devoted to deer forest and the ordinary grouse moors. Most of the deer forests have low ground shootings attached to them, but it is as deer forests that they are organised, and everything is sacrificed to that Royal sport. In Argyle, Inverness, Ross, Sutherland, and Caithness there is not much else in the way of sporting territory except deer forests, and these extend to not far short of two millions of acres lield by about a hundred persons. In the deer forests grouse and other small game are looked upon as a nuisance to be kept under at any cost. At the critical moment of the stalk, the whirr of a grouse, or the rousing of a mountain hare may spoil the result of a day's work by putting the stag on the alert, and the gamekeeper, when he falls in with them, shows them no mercy. For the same reason the eagle, the fox, and other natural enemies of ground game are encouraged to thrive in the forests, and the seclusion of these vast areas is also enabling the marten and the balger, which have been regarded in some places as practically extinct, again to increase in numbers.

For the deer the season has been an exceptionally favourable one. The herds are numerous, and the calves have progressed so well that already they are almost as big as their mothers. The stags at this season of the year have a habit of keeping pretty much to themselves and well out of sight in the high grounds; but they are reported to be in grand condition and unusually well advanced. The sportsman has therefore good reason to expect that his 
average of weights should be a fairly heavy one. The forests have been well let, and one scarcely hears of a single one without a tenant. The rents which are being paid are as high as ever, and as an example may be quoted the deer forest of Auchnashellach, in Western Ross, which Lord. Wimborne has let this season to the Postmaster-General and Mr. A. von André. The forest, one of the finest in the north, extends to 50,000 acres, and the rent is $£ 4,500$ - not a bad sum to pay for a couple of months' shooting, though it is not to be compared with the $£ 10,000$ or more which Mr. W. L. Winans has been paying annually for his Highland moors, in which he has not fired a shot for the last eight years.

The great grouse districts of Scotland are the moors of Perthshire and of Galloway, and there the prospects are of the brightest sort. The moors last year had been shot sparingly and there was a strong brood of healthy birls left on them. The dry spring weather was most favourable for nesting, and the warm and early summer brought on the young birds to such a state of maturity that, by the middle of July, they could scarcely be distinguished from the old grouse. The coveys are large all over. Half a dozen in a covey is not an unusual number, and on some moors they number nine and ten. The reports show all but entire absence of disease, and only on high gronnd and on dry shootings has the lack of moisture had a hurtful influence. The same applies to all kinds of winged game, and similar accounts come in from all the Scottish moors. The only fear is that the weather, which has been so phenomenally brilliant during the earlier part of summer, may not hold.

The article which appeared in the D.T. of "The Twelfth," 1893 , is most interesting, giving, as it does, a charming extract from the diary of a man who is, evidently, a sportsman. With infinite pleasure I put it into my book. I wish I knew his name, so as to record it :-

Happy indeed should be the sportsman who wakes this morning with the knowledge that for a whole month to come keepers, gillies, and dogs will be at his beck and call so soon as it pleases him to tub and breakfast. To a keen man there is no pleasanter sensation than the consciousness that for an absolutely fixed period-a time long enough to insure him against all freaks of the clerk of the weather-he will be at liberty day after day to tramp the moors while sound lungs and tough sinews carry him up hill and down dale in search of the bonnie red grouse. Some "Twelfths" are fine and hot, some fine and cold, some pelt with rain and blow with wind that drives the moisture through and through all protection; other "Twelfths" are foggy, drizzly, and close, and in 1884 there was one special opening day marked by thunderstorms of phenomenal severity and mouruful tragedy, for on that day Lord Lauderdale and his pony were killed by lightning whilst shooting on his moors in Berwickshire. As this sad occurrence took place but a few miles from where I was beginning my campaign against the grouse, the melancholy event is still strongly impressed on my memory. The same storm overtook our party just as we reached the top of a hill 2,000ft. high, and for a long time we laid flat on the heather, at a distance from our guns, literally afraid to stir. Not 300 yards from us a flock of sheep had taken refuge under an overhanging cliff of rock, and, as nine of them were killed by lightning, our precautions and state of "funk" were fully warranted.

On moors where a good stock of birds was left last year, the season commencing to-day will be nearly as good as the great grouse year of 1881 . 
In that year and in the one following I had the good luck to shoot over the same 30,000 acres of moor ; but in the season of ' 82 the bag to our two guns was nearly 350 brace less than that which we put together in the good year; thus it may easily be seen what a great difference favourable weather and a good nesting season makes to a moor. The sport of the first month of season 1881 was so good that a record of it may anuse old grouse-shooters, and perhaps convey information to those younger ones who are hoping to have their turn on the heather. It will be seen that, although we had great sport, we yet had a sufficiency of contretemps and rough weather to make the good days doubly pleasant.

Commencing with August 11, it is recorded that, having left Euston the previous evening, we arrived at a small station on the Highland line about ten o'clock that morning, and then by posting thirty-two miles we reach Ossian Lodge some time in the afternoon, and spend the rest of the day in getting ready for the morrow. Our establishment consisted of my host and myself, butler, cook, housemaid, dairymair, and laundrymaid, three keepers, two gillies, four ponies, six brace of well-broken Gordon setters, three deerhounds, two tame red deer hinds, and a ghost that kindly kept in the background during our stay.

August 12, 1881.-A dark, windy, showery day, with a very bad light, and this, combined with the shaking up in the limited mail and the jolting of the "machine" during the long drive here, which had made us both a little bit "livery," helped to save the lives of a good few wild-rising birds. We agree that neither of us are shooting up to concert pitch, and so we stop early, and come in at about six o'clock with sixty-two and a half brace and two white hares.

13th. - Weather much the same, but we shoot up to our best form, and carry on the war till dusk, and bring home seventy-nine brace.

14th (Sunday).-Glad of a rest. While taking a stroll in the afternoon we came across a small herd of deer standing on the pony track and with them was a splendid royal stag, and though his horns were yet covered with velvet, it was at once arranged that we would be called quite early tomorrow and start off to see if his majesty yet lingered on the grounds of Ossian.

15th.-Called at three o'clock only to find the hills enveloped in a very dense mist, so turned into bed again, and eventually sallied forth about eleven o'clock, and returned with fifty brace taken from Corrie Bran.

16th.-Very, very wet; impossible to shoot. About midday my host spied two stags and five hinds from dining-room window. Started in pursuit, and after an hour's hard crawl the deer "picked us up" just as we were near enough to shoot. I, being nearest the deer, ran forward at best pace and killed one stag and wounded another, and they were both going full tilt at about 130 yards away. We chased the wounded one for over two miles, and got him eventually.

17th. - Torrents of rain. Went out at 4.30, and bagged twenty brace.

18 th and 19th. - Very fine. $118 \frac{1}{2}$ brace and four hares in the two days.

20th.-Fished Loch Fingal, and caught about 200 small trout; the monsters reported to be in the loch would not look at any lure we could offer them.

21st (Sunday). - A lazy day of letter-writing and pottering in general. 
22nd.-On meeting our men in the morning we found all of them half stupid, and evidently not recovered from an over-night drinking bout. Host very angry with the butler for giving them whisky. It turned out, however, that they had saved up their daily flask "allooance" all through the week, and had determined on a Sunday booze. Took good care this did not happen a second time. Sent for head keeper, and got out at midday, and came back with fifty-two brace.

23rd. - We each went different ways for deer that had been seen. Host did not get a shot at a stag, but he spied a fox asleep on a rock, and stalked and killed him without ever waking him. I had two stalks, but was not very well taken up on the first occasion, and had a long shot at a running stag half hidden by rocks, and missed. In the second stalk the stag defeated us before there was a chance of a shot. Did not get dinner till the fashionable hour of 10.30 .

24 th, 25 th, and 26 th. - Three very fine llays, and we bagged 168 brace, seven hares, and fire teal.

27th. - A gale by mid-day, and we came in at three o'clock thoroughly wet through.

28th (Sunday). - Rain and gale.

29th.-Torrents of rain and gale continues, and we hear that during the night our ponies have bolted for shelter. Keepers sent in pursuit, and the strayed ones were eventually found twelve miles away and safely brought back.

30th and 31st.-Gale changed from S.W. to North; bitterly cold, with heavy snow showers. Thirty-nine and a half brace and a stag to host's rifle was all we got in these two days.

September 1.-Host went after deer. I shot fifty-five brace of grouse by myself. Very fine again, and quite hot. During the day we saw an eagle take a grouse, and, having seen it settle, waited for it to take its meal; then stalked it, but we had marked the place badly, and the bird sailed off a long way out of shot.

2nd and 3rd.-Both days fine, and we got 118 brace and two teal.

4th.-The usual Sabbath. We were twenty-four miles from any kirk.

5th.-A splendid still, clear, hot day. So we attacked the ptarmigan and got twenty-one brace, five and a half of grouse, and forty-six hares-a fine day's sport in splendid weather and magnificent scenery.

6th. - We spied a large herd of nearly a hundred deer. I was sent in pursuit, and after a very long and wet stalk an old cock grouse rose and put them all into a trot just as I was preparing to shoot. Fortunately they went off bruadside to me and I marle a good right and left. Both very fat beasts, one a royal, the other an 8-pointer. Reached home at 10.30 , and found host asleep in front of a peat fire. He had bagged forty-seren brace and two teal.

7th and 8th.-Ninety-five and a half brace. Both days fine.

9th.-Attacked ptarmigan again ; but had no sooner reached the top of the hill than down came a dense mist, and, after getting five brace of ptarmigan, two brace of grouse, eighteen hares, and three golden plover, we were forced to give up.

*10th. -Sunday. Dirl a lot of packing up.

* A slight inaccuracy in the date occurs here, and also in the total of bag, but so it appeare 1 in D.T.-[A [THOR.] 
11 th and 12th.-Very, very wet, and the two days yielded but twentyseven brace.

13th. - We stalked. Host got no shot. I got an 8-pointer. Iroquois won the Leger. We both had backed him.

14th.-Finished packing, and with great regret turned our faces London. ways. Our bag was 6 stags, 1,875 grouse, 52 ptarmigan, and 86 various-a total of 2,023 head.

In Chapter XXII. will be found records of the shooting of Mr. Osbaldeston, Captain Ross, and Lord Kennedy, which quite equal any of those given in this chapter.

That Rhedmatism is a dreadful complaint everyone who has suffered from it will readily admit. Right well I know what it is, having been laid up a cripple for nine months with sciatica and able to move about only on two sticks, and for years past I have been subject to terrible attacks of lumbago. At times so helpless was $I$, that had the bed or couch caught fire, I could not have got up. By adopting preventive measures, these attacks are now not nearly as frequent as they were, while the remedies I use cure, in a day or two, the horrible malady. I shall, therefore, for the good of my readers, and sportsmen in particular, tell what I do.

First I may state that I attribute my lumbago to a bad "rick" which I got out hunting many years ago, from the effects of which I was laid up for a long time.

Prevention is better than cure, and being convinced that to keep the back extra warm is the best, I always have on one of Allcock's Porous Plasters, and next my body I wear night and day, round my waist, a band of red flannel ( $I$ don't know why red is better than white, but it is), and also by day I wear outside my vest a body-belt of worsted thickly knitted.

Owing to these precautions, which I adopted only within the last three years, the attacks are less frequent than they were, but my old enemy pays me periodical visits. Directly I feel the first twinge I tackle him. If attacked in the daytime, I get hot salt tied up in a sock clapped to the small of my back, which I keep on in relays, according as it gets cool. Before going to bed I sit in hot water, with plenty of mustard in it, for fifteen or twenty minutes; after that I take off the porous plaster and get my back well rubbed with the following liniment: Spirits of turpentine, $\frac{1}{2}$ oz.; spirits of hartshorn, $\frac{1}{2}$ oz. ; spirits of camphor, $\frac{1}{4} \mathrm{oz}$. ; laudanum, 6 drops. In addition to the red belt, I wear, during the nights of visitation, the worsted belt. I get my back rubbed with the liniment twice a day, and I repeat the hot salt application while the pain continues. I also take two or three glasses of gin a day. Directly I stop the liniment I put on a fresh plaster. By using immediately these strong though simple remedies I hunt the lumbago in a day or two, but if not taken in time he will hold on for a week. I have been told that a dose of cubeb is excellent, but I never tried it. I am certain, 
however, that to dry-rub oneself with a magnetic towel regularly after the matutinal tub, and before getting into bed, is a capital thing. tried it for some time, but being somewhat troublesome I gave it up. To substitute washing soda for mustard in the sit-bath might be very good. I will try it next time.

To cure the Gort is often to kill the man. To assuage the pain so as to allow the patient to obtain a few hours' sleep is a different thing. Now the following process will effect the purpose :-

Into a foot-pan of hot water sufficient to cover the foot put $\frac{1}{4} l b$. of common washing soda, and soak the foot in it for at least half an hour, keeping the heat up by wrapping over with flannel and renewing the hot water. Then stesp flannel in the solution, wring out, and wrap the foot up in the hot damp compress, covering it over with oil-silk and dry flannel.- Then go to sleep.

P.S.-The season of 1893 will be memorable as having been one of the best on record for shooting and the very worst for angling ever known. It was not until the last fortnight that the rivers had water in them sufficient to permit of sport. Enormous bags of grouse were made, while sport in the forests was magnificent, and never were so many exceptionally good heads got. Lord Burton, on Glenquoich, beat all previous record by bringing down a stag with a head of twenty points. The stag was very old and not in good condition, but he had the best head that was ever got in Scotland. In many of the deer forests stalking ceased earlier than usual. From returns given in the papers I find the ten best records as follows:-Major W. H. Walker on Fasnakyle, 185 stags ; Mr. A. W. Merry on Affarick, 136. These two forests being in Mr. Winans' possession, were not shot for several years. Lord Burton on Glenquoich, 112; Mr. T. F. Laycock on Letterewe, 107 ; Lord Tweedmouth on Guisachan, 105 ; Sir John Ramsden on Ardverikie, 92 ; Sir Charles Mordaunt on Memore, 80 ; Mr. F. Shoolbred on Kildermorie, 67 ; Mr. Walter Shoolbred on Wyvis, 57; Mr. Bradley Martin on Balmacaan, 57. Thus we have shot on ten forests 998 stags, for which sport the owners or lessees had to expend every shilling of $£ 55,000$, and probably a great deal more. 


\section{CHAPTER XVI. COURRSING.}

Coursing as a Branch of Sport-Expenditure and Employment-Author's Estimate-Unfair Play and Cruelty-Public Coursing-Sport on a Mountain-Jorrocks's OpinionGambling-Breeding Dogs-Physiological Facts-Mr. W. H. Dewe's Article on Greyhound Breeding-Size and Quality-Weight of the Bitch-Worms-FeedingPhysicking-Mange-Choosing a Brood Bitch-Running Blood-Rearing WhelpsWeaning Them-Feeding Them-Walking-Shoulder Action-Exercise-The FoodPuppy Diseases-Their Teeth-Luck-Exercise Again-Fascinating OccupationTraining Kennels-Warmth and Cleanliness-Medicines-Worms and DistemperBenbow-Kidneys and Liver-Mischief-Results-Additions by the Author-Vermifuge-Rackham's Balls-A Simple Emetic-The Stomach of a Dog-Walking Greyhound Puppies-Not Suitable to Other Breeds-Brainlessness of the GreyhoundHistory of Master McGrath-His Early Days-His Escape-His Coursing CareerMcGrath for the Waterloo-The Lamb for the Liverpool-Visit to the Queen-His Death-His Performances-Dogs he beat-His Measurements-Description-His Grave-Names Given to Dogs-Those given to Greyhounds-Physiognomy and Phrenology-Characteristics of Various Breeds-The Foxhound-Author's EnthusiasmThe other Breeds-The Setter and Pointer-The Author's Opinions of Coursing Justified-The Waterloo of 1893-Records of that Memorable Meeting-FullertonKennel-Companions Left in for The Final-Luck-Colonel North and The WaterlooLcrd Derbyzand The Derby-William Irvine-Muriel's Waterloo.

Coursing, as a branch of our sport, no doubt stands high up in the scale of popularity. To a vast number of people it is a source of great enjoyment, and it can be carried on without any great expenditure of money.

At the same time a large amount is, on the aggregate, expended upon coursing in the year, and keeping up a kennel of greyhounds necessitates a fair share of expenditure and gives a good deal of employment.

Notwithstanding all this I must say I never cared for it, more particularly for public coursing as it is at present generally carried out.

As to the enclosed business, with newly turned-down hares let out one by one from pens like sheep, I dare not trust my pen to deal with it, hating as I do unfair play, and being unable to endure anything which has even a taint of cruelty.

To my mind, coursing as conducted at public meetings, has not a particle of fair play in it. I consider it a very cruel type of amusement, and not sport in its true form. A brace of dogs, in the best condition, are slipped at a fat over-grown hare with its belly full of food, and that on level ground, sometimes covered with thick and perhaps high herbage. The consequence is that after a few turns the poor animal is killed in nearly every course.

If, however, we could hold meetings on the side of a hill or mountain, where the ground would be smooth enough for the dogs, and the scant herbage favourable to the hares running, then I should like to see what a brace of greyhounds could do with the tight, hardy little jack hares which are only to be found on mountains, and where, with the hill in 
their favour and themselves in good condition, they would start with an "odds-on" chance of escaping.

However, all being said, I go a long way with my old friend Jorrocks in what he says of coursing in his famous after-dinner speech on the evening of Doleful's Ball, and I agree with him in thinking that "of all the damned daft devils under the sun a greyhound is the daftest"!

Bar that I believe a good greyhound goes from the slips to his hare at a greater pace than any other animal csn travel at, I see nothing in coursing to commend itself as sport, or anything but a cruel and unfair pastime eminently calculated to produce and encourage gambling.

Racing is uncertain, but coursing is doubly so. A dog to win a 64 dog-stake must win 6 courses, a 32 dog-stake 5 courses, and a 16 dogstake 4 courses. Still, we see fools and partisans taking odds as short as if the lot were slipped in a pack and one course was to decide the winner.

- Holding the opinions I do on coursing I cannet enter upon any of the details, but having begun a chapter on the subject I must fill it up somehow. I shall begin by saying something about the breeding of dogs in general.

The principle of breeding in accordance with physiological doctrine applies equally to all species of animal, as has already been stated in the chapter on the breeding of horses.

One should nerer breed from a bitch which has had her first litter to a dog which is not of her own species, for females of every race are liable to throw back in future conceptions to their first impregnation. In the canine race this is particularly so. If a greyhound bitch bas her first litter to, say, a water dog, she will be liable to throw puppies like water-dogs in every litter she has afterwards, no matter how purely bred her mates. It therefore behoves breeders of hounds and dogs of all sorts to ascertain that the bitch they want to breed from has not had her first litter to any dog other than her own species, and he should be well bred.

I never had any experience with greyhounds, therefore I don't know how they should be treated when puppies or at any other time. I have been told they require a deal more care and attention than other dogs by reason of their want of sense and high spirits. This I readily accept as a fact, for no other species of dog has so small a head in proportion to its body, ergo, so little brains. Their eyes, expressive of frivoiity without a particle of sagacity, and set in a forehead as flat as a hawk's, at once show what harum-scarum creatures they are.

An article upon greyhound breeding appeared some time ago in The County Gentleman, by Mr. W. H. Dewe. It is evident that gentleman knows what he wrote about, and the article being published by a sporting journal of such high standing must be a guarantee for the soundness of the principles. I therefore reproduce $\mathrm{i}^{\text {r, }}$ knowing as I do that some of the treatment (but not all) is good for pointers, setters, and foxhounds. 


\section{Greyhound Breeding.}

The rearing of greyhounds is quite as much an art as the rearing of thoroughbreds. There are two things that must be constantly kept in view -viz., size and quality. In breeding greyhounds it is useless to expect satisfactory results without these qualities, though exceptional instances occasionally occur. Short, undersized dogs rarely distinguish themselves, and a really good strain of blood will invariably be found in all our great and consistent performers. To obtain the first there are many things that help. There is size in the dam, the number of the litter, and the way in which they are reared until they are six months old. I much prefer to breed from a bitch of at least 55lbs. weight-she generally carries her puppies better-although a small bitch from a big stock often throws large whelps, but then there are generally several small ones as well among them. A litter over seven rarely proves a large-sized lot, and to prevent a greater number it is best to cross young bitches with old dogs, and vice versit.

It is perfectly useless to breed from unhealthy bitches, as their whelps are always very delicate, and liable to distemper, yellows, etc. Greyhound bitches that have been run liard, and have had much training, however good, seldom produce their equals, and this may be attributed to their constitutions having been undermined. It stands to reason that a bitch worked hard and fed lightly during the winter, then allowed to have her fill and lie about all the summer when not in training, must injure her liver, etc., which I am positive she transmits to her progeny. Coarse and badly-cooked food also helps the mischief, with the result that worms are transmitted to the whelps. It seems as if few people take the trouble to physic their kennel now and again, and thus drive out these fearful scourges to the dog. Half the diseases of puppyhood may be attributed to these parasites. I once had a whole litter of whelps down with "yellows," and I had them killed and opened. They were literally full of worms, although not six weeks old. Since then I have physicked the brood bitches twice a year, and the whelps (if it appeared necessary) once a week for a month when six weeks old. A little areca-nut and santonine mixed with jalap and a little opium, and given on an empty stomach first thing in the morning, is all that is required. Feed as usual one hour and a half after. The physic has no ill effects at all on the whelps. It is best, therefore, in procuring brood bitches to know their antecedents. If possible have them in your own hands from the time they are whelps, and keep them specially for the purpose. Of course, putting them by is very risky. The litter may not be a success as a running lot, and constantly the bitch comes in season wrong, and is useless for years. Never breed from a bitch that has had mange badly, as her whelps will always be subject to heat of blood.

In choosing the brood bitch always carefully examine her dam's pedigree. It is most important the dams of both father and mother should be nailers, and this is a great help to success. So many exemplifications of the above fact are to be seen in the best running blood of the present day. Look at the Gallant Foe blood reproduced in Fullerton; the Annie Macplerson blood, the Terrific and Hush; Stargazing II. in Herschel; the Ruby and Lady Lizzie, and many more that could be mentioned.

With regard to the rearing of whelps, however, this fact must always be before the breeder, that his whelps must never stand still. The best of food 
must be given, and that often. Directly the bitch has pupped down a dose of castor oil should be given her. I generally give two tablespoonfuls of warm oil directly the first puppy makes its appearance, and invariably find it assists the bitch, also thoroughly cleanses her. After two days on slops, which must be judiciously regulated-viz., if a small litter, and the bitch. has much milk, little liquid food should be given; if the reverse, give as much milk and broth as she will take-feed the bitch three times a day plentifully, bread and milk morning and evening, and a good dinner of meal, meat, and broth at midday. Fed thus a good-sized bitch will rear seven whelps with ease, but would of course manage a smaller number better. At three weeks old whelps will generally begin to lap warm milk from a sancer. Let then take a little (sweetened with sugar) twice a day at first, and in. crease to four times a day, when, if they feed readily, begin to thicken the milk with flour, and feed five times a day, taking away the bitch from early morning until evening. Begin weaning at about four weeks old, and take the bitch away altogether at six weeks. In this way the whelps do not miss their mother or fall away, losing the puppy fat which it takes months to recover. I am certain that during this period the size and strength of the greyhound is to a great extent made or marred.

Directly you have weaned your whelps put them into the largest and airiest kennel you have, taking care not to put them too thick-in fact, the fewer together the better. They should have a nice warm nest to lie in, with fresh straw every day, if necessary twice a day, and be kept rigidly clean; here let them remain uutil at least ten or twelve weeks old. The least change in the weather, if let out, affects them, and they pick up every bit of filth it is possible to get at, which quickly upsets their stomachs. They will take all the exercise that is necessary if given room enough, and will play nearly all day long together. Of course if late whelps they can go ont sooner in the summer weather. Feed at least five times a day. At seven o'clock give milk straight from the cow, nine o'clock bread and milk and water, at twelve o'clock oatmeal porridge and good broth (and after four weeks old with sheep's head in it minced or torn up very small indeed), at. $4 \mathrm{p} . \mathrm{m}$. milk, and at 7.30 oatmeal porridge and broth, taking care to leave enough by them at night, so that they can have a light feed directly they begin to play in the early morning. Little and often prevents pot-bellied whelps, indigestion, hicconghing, etc. When three months old the whelps can go into a field or yard twice a day for an hour each time, and let their feeding be knocked down to four times a day. Increase the exercise as they grow older, and when four months old feed three times a day-bread and milk morning and evening, meat, porridge, and good broth midday. I almost think that whelps do best when they have milk once a day and broth twice, but where cows are kept it makes a considerable difference as to cost.

Many people hold that greyhounds should have their entire liberty, but if you wish to bring saplings to perfection and to extend themselves this is quite a mistake. They grow crooked on their legs if left to lay about the cold, wet ground, and they never have the size and development as when kept in kennel part of the day. If a puppy is born crooked on his legs, then I should send him to walk, as he gets a lot of slow exercise, which keeps his body light, and he lies about instead of galloping, as puppies reared in the way mentioned always do. Young greyhounds should always be marle to 
gallop, as they then use their shoulders. Prppies at walk seldom gallop, but shut up that puppy a bit, and when let loose he will gallop freely, which is so necessary for the full development of his shoulder action. At six months old puppies should be led and taken on the hills, or any strange ground, and let loose. The downs are preferable, as it is necessary to teach them to gallop up and down hill. I always prefer down hill, as it brings the shoulders more into play. This is the period when greyhounds inprove and lengthen out. After they are six months old, twice a day is ample feeding, say morning at eight o'clock, afternoon at three o'clock. About twenty minutes in the home fields after last feed is advisable if the weather will admit.

The food used should be the best oatmeal, bullocks' and sheeps' head broth (with the meat therefrom), and plenty of onions in it. During the winter celery and vegetables and sheep's tripes mixed with the above, well boiled. The latter are light of digestion, nourishing, and inexpensive. Sheep's and bullocks' liver (baked or boiled) is an excellent change, dogs being extremely fond of it, especially when baked, and, if given underdone, it is a good substitute for a mild dose of physic. During the summer months, when you cannot stew vegetables in the broth, have at least two vegetable boils a week. In this way you save chemists' bills, and your pups are always healthy in skin and body. Rice boils are useful for a change, but it is not a good article of diet, being too fattening and binding. Brown bread is also useful, but inclined to be heating if used too freely. Ship biscuits are a capital help, and saving good bread in the mornings and evenings. Of course, they must not be used for very small puppies, but after abuut four months' old, and Spratt's fish and meat biscuits can be given with wonderfully good effect once or twice a week. Change of food is everything for health, and with a little management this can easily be done.

As to puppy diseases, I rarely have distemper in my kennels. Yellows is the bête noir, though I did not have a case until I had bred greyhounds for several years. I have latterly lost many from this awful complaint, and attribute it to having had so many dogs on the same ground, and, in a measure, to the style of feeding. Which, however, is best? Feed high, and rear a magnificent lot of whelps, chancing yellows, which is not infectious, or feed poorly, have a moderate lot, and, if you have distemper, lose many. I prefer the former, and find very few of the puppies succumb to distemper -in fact, for several seasons I knew of hardly a case, becanse they are so strong in constitution. Another important point, they always get over their teething very easily, and the size of their teeth is enormous. Plenty of good hard bones should be given, and also have an old bag or sacking in the field where the whelps play when they are teething. They will invariably tug one against the other, and in this way will soon loosen and extract their puppy teeth.

Luck is a most important factor in rearing greyhounds. You may have the luck to get a dam who will throw nearly all winners, like many I could mention. Then, whatever you do, or however they are reared, they turn out trumps. Fresh ground has much to do with success, also whether you live in a civilized part of the world or not. Rear dogs in the North of England, the Hampshire Downs, or in the wilds of Wales, and they will do well, as they can have free liberty when walking; but wherever there is much traffic 
or many other dogs about, it is impossible to take the pups out without leads, as they chase every :mortal thing they see, and chastisement, especially when little, is most injurious, as it kills all the finest instincts in the greyhound, and destroys their fire and dash. To a certain extent Sussex is well situated, as once on the South Downs, with no flocks of sheep about, you can walk for miles, with the puppies playing about loose. You must, however, have a couple of men-one on either side of the "pack" - to prevent them from getting too far away.

Greyhound rearing is a most fascinating occupation. To see a favourite win a stake or to go well, is ample recompense for many disappointments; while the summer spent in the fields watching the gambols of the youngsters makes many amends for their obstinacy and foolishness when they arrive at more mature age. One thing is certain-if a puppy can get killed it will; therefore too many precautions against casualties cannot be taken. The chances against success in breeding good greyhounds are great. Much depends upon the kennel a puppy goes into for his running career. Injudicious treatment in running or feeding quickly spoils a good one. Some coursers seem to think that a greyhound can run for ever. Others think that they can keep dogs cheaply. A greater fallacy never existed. The best of food and plenty of work is the only recipe for getting to the end of a good stake. The dog most likely to succeed is one who goes into a small kennel. A large kennel is generally fatal unless he is a flyer of the first water, and his trainer finds it out. How few big kennels succeed unless they are split up and put in different parts of the country. The best trainers of the day refuse, however tempting the offers may be, to train more than a certain number. It is impossible also to do more than a fixed number of saplings properly, and I think six to each man kept is ample. It is far better to do a few well than a lot badly, and the success will be much greater.

The only other important points I can bring before a would-be breeder are to spare no expense as to straw and keeping his puppies warm, also keep very clean, with plenty of sawdust on the floors. Directly you notice a puppy not quite the thing, give it a dose of castor oil (with warm milk afterwards), and knock off his feed for a few hours. Then if no better isolate it, and if the case is beyond your knowledge send for your vet at once, as a few hours' delay in many illnesses proves fatal. The less physic puppies have the better, and if healthy, and kept and fed as directed, they will seldom, if ever, require it. I have found Messrs. Holman and Harris' (Exeter) pills for distemper and yellows very useful, and Shaw yers' tonic pills are excellent for dogs not quite the thing. This letter merely deals with practical breeding and rearing of greyhounds, and, therefore, does not touch on their later management.

Another breeding season has passed since I wrote the above, and I find my ideas are practically the same. I have experienced good luck on the whole, and have as grand a lot of whelps as a man need wish to see. Un. fortunately my hest bitch was full of worms, and unable to eradicate them, I lost five out of seven of her whelps at six weeks old. I was sure what was wrong, and told my man to kill one at once and open its inside. He tells me it was "heaved some minutes" by the worms inside. This was a bitch which was the best performer I had, but whose coursing career had been too. 
much for her breeding one. I now give the whelps a worm pill at five weeks old while on the mother, and another at six weeks old a day or two before I take her away, as they will always suckle when you can't get them to feed. I hear muny trainers and others say their whelps had distemper when being weaned. I am sure it is worms. To show how hard it is for a sucking whelp to take distemper, I had one last year reared on a bitch fiom the "Lost Home." I destroyed the bitch when the pup was about four weeks old with the most virulent kind of distemper on her, yet the pup never took it, nor did the litter into which I put her.

I also find that Benbow is very useful to put whelps on their feed, but I do not find it the slightest assistance in getting rid of worms. I give it freely, however, whenever a whelp goes off its feed. I lost a great many whelps last year through yellows, but in the last few cases was wonderfully successful. I think we saved five out of the last seven. The great thing was to make the kidneys work, and also to give a strong liver tonic, and in this way, by diffusing the disease and working it out by other means than the old-fashioned way of purging the liver, we were very successful. No rich food, but as much nourishment to be given as possible. The most avnoying and aggravating part of the business is the persistent way in which greyhounds try to kill themselves. Leave a door open and they gallop straight for the most dangerous places. Let them loose in a field, and they gallop into one another and do all they know to break their own or one another's necks, and if one does go wrong you may be sure it's the best, not the worst. However, there are many worse amusements than sitting in a field of three or four acres, and watching the youngsters play during this splendid weather.

I may add to the foregoing-from long experience of my own-that as a VERMIFUGE-or a preventive of worms would perhaps be the better term-nothing is better than the skin of any furred animal, such as the rat, rabbit, or hare, chopped up raw in the dogs' mess.

Messrs. Rackbam, chemists, of Norwich, supply dog medicines which I found wonderfully efficacious, notably their balls for DISTEMIPER, and those for YeLLows.

Nearly every ailment a dog is subject to proceeds from his stomach, and an emetic, if given in the early stage, generally prevents bad consequences; therefore, the moment a dog seems to be ill give him an EMETIC of butter and salt. The quantity, of course, is to be regulated according to his age and size.

I don't know anything about greyhounds being sent to the country to walk, but I do know that pointers, setters, foxhounds, and even terrier puppies, if not sent to the country, seldom turn out satisfactory. They are far more likely to get crooked if kept in the kennel while they are young, than if they be allowed to enjoy the freedom of a farmer's home.

The breeds I refer to are not so brainless as greyhounds. They have too much sagacity to try conclusions between their heads and a stone wall, overloaded though they invariably are with jouthful impetuosity quite equal to that of the long tails. 
Bred by one of my greatest friends, and claiming as I do the famous Master McGrath as my own county dog, I shall give a short history of the best greyhound that ever coursed in public, some portion of which was never published before. His sire was Mr. Douglas' Dervock, his dam Lord Lurgan's Lady Sarah, and he was whelped at Colligan on February 16, 1866. His brothers and sisters were Master McFaddin, Master Herne, Lady Meta, and Lady McCarthy.

Mr. James Galwey of Colligan was at that time the coursing confederate of Lord Lurgan, and being a first-class judge of greyhounds, their breeding, and their work, he looked after the kennel while the nominations ran in his lordship's name.

The dogs had "Master" and the bitches "Lady" as a prefix to their names, which were usually taken from the family who walked them.

Master McGrath was sent to walk with Mrs. McGrath, who lived between Colligan and Dungarvan in Co. Waterford. Her son Johnaie and the puppy soon became the greatest friends; it was the delight of the lad to have the $\mathrm{dog}$ held at one end of a large field, which was intersected by a wide stream, while he went to the other end the dog was then let go and ran at his best pace to the boy, jumping the stream in his stride. To this early training the Master owed much of his future prowess over Altcar, for he there took the drains without hesitation, gaining several lengths, and more than once actually caught his hare in the jump.

When the puppies returned from walk the Dervock and Lady Sarah litter did not appear to Mr. Galwey a promising lot, so he gave orders to have them sent as a present to some young gentlemen in the neighbourhood, who were home for the holidays. Tom Hennessy, who then cared the Colligan greyhounds, luckily thought better of the puppies, so he kept them and sent otbers to the schoolboys.

Next time Mr. Galwey saw the saplings he was astonished with their improvement, and upon trying them found they were most promising, while Master McGrath showed at once extraordinary powers.

His first essay before the public was in October, '67, for the Visitors' Cup at the Lurgan Meeting for thirty-two puppies, which he won. Within a week he divided the Moneyglass Purse for thirty-two puppies at the Creagh Metting with his kennel companion Master Nathaniel showing splendid form. He next won the Waterloo Cup of ' 68 , his performance being so truly excellent as to tamp him a greyhound whose equal it is the fortune of few owners to breed in a lifetime. Well he earned his fame, for although a puppy he beat for that stake such clinking good greyhounds as Belle of Scotland, Kalista, Marionette, Brigade, Lobelia, and Cock Robin.

He was then put by till the following October, when, on his own ground, he had no difficulty in finding his way to the end of the Brownlow Cup, which he divided with Mr. E. W. Stocker's Sir William. L- rd Lurgan, like a sportsman, would not run it off against 
a visitor to his own meeting, and handsomely presented the cup to the Englishman. McGrath was then looked upon as invincible, and was freely backed for the next Waterloo at 6 to 1 .

He was the model of a greyhound when he appeared at Altcar the following February, and he was slipped for the first round a strong favourite. When in the last four, 6 to 4 was absolutely laid on him against the field, which comprised Lobelia, Bab-at-the-Bowster, and Ghillie Callum, all of whom he bowled over, and thus won his second Waterloo.

The great dog was not again asked to run in public till the following anniversary. Money was piled on him at 3 to 1 for the Waterloo of 1870 , scarcely anything else getting substantial support, and of course he was again favourite.

The night before some scoundrel, paid well, no doubt, by still greater ruffians, got at the dog and drugged him. Johnnie Walshe, his trainer, had ample evidence of this in the piece of liver he found beside the dog early next morning. The consequence of this villainy was that McGrath went down pointless to the moderate Lady Lyon in the first round.

Lord Lurgan naturally felt greatly annoyed, and resolved never again to run the dog. However, in the following September he put him through the mill in a trial at home, and having disposed of all the private tackle with ease, his lordship slipped him for the Brownlow Cup in the next month. Through it, for the three days, he showed quite as good form, pluck, and killing powers as ever, and won the stake, beating such cracks as Smuggler and Fritz. Accordingly, the now old dog was put in training for his fourth Waterloo, and again was he made favourite, but at longer odds than previously.

Some weeks before the day, Master Ronald and Lady Grafton, most excellent puppies of Lord Lurgan's, and the best in his kennel, were selected as the trying tackle for McGrath, but he cleared them out with consummate ease. No secret was made of the result, so Ireland got on to a man. Not so the English, who went for Bendimere, Smuggler, Countryman, and Pretender, believing it to be out of the power of an old dog to beat such slashers. Still the Master was second favourite to Bendimere the night of the draw. Time soon told its tale, and although the little black had, in this Waterloo, once or twice luck on his side, he ran in simply magnificent form, no one attempting to dispute his right to any of the courses.

When Wilkinson, then a very young man, put into the slips for the "decider" of 1871 Mr. Punchard's Pretender and Lord Lurgan's Master McGrath, never before or since was there such intense excitement on Lord Sefton's plains, and probably there never will be again. Waiting for a good hare, Wilkinson delivered his dogs to a long and splendid slip. Amidst profound silence the cracks raced head and head for sixty yards, when McGrath drew to the front, and, well clear of the fawn, shot like a flash of lightning into his game, effecting a brilliant kill without allowing his adversary to gain a single point. Tremendous 
was the cheering over the gallant victory, losers joining with the winners; nor did it cease for half an hour. Thus, out of four essays, did our Irish crack land himself three times the winner of the blue riband of the leash.

A great amount of money went to Ireland ovar this event-more, perhaps, than upon either of the other wins. A small and humble: tradesman in Waterford had, as his first bet, backed (coupled) McGrath to win the Waterloo and The Lamb the Grand National, which double event landed him $£ 1,300$. Directly he got paid he invested for his family, beyond reach of all others, $£ 1,000$ of it, and went, with his wife, a Continental trip on the balance. He never made a bet afterwards! That is what I call a sensible man.

Winning his third Waterloo brought our little dog into such notoriety that a command was graciously given by the Queen that he should visit her at Windsor Castle. This he did soon after, led by his owner, who was then Lord-in-Waiting on Her Majesty. After paying visits to other distinguished personages, he returned home to end his days at the stud.

Marvellous as it may seem, McGrath proved himself still the cream of the Brownlow Kennel, which during all the season of '71 was in tiptop form.

No sooner was it known that at home he was infinitely superior to. Master Nat, then the best puppy in Ireland, than Lord Lurgan's chance for still another blue riband was esteemed second to none, and his nomination for 1872 became, for the fifth year in succession, first favourite, and was freely backed early in December at 7 to 1 . Had the dog lived a few months longer he would have, in all probability, started, for the fourth time, first favourite.

"Dixie," as was his kennel name, appeared a bit dull on December 23, '71, but nothing to alarm Walshe occurred till next morning, when he refused to leave his bench. He rapidly got worse, and despite every attention and medical assistance procurable, the great dog died at Brownlow House Kennels on Sunday, Christmas Eve, 1871.

Sorrow for the gallant dog spread all over Ireland, while absolute grief spoiled the Christmas of every inhabitant of Lurgan.

A post-mortem examination showed he had long suffered from tubercle in the lungs, and that the immediate cause of death was acute pneumonia. A report having gone abroad that he was poisoned, it was pleasing to. hear that there was not the least appearance to justify any suspicion of the sort.

During the career of this wonderful greyhound he appeared in public eight times altogether-at Lurgan three times, when he won the Visitors' Cup as a puppy and the Brownlow Cup twice as an aged deg; four times at Altcar for the Waterloo Cups-three of which he won; and once on the Creagh Meadows, Co. Antrim, where he divided the Moneyglass Purse, winning in all thirty-six publis coursez and losing only one ; whilst he ran but three undecided courses, namely, 
with Belle of Scotland, Sir John, and Eyes of Fire. His first undecided was in his first course for a Waterloo, but he ran it off successfully, whereas both Sir John and Eyes of Fire were drawn from him.

The following will be found a correct list of the greyhounds vanquished by the mighty monarch, and amongst them will be found a long line of celebritie : Polly Pelham, Louie, S. S., Cricket, and What's the Tip, at Lurgan, October, '67 ; Brilliant, Master Frederick, Little Sly, and Warranted, at Creagh, October, '67; Belle of Scotland, Kalista, Marionette, Brigade, Lobelia, and Cock Robin, at Altcar, February, '68; Lady Meta, S. s., Sir John, and Sir William (Lonsdale's), at Lurgan, October, '68 ; Borealis, Hard Lines, Charming May, Randolph, Lobelia, and Bab-at-the-Bowster, at Altcar, February, '69; Old Rosy Maid, Precentor, Double-or-Quits, Smuggler, and Fritz, at Lurgan, October, '70 ; Wharfinger, Eyes of Fire, Rocketer, Letter T, Black Knight, and Pretender, at Altcar, February, '71, suffering defeat alone from Lady Lyon as already described.

I have before me an authentic record of his measurement as taken most carefully just before the Waterloo of 1871 by the late Mr. W. J: Dunbar, editor of the Irish Sportsman, and a prominent member of the Leash. I therefore give the particulars :-

HEAD.-From tip of nose to neck, $9 \frac{1}{2}$ ins. ; girth between eyes and ears, 14ins.; girth of snout, $7 \frac{1}{2}$ ins.; distance between eyes, $2 \frac{1}{4}$ ins. NECK.-Length from joining on of head to shoulders, 9ins.; girth round neck, 133ins. BACK.-From neck to base of tail, 2lins. ; length of tail, 17ins. Intermediate Points.-Length of loin from junction of last rib to hip-bone, 8ins. ; length from hip-bone to socket of thigh joint, 5ins. FORE LEG.-From base of two middle nails to fetlock joint, 2ins. ; from fetlock joint to elbow joint, $12 \frac{1}{4}$ ins. ; thickness of fore leg below the elbow, 6ins. Hixd LEG.-From hock to stifle joint, $9 \frac{3}{4}$ ins. ; from stifle to top of hip-bone, 12ins.; girth of ham part of thigh, 14ins.; thickness of second thigh below stifle, $8 \frac{3}{4}$ ins. BoDy.Girth round depth of chest, $26 \frac{1}{2}$ ins. ; girth round the loins, $17 \frac{1}{4}$ ins. $\mathrm{He}$ stood $26 \frac{1}{2}$ ins., and weighed 54lbs., never rarying $2 \mathrm{lbs}$. whether in or out of condition.

Thus is seen how wonderfully well shaped he was. Although not tall, he was $b i g$, and could cover an immensity of ground in his stride, He displayed extraordinary muscular development, had a plain, short, but honest head, good neck and shoulders, and stood on the very best of legs and feet. His tail was short but remarkably fine; in colour he was black, ticked with white spots and a blaze down the front.

That McGrath was metaphorically a great-hearted dog few will deny. but he was one in reality, for when taken from the carcase at the postmorten examination his heart was found to weigh fifty-four ounces, just double the ordinary size for a dog of his weight.

In every detail of his working he was first-class. Although his tail was shortish he could turn as quickly as his game, while a better killer was never slipped. Except on the one occasion, not alone was he never 
beaten, even in private, but he was never led to his hare, while every hare he was slipped at was killed-generally by himself.

He served at the stud for a few months before his deatb, and, unlike the modern crack Fullerton, proved himself a sire.

He was buried near the kennels in Brownlow Park, and over him stands a bandsome white marble monument to mark the grave of the best greyhound that ever went from slips.

Few people are aware that Master McGrath was descended from a champion thoroughbred English bull-dog, hence his courage and stoutness.

Our forefathers assigned to each species of dog a certain peculiarity of nomenclature, and that style has been perpetuated. For small dogs a short name is generally chosen, while to the larger breeds names of greater import are assigned. To my ear no class of name has such a ring in it as that which has been assigned to foxhounds, particularly when tri-syllabled. For instance, compare Grouse with Gossamer, Ponto with Paragon, Wasp with Warbler, Wag with Warrior, Sting with Statesman, Suap with Senator, Nip with Niobe, Mag with Marigold, and so on. Defend me, however, from some of the names given to greyhounds. Looking over the pedigree of Fullerton I find ancestors of this illustrious dog rejoicing in the names of Bed of Stone, Bab-atthe-Bowster, Bit of Fashion, Repealed Hop Duty, Rocca Chica, while Colonel North's famous dog is descended on the side of both dam and sire from a bitch rejoicing in the crack-jaw name of Racketty Hop-picker !

We can form an opinion of a dog's character from his countenance and bearing quite as well as we can a man's. Moreover, I think the physiognomical cast and phrenological development peculiar to particular breeds indicate the characteristics of each. To explain, I think the following breeds enunciate their proclivities as follows:-

The St. Bernard-supercilious self-conceit, with resultant indolence ; the Mastiff-domineering overbearance, demonstrated at times ; the Great Dane-capability for re-capturing an escaped convict, whom, with close-cropped skull, he so much resembles; the Bulldogsensuality and brutality; the Setter and Pointer-sagacity and truth ; the Spaniel-docility and meditation; the Terrier-energy and devilment; the Greyhound-nervous excitability and mental incapacity ; the Pug and Lap Dog-good-for-nothingness; the Sheep-dog-vivacity and intelligence, with treachery; the Dachshund-with all the points considered bad in other breeds centred in this and constituting its excellence, we plainly see how useless the creatures are; the Bloodhound is an exception to other breeds-his eyes like poached eggs, long beaglelike ears, and drooping jowls betoken docility rather than sanguinary propensities; the long "flue" shows, however, wherein the power lies which makes this breed useful and by which it has got its title.

But now we come to the Foxhound. Whatever difference of opinion there may be with regard to what I have said about the other breeds all must admit, despite bias or prejudice, that we see depicted in the 
English foxhound, in head, face and form, all the higher qualities with none of the lower discernible in the aforesaid breeds. Whether we take him on the flags of his kennel, returning to the benches with hackles up, or in any of his out-of-kennel paces or work, aye, even in riot, $w \theta$ cannot fail to admire the uniform dignity and elegance of mien, with perfect poetry of motion which characterises the wellbred, true-shaped foxhound. As to contrast, the howling and growling, barking and yelping of the others with his medodious tongue is to compare the organ of a grinder to the band of the Guards.

Again, contrast a pack of well-disciplined foxhounds, with sterns up, trotting gaily along to cover on a fine morning, with any congregation of other dogs, whether they be led, loose, or muzzled, and see what a difference there is between them in character, mien, and motion.

Of course the other breeds of dog deport themselves in all becoming manner to the different callings they so nobly and sagaciously fill in useful requirements of man. None of them are, however, required to fulfil as high or important duties as the foxhound, and therefore they need not to be so aristocratic. As long as the proud St. Bernard and stately Mastiff be used to defend a man and his property; the denuded Dane to kill boars and wolves (very useful requirement in England!); the savage Bulldog to fight ; the beautiful Setters and Pointers to find live game; the hardy Spaniels to retrieve it when dead ; the jolly little Terriers to hunt, worry, and kill; the Greyhounds to win Waterloos; the Collie-dcgs to collect sheep (and not to kill game or eat eggs); with the Pugs and Dachshunds to amuse the ladies-nothing more is required of the lot beyond a general and uniform observance of good manners.

Next to the Foxhound in standing of elegance and utility to the sportsman come the different breeds of Setter (particularly the Irish red) and English Pointer, while their extraordinary sagacity in finding game, indicating in beautiful attitude the precise spot the birds are, is in itself unique to a degree. In the eye of the sportsman it is as much to be admired as anything even a foxhound can do. I go farther and say that a brace of dogs, be they setters or pointers, standing properly to a pack or covey of birds, is a finer sight than any which a couple of foxhounds can show us.

I wrote the foregoing many months ago. Since then I have seen the first day's coursing at the Waterloo Meeting of 1893, and as I am just in time before my book goes to print, I shall describe it in justification of what I have said about coursing as sport.

The Press, and all others competent to judge, are consentient that this meeting was the very best that was ever held over Altcar. The stoutness with which the hares ran was the admiration and astonishment of everyone. With very few exceptions the courses were good, while many of them were as fine as ever were seen with greyhounds, and the trimming some of the dogs got will be remembered by them for some time.

Notwithstanding this, every hare slipped at during the three days 
was killed; 63 in the Waterlon Cup, 31 in the Purse, and 15 in the Plate. In all 109 of these game little creatures killed in 109 consecutive courses! This would not have been the result if the hares had had fair play. They would have beaten the dogs many times to the coverts for which they were making, if they had not been cut off by the crowd who were congregated along the bank which intersected the coursing grounds. Several were killed actually amidst the spectators.

Amongst the vast assemblage of people who attended this meeting not one could have admired those magniticent courses more than I did, but to see the gallant little hares, after well gruelling their dogs and still full of running, cut off from the refuge they were well able to gain made me indeed sick and disgusted. I would not go to the meeting on either of the succeeding days, nor shall I ever go again to public coursing where hares won't have a fair and clear run to a refuge, and that up hill.

As the Waterloo Meeting of 1893 is put down as being phenomenal, and as it brought forth, in the Cup, exceptional features, I shall record shortly some of the leading particulars.

Not for ten years did wagering over this event rule as high as it did upon the night of the draw. Colonel North's dog, Fullerton, who had won it for the past three years, and divided with a kennel companion the year before, was favourite at 4 to 1 -the ridiculous price at which he had stood for some weeks previously. Curiously enough, his was the first name drawn from the jug.

In my judgment there was not a dog slipped on the first day who appeared to run as badly as he did. The poor old fellow did not show to advantage even in the first course, which he won, while in his second, when he suffered his first defeat, he seemed quite unable to use himself even before he fell helplessly into a drain. This was explained by Colonel North in a letter to the Press a few days after, wherein he stated that Fullerton sustained a severe injury to his knee early in the first course, and, in the owner's opinion, to that alone is to be attributed his not, for the fourth time, winning the coveted prize.

Be that as it may, it appeared to many, as well as to myself, that it was a pity to send a dog of his age, with such a brilliant record, to compete with young ones.

When Full Captain beat the crack there was a lot of cheering from the bookmakers who made a big haul over the result; but it would have been more seemly and sportsmanlike had they kept silence over the defeat of a good gallant greyhound. Outside that fraternity regret was general, and had Fullerton won the Waterloo of 1893, he would have received an ovation such as was given to Frigate when that equally popular favourite won the Grand National in 1889.

All the favourites except FitzFife were beaten before the third round, and he was beaten in the fourth. The long odds against the winner and runner-up on the night of the draw were 1,000 to 15 and 1,000 to 10 respectively. which does not speak much for the sagacity of our coursing cognoscenti. 
Only four times in the history of the Waterloo Cup have kennel companions been left in for the final, and they occurred within the past nine meetings. Strange also is the fact that the honours were shared equally by two public kennels. Mr. Edward Dent in 1885 with his own bitch, Bit of Fashion, divided with Mr. C. Hibbert's Miss Glendyne. Again in 1889 the same trainer brought out Colonel North's two dogs Fullerton and Troughend, who also divided. In $1887 \mathrm{Herschel}$ for Mr. T. D. Hornby and Greater Scot for Mr. R. F. Gladstone divided, both being trained by Mr. Archibald Coke of Southport.

It remained, however, for the memorable meeting to which I am alluding to have all such records broken, when for the first time devolved upon the one trainer the high honour of leading to the slipper, to run off the deciding course for the Waterloo, two dogs trained by himself. This fell to the lot of the son of the trainer of Herschel and Greater Scot, when in each hand Mr. John Coke led to Bootiman his own dog Character and Mr. T. Baxter's fourth-season dog Button Park. The former won the stake, and, as has been shown, they were both rank outsiders on the night of the draw.

Character, who was whelped in August, '91, ran unsuccessfully four times when a puppy, and never won a stake before he won the blue riband. So little was he thought of two months previously that he could have been bought for $£ 25$, yet he has the best greyhound blood in his veins, including that of Master McGrath.

The trials on Monk's Carr on the first day were pronounced to be the best hitherto seen at Altcar, while those on the second day, over the Engine House Flats, were still better. Those of the concluding day at Lydiate were not so good. The going there, and on the Withins for the last seven courses on the first day, was sloppy and greatly against the hares, but Monk's Carr and the Engine House Meadows afforded the best of going. The attendance has been estimated at the greatest which ever visited Altcar-that on the first day being put down at 30,000 people.

For the information of those who never saw the Waterloo or other such big coursing meeting, I may state that on the first day the crowd had a full view of forty-one courses without having to move from the ore spot. And if hares had come to hand in as great numbers as they did on former occasions, the whole forty-eight courses, which were set down for the day, could have been run off in the same place. The conduct of the spectators at this meeting was beyond all praise, and so were the arrangements except in the one cardinal point-fair play to the hares. From the nature of the ground at Altcar it seems to be an impossibility to provide such, and without it, coursing there cannot be included in the category of, what I call, Sport.

What a rum thing is luck! Men have spent a lifetime striving to win a Waterloo and can't succeed. Those who from their practical experience and thorough knowledge not only of the sport but of how greyhounds should be bred, reared, and trained for an $€$ vent of the kind fail year after year in their endeavours to win the blue riband. Yet Colonel North at 
his first attempt had his two dogs, Fullerton and Troughend, left in to divide the stake in 1889, and the next three years in succession Fullerton. won outright.

No one begrudges this to the gallant Colonel, for he is a downright good sportsman. It only shows what luck is, same as does the Derby, which, despite their many endeavours, was never won by either the nobleman who instituted the race a hundred and fifty years ago or by any of his successors, while it has been won by men the very first time they tried.

The late Mr. William Irvine of Hawick was a man highly cultured and endowed with great refinement of taste. In every phase of life he was poetical, and no companion was more genial. He loved coursing and enjoyed friendly relationship with the leading coursers of the day, with none more than Mr. Robert Jardine of Castlemilk. When that gentleman's bitch Muriel won the Waterloo in 1873 Irvine composed a song to commemorate the event, a copy of which in manuscript he gave me, and as I don't think it ever appeared in print, I now produce it in memory of my very dear friend.

MURIEL's Waterloo Victory.

AIr: "Adieu, a warm, a fond adieu."

Auld Scotland now may raise her pow, Her coursers one and a' git fow,

For twal lang years hae come and gane Sin' she has won "the Waterloo."

But now the thistle brags the rose And shades the shamrock in the vale;

The Cup has gone to Castlemilk And Jardine's fame rings in the gale.

Prince bow'd the knee to Muriel's power, Chamelion flashed her hues in vain,

The haughty Croesus bii the dust, Magenta's laurels strew'd the plain.

The Welshman's Peasant Boy looked grim While touts and backers yell'd his name ;

The sprit-like Muriel bowl'd him out And bore away the wreath of fame.

Down clash'd the Welshman's brimming pot And up went Jardine's spotless silk ;

While shouts of triumph rent the sky To cheer the Laird o' Castlemilk.

Long live the Laird o' Castlemilk! A sportsman good and true is he,

And few will grudge our genial Laird. His beauteous Muriel's victory.

The above when sung by por Irvine in his rich melodious voice was indeed a treat to listen to. 


\section{CHAPTER XVII.}

\section{SPOR'T}

\section{A NATIONAL BENEFACTOR.}

I A M not going to put a heading of reference to this chapter; it is too short to require one, and it is of such importance it should be read from end to end, and the contents indelibly impressed upon the memory.

From this short chapter can be learned the enormous amount of good which, in the most practical manner, is done to our nation by SPORT pure and simple.

In this book I have not dealt with Yachting because I know nothing about it. I am, however, enabled to make an estimate of the amount of money spent upon it, by reason of the courtesy of the Editor of the Field, who gave me figures to start with. He tells me that approximately there are 3,300 craft belonging to members of our various yacht clubs. Their tonnage comes to something like 140,000 tons, the cost of building is about $£ 40$ a ton, and that of maintenance $£ 10$ a ton yearly. That about 8,000 able-bodied seamen are employed during the season at an average of $25 \mathrm{~s}$. a week, they finding themselves in food. The pay to skippers averages about $£ 75$ a year. These estimates refer only to yachts of ordinary construction whether for steam or sailing. In no way do they deal with vessels built for millionaires, nor yet for race yachts of the extraordinary class.

According to these figures, and putting the season at four months, I shall bring out the cost of yachting in a table with the four grand and cardinal branches of sport with which I have already dealt.

When dealing with hunting, I made no allusion to what is expended by gentlemen upon clothing requisite for that sport, nor did I provide for wear and tear of their hunters. These are items of such importance I shall now bring them in. With regard to wear and tear of racehorses, I consider that, as so many of them increase in value to such a wonderful extent, depreciation in the others is thereby fully provided for. Not so with hunters in a gentleman's stable. They seldom sell at a profit, and most of us know they get torn and worn out with marvellous rapidity.

As is shown in a former chapter, the value of our private hunters is $£ 9,900,000$. For wear, tear, and renewal that must be calculated at 15 per cent., therefore it represents $£ 1,485,000$ a year. We have 33,000 hunting men. Say the value of the hunting wardrube of each is $£ 25$, and that to renew it annually costs $£ 10$, we would have invested in hunt toggery $£ 825,000$, which, to keep up, takes $£ 330,000$ a year. 
With this explanation and adding the figures to those which I have already given,

The Cost of our Five Great Sports will work out as FOLLOWS :-

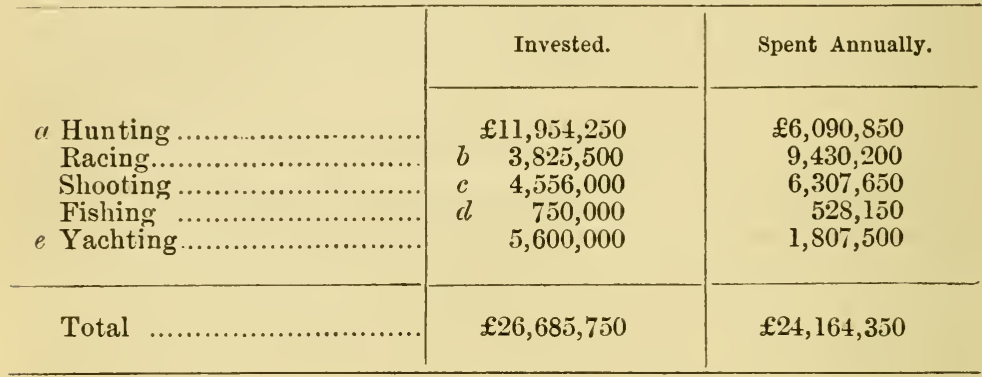

a Hunting-as per page 81 , and items in this chapter.

$b$ Racing-Horses only.

$c$ Shooting-Guns, dogs, requisites, and clothing.

d Fishing-Rods, requisites, and clothing.

$e$ Yachting -as per items in this chapter.

The value of Shootings and Fishings can be fixed at any number of years' purchase which the readers choose.

Were this account to be dealt with according to commercial principle, it should be charged with interest at 10 per cent. on the invested or sunken money, and that would further handicap our sportsmen to the tune of nearly two millions and three-quarters per annum.

To some people, probably, the minute explanation I gave under the respective heads may be wearisome, but to those who are sportsmen I hope they will not be so. Anyway, it is plain to be seen that I have put down nothing in the shape of expenditure which is not absolutely requisite towards carrying out the above branches of sport. Nor is anything provided for extravagance or bad management. To keep within my figures men must know what they are about and exercise economy.

Amongst other items I forgot to include racing caps and jackets. We have about 1,100 men whose colours are often seen, ard at $£ 10$ a year we have expended in the " silks and satins" $£ 11,000$ a year.

The tax on hounds and doys used for shooting, together with game and rod licences, amount to something like $£ 460,000$ a year. To this has to be added what is paid on greyhounds and terriers, the number of which I can't assess. However, we may safely take it that the British ratepayer is relieved annually by the sportsman of nearly half a million taxation.

With the exception of the rents paid for Shootings and Fishings, the remainder of the above colossal sums is spent among our farmers, tradesmen, and in wages. The latter item absorbs fully one quarter, 
and in our racing stables alone goes to pay a number of men and boys, which exceeds, as I said before, the full strength of ten regiments of the line.

The added money given to racing in England and Ireland in 1891 has been shown to have amounted to $£ 617,839$. To this has to be added the cost of the various cups, including, of course, those of Ascot, Goodwood, and Doncaster. These moneys and cups, being premiums, as it were, are not to be added to the cost of racing, but if it had not been for the sport that money would not have been subscribed for or laid out.

I have not dealt with what may be termed "consequential " expenditure-such as houses kept permanently or temporarily, but specially for hunting, racing, shooting, or fishing, nor with entertainment therein of guests invited for the sport. Neither have I provided for the enormous amount laid out at Newmarket and other places upon residences and stabling. Were I to have done so the totals to be brought out. would have been so astounding they would not be credited. I therefore refrained from attempting to enter in to that labyrinth.

To calculating what is spent upon the minor branches of sport and upon our pastimes, I have no time to devote at present. I shall, however, in a cursory manner, refer to some, and to institutions, the offspring of sport.

To play polo regularly and in proper style costs a man as much as to hunt. Four-in-hand and tandem driring, also otter-hunting and coursing cost a lot of money in their way. Cricket, football, and the newly-introduced golf cost the players more or less according to the distances they travel, while the multitudes of people who go weekly to witness matches of their favourite games cause thousands upon thousands to be circulated, even though but a trifle is spent by each individual. The same remark applies to regattas, foot, boat, and cycle races, while the prizes given for these sporting contests total annually an enormous sum.*

Stud farms are numerous in many parts of the country and cause vas s employment. No doubt, with few exceptions, they are got up for commercial speculations; nevertheless, were it not for our hunting and racing there would be no need for such establishments.

Horse and Dog shows are got up as a direct result of Sport. Hotelkeepers, ladies with "rooms to let," and hackney trap drivers, not to speak of railway managers, know full well what sums of money come to them out of these annual réunions. There is more money spent in Dublin during the weeks of the Dog Show in spring, the Horse Show in August, and that given in April jointly to Punchestown and Leopardstown, than there is probably during the rest of the year !

* A leading paper in the spring of 1893 stated that "nearly seven millions sterling are paid annually by spectators as gate money at football matches in Britain !" 
Thus have I shown what a gigantic medium SPorT is for the circulation of money-the vertebræ of our common weal.

To these facts and figures would I draw the attention of those who, through humanitarian or ultra-righteous ideas, are detractors of sport.

To the subject I invite the consideration of Radicals and Socialists. Let these step-political brethren ponder well before they strive to injure the classes who maintain our sports. Let them recognise the fact that, as a universal benefactor in lringing to the poor the rich man's money, A SUBSTITUTE For SPORT CAN NEVER BE FOUND.

These revolutionists should also assure themselves of the fact that never can they devise a system which will carry out the principle of communism as practically and universally as that which has always been adopted by our territorial landlords. Be it $£ 5,000, £ 20,000$, or $£ 100,000$ a year which may be focussed in the one individual, he spends it all among the community. Yet these are the men who are marked for destruction by the Radical, the Socialist, and the Anarchist, and not the andlords alone, but all other moneyed-men, no matter of what class. 


\section{CHAPTER XVIII.}

\section{MANLY GAMES AND EXERCISE.}

A Comparison-"The Noble Art of Self-defence"-Natural Weapons-Wrestling-A Few Remark8-When you Hit, Hit Hard-Tips from Jem Nace-The Fists-Nose TappedBlack Eye-To Box Scientifically-Results-Ill-conditioned Fellows-To go FurtherBullies-Best way to settle Matters-Author's Experience- "Tom Smith" and "Jack Musters"-Masters of Schools-Another Tip-Hints to Young Boxers-Pierse Netterville Barron-Vast Improvement in Manly Games-Archery-Croquet-GymnasticsThe Gloves-Cricket-Football-Handball-Rackets-Lawn Tennis-Cycling-PoloTennis Parties vice Dinner Parties-Cycles v. Horses-James Selby-His Record Beaten-Author's Estimate of Cycling and Cyclers-Marvellous Record-Mr. Wedderburn Webster-"Sportascrapiana"-A Nut to Crack-Hunt Runners-Nickey Conoran-Wonderful Feat-Swimming-Dunmore-Kelly's Rocks-What we Did There-"The Forty-foot"-Author in the Bay of Biscay-Awkward PredicamentSkating-“The City Man"-Thirty Years Ago-His Tastes-His Sons-His ClerksOffice Hours-Holidays-Author a Scamp-Warehousemen-Work, Work-Great Change for the Better-Exhaustive Particulars-What is the Cause ?-A National Calamity-Stock Exchange of London- "On the Flags" of Liverpool-Commercial Buildings of Dublin-Rattling Fine Fellows-Good Sportsmen-A Question-The Answer-The Volunteers-Bank Holidays-Results-Author's Notion-Convincing Evidence-Author Frames an Act of Parliament-Half Holiday Weekly-Whole One Monthly-Beneficial Results-Alfred the Great-The Twenty-four Hours-All Work, no Play-A Mighty Bad Rule-British Trading-Uniform Hours-StrikesRadicals-Early Hours-Advice to Young Gentlemen-A Fact-A Disgraceful Record.

ALthough glorious are the subjects of some of my chapters up to this, most of them, from one cause or another, have been at times somewhat unpleasant to deal with.

Some of the chapters may be likened to vast woodlands where, when the trees were young and before the undergrowth became entangled, good scent lay. But now overhung as the ground is with offshoots and deprived of the sun's influence, it has become in places a slough over which scent lies badly and it is difficult to ride in safety.

We now leave such dark and dismal regions and come to a fine open country wherein there is nothing but oceans of grass and not a covert to be found but that of the ever green gorse!

Yes, we now reach a chapter the subjects of which we cannot find fault with; on the contrary, everything connected with it is to be highly commended, for boxing, athletics, and manly games never stood in this kingdom as high as they do at present, and they are fast progressing. I must not, however, put the car before the horse.

Boxing, I consider, stands first in the category, I therefore begin with it.

For over two centuries this fine old sport has been dubbed the "Noble Art of Self-defence." Rightly it deserves the title, for it is a noble art, and the very best means by which a man can defend himself. The fists are man's natural weapons, and, unlike those wrought, they 
cannot be taken from him and used upon himself, and, as long as his wind lasts, he never runs out of ammunition. They are always ready at hand upon an emergency, no matter how sudden it be. Even if in a man's pockets on a cold night the fists are out in a second, and, like a flash of lightning, can be gent between the eyes of the intruder or obstructionist, to be followed up as fast and effectively as the skill and condition of the owner can send them. As wrote someone: "The fists are the formidable antagonists of the knife, the bludgeon, and the heavy boot."

Boys, from ten years old up, should be taught how to box scientifically. In the first place there can be no better exercise for the body and limbs than a few rounds with the gloves, for if they be merry ones, every thew and sinew will be in use ; the wind is improved and the chest enlarged, while the eye is made quick and sharp.

Gloves should be small and hard. Large ones often stop a welldirected blow, and to have them soft they must be large.

In conjunction with boxing wrestling should also be taught. At times to be able to use one's feet in tripping up, or one's arms in giving a cross buttock, is highly advantageous. A man who can both box and wrestle is indeed an awkward customer to tackle.

They, like so many other accomplishments, cannot be taught on paper. A good master and constant practice, with natural taste for the art, are the only ways by which proficiency can be acquired. There is, therefore, no use in my trying to give a lesson even if I were qualified, which I am not; I may, however, make a few remarks.

Don't hit a man for insufficient cause, but when occasion or provocation requires you to hit another, let there be no half measures adopted. Therefore, never hit till you mean to hurt; so when you hit, hit hard, and let him have it-quick as a flash, and straight from the shoulderright on to whatever portion of his head, face, or body you can land with the most effect and the greatest readiness. Such work generally shortens the businesa, while half measures only prolong it, and what is worth doing at all is worth doing well. A blow is a blow, and in law a silly little tap constitutes an assault, and will count against a man just as much as if he had sent his antagonist flying heels over head.

Above all things, never lose your temper when boxing.

If a man can get well home with a hot one on to the side of the chin of his adversary, there is no better means of instilling into his head the illusion that he has two skulls, and that one is clattering inside the other, while every tooth in his head chatters time thereto. It was Jem Mace gave me that and the following tip, and both are worth taking.

Practise to box equally well with either foot forward, which of course necessitates the corresponding fist being forward. A man who can box so has a decided advantage over the man who can box only in the usual position of left foot and left fist foremost.

The hands should be closed in the natural way with the end joints of the fingers doubled in such a position that they won't get hurt from 
the concussion of the blow; the middle joints should recede from the index to the little finger.
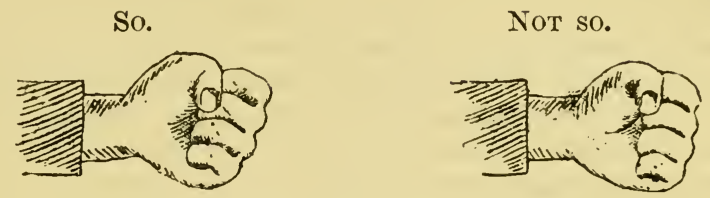

The fists should be kept loosely closed until just going to strike; they should then be clenched like a vice, and the blow driven straight from the shoulder, throwing as much weight into it as possible. While a hard fist will punish better than a soft one, the effect of a blow is regulated by the force with which it is sent from the shoulder and not by the consistency of the fist alone.

When the nose gets tapped, snuff up and don't blow out. The best thing for a black eye is to clap a piece of raw beef to it and keep it there for a couple of hours.

It is all nonsense for some people to say that a knowledge of boxing induces a boy or a man to become quarrelsome and often a bully. Even if such were the result it would not be sufficient reason for his living in ignorance of the best means of defence God has given him. Knowing how to box scientifically has, however, quite the contrary effect with well-conditioned and well-educated men, and this has been demonstrated by thousands of examples where men who were good with their fists never gave offence, and were the very last to get into a row. When in it, of course they knew how to get out of it. I do not allude to ill-conditioned fellows; they are the exception and only prove the rule.

But to go further into the subject. If nearly every man was known to be handy with his fists there would be little or no fighting, for most fellows would know they were likely to get as much as, if not more than, they could give, and the bully, almost always a coward, would be the most sensitive on that point.

If two young fellows are constantly squabbling, or have a serious misunderstanding, the very best way for settling the matter is to have it out with the gloves-by no means with the naked fists. Seconds to each and a referee should be provided, and, if they be boys, they should be of fairly equal height, weight, and age. Unless they are badlydisposed chaps they will most likely be good friends for ever after, even though one may have given the other a sound thrashing.

I know an instance myself where two fellows could never agree, and were always wrangling, making it most unpleasant to those they might be in company with. At my suggestion one day they both peeled off, and at it they went with the bare fists. They certainly gave and took punishment like men, and for some three or four rounds they milled merrily. We then separated them before either had got the best of it, 
although each showed unmistakable evidence of the other's handiwork. They shook hands, and ever since, just five-and-twenty years ago, they have been good friends and allies of each other.

It is well known how the great Thomas Assheton Smith and the equally famous John Musters ("Tom Smith" and "Jack Musters" in hunting history) had, at Eton, one of the greatest battles ever fought there, but for the remainder of their lives the greatest friendship existed between them, which even their rivalry as masters of hounds and as the rery best men to hounds in England of their day was unable to undermine. Hundreds of similar instances could be quoted of lifelong friendship arising out of a fair stand-up fight.

Masters of schools should adopt a similar system among their pupils for settling their disputes; instead of which they punish boys for fighting, no matter how great the provocation may be. Squabbling and wrangling should be severely dealt with, but not a fair fight, fought for sufficient reason.

That excellent periodical Cassell's book of "Sportsand Pastimes" contains what may be considered all the instruction upon boxing which can well be given on paper. I shall, therefore, offer to my young: readers the benefit of it.

\section{Hints to Young Boxers.}

It is a singular fact that the beginner is alnost sure to put himself in an attitude which conbines every possible fault. He plants himself firmly, braces up every muscle, and holds his hands high. Now it is impossible to be too easy and unconstrained, or to let the limbs play too freely. It is only at the moment of striking or parrying that the fist should be clenched tight and the muscles contracted. The left foot should be in advance, with the sole flat on the ground; the right foot about half an ordinary pace in rear, with the heel slightly raised, and the toes in line with the left heel; care being taken not to bring the left foot too far to the right, which would destroy the balance. The knees should be very slightly bent, just as in dancing. And mind carefully that when you advance, the left leg must always step out first; when you retire, the right leg nust step back first. When you move to the left, the right foot takes the pace, the left foot following it. When you move to the right, the left foot is first shifted, then the right. All this is very important, for if the legs and feet get confused, their owner must lose his balance, and become powerless either for attack or defence, and a slight blow will suffice to knock him down. You require to step forwards, backwards, sideways as lightly and quickly as possible, always keeping the right foot in rear of the left. Thus, when you deliver a blow, the whole weight of your body is thrown into it; when you receive one, you give to it, as it were, and much of the force is lost. Or, if you step back very smartly, it falls short altogether, while, your left foot being still in advance, you are ready to step up again at the instant and deliver your return before your opponent can recover himself. The left arm must be in advance, playing backwards and forwarls easily, the fist on about a level with the centre of the chest. The right arm held across the body, but not stifly. Keep the chin down and the mouth shut. If you want to know the 
reason for this last recommendation being printed in italics, you may have your mouth open, just for once, and get somebody to give you a slight tap on the jaw. But you had better take the hint without trying the experiment.

Before leaving the subject I may impart to my readers the advice I got myself nearly forty years ago from one of the greatest friends I ever had, and a splendid exponent of The Art, the late Pierse Netterville Barron, of Waterford: "Kick a cad, snub a snob, beat a bully."

As I have said there has been a vast improvement brought about in manly games during the past quarter of a century, and the youth of to-day have far and away more advantages than were to be had when I was a boy.

Except handball and rackets, we had scarcely any outdoor game in Ireland carried on under recognised rules. Cricket was only then being taken up. Football was played without rules, and consisted in merely kicking the ball to the goal or the shins of the opposite side for opposing its progress.

Beyond what we could do on parallel or horizontal bars, gymnastics were very little practised. Even the bars were not to be found in every playground, and if they were, there was no one to teach us how to perform on them. The "wild cat," therefore, was the extent of our achievements thereon. Boxing we were never taught either, and when a dispute had to be decided by the fists, the performance was nothing but a slogging match in the Ball alley without the least attempt at science. Archery certainly we had, and there was a club of toxophilites in most of our counties, but that can hardly be classed among manly games. We had also the ladylike and innocent croquet, not very scientific or exhilarating either; no doubt if the game was a private match it afforded means for quiet flirtation, while it gave a pretty girl the opportunity of showing what sort of a foot and ankle she had. Archery and croquet are now nearly extinst.

Nowadays, we have public and private gymnasiums in most of our important towns, where men and youths are taught by competent masters to develop their muscles and agility, and to use the gloves properly. Cricket is now as great a favourite in Ireland as ever it was in England, and we have men who can handle the willow with ary Saxon.

Football, too, is played all over the country under regular rules, and there is no game more conducive to manliness. In it, particularly if played under Rugby rules, has to be displayed an amount of courage, endurance, and determined combativeness not required in any other.

Handball and rackets have, I am sorry to say, nearly disappeared in Ireland, which is a pity for they were rattling good games. I can't say I lament the loss of archery and croquet, for they have been succeeded by lawn-tennis and cycling, both being infinitely moreactive, healthy, and useful, and are for ladies the very best outdoor recreation ever yet invented. Cycling, from its pre-eminent utility, has become simply universal as a means of locomotion. To people who could never do 
so before, it affords a facility for travelling and seeing the country at no expense beyond the first cost of the machine.

Polo, although alluded to by me last in the series of manly games, takes the first rank, for it is the game of games, the cream of the cream of summer amusement. In fact, I look upon polo as the connecting link between pastime and sport. It has been introduced into this country only within the last comparatively few years, although a game in India of very ancient origin. From the East it was brought to England by, I think, the 9th Lancers in about 1875. It was not in Ireland when I could have gone in for it, and never do I look on at the grand game without regretting the fact.

Many and great as are the advantages derived from lawn tennis and cycling they, like most new institutions, liave done injury to the old ones. Owing to scarcity of money in Ireland amongst those who formerly gave them, the good old-fashioned dinner-parties began some years ago to disappear, but directly lawn-tennis went to the front the dinner-parties vanished altogether from the country. It was soon found that with sandwiches, tea, and light claret, people could be brought together in social intercourse in much grexter numbers and at a cost of a shilling in the pound as compared with the good dinners and better wines of years before. Pity it was, for at these festive gatherings friends and acquaintances met, and over the mahogany the latter became the former and the former became the faster.

Cycling for its part is interfering greatly with the utility of the horse, and in many places livery stable owners feel the effects greatly.

Yes, truly cycling has driven itself rapidly into a most important position on "the road." There it takes the lead, in every sense of the word, of all other means of locomotion. Even coaches, horsed with the best of cattle, changed every seven or eight miles and driven by the best "whips," cannot hold their own with a good man on a bicycle, whether it be over a short or a long distance. The late James Selby's unparalleled performance with four horses from Piccadilly to Brighton and back in 7 hre. 50mins. has since been beaten upon two or three occasions by bicyclists.

The best record which I have seen was that of Mr. S. F. Edge who, in July, 1890 (evidently to beat Selby's record), started from the White Horse Cellars at 9 a.m. and did the journey from thence to the Ship at Brighton and back in $7 \mathrm{hrs}$. and 3 min., taking only three rests $-8 \mathrm{~min}$., $3 \mathrm{~min}$, and $2 \mathrm{~min}$. This was at the rate of fifteen miles an hour for nearly seven hours, and that, too, without a change.

Selby's fame nevertheless is safe. He will ever be remembered as the prince of coachmen, not alone for this one performance to Brighton and back, but for his well-known skill as a whip all his life. Men may have been able to drive four horses as well, but no man was ever able to drive them better than James Selby. I knew him, and as a tribute to his memory I make these remarks. For the information of my readers, who do not know the particulars of his Brighton feat, I refer them to my chapter on Driving. 
Notwithstanding all that may be said in favour of cycling, I confess I am personally prejudiced against it. Probably it is because I don't like to see an infringement on the prerogative of the horse, or it may be from the fact that one of the worst falls I ever got in my life was from a bicycle, when learning the art of straddling it years ago. Be that as it may, personally I do hate the sight of a cycle, whether it be a "bi" or a "tri." I think a man looks more to disadvantage riding one, no matter how artistic he may be with the pedals, than he could do at any other work he might engage in, bar, perhaps, running after bis hat. The position is ridiculous and the motion is truly absurd.

Why can't the pedalists adopt a better and more upright seat? That contracted chests and round shoulders will be the results of their crooked position I have not the least doubt, and what is worse, they may transmit to their offspring the horrid deformities.

Nevertheless, the records made by bicyclists are wonderful. The twenty-five miles champion race in July, 1890, was won by Mr. F. J. Osmond in less than one hour and fifteen minutes. Out of the eighteen who started in the race, thirteen did the twenty-five miles within the standard time, which was $1 \mathrm{hr} .19$ mins. 50secs. Since then probably that record has been beaten, marvellous as it was.

To raturn to coaching, but as an example of hardihood, I will relate, upon the authority of the Licensed Victuallers' Gazette of May 6, 1890, what occurred as far back as 1809 . A match similar to Jim Selby's was made by Mr. Wedderburn Webster, of the 10th Dragoons, who backed himself for 1,000 guineas to drive a curricle and four from Brighton to London in four hours, and for a similar amount that he would ride the same distance in three hours. Neither match, however, came off, owing to the heavy losses Mr. Webster sustained to Captain Barclay over the latter's celebrated walk of 1,000 miles in 1,000 hours at Newmarket. Now, although these matches were never decided, it is clear that there were men eighty years ago who were considered to be able to accomplish these prodigious feats.

This same Mr. Webster in 1809, at a moment's notice and without any special training whatever, set off to walk from Ipswich to London, a distance of seventy miles, which he backed himself for 500 guineas to do in twenty-four hours. He accomplished sixty-five miles in nineteen hours. He then rested, having five hours to complete the remaining five miles. A week or two later he covered the same distance on his favourite mare Buzzard in four hours and fifty minutes, winning another 500 guineas. Again, on May 25 of same year he rode one of his leaders from Brighton to Westminster (fifty-two miles) in three hours and twentytwo minutes, the wager being 1,000 guineas that he would not do it in three hours and a half. He stopped twice, two minutes on each occasion, during each of which he drank two glasses of port and gave the remainder of the bottle to his horse.

"There were giants in those days." If the young athletes of the present day will but read Sportascrapiana, they will find many such 
feats recorded, and, with all the advantages they have now over the men of old, they may find more than a nut to crack in beating the records of Gecrge Osbaldeston, Edward Budd, Captains Ross and Barclay, or Lord Kennedy.

Long ago, and up to a few years since, many hunts had "runners." These were men deeply imbued with the love of sport, and they at times performed most wonderful feats of pedestrianism. I remember some of them myself with the Tipperary and Curraghmore. They generally wore a cast-off $r \in d$ coat and hunting cap and ran barefooted. They seemed to know every field in the country and every line a fox would take, and marvellous was it how these half-clad, half-fed men would turn up at the end of a long run. Extraordinary are the stories told of them, but none that I ever heard of comes near that which is narrated in Sportascrapiana of one James West, who some sixty years ago was in the habit of running with the Berkeley hounds. $\mathrm{He}$ is accredited with having made in one day "a pretty little run of about a hundred and twenty-six miles!"

Be that performance a fact or a fancy, I shall record a feat of pedestrianism which I know to be a fact. My step-brother, the late Mr. John Richards of Grange, in the County Wexford, had in his employment a gamekeeper named Nickey Conoran. In the year 1855 this man, then nearly fifty years old, had occasion to go to Waterford, which from his house was twenty-four Irish miles. He started at $4 \mathrm{a} . \mathrm{m}$. and walked to New Ross, a distance of nearly twelve miles. There he expected to catch the steamer which plied daily to Waterford and back, but he was late. He then walked to Waterford-twelve miles-did his business there, which nezessitated some two miles; returned by steamer to New Ross, and walked from there to Grange. At the entrance gate, about 9 p.m., he met my brother, who was going in search of his groom who he feared had met with an accident, as he had not returned from Enniscorthy where he had gone with a horse in the morning. Conoran, without a moment's hesitation, joined his master and walked to Enniscorthy, a distance of eight Irish miles. They found the groom all right, and straightway returned to Grange, where they arrived about 2 a.m., Conoran all the way keeping up with my brother, who was a very good walker.

Thus, in the ordinary condition of a cottier tenant, and without the least preparation, did Nickey Conoran, in twenty-two hours, walk some fifty-two Irish miles, which equal sixty-six English. He had no rest, except. an hour and a half while on board the steamer, which gives an average of nearly three miles and a quarter per hour actual walking. $\mathrm{He}$ had no refreshment except a very light dinner in Waterford about 2.0, for nothing could be got in Enniscorthy. The hardy old fellow told me he was not a bit the worse for the walk, and the only inconvenience he suffered was that on the return journey from Enniscorthy, having no matches, he could not get a smoke, and upon going to a house for a light, he found the family wailing over the corpse of an old woman they were "waking," so he bolted without effecting his purpose. 
In none of our manly exercises has more advancement been made of late years than in swimming. In the generation before my own it was little practised in Ireland, nor was it, I think, in England. Beyond having a bathe in hot weather I am afraid our fathers were not over-fond of immersing themselves in water at all; nor was the morning tub considered a necessity to a gentleman in his preparation for the day. Even in my own boyhood lads were not, as a rule, good swimmers, and many could not swim at all, but most of us took our matutinal tub.

There is a village at the opening of Waterford Harbour called Dunmore, and to this charming seasid $\rightarrow$ resort many of us went every summer. "Kelly's Rocks" afforded excellent bathing, and at the lowest ebb tide we could get headers into at least ten feet of water, pure from the sea. A great many young men bathed there daily, and all of course were swimmers, but there were only about half a dozen who were really good ones. There is no doubt these few were very clever in the water. I never saw a feat performed by anjone, not even the Beckwiths, which some of us could not do five-and-twenty years ago. None of us went in for swimming long distances, neither could we swim very fast, but we could do almost anything in or under water-leap-frog, porpoise turning, diving, swimming under water, and numbers of other feats we thought nothing of. A couple of us often jumped in fully dressed with collars and ties, and having our boots laced, all of which we were able to take off in twenty feet of water. I once got my feet tied closely together at the ankles, and my wrists equally so behind my back, and in that hobbled state threw myself into Kelly's hole when the tide was full in. Still, up I came, and by not moving boly or limb my face kept well over the surface for the few minutes I chose to stay in the position. I was perfectly powerless, as may be supposed, and had to be towed ashore. I allude to the event to show how easy it is to keep one's head above water-nothing being required except a little self-reliance. At the same time, a feat of the sort could only be performed in strong deep sea water.

"The side stroke" was only just coming into vogue in my young days, but I never cared for it, and always stuck to the old breast stroke.

There is nothing more useful to learn in the water than how to save a drowning man, and it should be practised as often as possible. To make the task the more realistic, it is requisite that the subject of rescue should do all he can to drown his rescuer. What fun we used to have at that work long ago !

Prastising feats such as some I have alluded to served me well twenty years ago in Waterford Harbour. A sail boat went down under me, and owing to the main sheet having got round my leg I was dragged with her but I was able to liberate myself, some fathoms under water, from the rather awk ward predicament.

Yes, I think few places in Ireland, perhaps not one, could produce 
better swimmers than Dunmore could from, say, 1860 to 1875 . But now lots of seaside places have tip-top aquatic performers, and nearly every boy, not to speak of young man, can swim well. They, too, have games in the water we never had-polo, tug-of-war, \&rc., and splendidly do we see them played, particularly in the "Forty-foot" at Kingstown, where hundreds of young and old men bathe every day in the summer. $\mathrm{Mr}$. Carson, to whom we are indebted for the comfortable accommodation found there, bathes all the year round, showing himself light with a lantern for the operation during the winter!

What a wonderful difference is to be found in the buoyancy of water, of course attributable to its degree of saltness and depth. I was returning home once from Oporto in a cattle steamer bound for London. The Bay of Biscıy was smooth as glass, the day intensely hot, the markets were low, so there was no particular hurry, and there was but one other passenger on board. I therefore asked the skipper, a goodnatured ftllow, to stop the engines and let me have a header off the steamer's side. He demurred at first, fearing I might not be as good in the water as I told him I was; or, if so, that there might be some hungry shark on the look-out for a meal. However, he consented at last, and in I went head foremost. The drop was, I should say, twelve feet, but so strong was the water I did not go more than two feet under. I could tread water with my body as far as the armpits over the surface, while to float was as e ssy as to lie on a sofa. I did not stay in long, however, f $\rightarrow r$ the water was very cold. I forget how deep the captain told me it was, but I think the fathoms represented something like a mile on land.

This long yarn must be wearisome to the reader, but as I considered a prank like that real sport in those days, thinking upon it now is quite on the line of my hunt.

That the British excel all other nations in manly exercise no one can deny, for to us all games and pastimes come easy. None, however, demonstrates the fact clearer than does skating. With only very few days in the year to practise this invigorating pastime, we have, taking them all round, as good performers on the ice as are to be found in any of the countries where skating is the principal means of locomotion. When hard frost comes on in England we see all through the country men and also ladies go on skates over our frozen lakes in style, whether as regards pace or in graceful execution of fancy cutting, which neither a northern European nor yet a Canadian can excel. For my part I did not take much to skating, and could never do more, when shod with iron, than go ahead. I disliked the frost because it stopped hunting, and in the early stages of its appearance I betook, with my dog and gun, to following snipe and wildfowl in preference to having anything to do with what had caused the stoppage of the king of sports, and thereby showing even a semblance of sympathy with it.

In selecting London, as I do in the next few pages, to show how great has been the improvement in the condition of men within the past five 
and thirty years, I do so simply because I know it better than I do any other of our large cities; but what I say applies equally to most other towns in the kingdom.

I was sent to London when a boy in 1855 , to learn my business, and I stayed there until 1857. Since then I have paid off and on a great many visits to our capital, and I have had ample opportunity of acquiring the knowledge which I am about to impart to those of my readers who may not already be in possession of it.

"The City man" of my young days was an awe-inspiring gentleman invariably clad in black broadcloth. His deportment and manner of speech were in accord with the sombre character of his garb. Beyond an occasional visit to the opera or theatre, with a fortnight at the seaside in summer, this old gentleman never sought recreation. Being brought up to business, to it he stuck, and he educated his sons pretty much in the same way. As to smoking in the streets, not to speak of the office, it was a thing a man would have been almost incarcerated for.

The clerks in the counting-houses of the City, from the strict discipline they were subject to duriog office hours, were as sedate in their behaviour as their masters. A visit to "Evans's" or "The Coal Hole," and occasionally to a theatre, where from "the gods" they witnessed the play, were all the amusements these poor fellows ever enjoyed. They knew of no other recreation, therefore they cared for no other. Their office hours were from 8 or 9 a.m. to 6 or 7 p.m. On Saturdays the hours were often even longer. A holiday was unheard of unless a fellow got off on the excuse of paying a visit to some dear aunt. Old Farley and his good-natured partner, John Boyes, thought I had more aunts requiring visits than all the chaps they ever met with !

Needless to mention an idea of sport, not to speak of a love for it, never entered the heads of either the principal of a City house, his sons or his clerks in the days I refer to. Because I entertained sporting proclivities, I was looked upon as a scamp bound to go to the devil. Upon several occasions I narrowly escaped being "rusticated," only because I came to the office with certain marks about the nose and eyes, indicative of a visit to Nat Langham's the night before.

Except in the parks upon the few occasions they visited them, the warehousemen and shop assistants of London might, and often did, live half their lives before they saw a green field.

Taking them all and all, the "business men"--employer and employed-of the City of London thirty to forty years ago were a community as uninteresting as could possibly be found. Work, work, and no play, was the daily order.

I shall pass over the transition state since then and come at once to what these men now are; and in no other section of the British public has there taken place during the present century so great a change for the better.

The "City men" nowaday", when they have occasion to do so, turn out in garb as orthodox as any man of the West End. The rig these 
gentlemen adopt generally has, however, an air of negligent elegance about it which betokens other than matter-of-fact business pursuits. Pot hats and tweed suits are quite as usual in Mark or Mincing Lanes as the topper and black: while a cigar is an indulgence during business hours, alike in the street and the counting-bouse. The lachrymose visage with doleful manner of speech nolonger exists as a qualification for business. The clerks are of a much better social class than were their predecessors, while they, too, bear upon them an unmistakable hall-mark. The workmen in the cellars, the docks, and the warehouses show in their complexions a healthiness which they never inherited from their parents.

What is the cause of all this change, a change brought about in such magnitude and within so short a time? I unhesitatingly reply, SPURT !

Business houses all over England, as a rule, have their doors closed upon Saturdays at from one to two o'clock. (I regret to say such is not as yet the custom in Ireland. It soon will be, I trust.) Directly the keys are turned away to the country go the clerks and the workmen, there to engage in sport-the younger portion to enter practically into the game of cricket, tennis, or football, while the elder look on with the most intense interest. I have seen old men get perfectly demented from excitement over a game of football when their local club played another, yelling with all their vehemence, "Go it, Leeds!" "Smash em, Everton!"

Saturday being so short a day, the heads of the houses often don't attend business but devote it to field sports of one kind or another.

When, therefore, a Saturday or Sunday, not to speak of a Bank Holiday, is spoiled by bad weather it is positively a national calamity.

In our commercial community a man devoid of knowledge of sport in a technical sense is now not to be found; nor can we except with difficulty find one without the capability of taking an active part in some branch of sport ; while men possessing all the attributes of the sportsman and well able to carry out in practical efficiency their proclivities are now to be met with in abundance among our merchants.

Yes, among the thousands who daily transact the business of the nation witbin the neighbourhood of Mincing Lane and the Stock Exchange of London, "on the Flags" of Liverpool, in the Commercial Building of Dublin, as well as elsewhere, are now to be found hundreds of as fine a lot of sportsmen as exists among the ranks of the patricians.

These rattlivg fine fellows, while maintaining the trade of our nation in a position by far the most honourable and gigantic in the universe, are well able to hold their own across country, over the moors or in hot corners, on rivers or in the cricket field.

What engendered in our present business man these newly-acquired tastes and to what do we owe the development? The answer is simple : Love for Sport is inherent in our nation, be the class what it may ; and shorter business hours affording the opportunity, the latent desire immediately burst forth. 
The Volunteer system which extends to England has on its part done much towards this happy result; for to be a soldier is to be a man. I wish heartily poor old Ireland could be got into a state such as would justify the Government in extending to it the Volunteer system. Perhaps some day it may, but at present the time seems far off.

Bank Holidays, too, have done much towards the development of manhood among the employee class. On the other hand, much harm is done by these Bank Holidays. They come so seldom, men naturally take all the value they can get out of them. Estimates of what is called enjoyment are various, and unfortunately include drunkenness. This vice is indulged in by hundreds on Bank Holidays, and for days afterwards they are incapacitated from performing their duties, and thus is the object of a general holiday abused.

Now, my notion is that we have too few general holidays; that if we had them more frequently little or no abuse would result. I speak from experience, and when I give my reason I shall be understood. Long ago we had very few race meetings either in England or in Ireland, compared with what we have now. When it so happened that we could go to a race meeting, say, only three or four times in the year, the event almost invariably culminated in a debauch of more or less degree. This is a general fact which no race-goer of as long experience as myself can dispute. Moreover, the propensity to get across the line was alike in all classes, even up to twenty years ago. Now, when an opportunity to attend a race meeting is afforded nearly every day in the week, and when it is availed of by the public to tenfold greater extent than it was long ago, what do we see? No drunkenness at race meetings, and no debauch overnight_-at least among respectable people.

This fact, which has been brought emphatically under my own immediate observation, I adduce as an example of what would be the result of having general holidays more frequent than they are.

I have no hesitation in stating that I believe if an Act of Parliament was to be passed by which every Saturday would be made a halfholiday and the first Monday in every month a whole one, little or no abuse of the indulgence would accrue, but on the contrary a vast deal of benefit. Those who, like the police, railway and post-office officials, could not be spared off duty on the regular days should be given others instead. In fact, every man in the kingdom should be entitled to a half-holiday in every week, and a whole one in every month. As a matter of course, no deduction in pay should accrue, but the present general holidays, except those attendant upon Christmas and Easter, should be abolished.

We must realise the fact that while bodily labour is less, that of the mind is vastly more arduous nowadays than it was thirty years ago. More is done in a week now within commercial circles than could be done in a month then, and everyone knows the mind needs rest more than the body. Therefore, occasional respites from labour such as I have suggested would bear results to the employer even more beneficial 
than to the employed. The strain upon his mental capacity which at present is continual would then be regularly relieved.

Furthermore, I will say that, in my opinion, no better allotment of the twenty-four hours can be found than that proposed by Alfred the Great just one thousand years ago. It was: "Eight hours for labour, eight hours for sleep, eight hours for feeding and recreation."

I write thus after having a long experience as an employer, and knowing well what the employed is capable of doing with such efficient results as will give his employer an adequate return for his wages.

By according to all men such privileges as I have mentioned, I maintain, first, that both employer and employed would alike benefit from their business point of view ; and second, that, having so much more additional time for recreation, our young men would develop into even greater and finer fellows than they are, by, as they are bound to do, devoting all the more time to manly exercise and to sport.

"All work and no play" has in England long since been found to be a mighty bad rule. Trading has in no way suffered from the weekly half and occasional whole holiday which have existed for some time. On the contrary, despite exceptionally bad times, Great Britain never stood firmer than she does at present, and the adoption of uniform hours for labour, with more holidays, would, I am strongly convinced, tend to make her stronger. Moreover, such a step would go a long way towards the prevention of strikes, the curse of everyone, and would frustrate many of the doctrines which are now being preached by advanced Radicals with such evil results.

For many years it has seemed to me a pity to keep in this country such late hours as we do. I speak still of the commercial class, for, of course, a suggestion to the upper classes to keep early hours would be as useless as that which I made in the chapter on Racing with regard to changing the Derby and other classic events into four-year-old races ! If we began business at, say, 7 or 8 a.m., and left off at 3 or 4 p.m., would it not be more rational and far better for employer and employed than beginning as we do at 9 or 10 a.m., and working away till 6 or 7 p.m. ? The evening hours could, with the holidays, be devoted to sport by the employers, and to manly games by those they employ, and we should then live the 7,300 hours more than we do in every ten years which I allude to in a following chapter.

The English and Irish are undeniably the hardiest nation in the world. It is sport and manly games that have given them that proud position: let us therefore the more encourage the cause so that the effect may be proportionately increased.

To some young gentlemen from our cities who may select hunting as their principal recreation or even a portion of it, I would take the liberty of here giving the following little bit of advice :-Read, mark, and inwardly digest what is inculcated by the master of the Gorse Covert Foxhounds, and also by his secretary, in the chapter of this 
book devoted to Hunting. I would also have them bear in mind that

The fox takes precedence of all from the covert ;

The horse is an animal purposely bred

After the pack to be ridden, not over-

Good hounds are not reared to be knocked on the head.

I venture still further with these young fellows, and I do so with all delicacy and with the sole object of promoting sport. Let them recognise it as a fact that any damage done by them in the hunting field is looked upon by masters of crack packs in a much worse light than would the same if done by members of the hunt. If on the other hand these young men from our cities conduct themselves like sportsmen in the field, are courteous and civil to the farmers, and subscribe liberally to the hunt fund, I am very sure they would be welcomed to the meet of any pack of foxhounds. If they don't behave themselves they deserve to be ordered away directly they appear.

Hurrah for old England and Ireland! Never shall we see in the annals of our sports a record so disgraceful and unmanly as the following the reproduction of which I trust may not pollute the pages of my book :-

Bull-Fighting Statistics.-During the past year (1892) the number of first-class bull-fights in important cities in Spain was 289, the bulls killed being 1,594. There have also been 307 fights of young bulls (novillos), in which 1,407 were slaughtered. Of the chief fights 26 took place in Madrid, 13 in Seville, 12 in Barcelona, and 11 in Valencia. Two men (picadors) were killed; one of the espadas and banderilleros, while 16 others were more or less seriously wounded. In each course from six to eight bulls are done to death; but recently in Madrid, in a fight which extended over two days, 18 were finished off. On some days 24 horses, or even more, are gored to death by the long horns of the Spanish bulls. The bull-ring in Madrid holds 15,000 spectators, "nor dames, in high rapture, the spectacle shocks!"

Thales, the greatest of all Greek philosophers, and renowned to this day for his wisdom, thanked the gods daily that he was a Grecian and not a Barbarian. We Britons should feel equally proud of our nationality and thankful for it. 


\section{CHAPTER XIX. \\ THE PRIZE-RING AND THE COCK-PIT.}

Author's Excuse for Referring to above-Dangerous Topics-Old Patrons-Prize-fighting: v. Cock-fighting-Brutal and Degrading-Admiral Rous' Opinion-RuffianismResult-Last Battles-Revival-Slavin and Smith-Marquis of Queensberry-New System-Boxing and Cocking-Wilts and Cheshire a Hundred Years Ago-Major Wheble-Harry Flowers-" White Piles"— "The Cheshire Drop"-The Cholmondeleys -Egertons-Warburtons-Mexboroughs-Meynells-The Knowsley "Black-breasted Reds"-A Great Doctor-"The Turf aud the Sod"-Great Cock-fights-Great MenEarl of Derby-Enormous Stakes-A Great Cock-setter-His Fees-Squire Legh and Major Wheble-A Level Thousand-A Match Made-More Great Men-Wiltshire $v$. Cheshire-William Keate-Preparations for the Fight-The Company-The Men-The Fight-Enthusiasm-Tremendous Fighting-Results-Major Wheble's GallantryRemarks by the Author-Royal Cock-pit in 1805-A Prize-fight Thirty Years AgoTom Sayers and John C. Heenan-Their Births-Early Days-Their Fights-Preparation for the Great Fight-The Attendance-The Men-Full Particulars of the Battle -After it-Opinion of the Author-How Both Fought-Belts for Both Men-Subscription for Sayers-His Death-Heenan-Author's Opinion of Him-His DeathOld Battles Compared with what are now called ".Fights."-Tom Sayers' Record.

Mx hand shakes and my heart palpitates as I write the heading of this chapter, knowing as I do how distasteful prize-fighting and cock-fighting are to so many of the present day. In fact I don't think I should have referred to these branches of old English sport but for the fact of having come across a copy of the Licensed Victuallers' Mirror, in which is iven an account of how they were organised and carried out a hundred years ago. The description is so interesting, I am tempted into reproducing the article, as it delineates perfectly the whole proceeding, and shows the class of society which surrounded the prize-ring and cock-pit in old times.

The subjects of this chapter are dangerous topics to offer an opinion on nowadays, but when the cream of the cream of English society showed the interest in them which they did up to about thirty years ago, as is described in the following account, they must have seen some useful as well as exciting end to be gained therefrom, at all events, as regards the prize-ring.

I can't understand what good they could have ever seen eventuate from the cock-pit. Beyond to view courage displayed in the highest degree, there could be nothing gained by setting two poor birds to fight to the death with artificial spurs, except brutal gratification of the lust for gross and most abominable cruelty. No bird in creation-perhaps no beast-has more courage, combined with combative propersity, than the appropriately-named gamecock. To let two evenly-weighted birds have a few bouts with the "gloves" (i.e., having their short-cut natural spurs well padded) is good fun and does no injury to the combatants, 
while their skill in offence and defence is displayed as much as when they have battle spurs. I am glad to say I saw only two cock-fights with artificial spurs, and most certainly I shall never look at another, but I often saw cocks spar with gloves, and I hope to see the same again.

Prize-fighting with the bare fists, as carried on formerly, was brutal and degrading, but, after all, the combatants were rational beings, and if they chose to batter each other till one was beaten, and to be well paid for doing so, why, it was their own concern. Therefore, I don't lonk on prize-fighting as badly as I do upon cock-fighting, where two poor birds are set at one another, and death alone decides the battle.

Men in the highest position in society have upheld prize-fighting down even to the very present day. Admiral Rous, only a few years back, looked upon its suppression by the authorities as a national calamity. He thought as many others did, and do still, that it tended to encourage and sustain the pluck and endurance that the British were always celebrated for. Whether it did or not, there is no denying the fact that prize-fighting could not, in this enlightened and sentimental age, be tolerated. At the same time, it must be explained that during the last few years of the history of the ring there was very much more brutality shown among the roughs and seum of the earth who were the spectators than was shown by the men within the ropes. In the days to which the following article refers there were seldom rows or bad conduct at the ring-side. It was later on that ruffianism crept in, until at last almost every fight ended in riot and disorder. This, of course, disgusted the upper classes, and they withdrew their patronage. When left without that support the P.R. soon got perfectly demoralised, and had to be stamped out by the authorities.

The last great genuine fights were on November 26, 1862, and December 8, '63, when Tom King on both occasions was victorious, beating, on the respective dates, Mace and Heenan. The former battle was decided by the most terrific blow ever given in the ring, King, with a counter, knocking Mace so completely out of time that he did not recover consciousness for over half an hour. Some time before that the celebrated battle between Sayers and Heenan took place at Farnborough, of which I give, later on, an account.

Prize-fighting was not attempted to be revived for some five-andtwenty years, but efforts were then made, and so-called fights were brought off. So disgraceful were the exhibitions, owing to the ruffianism of the spectators, the cowardice and want of skill of the men, and the fact that each "fight" was invariably got up for dishonourable motives, that the public immediately got quite disgusted and would not tolerate a revival of prize-fighting, and it is to be hoped we have seen the last of it. The fight at Bruges between Slavin and Smith, where a brave and good boxer like the former was denied even the fair play Englishmen always boast of showing, particularly to a 
stranger, should for ever wind up the annals of the P.R., which, according to "Fistiana," began in 1700 .

While rejoicing to see the demoralising exhibitions alluded to abolished, I should be sorry to see the "noble art of self-defence" interfered with, and glad $\Gamma$ am to know that boxing is as popular in England as ever it was, while in Ireland it is far more so than ever. The Marquis of Queensberry has done much for it, and has introduced rules, some of which are sound and good.

As experience has shown, however, he made a great mistake in trying to bring back prize-fighting by means of glove contests to be decided in a limited time, or within a certain number of rourds. Anyone might have seen such a rule could not work out, and it has now been shown plain enough these "glove-fights" are far more brutal than were the old fights with the fists, while they have not one single redeeming quality. Little science is attempted in the first round, and after that none whatever. Hammer and tongs the men go at each other like wild beasts, and to decide the fight is simply a matter of which in the shortest time, by the most powerful blow, can knock the other out of time. From curiosity I went to see a couple of these affairs. Fights they are justly called, and it is, I thiok, impossible to conceive how the word, in its sense of savageness, could be more practically demonstrated.

Very soon will these exhibitions be put an end to if they be continued on the system on which they have begun.

I now reproduce the article I alluded to in the first paragraph of this chapter. Not alone does it describe the ring and the pit of long ago, but it gives curious particulars and interesting information of the men and manners of a past age.

The Old Ganesters of Wilts.

Major Wheble and his Fighting Coachman. A Main of Cocks in the Old Chester Pit.

A Fight in the Major's Park 7 TH JULY, 1809 .

THERE are few counties in England where you will find such a marked difference existing between the one half of the shire and the other as in Wilts. The southern part of the county consists of wide plaius and rolling downs, now sinking into valleys, now rising into hills, a varied sea of "chalky waves." The northern part is a broad, flat track of alluvial soil, thickly wooded and watered by the Thames, the Kennet, and the Lower Avon, where rich pasture alternates with fruitful corn land. And the inhabitants of the two districts are equally distinct in character. The simple shepherds of the South, the "moonrakers," are as different as possible from the sturdy agricultural labourers of the North, from time immemorial renowned for their prowess as cudgel players. It is in this portion of the county that the scene of our present narrative is laid. Up in the Northeastern corner of Wilts, about ten miles from the borders of Berks, in the 
little village of Dunsden, at the time of which we are writing, there had been settled for several generations a family named Flowers, of the small yeoman class, which had produced a race of singularly athletic and stalwart men. Personal strength, high conrage, and a fine, hearty, old English love of fair fighting were hereditary qualities in the house of Flowers, and had been handed down withont a break throngh all the males of the stock. There was no record of a Flowers who had not been an enthusiastic lover of fighting-whether with cudgel or fist-and the family had largely contributed towards upholding the honour and glory of Wiltshire in the annual matches at stickplay against the men of Berks, Somersetshire, and Gloucestershire.

A fine old English sport, by the way, that same stickplay, or backswording, was, and one we should dearly like to see revivel. J.et whoso doubts our word read the graphic description of a bout at stickplay, as one of the features of the good, old-fashioned "Veast," given in that manliest and healthiest of all boys' books, "Tom Brown's Schooldays."

The head of the family at this time was Harry Flowers, the blacksmith, who, we should imagine, realised the picture which Longfellow has given-

"The smith, a mighty man is he,

With large and sinewy hands;

And the muscles of his brawny arms

Are strong as iron bands."

He had two sons, Harry and Bob, both of whom were famous fighters in their time; but it is with the former that we are now concerned. Though originally brought up to his father's trade, young Harry, who was from his boyhood fond of horses, eventually found more congenial employment at the stables of Major Wheble, of Tockenham Park, close by, who was also the owner of Bulmershe Court, near Reading. Now, the Major was a fine specimen of the good old Lnglish country gentleman. He loved sport of all kinds-hunting, racing, shooting, cocking, bruising, and was an enthusiast at all of them. At the cockpit, on the racecourse, by the ring sile, there was no more familiar figure than that of the burly, jolly-faced squire of Tockenham. The Major had known the whole family of Flowers from his boyhood, and had heard countless tales of their prowess. He took a particular fancy to young Harry, who was in due course promoted to the higher post of coachman, but this by no means precluded the young man from indulging his fighting propensities. On the contrary, the Major encouraged his coachman to keep up the prestige of the house of Flowers, and constantly backed him to fight. Up to the year 1809, young Flowers had never known defeat. He had thrashed Black Jem, the famous gipsy fighter; Sweet, the Somersetshire champion; and half-a-dozen other men of lesser note. On the 20th of January, 1809, Flowers fought a big sawyer named Rossett, whom Mr. Charles Dalbiac, of Hungerford Park, had backed for a hundred guineas against him. Rossett's patron made sure that the Berkshire man would win, and wagered heavily on him, but Flowers hit his foe all to pieces in ten miuutes, and the unfortunate sawyer was carried away senseless from the field of battle. After this signal proof of the coachman's prowess it was not easy to get anyone to stand up before him, and young Harry's next 
antagonist was imported from a far away shire, to which the fame of Flowers had never reached. It came about as follows :-

Major Wheble, as we have said, was an enthusiastic turfite and cocker.

Now, in those days (1S09) the two counties which were pre-eminently famous for their combination of both these sports were Cheshire and Lancashire. Chester and Preston were the two great centres of cocking in the North. Lord Sefton, Mr. Price, of Brynprys, Captain White, Mr. Bold Haughton, and Doctor Bellyse all fought at Cliester. Lord Derby and Mr. Legh, of Lyme, reserved their cocks for the Preston mains. There was a famous breed of "white piles" in Cheshire then, which carried such a wonderful spur that "the Cheshire drop," which would occasionally come out in a long battle, when the odds were 20 to 1 , was considered as fatal as " the Chifney rush." These were the cocks with which the Cholmondeleys, the Egertons, the Warburtons, the Cottons, and the Roylances fought all the great county mains, sometimes against each other, but more often against the Mexborough and Meynell families. The Cliester race meeting was always a great trysting place for cockers from all parts of England. That grand old English sportsman, the twelfth Earl of Derby, great-grandfather of the present Earl, was always a conspicuous figure there in his gorgeous family coach, drawn by six superb horses, and attended by a numerous and imposing retinue. Fond as he was of seeing his home-bred horses carry the black and white to victory, if it were possible for him to love anything better than a thoroughbred horse, it was a thoroughbred game-cock, and the Knowsley breed of black-breasted reds were deemed well-nigh invincible in the North. It may be,truly said of him that he was the greatest cocker that ever lived. And next to him, at no great distance, we might place another familiar figure in Cheshire sport, the celebrated Dr. Bellyse, of Audlem, who was not only renowned for his medical skill, but was perhaps the greatest authority of his time on the pedigrees of racehorses, the rearing of greyhounds, or the breeding, training, and feeding of game-cocks. The doctor's professional duties forbade his going far afield in pursuit of the sports he loved, and keen as he was on horse-racing, he never in his life saw either a Derby or a St. Leger run. But he was in his glory at Chester. Nothing would have induced him to forego his annual week on the Roodee. Patients, no matter how important their cases, had to give up all hopes of seeing the Doctor for that week. On the Saturday previous to the races his yellow gig with his fourteeu-one, Brown Tommy, turned up as regularly as the seasons themselves in the yard of the Hop Pole Inn at two o'clock in the afternoon. On the Monday he sallied forth to the Hotel Row and received a liearty annual welcome from the lovers of the "Turf and the Sod," to whom from his quiet worth and his wonderful memory and information on every point, he had become so endeared. Years wrought no change in the dress or figure of this fine old Cheshire worthy, nor quenched his love for either science. Everyone knew the blue dress-coat with brass buttons, the lightcoloured kerseys and gaiters, the buff waistcoat, the golden greyhound, the gift of his friend Lord Combermere, which lent a tasteful finish to his snowy frill, and the pig-tail just peeping from beneath a conical low-crowned hat, which completed the attire, from which he never raried. The cock-pit began at eleven, and the go-in ended soon after one ; and then, before a grand stand was known, the Doctor was always to be seen stationed on Tommy in the 
middle of the Roodee, to watch what the horses were doing, armed with a gigantic umbrella. For he held the belief that there were "always a swarm of fools on a racecourse," and hence he kept the huge "gamp" to shoot it in self-defence in the faces of the young blades as they galloped recklessly across him from the curds to the rails. His great friend was Squire Legh, of Lyme Hall, who was as famous for his breed of cocks as for his breed of mastiffs, and they both employed the greatest cock-feeder that ever lived, Joe Gilliver, of Polesworth. Cocking was then the chosen amusement of the race mornings, and vied with the Turf itself in the interest it excited among aristocratic sportsinen. The old families in Cheshire and the neighbouring counties were as proud of their breed of black-reds or birchen duckwings as Sir Tatton Sykes of his Sledmere Leicesters, or Lord Wilton of his Melton hunters. The feeling had struck deep root for years. It had penetrated almost within the sombre walls of York, and quiet burgesses remembered how Harry Mellish and Sir Francis Boynton had fought main after main at Bootham Bar. There was a dim story, too, that Colonel Thornton had matched his best hawk against a game-cock at Preston or Knutsford, for 1,000 guineas a side. Ten guineas a battle, and two hundred the main, was the usual standard. At race meetings they of ten fought one "in-go" by candlelight, amid a perfect Babel of bets; and in the Royal Westminster Pit of yore no mains were ever fought by day. The Earl of Derby built at his own expense at Preston the best appointed and most commodious cockpit in the kingdom, which now - such is the irony of fate-lias been converted into a temperance hall. Here his lordship attended in state. Five shillings was the price for admission when the Derby mains were being fought, and the "main-bag," which was generally a mere calico affair, was on these state occasions of embroidered needlework, bearing the arms of the Derby family wrought in gold, and ornamented with the richest lace. The stakes in these big combats were sometimes enormous. The largest ever fought for were, we believe, a thousand guineas a battle, and five thousand the main. The cocksetter's fee was from fifteen to thirty guineas a main, and old Joe Gilliver managed to save quite a snug little fortune out of his fees. It was generally one of the articles that the cocks were to fight in "fair reputed silver spurs," but these were little more than steel, thinly washed over with the more precious metal, and a single crashing stroke through the skull from one of then administered the death-blow as instantaneously as a pistol-bullet would have done. The reader must pardon us for digressing into a dissertation upon a sport for which, at the time of which we are writing, there was a passionate craze among the nobility and gentry of England. And now to return to our muttons.

At the Chester Races of 1809 it had been arranged that there should be a great main between the Gentlemen of the South and the Gentlemen of the North, for five-and-twenty guineas a battle, and five hundred the main. This event naturally attracted a great number of sportsmen from the southern shires, and among them Major Wheble, who had sent his choicest cocks to contend for the honour of the South. We need not dwell upon the sport-it is enough to say that the Gentlemen of the North were victorious-what we are concerned with is an outcome of this meeting between the Northern and Southern sportsmen. Squire Legh, of Lyme Hall, overheard Major Wheble boasting of the prowess of his coachman, and was 
nettled at a remark of that gallant officer's to the effect that the North had never produced a great fighter yet, and that the South was the true nursery of British boxers. "I'll lay you a level thousand, Major," said the Squire, " that we in Cheshire will find a man within three months who'll thrash your coachman." The NIajor promptly accepted the bet, feeling sure that in a match of this sort he should recoup himself for his losses over the cocking. Several other Cheshire gentlemen present backed up the Squire of Lyme Hall, Mr. Egerton, of Tatton Hall, to wit, Mr. Thomas Cholmondeley, of Vale Royal Abbey, and young Sir Uswald Moseley, of Bolesworth Castle. The terms of the wager were that the Cheshire gentlemen were, within three months, to produce a man who should thrash Major Wheble's coachman, Harry Flowers, the prize for the combatants to be two hundred guineas. The Wiltshire gentleman and his friends were so confident of success that they betted heavily, and many thousands of pounds were laid on the event. In due course Major Wheble returned home, and within a week of his return. he received a letter from Squire Legh, informing him that they had found their man; that his name was William Keate, and that he would be ready to fight Flowers six weeks from that date.

And here let us say a word or two about this Cheshire worthy whom Squire Legh and his friends had unearthed. The man was an iron-worker by trade, and had been picked up first at Nantwich by Mr. Peter Legh, of Booth Hall, who had seen him thrash a big salt-miner there. He was a powerful young fellow, over twelve stone in weight, and had a slashing style of hitting, which attracted Mr. Legh's attention. It subsequently transpired that this Keate was a well-known man in that part of the county, and had. fought many battles with unvarying success. But outside Cheshire he was. uuknown. Such was the man, then, upon whom the Cheshire squires relied to win them their money against their Wiltshire rivals. The battle was to take place at Major Wheble's park, at Bulmershe Court, near Reading, on Saturday, the 7th of July, to suit those Cheshire sportsmen who were coning up to London for Goodwood. The news had spread far and wide over Berks and Wilts that Harry Flowers, of Dunsden, was to fight the Champion of Cheshire, and there was great local excitement over the event. Major Wheble had offered the hospitality of Bulmershe Court to a number of. Cheshire sportsmen, among them the Earl of Grosvenor, who was as fond of prizefighting as William Windham himself; Lord Penrhyn, of Winnington Hall ; Mr. Peter Legh, of Booth Hall, and his brother, Tom Legh, of Lyme Hall ; young Sir Oswald Moseley, and Mr. Egerton, of Tatton. 'The inns at Reading were full of visitors from varions outlying parts of Wilts and Berks, and even from London, forty miles away, and much grumbling there was at the accommolation. For the lieading of 1809 was a very different place from the lieading of 1890. It was then one of the dirtiest, the worst lighted, and. the worst paved towns in England. Of course, many of the country people drove straight from their own residences to the field of battle. Sir Francis Sykes had tooled over his dashing four-in-hand from Basildon, and had. brought with him Mr. Pichard Benyan, of Englefield; Mr. Charles Fyshe Palmer, of Luckley House ; and Squire Brummell, of Dorington Grove. TheMarquis of Blandford, too, had driven his drag over from White Knight's, and so had Viscount Folkestone (Lord Radnor's eldest son) from Coleshill. House. Charles Dalbiac, of Hungerford Park; Lord Craven from Benham 
House, and many others had ridden to the rendezvous. Wiltshire, too, had sent out a strong contingent. Sir Henry Daryell, Master of the Sonth Wilts Hounds; Mr. Barnard Dickenson, of Bowden Park; Lord Ailesbury from Savernake; Mr. Paul Methuen, of Corsham House, one of the most liberal. and enthusiastic patrons of the Prize Ring then living; General Popham, Sir George Dashwood, Captain Unwin Smitl, young Fulwar Craven, the Squire of Chilton, who had not yet attained his majority, and other good. sportsmen and true.

The spacious park encircling the mansion of Bulmerslıe Court presented a lively scene of bustle and activity on the morning of Saturday, July 7, 1809.* From an early hour in the morning vehicles of all descriptions and pedes. trians by hundreds had been making their way towards the scene of battle. As many guests as the Major's house would hold had been accommodated within its hospitable walls on the previous night, and every spare bed in the little neighbouring village of Earley had been tenanted by ardent sportsmen, who had come froin thirty miles and more away. From Reading crowds of foot people and carriage folk of every degree were flocking towards Bulmershe Court before the clock of St. Mary's had chined six. For his aristocratic visitors, who nust have numbered upwards of a hundred, the genial master of Bulmershe Court had prepared a hearty breakfast such as country squires of the good old times loved to do justice to-mighty joints of beef, and chines of pork, and towers of brawn and vast veal pasties, washed down by the famous Kennet ale. After breakfast the lawn in front of the house presented. almost as gay an appearance as when the meet of the season was there. Thehunting scarlet, of course, was absent, but there was plenty of variety in the colours of the gentlemen's coats. Nor were the fair sex unrepresented. Even if they did not propose to witness the fight, the dames of the country squires. saw no harm in accompanying their husbands to a jolly sporting gathering: where they could meet the wives of their neighbours and gossip over the matters that interest matrons. In the park below the crowd was less select, but quite as jolly. It was a glorious July morning, and cveryone was in the best of humours. Half-past ten was the time fixed for the fight, in order that it might be over before the sun reached its meridian height and heat, and long before that time the Ring, which had been carefully formed by Bill Gibbons and old Joe Ward, specially retained from London for that purpose, was surrounded by a dense crowd, which could not have numbered less than. three thousand persons. A wooden stand had been erected for Major Wheble. and his friends, wbilst a circle of a score or more of waggons offered excellent views of the ring to those who were willing to pay a shilling or two for sitting. or standing room. Keate had come up from Cheshire on the previous. Wednesday in company with his trainer, Isaac Bittoon, whom Lord. Grosvenor had paid to come down and look after him. During the interval. the pair of them had put up at a neighbouring farmhouse, where Major Wheble had procured them rooms. Flowers, of course, was under his. master's eye at Bulmershe Court.

When at last the two champions appeared on the wooden stage which had been erected-for the Major was a stickler for the old style-there was tremendous excitement. Flowers, of course, as the local champion, received.

* "Fistiana" gives 7 th July, 1810, as date of this fight. 
all the cheering, for the other man was an absolute stranger to everyone present except the gentlemen from Cheshire. Keate was waited upon by Isaac Bittoon and a man named Jacomb, from Nantwich. Flowers had the invaluable assistance of the experienced veterans, Bill Gibbons and Joe Ward, who were objects of much reverence to the admiring yokels. Mr. Paul Methuen was referee. Mr. John Isherwood, of Maple Hall, Cheshire, was umpire for Keate. Mr. Charles Dalbiac, of Hungerford Park, Berks, for Flowers.

Neither man had ever set eyes upon the other until they met on the stage. As they stepped forward and shook hands, the crowd cheered lustily, whilst the men themselves eyed each other curiously and critically from head to foot-then parted to join their seconds in their respective corners, and to make ready for the fray.

When at last Mr. Paul Methuen, in that clear, melodious voice on which he prided himself (he was a distinguished amateur actor as well as a keen sportsman), called "Time," and the combatants, stripped to the waist, stood up face to face and foot to foot in the centre of the stage, every eye in that vast concourse was eagerly fastened on them. The Cheshire man was obviously the taller and heavier of the two. He could not have been far off 5ft. 10in., and his weight was certainly not less than twelve stone. Flowers, on the other hand, stood but $5 \mathrm{ft}$. Sin., and scaled only just eleven stone. The stranger was certainly a fine, powerful man, with a look of dogged resolution on his fair, florid face; but his attitude was awkward and he lacked the lissomness and spring which characterised his opponent. Henry Flowers, indeed, was a model of what a man of his size and weight ought to be. A hardy-looking, swarthy, black-haired man, firm and well-knit, with bold, bright, dark eyes and a beautifully symmetrical figure. He was, moreover, in splendid condition, and had the confidence begotten of an unbroken series of victories.

It was evident that they meant business these two sturdy countrymen. They had not been spoiled by the affectations of the Fives and Tennis Courts. It is to fight and not to spar that they have come here, and after just one long steady look at one another from head to foot they put up their hands, set their teeth, and prepare for a battle even to the death. The Wiltshire man leads off with a hot one from his left which grazes Keate's right ear. The Cheshire man is just in time to jerk his head on one side and avoid the full force of the blow, and straightway swings a roundhanded crack with his right into Harry's face; thump it goes against the man's cheek, and the little kuot of Cheshire sportsmen applaud vigorously. Another roundhander from his left catches Flowers on the side of the head just over the ear, and Squire Legh, in his excitement, stands up and waves his hat, as though he were hallooing on his hounds. "Hammer him, Keate, hammer him !" shout Mr. Egerton and Lord Grosvenor simultaneously, and he does so. Smash goes his fist again into the Dunsden youth's face, and this time blood follows the blow. What is the Wilts man after? Three clinking hits he has napped, and given never a one in return. This is not what his friends have been accustomed to from Harry Flowers. But he is not long idle; crash goes his right, straight as a dart, at Keate's mouth. Whew ! "That's a warm one," cry the swells on the Stand, for home the horny fist of Flowers has gone with a vengeance, and the blood spurts from 
the Cheshireman's lacerated lip. Close quarters, yard arm to yard arm, each fibbing like mad at the other till they roll over together. It is hard to tell which has liad the best or worst of it.

It needs more sponging than can be done in half-a-minute to wipe the traces of battle from the faces of the two men, and both are still bleeding when they come up once more to the call of "Time." Not a fraction of a second is lost in sparring: Keate walks up to Harry, and lets fly withont ceremony. The blow catches Flowers on the shoulder, near the collar-bone, but the counter, swift as Tom Belcher's, from Hal's right lights upon the Cestrian's nose, and seens to flatten it all over his face, sending the blood squirting to right and left. "Bravo, Wiltshire!" The Cheshire lad, wlio will not hit straight, though bis friends say straight hitting is his forte, aims a terrific roundhander at Harry's nob, but the keen eye of the Southerner sees it coming, he ducks, and the iron fist of Keate whistles harmlessly past his ear. Not so his own return, for he sends in a cruel uppercut, which jerks Keate's head up, and lifts his chin suddenly to an angle of forty-five degrees. Tremendous cheering and chevying from the hearty lungs of the Wiltshire and Berkshire sportsmen. Keate was stung by that blow-he comes on with a sour and fierce look on his face-from which the blood trickles steadily. And now, for full two minutes, there is such fighting as works the spectators into a perfect frenzy of enthusiasm. Without the faintest attempt to stop or avoid a blow, the two men stand up and punch away, left, right, left, right-the blows falling like the strokes of a hammer on the anvil-every hit tells, yet neither flinches or quails. The air is rent with shouts of "Well done, Flowers!" "Bravo! Keate!" "That's one for old Wiltshire. Go it, Harry.". "Cheshire for ever. Hammer away, Keate." The excitement is maddening. Forgetful of everything but the two panting, struggling gladiators before them, the spectators press forward, wave their hats, and shout themselves hoarse as if their very lives depended upon the issue of the combat. Both men are pretty nearly hit to a standstill, yet both have their wits about them, when Flowers dashes a tremendous lefthander full into the pit of Keate's stomach, which doubles him up and tumbles him over in a heap almost at the feet of his seconds. And so, amid loud and continued clapping of hands, the round ends. The Southern gentlemen are in ecstasies, ready to bet 6 to 4 on their man, but their rivals are equally ready to take these odds for the latter, thinking their man has given quite as good as he has got.

Both men are very slow in coming up to the call of tine, and no wonder, for that desperate, hammer and tongs, ding dong, give-and-take business in the last round was enough to take the buckram out of the best trained man that ever chucked his castor inside a twenty-four foot ring. For quite a minute they stand facing one another with their arms down-each panting and breathing hard-then Keate wakes up, and sends in a terrific righthander; but Harry dodges it cleverly, and then dashes in his own right straight as an arrow full and fair between the eyes, with a spank that is plainly heard by those on the very verge of the crowd. The blow would have felled a bullock, and Keate after one long stagger backwards again measures his length on the stage.

But somehow those knock-down blows do not seem to affect the Cheshire man much. He comes up looking as resolute and contident as ever, though 
his face is sadly altered in shape. His eyes, moreover, have begun to swell, and old Joe Ward tells Flowers to make that his aim now, and in a few rounds he will have his man completely blinded. Harry follows the sage counsel of his mentor. But though Flowers almost invariably succeeds in planting a stinger the instant he meets his foe, it is noticed as the fight goes on that Keate generally lasts the longest, and despite the punishment he receives, often has decidedly the best of the latter part of the round. Evidently the Cheshire man is as gane as the best black-breasted red that Lord Derby ever bred at Knowsley, and is as hard as the metal in which he works. But he will not hit straight, and that is where Flowers has such a pull over him. Keate's roundhanded blows catch Harry on the back and side of the head. Harry's arrowy hits go straight from the shoulder into Keate's face. The blood is flowing from half a dozen deep cuts on the Northerner's visage; whilst Harry's punishment consists mainly of bruises; bad enough some of them are, no doubt, but they don't show much. All this time Flowers has been stfadily pegging away at his opponent's eyes, which are now badly swollen and discoloured. It is clear that in a few minutes more the man will be blind, unless he succeeds in knocking his foe ont of time. A conple more taps from Harry and the shutters are pretty well up-2 to 1 on Wiltshire is the cry, and things look very fishy indeed for Keate. But an idea has struck Mr. Peter Legh, of Booth Hall. He leaves his seat on the stand, hurries up to the stage, and says to Bittoon, "Here, Isaac, you must lance his eyelids; take this lancet, and lose no time." Keate has no objection, he is delighted, indeed, at the idea of recovering his sight, for he feels quite strong enough to win the fight yet. So the Cheshire Champion has his eyes lanced, and from that moment fortune begins to smile upon him, and Flowers is a bit disheartened when he sees that all his steady hitting at the eyes has gone for nothing, and that his adversary can now see almost as well as ever. Nerertheless he fights desperately, and one of the finest rallies in the battle follows. The blows fall so fast and thick that it is impossible to note the effects of each. Flowers hits the straighter of the two, and seems to do the more damage becanse his hits draw more blood; but the round blows of the Cheshire man come with a thump and a thud on the side of Harry's head, on the back, and around his throat with stupefying force. The din and uproar among the crowd-now frightfully excited-is terrific, for two minutes this slashing business goes on as hard and fast as the men can hit. Flowers lashes out and sends a sledge-hammer blow into Keate's mouth which knocks one of his teeth out. But William gives a counter with his right on the neck, which, though less showy, does quite as muclı harm, and then for the first time they close and grapple for the fall: Flowers tries all his wrestling tricks in vain upon the Cheshire man, who stands like a tower, till the other's grasp weakens, and then Keate grasps his man round the middle and flings him with such force on the boards that the whole stage trembles and threatens to collapse. Flowers has had a bit the best of the hitting in this round, but the Cheshire gentlemen think that the bursting fall has made natters even.

Keate, despite the gap in his gums, comes up the fresher of the two, and has evidently almost got his second wind, whilst the other man is still puffing and blowing with his mouth open. The Cestrian sees his chance and avails himself of it. He hits IFarry a blow on the side of the head with his left 
and follows it up with another on the throat which knocks him clean off his feet. The Cheshire gentlemen are greatly excited; their man has had it all his own way this round-has put in two tremendous blows and not been touched in return. 5 to 4 on Keate, and the IViltshire men are for the first time rather shy about taking the odds, for their man's wind is dicky, and unless it speedily improves t'other chap will assuredly knock all the fight ont of hin. But, alas! for poor Harry, that tremendous fall had so shaken him that he couldn't get back his wind. He grows weaker and weaker-it is pitiable to witness his gallant but unavailing efforts to turn the tide of battle in his favour-he can scarcely steady himself to strike-when he does hit, his blows are delivered so slowly that his antagonist easily avoids them - he has shot his bolt-Keate either knocks him down or throws him in every round, till at last the brave fellow cannot leave his second's knee, and the sponge is thrown up to signify that Keate has won his hard-fought battle, which lasted seventy minutes.

The downfall of the Wiltshire Champion is, of course, a terrible disappointment, not only to Major Wheble, but to the vast majority of the spectators. But they bear it like true Englishmen, and the stalwart Cheshireman is heartily cheered as he steps down from the stage and makes his way to the stand where Lord Grosvenor, S̈quire Legh, Mr. Egerton, and the rest of his backers shake hands with him, and warmly congratulate him on his victory. The gallant Major, after seeing his brave coachman taken up to the house - the crowd cheering him, too, all the way, for Harry has fought like a hero-comes back, and going up to Keate shakes hands with him and says: "You're a game man and a good fighter, and you've beaten my man fairly." Loud cheers greet this manly speech, and then the great crowd disperses.

The foregoing gives a perfectly true description of how prize-fights were conducted in old times, supported as they were by the first families in England, both noble and gentle. If we could have them carried out now upon similar lines with the same class of patron , and to the exclusion of rowdyism, perhaps there would be found many of the present day who would still like to see British skill, courage, and endurance thus tested within the twenty-four foot arena.

Those of my readers who may turn up their eyes in horror at what I have just recorded and will record before I finish this chapter, should bear in mind the fact that in doing so they express horror at what the.r own fathers and grandfathers in all probability gloried in !

In an interesting work entitled "The Dawn of the Nineteenth Century," there is much mention of cock-fighting, which at that period used to be largely advertised in the fashionable Morning Post. One advertisement is quoted; it runs :- "Cocking, to be fought on Monday, January 7, 1805, and continued all the week, at the Cock Pit Royal, south side of St. James's Park, the gentlemen of Suffolk and the gentlemen of Hampshire's main of cocks, for five hundred guineas the battle, and one thousand guineas the odd. To begin fighting each day precisely at half-past five o'clock." This pit was in Birdcage Walk, and on 
such occasions the peer and the corner-boy met on the common ground of sport; and very lively times they seem to have had, judging by the description of the scenes.

What extraordinary adventures were had by many who attended prize-fights during the last years of their history! One had to remain up all night or to get up at two or three in the morning to be in time for the special train which we were told was to start punctually at an hour which was usually long before daylight. Provided with tickets the day previous, as most were, we sallied forth in the dismal morning, and in due time arrived at the station. There was encountered, no matter how secretly might have been kept the rendezvous, oh! such a crowd of ruffians. In fact, the scum of the scum of London. These rascals might perhaps let pass, without much molestation, any of the respectable class or upper ten who they might know, but a man like myself who was not honoured with their acquaintance would be badgered for tickets, and upon his not giving money for or getting them, he would, amidst the foulest abuse, be jostled and knocked about. After elbowing his way on to the platform and securing a seat in a first-class carriage, he would have to wait goodness knows how long before the train would start, but before its doing so the carriage would often be filled by representatives of the class met outside the station, many without any ticket, the rest with third-class tickets. Needless to say the conduct and language of these barbarians during the journey to wherever the fight was to take place was of the most disreputable sort. Arrived there, in the early morning, after a tedious and horrible journey often of from two to three hours, we made the best of our way to the scene of battle.

First thing the stakes and ropes would be produced, and the ring pitched. The seconds to the men would be selected beforehand, not so the umpires and referee. As a rule, these officials were not chosen until the ring was made, and over their nomination and election rows and ructions at times took place.

Well, in process of time these preliminaries would be arranged and with a rope run through posts, stuck some few feet outside the fighting arena, the inner ring was formed. This was the dress circle, and to it only those holding special tickets were admitted-at least, during the beginning of the fight. I should have mentioned before that for train-fare and admission to this exclusive circle a sum of from one to three guineas had to be paid the day before. Men provided with chairs accompanied the party, and those of the inner ring. who desired the luxury of one was accommodated upon shelling out four or five shillings extra. Outside the oi polloi congregated. Between the seconds a toss for corners was made, according to the result of which they took up their places. Around the stake of their respective corners would the colours of the combatants be tied. These consisted of common cotton pocket-handkerchiefs, of whatever colour or device each man might have chosen. They would be sold to those 
assembled at as many shillings as would represent the enthusiasm the purchaser might have for his man. After each of the combatants had shied his hat or cap-or as old Bell's Life used to call it, his castor-into the ring, they entered. Immediately they were disrobed by their seconds, and stood clothed only in light breeches, stockings and shoes or boots, with, at times, their colours tied as a sash around their waists. Advancing to the scratch, the men shook hands, in accordance with P.R. etiquette. Then, upon "Tine" being called by the referee, the fight began.

For the first few rounds between two well-matched scientific boxers, in good condition, and fighting to win, there is no doubt a great deal to interest a man who is fond of the science. After that, however, when the men get badly punished, the exhibition, to a man of ordinary susceptibility, ceases to have interest, and it gradually becomes to him disgusting.

No need to describe a prize-fight, as the narratives of Flowers and Keate, and that which I shall give of Sayers and Heenan, suffice; ; but I shall describe the conduct of those who, in greatest numbers, constituted the outer ring. During the whole time the fight lasted these demons would keep up tumult and uproar, each shouting remarks upon the fighting or encouragement to the man he wished to win. According as the fight was prolonged, and became doubtful as to result, the excitement and rociferation increased until at last Pandemonium could not possibly surpass it. Along the line of demarcation would usually be arrayed a lot of bullies and prize-fighters, to keep from breaking into the inner ring those of the outer. Sturdy and determined as these fellows were to do their duty, towards the end of nearly all great and protracted fights the precincts would be broken and the reserved space invaded by a crowd of howling ruffians maddened with the most brutal excitement. Owing to their conduct, seldom had there been for years a conclusion of a prize-fight brought off with fair play. And, as was the case in the great fight between Sayers and Heenan, the ring itself was continually broken into.

Degraded as these men were, and with organisation not superior to the brute creation, some of them possessed a degree of courage quite phenomenal; and many of them would fight until they died rather than give in to an antagonist.

With all their brutality these roughs were to some extent amenable to the law, for a few policemen were, as a rule, sufficient to put a stop to a prize-fight around which would be gathered two hundred of the greatest ruffians in London.

Rum conditions exist even in English law. A prize-fight would be stopped by the local authorities, but by removing into the next county, which might be within a few hundred yards, the fight could be continued and ended, the same officers of the law who had prevented it in the first instance looking on, inasmuch as it was then conducted on ground outside their jurisdiction! 
The return home from these gladiatorial exhibitions was generally as fraught with adventure as was the journey down. Between one extortion and another no man going to the inner ring of a prize-fight thirty years ago could return under the cost of at least three sovereigns, and a vast deal more if he was at all indiscreet or happened to get into more than the ordinary bad luck attendant upon them.

In olden times, before railways offered to the town roughs facility for attending prize-fights, these horrible scenes at the ring-side were unknown. Fights took place in the country, and the only spectators outside the upper ten were the yokels from the neighbourhood, and they behaved themselves.

The fight between Sayers and Heenan, occurring as it did over thirty years ago, is now never referred to or even thought of. Nowadays, when everything is carried out at high pressure, recent events, no matter how great, are soon forgotten, while those of a decade or two ago are looked upon as ancient history.

Dealing with the subject of this chapter and especially after referring to the sham fights of the day, it would be wrong of me not to say something about the greatest battle, and the one of all others the most sensational that ever took place in the annals of the British Prize Ring. To do so will recall to men like myself, who took deep interest in the manly fights of old, memories of their heyday, while some of the youngsters will learn the particulars of a great historic event which, hearing of it only by tradition, they know no more about than probably they do of the fight between David and Goliath.

Tom Sayers was born at Brighton on May 15, 1826, and began life as a bricklayer. He stood only $5 \mathrm{ft}$. $8 \mathrm{in}$. to $9 \mathrm{in}$. in height, but being a remarkably active and muscular youngster he was taken notice of by some of the fancy and taught to spar, and when nearly twenty-three he fought his first battle. It was with one Abey Couch for a modest fiver, and Tom beat him on March 19, 1849. He then, within the next few years, fought and beat, in succession, Dan Collins (after a draw), Jack Grant, and Jack Martin. Then came upon Tom his first and only defeat. It was given to him by the celebrated Nat Langham on October 18, 1853, but not until after a most determined and desperate resistance throughout sixty-one rounds, which occupied two hours and two minutes. "Old Nat" found Sayers so rough a customer that he refused to fight him again when Tom challenged hirn soon after.

In four months after he backed himself at $£ 50$ to $£ 25$ to beat George Sims, which he did easily in five minutes.

Sayers did not then fight until 1856, when, with Harry Poulson, he again showed what a wonderful man he was. Poulson was about the best middle-weight of the day, but after a tremendous fight, which lasted three hours and eight minutes, and after the 109th round, Tom was declared the winner. Then in February, 1857, he fought Aaron Jones, but, night coming on, the fight ended in a draw, but was brought off soon after, when Sayers won. This victory established him champion of the middle-weights. 
William Perry, "the Tipton Slasher," then held the Champion's Belt, and although he stood over six fee' and weighed nearly fifteen stone, the gallant Tom challenged him. Up to then no fight had ever caused more interes ${ }^{2}$, for although Sayers had proved himself by far the best of his class, he was not considered good enough to be Champion of England, and being so much below the Slasher in height and his weight being only 10st. $5 \mathrm{lbs}$., the pluck he displayed in challenging him was greatly admired.

The fight came off on June 16,1857 , and after one of the most determined and desperate of battles Tom, to the surprise of many, beat Perry, and thus took the Belt and became Champion of England

Bill Benjamin was the first to challenge Tom for the trophy, but he was beaten easily in three rounds, in January following. On the first anniversary of his winning the Belt he had again to defend it against Tom Paddock, another heavy-weight, whom he also beat. In April, '59, Bill Benjamin again tack'ed Tom, but he was beaten in twenty-two minutes.

Sayers was so fond of fighting he would allow himself little rest; so fiv months after, basking himself at $£ 600$ to $£ 400$, he fought and beat Bob Brettle in fifteen minutes. This fight was not, however, for the Championship, for Sayers would only consent to have the Belt thrown in if the match were at even money.

Sayers had by this time shown that, irrespective of c'ass, he was, bar none, the best man in England, but he was not long left alone, for his old antagonist, A+ron Jones, again challenged him. Soon after signing articles news came from America that John Heenan wished to fight Sayers for the Belt of England, whereupon arrangements were made with Jones to withdraw in favour of Heenan.

Sayers had up to this tims fought no less than fifteen battles, including the draws with Collins and Jones, and was beaten only once.

Jobn Carmel Heenan was born of Irish parents in May, 1834, at West Troy, New York, when Tum was exactly eight years old. At the age of twelve he was sent to his uncle, who lived at Benicia, Califorcia, and there he got apprenticed to a smith. Young Heenan soon developed into a splendid specimen of manhoot, and be:ame powerfully muscular through wielding the sledge-hammer; he was very fond of the gloves, and so $\mathrm{n}$ got so handy with them that he was dubbed among the Califor nian miners their "Benic:a Boy."

At th's tima Cusick the pugilist visited the West, and meeting the young giant, who s ood $6 \mathrm{ft}$. $1 \frac{1}{2} \mathrm{in}$. an 1 weighed between $13 \mathrm{~s}^{\mathrm{t}}$. and $14 \mathrm{st}$., persuaded bim to come Exst and aspire to first honours in the pugilistic circle. $\mathrm{H}$ enan accordingly arrived in New York in 1857, and to $\mathrm{k}$ a position as a leading pugilist, but, bolding a Government appointment, he d d not show inclination to enter the Prize Ring. After a time, however, he fought John Morrissey for the Championship of America a $d 5,00$ dollars a-side. The battle was decided at Long Point, Canaca West, on October 19, 1858, and after a slogging conttst of eleven rounds 
in twenty-two minutes (the first lound lasted six), Morrissey was declared the victor. It is justice to Heenan, however, to state that the latter part of his training was interfered with by an old sore in his leg breaking out, which necessitated his lying in bed for the week before the fight. Albeit, he fought well and with great courage.

Growing into still finer physique, and improved greatly in the science of boxing, Heenan, towards the end of 1859, determined to have a shy at the Championship of England, then held by Tom Sayers. To effect his purpose, on January 17, 1860, he landed in Liverpool. Next day he called on Mr. Frank Dowling, the editor of Bell's Life, for many years the acknowledged head of the P.R., to open negotiations. The gentlemanlike appearance and courteous demeanour of Heenan, contrasting with wonderful advantage over what they were accustomed to from English pugilists, quite astonished the staff of good old "Nunquam Dormio." They were still more surprised and taken with the man when he assured them that "he came to this country with the express purpose of measuring his strength with our champion, and was. influenced by no other feeling, speculative or otherwise; if defeated he could not help it, and if he should be so fortunate as to win, it would be to him for ever a source of the greatest pride." Preliminaries were soon got through, and after signing articles to fight for the Belt of old England and $£ 200$ a-sice, Sayers and Heenan went at once into training.

Then commenced, both in this and the new country, excitement and enthusiasm over this match the like of which was never known in respect to any cther; proportionate with which came zeal among the authorities to prevent its coming off.

Whether the fact that Sayers was more judicicus in the selection of his training ground and kept more in seclusion than Heenan prevented his being interfered with by the authorities I know not, but certain it is that his training was not interrupted. Not so with Heenan. No stone was left unturned by meddlesome and officious persons to cause annoyance to the Benicia Boy. Three times had he to change his quarters, and finally, upon taking refuge at Trent Lock, near the junction of Derbyshire, Nottingham, and Leicester, he was betrayed, and after a chase of a mile and a half across country, without shoes or stockings, he was captured by the police, and lodged in gaol only a few days before the fight was to have taken place. $\mathrm{He}$ was liberated next day on bail, himself in $£ 50$ and two suretif $s$ of $£ 25$ each. Owing to this interruption and the continued pestering he got from the police, the day originally fixed for the fight had to be postponed.

Had the authorities worried Sayers it would have been bad enough or had they treated each man alike nothing could be said against them but to leave unmolested our own countryman and hound down the brave foreigner who came to England to fight her champion was little short of a disgrace to the nation.

The nation, however, was not to blame; all true Englishmen 
denounced the treatment to which Heenan was subjected, unnational as it was in every one particular. It was all occasioned by a clique of goody-goodies and a handful of J.P.'s-custodians, no doubt, of the peace, but assuredly devoid of ail notion of justice.

Luckily, the harassing he got had no effect upon Heenan, for he stripped on the morning of battle in as fine condition and as grand a specimen of a gladistor as ever pulled off a coat.

The first man who aspired to the title of Champion of England was the celebrated Figg, who, in about the year 1719, first wore the Belt. Since then many scores of brave men have toed the scratch, and within the twenty-four foot arena fought doggedly and scientifically for the championship. Excitement, at times intense and widespread, prevailed over some of these fights, but it may with safety be said that never did any fight for the championship produce quarter the excitement and enthusiasm as did that between Sayers and Heenan. Every paper in the country, including those of the bighest class journalism, opened their columns to the all-engrossing topic and, to the credit of their editors, by far the greater numbar abstained from adverse criticism, while many gave to the great event friendly comment.

The authorities as the day approached redoubled their efforts to prevent the fight, and sought diligently, luckily without success, for the principals. With such publicity and with every man in the kingdom talking about it, to keep secret to the last moment when, but more particularly where, the fight was to come off was a task difficult in the extreme. Effectually, however, was it performed. The day at last became generally known, but not until it had almost arrived. To put the authorities off the scent no end of ruses were adopted, and on many a wild-goose chase were hundreds of police sent to places given out as being selected for the battle.

Considering the amount of interest which had centred in this, a great international contest, not alone from every part of our own kingdom and America, but from, I may say, all over the globe, I do think the heads of our authorities would have shown more discretion and diplomacy had they shut one eye, at least, and let the great question be decided without the worry which they occasioned. To have done so would, at all events, have saved them from the ridicule heaped upon them at the signal and humiliating discomfiture they happily sustained.

About one o'clock in the morning of Tuesday, April 17, 1860, the rendezvous was made public. "London Bridge at four o'clock." The scene at Owen Swift's and Harry Brunton's, at Nat Langham's and Alec Keene's beggars description. It was known towards midnight that the announcement would be made at these houses, and that tickets would be issued, so each place was crammed.

Two monster trains were prepared and in readiness at the station. The first, consisting of no less than thirty carriages, was despatched, full as it could hold, at 4.30. The second, nearly as long, and quite as full, followed soon after. All along the line for nearly twenty miles 
were police on the look out, both mounted and on foct, and all armed with swords; however, the only reward for their early rising these poor baffled fellows received was booing and grimacing from the occupants of the flying trains. Great preparations to stop the mill were also made further down on the Dover and Brighton lines. They, too, were needless, for our trains, turning off at Reigate Junction to the Guldford line, gave them the slip, and along it there seemed to be no preparation. Near here the engines, for the first and only time, stopped to take in water. Starting immediately, and not knowing where we were going to be set down, on they rattled till they reached, at nearly seren o'clock, on a lovely spring morning, Farnborough Station. Here all got out and, led by the only three men in the world who up to then linew where the fight was to take place, adjourned to a field close by and on the borders of Hampshire and Surrey.

On a spot which had been selected beforehand with excellent judgment-for it was level as a billiard table-the ring was quickly staked off by old Tom Oliver and his son.

Around it immediately gathered over twelve hundred spectators to see this, the great and long-talked-of fight for the Champion of England's Belt and $£ 200$ a-side. Within the inner circle congregated representatives of the highest classes in England. I had not the honour of being acquainted with any of them, but I was told that among the lot were to be found high dignitaries of the Church and State, ex. Prime Ministers and Cabinet Councillors, Generals and Admirals, while M.P.'s and officers of both services mingled thickly with scores of those who held distinguished positions in the pages of Burke and Debrett. In fact, never before that memorable morning of April 17, 1860, did an assemblage nearly as numerous, much less aristocratic, stand round a public prize-ring. Anticipating, as everyone did, a great fight, the most sanguine could not have expected to see anything like what was in store for them.

All being in readiness and the enormous crowd disposed in tolerable order, Tom Sayers appeared, and, chucking his hat before him, was the first to enter the ring. He was attended as seconds by Harry Brunton and Jemmy Welch. Heenan followed immediately, with Jack Macdonald and his trainer Cusick as attendants. The men had never met before and, after eyeing one another curiously for a few seconds, they advanced and shook hands most cordially, engaging at once in friendly conversation which they continued while the umpires and referee were being chosen. This manly demonstration called forth from all present most tremendous cheering.

Sayers' colours were the Royal Standard of old England, while Heenan's were the immortal Stars and Stripes. Heenan won the toss for corners and took that next the sun, whereupon the colours were tied to their respective stakes.

When the men had stripped and advanced to the centre for the final shake, two specimens of manhood grander developed or in more perfect 
condition were never before seen. The contrast as regards height and weight was, however, most remarkable. Tom was within a month of being thirty-four years old, stood 5ft. $8 \frac{1}{2} \mathrm{ins}$. , and weighed $10 \mathrm{st}$. 9lbs., as recorded by Sam Rogers' racing scale in which Johnny Gideon, his backer, weighed the champion two days before. Heenan, who was exactly eight years younger, towered above him by $4 \frac{1}{2}$ ins., and scaled just half a pound under 14st.

There was still further contrast between them. Tom was swarthy as a gipsy, wich a hide tough as an otter, every thew and sinew was strung like catgut, while the muscies showed like hempen hawsers. His back and loins were magnificent and his thighs were those of a giant, and with his short thick neck, close-cropped head, disfigured face, and agile frame, truly Sayers looked the personification of a prizefighter.

Not so Heenan. His skin was white as a woman's, but through it shone muscular development most remarkable, that of the biceps and deltoid being prodigious. His chest and back, broad to a degree, were likewise covered in rolls and flakes, but he had neither the loins nor the legs of Sayers. His neck was also thick but long, while with his well-shaped head covered with curly black hair, and particularly handsome face, he looked a gentleman. Standing forth in the prime of youth with such magnificent bodily development, Heenan presented symmetry perhaps as perfect as was ever seen in a prize-ring. Of a truth he was a model for a sculptor.

As far as appearance went, and their powers subsequently proved, human art could not turn out men in more perfect condition than were these two gladiators.

To refresh my memory I have before me Bell's Life, of April 20, 1860, wherein is given, in most minute detail, the particulars of each round, but I shall not enter upon them further than to summarise generally.

The fight began precisely at 7.29 a.m., with odds of 2 to 1 on Sayers.

When the men put up their fists it was seen how much longer was Heenan's reach than Tom's, and that the latter must use all his science and activity to keep beyond it. Notwithstanding which, Tom drew "first blood" in the first round.

In the second, after some pretty fighting, Heenan caught Sayers, and throwing him heavily fell on top of him.

In the third Heenan knocked Sayers clean off his legs with a tremendous left-hander on the bridge of the nose, which was "first knock down" for Heenan.

Tom seemed greatly bothered with the sun which shone straight in his eyes, and he was again knocked down in the next round, and odds of 6 to 4 were offered on Heenan, the Sayers' party looking very blue. The fifth round also was all in favour of Heenan, who, although hit hard by Sayers in every round, had not a mark on him, while Tom showed plainly "the Boy's" handiwork.

In the sixth round, when stopping one of Heenan's tremendous left- 
handers, Tøm's right arm received its full force, and was dashed against his face.

When coming up for the seventh round it was plain that Tom's right arm was badly hurt, for already had it become swollen. In this round was displayed an amount of skill on the part of Sayers combined with pluck and determination never before exceeded. With his right arm resting across his chest useless, and giving him most excruciating pain, did Sayers fight his man all over the ring. In vain did Heenan strive to get away from Tom or administer another knock down. After him Sayers went, planting shot after shot from his left fist straight on to Heenan's right eye. Three times in this round did Heenan retire to his corner for rubs down, while the gallant champion waited for him in the centre of the ring, getting but one wipe from his sponge. Upon one occasion, when Tom got Heenan into his own corner, he seemed to have the giant at his mercy, and the crowd yelled to him to use "the auctioneer"; but there it lay disabled. Had this not been the case, Sayers would then have finished the battle, for he never hit a man with the full force of his right arm without knocking him out of time. Not using it in this instance, with Heenan partially demoralised and nearly blind of his right eye, everyone knew that Sayers' arm was broken. This round lasted thirteen minutes, and was all through fast and furious. Odds now veered back to 2 to 1 on Sayers.

No. 8 was a repetition of the former round; equally magnificent was the fighting, but Tom hit his man nowhere except on the right eye. Heenan, again preferring his corner to the scratch, sought several times the advice and consolation of Jack Macdonald, and upon one occasion, while sitting on his second's knee, Tom went close up and, after scrutinising the damaged eye, came away satisfied and smilingly informed the spectators that having bunged it up he would now see what he could do with the other one! This round was closed after twenty minutes' fighting by Heenan giving poor Tom another clean knock down.

Both men now showed signs of heavy punishment, Heenan much the worst, while Sayers seemed the weaker and most in want of wind, so much so that in the tenth round Heenan lifted and threw him heavily with the greatest ease.

The men had then for a few rounds to spar for wind, and neither answered with alacrity the call of "Time." In the thirteenth Heenan again knocked Sayers down.

Tom was very weak in the fourteenth round and Heenan forced the fighting, but with consummate skill Sayers sparred till he somewhat recovered wind, and then, with extraordinary activity, let fly stinger after stinger on to Heenan's left eye, and both men closing, Tom, amidst tremendous cheering, threw the Benicia Boy and fell on him.

So matters progressed till the twenty-third round, when a stool was given to Heenan to sit on, but it was ordered out of the ring by the referee as being contrary to the rules. Heenan's hands had now 
become much swollen and did not do their work as effectively as before. One hour and eleven minutes had run off at the end of this round, with Heenan favourite at 5 to 4 .

Strange to say, both men recovered wonderfully in the next round or two, so that in the twenty-sixth was desperate fighting ; in the end Tom got down and Heenan by accident struck him. An appeal of "foul" was made, but it was properly overruled.

The twenty-seventh was also hard fought. All this time Tom continued popping on to Heenan's left eye, which was now fast closing up, the right having gone totally blind long before. He was stronger on his pins but showed far more punishment than Tom, who, wonderful to relate, showed little considering all he bad gotten.

Heenan in the thirty-first round again stuck to bis corner and had to be drawn by Tom, who went again to see how the left eye was improving, but another sock dollerger sent the gallant champion for the ninth time heels over head.

In the next round Tom was very groggy and had to be visited in his corner by the Boy, and after a lot of heavy in-fighting Sayers was again floored. Heenan was now fast getting totally blind, and although stronger than Sayers, unless he could finish the battle within a few minuter, he would be unable to do so. He then forced the fighting while Tom dodged for wind and rest.

In the thirty-fifth round Heenan so peppered Tom that he turned and ran with Heenan after him, but turning short he landed another stinger on the fast-closing eye. Then followed rapid fighting, when both fell, Tom under. Time up to now exactly two hours.

Coming up for the thirty-sixth round, the Benicia Boy's face was a spectacle to behold, while Tom was very weak. Heenan at once rushed to a close, and eatching Tom round the neck tried to get him across the ropes ; but getting free, he slipped down. The police, who had arrived a long time before and had been trying to get to the ring, now made a determined effort to stop the fight, but were again kept back by the crowd.

For the thirty-seventh and last round Sayers came up first and seemed the better man, while Heenan was almost totally blind; but catching Tom round the neck he then got him across the ropes, and with all his weight lay across the poor fellow, who, nevertheless, kept pegging into his man. To prevent Sayers being strangled, for he now could not get away, the ropes were cut at exactly 9.35 a.m., after two hours and six minutes' fighting.

There was immediately a general rush made by the crowd into the ring, and with the police striving to take into custody the men and the seconds, a most furious riot ensued. What in reality took place no one could tell, for everyone was hustled about, while the umpires and referee were chucked clean out. There is, however, no doubt that the combatants got together and fought five more rounds in a small space made for them in the crowd, but there being no referee present, 
and he haring ordered that the fight should cease when the ropes were cut and the police appeared, the men should have been taken away; no cognisance was therefore taken of these supplementary rounds.

Heenan, seeing how matters stood, and that the fight must be declared "a draw," behaved himself, it must be regretfully stated, in a most scandalous manner, and, to quote the words of Bell's Life, "while Sayers was on his second's knee, Heenan rushed at him in an excited state, let fly left and right at Tom's seconds, floored them, and kicked them when on the ground in desperate style, after which he closed with Sayers, and after a wild rally they fell together."

The referee was then able to get near and again ordered the men to desist from fighting. They did so after having added five rounds and fourteen minutes to the authorised termination. Many accounts of this fight give forty-two rounds with two hours and twenty minutes. But what I here state is the fact of the matter.

That Heenan was comparatively fresh, although terribly punished and almost stone blind, is proved by his having rushed with the crowd and run for some distance with the activity of a deer, immediately after which he lost his sight totally, and collapsing altogether, he had to be lifted bodily up the embankment and into the railway carriage.

Sayers became quite fresh after a few minutes, while his eyes were as good as ever, and, with the exception of his broken arm, he showed comparatively few sigus of the fearful punishment he sustained.

Upon returning to London, Heenan had to be put to bed, and did not turn up for some days. Sayers, on the contrary, appeared in the evening at one of the fighting pubs-I think at Langham's-and went about London next day apparently as well as ever, but with his arm in splints, hung in a sling, the radius bone having been broken.

Never in the annals of British prize-fighting was there such a battle as this ; skill, science, and tact were displayed by both men to a degree perhaps equalled but never surpassed, while each fought with courage and determination to be admired for all time. Manliness and fairness were displayed by both men, and without an attempt at shifting, each scorned to take a mean advantage. Evidence of this they frequently gave during the fight, for which they were loudly and repeatedly cheered alike by backers of both.

While according to each equal share of courage, manliness, and dogged determination to win, there can be no doubt Sayers was the best man. This is abundantly proved by the fact that for thirty-one rounds, occupying just one hour and forty minutes, he, with his left hand and bothered with the sun, fought, until he blinded him, the man who was four inches and a half taller, weighed three stone five pounds more, and was eight years younger.

Of course it was Heenan's blow broke Sayers' arm ; but that, it cannot be denied, was nothing but a chance blow. If that fluke had not 
occurred, Sayers most undoubtedly would have beaten Heenan before the tenth round, and in all probability would have done so in the seventh, when he had him so at his mercy in his own corner.

To see Sayers continually knocked clean off his legs and sent spinning over and over like a rabbit from Heenan's terrific left-handed blows, which he was no less than ten times, was lamentable in the extreme; to see the gameness with which he picked himself up and retired smiling with good humour to his corner was admirable beyond measure; and to see what little effect that terrible punishment had upon his tough and wiry frame was simply marvellous. Besides the ten clean knock-downs, Heenan in wrestling and rallies threw Sayers six or seven times, always falling on the little man with all his weight.

This only shows to what a degree of hardihood the bodily frame of man, when sound and well developed, can be brought by "condition."

When he found his right arm was broken, Sayers throughout the remainder of the fight strove only to blind Heenan. This he did by beginning with his right eye and never leaving it till he bunged it up, and then until the end directing his attention only to the other. Many times he had to give up grand chances he had at other parts, while Heenan pegged away at any place he could find on Tom.

It is generally conceded that Jim Mace was the most scientific boxer that ever crossed fists in a ring, and having often seen him spar I readily agree with the decision, but lacking pluck and stamina, he could not for five rounds stand against Sayers. Knowing well Sayers' history, and how he fought men so much above him in height and weight, considered as they were the best of their day, never will I believe that a better man was ever stripped than Tom Sayers.

At the time I felt pleased this great fight ended in a draw, for it would have been a pity that either of these brave men should have been put in a position to crow over the other. Consistent with fair play-the magnificent and leading trait of British character-Sayers and Heenan were, by the oracles of the P.R., declared equal, and each was presented with a belt, a facsimile of the original champion's. This excellent and admiral arrangement was brought about by Mr. Frank Dowling; the editor of Bell's Life, who, at the Alhambra in London, on May 30,1860 , presented on the part of Great Britain each man with his belt.

In addition, members of Parliament, the Stock Exchange, and Lloyds, together with London merchants, subscribed for Sayers in recognition of his gallantry, a sum of three thousand pounds. This was invested for him, so that he could only draw the interest during life and dispose of the principal at his death. He then came to live in Camden Town, where, for some time, he stayed at the house of Mr. Menzies, the bootmaker in High Street, and there he died. Poor Tom, like too many other fine fellows, did not possess moral courage equal to the physical, and despite all persuasion he took to drink which hurried him into consumption, and he died on November 8,1865 , 
aged only $39 \frac{1}{2}$ years. He was buried in Highgate Old Cemetery near the top gate. A massive marble monument, with an excellent likeness of the gallant fellow carved on the front and another of his favourite mastiff at the foot, now marks the resting-place of the greatest prizefighter that ever lived. Two days ago I hung a wreath of oak leaves over the poor fellow.

I met Heenan soon after his fight with Sayers and we spent some evenings together. No one would ever take him for a prize-fighter unles 3 they crossed fists with him. He was refined both in manner and taste, while in figure he was about the most perfect model of a man I ever saw. Some of the old folk of Waterford may still remember the time when he came there with some big travelling circus, and when "a local amateur" entertained a large audience by putting on the gloves with him in the sawpit.

He subsequently fought Tom King for the original belt and $£ 1,000$ a-side on December 8,1863 , but was defeated in thirty-five minutes after a hard fight of twenty-four rounds. Observing the etiquette of the P.B.A., Sayers seconded Heenan in this fight. Alas! what a miserable and melancholy remains was he of what he was when the two met but a few years before in the famous Farnborough field.

Heenan also went into consumption, but I don't think it was produced from dissipation. When travelling south to a warm climate he was seized with violent hemorrhage at Rawlin Station, in Utah County, on the Union Pacific Railway, where he bled to death in a few minutes on Octsber 25, 1873, aged, by a curious coincidence, exactly the same as Sayers, viz., $39 \frac{1}{2}$ years.

I suppose I shall be pitched into by some of my friends for thus describing at such length the prize-fight between Sayers and Heenan. Valuing as I do the good opinion of everyone, I care not if I be. To give an account of a fight such as this, unparalleled as it is in every way for magnanimity, is what I feel pleasure, if not pride, in being able to do. Were I to allude in these pages to other so-called fight;, particularly those which have taken place within recent years, I would indeed not alone deserve condemnation but, absolutely, I should disgrace my book.

The "fights" of the present day with stakes of $£ 2,000$ and upwards are more inferior in manliness to the old than are the stakes superior in value.

Throughout portions of this book, when making comparisons between the past and present, I gave my opinions. Many of them, including what I now say about the old and new system of prize-fighting, will doubtless be traversed by my readers. I shall therefore bring evidence to back me in this case as I did in others. It will be found in the following record of Tom Sayers, by which it will be seen that out of sixteen battles he was beaten only once. He fought three draws, and won outright twelve battles. He won the Belt by his victory over the Tipton Slasher, and had four times to defend it (marked $a$ ). Deduct- 
ing the defeat and draws, all he netted for fighting 381 rounds, which took fourteen hours, was $£ 1,505$, or $£ 1258$ s. 4 d. a battle !

Some of the fellows of the present day, with neither the pluck nor the science of Sayers, would make more money in ten minutes in a glove fight of three rounds!

The Battles Fought by Ton Sayers.

\begin{tabular}{|c|c|c|c|c|c|c|}
\hline Date. & & Stake. & Rounds & \multicolumn{3}{|c|}{ Time. } \\
\hline Mar. 19,1849 & Beat Abe Couch & $\stackrel{\dot{L}}{5}$ & & & $\begin{array}{l}\mathrm{m} . \\
12\end{array}$ & s. \\
\hline Uet. 22,1850 & Draw with Dan Collins. & 2.5 & 48 & & 19 & () \\
\hline April 29, 1851 & Beat Dan Collins ......... & 25 & 44 & 1 & 24 & 0 \\
\hline June 29,1852 & Beat Jack Grant .............. & 100 & 64 & 2 & 30 & 0 \\
\hline Jan. 26, 1853 & Beat Jack Martin... & 50 & 23 & 0 & 55 & 0 \\
\hline Oct. 18,1853 & Beaten by Nat Langham. & 100 & 61 & 2 & 2 & 0 \\
\hline Feb. 28,1854 & Beat George Sims......... £50 to & 25 & 4 & 0 & 5 & 0 \\
\hline Jan. 29,1856 & Beat Harry Poulson $\ldots \ldots \ldots \ldots \ldots$ & 50 & 109 & 3 & 8 & 0 \\
\hline Jan. 6,1857 & Draw with Aaron Jones........... & 100 & 63 & 3 & 0 & 0 \\
\hline Feb. 10,1857 & Beat Aaron Jones............ . & 100 & 85 & 2 & 0 & 0 \\
\hline June 16,1857 & $\begin{array}{l}\text { Beat William Perry, "The Tip- } \\
\text { ton Slasher," for" the Belt and }\end{array}$ & 200 & 10 & 1 & 42 & 0 \\
\hline Jan. $\quad 5,1858$ & Beat Bill Benjamin .............. & 200 & 3 & 0 & 6 & 30 \\
\hline June 16,1858 & Beat Tom Paddock ................ & 150 & 21 & 1 & 20 & 0 \\
\hline April 5,1859 & Beat Bill Benjamin ............... & 200 & 11 & 0 & 22 & 0 \\
\hline Sept. 20,1859 & Beat Bob Brettle ......... £600 to & 400 & 7 & 0 & 15 & 0 \\
\hline \multirow[t]{3}{*}{ April 17,1860} & Draw with John C. Heenan .... & 200 & 37 & 2 & 6 & 0 \\
\hline & Total, sixteen battles & 1930 & 590 & 23 & 20 & 58 \\
\hline & Average of each ........ & 120 & 37 & 1 & 28 & ? \\
\hline
\end{tabular}




\section{CHAPTER XX.}

\section{BETTING.}

A uthor's Object in Writing This B rok-A Parasite-Antithesis of Spor:-Birth of BettingEarly History-As Time Adranced-Bookmaking Born-The Upper Ten-Method Changed-The Patricians-"The Betting Ring"-Gambling on Cocks an 1 Cards-The Professional Bookmaker-Crockford-Gully-Davies-The Derby-Greatest Betting Race-Great Bettors-Leviathan Bets-Miserable Examples-Betting ListsOrigin-Race Meetings Increased-So Did Backers and Bookies-Betting in the Abstract-Universality-Infatuated People-Unreliable Tips-“'In the hinow "-Odds Against-Sure to Lose-Lofty Principles-Author Often Made a Book-Always Won -A Trainer's Opinion-That of Shop Boys-Their Fancies!-Great Fun-“ Romped Home"-Criticism-A Knowing Shot's Opinion of the Hardwicke Stakes, 1887Pitiable Sight-Heads or Tails-Simpletons-Paying Bookmakers Beforehand-The Bishop of Durham-Author's Enjoyment on a Racecourse-Bookmakers-Author takes Their Part_ "The Noble Army" v. Other Communities-Insurance Companies -A Simile - "Lloyde" v. "Tattersall's"-Downs and Ups-Great Changes-Equality -Ultimate Result-Money -Betting the Socialist's Ally-Magnitude of ExchangeDifficulty in Dealing with Betting-Certain Result-Impregnates other Branches of Sport-How to Deal With It-Make it Lawful-Existing Laws-Stock Excliange v. Tattersall's-Horses v. Bulls and Bears-A Gruesome Story.

I HAVE strive through the various chapters of this book to deal with sport, or what pertains thereto, as best as I could towards its advancement. I now come to treat of a subject which partakes of the nature of a parasite of sport; in fact, betting must be losked upon as the very antithesis of sport.

Neither the birthplace of betting nor the date of its birth do I know. Assuredly when horse racing was frist introduced to England it was uaborn, for in the early history of the Turf no mention is made of it. After awhile, however, we d) find records of wagers, but they seem to have been confined to the owners of the horses and their immediate friends or followers. Most of the races in olden times were matches, the:efore the wagering had to be confined to backing one horse against the other, so there could have been no bookmaking.

As time advanced a change took place in racing, and consequently in th 3 wagering; numbers of horses being started, bookmaking came into creation, but the practice, as well as backing, was followed only by the Upper Ten.

It was the custom of these patricians of old to congregate on the morniog of the race meeting either in the town, near the course, or on the course itself, and there make their bets amony themselves. This they did by forming a ring, to the centre of which he who wished to wager advanced and proclaimed whatever bets he wished to offer or to accept. Hence comes the word "Betting ring," so very well known at present. 
In these old times large sums were also betted upon cock-fighting. Lord Derby's "black-reds" would be matched against the "Cheshire piles" for enormous amounts. Five-and-twenty guineas a battle, with fire hundred on the main, was a stake often fought for in the Chester and Preston Pits. On one occasion, as is recorded in the previous chapter, the stakes were a thousand a battle and five thousand the main. As in racing, betting on cocks was restricted to the upper classes.

Gambling over cards also took place to a fearful extent, as the early minutes of "Brooks's" and "White's" record. It is related of the celebrated Henry Mellish that after having lost $£ 100,000$ one night at hazard he was going home, but met one of the Royal Dukes who persuaded him to return and see if luck would change. It did change, whereby he won back what he liad lost, and, in addition, a great deal more than $£ 100,000$ from H.R.H. This debt was squared by settling on Colonel Mellish for life $£ 4,000$ a year. Fancy what the play must have been to have enabled a man in one night to lose $£ 100,000$ and then win over $£ 200,000$ !

In due time the professional bookmaker made his appearance on the racecourse, but I can't fix the date of his advent. I should say Crockford was one of the first; at all events, a hundred years ago he was a bookmaker, and of the greatest magnitude. He afterwards started a gambling club in St. James' Street, where the Devonshire Club now stands. In this place numbers of the finest fellows in England were ruined, while the owner amassed a tremendous fortune. This fiend, hideous in body as in mind, was dubbed "the father of hell and hazard," a title which, by infernal right, was truly his own.

Then came John Gully; then William Davies, called the "Leviathan," from the magnitude of his transactions, and numbers of others. With them the upper classes gambled to a fabulous extent, and wagered sums now happily unknown.

From an authority of the day I learn that in 1810 John Gully, who essayed to be champion of England, began as a bookmaker. This he did with a capital of three or four hundred pounds, which he won in his last battle with Gregson. Gully, in a very short time, made a lot of money upon bookmaking and became the owner of several racehorses. For nearly forty years he was among the most prominent men on the Turf, and was one of the heaviest bettors. This quondam pugilist died with a racing reputation which any patrician might be proud of.

As far back as 1823 the Derby was a race upon which tremendous sums of money were laid out, and from then up to even now it has remained the heaviest betting race in the world.

We have chronicled among the heaviest bettors of their day such men as the Duke of Queensberry, Colonel Mellish, Lord Foley, Sir Charles Bunbury, Lord George Bentinck, Sir Joseph Hawley, Mr. James Merry, Mr. R. C. Naylor, the Marquis of Hastings, and Mr. Henry Chaplin. For these men, and scores of others, to lose or win on a single race $£ 10,000$ to $£ 50,000$ was by no means uncommon. 
To illustrate some operations which took place, Davies, in two bets, lost $£ 55,000$ to $£ 1,000$ over Daniel O'Rourke, $£ 30,000$ to $£ 2,000$ in one bet over Teddington, and $£ 25,000$ to $£ 1,000$ over West Australian. But this was when winter and yearling books were made on the Derby, and long before post and starting-price betting was thought of. This same Davies lost over the Derby several thousand pounds to a man who died suddenly after the race, but Davies found out his widow and paid the amount to her, which she was very much in need of. In acting so Davies did only what any honourable man would have done, and what scores of the "noble army" of present-day bookmakers would do, for among them are many possessed of the highest principles of honour. Like Gully he sprang from very low origin and left after him an honourable reputation.

So far as tigures go, the largest stake ever won by a man is accorded to Mr. Chaplin over Hermit. His account is said to have shown a credit balance of something like $£ 150,000$, but a considerable part of it was on paper, and is owing to this day. The person who won the most money, and got it, was Mr. Naylor, who had over $£ 100,000$ paid in to his bankers the week after Macaroni won the Derby. Mr. Merry is pupularly supposed to have won upwards of $£ 100,000$ over Thormanby, but those in a position to form a proper judgment believe the sum did not exceed $£ 70,000$, which is about what Sir Joseph Hawley won on Teddington, and also on Musjid. Next to these probably comes the Marquis of Hastings' coup over Lecturer's Cesarewitch, which was put down at some $£ 60,000$, while the owner, trainer, and two stable commissioners netted between them $£ 47,000$. His winnings over Lecturer did not benefit the youthful marquis much, for by backing Vauban and laying against Hermit in the next year's Derby he lost $£ 95,000$, and the year following, in the same race, his own mare, Lady Elizabeth, lost him $£ 80,000$.

Lord George Bentinck's transactions with the Ring were of a magnitude as gigantic as was ever chronicler. Unluckily for himself the losses far exceeded the winnings, and had he gone on it is highly probable his financial end would have been similar to that of the unfortunate owner of The Earl and Lady Elizabeth. It is said that ine went in for breaking the bookmakers. I thiok it likely his lordship did nothing of the sort, but if he ever entertained the idea he went about it in an honourable straightforward manner. He stood to win $£ 160,000$ on his horse Gaper for the Derby of 1843, but Bill Scott on Cotherstone frustrated the object.

A man named Walton came to England from America in about 1881, and through disreputable means got possession of stable secrets by which he won large sums. $£ 75,000$ was put down as his winnings over Foxhall and Iroquois in the Cesarewitcb, Cambridgeshire, and St. Leger. This fellow wished and tried to break the Ring, but I am happy to say it broke him.

Like breaking the bank at Monte Carlo, to break the Ring is easier 
talked about than accomplished. No one has ever broken either the bankers or the bookmakers, while they have broken and beggared thousands upon thousands of people. The Ring had an escape, however, in 1852, for had Hobbie Nobls won that year's Derby, Mr. Merry would have hit it for the greatest amount that man ever won over a horse. I heard the sum estimated at nearly a quarter of a million of money, but I don't vouch for the accuracy. At all events, instead of winning, he lost a sum which no one but a millionaire like him could afford, and which, going to the Ring, made it all the more invulnerable.

For one man that makes money by backing horses at least one hundred lose. Thousands of instances have we of members of some of the oldest families in England, not to speak of parvenus, ruining themselves through betting. Happily, however, most of them did so without dishonour, and many are to be pitied for their folly and-shall I say it ?-bad luck.

We Irish are not, as a rule, credited with having more wisdom and aiscretion than the English, albeit I can recall to memory only two of my countrymer, who moved in the best society, having come to utter grief through gambling on horses within the past thirty years; yet it cannot be said that we have been backward in the game of betting. Proud also am I to be able to state that during that time an Irishman of position has never been accused, much less found guilty, of dishonourable conduct on our Turf.

The fashion as well as the method of betting has, like other things, undergone changes for the worse within the last half century.

In the beginning of the sixties race meetings began to increase and multiply in England. At that time first came out betting lists, while Holt and Crook, also Reynolds and Fisher were those who first circulated them. These documents were sent broadcast all over the country and were got up in a most comprehensive manner, quite as much so as were the circulars which emanated from the most precise of business firms. To these lists I attribute the first conception of betting in the minds of the middle classes. Up to their appearance betting was restricted to the upper and wealthy classes; the others scarcely knew of any races beyond the great events, but these and such like catalogues soon enlightened them and sowed the seeds of bitter fruit, for immediately began the middle and poorer classes to back horses.

With the Derby and other classic races the newly-started meetings shared the patronage of the betting public. Race meetings still continued to increase, with them increased the backers, and to meet their requirements the ranks of the bookmakers were proportionately added to. Thus progressed matters till within the last ten or fifteen years backing horses has become part and parcel of the daily occupation of the greater portion of our population.

There is scarcely an establishment in the kingdom, from Somerset House down to that of the humblest trader, which has not in it employees who habitually back horses, not alone for the principal, but for the 
minor events of the year. These men indulge their taste for betting without the slightest knowledge of the horse they put their money on; they know absolutely nothing about him, but act on the "tip" they get from a friend, perhaps as ignorant as themselves, or from those "selections" seductively given in almost all the daily as well as all the sporting papers. These infatuated people are, as a rule, innocent of every sense or love of the sport on which they risk their hard-earned pay, and only take to the vice of betting for the sake of gambling or to supplement their salaries, which are, too often, scant. It is to this betting and to its twin brother, stock-jobbing, that many a man who was naturally honest and honourable has to attribute his downfall.

Of course there is no harm in a man backing his fancy according to his means to give him an interest in the race, particularly when he would have none in it from a sportsman's view ; and it is very productive of innocent excitement to have a friendly bet for a trifle with a companion while seeing the race run. Neither is there much harm in having a little on something for the great races, such as the Grand National, Derby, or St. Leger. But what I do object to is the all-round betting for the pure love of gambling by men who can't afford to lose the stakes they put on; and it is to them, and them alone, I wish to give the steel!

Some men take from the betting ring the same pleasure as others do from the theatre and the opera. Therefore let them indulge their propensity, but keep within bounds, and spend on betting only what they can afford, same as the others do upon the drama and music.

It is all very well for those who can afford to lose, and have the mania for gambling, to bet heavily, for it is about the most practical way for them to part with the money they so little value; but it is dreadful to think of the many thousands who, unable to afford to lose, back horses, every one of whom lose sooner or later.

What do these fellows know about a horse? What can they know about the intentions of a rider or an owner in respect to any giren race? Certainly they are always well posted in the previous performances of the horse-thanks to the records of "Ruff," their constant vade mecum. But without the essentials of practical knowledge they risk their money upon unreliable tips of one sort or another.

A man who is "in the know," and is sufficiently sagacious, may occasionally win money by judiciously backing horses even though the odds are immensely in favour of the layer, but the outsider cannot; on the contrary, he is bound to lose, and so is the man "in the know" if he only sticks to it. Even with sagacity and a knowledge of what is "intended," and all else that may be in the backer's favour, there are so very many more chances against his favourite winning, not to speak of squaring, roping, and scores of other means of robbery, together with unfair odds given, at times, by bookmakers, that backing horses is about the most certain method of losing money at present invented. Though a man has the funds of a millionaire at his back he will lose all if he backs horses heavily and habitually. 
Let not the reader imagine that it is from the standpoint of lofty principles I write against backing horses; for if I thought I could win I would do it myself. But I know I cannot, therefore I do not, and during the many years I have been going to races I never backed twenty horses in them all. I only made one bet at Punchestown during the thirty-two years $I$ have b-en going to it, and then I won $£ 7$ on Pacsion Flower with Mick Widger up. When I vas a youngster I often made a book in a small way among friends; and though I had few backers and could seldom get "round," I always found myself a winner at the end of the year. This perbaps first showed me the folly of backing horses, and the experience of years since has contirmed me in the opinion that it is folly.

As I said elsewhere, one of the greatest trainers in England, knowing as he did the uncertainty of racing, allowed a great portion of his horses to run unbacked by him, and that in the face of the fact that he seldom ran a horse that had not a reasonable chance of winning.

Now, when a man in the position of him to whom I have alluded, possessing as he did good knowledge of the horses which were engaged against his in a race, and knowing all about the capabilities of his own, considered it to be a losing game to back horses, how in the name of wonder can the general public imagine that they can make money by the process? Still, we hear bank and insurance clerks, draper's assistants, grocer's counter-hands, aye, even the very newsbove in the streets, giving their opinions of horses and backing their fancies. Their fancies! At the same time I must confess that I have had great fun listening to some of these fellows talking to each other on a race. course and elsewhere. One chap having landed three or four sorereigns, after dropping twenty on the day, jubilantly assures his h'arers that his selecti un "simply romped home," the fact being that he had won by a short head, and entirely owing to jockeyship.

With nothing else to do I have also listened to these simpletons critici-ing this jockey for making the running, and another for lying too far away, they being as qualified to give an opinion on what they were talking about as they were of giving a practical lesson to the jockeys. It is pitiable that these men should be so egntiatical, although hugely amusing to hear them display their ignorance with such confident effrontery.

In the railway carriages en route to the meeting are these fellows marking their cards with the "winners" (?) given by the daily papers, every one of which these boobies back, and often two or three in the one race. Arrived within the enclosure nothing is heard among them except the question, "What's to win?" To look a horse over much less walk the course never enters their heads, nor would they look at the race if doing so would in the least degree interfere with their betting opgrations. This is very, very sad.

We hear funny opinions given upon racing by others besides the shop-boy lot. A man who considers himself a good judge of racirg 
and a "knowing shot" said to me, not long ago, that Ormonde beat Minting for the Hardwicke Stakes at Ascot "in a walk," and when I laughed at him he pompously informed me that he saw the race, and that I did not. Upon this Juggins' dictum I was therefore to assume that Fred Archer was wrong when he said that the only horse in England able to stretch Ormonde's neck was Minting, and that the Hard wicke Stakes at Ascot, in 1887, was not entitled to be enrolled among the greatest races of the century!

Such are examples of the nonsense we hear from scores of people on every racecoure in the kingdom.

How pitiable it is to see scores of these infatuated young men shelling out, with long-drawn faces, the sovereigns they can so badly spare, and nearly as pitiable is it to see those few who do win a trifle pocketing their gains.

Yes, the winner over horse racing is almost as much to be pitied as the loser, for the winnings are seldom put to good account, nor are they usually reserved to meet the losings. As soon as a young fellow has had what he calls a "good day" he proceeds to trat his friends, and so scatters most, if not alı his winnings, thus annihilatıng the only means he has of recouping his losses, and shows conclusively that "heads" he loses and "tails" he does not win.

Again, what simpletons some of these young fellows exhibit themselves to be when, to a man they never saw before and know nothing about, because be is a bookmaker, they pay their stake beforehand. Surely when they have lost the bet is time enou hor them to pay. The bookmaker does not pay before he loses. Why, then, should the backer do so?

To borrow some of the phraseology employed by the Bishop of Durham when he, not long ago, delivered a lecture in condemnation of this horrible vi e, I will say that betting to the extent it is at present practised disturbs and discredits honourable, resolute and patient labour, and tends to encourage recklessness. It isola es, hardens, and deadens sympathy, and it destroys alike social life aud domestic happiness. Betting is the embodiment of selfishness, and selfishness is the $\epsilon$ ssence of sin, and, with his lordship, I feel convinced that gambling is becoming a national peril.

I don't care for any sort of gambling. I don't want to possess myself of cther people's money, nor do I want others tn get mine; but I do dearly love to look at a good and well-ridden race. My chief enjoyment at a race meeting is first to inspect the coure, then to look over as many hories in the paddock as I can get the chance of, and therefrom to pick out the one I fancy most. If be pleases me in his preliminary gillop I watch him tbrough the race, and by the manner in which he acquits himself I flatter, or nor, inyself upon the iudgment I showed in selecting him. As a rule it is a matter of perfect indifference to me which horse wins other than the one I select myself, unless a fiiend of mine rides or has a horse engaged. All I 
want is to see the best borse win, and that after a good race, each horse having been ridden out in artistic style.

Among some people it is at times the habit to speak of bookmakers in a hard and disparaging manner. To best a bookie is considered a fair game by a great many men; to send him an excuse on a settling day for not piying punctually what is owed him is by no means unusual, while the bad debts in the books of most pencillers total a large amount, and among the list are to be found the names of men of noble as well as gentle birth.

Although never a betting man I have, all my life, associated with men who bet, and that heavily. From my observation I am led to the decided opinion that a bookmaker to start fair with his clientèle must at all times keep his weather eye open. The backer strives to get 6 to 4 the best of the layer, and it behoves the lat:er to see that the object be not attained. Among the "fraternity" are to be found men, if not as cultured in manners or as well bred, quite as honourable, fine principled, and generous as are to be found among the classes they lay the odds to ; whila among the first and second cliss bookmakers an account is never left for a day unsettled. I am of opinion that the members of Tattersall's are as a body quite as honourable in their dealings as are the members of the Stock Exchang ${ }^{\prime}$ or the Law, the Banking or Insurance Societies, aye, or of any other commercial community.

By the way, has it struck any of my readers that insurance companies are, to all intents and purposes, bookmakers? They lay the odds against a man dying or having his property burned. Those who insure simply back themselves to die or their property to be fired within a given period. Furthermore, if a risk upon any given life or property be considered too great--in other words, that the insurance company has laid too heavily against it-it will cover itself with other companies precisely as bookmakers lay-off or hedge their bets upon too heavily laid horses.

Among the directorate and managers of various insurance companies I have many old and valued friends, some of whom look up in quite as bad a light as I do, so I tıust their feelings may not be hurt by the simile I have just drawn. However, if they analyse the vocation of the book maker and compare it with their own they cannot fail to see that I am right. What is "Lloyds" to the sea but as "Tattersall's" to the Turf? Are not the Sun, the Scottish Widows, and the Globe of assurance the Silk, Kavanagh, and O'Connor of the Ring?

We see every day of our lives great men falling, small men rising. The gulf which twenty years ago separated the aristocracy from the middle classes has now become but a stream. Aye, a stream which in many places can be stepped across.

The lower classes are acquiring thrugh advanced education exalted ideas, and having acquired wages for their labour which their grandfathers never dreamt of are fast raising themselves to the level of the 
old middle classes. Other and many instances there are before us of similar lowering down and rising up. Signs around us show plainly, to all who are not blind through bigotry, that a gradual but steady advancement is being madt towards "equality," and anyone possessed of ordinary mental capacity can gange what the ultimate result of that will be.

The main root of all this radical growth and these latter-day ideas is MONEY. We all agree that there is no means mord conducive to the attainment of socialism than the circulation of money, and the quicker the process of course the sooner will come the great equalisation.

Becting on horse racing causes a larger amount of money to be circulated than does some of the greatest branches of trade we oave in the kingdom, and it is the readiest means under the sun for circulating money.

Betting, therefore, is about the greatest ally the communist possesses!!

How to deal with this terrible malady-this pestilence-I know not. Legislation has failed even to influence betting, not to speak of controlling it; all other means have been equally unsuccessful. Yes, even the experience reaped, as it is in bitterness, does not influence the backer of horses, he still persists in his downward course. Not alone does the habit bring ruin upon thousands, but assuredly a continuance of it iu its present magnitude will before long thoroughly demoralise the sport of racing. Of late years betting has becıme a feature of not alone racing, but of nearly every one of our games and pastimes. Football, cricket, boat-racing, all are impregnated with the same horrible adulteration.

Perhaps the only means whereby a check at all appreciable could be brought to bear upon the vice would be for employers to insist that those in their service should, under pain of dismissal, refrain from the jropensity.

Inasmuch as it is impossible for legislation to suppress betting, perhaps it would be wiser for the auchorities to open their eyes to the fact and trame laws to govern it, and so admit it into the cumpany of other iniquitous institutions of the country.

Under the crrcumstance of betting being kept outside the pale, our legislators have, I think, done pretty nearly all they could to curtail it and lessen the evils; assurealy they have done a lot towards harasising those who bet. Some of the laws, however, appear very absurd.

A man may bet in thousands on a racecourse so long as he stands on the ground in the open air; but if he stands on a stool or holds an umbrella over him he can be had up.

In drawing the line between betting in a social club and a publichouse the authorities are accused of making one law for the rich and anotner for the poor. They certainly have done so in this case, but very properly. Their object manifestly is to protect the poorer members of society and prevent them from engaging in the pernicious practice. Likewise is it right and proper to make raids upon houses notoriously 
kept for the poor people to bet in. These dens of iniquity are all well known to the police, and every one of them should be swept from out of our cities the same as any other abominable matter.

Iniquitous as gambling on horses undoubtedly is, compared with transactions on the Stock Exchange those on the Turf stand far away higher in the standard righteousness. No bogus race meetings are floated at Tattersall's. No owner enters to be started a horse which he has no right to, not to speak of one which never was foaled and never will be. To peruse the list of a bookmaker we see in it none but horses which are in existence, and which have some sort of chance to win, while the prices set opposite them are bonâ fide. Do we ever find emanating from the Stock Exchange such affairs as "bogus companies"? Do we ever know of brokers buying and selling shares which are not, and never were, in their possession-aye, perhaps, never in existence?

Comparisons, however, are odious, and two blacks do not make one white; I shall therefore leave to others to deal with gambling on the Stock Exchange. I allude to it only to show that, at all events, we get a fairer run for our money by backing horses than by backing bulls and bears.

I wind up this chapter by relating a gruesome story told some years ago, the truth of which I have no reason to doubt. A young man employed in a Dublin place of business had, through betting, got into extreme difficulties, but determined upon a venture in the hope of extricating himself. $\mathrm{He}$ made a book on the Curraghmore Hunt Plate of 1874, for which he backed Scot's Grey for all he could get on, and laid against everything else, particularly a mare named Departure. He saw the race run at Williamstown, and thought, as everybody else did, that Departure had won ; but the judge awarded it to Scot's Grey by a short head. The man I allude to was never heard of afterwards. The conjecture was that directly the race was over, and before the numbers were hoisted, he, thinking he had lost everything, bolted, and as he never turned up to claim his bets, all of which he had won, it was supposed that he had drowned himself in the river Suir!! 


\section{CHAPTER XXI. HYGIENIC PRINCIPLES.}

Prevention better than Cure-Author's Rules-Sleep-Second Death-Boys will be BoysA Curious Calculation-A Cold Bath-Author's Experience of Drowning-Dumbbells-Eating and Drinking-Bad Outside-Best Inside-Advice-Smoking-Cigarettes-Juvenile Smoking-Inductive Philosoplyy-Wine and Whisky v. MeatFashionable Cooking-Author's Ideas-A Modern Dinner-To keep Meat-Professed Cooks-Their Incapabilities-Their Capabilities-Good Plain Cooking v. ProfessedOut of Season-Eat too often-9.0 a.m.-7.0 p.m.-Exceptions-Round-of-Beef Breakfast-A C $\mathbf{A r}_{1 \mathrm{r}}$-What an Eminent Doctor said-Digestive Organs-Their Work-Day Drinking-After Dinner-The Author-His Peculiarities-Likes and Dislikes-A Pernicious Habit-Its Origin-Grood Old Custom-Dr. Abernethy-His Practical Illustration-Hints by the Author-" Hignorance is Bliss"-A Mutton Hash-Sleeping Hours - Fresh Air - Night Air - The North - Exercise - Dumb-bells again - A Rough-up-Same Age and Weight-Boxing-Foot Beagles-A "Night-cap"v. Fresh Air-Clothing-Warm v. Heavy-Texture-The Sailor's Opinion-Banting-WeightWhat to Eat-What to Drink-What not to-Verb. Sap.-A very bad Habit-Gosd Proportions-In a Nutshell-A Homily on Rheumatism.

To engage in field sports, not to speak of to follow them energetically, a man must be possessed of fairly good health and be in pretty hard condition. I shall, therefore, give a short treatise upon hygienic principles, and as I followed pretty nearly the rules I advocate in the following pages and had not to fee a doctor from boyhood for anything except accidents until I approached the "nasty half hundred," they may perhaps be considered worth mentioning.

As a rule men eat, drink, and sleep too much, and don't take enough exercise.

Now, in my younger days I looked upon sleep as a second death, during which all the pleasures of life are, so to speak, dead-consequently I spent as little time in bed as possible. I am afraid, however, that in addition to getting up early I often went to bed late! Boys will be boys, and having a good constitution it did me no harm, and I had lots of fun at the old Waterford club which I could not have asleep in bed.

Most men require their eight hours' sleep and can't do without that complement. Many, however, do very well with six hours, and they in ten years have lived 7,300 hours more than the fellows who have slept eight hours. That is just ten months, but as the whole time will be spent awake it is in reality equal to one year and eight months of extra life. If my six hour friend does not enjoy and improve himself during that time more than the eight hour chap he is not, in my opinion, much of a fellow!

A cold bath every morning, I need not say, is indispensable to thoroughly good health, but in very cold weather the water should be 
brought to the temperature it is in at ordinary times. The shock of icy cold water is very bad, and though a fine hardy young man may enjoy it for years, it most assuredly lays the basis for rheumatics in his after life.

Before getting into a cold water bath a man should wet his head so as to prevent an effusion of blood thereto. This is all the more essential in the case of full-blooded men.

Let me, while this hardy fellow is having his bath, relate what happened once to me. I was dressing in a hotel in Dublin many years ago, and was in a great hurry as I bad to meet the Meath Hounds fifteen miles off, and I was very late. The bath in the bath-room being of stone had an obtuse-angular bottom, so that the sides slanted downwards, unlike a metal bath which has the sides and bottom hollowed out. Well, as is my custom I stretched full length, but doing so hurriedly and with more than ordinary force, my shoulders got completely wedged in between the sides of the bath, and there I was absolutely drowning with about an inch of water over my nose. It was only after a life or death struggle that I got myself extricated from this most ludicrous but at the same time unpleasant fix. People talk of drowning as being a pleasant death. After having had two rehearsals, bosh say I as far as the first part of the play goes!

Let us now return to the poor fellow we left in the other bath, without, perhaps, having reduced its temperature from forty degrees of Fahrenheit! After a good rub down with a rough towel, and five or ten minutes devoted to the vigorous use of 7lb. dumb-bells, he should feel warm enough.

Hot or even tepid baths are enervating and should not be indulged in by hardy fellowg exc $\lrcorner$ pt under peculiar circumstances.

Be it in the sea, bath, or basin, the eyes, when under water, should be kept open, the action of the water being most beneficial to them.

We all know that eating and drinking are the most important matters a man has to consider if he wants to keep in good health and the fair condition requisite for the enjoyment of field sports or any other occupation he may have. I am quite confident that half the disorders men are subject to are caused by improper use of "the table."

Everything we eat, drink, and smoke should be of the best quality; one may wear cheap and bad clothes, but what goes inside should be the best. As a rule men order the best meat and pay the highest price for it; not so their liquor, cigars and tobacco. They ofttimes strive to get the best at the lowest price and deceive themselves by imagining they succeed. If a man cannot afford to pay for good wine, let him drink the best whisky ; if he can't afford that let him take to the best ale or porter ; and if he can't afford them, let him have the best milk or spring water.

Smoking should be dealt with in the same way. It is a much better plan to smoke the best and purest tobacco from an honest pipe than to impregnate the system with fumes which come from indifferent 
cigars, and most assuredly a good cigar can't be bought at as low price as the best loose tobacco. As to cigarettes, no matter of how good quality, I am sure they are in this country very injurious to anyone who smokes them. In hot countries it may be different.

That smoking in any form is bad for youths goes without saying, and as I have just read in the Liverpool Echo an article, portion of which, if written specially for this page of my book, could not be more appropriate, I shall reproduce it.

"There is no doubt that juvenile smoking is very largely on the increase. The too early adoption of the nse of tobacco is recognised by all anthorities as a most pernicious evil, stunting both frame and intellect, and cramping the moral no less than the mental and physical development. Yet, especially since the introduction and wide extension of cigaret te smoking, itself the most injurious, because most insidious form of tobacco smoking, boys of immature years have taken to the habit with an avidity unknown when the terrible ordeal of the first pipe had to be passed before the practice could be reduced to a habit. The first cigarette has no terrors for a fairly strong stomach, and consequently it is fearlessly indulged in, and it carries no warning against the consequences of future excess. What the result of this injuriously early indulgence in the tobacco habit upon the physical growth and intellectual development of the country may be, the next half-century will probably show; but if we may judge from its present tendency it is not unlikely that the nervous dyspepsia which is so prominent a feature of the present generation will be greatly intensified, unless a more healthy and manly tone can becultivated amongst the growing youth of the nation."

I would add to the above truthful exposition that a law should be introduced prohibiting the sale of tobacco in any form to youths, and that anyone under the age of eighteen found smoking should be prosecuted.

I think it was Lord Macaulay who said that "inductive philosophy" was to eat what agrees with you and not to eat what disagrees.

Although best be the quality of our meat, in the cooking is harm often done. Meat plainly roast, boiled, or broiled, with an occasional well-made hash, is decidedly the most wholesome food. Dinners with numerous made-dishes served up with all sorts of sauces and flavouring till not a trace of the natural taste of the meat is left are the source of gout, "liver" indigestion, and a hundred other ailments. Besides, they enervate a man. Nor do I think the present system of large fashionable dinner-parties is rational. A lot of entrées are handed round, one in particular a man might like to have more of than the small portion he has taken, but he does not get the chance. Then, again, game, the most delicious food of all, is kept until the end of the dinner, when men's appetites have been nearly satisfied.

My idea of a good dinner is to have few courses, each of the best, and cooked in plain fashion. Soup, fish, one meat, vegetables, one sweet 
or savoury, salad and cheese, with plenty of fresh fruit after, ought to suffice most men. I would have a total change every day, and no matter how partial a man might be to a certain dish, he should not have it oftener than once in eight or ten days, so that when it comes to table he might be able to enjoy it with all the more relish. Instead of getting a slice off the breast of a grouse or half a snipe after he has dined, a man should, if he likes game, eat his entire dinner off one sort one day and another the next, likewise with other meats.

To have a good dinner three things are essential-the meat must be of the best quality, it must be sufficiently long kept to render it tender, and then it must be properly cooked. Simple as they are we don't always find the triple alliance. I believe in the old-fashioned plan of having meat roasted before a good bright fire and having it well basted the while thus preserving all the natural gravy. When cooked in a range meat gets dried up through want of basting, and the flavour is not nearly as good as when the old plan is followed.

To preserve meat in hot weather no better or simpler plan can be adopted than placing around the joint pieces of dry turf [peat], same as they are cut for fue. Flies then will not go near the meat, and it will keep good for ten days in the hottest weather; besides, a dozen pieces of turf will suffice an ordinary larder for years.

Many of the "professed "cooks of the day whose places are worth $£ 100$ to $£ 500$ a year would scorn to follow plain old fashioned cooking. They must have the Continental. The consequence is their lords and masters are often kept in ignorance of the natural flavour of a leg of fouryear-old mountain mutton ten days hung, and sent to table done to a turn and so full of delicious natural gravy that the dish well is half filled after the joint has got the first cut. Neither do they know the taste of a snipe or a woodcock one day killed, cooked before the fire and served with no other condiment than their own trails. No, those and other joints are glazed, and braised, and baked by swell chefs, but they are seldom roasted before the fire and sent up plain.

I am not for a moment to be understood as finding fault with firstrate fashionable cooking for any reason other than that I believe plain cooking to be more wholesome, and that, personally, I like it better. That the entrées and other dishes handed round at large dinner parties are, as a rule, most excellent in taste there is no manner of doubt, and as fashion at present exists this mode of serving dinner must be followed, and I confess I enjoy very much dining occasionally at these recherché repasts, while no man accords more credit to the chef. All I would ask these professors in the art of cuisine to do is to occasionally send up a joint or a dish of game dressed in the old English and Irish style, for I do think that while nearly all their dishes are good for the mouth some of them are bad for the stomach. Anyhow, after dinner a very refreshing thing is to dip a finger of each hand in the finger-glass and apply a drop of the cold water to the back of the ears.

Dining after 7 p.m. is, I am sure, very bad for health and diges- 
tion, so, also, is eating things out of due season. Think of lamb at Christmas, ducks in February, or turkeys in June. Why, they have not attained quarter their natural flavour; they are tasteless and indigestible instead of being tempting and wholesome. Forced fruit and vegetables are equally to be objected to.

Many people eat too often, even though they may do so in a small quantity at a time. A good substantial breakfast of meat and eggs, or whatever else a man can make best his morning meal off, at 9 a.m., and a good plain dinner, such as I have described, at 7 p.m., with a biscuit or small sandwich for lunch, is all a healthy strong man ought to require for food in the twenty-four hours. To be sure, there are many who cannot eat a substantial breakfast, and to them their midday meal is the meal of the day; but give me the "round-of-beef breakfast." Decidedly if a man has breakfast earlier than 9 a.m. or dinner later than 7 p.m. he must have a fairly good luncheon, but what I find fault with is eating little and of ten.

There are many, both men and women, who eat daily as follows :-
8.0 a.m. Tea with bread and butter, generally in bed.
10.0 a.m. Breakfast, often in bed
1.30 p.m. Lmmcheon, three courses.
5.0 p.m. Tea and cake.
8.0 p.m. Dinner, six conrses. 9.30 p.m. Coffee.
11.0 p.m. Tea.
1.0 a.m. Supper, two courses.

Could any except cast-iron organs stand such wear and tear?

An eminent doctor once told me-and I think his observation from a common-sense point of view is conclusive on the subject-the digestive organs require rest just as much as any other portion of the human structure. Thus if through continuous eating the gastric organs are kept in perpetual exercise, they break down just the same as any other machinery would do. Directly food enters the stomach digestion begins, and continues till its work is finished which takes some three or four hours, more or liss. If, therefore, a man eats, though little, every three of four hours, the organs of digestion never get auy rest, and so they in a very short time wear out. Whereas if a man feeds, no matter how heartily, only twice a day, with a light collation in the interim, those most important functions get a chance, and they return it by doing their work effectually, thus promoting both good health and long life.

Of all things in the world a man should never touch a drop of liquor between meals. Let him drink what he may wish for at and after his seven o'clock dinner, but at no time else. Day drinking and nipping are some of the curses of the present generation. As I said before, fifty years ago a man would be blackballed for a club if he was known to drink before diıner.

I am louked upon by some people as a sort of lusus naturce because I neither back horses nor drink in the daytime, but, adopting Jorrocks's translation of the appellation, I think the "loose 'uns by nature" are generally found among those who practise both. To my mind, anyway, 
there is nothing under the sun more calculated to lessen a man's stock of cash than backing horses, or to diminish his stock of vitality and manbood than "tippling."

As in the case of not backing horses, exalted principles of morality are not the cause of my abstaining from drink in the daytıme. I simply dislike the taste of all intoxicants before dinner, and I know to indulge in them is highly pernicious to health. There is, however, no man who enjoys his liquor much more than I do at dinner, nor a judicious continuance of the supply from that hour until bedtime. In fact, as I often say, I am a teetotaller for some twenty hours out of the twenty-four. I also proclaim the fact that although I don't drink before dinner I do so plentifully every day of my life before breakfast [i.e, after dinner !].

A source of great annoyance to me is the fashion which has of late years crept in - that of coffee and cigars immediately after dinner. In they come just as I am about to tackle a bottle of prime claret or old "beeswing." This to me pernicious habit has been contracted from various sources. Men travel now so much on the Continent where drinking wine after dinner was never the custom, they have got broken off the good old fashion. Then the late hour dinner is now served at, and the length of time it takes owing to the number of courses, gives men sufficient time to drink what they want at dinner, and leaves little time to do so after ; besides, owing to their drinking a good deal before they are not able for much during or after dinner. Another factor in the matter is whisky having taken the place of wine on our dinner tables as much as it has done of late years. For my part I heartily condemn the causes and the effect.

A story is told of the celebrated Dr. Abernethy that upon a patient coming to him with a disordered constitution, the result of improper mixtures of food and eating too often-a fact the patient could not be persuaded of-the doctor, wishing to try an experiment, asked his patient to dine with him. There was for dinner but ordinary fare, but the host told the servant to put into a large bowl an equal quantity of everything the guest eat and drank, and just before his leaving to mix together the whole mass. As the patient was about taking his departure Dr. Abernethy expressed his hope that he liked the humble fare provided, it being so much inferior to that he was accustomed to. The guest replied that for a plain homely dinner it was very good indeed. The doctor then showed him the contents of the bowl, telling him what the servant had done, and that the contents of the bowl represented precisely those of his stomach! So horritied was the man at seeing claret and coffee, soup and sirloin, sauce and champagne, cutlets and cream, fish and fruit, all mixed up in an abominable mass, that ever after he dined upon the plainest food he could get and took that seldom and sparingly, with the result that his constitution was thoroughly restored to health and vigour.

The above raminds me to caution my readers against taking coffee 
with milk and sugar after having drank claret. I can't conveniently explain the "why," but if some of them will just put a small quantity of both into a cup or wine-glass and smell the decoction I'll be bound they won't taste it. Still, that is the mixture which is usually in their stomachs after dinner.

We had many years ago in Ireland a baronet celebrated for his wit and repartee who was over fond of port wine, with a result that he got into bad health. His medical man cut him down to one bottle a night, and after a week found such improvement that he remarked that if the Sir restricted himself to that allowance he would live a long time. To this the wit replied, "I don't doubt it, doctor, for the last few nights were the longest I ever spent."

A friend of mine some years ago also got into a bad state from too much grog, and on consulting his doctor he was cut down to one glass a day. This seemed such a terrible sentence that the patient suggested that he should drink nothing during the week, but take the seren glasses on Sunday.

Yet another hint-never put ice into your glass of champagne; at best melted ice destroys the flavour of the wine, but if the ice has been frozen upon dirty water the consequences are not pleasant. Yet we often see men, who should know better, put a lump of ice into a glass of prime old champagne and afterwards light a big strong cigar just when a bottle of Lafite '64 is making its first circumnavigation of the mahogany. As my friend Jorrocks says, "If hignorance is bliss, oh 'ow 'appy they must be!"

To those who, like myself, think a mutton hash a good thing I can recommend the following recipe, which was given me by Mr. William Macdonagh, who was our excellent house steward at the Waterford County and City Club for many years. Cut the mutton in thin slices, flour and season them over with pepper and salt, and set them aside on a plate. Then put some chopped shalot in a stewpan with a dessertspoonful of King of Oude sauce, a piece of glaze the size of a walnut, two glasses of port wine, a little Harvey sauce, and a tablespoonful of currant jelly, well stirred up in about half a pint of good unsearoned but well-skimmed gravy. Add the prepared mutton, and simmer together for five minutes. If King of Oude sance and glaze are not procurable, half a pint of good rich beef gravy and a little Worcester sauce will do instead. The above proportions are for about $2 \frac{1}{2} \mathrm{lb}$. of mutton.

People should make better provision for their sleeping hours than they are in the habit of doing. The windows should he left open at night at least two inches at top and one inch at bittom, and they should run as close to the ceiling as possible so as to allow the foul air to escape. To provide ready exit for the foul air is far more important than letting in the fresh, which is pretty sure to find its way in according as the foul leaves room for it. Sleeping in unventilated rooms is one of the very worst things for health. Where windows don't run up to the ceiling ventilators should be put in, more especially 
in bedrooms with alcove ceilings. It is the height of ignorance to think "night air" is bad. What other air is there to breathe at night? Do we ever suffer from it when travelling at night, or does the fear of breathing it prevent our going out at night? Yet how often do we hear people talking of the bad effects"of "night air"! I have not slept with my windows shut these thirty years and I have never found bad effects from the practice, but quite the contrary.

We should also sleep with our heads to the north, or as nearly so as possible. Those who know the fact that our bodies are charged with electricity, and that during the day it has free escape towards the point of the compass nature induces it to select, will understand the reason of this remark, and the danger there is in frustrating any object of nature. They can explain it to those not so versed in physiology. It would be too long and tedious for me to do so in these pages.

No matter what a man's calling may be, he should manage to take sufficient exercise daily to keep him in good health, and if he is not of the eight-hour-sleep sort, he can easily manage to do so if he chooses.

First thing in the morning and last thing before going to bed a man should work medium-sized dumb-bells-about 7lb. weight-for five to ten minutes. Heavy ones are bad, and light ones are no use. Nothing can be better than this exercise for those who can't regularly attend a gymnasium, and it should be practised all through life, even up into the "sear and yellow leaf." It will keep the body fairly supple and the muscles fairly strong, and will maintain a man in a tolerable state of condition for being able to tackle another in a rough-up when necessary. In fact, every man should keep himself in such a state of bodily vigour that at any time he will be able to hold his own against any other man of, at least, his own age and weight. When dumb-bells are not to be had, a man should exercise his arms without them.

A propos to the subject of this chapter, and particularly to the last paragrapb, boxing is a thing all men should keep up as much as they can. I allude to this most important requisite to a man (I employ the word requisite advisedly) in another chapter, but I may here add that no grander, no more healthful, or more useful exercise than "the gloves" can boy or man practise. We all know how useful the fists are at times, if a man can use them properly, whilst a hout with the gloves is jolly and invigorating.

I kept a small pack of foot beagles for some years which I hunted two or three mornings of every week in the year except just immediately before harvest, and as I had to be in my office by 10.0, to have my sport necessitated my being out with the little fellows just as soon as I had light to see. This gave me plenty of fine exercise, often twenty miles before breakfast. I merely allude to this fact to show that if a man chooses he can find time to take exercise. It was no particular pleasure to me to have to get up at daylight and trudge over a country in bad weather, though I enjoyed it hugely on all fine 
bracing mornings; but if I did not get up I could not have either the exercise or the sport.

There is nothing worse for a man's health than to take a "nightcap," in the shape of a glass of grog, shortly before going to bed. If he took instead a mouthful of fresh open air for five or ten minutes it would do him a great deal more good.

Men should wear warm but not heavy clothing; thə former can be got light in weight if of good quality, and very often the latter with all its weight may not be nearly as warm. Texture of an absorbent nature should be worn next the skin when taking exercise of any sort, whether it be in summer or in winter ; in fact, it is the more requisite in summer when one perspires so much more. When I was "young and foolish" I never wore anything but linen shirts, not even calico, and well do I remember the icy feeling they gave me on a mountain in August, when wringing wet with perspiration with a breeze blowing. It was enough to give anyone rheumatism for life, but I escaped. At the same time I soon learned that to do work comfortabiy in hot weather, inside clothing of woollen texture is the thing. The sailor says of flannel, "When you are cold and wet, it keeps you warm and dry"and so it does.

I may be wrong, but I have a notion that a great many people bundle into their beds at night without any previous preparation beyond undressing. If such should be a practice it is undeniably a very bad one. That partial ablution before going to bed is essential to good health, there can be no manner of doubt. To those who live sedentary or inactive lives such observance is requisite, while to those who take strong or eren moderate exercise it is manifestly more so. Apart from cleanliness, nothing tends more to peaceful and undisturbed sleep than a nocturnal sponge over, while nothing causes the teeth to decay more than particles of food remaining in them during the night; it is therefore necessary that they should be brushed before going to bea as well as in the morning. A most excellent stimulant to the nerves of the eye is to bathe with cold water behind the ears before going to bed.

It is infinitely better for a man to keep down weight than to have to reduce it, and proper regulation of diet somewhat on the principles of Banting is the only safe way to prevent a man throwing up flesh. I am quite sure doing so by means of medicine-patent or otherwise-will reduce the stock of a man's good health and chance of long life equally with his weight. From the age of "sweet two-and-twenty" till I was over forty I kept myself at or about 12st. 7 lbs. by means of the following dietary. I adopted it for ten months of each year, and no man need wish for better health than I enjoyed all the time. During the two midsummer months I indulged plentifully in cream, fruit, and vegetables, whicb always put me up some pounds, but I soon returned to my normal weight after knocking them off. Physic of any kind I never took. 
The dietary was as follows :-

Plain clear soup, all sorts of fish except salmon, all sorts of meat, all vegetables that are eaten raw, such as lettuce, radishes, celery, ic., fresh fruit, eggs, hard biscuits or "pulled-bread." My drinks were tea without cream, milk or sugar, pale dry sherry, claret, and cold whisky and water. Very little plain water and never a "long drink" of anything.

I did not eat or drink the following: Rich thick soup or gravies, salmon, potatoes, cooked vegetables, cheese, bread, butter, sweets, sugar, pastry, preserved fruits or porridge, never a drop of milk, cream, golden sherry, champagne, ale, porter, port or punch.

I believe anything that produces sugar or starch is fattening, but the fat of meat is not, and taking long draughts of anything, even water produces corpulency, and nothing makes one fat as much as parsnips, carrots, turnips, bread or potatoes.

Since I had to give up hunting and strong exercise I eat and drink everything that is good whenever I get the chance, with the result that I am now 14st. weight! Were I to reduce this to my old 12st. $7 \mathrm{lbs}$. form I am pretty certain bad health would be the result.

We know that animals of medium size are the best for doing hard work with ease to themselves. The same, I think, applies to the human being. Men 5ft. 8in. or 9in. and weighing about 12st. 7lbs., and women of stature 5in. shorter and 2st. less in weight, if well made, are, in my opinion, the best at playing the game all round.

I have for years been addicted to what I am sure would be to many a very bad habit. I smoke before breakfast and immediately before dinner. From so doing I have derived no bad effect, and I look upon these two smokes as the most enjoyable of the day, doubtless from the fact that upon an empty stomach the flavour of the tobacco acts more pungently than it does after meals. That I am singular in this taste is proved by that, with the exception of Lord Waterford, I never met anyone to agree with me on the subject. During cub hunting his lordship acquired the habit of smoking before breakfast, and I learned it while hunting my foot beagles in the early mornings. I am far from recommending others to follow this example of mine.

To sum up the rules which, in my opinion, are best to follow so as to preserve good health and give a man the best chance of a long life, I should say :-

a. Early to bed, early to rise.

b. A cold bath after sleeping in a well-ventilated room with his head to the north.

c. A substantial breakfast and dinner cooked plainly.

d. No drink in the daytime, but a fair allowance of best quality at and after a seven o'clock dinner.

e. Gloves, dumb-bells, outdoor evercise, and Sport of any sort.

This régime can be adhered to even by those employed many hours a day at business, and until they become octogenarians, if they only choose to do so. 


\section{CHAPTER IXII.}

\section{OSBALDESTON, ROSS, KENNEDY, BUDD, AND BARCLAY-ALLARDICE.}

His Youth - The Monson Blood - His Hunting - Many Incidents Thereof - Price of his Hounds-"To the Best Sportsman of any Age or Country"-His FallHis "Two Hundred Mile" Match-Full Particulars-From Start to FinishWhat Bell's Life said in November, 1831-Good old "Nunquam Dormio!"Osbaldeston's Challenge to the World-His Age at the Time-The Squire as a ShotVarious Records-His Pointers-As a Cricketer-As a Steeplechase Rider-The Clinker and Clasher Match-Grimaldi and Moonraker-His Gallantry to a Lady-His Gallantry to a Lad-Six Pipes of Madeira-His Temper-His Death-Post-mortem Opinions-That of the Standard-That of Captain Ross.

Captain Horatro Ross.

IIis :Early Days-Deer Shooting-Early Training-Ross and Anson Match-Particulars -Result-The Bag-Spectators-A Challenge-The Hay and Kennedy Match-Smart Work-Result-Ross as a Shot-Wonderful Pistol Shooting-An Expensive EntréeGrouse Shooting-Deer Stalking-Extraordinary Records-Pistol Shooting at a Target -Ross and Coke Match-Full Particulars-The Squire's Dogs-Their Performance among Partrirlges-A Fine Old English Farmer-His Advice and Assistance to RossResult-Different Training of Dogs-Author's Experience-Mr. William Coke-His Field Craft-His Dogs-As a Deer Stalker-Ross as a Gun, Rifle, and Pistol ShotHis Wonderful Endurance-His Mode of Living-What was Written of Him-Unlile Osbaldeston-His Popularity-His Family-Clinker and Radical Match.

LORD KEXYEDY.

A Marvellous Feat-Great Match at Partridges-Mr. William Coke again-His Lordship's Perversity-Its Result-A Great, Bag-Lord Garlies-A Good Day's Sport-"The Hundred Brace Match."

EDWARD HAYWARD BLDD.

His Strength-As a Cricketer-As a Boxer-As a Shot-John Musters-T. Assheton Smith.

CAPTAIN BARCLAY-AlLARDICE.

IIis Ancestors-His Father-His Mother-Author's Ideas on Good Breeding-Barclay's Birth-Pedestrian Feats-All Distances-Full Particulars-Four Celebrated Matches with Mr. Fletcher-Heavy Wagers-Deaf Burke-Nore Great Feats-His Regiment -More Achievements_ "One Thousand Miles in One Thousand Hours "-Exhaustive Particulars-From Beginning to End-Table of the Time-Analysis-His DressHis Diet-His Age, $\mathbf{H}$ ight, and Weight-During the Match-His Winnings-His Staff of Attendants-The Walcheren Expedition-Two Subsequent Matches-Sad Falling Off-As a Shot, Rider, Whip, and Boxer-Tom Cribb-Pugilists of Old different from Now-Hard Training and Long Life-Barclay's Death-Sceptics-Scandalous Charges - Completely Refuted - Letter from Captain Ross-Opinion of Bell's LifeRemarks by the Author-Sportsmen Past and Present.

Hinself a good general sportsman, Mr. C. A. Wheeler of Swindon in $\mathbf{1} 867$ brought out a book under the title of "Sportascrapiana." In it he gives most interesting records of the prowess of notable sportsmen who were in their heyday from the beginning to the middle of the present century. Occasionally, when collecting my thoughts for this volume, some of these records cropped up, and upon the authority of $\mathrm{Mr}$. Wheeler I referred to them, but I shall now borrow more fully 
from his book and other authorities in my possession, and in totally altered phraseology and changed order give records of five patrician sportsmen who, in bygone years, made the world ring with their deeds of skill, pluck and endurance in all that pertained to manhood. Besides being contemporaries, they were all great personal friends. Necessarily my reference must be brief and cannot be adequate to the subject, but it will show that neither in ancient nor modern times have we had such prodigies, while to our rising generation these men are, as regards manliness, noble examples to take pattern from. I begin with

\section{Mr. George Osbaldeston}

of Hutton Bushell, near Scarborough. He was born in Wimpole Street, London, on December 26, 1787. At Eton his skill as a boxer soon developed itself and he became "Cock of the School." In cricket he took an equally high degree. Directly upon leaving Oxford he established a pack of harriers, which he hunted from his own place in Yorkshire; but after a few years he purchased Lord Monson's foxhounds and began as M.F.H. in the far-famed Burton country. He always swore by the Monson blood, and it was from that stock he bred the best pack of working hounds then in the three kingdoms. His renown as a huntsman and rider to hounds has been chronicled many times, I shall therefore refer to his hunting in but cursory manner.

After hunting the Burton country for five seasons, then under thirty years of age, he took Mr. John Musters' country in Nottinghamshire, but not liking it he soon after became master of the Atherstone. To that country he added what Lord Vernon hunted in Derbyshire and purchased the best portion of his lordship's pack to strengthen his own, making his kennel up to ninety couple of hounds. Things in Staffordshire did not turn out to his satisfaction, so when Mr. Assheton Smith resigned the Quorn in 1817 The Squire succeeded him and showed wonderful sport in Leicestershire until 1821, when, for a season, Mr. Bellingham Graham was master, but The Squire resumed office in 1823. His second term, as the annals show, was one of the most brilliant epochs of the Quorn Hunt, but while hunting with Lord Anson's hounds in 1826 Osbaldeston met with a terrible accident through having his leg broken, which laid him up for a year and necessitated his giving up the Quorn.

In 1827 he became master of the Pytchley. In that country, as in the others, he showed the best of sport. In one season he had forty good days out of fifty and no less than twenty-three first rate runs in succession.

Mr. Osbaldeston was always his own huntsman, bred his own hounds, and had for many years as first whip the celebrated Dick Burton; also Jack Stevens. During his Pytchley reign he hunted the Thurlow country in Suffolk for two seasons. To accomplish which he underwent marvellous exertion, for to meet each pack on alternate mornings he had to travel most part of nearly every 
night-and travelling in those days was no joke. Upon one occasion, after having had three good runs and wishing to go to a ball at Cambridge, he first rode to Northampton, then back to Cambridge, danced all night and rode back to Sulby Hall, a distance of sixty miles; he hunted the same day, killed a brace of foxes and rode fourteen miles home in time for dinner. During those two days and one night of incessant hard work he never once closed his eyes in sleep.

After thirty-five seasons' hunting The Squire laid down his horn and ceased to be M.F.H., when the followers of the Pytchley presented him with a splendid snuffbox, on which was engraven, "To the best sportsman of any age or country."

Mr. Osbaldeston's was admittedly the best pack of foxhounds in England. None other for breeding, work or stoutness equalled it, and to the present day are to be found in our crack kennels some of the best strains running in direct line back to his blood.

Of course we have had a great many gentlemen huntsman who were quite first-rate at the business, and for many years continued to show the best of sport; but most of them confined themselves to only one or two countries, so that they acquired a thorough knowledge of the entire area-the good scenting parts and the bad--as well as the run of foxes.

Now, Oshaldeston hunted his hounds six days a week for more than thirty-five years, and did so over the Burton country and the Spilsby in Lincolnshire, Mr. Musters' in Nottinghamshire, Lord Vernon's in Derbyshire, the Atherstone, the Holderness, the Suffolk, the Quorn, the Pytchley, and Hampshire. Together, ten countries, representing as they did all sorts-grass, plough, and woodland-with peculiarities different in nearly every one. In them all, and during that long tenure of office, he showed good sport to an extraordinary degree. To say that he was favoured all the time with the attention of the fickle goddess would be ridiculous, although no doubt he had his share of good luck, and as he could not have had much knowledge of the countries when he took them up, or have had time to acquire it during his short stay in each, it is manifest that the result was produced simply and solely by his own inordinate ability as a huntsman.

It must therefore be accorded to George Osbaldeston the palm for being the very best man who has ever handled a pack of foxhounds. I have many histories of him written by those well qualified to form an opinion, and they are all consentient on the subject. Whether the country was cramped or open, the field of horsemen in bundreds or in tens, to handle his hounds was all alike to this grand sportsman. He rode the nice weight of 11 st. 7lbs.

From Mr. Vyner's able book, "Notitia Venatica," I learn, however, with surprise that The Squire did not personally superintend the feeding of his hounds, but left it entirely to his kennel huntsman, William Gardner. This man must have had wonderful ability for his calling, for without being able to see them in their work he was able 
to regulate the feeding of each hound so that the lot was kept uniformly in the very best condition, and to quote what Mr. Vyner says at page 83 of his book, "I never saw any pack of hounds in the whole course of my experience as a foxhunter which could go so killing a pace both in cover and in the open, run so well together, and carry so fine a head, or last out such long and tiring days as those of $\mathrm{Mr}$. Osbaldeston; they would not only go like a flock of pigeons with a burning scent, but could cold-hunt a fox with as much patience as any pack of hounds in England."

That the hounds were the best in England and the Osbaldeston blood the best too, is proved by the fact that in 1830 when drafting twenty-five couple (of course, the worst) out of his pack of seventy-five couple, they fetched at his sale at Brixworth 625gs. Again, in 1842, after having previously passed into the hands of Mr. Harvey Combe, Osbaldeston's old pack, consisting of sixty-three and a half couple, were sold at Tattersall's for 6,51lgs., or over 103gs. a couple. This price has never been even approached.

The accident I alluded to was not alone terrible in its nature but left a disastrous effect ever after upon The Squire. It occurred as follows :In a fast run with the Holderness his horse gave him a fall over a high stake and bound fence, and while stretched on the ground the horse of Sir James Musgrave, who was ridden close in his tracks, jumped on him, breaking his leg in such a dreadful manner that the bone protruded through his boot. The Squire never afterwards rode so hard to hounds as he did previously, and he was exceedingly nervous if anyone rode close to him, while if Sir James Musgrave happened to be out he was constantly in the greatest dread of him. Nevertheless he continued to hunt his hounds, and was always handy to them. He was lame ever after which prevented him from taking part in shooting matches which required long walking, and from enjoying his favourite summer sport, cricket. His fall did not, however, interfere with his riding steeplechases. He first rode over the course and then, knowing what he had to ride at, no man cared less for a big place or rode more determinedly.

In 1831, when in his forty-fourth year and at his zenith as a sportsman, he backed himself with Colonel Charrité for 1,000 guineas even that he would ride two hundred miles in ten consecutive hours within the Houghton meeting week at Newmarket. The event came off on Saturday, November 5 , of that year, and was won by The Squire in exactly eight hours and forty-two minutes, including stoppages.

I should remark that long before then he was dubbed "The Squire" -a name he was universally known by.

From Bell's Life of November 13, 1831, I compile the following particulars of this wonderful performance :-

Although the match was made some three months previously, Mr. Osbaldeston did not go into severe training till the last week, when he increased his ordinary riding to 80 miles a day. This he performed at 
full speed, and on the horses he had selected for the performance, to the number of which there was no limit. As the day approached, betting became brisk, and on the night before 100 to 40 was freely laid against time, while a bet of 1000 to 100 was taken by Gully, who backed the Squire heavily, against his accomplishing the distance in nine hours. Of this Tne Squire took a large part.

As early as six o'clock on Saturday morning all was prepared at the Duke's Stand, near the Devil's Ditch ; stoves were lit, and every accommodation afforded for the assemblage of the parties interested. Four miles had previously been measured on the round course, commencing and ending opposite the stand parallel to the Cambridge Gap, and on this spot a turf stage was erected for the purpose of Mr. Osbaldeston mounting and dismounting; of this he made no use, from the difficulty of getting the horses to stand in position, but got the "leg-up" instead. An area was enclosed with ropes and stakes to keep the start and finish clear of people, and this was found most useful.

Mr. Osbaldeston arrived on the scene in a post-chaise at 7 a.m., attired in his racing colours of purple silk jacket, black velvet cap, doeskin breeches and top boots. His weight, with saddle and bridle, was estimated at 11st. 3lb. The saddles on which he rode were covered with sheep skins with the wool on, and it was arranged that each horse at one start should perform four miles. Mr. John Edward Bowater acted umpire for Colonel Charrité, and Mr. T. Thellusson for Mr. Osbaldeston. They were prepared with stop-watches which at the start were set going and placed together in a box.

The morning was extremely unfavourable, commencing with a drizzling rain which increased to a downpour accompanied by a high and piercingly cold wind. This did not damp the spirits of the rider who was in the greatest glee and fullest confidence of success, offering any odds he won or an even thousand guineas that he did the journey in nine hours, but betting was at a standstill.

At precisely 7.12 a.m. he was started, riding a mare called Emma.

Here follows in Bell's Life a record of the time taken by each of the fifty mounts to cover their four miles, but I shall merely relate the leading particu'ars.

The first twenty-four miles, including stoppages for mounting and dismounting, were done in two minutes under the hour. His tenth mount, Clasher, broke down and came in at a trot, but the 40 miles were covered in $1 \mathrm{hr} .40 \frac{1}{2} \mathrm{~min}$, and the 48 miles in $2 \mathrm{hr}$. $1 \mathrm{~min} .5 \mathrm{sec}$. On his fifteenth mount (Emma for the second time) Mr. Osbaldeston went to the wrong side of a post, but immediately turned and went back to the point of error. This round completed 60 miles, which were covered in $2 \mathrm{hr}$. 33min. Long since wet to the skin, Mr. O. now took a little weak brandy and water, up to which he had taken nothing except a small piece of gum arabic which he held in his mouth. Seventy miles were done one minute under the three hours, and the 72 miles in four minutes beyond the three hours. At the end of 80 miles the rain 
subsided, but the weather continued cold and cheerless; time, $3 \mathrm{hr}$. $25 \mathrm{~min}$. 30sec.

The hundred miles were completed in four hours, nineteen minutes, and forty seconds, and any odds were offered on The Squire. As he appeared a bit stiff, though still in good spirits, a proposition was now made to him to change his wet clothes, but he declined. At the end of 104 miles he took a crust of bread and a mouthful of brandy and cold water, stopping rather more than two minutes. Soon after the rain came down again in torrents but cleared off after a round or two.

When he had completed his 120 miles, which hedid in $5 \mathrm{hr} .11 \mathrm{~min} .30 \mathrm{sec}$, he proceeded to the stand house for refreshment, declaring he was as hungry as a hunter. He eat heartily of cold partridges and drank a glass of sherry, but stopped only $6 \mathrm{~min}$. 20sec., during which he conversed jovially with his friends, many of whom were ladies. His next horse-the thirty-first change-was Ikey Solomons, who, like the man he was called after, did badly, for soon after starting he pecked and The Squire, who was standing high in his stirrups at the time, was sent clean over the horse's head and fell full length on the ground. The brute ran away but was caught 200 yards off and being brought back was set going again, but that heat took $12 \mathrm{~min}$. On alighting the rider seemed flurried and distressed, but he pulled himself together immediately and set off again in high glee. 25 to 20 was then offered against his doing the distance in nine hours, the fall giving new hopes to the backers of time. At the end of the next eight miles The Squire showed slight weakness, and for an instant sat on a friend's knee, nevertheless he was on the road again in 30sec.

One hundred and fifty-six miles were performed in $6 \mathrm{hr} .49 \mathrm{~min}$., thus leaving $2 \mathrm{hr}$. $11 \mathrm{~min}$. to do the 44 miles to win in nine hours, or at the rate of 20 miles an hour, which, from what had already been done, was deemed easy work, the more particularly as The Squire was as fresh and gay as a lark. He laughed heartily, took a glass of sherry and said he was as hungry as a hawk. In 40 sec. he was mounted and away again amidst loud cheers, and with 6 to 4 on his doing the journey in nine hours and 10 to 1 on his winning the match. After the forty-second mount the weather suddenly changed into brilliant sunshine, and as the gallant fellow came in, sitting as firm as a rock and apparently as fresh as ever, he was received with great applause, and started again in 6 sec.

The weather became again unfavourable after 180 miles, but The Squire was undaunted. So bad was it soon after starting for the fortyseventh round that Streamlet, the mare he was riding, actually stopped and turned about, afraid to face the tremendous storm. This gave. the "timers" hopes, only to be dispelled immediately, for the time taken for this four miles was only $10 \mathrm{~min}$. $15 \mathrm{sec}$.

Surrounded by a tremendous crowd of spectators, the gallant horseman started on Skirmisher for the final and fiftieth heat. This was: done in $9 \mathrm{~min} .40 \mathrm{sec}$, amidst thunders of applause, making the whole time for the 200 miles, including all stoppages, exactly $8 \mathrm{hr} .42 \mathrm{~min}$. 
Thus by eighteen minutes Osbaldeston won every bet he made and had an hour and eighteen minutes to spare for the original match. Fearing any dispute might arise as to the distance, he proposed before dismounting to ride another mile, but the umpires declared themselves perfectly satisfied upon all points of the undertaking. After receiving congratulations from lis friends and putting a top-coat over his drenched and muddy clothes, he mounted a favourite hack and, surrounded by a large field of horsemen, cantered off to Newmarket. After taking a warm bath, he turned into bed for a short time and joined his friends so fresh that he played billiards for a couple of hours.

As has been seen, he had fifty rides of four miles each and for them he used twenty-eight different horses. Tranby, the property of John Gully, was ridden no less than four times and on the second occasion did his round in eight minutes which was the shortest time of any. Streamlet and Skirmisher were each ridden three times, Emma, Paradox, Liberty, Coroner, Oberton, Don Juan, Morgan Rattler, Cannon Ball, Ultemar, Fairy, Dolly, Guilford, Coventry, Ringleader and Ipsala were called on twice, while Clasher, colt by Tramp, Acorn, Ikey So omons, Tam O'Shanter, Eldorado, Donegani, Hassan, filly by Surprise and a horse by Smolensko were ridden once. Streamlet, by reason of the storm, took $10 \mathrm{~min} .15 \mathrm{sec}$. to do the four miles, while Ikey Solomons, through falling, took $12 \mathrm{~min}$. and these were the two worst records.

By reference to old calendars it will be seen that some of these were racehorses of high class; most of them were lent to Mr. Osbaldeston out of the Newmarket stables, but several were his own property.

Bell's Life, through a slip of the writer's pen, states that twenty-nine different horses were used, overlooking the fact that good little Fairy who did her second round in 8 min. 8 sec., next best to Tranby's time, was ridden twice.

The time actually occupied in riding this match as taken from the record opposite the name of each horse, which does not include stoppages, was $7 \mathrm{hr}$. $34 \mathrm{~min}$. $34 \mathrm{sec}$. This, for each four miles, is an average of $9 \mathrm{~min}$. $5 \mathrm{sec}$, and for a mile $2 \mathrm{~min}$. $16 \mathrm{sec}$. and is a little over 26 miles an hour. The stoppages, including $6 \mathrm{~min}$. 20sec. for luncheon, came to $1 \mathrm{hr} .7 \mathrm{~min}$. $16 \mathrm{sec}$. but deducting the luncheon they averaged $1 \mathrm{~min}$. $13 \mathrm{sec}$. and were from 6 sec. to $2 \mathrm{~min}$. Of course the first mounting and last dismounting are not counted.

Mr. Wheeler, quoting from the Standard, gives in his book $1 \mathrm{hr} .22 \mathrm{~min}$. $56 \mathrm{sec}$. as the total time occupied in stoppages, but I prefer to rely upon good old "Nunquam Dormio," who, on all matters sporting, was in those days immeasurably more reliable than any other paperand, for that matter, remained so until its eyes were closed many years after by newspapers issued daily upon sport.

Independent of the stake Osbaldeston won a very large amount over this event, having at first taken all the odds that were available and ultimately laying odds on. Gully, also, was a big winner. Considering 
the weather and the cut-up state the ground was necessarily in, the time even for a short distance must be considered good ; but when it is recorded that many of the horses when brought out were lame and that Guilford was badly string-halted on both hind legs, the feat, on the whole, was the greatest of its sort that ever was, or perhaps ever will be, performed.

In summing up its article on the match, in its issue of November 13, 1831, Bell's Life says:- "Mr. Osbaldeston, by this matchless feat, proved himself a number one at almost every manly exercise save boxing.* He has carried off the palm at hard riding, steeplechases, aquatic feats, shooting, and pedestrianism. In fact, he is in his way a perfect nonpareil, and outstrips all competitors."

Owing to objectionable criticisms appearing in the press and elsewhere on his "200 miles in 10 hours" match, he soon after publicly challenged any man in the world of his age and weight (or carrying it) to ride any distance from 200 to 500 miles for $£ 20,000$; or that he would take $£ 10,000$ to $£ 3,000$, or $£ 20,000$ to $£ 6,000$ that he would ride 200 miles in eight hours. No one took him up !

Mr. Osbaldeston's age at the time of the match just described has been put down at forty-six and forty-seven years, but inasmuch as he was born the day after Christmas, 1787, and the match took place on Saturday, November 5,1831 , it is pretty plain that he was just within seven weeks of being forty-four years old when he accomplished the feat.

This wonderful man shot in the presence of the then Sir Richard Sutton ninety-eight pheasants out of one hundred shots. And as the annals of the old Red House at Battersea record, no man of his day was a much better shot at pigeons.

Mr. Edward Budd, who was an intimate friend of Mr. Osbaldeston, once backed him with Mr. Thellusson to shoot eighty bracs of partridge in one day. The match came off over The Squire's property at Ebberson in Yorkshire, when he bagged ninety-seven brace and a half of partridge, nine hares, and a rabbit, but as there were five brace and a half picked up next day he in reality shot 103 brace of partridge besides the hares and rabbit-a feat at that time unequalled in the annals of shooting. This was, of course, with the old fint muzzleloaders. The date is not given, but it was before his fall, about 1825 .

He had a wonderful breed of pointers. For a brother and sister, Mark and Flirt, he refused sixty guineas, equivalent to a hundred and sixty nowadays. With this brace he offered to back himself for $£ 10,000$ against any man and brace of dogs in the kingdom, but no one dared to take him up.

Mr. Wheeler devotes many pages to Mr. Osbaldeston's prowess as a cricketer but I have space only to say that, except Mr. E. W. Budd,

* I don't know why boxing should be excepted, for The Squire was a capital man with his tists.-THE ACTHOR. 
Lord Frederick Beauclerc and Mr. Ward, no amateurs of his day were nearly his equal, nor were many professionals. He was most noted for his tremendous-paced bowling, requiring always two longstops, while at single wicket he was almost invincible. He was also one of the best billiard players in England.

Steeplechasing in those days, compared with now, was little practised, but The Squire was the best man then in England to ride one, and it is recorded of him that he won every such race he rode. I doubt, however, he was as good in silk as were our Irishmen-the brothers Allan and William McDonagh-who rode about the same time. Amongst his most celebrated matches was that on Clinker against Dick Christian on Clasher. It was for 1,000 guineas, and the line chosen was about four miles in the Quorn country, from Dalby Windmill to Lipton. Christian, as a horseman, was then in his prime, and, with a view to frightening The Squire, the Clashers told Dick to follow close in his track. These tactics were adopted, but had only the effect of making him the more determined to get away. A desperate race this was, and both horses jumped the last fence together, but Clasher here came down a purler, leaving Clinker and The Squire to win in a walk.

It is interesting to inspect the exact ground over which some of the great races of old were run, so I shall tell of a course which can easily be looked over, and at the same time describe another match of historic fame. In March, 1832, Mr. Elmore and Mr. Evans made a match for $£ 500$ a-side, between their horses Grimaldi and Moonraker. It came off on Tuesday, the 13th of that month, and was from a field on Mr. Copeland's farm near the seventh milestone on the Edgware Road, down the gradual descent and across the flat country to the foot of Harrow Hill, where in front of Mr. Hawkins' farmhouse on Harrow Weald a drain across the meadow marked the goal-distance four miles. Grimaldi was a grey gelding, then twelve years old, and was by Grimaldi out of Miss Bab, by Highland Fling out of Lady Bab, and was bred by Mr. Clifford of Gloucestershire. Moonraker was a bay, his age or pedigree was not known, but he was then in his prime and must have been well bred, for he with Grimaldi, Vivian, and Lord Waterford's Lancet and Cock Robin were then about the best steeplechase horses in England. The Harrow course was not as stiff as those of St. Albans and Leicestershire, but it was trappy and brought to grief a great many of those who rode over it with the two jockeys before the start. That ladies could ride well across country in those days is shown by the fact that no one rode better than "a young and be zutiful lady" who accompanied them, and she did so without a fall. Her name, unfortunately, is not recorded in Bell's Life of March 18, 1832, from which I am now taking these particulars. Mr. Osbaldeston rode Grimaldi for Mr. Elmore, while Mr. Dan Seffert rode Moonraker for Mr. Evans. Colonel Charrité was umpire for the latter and Mr. Meyrick acted for the former. 
This match created a great deal of interest, and thousands flocked on foot, horseback, and in carriages to see it, among them being a great number of ladies. Mr. Elmore, who lived near the start, entertained a large party to luncheon, after which the race was started a little after five o'clock. 11st. 7]bs. was the weight which Osbaldeston had little trouble to make up, but Seffert had to carry sixteen pounds of lead, which be did in a belt strapped round his waist. Moonraker was favourite, notwithstanding that The Squire had given Elmore $£ 50$ to make the match, so confident was he of winning. The race was run at a good pace and without a fall, but a collision took place which caused a terrible wrangle afterwards. Seffert made a couple of detours which lost him ground, but Osbaldeston rode straight as a line from start to finish and won easily, Moonraker being dead beat. After the race Seffert lodged a complaint against The Squire for foul riding, and there was no end of a row ; nor could it be decided who was entitled to the stakes till finally, after a week's finding and proving, the case was left to Colonel Anson to decide, and he awarded the race to Grimaldi, exonerating The Squire from all blame.

Like most foxhunters, he was not insensible to the charms of beautiful women. One night, at a dinner party previous to a ball in Lincolnshire, were two rival beauties, one of whom had in her bouquet a hot-house flower of exceeding rarity, and in the hearing of The Squire she twitted the other with not having in hers one of equal elegance. Pleading excuse for leaving the wine party after dinner, he got on his horse and rode twenty-five miles distant to the house of the gentleman from whose conservatory the flower had been obtained, and returned with a still more brilliant specimen. This he presented to the other lady and she wore it in triumph at the ball supper. He did the fifty miles in about four hours on the one horse and a dark night.

Running a fox near Bracebridge, in Lincolnshire, the hounds crossed a river, and while looking at them from a barge a boy fell into deep water and was drowning. Without a moment's hesitation The Squire galloped to the bank, jumped off his horse and plunged in and after diving for him brought the lad safely to land. He then remounted and followed his hounds as if nothing had happened.

Like too many of his good sort Mr. Osbaldeston was quick-tempered and irritable-proud of his abilities and jealous of rivalry-consequently, at times, he got into trouble with his friends ; nevertheless he was in his day one of the most popular men in England.

To instance the large quantities of wine which were laid down by gentlemen long ago and as an example of the improvidence of the age, I may state about The Squire that in his wine cellars at Hutton Busheli were discovered by Mr. Budd six pipes of Madeira which had been entirely lost sight of !

The manly deeds of George Osbaldeston would fill a volume of considerable magnitude. I am, however, unable to devote more space to the subject, so will conclude my reference with opinions expressed 
about him post-mortem which go to prove that since the days of the Assyrian Nimrod we never had a greater sportsman.

The Standard of Friday, August 3, 1866, gives an obituary, in which it states :-

"In recording the death of Mr. George Osbaldeston, in his seventyninth year, which took place at his residence, Grove Road, St. John's Wood, on the 1st inst., we would make a few remarks respecting his unparalleled career, believing, as we do, that he was the greatest practical sportsman that England or any other country ever produced; indeed, there is not a foxhunter, shooter, angler, cricketer or billiardplayer either in this or the last generation who has not, at least, heard of the wonderful performances of 'the old Squire.'

"There are and have been several 'old Squires' in various parts of the country, and worthy sportsmen too, but for the last thirty years the question, 'Which old Squire?' was never put, as everybody knew that Mr. Osbaldeston was the gentleman referred to. Nor can this be wondered at, for his deeds far outshone those of any sportsman either dead or alive. He may have been equalled in one particular branch of sport, as the generality of men excel only in one line, but Mr. Osbaldeston excelled in everything he undertook, and in his day conquered evergbody with whom he came in contact."

Captain Ross, writing of him soon after his death, testified that "as one who went in at everything in the ring he was the best man England had produced during the present century. He was generous and kind-hearted, and never spoke harshly of others or allowed it to be done in their absence."

Owing to his confiding disposition he was robbed and deceived by some of those he trusted most, with a result in the end that his financial affairs got into confusion, and not having sufficient moral nerve to pull up in time, or business capacity requisite to get himself out of his troubles, this great man who had started in life with the heritage of a splendid estate and a brilliant fortune had to succumb to circumstances and end his days in comparative oblivion.

Deep, deep is the pity that such should have been the fate of perhaps the greatest sportsman England ever produced.

\section{Captain Horatio Ross}

of Rossie Castle, in Forfarshire, was another of our great all-round sportsmen. Born in 1801, he was fourteen years younger than Mr. Osbaldeston. In his early days, with a large stud of good hunters, he spent the winters at Melton, and the greater part of the rest of the year in the Highlands. There, for a trifle, he rented huge tracts of land, which, nowadays, fetch thousands a year. Deer were then scarce, but young Ross was constantly in pursuit of them, and, after roaming over enormous extents of hill country, would leave off perhaps twenty or thirty miles from his shooting lodge. To this he had to walk for there were no roads to ride, much less to drive over. 
Doubtless by this early training he acquired the astonishing power of endurance which he so often displayed in walking long distances without showing symptoms of fatigue.

"The Ross and Anson Match" is of historic fame. It took place on November 10, 1828, and came about by Lord de Roos backing Colonel Anson to shoot more partridges in a day than Captain Ross. The terms were: Both to shoot in company over Milden Hall estate in Suffolk, which his lordship then rented; no dogs; each man to walk forty or fifty yards apart, with two or three beaters between, and it was not necessary to pick up the birds, the umpires seeing them drop being sufficient. Time, from sunrise to sunset. Colonel Anson being a particularly fast and strong walker, fancied he could beat Ross, so he set off at the rate of four and a half miles an hour. This pace they kept up until about two o'clock, when the Colonel showed evident signs of getting pumped. The attendants were all beaten before twelve o'clock and fresh ones had to be found. Although the match was carried out in the fairest manner and the men changed order every hour, the Colonel had luck on his side, getting eleven shots more than Ross and was seven birds ahead of him at two o'clock. Ross was, however, as fresh as when he started, so he went right away from Anson and was thus able to make up leeway. A quarter of an hour before the expiration of the time a message came to him from Lord de Roos that Anson was unable to walk any more, but was one bird ahead, so he proposed to make it a drawn match. This, although as fresh as when he started, Ross agreed to for it was uncertain he could get another brace within the time, the birds being then all upon the stubbles and very wild.

The bag made was ridiculously small (only about twenty-five or twenty-six brace), but that was easily explained, for in November partridges in Norfolk and Suffolk are always very wild, but on the day in question they were made more so by the fact that the shooters were followed all the time by a multitude of men both on foot and horseback who, talking and betting on every shot, caused such a row that when a field was entered hundreds of birds went off in one great flight at the other end. Scarcely a shot was got within forty yards, while fifty and sixty yards was the distance of most of them.

After the match, so fresh was Captain Ross, and in the excitement of the moment, he said to the assembled concourse of people, numbering five or six hundred, that he would there and then start against any of them to go to London on foot for $£ 500$, a distance of seventy miles, or that he would shoot the same match next day against anyone present, except Mr. Osbaldeston, for $\$ 500$.

No one took up either challenge, but a young farmer said he would try a race against him to an inn which was over two miles distant For the fun of the thing Ross agreed and off they started, accompanied by half the crowd; but fioss won by over a hundred yards beating out of sight nearly the whole lot! 
In "barring" the Squire when offering to shoot against anyone present, Captain Ross was actuated by magnanimity towards his friend, for he knew the Squire would be the most likely to accept the challenge, but not being able to walk fast or long, owing to his accident, he would have no chance ; and, besides, Ross knew his friend would be gratified by being "barred," and attribute the reason to his excellence as a shot.

On another occasion, July 19, 1826, when staying at Blackhall, the seat of his friend, Mr. Farquharson, in Kincardineshire, he had spent seven or eight hours up to his middle shooting flappers, and after a good dinner, when the ladies had gone to the drawing-room, he fell asleep. About nine o'clock he was awakened by the late Sir Andrew Leith Hay, who said, "Ross, old fellow, I want you to jump up and go as my umpire with Lord Kennedy to Inverness. I have made a bet of $£ 2,500$ a side that I can get there on foot before him." Nothing came amiss to men like him, and the reply Ross gave was, "All right, I am ready." Off they started there and then in evening costume, with thin shoes and silk stockings! Their servants followed with more suitable clothing; but the boots brought Ross were a pair of tight new Wellingtons. Lord Kennedy took the direct line which led them over the Grampians, walking all night, next day, and the next night, and arrived at Inverness at 6 a.m.--raining in torrents all the way. Sir Andrew Hay went by the coach road-which was thirty-six miles longer-but, although level, he did not appear until 10 a.m. The sole of one of Ross's boots vanished when twenty-five miles from Inverness, and he had to finish the walk barefooted; but did so comparatively fresh. The distance he went over was about ninetyfive miles. This match was, however, by Captain Barclay-Allardice, declared drawn, as Lord Kennedy, when a good deal beaten, leant on the arm of his attendant while ascending and descending some of the hills towards the end.

lioss betted Lord Kennedy $£ 20$ be would, in a day, shoot with a gun twenty brace of swallows, which he readily did at Rossie where these birds congregated in great numbers. He sent the lot in a basket to Lord Kennedy and they were brought to him while at dinner. When sending the money he wrote Captain Ross that it was the most expensive entrée ever handed him.

Two years after, one morning before breakfast, for a bet of $£ 100$ with Mr. George Foljambe, Ross shot, flying, ten brace of swallows with pistol and single ball, also at Rossie Castle.

Ross did not go in for record bags of grouse ; sixty-five brace in one day was about the biggest he ever made. Not so deer.

In 1828 he rented, from the Duke of Athol, Feloar, and on it shot to his own rifle eighty-seven deer. It was in the following November he had the match with Colonel Anson, and he attributed the good condition he was in to the grand training he had deer-stalking.

In 1837 he killed seventy-five deer in Sutherlandshire. In 1851 he 
shot 118 deer in Mar Forest, one day killing no less than thirteen with fourteen chances.

In a forest in Inverness-shire he shot eight stags in twenty minutes, date not given. The deer were driven into a wood and got stupefied. He had only a muzzle-loading rifle, while loading which he lost sight of the deer. If he had had a breech-loader, so that he could have run while loading, he could have killed a great many more.

Matches with pistol and ball were common in England in those days, and Ross entered into many, but never was he beaten. Once with a Spanish gentleman he shot for $£ 50$ at the old Red House at Battersea, the best of fifty shots. The target was a common playing card and the bull's-eye exactly the size of a sixpence. The distance certainly was only twelve yards but he won the wager by remarkable sho iting, and out of the last twenty-five shots hit the bull's-eye twentythree times. Short distance alone was not his forte with the pistol, for he made nearly as good shooting with it up to a hundred yards as with a rifle. Moreover, with a pistol he killed deer, both roe and fallow.

In 1825 or 1826 he and Mr. William Coke had a two-day match at partridges over the Holkham estate. The conditions were as follows: - Two beats were named and to toss for choice; a day to intervene between the first and second day's shooting, when they were to change beats ; to start as early as they pleased; to load their own guns; to hunt the dogs, and to pick up the birds killed; to be allowed two attendants each to help in any other way.

Ross had lost by madness his best dogs, but he borrowed from Mr. Osbaldeston a brace, which in Yorkshire were perfection.

The Squire was Captain Ross's umpire and walked with Mr. Coke, while Captain Greville, R.N., walked with Ross on the part of Coke. They started at daylight, but the first turnip-field Ross entered away went the Squire's fleet, high-bred dogs, and before they had got half way down it between four and five hundred partridges were flushed and went off in crowds. The dogs found a scent under every turnip and in a few minutes "lost their noses" altogether. They rushed here and there, and partridges rising every instant they got totally bewildered. In their excitement they jumped in the air trying to catch the birds and finally rushed after some which they followed into the next field and cleared it also, giving tongue like hounds. Not a shot did Ross get during the first half hour, while he heard his opponent hard at work. Trying and provoking as it was, this performance of the $\operatorname{dog}_{3}$ was so absurd that he and Captain Greville burst out laughing. At last the dogs were caught and put in couples. A man was put on each side of Ross, and by walking them up he at sunset had bagged forty brace of birds.

On his way to the Hall, Mr. Denny, a true type of a fine old English farmer, joined him, and, although a tenant of Mr. Coke's, he wished that Ross should have fair play, for he said he was the best shot they 
had ever seen but that he knew no more how to work Norfolk partridge than a child, and unless he altered his system he must be beaten. It was then arranged that next day Ross was to come to the good old fellow to be shown over the ground and get instructions.

Mr. Coke on the first day killed fifty-four brace, so Ross was fourteen brace behind him.

Mr. Denny's instructions next day were to this effect :-Early in the morning to drive the partridge from the stubbles to the turnips. Then, with two old setters he would lend him which between them had only two eyes, and would potter about within fifteen or twenty yards finding the dead and wounded birds, and with a man on either side, he was to beat the turnips in small circles. If he went straight through the field the birds would run along the drills to the end and then rise in one great pack, but by making small circles they would be cut off and shots could be got.

Captain Ross followed the old gentleman's instructions to the letter. In the first field, by 9 a.m., he got fifty shots and bagged fifty partridges. He missed once but killed two in a shot afterwards. The result of the day's shooting was that Ross bagged fifty-nine brace and Mr. Coke thirty-six, so that on the two days' shooting Ross won by nine brace.

Thus is shown what different training is required for dogs where birds are in great numbers to that necessary for wilder shooting. It reminds me of what occurred over thirty years ago with myself. Among other good dogs I had a wonderful bitch called Sappho. I have had as good, but none better. For her I refused several offers of from $£ 20$ to $£ 30$, but I would not have taken $£ 50$ for her. A friend of mine from Lincolnshire was shooting with me one day and greatly admired her working, but told me that, except for a retriever, he never saw a dog which would be worth $£ 10$ for the sort of shooting they had in the eastern counties of England.

Mr. Coke, with whom Captain Ross had the match just alluded to, was not a first-class shot, but he thoroughly knew how to get at game in his own county, with the result that he generally bagged more than men who could shoot better but had not the same field-craft. His dogs were perfectly adapted for Norfolk or other crack partridge shooting; but were bred between setters and water spaniels. When on the scent they never pointed, but walked on with their tails straight out and put their birds up; but as they were broken to keep within fifteen or twenty yards of their master, they did no harm in this free and easy manner of flushing birds for they dropped to shot and retrieved beautifully. This Mr. Coke was the first man who went in earnest to stalk deer in the Highlands.

Seldom do we find one as a horseman equally good between flags and with hounds. Still more rare is the man who is first-rate with the gun at game and the rifle at a target. But in Captain Horatio Ross was a man still more phenomenal, for he was equally good with shot-gun, rifle, 
and pistol. Inasmuch, however, as I have not dealt in this book with target-shooting, my readers must seek elsewhere for his records at Wimbledon and other places, when they will find they are, on the whole, unsurpassed by anyone, and that up to when he was nearly three-score years and ten.

Of him it was written, some thirty years ago, by one qualified to judge, "that since the invention of gunpowder no other man has yet been born who was such a complete master of the fowling-piece, rifle and pistol ; and for many years he offered to back himself for $£ 5,000$ against any man in the whole world for a three-cornered match with these weapons."

Captain Ross attributed his preserving until late in life more activity than many young men and most men of middle age, to the fact of his having habitually kept himself in a state of moderate training. This he did by living well and drinking moderately ; taking a cold bath every morning, and walking daily, no matter what might be the state of the weather, from eight to twelve miles. At the $a_{c} \mathrm{c}$ of sixty-five he was able, without fatigue, to go right ahead for fifty miles at three and a half miles an hour.

Unlike his friend Osbaldeston, Captain Ross was all through his life a prudent man, showing great judgment and sound business capacity in managing both his own affairs and those which devolve upon a country gentleman. For some years he turned his attention to politics and represented in Parliament the town of Montrose, which was close to his ancestral home, and what was his popularity may be inferred from the fact that out of four hundred votes he polled three hundred and sixty. He was familiarly called "The Laird."

In 1833 he married Miss Macrae, a Highland lady, and had five sons, all of whom bave followed their father's good example and are sportsmen of high order. After his marriage Captain Ross gave up his Melton establishment, and lived almost entirely in the wildest and most out-of-the-way part of the Highlands as suiting his taste and that of Mrs. Ross, who one of the sons described as being "one of the very best of mothers that a lot of sons ever had to look up to and love."

He died at Rossie Castle, December 6, 1886, in his eighty-sixth year, having retained his good health to the last.

For Captain Ross's match on Clinker against Captain Douglas on Radical, see Steeplechase chapter.

As a contemporary of Osbaldeston and Ross,

\section{LORD KENYEDY}

was an all-round sportsman of the first water, but he never attained the superlative brilliancy of the other two.

Of his lordship I shall narrate a performance which, if equalled, was never surpassed. He backed himself for a considerable sum to ride from his shooting quarters, then at Feloar, in Perthshire, to 
Dunottur, his own place near Stonehaven, a distance of eighty miles, there to shoot forty brace of grouse and return to Feloar in a day. He started soon after midnight, and with relays of horses arrived at Dunottur. By 9 a.m. he had his birds bagged. He then changed clothes on the hillside, and riding the same horses he reached Feloar about 8 p.m. Thus in less than trenty hours he rode 160 miles and shot forty brace of grouse. It rained during part of the time, and some fifteen miles of the ride was over ground without a road.

In October, 1823, there was a great match shot off. It originated by Sir Wm. Maxwell backing himself to find a man who would shoot 100 brace of partridge in one day over his estate in Wigtownshire. $\mathrm{He}$ asked Lord Kennedy to do it for him, but, after pronouncing it impossible, his lordship backed himself to shoot partridges two days in Scotland against Mr. W. Coke two days in Norfolk, chance of weather to be run by both parties.

Lord Kennedy was disappointed the first day in the ground he intended to shoot over and had to take ground of Sir Wm. Maxwell's at Moureith, which had already been shot. Nor could he begin till 11 a.m. He shot that day between forty and fifty brace. Coke, shooting the same day at Holkham, got ninety-three brace.

On the second day the "one hundred brace match" was to be decided, but it did not come off for some days after the first. Sir William wanted Lord Kennedy to look over the ground the day before but he would not do so. Nor on the day would he use the steady old dogs provided by Sir William, but insisted upon using his own which were never before shot over except on moors. Moreover, he would not go to coveys marked into whins nor take any advice from the keepers, seeming to think that it would not be fair, although Mr. Val. Maher, Mr. Coke's umpire, agreed that he ought to do so.

By 11.30, when they halted for refreshment, Lord Kennedy had sixty brace in the bag and the best of the ground still before him; but instead of taking the advice proffered, he persevered over a line of bare grass fields, with the result that he lost the match he had with Mr. Coke and also that for Sir William Maxwell. As it was he got ninety-three and a half brace, while Mr. Coke, at Holkham again, got ninety-six. A great many dead and wounded birds were picked up a day or two after on the ground over which Lord Kennedy shot, and it was estimated he actually shot, though he did not bag, one hundred and twenty brace that day. No one had the least doubt, nor had his lordship himself, that he would have bagged far over the hundred brace had he not been so self-willed.

In September, 1822, Lord Garlies backed himself to shoot fifty brace of partridge in a day over his father's ground in Wigtownshire-there to be no preparation whatever. He went out with two guns and his pointers on a wet and stormy morning, and by ten o'clock had only fifteen brace in the bag. The wind soon after fell and the sun came out, and as the birds lay well he had before three o'clock between forty 
and fifty brace. He then offered to double his bet that he would shoot eighty brace, but the ease with which it might be done was so apparent that no one would take him up. He stopped at three o'clock, having killed fifty-six brace. If he had shot the eighty brace it would have heen a greater performance than either Lord Kennedy's or Mr. Coke's the year after, for he shot over his dogs as in an ordinary day's shooting, without preparation or assistance, and was baulked a great deal by his two guns having stocks of different lengths.

It was considered that had Lord Garlies undertaken the "one hundred brace match" for Sir William Maxwell he would have won it. Not that he was a better shot than Lord Kennedy, but he would have taken advice and kept his temper better.

Lord Kennedy was, when things wera going all right, a most charming companion, and his home, Dunottur, was the pleasantest place to visit. Unfortunately, however, this great sportsman was cursed with the infatuation for gambling, and being of an uncontrollable disposition and violent temper he would take advice from no man. The consequence was Dunottur, which was the property of his wife, had to be sold, and this unfortunate nobleman, heir to a marquisate and $£ 40,000$ a year, fell like many others, and died young.

\section{Mr. Edward Hayward Budd}

of Elcombe House, near Swindon, born February 23, 1785, was a contemporary and associate of all the men I refer to in this chapter. He was powerfully muscular, and one of the best cricketers that ever handled a bat, and when four-score years old played in good style. Lillywhite said that he was the hardest hitter and best-made man he ever saw. No man of his day could run or jump with him, and as a boxer no pugilist was more artistic. He was also an excellent shot. In fact, no man in the world had a chance with Budd in an all-round match of the sports I have associated him with. My readers must, however, consult "Sportascrapiana" for particulars. Like most men of his time he hated tobacco smoking.

Mr. Wheeler leaves out from his book the names of such men as Thomas Assheton Smith, John Musters and others who were celebrated contemporaries of the men I have mentioned, possibly for the reason that they were not the all-round sportsmen the others were. Hunting was in their line predominant over all other sport. Inasmuch as special histories have been written of these men, not to speak of countless allusions made in the press, I need not make mention of them.

Never in either former or present generations have we had in a gentleman such a pedestrian as

Captain Barclay-Allardice.

Bell's Life was not started until about the year 1822, so from its own columns it was not able to take particulars of this officer's feats ; how- 
ever, in 1874 that paper published a history of them. It was compiled from authentic sources, including the testimony of his graudson, $\mathrm{Mr}$. R. Barclay-Allardice of Jordanstone House, and contemporaries such as Mr. E. H. Budd of Swindon, Captain Ross of Rossie Castle, also Mr. A. W. Kinnear of Stonehaven, who, for many years, was his agent and factor. It may, therefore, be taken that the record is perfectly truthful, so from it I extract some particulars, which are as follows :-

The Barclsy-Allardice family can boast of a genealogy as old as any in Scotland. It can be traced back to A.D. 1110. Originally the name was spelt Berkeley, and they were described as "of Mathers," but some three hundred years ago it was changed to Barclay, and the head of the family came to Ury, since when, until near the end of the last century, they were called the "Barclays of Ury." The paper from which I am taking these particulars gives an exhaustive history of the family, by which is seen it always held the highest position in society, and among its members were some of the most celebrated men of the day and friends of the reigning sovereign. I skip all this and come to the father of the subject of this present memoir. He was Robert Barclay, and is described as a most handsome man of six feet high and very athletic. He was a great pedestrian and often walked from Ury to London, on one occasion doing the 510 miles in ten days. William Pitt was his great friend, and he represented the county of Kincardine in three Parliaments. He was a great agriculturist, and by his good management reclaimed his large property from a treeless wilderness into one of the most beautiful in North Britain. $\mathrm{He}$ married Miss Sarah Anne Allardice of Allardice Castle, about nine miles from Ury, and with her the Allardice estates, which were in the possession of that family since 1167 , came to the Barclays, and Allardice was added to the surname.

Believing as I do that good breeding is a necessity in man, even more so than in an animal, to enable him, when the pinch comes, to go straight, I make this short reference to the pedigree of the man some of whose deeds I am about to record. "Soft cnes" we have in man and animal, no matter how well-bred they may be, but when in a difficult position, either as regards honour, pluck, or determination, give me the man who has had, at least, a grandfather!

The other gentlemen to whom I have made mention in this chapter were likewise descendants of ancient families of the highest standing, but not having any record of their pedigrees or means of obtaining them I am unable to give reference thereto.

Captain Robert Barclay-Allardice was the eldest son of Robert Barclay and Miss Allardice just mentioned, and was born at Ury on August 25, 1779. He was thus twenty-two, six, and eight years older respectively than Captain Ross, Mr. E. H. Budd, and Mr. George Osbaldeston, all of whom in after life were intimate friends of his and witnessed most of his extraordinary feats.

Omitting reference to his boyhood, I come to August, 1796, when 
his first public pedestrian feat took place. For 100 guineas level he backed bimself to walk six miles in the hour, fair heel and toe. This he won without difficulty and in the shortest time then on record. The exact time is not given, but it was considered a wonderful performance for a lad of seventeen.

In the April following his father died and he succeeded to the family estates, which remained under guardians till he came of age. His second match was against Ferguson, the celebrated City Walking Clerk. It was a seventy miles run, from Fenchurch Street, London, to ten miles beyond Windsor and back. The Captain performed the distance in fourteen hours on a very hot day in August, 1798, the clerk being "nowhere." The amount of the stakes is not given.

Captain Allardice then went to Cambridge, but staye 1 only a year and did not graduate. Beyond taking "constitutionals" of sixty and seventy miles to and from London, Oxford, Birmingham, etc., he does not appear to have made any matches while at College.

In the fall of 1800 he made the first of four celebrated bets with Mr. Fletcher of Ballingshoe, a gentleman well known on the Turf. The first was for a level 2,500 guineas that Mr. F. did not do sixty miles in fourteen hours, go as he pleased. This he just managed to do at Doncaster; but so knocked up was he that he expressed himself certain that no one could achieve another thirty miles at comparatively the same rate. The Captain at once backed himself for 500 guineas to go ninety miles in $21 \frac{1}{2}$ hours. The affair was fixed for December, 1800. He ran a good trial of sixty-four miles in twelve hours, but caught a chill and had to give up the match and pay the stake. In the following spring the Captain's unceasing perseverance nerved him to have another shy at Mr. Fletcher, so " 90 in $21 \frac{1}{2}$ " was again booked; but this time for no less than 2,000 guineas a-side. The match came off over a measured mile on the high road between Brechin and Forfar. He ran his first sixty-seven miles in thirteen hours; but then, owing to having taken some bad brandy, he suddenly became ill, and thinking his chance hopeless, gave up the match. Two hours afterwards he was all right and could have easily run the other twentythree miles in the remaining five and a half hours har he not previously given up and the umpires accordingly left. Here, therefore, was our hero, within six months, at the wrong side of his book to the tune of 5,000 guineas-exclusive of expenses.

At this early age young Allardice seems to have got hold of the dogged perseverance which characterised him all through life, for next year we find him tackling Fletcher again over the " 90 in $21 \frac{1}{2}$." This time the stakes were for 5,000 guineas, and so confident was he that he allowed November to be chosen for the match to come off in, just about the worst month of the year, he to choose the ground. Allardice went into strict training in September under a knowing old tenant of Lord Fauconberg's in Yorkshire. In a "dark" trial, which came off in his lordship's demesne of Newburgh Priory at the end of October, the Cap- 
tain ran 110 miles in $19 \mathrm{~h}, 27 \mathrm{~min}$.--i.e., at the rate of 5 miles 5 fur. $53 \mathrm{yds}$ an hour. This was considered good enough for anything; so every available bet was snapped up, and the agreed-on eight days' notice to start was given to Mr. Fletcher. The Captain selected a mile on the Hull road, about sixteen miles from York, and a post was set up at each end for him to turn round, while lamps were placed along the line to give light during the dark hours. Wisely, ground was chosen on which were a few gentle slopes which would relieve the muscles.

Precisely at midnight, November 9-10, 1801, he started on his journey, weather unfavourable. His first sixteen miles were done at the rate of about twelve and a half minutes to the mile. A rest of ten minutes was then made for refreshment and change of clothing. After another fifteen miles a similar halt for like purposes was made, and he appeared dull from the damp night air. After sunrise, however, the weather became fine and continued so for the rest of the match. Fifty miles were covered in eleven hours, and the betting was 5 to 1 on him. The seventh and last halt was made at the end of the eightyfourth mile-15 to 1 against time-and he gallantly completed the ninety miles at 8.22 .4 p.m. on November 10 , in $20 \mathrm{hr}$. $22 \mathrm{~min}$. 4sec., being lb. 7 min. 56 sec. under his time. Thus, by sheer determination, pluck and endurance, did Captain Allardice win back his previous losings to Mr. Fletcher. In fact, he finished so strong and well that he could have gone twenty or thirty miles further. Thousands of people, at times, accompanied him upon foot and horseback, and all traffic on the road willingly made way for him. His dress was flannel shirts, trousers and night-cap, lambs'-wool stockings and thick-soled leather shoes. Diet-broiled fowls and mutton steaks, with old ale to drink.

In 1803 he joined the 23rd Welsh Fusiliers.

After the above mentioned big match he found no foeman till June, 1803, when he ran a mile and a half against Deaf Burke, the pugilist, whom he beat easily. Time or stakes not recorded. After running from London to Newmarket-about sixty-four miles-in ten hours in the following month he did nothing till December. He then in a quarter-mile match with Mr. J. Ward, one of the most noted amateur sprinters of the day, showed the world that he was possessed of speed as well as staying powers. It came off in Hyde Park, and was won by the Captain in fifty-six seconds, beating Ward by ten yards, after a terrific set-to up to within forty yards of the finish, when Ward completely collapsed. In March, 1804, he matched himself for 200 guineas to run twenty-three miles in three hours, but he became ill and had to forfeit what would have been a certainty bar accidents. On August 16, 1804, when quartered with his regiment at Eastbourne, he ran two miles in $11 \mathrm{~min}$. $57 \frac{1}{2} \mathrm{sec}$. - the fir $\mathrm{t}$ mile occupying $5 \mathrm{~min}$, and he backing himself to do the distance in $12 \mathrm{~min}$. The going was very bad owing to heavy rains and a strong wind was against him, which accounts for the bad pace of this match.

Up to then no one had tried Allardice at a mile, but at the same 
place as the last match and in the following month, he ran Captain Marston of the 48th Regiment that distance for 100 guineas a-side and beat him easily in 5min. 7sec., Marston being then the best amateur "miler" in England.

John Ireland of Manchester, probably the best jumper that ever lived and no mean professional miler, was now sent to lower the Captain's colours. The stake was 500 guineas a-side, the date October 12, 1804, and the venue again at Eastbourne ; but Allardice ran him to a standstill at three-quarters of a mile and did the full distance in four minutes fifty seconds, then the fastest one mile time on record, and remained so for twenty-one years, when Netcalf accomplished four minutes thirty seconds.

The 23rd Fusiliers now going abroad with Lord Cathcart's army for the protection of Hanover, Captain Allardice had no leisure for pedestrianism until he returned, when on August 4, 1806, he ran Mr. Goulbourne of the Royal Horse Guards a quarter mile at Lord's Cricket Ground, but he cleared him out at the end of 300 yards, th9 Captain finishing alone in sixty-two seconds. In the last month of that year he ran 100 miles from Ury to Craithynaird and back over bad roads and at the break of a heavy storm in 19 hours.

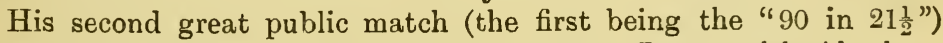
came off at Newmarket on October 12, 1807. It was with Abraham Wood, the celebrated Lancashire professional, who was backed against the Captain for 500 guineas a-side as to which of the two could run the farthest in twenty-four hours, the Captain to receive twenty miles at the finish. Never did Wood's backers assign him a more hopeless task. No man then, or probably ever living, could have given Allardice such a start in a twenty-four hours' run. The Captain trained at East Dean under the pugilists Gully and Ward. An enormous crowd assembled to see this match, which was over a measured mile roped and staked between Newmarket and the Ditch. It resulted in the Captain's winning, but Wood gave up at the end of forty miles, having been drugged with laudanum at the end of twenty miles by some of his own "backers"(?) who had been betting against him all along. Had Wood stood up he, bar accidents, could not have beaten the Captain, who, by his ninety miles match, showed that he could go a little over six miles an hour for twenty-four hours, which would total some 150 miles, and would necessitate Wood going 170 or perhaps 175 miles, a feat quite beyond his power.

A great deal of unpleasantness arose over the settlement of bets on this match, and while no aspersion was made on him or any of his backers, and they were paid their bets, the Captain regretted ever after that he made this match, the parties being altogether outside his own social standing.

In December, 1808, he won a nineteen miles match against Baxter, the Duke of Gordon's celebrated runner, from Gordon Castle to Huntly Lodge. He ran the first nine miles in 50min., and the whole 
distance in $2 \mathrm{hr} .8 \mathrm{~min}$, over a hilly road, his opponent being five miles to the bad at the goal.

N.B.-Of course, in some of the distances, better time has been made of late years than that made by Captain Allardice, but if so it was over cinder paths as smooth and level as tables, while his was made over fields or on the common high roads of ninety years ago, when even macadamising was unknown.

I now come to describe the greatest feat of this the greatest pedestrian that ever lived. Of course it is the "one thousand miles in one thousand hours."

In October, 1808, Mr. Wedderburn Webster,* a gentleman well known on the turf, laid Captain Barclay-Allardice a level 1,000 guineas that (to quote precisely the wording) "he would not walk one thousand miles in one thousand consecutive hours, neither more nor less than one exact mile to be walked in each hour."

Inured as he then was to hard exercise and long journeys, Allardice thought it unnecessary to go into any special training for this extraordinary undertaking, so he merely continued his usual out-of-door life ; but went to Brighton to obtain sea-bathing in the early part of the following summer.

The match was set to commence at midnight, May 31-June 1, 1809, over a measured mile on Newmarket Heath, and that a journal of the exact time he started for and completed each mile should be kept and certified by the umpires-two of whom should be in constant attendance to see that he faithfully performed the task without assistance in any way.

The course chosen was on the high road passing Mr. Buckle's house, where he lodged, but this is not likely to have heen F'rank Buckle the jockey, for he lived at Peterborough.

Bell's Life gives a "log" of each day's work, with particulars of the weather and the state of the walker; but I need refer only to the most important incidents.

He started at 0.2 a.m. on June 1, 1809, with 2 to 1 on him. He did not sleep well the first night owing to the novelty of his position and an uncomfortable bed; nor did he for the first couple of days lie down in the daytime, but walked about the streets of Newmarket. All went well until the tenth day, when he became much fatigued from rain and high wind; but continued to sleep and eat well, and was in the best spirits.

On the twelfth day he complained of pains in the nape of the neck and shoulders, caused by insufficient clothing at night and sitting in a draught. On the thirteenth the back tendons of his legs became painful and he found difficulty in starting. Up to the sixteenth he had been very uncomfortable at Buckle's house, and annoyed with the

* It has been erroneously stated that the match was made with Mr. Fletcher Reed. 
smell of cooking and want of room for his attendants, so at noon on that day he moved to other lodgings near the "Horse and Jockey," and there received every attention till the end of the match. His walking course was necessarily shifted, and a fresh half-mile was measured across the Norwich road, up the heath, out and home. This would be on Mill Hill and near to where the Square now is.

Pain in his legs now increased and ascended up his thighs, which interfered with his sleep.

Twentieth day. Still troubled with the pains in his legs, which had to be frequently bathed with vinegar, but his appetite remained good.

Twenty-first day. Pain became much worse, his action stiff and for a time he went amiss in the right foot. He now began to lie down during every interval.

Twenty-second day. Pains, which had hitherto abated at daylight, now became more intense and prolonged, and the ground, although kept well watered, got hard from the spectators walking on it. Dr. Sandiver was called in and ordered warm baths and liniment.

On the twenty-fourth toothache, in addition to his other pains, assailed the gallant fellow, and prevented sleep. The baths softened his feet so they had to be discontinued, and flannels soaked in boiling water were substituted but no permanent relief was afforded.

The twenty-sixth day saw him so stiff and ill that he had to be dressed and taken out before he was wide awake. The flannel appliances, with oil and camphor liniments, at last began to do good; nevertheless, he was gradually becoming weaker.

The twenty-seventh was the worst day so far, and the slowest mile of the whole match was then walked. Heavy rain having come on which necessitated his wearing overcoats, he was greatly hampered.

The thirtieth day he was very ill indeed, and could scarcely stand owing to the pain in his legs, his pace necessarily getting slower and slower.

From the thirty-first to the thirty-fourth day the sufferings of this wonderful man were intense and almost continual, so much so that he could get little or no repase, for during nearly all the time for rest his legs had to be rubbed by his attendants. Before starting he had to be moved about to get suppled and the pain occasioned him to cry out on several occasions, but so indomitable was known to be his pluck that 10 to 1 was offered on him, but few would take the odds. Luckily the pain subsided a little on the thirty-fourth, so that he got some good sleep and could again awake readily.

On the thirty-sixth day the poor fellow was in a pitiable state. I required the utmost powers of his servants to keep him up to time and his pace was so slow little time was left for rest. It appeared impossible that he could continue, but neither his pluck nor his appetite had deserted him in the least, and on he went.

On the thirty-eighth day there came a heavy thunderstorm which added much to his torments, and for the first and only time he felt disinclined to eat. 
The thirty-ninth day was Sunday, July 9, and multitudes came to see the Captain struggling gallantly on in pains and aches, while 100 to 1 was offered on him without a single acceptor. It was proposed to have the course roped to keep the crowds back, but this he would not allow for fear of making too much parade.

Forty-first day. Less time than ever for rest as his legs required incessant rubbing, and it appeared nearly all up with him. He was in capital spirits, however, as the end was fast approaching. The crowd was now so great that it became imperative this morning to have the ground roped and staked.

Forty-second and last day, Wednesday, July 12, 1809. A hundred to one was still on offer against time without a single taker among the ten thousand spectators who had assembled. He started for his last mile at 3.15 p.m. after a rest of twenty-three minutes, and completed his Herculean task at 3.37 p.m. amidst vociferous cheers.

Bell's Life gives a table of each day's work, commencing and ending at midnight, but I shall merely give the average of each week's work, which I have carefully compiled from it, leaving out fractions of seconds :-

\begin{tabular}{|c|c|c|c|c|c|c|c|c|c|c|}
\hline \multicolumn{6}{|c|}{ Ni. } & $\begin{array}{c}\mathrm{Hr} . \\
\tilde{5}\end{array}$ & $\mathrm{Min}_{57}$ & $\begin{array}{c}\text { Sec. } \\
47\end{array}$ & $\underset{14}{M i n .}$ & $\begin{array}{r}\text { Sec. } \\
54\end{array}$ \\
\hline Second &,$\ldots$ & $\cdots$ & $\ldots$ & $\ldots$ & $\begin{array}{l}\cdots \\
\ldots\end{array}$ & 6 & 23 & 55 & 15 & 58 \\
\hline Third & , ... & $\ldots$ & $\ldots$ & $\ldots$ & $\ldots$ & 6 & 40 & 38 & 16 & 42 \\
\hline Fourth &,$\ldots$ & $\ldots$ & $\ldots$ & $\ldots$ & $\ldots$ & 7 & 26 & 56 & 18 & 37 \\
\hline Fifth &,$\ldots$ & $\ldots$ & $\ldots$ & $\ldots$ & $\ldots$ & 7 & 54 & 4 & 19 & 45 \\
\hline Sixth &,,$\ldots$ & $\ldots$ & $\ldots$ & $\ldots$ & $\ldots$ & 7 & 53 & 51 & 20 & 46 \\
\hline
\end{tabular}

Sixteen miles only on the forty-second day.

His quickest mile was the 35 th, walked in 11 min. between 10 and 11 a.m. on the second day, June 2, whilst his slowest was the 629 th, in $36 \mathrm{~min}$. 30sec, between 4 and 5 a.m. on the twenty-seventh day, June 27. The average time per mile throughout was $17 \mathrm{~min}$. $45 \frac{1}{2} \mathrm{sec}$, and the average rate of walking throughout was 3 miles 3 fur. $5 \frac{3}{4} \mathrm{yds}$. per hour. The actual time occupied in walking the 1,000 miles was 12 days $8 \mathrm{hr}$. 1 min. 30 sec., which gives an average rate of 81 miles $134 \mathrm{yds}$. $2 \mathrm{ft}$. per diem."

On finishing, Captain Allardice was immersed in a hot bath for a few minutes, well rubbed down with flannels and put to bed at 4 p.m. He slept soundly till midnight, then he took some water-gruel and slept till 9 a.m. next morning, when he got up as well as ever and attended the July meeting on the racecourse for four hours.

* I copy these averages from Bell's Life without checking them.THE AUTHOR. 
His dress whilst walking was nearly all of flannel, with breeches and lambs'-wool socks or stockings according to the weather, light or heavy shoes according to state of the ground, and a soft felt hat. He breakfasted always at $5 \mathrm{a} . \mathrm{m}$. on animal food (generally roast fowl), a pint of strong ale and two cups of tea or coffee with bread and butter. Luncheon at noon on the best of beef or mutton, plainly roast or broiled, with a pint of strong old ale. Dinner at 6 p.m. of same materials, with the addition of a couple of glasseS of port wine. Supper at 11 p.m., same as luncheon. No boiled meat was allowed, being more difficult of digestion, but his consumption of animal food during the twenty-four hours was from 5lbs. to $6 \mathrm{lbs}$., besides as much as he could eat of all vegetables in season. The private families in Newmarket supplied him with their best home brewed ale (there was no Bass or Guinness in those days), and when thirsty between-whiles he drank Madeira and water.

When Captain Allardice started on this match he was $29 \frac{3}{4}$ years of age, stood $5 \mathrm{ft}$. 10in. or $10 \frac{1}{2}$ in., and weighed as nearly as possible 13st. $4 \mathrm{lb}$. After his seventeen hours' sleep at the end, he went to scale and was found to have lost just 2st. $4 \mathrm{lbs}$.- probably he put up 3lbs. or 4 lbs. during the sleep, for weight thus lost returns with marvellous rapidity. No doubt he wisely trained "big" for this occasion, in order to allow for wasting by perspiration and want of sleep, for 13st. $4 \mathrm{lbs}$. would not be the ordinary training weight of a man $5 \mathrm{ft}$. 10in.

He was allowed to choose his own time of year for the match, so he took that when daylight was longest. According to Bell's "log" the weather was variable all the time, but with the exception of a few visitations of heavy rain and wind, with a thunderstorm on the thirty-eighth day, it kept fairly good. Sunset and sunrise were his worst times, owing to weariness of the brain from want of sleep, which even in the commencement he could never get more than an hour and a half off the reel. His greatest trouble was with his legs, and he suffered fearfully after the twelfth day from cramps. These were, I should think, caused by his wearing tight breeches and long stockings, and if the light, loose clothing now worn by pedestrians had been then in fashion, the Captain would have had more ease. During the periods for rest he went to bed when inclined but never without entirely undressing, otherwise he lay on a sofa and conversed or read. The advantage and comfort he derived from a thorough change of clothes when he turned-in must have served him well. Luckily his appetite and digestion never failed him, as is shown by the enormous quartity of food he consumed daily, nor did his good spirits or confidence in his ability to win flag in the least. Throughout the whole time he got the most careful attendance and nursing, which of course aided materially, but the greatest of all the causes of Captain Barclay-Allardice's success was his indomitable British pluck and dogged determination to "do or die."

I see no allusion to his having taken cold baths, but of a truth the 
men of those days seemed to have a sort of hydrophobian horror of cold water. My opinion is that had this match been brought off near the sea where salt water baths or bathing could have been indulged in daily the gallant Captain would not have suffered so much. Even cold fresh water and less of the hot would have been better.

He won a very large amount over this match, for he backed himself whenever he could, but necessarily the expenses were very great. $\mathrm{He}$ had three relays of attendants of at least three each, three cooks, three sets of umpires, so as to keep watch, one on and two off. To board and lodge all these people and himself, let alone medical attendance and innumerable other items during his six weeks' work, cost a round sum.

Towards the close of the match so great was the attendance of strangers that every bed in Newmarket, Cambridge and the neighbouring villages was engaged. A. large proportion of the aristocracy of the kingdom was present on the last day, and as select an assemblage has probably never attended a foot race before or since.

On July 14 he posted to London in perfect health, and attended to his usual pursuits till the 17th, when he left for Ramsgate and joined the ill-fated Walcheren expedition.

After the feat of the "Thou in a thou," Captain Allardice competed in only two public matches. They were got up impromptu, without previous training on his part, and he was beaten in them both. One was on July 9, 1812, when he backed himself to run nine miles in the hour. He ran seven miles in $49 \mathrm{~min}$. and only eight miles and a half in the full hour. The second match came off on June 15, 18I3, when he was backed for 100 guineas against an officer in the 7 th Dragoon Guards to run two miles. It came off in Hyde Park but Allardice was beaten, much distressed, by 100 yards.

What a sad falling off from his old form, and it seems a pity he ever "toed the line" after the big match.

In addition to being so able a pedestrian he was a first-rate shot, an ardent follower of the chase, a capital whip, and could hold his own with the gloves against the best pugilists of the day. So highly was he thought of as a boxer that he was entrusted with the entire training of Tom Cribb, the champion, for his great battle with Molyneaux. Cribb was at Ury for the seven weeks previous, weighing on arrival 16st., and as he entered the ring fit to fight for a kingdom on September 11, 1811, it is evident his mentor was no novice in the art of pugilistic training.

Let it be clearly understood by my readers that pugilists of those days were, as a class, men very superior to those we now have.

For a heavy wager Captain Allardice is said to have once driven the Scotch mail coach from London to Edinburgh without getting off the box.

Although not going in for matches, he ever after kept up his walking and lived a useful country gentleman upon his property in Kincardineshire. As in Rudd, Poss, and Osbaldeston, so we 
have in Allardice an instance that hard training and exercise do not shorten human life provided after-excesses are not indulged in, for he lived until he was nearly seventy-five years of age, and died at Ury on May 1, 1854, of paralysis, of which he had two previous attacks.

Naturally sceptics were not wanting who disbelieved in Captain Allardice having done the 1,000 miles in 1,000 hours fairly, and most unjustifiable allegations were made soon after, and often since, against him, the principal one being that his brother took his place at night. These scandalous charges have been set aside by several good authorities, notably by Captain Horatio Ross, who, in reply to the editor of Bell's Life on the subject, wrote as follows:-

"I lose no time in replying to your letter, as I am anxious at once to vindicate the memory of my old friend, Barclay-Allardice, from an attack, the news of which, for the first time, has reached me. I knew him as intimately as I could know anyone, and I have no hesitation $n$ saying that he was one of the most honourab'e and rigidly correct men I ever met. Rather than connive or take part in such a swindle as —- Was charged him with he would at once have submitted to be shot. As to anyone walking for him at night it was simply an impossibility. Immense sums were depending upon the result, and he was watched every hour most rigidly. His brother was much younger than he was and just about half his size."

In conclusion I shall quote from Bell's Life what it says, with editorial authority, on the subject :-

"So reliable an authority as Captain Ross thoroughly dispels the probability or possibility of any substitute taking his place at night. Then again, Captain Barclay-Allardice in this instance, as in all his other matches, stood every penny of his own money, besides taking all the odds he could get. He was not at the beck and call of any blackleg or bookmaker, like, alas, many of our modern professional pedestrians. The number of 'quacks' amongst the latter class who have attempted the 1,000 miles feat, and are SAID to have been successful since 1809, is legion, and we here emphatically reassert what has repeatedly appeared in the 'Answers to Correspondents' column of Bell's Life in London, viz. :--'That no one but Captain Barclay-Allardice ever has walked 1,000 miles in 1,000 consecutive hours, one mile in each hour. Such barefaced impossibilities as 1,000 miles in 1,000 half hours, or in 1,000 quarter hours, are too absurd to require comment at our own hands. It is almost any odds against the feat being achieved again. No amateur of the present generation is sufficiently fond of match-making or could spare the time to attempt it, and the expenses are too great to admit of any professional being able to afford them." "

* The name of this traducer is left blank by Bell's Life, which is a pity. -The AUthor. 
I don't agree with those who think the present generation of sports men is inferior to those of former days. We have as good men now as we ever had; but men change in habits and tastes, and few are now to be found who would care for the exploits in which their ancestors gloried, so they don't go in for them. Consequently the fatigue which two generations ago our fathers and grandfathers unflinchingly sustained and the endurance they showed could not be borne by the constitution or muscles of their descendants. The Britain over which the men of old hunter and shot is passing rapidly away, and with it are disappearing the memories of deeds which will never be repeated. Nor shall we often (perhaps never) see again men who each possessed the combination of tough muscles and activity with skill in handling hounds, a horse, the gun, the gloves, the fishing rod, the billiard cue, or cricket bat, for which so many men of olden times were conspicuous.

Young men of the present day look upon some of the deeds which I have narrated as foolish, if not mad. Perhaps it is well they do so. For my part, I agree with many that there was a groundwork of energy and determination in the wild deeds of sportsmen of bygone days which was useful; for, however imprudent it may have been at times on the part of the performers, financially and constitutionally, such examples of pluck, endurance and disregard of bodily suffering shown by the upper classes of society must have a salutary effect upon the people at large ; and in these times of tennis, cycling and moneymaking it would do the present generation no harm if we could bring back to life some of the old race of men, with all their so-called madness and reckless disregard of life and money.

We have, and shall have, many first-rate foxhunters but scarcely another Osbaldeston. Many first-rate shots, but not another Captain Ross. Many tip-top cricketers, shots, runneri, jumpers and sparrers, but not likely one to excel in all as did Edward Budd. Pedestrians we have, and shall have, but certainly never another Barclay-Allardice.

Perhaps I should have included some of the shooting recorded in this chapter in the table of remarkable sport given in Chapter XV., but giving the record in a separate chapter renders it the more emphatic. 


\section{CHAPTER XXIII.}

\section{JOHN SCOT'T AND MAT DAWSON, GEORGE FORDHAM AND FRED AR.CHER.}

Histories of Racehorses Often Given-Those of Trainers and Jockeys Seldom-Record Unparalleled-"Glorious Reminiscences"-Original but Authentic.

JоHN Sсотт.

HIs Birth and Farly Days-His Apprenticeship-Filho-da-Puta-Mr. Houldsworth-The Hon. E. Petre-Mansfield-His Marriage-Removes to Whitewall-Success for Mr. Petre-His Achievements-Long List of Winners-Wonderful Records-Difficulties in those Days-Scott's Patrons-Mr. John Bowes-Some of His Horses-Escape of Stockwell-Lord Derby and The Derby-James Perrin-Scott's Jockeys-Bill ScottSome of His Records-Desperate Races-His Characteristics-John Scott's Ability with Unsound Horses-Extraordinary Performance of Cyprian-Savage Horses"Nobbling"-His Bloodhound-Incidents-Scott's Own Horses-Horses at Whitewall - Scott as a Trainer-His Hospitality, Mutton, and Port Wine-Isaac Walker-St. Leger Festivities-Rearer, Trainer, and Rider-Cock-fighting-Lord Londesborough's Sale-Scott and the Touts-His "Surprises"-He Ran to Win-His Rectitude-He Plunged-Ups and Downs-In Harness to the End-His Death-His Popularity-Old Do rrs of Whitewall and the Plates-An Interesting Relic-Generosity of Mr. Bowes.

Mat Dawson.

His Birth and Early History-Lord John Scott-Hobbie Noble-Mr. Merry-RussleyWhat Mat Did for Merry-Heath House-Remarkable Record-Long List of Wonderful Horses-All Trained by Him-His Patrous-Lord Falmouth-An Unparalleled Record -Lord Falmouth's Sale-His Return to the Turf-More Successes-Duke of Portland and St. Simon-Mr. Fenwick and Mimi-Mr. Vyner with Minting and LambkinLord Hastings and Melton-Another Score-" Races of the Century"-What Constitutes Them-Three of Them-No Surprises-No Mystery-Did Not Plunge-Removes to Exning-George Dawson-Mat Dawson Reti:es by Degrees-Mr. Noel FenwickAnother Great Record-Melton House-Its Pictures and Trophies-An Escutcheon Untarnished-Trains Now Only Privately-His Stud Farm-High Prices for Two Colts-Mat's System with His Patrons, Employés, and Horses- "The Master "- "An Honest Man "-Hearty and Healthy-Ladas.

GEORGE FORDHAM.

His Birth and Boyhood-His First Big Win-A Long List of Winning Mounts-And Horses He Rode-Number of Races Won by Him-Long Career-Some of His Patrons-His Last Win-His Last Mount-An Instance Rarely Met With-His Riding-His Integrity-..."Fordham's Mounts "-“"The Kid"- " The Demon "-His Death.

\section{Fred ARCher.}

His Birth and Childhood-First Rices-Cesarewitch of 1872-A Marvellous Record-Never Approached-1874-'86-At the Start-A Homily from Lord Marcus-His Iron Nerve -Riding-"The Jockeys' Ring"-His Fasting -His General History-His MarriageAmerica - Ireland-Curragh October Meeting, 1885-His Reception-The Cambridge. sbire of '85-His Last Win-His Last Ride-His Death-Effect of the News-The Funeral-Remarks Upon His Riding by the Author-His Manner and Manners -His Popularity-His Income-Steeplechasing-His Racing Wardrobe-A Gentleman by Nature.

HisTORIEs of racehorses and their owners are constantly published, while the daily doings of the former, be they cracks or crocks, are reported in every paper in the country. A history in skeleton form at times is given of some remarkable trainer, but one of a 
jockey is seldom seen. In book form a lengthened and authentic history never appears. This to some people doubtless seems strange, but to me it is especially so, holding as I do that the credit for a horse turning out well should be accorded to the trainer and jockey rather than the owner, as already alluded to in another chapter.

As is seen by the heading, I am about to make mention of two trainers and two joskeys. In selerting the late John Scott and the present Mat Dawson with the late George Fordham and Fred Archer, I cannot by any possibility find representatives of their callings more able or more honourable, nor any who by mighty deeds have gained such celebrity on the Turf. Their records stand not alone unparalleled, but unapproached. Moreover, by selecting these men I am enabled to allude to most of the great racehorses which have run in England for the past seventy years, and I hope some of my readers will enjoy as much as I do the "glorious reminiscences" which are called up by the names of the celebrities I am about to enumerate, and which in their day were the Bendigos, the Mintings, and the Ormondes of our own. With limited space only at my disposal I cannot give a lengthened history of either the men or the horses; all I can now attempt is to furnish for my readers memoranda of each, but they will be found correct.

I have in my possession cuttings from newspapers and magazines dealing with their histories, but finding so many inaccuracies when I consulted them for the purpose of my own sketch I gave them up, therefore what I now produce is almost entirely original, the particulars being put together by myself from authentic sources, official Calendars, or on the authority of parties well conversant with the subjects and who vouched to me their accuracy.

As is usually the case with great men and public favourites, the subjects of my following allusions are universally referred to without prefixing to their names the conventional title of Mister. To do so would obscure the individuality. Fancy alluding to the great York shire trainer as "Mr. John Scctt"! Unless you began by explaining who was meant, the hearers or the readers might take him for a dignitary of the Church or some commercial potentate, whereas by eliminating the title any dunce of the day would recognise who it was.

Thus far for preface; so I now proceed with my subject, and shall commence with the same

\section{JоHх SCOTT.}

$\mathrm{He}$ was born at Chippenham, a village near Newmarket, on November 8, 1794, where his father was a well-known trainer for many years but moved afterwards to Oxford.

As a mere child little John evinced extraordinary sagacity, and was so precocious at the age of thirteen that he was entrusted by his father with the charge of horses sent from home, having before that become a good horseman. 
Although born near Newmarket, he was always a thorough Yorkshireman, for long before he could imbibe Southern notions of horses or training he was transferred to the county of many acres, and ever after bore the hall-mark for shrewdness and judgment of horse flesh so remarkable in the sport-loving and manly Tyke.

Franks was a trainer of celebrity in those days and owned the great Middleham establishment in the North Riding of Yorkshire. To him young Scott went, and there learned the duties of trainer. Croft succeeded Franks at Middleham a few years after, and he promoted Scott-then a very young man-to the position of Head Lad. He had the care of the renowned Filho-da-Puta, and prepared him for his great match with Sir Joshua. A short time before the race the horse was taken out of his hands and a different system of training adopted, and as Filho was beaten in the match a row took place between Croft and Scott, which resulted in their separating. Luckily for Scott this rupture occurred, for it was the means of getting him a start in life to which in all probability was owed his future fame.

Mr. Houldsworth, then occupying a conspicuous position on the Turf, considered the young trainer was unfairly treated, so he took him up and put him in charge of his horses at Rockhill, in Sherwood Forest. In his new situation he was very successful and trained a great many winuers for Mr. Houldsworth, among them the famous Magistrate. After ten years his patron retired in 1822, and the Hon. E. Petre took Scott as his private trainer at Mansfield, on the confines of the Forest. Here he continued to rise in his profession and gave the greatest satisfaction to his new master, but remained there only two years and married Miss Barker, the daughter of the innkeeper at Mansfield.

Whitewall House, with its stabling, then came into the market, so Scott purchased them, and moved his establishment thereto early in 1825, bringing with him the horses of Mr. Petre. He then launched forth on a great scale as public trainer, and from that date his fame really counts, for from then until his death in October, 1871, success attended him to an extraordinary degree.

It would be tedious to my readers to go through the long list of winners which John Scott trained, I shall therefore give only some of the principal. Before he came to Whitewall he had, as I have said, the charge of Filho-da-Puta and Magistrate. Subsequently the following horses came to him, and with them he won the classic three-yearold races in the order annexed :-

The Two Thousand in 1842 and 1843 for Mr. Bowes with Meteor and Cotherstone, Nunnykirk 1849, West Australian, again for Mr. Bowes, in 1853, Fazzoletto 1856, The Wizard 1860, and The Marquis 1862.

The One Thousand he won with Canezou in 1848, Impérieuse 1857, Sagitta 1860, and Hurricane 1862.

The Derby he took with St. Giles in 1832, Mündig 1535, Attila 1842, Cotherstone 1843, Daniel O'Rourke 1852, and West Australian 1853, 
and in 1828 The Colonel ran a dead heat with Cadland, but was beaten in the decider.

The Oaks he carried away with Cyprian in 1836, Industry 1838, Ghuznee 1841, The Princess 1844, Iris 1851, Songstress 1852, Marchioness 1855, and Queen Bertha 1863.

The St. Leger seemed to be his prerogative during five-and-thirty years, for he won it off the reel for Mr. Petre with Matilda in 1827, The Colonel 1828, and Rowton 1829. Then followed Margrave 1832, Touchstone 1834, Don John 1838, Charles XII. 1839 (after a dead heat with Euclid), Launcelot 1840, Satirist 1841, The Baron 1845, Newminster 1851, West Australian 1853, Warlock 1856, Impérieuse 1857, Gamester 1859, and The Marquis 1862, after a desperate race with Buckstone, trained by Mat Dawson, referred to further on.

In 1843 Cotherstone won the Guineas and Derby, as did Meteor and Attila the year before; West Australian in 1853 won for the first time the treble event of the Two Thousand, Derby, and St. Leger. Scott's own mare, Impérieuse, carried away the One Thousand and St. Leger in 1857 , and The Marquis in 1862 did the same with the Two Thousand and Leger, while Hurricane won the One Thousand. In 1838, '41, and '51, with separate horses, Scott won the Oaks and Leger, so he did the Derby and Leger in ' 32 ; the Derby and Oaks in ' 52 ; the Guineas and Leger in '56, and in ' 60 both the Guineas. A marvellous record was this even if it ended there, but far from its doing so.

Scott's fame was added to by the performances of such horses as Velocipede, which was one of the best he ever trained. He was better than The Colonel, and would have won the Leger in 1828 but for an accident in the race, and thus would Whitewall have supplied the first and second. With Toxophilite, Legerdemain, Prior of St. Margaret's, Glaucus, Cardinal Puff, Backbiter, Epirus, Hetman Platoff, Grand Inquisitor, Vandal, Vanity, The Spy, Elvina, Taraban, Madge Wildfire, Nobleman, Ammonia, Tramp, Morgan Rattler, Hornsea, Scroggins, Carew, Gladiator (the sire of Sweetmeat), also Queen Mary (the dam of Blink Bonny and granddam of Caller $\mathrm{Ou}$ ), and scores of other cracks, Scott at times "played havoc among the classic cups" and swept them off the shelves of Ascot, Goodwood, and Doncaster literally in chestfuls. In big Handicaps, particularly with the Great Yorkshire Stakes over Knavesmire, near his home, he wrought wonders. In two-year-old races he was equally formidable.

Thus he won the classic races forty-one times in thirty-seven years.

Many of the horses were rank outsiders, notably Touchstone, in 1834, when he won the Leger, beating to fits Newmarket's Plenipotentiary, whose attendant, William Martin, is alive and still swears that "Pleno." was the best hor $\varepsilon$ e that ever ran a race!

Most of these feats were performed in days when there were no railways by which in comfortable boxes he could transport in a few hours his horses from the centre of Yorkshire to that of Cambridge, Surrey and Sussex. To these far-off shires to fulfil their engagements 
Scott's horses had to be walked until about the year 1850 or perhaps later. The journeys to Epsom and Goodwood of course necessitated weeks on the road, during which the horses had to get their gallops as best their attendants could give them, suffering from vicissitudes of the weather and a change of stable every night. In face of these difficulties and disadvantages many of the Northern trainers gave a good account of themselves when they migrated South, while the subject of my reference was a terror alike to every trainer in England and every bookmaker in London.

As their successors did to Mat Dawson, the great racing men of his day patronised John Scott. Among them were the Duke of Beaufort, the Marquis of Exeter, LordsWestminster, Glasgow, Derby, Fitzwilliam, Colonel Anson, \&c., \&c. His longest connection was with that great pillar of the sport, Mr John Bowes of Streatlam Hall, in Durham. It began prior to 1835, and continued until Scott's death in 1871 . During those at least thirty-seven years the career on the turf of Mr. Bowes was remarkable for its success, for he began in 1835, before he had attained his majority, by winning the Derby with Mündig and finished with the Goodwood Stakes in 1871 with Taraban, just two months before his trainer died. With the exception of Lord Egremont early in the century, no one wore so many "blue ribbons" as Mr. Bowes, for with Mündig, Cotherstone, Daniel O'Rourke, and West Australian he won four Derbys.

Daniel O'Rourke, who was by Birdcatcher, in the Derby of 1852, fetlock deep in mud, beat his nephew, the renowned Stockwell, and the clinking Hobbie Noble, a feat both Bowes and Scott were always proud of. Yet this great horse was allowed to be taken out of the country by the Germans for a sum of 800 guineas!

Mr. Bowes bred West Australian, and owned him when he won all his races. Many people aver he was our "best horse" ; yet at Lord Londesborough's sale in June, 1860, the magnates of our Turf allowed the Count de Morny, for a miserable 3,000 guineas, to buy and take to France our great West Australian! At the same sale, but for Mr. R. C. Naylor buying him for 4,500 guineas, STоскwELL would have shared a like fate!

Although Scott did wonders for Lord Derby with his two-year-olds, he could never win for him the race called after his ancestor, or even a St. Leger. He tried hara, but could never get nearer than second.

There lives in Malton at present a man who was identified with the Whitewall stables for many years, and to him, with the assistance of calendars and records, I am indebted for the information I am now laying before the public.

James Perrin entered the service of John Scott early in the thirties, and continued until the death of his master in 1871. Most part of that time he held the position of Head Lad, and as he still retains his memory unimpaired, although an octogenarian, what he related to me may be relied upon. My time was limited when I 
visited Malton, so I was not able to learn from the fine old fellow as much of his master's history as I wished; but I highly enjoyed his stories, told, as they were, in the quaint and matter-of-fact style peculiar to him and otbers of the most sporting shire in England.

As second jockeys, those whom Scott employed most were Jim Robinson, Simon Templeman, Frank Buckle, Elnathan Flatman, and Frank Butler.

Until about 1845 Whitewall's first jockey was William Scott, a younger brother of John, and as he was about the best man of his day, I may here sandwich part of his history with his brother's.

In physique they differed, for while the jockey was little, the trainer was of goodly proportions, although not tall. Bill Scott had a great knowledge of pace, and as a jockey ranks among the best in our history, while his career was, with one or two exceptions, quite the longest.

$\mathrm{He}$ rode in public for thirty years, and won nearly all the great races, among them being three Two Thousands, four Derbys, three Oaks, nine St. Legers, together with the Champagne Stakes nine times, and the Doncaster Two-year-old Stakes six times. His principal cup victories were achieved on Touchstone, Glaucus, Hornsea, Cardinal Puff, and Hetman Platoff.

His St. Leger wins were :-

1821 on Mr. Powlett's Jack Spigot

1825 , Mr. Watts' Memnon

1828 ," Mr. Petre's The Colonel

1829, Do. Rowton

1838 ," Lord Chesterfield's Don Joln

1839 on Major Yarburgh's Charles XII., after a lead heat with Euclid

1840 ,, Ld. Westminster's Launcelot 1841 ," Do. Satirist

1846 ,", his own horseSirTattonSykes

His Derby wins were :-

1832 on Mr. Ridsdale's St. Giles

1835 ," Mr. Bowes' Mündig

1842 on Colonel Anson's Attila

1843 ,, Mr. Bowes' Cotherstone

His Oaks wins were :-

1836 on his brother's mare Cyprian

1841 on Lord Westminster's Ghuznee 1838 ,, Lord Chesterfield's Industry

His riding of Mündig in the Derby of 1835 and of Satirist in the Leger of 1841, as described by "The Druid," "were the finest specimens of his style, which, as far as daring and decision went, has, perhaps, never been matched."

He rode another desperate finish in the Leger of 1829, when for Mr. Petre he won it on Rowton from Voltaire. Bill rode The Colonel in the dead heat with Cadland for the Derby in 1828, but standing to win $£ 10,000$ on his mount, it affected his nerve and he lost the decider. He rode Charles XII. in the dead heat with Euclid for the Leger in 1839, and, standing to win on either, won the run-off.

Bill owned Sir Tatton Sykes, and at York, in 1847, had a great match with him against Traverser, owned by the eccentric Mr. J. O'Brien. This race was a mile, and is remarkable for being about the fastest ever run-time, 1min. 42sec. Traverser was considered 
the best miler in England, and beat Alarm, who had won the Ascot and Goodwood Cups, also the Derby winner Pyrrhus the First; but in this match Sir Tatton Sykes beat him easily by three lengths. Frank Butler rode for Bill Scott and Job Marson for O'Brien.

Bill's horse was first called Tibthorpe, but turning out about the best he ever rode, he called him after the man he considered the best he ever knew. He won both the Two Thousand and Leger on him, and lost the Derby by only a head, having remained at the post to abuse the starter till the others had gone a hundred yards.

Bill was like his brother, wideawake, and when he had a good mount he backed it heavily. He was quite a character, with language peculiar to himself, which, when he got excited, became exceedingly "strong." $\mathrm{He}$ was very charitable and hospitable, and possessing rare wit with exuberant spirits he was a great favourite with everyone. The little fellow was wont to say to youngsters when they came to him for a tip that "Prudence, a clever old animal, got by Holdfast out of Careful, was the best he could give them." "Sylvanus" relates that he continually talked during a race, and swore terribly at any jockey who interfered with him. In the Oaks of 1838 , which he won on Industry, Arthur Pavis struck him, and they finished the race flogging each other!

The brothers were not friends for some years before Bill's death, which accounts for John not having trained Sir Tatton Sykes.

Bill acquired a large property and lived for years near the gate leading on to Knavesmire racecourse, 'where he died in 1819 , aged about fifty-two years, and was buried at Meaux in the East Riding of Yorkshire, regretted by everyone.

To train fit a sound horse that feeds well is comparatively an easy job, but to deal with one of a delicate constitution, and having bad legs and feet, is altogether a different thing. It was, however, in his treatment of that sort John Scott prided himself the most, and with many such he did what no other man could do.

Velocipede gave him a great deal of trouble with his legs, and Touchstone gave him more; still, he was able to keep the latter going and win races with him until he was a five-year-old. The Baron also had bad legs and feet, and but for the skilful treatment he got at Whitewall we might never have seen Stockwell.

Touchstone was a very peculiar horse in many ways-besides having bad legs, his action with wide-spread hocks was the oddest ever seen on Langton Wold. He was also a tremendous puller. This great progenitor of the English racehorse stood at Eaton Hall, and died there in his thirty-first year. As a sire he is best known through Orlando, Newminster, Cotherstone, and Surplice, and though he begot other celebrities he was not nearly as reliable as other of our great sires, for some very bad horses sprung from him. His own brother Launcelot pulled even harder than Touchstone, and at times, no matter what was the bridle, Bill Scott could not hold him. 
Ghuznee was only a pony-just $14 \frac{1}{2}$ hands-but she had the best of legs, which old Perrin still describes as being of iron. He also says that Elvina was the most beautiful mare he ever set eyes on, and that John Scott often said the same of her.

As an instance of the long journeys which horses had to travel to race meetings in former days, I may mention that in 1836 Scott's own mare, Cyprian, was walked from Whitewall to Epsom, where she won the Oaks, thence back to Newcastle, where she won the Northumberland Plate, and returned to Whitewall within six weeks, doing on an average twenty miles of road work every day.

She was a very vicious mare, and continued so till her death at the age of nearly thirty. Perrin showed me the stall where her colt Artful Dodger with a kick knocked the brains out of his lad who was at the time combing his tail. The Princess was another devil, and seemed to hate everyone at Whitewall. She and Cyprian were more dangerous and caused more trouble to shoe and to look after than all the other horses.

"Nobbling" favourites was in vogue in those days much more than it is at present, and the Malton stable was often visited by ruffians for the purpose of destroying a horse. Scott had, therefore, to be ever on the alert, and for the better protection of the place he got a huge and ferocious Cuban bloodhound which had been trained to hunt and capture runaway niggers.

This dog many times did good service, notably with Attila before the Derby of 1842 , when a determined attempt was made to get at him, but his faithful guardian nearly tore to pieces the scoundrel who tried it. This horse when not so protected was nobbled three or four times afterwards.

Jereed in 1835 nas tried to be as good as Touchstone at weight for age, and so was considered to have a great chance for the Derby, but he was got at one night, and with a hammer the tendons of both forelegs were battered fearfully.

An onslaught was made at Leatherhead on Cotherstone just before the Derby of 1813, but it was frustrated by Bill Scott, who, like the bloodhound, nearly killed the rascals.

More than once Mrs. Scott saved her husband's horses from these fellows, and, assisted by the shoer and the dog, on one occasion she captured three of them, to whom were given such a ducking, with a subsequent towelling and dressing, they never again visited Whitewall.

Magistrate in Scott's Forest days ran a desperate race at York with the famous Blacklock. It was four miles, and such was the effect upon the horses that neither ever recovered, and it ended their racing. West Australian, although a magnificent yearling, was for a time a backward and unpromising colt, and it was not until Scott tried him with Longbow a short time after the Two Thousand that he found what a jewel he had. The stable then planked the money down for the Derby and Leger, and won a tremendous stake. Epirus was the 
best horse they had at Whitewall in 1837 , and they expected him to win the Leger, but he was disqualified for it. Perrin told me that owing to his being delayed in London for over a week he gave this horse his exercise and kept him fit by jogging him up and down Regent Street in the early mornings !

Seldom was seen in a race a greater contrast in size of the horses than was in the Leger of 1827 , when the little Matilda, with Robinson up, beat Sam Chifney on the mighty Mameluke, whereby Gully lost $£ 20,000$ to Crockford. From what Perrin told me, the difference between the two was greater than that which at present exists between Baron de Hirsch's cracks, La Flêche and Watercress.

If $I$ thought my readers would appreciate them I could recount many more such like yarns of famous Whitewall horses.

John Scott bred and owned racehorses and ran them in his own name, notably the mares Impérieuse, Cyprian, and Songstress. The two latter won for him the Oaks, and the former the One Thousand and the Leger.

For several years the number of racehorses under his charge at Whitewall was over a hundred, and it was never less than sixty.

As a trainer he is described in a history I have consulted as being what "Wellington was as a general and Nelson as a naval genius; and to witness him on Langton Wold directing the work of his teams was like watching a field-marshal handling a brigade of cavalry at Aldershot." His boundless hospitality and genuine kind-hearted disposition were proverbial, and seemed only to be equalled by his honesty of purpose and gentlemanlike deportment. He possessed what seemed an inexhaustible fund of anecdote which he retailed in amusing style quite unique, while his mutton, fed in sheephood until three years old on Yorkshire wolds and for six months "finished" on the home meadows, together with his vintage ports, were well known to be about the very best in England. Under such circumstances it is easy to imagine how pleasant were visits to Whitewall in those days. No one enjoyed himself more than the noble patrons, and there they would be seen conversing with the proprietor in terms of familiarity such as they would not deign towards others outside their own circle.

There was always a great gathering at Whitewall for the St. Leger, and for nearly thirty years Isaac Walker, Mr. Bowes' stud groom, made it the occasion for bringing the yearlings from Streatlam. John invited cronies from York and Ripon, and his jovial brother was never absent. It is, therefore, easy to understand how the old white walls were made to ring again upon occasions such as these, when the trainer and the jockey entertained the followers of their stable and the man who reared the horses of their best patron. Yes, in the little dining-room at Whitewall were told many yarns, and therein was discussed many a plan which it would be interesting now to hear, particularly those laid by the men who, in their individual capacity of 
rearer, trainer, and rider, had made so famous the "black and silver" of Mr. Bowes.

When West Australian won the Leger, ard thereby broke all previous record, so frantic with delight was old Isaac that he gave him that night a bottle of champagne in his water, which the good horse seemed very much to relish.

Malton, like other places in England at that time, was famous for its gamecocks, and no one had a better breed than the mister of Whitewall. Many a battle was therefore fought, and that too, in the selfsame cosy little dining-room.

As I made allusion in this chapter to Lord Londesborough's sale, and for comparison with others which I particularised elsewhere, I may here state that it was quite the greatest ever held up to its time, June, 1860, nor does it contrast badly with many of those which followed. It realised :-

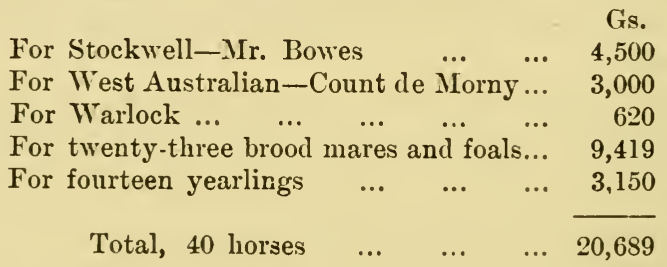

Considering the fact that John Scott was at the head of his profession for over forty years, and trained in public for some five-andfifty, it is not surprising that a continuance of uninterrupted popularity did not attend him.

Besides being an artist at his trade, and, as I have said, a man of extraordinary sagacity, he was endowed with great perception and resource. In his early and middle life, when in the zenith of his glory, there were no telegraph wires by which could be flashed all over England the doings of his cracks almost before they had quitted the Wolds. Touts, the bugbear of trainers ever since racing was estab. lished,infested the region, but these pests crafty old John was generally, by some artifice or other, able to deal with. Malton, although a town of ancient history, was then comparatively an isolated spot, its fifteen miles from York, the nearest town, being considered a longish journey even sixty years ago.

Under those advantages, personal and local, "John," as the Tykes called him, was enabled to train his horses in peace, and keep dark until the proper time those which had important engagements. Moreover, he could, and often did, get reports circulated concerning them not altogether in accordance with facts.

When, therefore, the day came, as it so often did, that an outsider from Whitewall carried off some great Southern race, loud at times would be the outcry, particularly so when it was known that the party had thrown in for a big stake. This they generally did, for 
everyone connected with the great Northern stable plunged upon anything of their own which they considered good.

Inasmuch as Scott ran his horses to win, he was perfectly justified to use any fair means to put the public on the wrong track, and so enable his employers to get on their money at a price which would reimburse them for the heavy expenses they were at in keeping horses for public sport. People did not then, no more than now, take this view and some said hard things of the great Yorkshire trainer, and dubbed him " the Wizard of the Nortb," simply because he was more sagacious than they and brought off more "surprises" on the turf, without letting the public know how, than did any other man before or since.-Good old John!

Like everyone else, Scott had his ups and downs, and at times was out of luck; which was particularly the case a couple of years before his death. But good foriune returned, and for some months his stable was in nearly as flourishing condition as ever, and so it was the day he died.

Old age seemed to have damped his ardour but little, for he held the reins of government to the last, and, with the exception of deafness, he suffered from no ailment until within a day or two before his death, while his jovial spirits lasted to the end, but on the 1st or 2nd of the month he contracted a severe cold, which turned into acute bronchitis, and it carried him off on October 4, 187l, aged seventy-six years.

As yet another example of the irony of fate, the news of the grand old fellow's death and the winning at Kelso of his own filly Pompadour reached Malton precisely at the same time. As with his health and spirits, John Scott retained to the last his widespread popularity. Among his brother trainers, even with their dread of him, he was well liked and respected. With many of his employers he was on intimate terms of friendship ; they all esteemed him for his worth, and in him placed implicit confidence ; while throughout Yorkshire, that county of more sportsmen even than acres, his death was looked upon as a calamity to the county at large.

As evidence of the veneration which his patrons entertained, not alone for their worthy trainer, but for his very stables wherein stood their horses, Mr. Bowes offered to buy from his widow, at any price she wished to fix, the doors and frames, covered as they were with the veritable plates in which the horses ran when they won their great races. Mrs. Scott, however, refused to sell them, and they remained intact until after her death in May, 1891, when the present proprietor, Mr. Bruckshaw, to ensure their safety, removed the plates from off the doors. They now hang in the little dining-room, arranged in a neatly got-up shield, and encircle a miniature of the horse that wore them, with his name and wins appended. This is a relic intensely interesting and of great value.

As proof of how Mr. Bowes acknowledged the services of men whom he found worthy, at the break-up of the Whitewall establish- 
ment after Scott's death, he settled, for life, $£ 100$ a year each upon James Perrin and John Peart, Scott's secretary.

Scott married a second time, in about 1845, but left no issue.

I now come to treat with

\section{Matthew Dawson.}

$\mathrm{He}$ is the son of George Dawson who over a century ago trained horses at Gullane, on the Firth of Forth, where, on January 9, 1820, Mat was born. Thus he was younger by a little over twenty-five years than John Scott, but was contemporaneous with him as a trainer for just thirty-one years.

He had seventeen brothers and sisters, most of whom died young. Of those who grew up none took to training except his elder brothers, Tom, and Joe, who died some years ago, and his younger brother John, who, still well and hearty, now presides over the Warren House establishment.

Like most others of his craft, from earliest boyhood Mat has been connected with the stable, and when only twenty years of age he began, in 1840, to train racehorses.

He started as private trainer to Lord Eglinton, and then for four years he trained publicly at Gullane. After that he resumed the private business, and until 1857 he trained for Lord John Scott aloneboth at Newmarket and Ilsley. Hobbie Noble, the great favourite for the Derby of 1852, was under Mat's charge when a two-year-old, but, acting on his advice, Lord John sold him to Mr. James Merry some time before the race. The price paid was 6,500 guineas, the highest figure a horse ever fetched up to that time. As history records, Hobbie could only get third to Daniel O'Rourke and Stockwell, and lost Merry a vast sum of money. Had he won, the feat of breaking the Ring, as I said elsewhere, would have been pretty nearly accomplished by the great Ironmaster.

In 1857 Lord John Scott, suffering from ill health, was obliged to give up racing, and, on the advice of Mat Dawson, Mr. Merry bought his entire stud, from Windhound down to the youngest foal. With the horses went to Russley their trainer, and from that time, as with Scott and Petre at Whitewall, dates the celebrity of both men.

Merry's horses ran into places for the Derby four years out of the five between 1860 and 1864. Thormanby, whom Mat purchased for Merry when a yearling, won in 1860, a year of exceptionally good horses, and Dundee would have done so the year after but for breaking down at the Road ; as it was he lost it from Kettledrum by only a length. I must, however, refer my readers to the Calendar for the extraordinary record which was run up for the plunging Scotchman.

In 1866 Mat Dawson returned to Newmarket and established himself and his horses at Heath House.

To enumerate his achievements as a trainer is impossible for me; suffice to say that his success followed him to Newmarket, and has 
continued to the present time. In fact he has trained so many winners he does not remember even all his great wins, but they include :-

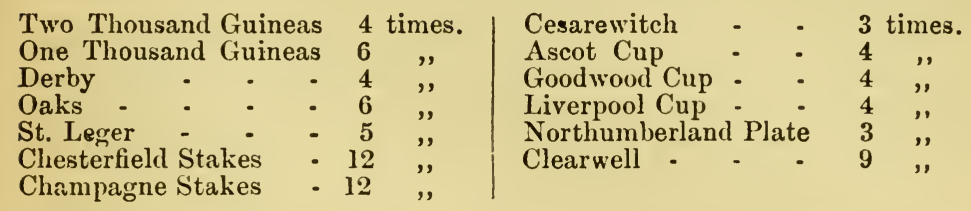

This shows that, like Scott, he could train for all distances, but he never trained the winner of the Cambridgeshire, Ascot Stakes, or Goodwood Stakes.

The following are a few of the horses with which this great trainer has shown sport to the British race-goer for the past half-century; and, with the exception of John Scott, no other man ever saddled such a lot of nailers:-Windhound, Thormanby, Kingcraft, Wheel of Fortune, Jannette, Dutch Oven, Silvio, Minting, St. Simon, Melton, Julius, Alice Hawthorne, Sterling, Catherine Hayes, Hobbie Noble, Lord of the Isles, Galliard, Lioness, Scottish Chief, Liddington, Zambesi, Student, Speculum, Thunder, Camballo, Cherie, Master Kildare, Lady Golightly, Gertrude, Farnese, Necromancer (which he bred), Rosy Morn, Langwell, Saunterer, Atlantis, Atlantic, Charibert, Spinaway, Sky lark, Queen's Messenger, Bal Gal, Childeric, Busybody, Harvester, Garterley Bell, The Lambkin, Mimi, Buckstone, and Sunbeam.

He has now been fifty-three years actively employed in his profession, and during all that time he has enjoyed the patronage of most, and the unlimited confidence of all the best supporters of the Turf. Among those who patronised him I may mention, in addition to those already named, the Dukes of Newcastle, St. Albans, Hamilton, and Portland, the Marquis of Londonderry, Lords Strafford, Fitzwilliam, Hastings, Falmouth, Lascelles, Charles Beresford, Rosebery, and Rosslyn, Messrs. R. C. Naylor, Henry Padwick, Clare Vyner, and his brother Robert.

His greatest patron of all was Lord Falmouth, with whose horses and Fred Archer jockey, Mat Dawson ran up for that nobleman a fifteenyear record, 1869 to 1884 , unequalled in the annals of racing. Besides nearly all the two-year-old races and some of the principal handicaps the "magpie and scarlet" was first past the post in the Two Thousand Guineas three times, Derby twice, Oaks four times, St. Leger thrice, and the Clearwell Stakes no less than nine times. Within the years 1877 and 1881 alone, the stakes won by Lord Falmouth's horses, trained by Mat Dawson and ridden by Archer, amounted to $£ 125,752$. The grand sum totalled about a quarter of a million, and these were days previous to races of $£ 5,000$ and $£ 10,000$ stakes.

When in the full swing of good luck, Lord Falmouth all of a sudden conceived the idea of giving up not alone racing, but breeding horses ; and determined to sell off everything he had in training, as well as 
his stallions, yearlings, brood mares and foals. The racehorses were sold by auction at Newmarket, on April 28, 1884, and the others at the same place on June 30 following.

All things considered, never has there been such an important sale of the sort in England. From all parts of the world men came to buy, and the prices averaged beat all previous record, while the magnificent condition in which Mat Dawson brought out the horses under his care was referred to in all the papers.

I allude to this sale because of its connection with my subject, but must confine myself to giving the totals, although the full particulars are beside me.

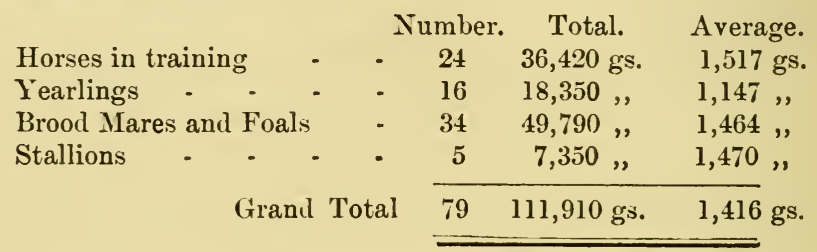

Mr. Geo. Alex. Baird (Mr. Abington) was the largest purchaser at for five lots $16,550 \mathrm{gs}$., including Busybody at $8,800 \mathrm{gs}$. Then followed Capt. Machell for four lots 12,150gs., and so on. Sir John Willoughby bought Harvester at $8,600 \mathrm{gs}$. on the advice of Mat Dawson, and, in a month after, his purchase and St. Gatien ran a dead heat for, and divided, the Derby. Busybody also repaid Mr. Abington by winning the Oaks and One Thousand Guineas the same year.

Hankering after the old game, Lord Falmouth returned to the turf in 1885 , but his stud was nothing like the one he sold. However, with Rada his old trainer won for him the Goodwood Cup.

After Lord Falmouth's death in 1889, Dawson ceased to train on the extensive scale he did previously, his nephews, John and George, relieving him to a great extent. Nevertheless his skill remained intact, and success continued, for, with St. Simon for the Duke of Portland, Mimi for Mr. Noel Fenwick, Lambkin and Minting for Mr. Vyner, and Melton for Lord Hastings, he in a few years ran up a score greater than many a man did in a lifetime.

Good races, and often between bad horses, are constantly seen, but what are called "the greatest races of the century" are very few indeed. To qualify for the honour the race must be in all respects sensational. The event must be of the highest importance, the horses must previously have proved themselves the best of their year, while the contest must be fought out from post to post and result in a desperate finish in which must be displayed, by first-class jockeys, horsemanship in the superlative degree of excellence. Exhibitions so unique can be counted upon a man's fingers, yet Mat Dawson as trainer has taken part in at least three of these extraordinary manifestations, a record which no other man could ever lay claim to. 
For the Leger of 1862 he trained Buckstone for Mr. Merry, and ridden by Fordham, he was beaten a head by The Marquis and Tom Chaloner after a most tremendous race. John Scott trained the winner. The following year, for the Ascot Cup, Buckstone, ridden by Arthur Edwards, ran a dead heat with Tim Whiffler and Sam Rogers. Each carried 8st. 7lb. and beat Caller $\mathrm{Ou}$ and three others. The decider up to within a hundred yards of the winning post was another terrible race, but Buckstone lasting longest won by two lengths. At Ascot in 1887, for the Hardwicke Stakes, Minting, trained by Dawson, was beaten a neck by Ormonde, with Bendigo three lengths off. These great horses were ridden respectively by the celebrated jockeys, Tom Cannon, John Osborne, and John Watts.

Not even the hi,toric match between the Flying Dutchman and Voltigeur at York on May 13, 1851, was a grander race than any of these three.

Mat Dawson was not a man for bringing off "surprises," although on a few occasions he did call forth a cheer from the Ring. As a rule his principal patrons did not bet heavily, neither did he, while Lord Falmouth never betted at all. It was therefore not necessary that the cloak of mystery should hang over his horses. If his case had been like Scott's, where both master and man piled the money on every good thing they had, he would have experienced a deal of trouble to effect his purpose by reason of the vast addition made in the ranks of the touting brigade of late years, and the facilities afforded by telegraphy.

Some years ago Mat purchased the Manor House at Exning, where Luke the jockey once lived. Here he built a magnificent range of stabling, and rebuilt the d welling-house, naming it after Lord Hastings' famous horse Melton, which he trained for all his races, and came to reside there in 1885.

He then gave up Heath House to his nephew George, to whom also was transferred by the Duke of Portland the care of the stud with which the young trainer immediately after did such marvels.

Gradually since then Mat has still further relieved himself of the duties attendant upon a great racing establishment. But that he still retains his old form and can run up with the young ones is evident. from the fact that in 1891 he placed Mr. Noel Fenwick at the head of winning owners with $£ 20,519$, no one coming within $£ 7,000$ of the amount, except Colonel North with $£ 20,113$.

He has now only Lord Rosebery's horses and his own under his care.

At Melton House he has the finest collection of portraits of racehorses perhaps in England, a list of which will be found in my Racing chapter. (I hope he will get done what I often asked him-the name of each put upon the frame.) All over the house are other pictures to gladden the eye of the sportsman, while the sitting-rooms contain many and costly presents from his patrons.

After having been before the public for over half a century, subject 
to the temptations which encircle every man of his profession, Mr. Dawson has thus practically retired from public training. He has done so with an escutcheon untarnished, and a character against which the foulest tongue cannot utter a word, surrounded as he is with everything requisite to make his old age happy. In future he will train only these few horses, which with his stud farm will give him pleasant occupation devoid of the worry and anxiety which attended his former calling.

In 1833 he leased from Lord Ellesmere the Heath Farm, which is separated from the July Course by the plantation, and near where Osbaldeston rode his famous match described in the previous chapter. Since he came into possession he started there a breeding establishment, to which exists no superior in England, and few equal it.

In boxes constructed on the best principle, and with paddocks convenient, are some fifty brood mares in whose blood run the best strains in the Calendar, and when I was last there Ayrshire and St. Serf were the lords of the harem.

I saw another stallion which struck me as likely to beget valuable weight-carrying hunters. $\mathrm{He}$ is Torpedo by Hermit-Strayshot, powerfully built and well balanced. At the moderate fee of fifteen guineas, which is all Mr. Dawson charges for his service, he is well worth the attention of breeders.

That his enterprise in starting such a concern and ability with which he conducts it seem to have a satisfactory result, I had evidence a short time ago when I saw despatched therefrom to America a colt by St. Gatien-Glance, and another by Hampton-Cherry, in exchange for Bank of England notes to the tune of 6,250 guineas.

To be shown over the Heath Stud Farm by the owner, or his studgroom Weatherall, whose father trained for Henry Lord Waterford, well repays a special journey from London.

Unlike so many other masters presiding over youth, human and equine, Mat was always gentle to a degree both in his speech and action towards those under his control ; withal there was not a regiment in the service nor an establishment in the kingdom where the observance of rules was carried out with more uniform regularity, efficiency and cheerfulness than in that presided over by the man I have been writing about. Suaviter in modo, fortiter in re was the style he adopted alike towards his employés and employers, with a result that from each class he received profound respect, and none came to him, either for service or to patronise, except the best of their sort.

With his horses he pursued the same course of treatment ; gentleness and not severity with the noble animal he always insisted upon.

Throughout his long career he has enjoyed the greatest and most widespread popularity, and the fact that in and about Newmarket he has for years gone under the title of "The Master" shows how he is esteemed at home. Like John Scott, he is a capital host, and has a wonderful cellar of rare old wines. 
All through his long life he has had singularly good health, and was exceptionally energetic, while his countenance, ever beaming with heartiness, evinces clearly that the mind is as healthy as the body. Long may he still live to enjoy the combination, and be to all a living example of what an "honest man" is, and how the vitality of youth may be preserved to age by leading an active outdoor life, keeping early hours, and living well without indulging to excess in anything. Like Scott, unfortunately, he has no children.

Numerous instances are to be found of men who served their apprenticeship to Mr. Dawson, and through his recommendation have filled high pisitions as trainers and jockeys. At present William Haywood is the Johnnie Osborne of America. Webb, for some years head lad to Dawson, now trains at Chantilly for Baron Schickler. John Reeves is a leading trainer in Germany, while Richard Waugh trains for the Emperor of that country ; and Kendal, one of the finest jockeys in India, graduated under Mat. George Blackwell, a rising young trainer now at Newmarket, also owes to "The Master" his proficiency.

Since putting together this history, I am pleased to know that Mat Dawson has under his care for Lord Rosebery a two-year-old colt which is likely to add still to his fame as a trainer. It is Ladas, by Hampton-Illuminata. Now, in the month of September, 1893, he is favourite at 4 to 1 for the Derby, the shortest price that any horse has at this season stood at for many years. What an explosion of applause will greet the veteran trainer and the most popular owner in England if he wins ! Curious enough, I was at Melton House a few days after this colt and two others arrived as yearlings from Lord Rosebery's breeding stud. When showing them to me Mat pointed to the Illuminata colt as the one he would win his next Derby with.-So may it be !

Having treated with two trainers, each paragons in their day, I shall now say a few words about two of our greatest jockeys, they also representing different epochs.

As a horseman the name of plain-polished but honest

\section{George Fordham}

will be handed down to posterity through many a succeeding generation in the same manner that the Chifneys, Robinsons, Templemans, Flatmans, Buckles, and Days of bygone eras have been received by us.

Fordham was born at Cambridge on September 11, 1837. At the age of ten he was apprenticed to Drewitt, who then trained at Mickleham, and subsequently at Lewes. Like many another great man, George as a boy was very unruly, but Drewitt's ash plant soon brought him to hand.

His first mount in public was on Isabella, at the Brighton Autumn Meeting of 1850, when his bodily weight was 3 st. 81 b., and he was a bad last in the race. His first win was at the same meeting the following 
year, when he rode Hampton, then a two-year-old. His first big win was the Cambridgeshire of 1853, when for Mr. W. Smith he rode Little David. His next good performance was winning on Epaminondas the Chester Cup in 1854. It was not, however, until at Stamford on Cock Pheasant, when he met Wells on El Dorado, that young George opened the eyes of the public to his merits as a horseman. Wells was then in his zenith, and considered our best light-weight jockey. After a desperate race for the Burghley Stakes, the two ran a dead heat, but in the decider the future "Demon " beat "Tiney" by a head amidst great excitement. Thenceforward Fordham rose rapidly in his profession, until in a few years he was found at its head.

Even with a list of his principal winning mounts before me, carefully detailed as they are, I can do no more than summarise them.

At Newmarket he won the-

Two Thousand - - twice

One Thousand - $\quad-7$ times

July Stakes

Cesarewitch

Cambridgeshire -

Clearwell - -

Criterion

Middle Park

At Epsom the-

City and Suburban

Metropolitan

Derby -

Oaks

At Paris the-

French Derby - - twice

Grand Prix - - - 3 times

At York the-

Gt. Northern H'cap - twice

Ebor Handicap

Gt. Yorkshire Stakes -
At Ascot the-

Stakes- - - - twice

Prince of Wales Stakes 4 times

Royal Hunt Cup- - 3 "

Queen's Vase - - 5 ",

Gold Cup (including dead heat on General Peel)

New Stakes

At Goodwood the-

Stakes-

Stewards' Cu

Cup

Chesterfield Cup-

At Doncaster the-

Gt. Yorkshire H'cap - twice

Cham pagne Stakes - 5 times

Doncaster Cup - - 3 "

The Lincoln H'cap - - twice

The Chester Cup - - "

Among the horses on which Fordham from time to time won, I find several of those trained by John Scott and Mat Dawson which I have already mentioned; also Chalice, Summerside, Formosa, Gamos, Reine, Thebais, Vauban, Petronel, Mayonaise, Nemesis, Siberia, Gabrielle d'Estrées, Suzerain, Fervacques, The Earl, Foxhall, Adamas, Dutch Skater, Lord Clifden, Saucebox, Vigo, Borderer, Epaminondas, Knight of the Garter, Paris, Stampede, Lady Elizabeth, Ecossais, Prioress, Odd Trick, See-Saw, Sabinus, Little David, Hannah, Happy Land, Klarikoff, Flageolet, Beaudesert, Beechnut, Elf King, Optimist, Rustic, Martyrdom, Winslow, Horror, Marie Stuart, Lectur $\in$ r, Mortimer, Doncaster, General Peel, Zaidee, Belladrum, Corisande, Tournament, Lady Clifden, Gomera, Paganini, Rogerthorpe, Starke, The Duke, Termagant, Drummond, Advance, Dollar, One Act, Ivanhoff, Oldminster, Zetland, Inez, King of Diamonds, Sunshine, Welland Ackworth, and nearly all the other great horses of their day. 
With the exception of Archer, Fordham won more races than any other jockey. They number two thousand five hundred and eightyseven. A wonderful record, even though his career was, with that of the long dead Bill Scott and the present John Osborne, perhaps the longest in history. But there were not as many races in his heyday as there have been since.

Strange to say, he never won a St. Leger, but, with that exception, the foregoing table shows that he won every other race of importance, and many of them several times. He won the Derby only once, and that not until 1879, when he did so on Sir Berys. Year after year he tried, but never got nearer than second. Luck, not ability, was against him.

From the list I have given is seen that he for some race or another rode nearly every great horse that appeared during the years of his jockeyship, which evidences the reliance which was continuously placed in him by their owners and trainers.

He rode a great deal for the Duke of Beaufort, the Rothschilds, Mr. Parr, Mr. Ten Broeck, and Mr. W. Stirling Crawfurd, while Mat Dawson considers him the best jockey he ever saw, not excepting Archer.

His last win was on Brag for the Brighton Cup in 1883, and his last appearance in the saddle was on Mr. Leopold de Rothschild's Aladdin at Windsor in August, 1884.

In Fordham we have an instance rarely met with. In about the year 1873 he contracted an illness which laid him up till 1878, during which time he did not ride, and lost nearly all his nerve. Once a man loses that essential for riding, even when young, he seldom regains it, but scarcely ever does so after he passes the meridian of life. Fordham was an exception, for he returned to the racecourse when forty years old with nerve as firm and spirit determined as ever. In fact, some of his best races were ridden after his retirement. In the first year, in slush and mud he won his only Derby on the roaring Sir Bevys, and in 1881 on Thebais he won for Mr. Crawfurd both the One Thousand and Oaks.

His scat was by no means nice, but it was firm as a rock, and his hands were perfection, while his skill as a jockey and judgment of pace, whether riding a short or long race, and on either a good or a bad mount, stamped him as a horseman surpassed by no one. Archer was perhaps a better jockey over a course with turns and inclines, but no one ever rode over Newmarket in the finished style of Fordham.

If he excelled in any detail of his riding more than another, it was in the extraordinary power he had of coming with a rush at the finish and driving his horse home a winner. This art he acquired to quite as great a degree as did Sam Chifney.

Deducting the few years of his retirement, he was before the public for fully thirty years, during which no man of his profession ever bore a higher character for honour and integrity. So great was the confidence 
reposed in him, that he became one of the most popular jockeys of al time, and for many years Fordham was backed, no matter what horse he rode, and thus was instituted the habit, which still exists, of backing jockeys' mounts.

During the first part of his career he was called "The Kid." $\mathrm{He}$ gained the name from his habit of gammoning jockeys in a race by pretending his horse was beaten, and as soon as they eased theirs he would come with a rush and do them on the post. Afterwards he was known as "The Demon." Truly a devil he was to beat, and deuced few could do so!

He was fond of Sport in every shape, was a eapital man to hounds, a good shot, and, though not in the category, a first-rate whist player.

In the end he suffered from a complication of diseases, and died at Slough on October 12, 1887, aged 50 years, regretted by all who admired a brilliant horseman and an honest jockey.

\section{Frederick JaMes ARCher}

was born at St. George's Cottage, Cheltenham, on January 11, 185\%. He was son of William Archer, the well-known steeplechase jockey, who was a contemporary of Tom Olliver and Jem Mason, and won the Grand National on Little Charley just fourteen months after the birth of the boy, who, in after years, made the world ring with his own deeds in the saddle.

Fred Archer was a born horseman, for when eight years old he could go like a bird across country on his pony Moss Rose and rode her in two races at Great Malvern. In neither was he successful, but he scored on the next occasion, and with a pony called Maid of Trent he won his first race when quite a child.

Continuing to show unmistakable ability, he was bound apprentice in 1869 to Mat Dawson, with a view to trying his hand at the "legitimate" business.* Young Freddy, then only twelve years old, was not long in displaying the grit he was made of, for, with more pluck than any of the other boys, he would mount any kind of awkward horse, and when in the saddle would stick there.

His master soon saw in the lad the makings of a great horseman, and before long entrusted to him the riding of important trials besides allowing him to sport silk. Bar the pony race, his first win was on Athol Daisy in the Nursery Handicap at Chesterfield, on September 28, 1870. His first important win was the Cesarewitch of 1872 , when, on Mr. Radcliffe's three-year-old Salvanos, carrying 5st. 7lb., he beat twenty-three others. This was a most meritorious performance, even for an experienced jockey, not to speak of a lad of fifteen.

* Will some of my readers tell me why flat racing is called "legitimate" while steeplechasing is not?-THE AUTHOr. 
To particularise the great races which Archer won would be a task beyond the powers of anyone. I shall therefore from ordinary Racing Calendars dissect some of the most important, and subjoin the list :-

\begin{tabular}{|c|c|c|c|c|c|}
\hline City and Suburban & $\begin{array}{l}\text { Wins. } \\
5\end{array}$ & $\begin{array}{c}\text { No. of horses } \\
\text { beaten. } \\
109\end{array}$ & Goodwood Cup & $\begin{array}{c}\text { Wins. } \\
\cdot \quad 2\end{array}$ & $\begin{array}{c}\text { No. of horse } \\
\text { beaten. } \\
45\end{array}$ \\
\hline Two Thou. Guineas & 4 & 45 & Ebor Handicap & $\cdot 2$ & 16 \\
\hline One Thou. , , & 2 & 12 & Champagne Stakes, & & \\
\hline Cesarewitch -" & 2 & 51 & Doncaster - & 7 & 36 \\
\hline Middle Park Plate & 3 & 26 & N'umberland Plats & e 1 & 9 \\
\hline The Derby - - & - 5 & 67 & Champion Stakes - & -5 & 24 \\
\hline The Oaks & 4 & 29 & Liverpool Cup & -3 & 43 \\
\hline St. Leger & -6 & 68 & Lincolnshire H'cap & $\mathrm{p} \quad 1$ & 34 \\
\hline Grand Prix de Paris & 3 & 23 & Metropolitan St'k's & s 1 & 1 \\
\hline Ascot Stakes & 1 & 7 & Manchester Cup & -1 & 17 \\
\hline Royal Hunt Cup - & -2 & 37 & Gt. Yorkshire H'cap & p 1 & 13 \\
\hline
\end{tabular}

The foregoing comprise nearly all our great events, but besides them Archer won all over the country races of importance, including the Clearwell Stakes a great many times.

He rode in public for sixteen years, and for thirteen in succession headed the list of winning jockeys. In 1878 out of 606 mounts he scored 223 wins and got placed in nearly all the remainder, while 246 was the number of races he won in 1885 .

To make a long story short, he won during his career no less than two thousand seven hundred and forty-seven races, which is an average of nearly one hundred and seventy-two a year. To accomplish which he must have ridden at least nine thousand races, or about five hundred and sixty a year.

By this marvellous performance has Archer established a record which stands not alone unparalleled, but quite unapproached by any other rider who ever sat on the back of a horse, and probably it will for ever remain so.

By reference to any Racing Calendar my readers can see that, for some race or another, he not alone rode, but won on nearly every remarkable horse that was on our Turf within the years 1874 and 1886 . In the face of such a phalanx of figures as I have just given, which represent his wins, needless to say to give a list of the horses he rode in a chapter like this is a simple impossibility.

$\mathrm{He}$ never won the Chester Cup, nor yet the Cambridgeshire, but was second for the latter on Bendigo in 1881, and lost it by a head on St. Mirin in 1886, just a fortnight before he died.

As a fox well found is considered to be half killed, so Archer thought a good start lessened by half the odds against winning a race. Consequently in his desire to get away in front he, in the early days of his riding, at times gave trouble to the starter, but upon Lord Marcus Beresford delivering to him a homily on the subject, and intimating clearly that he expected the elder jockeys to set the younger a good example, Archer ever after behaved himself at the post.

During the race he showed himself possessed at all times of iron 
nerve by the way he hugged the rails as he thundered down inclines and rounded dangerous turns. In getting through a crowd of horses his determination combined with coolness was conspicuous in the extreme. In finishing he was an artist of the first water, and whether to win was easy cr difficult, he never either lost his head or gave away a chance; while a mount on the favourite or an outsider made no difference whatever in his riding.

His proficiency and courage caused him to be sought for by owners and trainers whenever he was disengaged; hence he had always the best mounts to choose from. This of course gave him a great advantage, and no doubt helpəd to swell his record. There was, however, another and still more powerful agency at work in his favour.

During a portion of Archer's career there existed a deal of malpractice on the Turf, and at one time a regular "Ring" was formed among some of the jockeys to decide beforehand which hor:e was to win the races they rode in. To carry out this nefarious arrangement, of course the best horse had frequently to be pulled.

Whether Archer was a party to this proceeding I know not, but at all events be was not had up, and, as he rode to win, the others had only to back his mount and bet against their own. By means of this desperate piece of villainy some of these jockeys amassed large fortunes, and so notorious became the scandal, that the Jockey Club investigated the matter and "warned off" those they found guilty.

From these facts I am led to believe that many of Archer's wins are to be attributed more to the rascality of others than to his own ability as a horseman, great undoubtedly as that was.

For a jockey he was remarkably tall, standing 5 feet $8 \frac{1}{2}$ inches, and although very slight, necessarily it took a considerable amount of flesh to cover that length of bone. For the light weights he could ride at first, but not of lats years, and it was with difficulty he kept condition down sufficiently to ride 8 st. $9 \mathrm{lb}$. No monk to fulfil his obligations ever mortified his body by fasting with greater rigour than did Archer to fulfil his engagements on the Turf. His self - denial was simply marvellous. For weeks in the racing season he would go in a state of semi-starvation; a hard crust of dry bread twice a day with a cup of "black" tea or glass of soda and whisky being ofttimes his allowance. He did not take long walks as they made him hungry, and would therefore increase his misery, so he dosed himself with physic instead.

By these means, together with the exercise he had daily in the saddle, he was able to get down so as to ride at 8 st. $91 \mathrm{~b}$. Long continuance of a practice so baneful to health no doubt predisposed the poor fellow to the malady which in the end suddenly overtook him, under the influence of which his death was caused.

During his apprenticeship, which ended in 1874, his master generously allowed him to retain the emoluments derived from his mounts, and having succeeded Tom French at his death in 1873 as Lord Falmouth's first jockey, they were very considerable. In fact, with fortune smiling 
its sweetest, he scored wins at every meeting, and sometimes three or four in a day.

The rolationship between master and apprentice was of the happiest description, and when he had served his time Mat Dawson presented him with a valuable watch. For the next seven years he followed his profession, and rode for whoever he chose, but gave the call of his services to his former master whenever he required them.

On January 1, 1881, he went into partnership with Mat Dawson, and then came to reside at Falmouth House, which, with the stabling, he had just built, and on January 31, 1883, ho married Miss Nellie Dawson, daughter of Mr. John Dawson, and niece of his friend and partner. She died on November 8, 1884, after giving birth to a daughter who is at the time of writing a girl of eight years old.

The death of his wife was a terrible blow to Archer, and I doubt if he ever recovered from it. After awhile he went to America for a change, and returned to England in March, 1885. He then, on the advice of his friends, resumed his profession.

He paid his first visit to Ireland a few weeks before his death. During the time, on October 20, he rode at the Curragh meeting for Lord Londonderry in the Lord Lieutenant's Plate, which he won on Cambusmore. Next day, in the Welters, he, on Mr. Charles Blake's Black Rose, and Mr. Tommie Beasley on Mr. John Gubbins' Spahi, had a rare set to, but our popular amateur beat him amidst the greatest excitement.

That Archer should get from the Irish a welcome of the heartiest degree, which he undoubtedly did, was only what he was entitled to, and would be expected of the people. But nothing, I think, showed the respect we had for the great horseman more than, while thunders of applause greeted his win on Cambusmore, and although every one of us rejoiced hugely to see our own man beat him in the Welters, we refrained from giving expression to our feelings by undue acclamation.

Immediately after the Curragh meeting he returned to Newmarket, and set hard at work to get off weight sufficient to enable him to ride St. Mirin, 8st. 6lb., for the Cambridgeshire, then fast approaching. To get to that weight was an impossibility, but he strove by every means to get as near to it as possible. That event being the only one of importance which he had never won, he was particularly keen to break the ice this time, and as he had an undoubted good chance of doing so on St. Mirin, he backed his mount to a very considerable extent, but he could not get down to ride less than 8 st. $7 \mathrm{lb}$.

The race resulted in a tremendous finish between him and Alfred White on Sailor Prince, but the latter won by a head. Although few, if anyone, agreed with him, Archer thought he did not ride that race in his usual style of excellence, and the idea took firm hold of him, and undoubtedly affected his mind. Of courso he was very weak from the excessive fasting, and may not have been able to finish as well as he was wont to do. 
The last race he ever won was at this same meeting, on October 29, when he rode Blanchland for his old patron Lord Falmouth in the Houghton Stakes. His last mount was on Tommy Tittlemouse, in the Castle Plate at Lewes on November 4.

He returned to Newmarket feeling very ill. Next day typhoid fever developed itself, and in a paroxysm of madness he shot himself in his bedroom at Falmouth Hous', on November 8, 1886, which, by a melancholy coincidence, was the second anniversary of the death of the wife he loved so fondly.

Very seldom did the death of an Englishman cause more sensation than did that of Fred Archer. Consternation spread broadcast over the kingdom when the news was flashed from Newmarket. Grief seized all his friends, while sorrow sprang upon everyone who knew him. Next day, when the tragic circumstances were learned, these feelings became the more intensified. Thousands who never saw a race, including old ladies and decrepit men, mourned for the man whose name was familiar to them as that of the Prime Minister, and whose glory they had so often seen heralded in almost every paper they had taken up during the racing seasons of the previous decade.

Archer's coffin was followed to the little graveyard at the top of the town of Newmarket by more people than was that of any other person who was ever buried there. Nor did the vast concourse attend through idle curiosity, as is often the case; all came to do homage to the memory of this great and popular jockey.

To assert that Archer's record is likely to remain unparalleled in the annals of racing is, I think, pretty safe ; but to speak with equal confidence regarding his ability as a jockey in comparison with others who have not run up anything approaching his record is a different thing, and as some of the best judges hold opposite opinions on that subject, I certainly am not going to express mine, for of course it would be valueless. It cannot, however, be denied that he was at times very severe upon his mounts, and many a two-year-old which at first enjoyed it, hated for ever the sight of a silk jacket after finishing a severely contested race with Archer riding him.

He was intensely popular with all classes. Apart from his doughty deeds as a horseman, which alone would make anyone popular among Irish or Englishmen, hisquiet, unassuming manner and gentle disposition, ever courteous, generous and considerate, made for him friends among all who knew him. Even his appearance was to be admired, for it was that of a gentleman, and his style of dress was in accord. To see the poor fellow riding hard over the Heath in covert coat, breeches and leggings, or strolling up Piccadilly at Ascot time in West End costume, no one would say "That is a jockey" unless they recognised the well-known features. Unlike many others, he never flew the flag except when he donned the cap and jacket.

Even among his brethren of the saddle he was popular, but most of them held him in awe and would make way for him in a race when 
they would not do so for another possessing less courage and determination. The deferential and respectful demeanour which he always observed to his old friend and master Mat Dawson was not the characteristic least to be admired in this young man.

His emoluments, alone derived from the statutabls fees of his profession, amounted to a very large yearly income, and eyualled that of many a nobleman, but they were nothing in comparison to sums paid him as retainer fees, nor yet what was given to hirn as presents after winning great events. Besides which he betted heavily, and backed his own mounts. The consequence was, he amassed an immense fortune.

What Archer would have turned out as a trainer of course cannot be known, but as his whole soul was in his profession as jockey, and as he was yearly increasing in weight, it is highly probable that he would have taken to the cross-country business. This was the more to be expected as he was very fond of it, and rode schools many a time for Captain Machell and Joe Cannon when their horses required steeple. chase practice.

A report went abroad in 1885 that he was to have the mount on a Newmarket favourite for the Grand National, and great was the desire of us Irishmen to see how the famous flat-race jockey would go between the flags, but the chance came not.

The number of caps and jackets in his possession, supplied by his regular employers, was considerable, but the quantity of boots and breeches was marvellous, and may be imagined from the fact that in the racing season he rode generally four or five days a week, and often as many times a day, and being very particular as to his turn-out on a racecourse, he always changed for clean ones mud-stained boots and breeches.

That we had in Fred Archer an object-example of where the true instincts of a gentleman are inborn in a man of humble origin is in evidence from the fact that neither his popularity nor his wealth, nor yet the familiarity with which he was treated by those in the highest social position, in any way changed for the worse his natural proclivities. It is a pity that such manifestations are not more frequent. Equally it is to be deplored that those destitute of the feelings of a gentleman, when they fall in sudcienly for a lot of money, do not always strive to acquire them, or, at least, good manners.

\section{Classic Races won by those mentioned in this CHapter.}

\begin{tabular}{|c|c|c|c|c|c|c|c|}
\hline \multirow[b]{3}{*}{ Two Thou. } & & \multicolumn{2}{|c|}{ TRAINERS. } & & \multicolumn{3}{|c|}{ JOCKEYS. } \\
\hline & & J. Scott. & M. Dawso & & V. Scott. & Fordham. & Archer \\
\hline & Guineas & s 7 & 4 & & . 3 & 2 & 4 \\
\hline One Thou. & Guineas & s 4 & 6. & .............. & 0 & 7 & 2 \\
\hline Derby - & . & -6 & 4 & ............ & 4 & 1 & 5 \\
\hline Oaks & - & - 8 & 6 & ....... & . 3 & 5 & 4 \\
\hline St. Leger & - & $\cdot 16$ & 5 & $\ldots$ & . 9 & 0 & 6 \\
\hline & & $\overline{41}$ & $\overline{25}$ & & $\overline{19}$ & $\overline{15}$ & $\overline{01}$ \\
\hline
\end{tabular}




\section{CHAPTER XXIV. WHOO WHOOP!}

Preceding Chapters-Sport does Further Good-England's Greatness-Manliness-Futurity - Manly Exercise-An Effeminate Man-A Sportsman-A Homily from the Author"Straight"-Education-Give as well as Get-Foxhunters and Game PreserversThe Prince of Sportsmen-Piuck-Harmonious Combination-A Happy FamilyBrotherhood-Short-sightedness-Humanitarians-A Word to Them-Circulation of Money-Communism-OurTraders-Our Nobility and Gentry-Examples neededSpendthrifts-Absentees-Progressive Age- Wbat may be-Prospective LegislationOur Sciences-Our Old Sports-The Wheel of Life-Levelling of Classes-Human Nature-Risen from the Ranks-The Upper Ten-Money-"The Oli Stock"Commercial Aristocracy-Territorial Aristocracy - A Delicate Question-Landed Properties-Agriculture-The Farmers-The Backbone of the Nation-Mainspring of Sport-They must be looked to-The Agricultural Question-Ruin-Downfall of England-Greatest Question of the Day-Our Duty-Who this Book is Meant ForA Request of the Author-Bad People-Statistics-A Challenge-An AssuranceVale, Vale:-Whoo Whoop:-A Couplet by the Author.

My task is nearly done-a task I undertook, as stated in the preface, to try to show that our national sports have in them more than they generally get credit for ; that Sport is, in a practical way, far more beneficial to the poorer than to the richer classes; and, in the words of the title-page, that, as a medium for the circulation of money, Sport stands unrivalled among the institutions of the kingdom.

To Sport is our nation very much further indebted. Great Britain owes to Sport most of its greatness.

What, may I ask, makes the English, Irish, Scotch, and Welsh the hardy men they are, but their manliness? What can create manliness better than Sport and manly exercise?

We see on the map those little specks, Great Britain and Ireland, not much larger than some continental principalities were a few years ago ; yet those little dots represent the nation which not only influences, but controls the rest of the world.

That supremacy has been attained by our manliness, and aided by our wealth is that supremacy sustained; with such-like alliance we shall in the future continue to maintain our position.

On the other hand, should we ever fail in either our manliness or our wealth, down directly will go Great Britain !

How to keep together our wealth, I certainly am not a fit person to explain ; but with regard to keeping going the sports of our country, and mayhap perpetuating them, I shall make a few more remarks before bringing to an end my "Thoughts upon Sport." In doing so I must refer to matter and current events with which the great subject of my book is so incorporated that the interest of the one is inseparable from the others.

In no country in the universe is to be found manly exercise so manfully followed as it is in Great Britain and Ireland. Look at the 
hardships and fatigue requisite to be endured by the foxhunter, the grouse-shooter, the deer-stalker, and the fisherman ; while polo, football, golf, and cricket demand exertion which brings every muscle into active requisition. And powerful brain faculty with quick decision of purpose are essentially requisite to the all-round sportsman. In addition to which our sports are all more or less fraught with danger. It is that danger which makes them so attractive to our countrymen. It is the constant engagement in these pursuits from earliest boyhood, inuring them to rough usage and hard knocks, that makes our countrymen the greatest men in the world.

A man afflicted by nature with a delicate constitution, which at times produces effeminacy, is greatly to be pitied; but a fellow who through indolence or other fault becomes effeminate is a horrible sight, worse even than a masculine woman-a fellow whose only object in life is to dress and to dance, eat, drink, and talk scandal. To see him going along with elbows squared over knocked and tottering knees, taking hold of things as if they were going to burn him, equals in abomination having to listen to him delivering himself, in drawl or penny-whistle squeal, of his meaningless and egotistical form of speech. These pusillanimous creatures, through want of exercise, are usually shapen with narrow shoulders, contracted chests, with arms and legs devoid of muscle. These deformities, though apparent to everyone else, they themselves never discern owing to the self-conceit inherent in them; nevertheless, feeling the necessity, they have to put in splints their wasp-like bodits by means of a woman's stays, while to give some sort of freshness to their peeledgarlic face they rouge it and dye their eyebrows! Oi a truth these "greenery-yallery, Grosvenor-Gallery, foot-in-the-grave young men," all collar and cuffs, bedecked in jewellery, with idiotic expression and lack-lustre eses, are the most despicable specimens of humanity.

Happy and thankful should be the man who is endowed with manly attributes! See him strutting along with hat cocked and coat cut betokening his readiness and ability to tackle anyone or anything, and nothing to adorn him but that negligence which is the elegance of the sportsman. The conversation of that man is often a treat to listen to, delivered as it is in manly tone, and able as he usually is to converse upon all topics. A man constituted with the true instincts of a sports. man is seldom a bad man, while in him are always found traits of character of the highest order. That is the sort of fellow-with ruddy face, twinkling eye, and jovial manner-women admire most and lavish their love upon, while they despise and ridicule the shivery-shakys.

Apart from other considerations what a fund is sport for enlivening the mind and creating in it a healthy state. After a day's toil or worry of one sort or another, when discussing sport or manly games around the festive board all troubles disappear, and no room is left for subjects unclean or topics which should not be broached. Let, therefore, sportsmen look the matter straight in the face and 
consider what they might have been had they not taken to sport, and let them feel thankful for escaping the bad habits they might have otherwise acquired.

As wrote someone: "To become rich, perhaps not until the power of enjoyment be over, some men labour hard and refuse themselves pleasures which can only be enjoyed when man is in his prime." In the case of a young and healthy mon without a family dependent upon him, I consider that to bo a very foolish doctrine. If he has the means he should enjoy himself when he is young and able. Life is short and always uncertain, it is therefore best to utilise the present, for the past is gone and the future we may not see. Then if we do come to the winter of life we need not repine but can, through its "flickering twilight," look back with pleasure, though mayhap with regret, upon the joys which sport in bygone days afforded us.

That being so, it is highly desirable that boys who show a love for sport should be encouraged, no matter how humble their station, so long as they don't do mischief. Let them bə taught what the little word "straight" implies, and how to the walk of life, as well as to sport, it can be applied. Act straight, think straight, speak straight, look straight, walk straight, ride straight, shoot straight, hit straight. Verily there is not a grander word in the English dictionary than this little monosyllabie.

Far better is it to give youth a good English education, and inculcate within him the sound principles of honesty and the advantages which are to be derived from manly exercise, than to stuff his head with dead languages and useless sciences. How to take the measure of one's opponents will not be learned by scanning Greek or Latin verse, nor can the battle of life be fought upon algebraic or trigonometrical principles.

Depend upon it, the man whocan best get through life and surmount the difficulties which surround him daily is he who has by nature manly instincts, which he gives effect to oy indulgencэ in Sport. Every soldier and sailor, be he officer or private, O.S. or A.B., that is any good, has in him love of and ability to take part in Sport.

No undertaking between man and man can have a lasting existence unless each party, in one way or other, derive mutual benefit therefrom. Each must give as well as get. Moreover, each must place confidence in the other, for without it harmony cannot be maintained. From a moral point of view these essentials should be the basis upon which all arrangements which are expected to be continuous should be made. In these days, when we see the fruit of equality fast ripening into maturity, the man is a fool who thinks he can make a onesided bargain. Farmers, if hunting is to be continued, must not use wire. Gentlemen who want sport must pay for it.

We all know scores of instances where foxhunters abuse gamepreservers because they object to have their coverts disturbed before they are shot, while the shooter, who does not hunt, will ofttimes 
destroy foxes to save a few head of game. This is alike deplorable and unnatural. If a man is a sportsman he will admire not alone every branch, but every bough and offshoot of sport, and will sustain them. If a man will countenance only the particular branch he himself happens to prefer, and does injury to others, assuredly he is not a sportsman. He is a selfish, miserable creature, and man's constitution has no charaeteristic lower than selfishness.

On the other hand the prince of sportsmen is the man who from inability or disinclination does not take active part in it, yet maintains Sport in all its branches so as to enable others to do so. That is the man who has the right to take the chair at all meetings of sportsmen.

So it is with regard to the man who is afflicted with weak nerve. If he rides hard and straight, although in a funk when going at stiff and dangerous fences, he is far away a more plucky fellow than he who is possessed of nerve that knows not fear.

Nothing under the sun is self-supporting; everything requires assistance from without. In nothing is this axiom more exemplified and demonstrated than in the sports of our country. To sustain and maintain them in the high position they hold in the kingdom all must pull together with harmonious combination. There cannot be any friction. Those who may not, perhaps, derive any very great benefit direetly from sport, or its consequent circulation of money, should not be so short-sighted as not to lend a hand in promoting our sports and pastimes. When we come to think of the many, many millions of money which I have shown are spent annually upon sport, percolating as that money does through so many channels, and re-circulating through countless rivulets, we must come to the undeniable conclusion that some portion finds its way, in a greater or less degree, everywhere, except back into the pockets of the original spenders. They get none of it back!

To maintain sport sportsman should give and take. They should constitute "a happy family" and work in unison for the common good. So long as the subject pertains to sport, it should have the sanction of all, and be sustained, quite irrespective of a man's individual predilection. Sport is sport, be it hunting a rat in a ditch with a terrier or a fox o'er the billowy grass. The hunters in both cases are imbued with the same object, and ofttimes the rat-hunter is the purer sportsman.

The man who cannot afford a shooting or fishing, but, with every instinct of the sportsman, loves a day with rod or gun should be given occasional leave over preserved land and water; and, if he can ride, the horseless foxhunter should at times be given a mount by rich friends.

Many is the hunt, small race-meeting, boating, fishing, and football club, together with other sporting associations, which are sorely in want of funds. If to them a fiver was sent occasionally by some of the many of our rich men, the members could carry on without difficulty, while no appreciable loss could accrue to the donors.

If by these means, in true friendship, a sportsman's brotherhood was 
to exist, taking all branches as community, sport would receive outward assistance greater than it does, and manifestly it would be the better able to resist the attacks of its enemies. Without a combination of the sort, off will come some of the principal branches of the parent tree, and that within, perhaps, a very short time!

No doubt we have many in the land who don't, or won't, take a liberal view of anything, being by nature, conviction, contrariety, or some other more or less unrighteous influence, stone blind to the general weal of the populace. With this class of people there is little use in arguing. Fortunate it is, however, they are in such a very small minority that they cannot bring adverse influence to bear to any appreciable extent.

We have in other spheres those of the humanitarian element to deal with. In them, like all those who hold fanatical notions, we find bigotry and intolerance which are so difficult to be got over. These parties assert that nearly all our sports are more or less attendant with cruelty. Perhaps in some of the details a few of our sports may be deemed somewhat cruel, but they are far away less so and are much more to be admired than are some of the pursuits which these priggish humanitarians themselves patronise and sustain.

While granting that pain is given at times when engaged in hunting, shooting, fishing, football, boxing, wrestling, polo, cricket, golf, cycling, archery, croquet, tennis, peg-top, tip-cat, and playing marbles, none except the most biassed and benighted can contend that the means does not justify the end. I am not aware, however, that the majority of those holding so-called humanitarian principles refuse to wear sealskin jackets or to decorate their hats with stuffed birds and waving feathers. Yet to procure them the most atrocious cruelty is practised in capturing: both the harmless seals and the lovely songsters!

As I said in Chapter ii., instead of interfering with the national sports of our country it would be better for these people to join together and strive to put down the barbarities which their own patronage encourages, and include in the category dog and cock fighting, badger baiting, coursing bagged rabbits, and shooting trapped pigeons, also. wage war against tippling and gambling. In a crusade upon such righteous principles they would get assistance from sportsmen.

Now, a man who would be wantonly cruel to any animal deserves. the severest punishment that can be meted out to him. I certainly would do to him what he had done to the poor beast, bird, fish, or insect. But sportsmen are not cruel. If a man is cruel he is not a sportsman, even though he may be able to hold his own in every branch of sport. He may be a "sporting man," it is true, but he is nothing better than a brute.

The general weal of the country, both politically and socially, cannot be obtained and maintained without circulation of money. Nor is it necessary that individual prudence should be observed in carrying out the object. Circulation pure and simple is what is required of money, 
for if gold be not put into and kept in exchange it is of no more use or value than rubbisb.

There are at present scattered all over the globe numbers of political robbers who, to get ho'd of other people's property, preach that there should be a community of all things. Now if these ultra-radicals were to give the subject honest consideration they would see that the riches of Great Britain and Ireland are practically as communistic as even they themselves could either make or wish them.

Our traders, from the smallest to the greatest, have to embark and employ their capital so as to produce a profit and revenue therefrom; but before helping themselves they have to hand over the greater portion of that income to their employees in return for work done in providing the income. Now as the employed class of the kingdom outnumber the employing class by an overwhelming majority, and as they are of the humbler grades of society, we thus have practical illustration of "community" of rich men's money among the poorer classes.

In like manner our nobility and gentry, who derive their incomes mostly out of land, return that money in some way or other. Take, for instance, the average resident country gentleman of, say, $£ 5,000$ a year, derivable out of land. He does not eat or such wise do away with the gold he gets from his tenants; he circulates it right and left in all directions and among all classes. To artisans, merchants, tradesmen, and the tenants themselves he pays for necessaries for himself and household. He employs servants and labourers about his house and establishment. He spends a large portion of his income in furthering and sustaining societies got up for the advancement of agricultural and horticultural science, as he also does towards promotion of the breeding of horses and live stock, while his purse is always open for a subscription towards purposes of religion, education, and amusement. Then, if he is inclined for a practical indulgence in field sports, I have already pretty abundantly proved what he expends upon them, and into what channels his money flows.

It is therefore plainly manifest, as said shortly in Chap. xvii., that, although $£ 5,000$ a year is focussed in the one individual, the whole sum radiates through countless outlets into the pockets of his fellow-creatures.

To the humbler classes it is a necessity to their advancement and good condition of life to have example set them by the higher classes. This is made manifest by comparing the state of the humble classes who live in the parts of the country where gentry are resident with that of the people who dwell elsewhere.

Thus is shown that it is out of the commercial and territorial portions of our community that nearly all the middle and humble live and thrive-which, but by righteous means, gives effect to the doctrines of communism.

The unfortunate spendthrift, who goes in for a short life and a merry one, subscribes still more directly to those principles, for he, in his folly, 
gives his all to the community. For instance, if all rich men were to run the same rig as did Mr. Ernest Benzon and the Marquis of Ailesbury, would not the object of the socialist be attained forthwith ? Others possessed of the same idiotic recklessness are this very day doing the same thing.

The foregoing remarks refer only to those of our moneyed classes who live and spend their money in their own country. Those who do not spend the money at home, whence they obtained it, are an injury to the community in whatever degree may be the proportion of their income which they spend abroad. Those who hoard up their money and do not spend it anywhere are not alone good for nothing, but they are bad for everything and everybody.

Yes, absentees have been for all time a curse to our kingdom, and more particularly to my own dear old portion of it. The evil is, alas, increasing and fast aggrandising the foreigners, who give us nothing in return.

I make these remarks to show that the very best way for keeping our rich men at home to spend their money in the country, is to uphold by every means in our power the sports of our nation, so that the rich man may, to the fullest desire of his heart, indulge in them.

We must all admit that we are now in a bigbly progressive age. Changes are taking place with such rapidity that we who are the spectators-eren though we at times see premonitory symptoms of what is coming-stand aghast in wonder and bewilderment. But what would our forefathers say if they were to rise from the dead and see the changes which have been brought about within the last two or three decades? With these changes fast revolving before us, may we not ask ourselves what is likely to happen within the next few years?

Judging by the past, it is not unreasonable to suppose that in a comparatively short time we may see the air as a highway additional to the land and sea. That electricity, lessening the use of coal, may be our principal motive as well as lighting power. That our present postal system may become obsolete owing to our having ready means for almost instantaneous universal communication, which may be carried on and paid for in a language and coinage common to the world. That instead of six days being occupied in transit between England and America, who knows but half the time may be sufficient for the purpose, and that, too, over a sea calmed by human invention? Labour may have become master over capital to an extent that the employed and the employer shall bear equally the profit and the loss of commercial undertakings-ay, to the extent that the class now known as "servants" shall have ceased to exist. The respect which bas from time immemorial be?n accorded to women by reason of the refinement which their nature so beautifully portrays may have been lost to them through their having undertaken duties the prerogative of man, and thereby changed for rude the gentle attributes which had hitherto been the birthright of women. 
None of the foregoing revolutions are impossible-they are probable. That many of them, and others as great, will take place within the next quarter century there can be no doubt.

Do we not hear doctrines allowed by the authorities to be preached in the most open manner, circulated further as they are by literature purchasable at our bookstalls-doctrines which, if established, would upset the extant laws and ideas of morality, doctrines which tell plainly that no man has a right to anything more than has his neighbour, that everything is to everybody the same as are air and water?

While those things, or some of them, are coming to pass, what is to become of our Sports?

I have very strong conservative opinions, inherited as they have been from ancestors similarly constituted, but I am far removed from a Tory. I think, therefore, that all constitutional requirements should be anticipated and should be provided before they are asked for. Prospective adoption of necessary measures by legislature would maintain the longer the great institutions of our country. Moreover, ccncessions when made voluntarily need be of lesser magnitude than they necessarily must be when they have to be made under compulsion. Without looking far afield we can see how these remarks apply to Sport.

From the days of Zenophon it has been the fashion of the passing generation to think the rising one is not equal to their time, nor is theirs equal to that of the previous generation. That is all nonsense. The world is steadily improving in condition; each succeedicg decade shows plainly this to be the case.

That the great national and social institutions of our kingdom have been improved within our own memory is as self-evident as is the improvement in the general condition of the humble classes brought about by education and increased circulation of money. There are, of course, individual items which are not improved, but on the contrary; while a spell of bad trading and agricultural depression which we are now suffering from must be expected periodically.

That many of our sciecces are still in their nursery there is no manner of doubt. The question is, will the further-not to speak of the full-development of their resources, while it may exalt the mental, won't degrade the physical capacity of our race?-I wct not.

Up to now our old sports have kept well in the general progress. Some require assistance and must get it, but others are on as good a footing, if not better and firmer, than ever they were, while new and highly important pastimes have been added lately to the list of our manly games.

The wheel of life has been revolving ever since the world began, but. of late years the velocity has increased to such an extent that the spokes can scarcely be distinguished, so rapidly do they fly round.

It is a pity that all classes do not alike share in the kaleidoscopic whirl. There is no room for all ; one has to make room for another. Such 
has been the experience of the world throughout all history, and so it will continue. The middle and lower classes are now, and very properly, as:ending the hill of prosperity, but unfortunately they meet the upper classes hurrying down. It is but a very few years since to engage in trade was considered by the aristocracy and higher grades of gentry derogatory; now we find members of those classes only too glad to join the commercial circles. The daughters of our leading merchants, who but an equally short time ago were considered eligible to associate with the higher classes only at public balls, are now sought after for wives for the sons-in-heir of some of those standing highest in the pages of the Peerage and Baronetage. The estates of some of the oldest families in England are passing into the hands of men who made their positioa alone by trade, while properties which are not sold outright are being brokea up by reason of the tenant farmers having purch ased their holdings.

Thus we have the levelling of classes by the lowering of the one and the raising of the other, and thus is being lost the supremacy which in former days was enjoyed by our territorial magnates.

What $\in$ ffect these changes in society will have upon the country in general is not here to be discussed, but we have a right to consider what effect they will have upon the Sports of the nation.

Practically speaking, it is since the present century began that the leading branches of our sport have come under proper system, and it is only within the last forty years they have developed into excellence. During that time they have been conducted solely under the guidance of the upper class, who in every way maintained them in prosperity, while their surveillance has kept together the minor branches.

It is a fact palpable to all endowed with reason that, by nature, we are prone to resp? ct those who by birth and social position are superior to us more than those our own equal, not to speak of those inferior. It is also human nature to look with envy and disrespect up $n$ those of our own class who have, even by their own ability and exertion, risen to opulence and have attained a position higher than ourselves.

These may be, and in some instances are, unworthy sentimentsnatural though they be. Experience, however, justifies our holding them, for examples are comparatively few of where a man who has risen to a position he was not born to is able to fill it properly. Examples to the contrary are found plentifully in every class and calling. Who makes a bad landlord like the tenant? Who makes the bad master like the man who was a servant? Who makes the martinet like the soldier who has risen from the ranks?

In former days men in high social position were as a rule possessed of good monetary means; alas, such is not the general rule now. By one reason or another theis incomes are all reduced, while many of them have no income at all. In olden times few men hunted or raced except those belonging to the upper classes. Now we find at the 
meet and in the paddock the commercial elemer.t in number far exceed. ing that of the upper ten.

Without money no institution can get along. Money, however, is not everything. Without leaders in whom subordinates place confidence, and for whom they hold respect, no institution can be maintained in either propriety or prosperity.

Luckily we have had a great accession of commercial men into the ranks of sport within recent years, and were it not for their money, hunting, shooting, fishing, yachting, and racing would, I fear, bs in a very bad way now. But, although not as well off as they once were, the "old stock" still holds the helm, and therefore all goes well. If, however, things continue to be as bad with them as they have been, their incomes, within a comparatively short space of time, will practically disappear altogether. In that event the commercial men must take their place.

Commercial men can make first-rate statesmen, soldiers, sailors, and sportsmen, and for dealing with great financial or other State questions they are of course much better qualified than the aristocracy. But in the interest of Sport, and without intending to hurt the feelings of anyone, I ask, will men possessed only of money, and no matter how honourable in feeling and intention, be able to command the respect, and thus the power of control, which was reposed in predecessors of higher social grade?-If they do it will be contrary to all precedent.

The commercial aristocracy have many means of acquiring wealth ; the territorial aristocracy have none other than that, which they have succeeded to-their landed estates. These properties have been vested in them for centuries, acquired as they have been by their forafathers or predecessors by conquest, grant of Government, or by purchase. Therefore to their estates are our landed gentry entitled by every law which governs rightful possession. The title to their properties is in all cases equal to that of Great Britain to her colonies, and in many instances much stronger. It is therefore the duty of our Government not alone to protect that title, but to protect the possessors, while it was nothing short of aiding and abetting robbery to pass Acts of Confiscation as has been done in recent years.

A systematic and all-round reduction of rents was not necessaly to be made, as it was, in Ireland; but that legislation with regard to rents on some Irish properties was needed no fair-minded man can deny, and it was highly proper that the interest of the agricultural tenant, in respect of unjust rents, should be provided for. So it has been; but a vast deal has yet to be done for the agricultural interest of the kingdom, and that by means more beneficial to the tenants while preserving intact the position of the landlords.

Mining, manufacture, and commercial enterprises of all sorts are, of course, tremendous factors in the maintenance of England in the posi- 
tion she holds. There can, however, be no doubt that Agriculture heads them all. Out of the land are derived the incomes by which the landlords dispense money amongst all classes. They do so to an extent far away beyond the traders; while English farmers spent vastly more money, when they had it, than ever did those employed by the whole commercial community put together. Moreover, it is from among the farming class we get our best soldiers and sailors, and there we find the most moral and best conducted men and women in the whole kingdom.

Without a doubt the backbone of the nation is the yeomanry and the farmers, while they are the very mainspring of sport. Withal, nothing has been done for them beyond reducing in Ireland the rents all round. Elsewhere through the country rentals adjust themselves.

Too long have our agricultural classes been allowed to suffer from unf ir and absolutely bad laws, resulting as it has done in the total ruin of thousands of our farmers and irretrievable loss to every member of the body. If, therefore, legislation does not devise means by which our farmers will be enabled to make more money by their calling than they have done of late years they as a body will be ruined. Ruin of the farmers means of course ruin to all landed proprietors, with consequential loss to the whole nationality, more especially the tradesmen and shopkeepers.

To reduce rents is all very well for the tenants, but it is proportionately bad for the landlords, and no one portion of the community should be aggrandised through means of robbing another. Some other plan must be adopted whereby both landlord and tenant will derive mutual advantage. Neither ability nor experience warrant me in suggesting what sbould be done, but assuredly coalition between "parties" in Parliament upon such a patriotic measure should be adopted; and if they would join together, instead of wrangling, a righteous measure could soon be devised and passed. But as long as each clique will alone look to its own selfish end, and oppose what is for the general good, the passage of great national measures becomes impossible, and they have to be shelved.

The great Agricultural Question cannot, however, be left on the shelf any longer, and the way to bring about its immediate adjustment is for the constituency of every county in the kingdom, at the next general election, to require from the men they return to Parliament a solemn promise to bring it forward directly the house opens, and not allow it to be dropped until finally settlf $d$ on a basis mutually beneficial to landlord and tenant--ergn, to the Nation.

To assist in thus binding our M.P.'s no one should take a more prominent part than sportsmen in general, and foxhunters in particalar. Farmers through all time have assisted sportsmen; it is now the bounden duty of sportsmen to aid the farmers in their distress.

Needless to say, if ruin be brought upon our farmers and landed proprietors, down immediately must tumble the leading branches of Sport, which alone cause the expenditure shown in this book, 
Then, deprived of the means whereby we have become the greatest nation in the world, and despoiled of those who were our leaders, and who so nobly backed us up, what will be the result?

Without hesitation I answer: THE ULTIMATE DOWNFALL OF ENGLAND !

Happily, there is yet time to avert such a catastrophe-dreadful, too dreadful, to contemplate!

Let the Government recognise the fact that the greatest question they have to consider, except our naval supremacy, is THE WELFARE OF THE FARMERS AND LANDOWNERS. All others stand as nothing to it.

To tackle that question, so omnipotent to the nation, Conservatives and Liberals should coalesce, and fearlessly go for what is right, unmindful of whatever support they may lose by doing so.

I have now no more to say upon the subject of my book except that our predecessors maintained in the highest degree of excellence our Sports, and handed them over to us in that state. It is our duty to deal in the same manner by those who are to come after us.Let us do so.

This book has been written by me for the purpose stated in the preface and repeated often in the chapters. The book generally is meant more for the detractors and enemies of Sport than for sportsmen; so I wish I could think the compilation, imperfect as it is, would find its way extensively among the class it is meant for, but I am prone to believe it will be read more by the others. Let me, therefore, request of my readers who are sportsmen to bring, upon all available occasions, the great facts which I have dealt with under the notice of those who are our enemies.

I am strongly of opinion that real downright Sport has few enemies except among those who are ignorant on the subject or are, perhaps, a trifle warped in their fancies. Some of these people are righteous in their own way and may be converted. Let them, therefore, on the off-chance, read "Thoughts upon Sport," at all events Chapter xvii.

For those who are cursed with wicked and vindictive propensities, combined with a crooked and contracted mind, which induce them to oppose Sport, this book is not meant except so far as to show how untenable is their position. To convert these people is impossible; in fact, the more good that is shown to be in any institution the more delight will bad people have in doing it injury, for such, of course, is their nature.

Statistics, with their inevitable accumulation of figures, were always, and still are, my detestation, and whenever their ghastly columns meet my eye I instantly look elsewhere from the hideous vision. Little therefore did I think that, in the autumn of my life, I should engage in compiling what was hitherto so abhorrent to me. Sport, however, exercises such an infatuation upon its votaries that there is no accounting for the results. Hence it is, I suppose, that while dealing with the glorious subject, my constitution-normal as regards 
ordinary concerns-became of a sudden, so to speak, regenerated. And although the effort was necessarily attended with much trouble and great care, I derived not alone interest, but absolute pleasure, in making the vast and important calculations which I now put before the public. Assuredly no statistics upon any subject other than Sport could, by any possibility, enlist my feelings to the degree which those under notice have done.

After having arrived at the results I freely confess I was astounded at the totals. Men whose knowledge is confined to their own surroundings may cavil at some of the estimates, but I don't think those who enjoy widespread and varied experience will do so, for they will know how to take the average. At all events no very serious mistake can be found except that the totals are under the real figures. To prove them otherwise I defy anyone!

No doubt I hit hard at times, but, as I say in the preface, I do so in the interest of my magnificent subject, and if I may, unfortunately, hurt the feelings of some people I cannot help it, but assuredly I do not mean to give offence. What I desire is to see recognised by all, and effect given to by sportsmen, what I convey in the following couplet:-

$\mathrm{Ab}$, Sport is the pride of the nation!

It made Britons the men that they be ;

It does good to the whole population, And knows neither class nor degree.

Therefore let us all pull together, And in harmony give it support; Around the one standard we'll gather, And manfully stick by our Sport.

And now, my readers, be ye who ye may,

"Vale, vale,-si quid novesti rectius istis Canditus imperti ; si non his utere mecum."

WHOO WHOOP! 


\section{APPENDIX TO RACING.}

Omission Explained-Drastic Measures required Immediately-Five Years of Bad TimesNo Likelihood of Improvement-Expense of Breeding and Racing MaintainedStallion Fees-Cost of a Foal-Cost to Produce a Good Horse-Purchasers of Fashionable Foals-Bad System-Paradoxical-Old Fees-Relationship between Owners and Racecourse Executives-An Analogy-Old Times-Times Change 1-Principle must be Changed Too- Entrance Fees, Forfeits, and Starting Fees-System in Ireland-A Scale for Entries - Same as Punchestown - Fees for the Derby of 1892-Owners' Blindness to their Position-Preposterous System-Recruits from the Middle Classes-What they Did-What they Should Do-A Homily on Past and Present-A Collapse Inevitable-Analysis of Owners-Sad Result-What may Eventuate-What Ought to Exist-Behind the Scenes-General Public-Racecourse Companies-Ignorance of Both-What is Required of the Jockey Club-The Author's Opinion-Trainers-Postcript-January, 1894-A Disastrous Record-The late Mr. G. A. Baird-The Duchess of Montrose and Others-Another Word to the Jockey Club.

OwING to having mislaid the MS., and forgetting all about it until it turned up recently, a portion belonging to Racing was not sent by $m e$ to the printers in time to come in near top of page 188. I am, therefore, obliged to bring it in as an appendix, but it should be taken by the reader in its proper place, and not in its present position. I wrote nearly all of it at Christmas, 1892.

As I said, racing may be perpetuated for all time-a long time anyway; but, if so, measures drastic and effective must be taken, and if they be not taken immediately the collapse of the sport is inevitable.

The Jockey Club must look to the interest of those who breed horses for the purpose of sale or racing them-they must also look after those forming the rank and file of "owners."

The last five years have been the very worst that were ever experienced by any man alive. There is not a community in the kingdom which has not suffered, nor is there probably a single great firm as well off now as it was five or ten years ago ; while the aristocracy, gentry, and farmers, having fared far worse than the trading community, are not half as well off as they were a decade ago. At the present moment things are worse than ever, nor does there seem the least chance of improvement; on the contrary, there is every likelihood of their getting still worse.

In face of this terrible state of national affairs the expenses of breeding racehorses and racing them are not alone kept up to what they were in good times, but they are absolutely increasing.

To get the service of a stallion of even moderate fame a man has to pay for his mare a fee of from $£ 50$ to $£ 100$, while to get near those of first-class renown he has to pay from $£ 150$ to $£ 250$. In addition to the service fee, thoroughbred foals in England stand the owner in pretty nearly $£ 100$ the day they are dropped; and by the time they go to the starting-post for the first time, as two-year olds, another $£ 150$ will 
have to be added. Therefure, when a man has paid, say, £100-not to speak of the maximum fees-his colts or fillies the day they first start will stand him in every shilling of $£ 350$ apiece. That would not be so bad if they all turned out well; but not one in five does so, and not one in twenty turns out first-class, while many, from one cause or another, never see the starter's flag. Add the loss of the dead plus that of the bad to the cost of the good ones, and then see what breeders have to lay out by the time they have produced a really good horse.

To cover the expenses of breeding alone, foals have to be sold at proportionately high figures. The purchaser who does not breed undergoes, of course, the sams expense with his young ones as the man who breeds and has to face the same uncertainties. If, therefore, he pays more than $£ 300$ or $£ 400$ for a yearling he has very much the worst of the bargain. What, then, is to be said of those who pay $£ 1,000$ or $£ 2,000$, not to speak of douole the latter sum, for yearlings?

To make that sort of business pay is simply an impossibility. Not oue in five of these high-priced yearlings pay their own way, and none of them pay the way of the bad and dead ones.

How paradoxical is all this! Long ago when times were good, and nur gentry had lots of money, with horses a vast deal better than they are now, Stockwell's service could be got for £50. Going back from his day, say only to Harkaway, whose fee was something like $£ 10$ or $£ 12$, we find all the great sires, including Melbourne, Touchstone, Birdcatcher and other pa'ricians of the Stud-book, standing at from $£ 15$ to $£ 30$ !

Another dreadful injustice breeders labour under is that in the case of a mare proving barren there is neither refund of fee nor other compensation made. Surely one-half the service fee should he returned and free service given next time. A man pays for the sight of a foal, and he should get what he pays for.

So far for our breeders and buyers of yearlings sired by fashion. able stallions. Let us now consider the case of owners as a community.

The relationship between owners of horses and executives of race meetings has for all time been carried out on a wrong principle, and quite at variance with the custom invariably adopted in cases which are, to all intents and purposes, identical. Race meetings have been, and continue to be, got up presumably for the purpose of showing sport to the public. The executives find the course, provide stand houses, etc., and advertise stakes to be run for. They have, however, never found it requisite to provide the factors who alone enable them to run their show. They have always been supplied. Not alone that, but money is paid by the factors to the racecourse executives which in nearly all cases equals the amount of the stakes, all the time allowing the latter functionaries to pocket the gate money.

Now, may I ask, what would be thought of Sir Augustus Harris or Mr. Michael Gunn, when advertising popular plays to come off at Drury Lane or the Gaiety in Dublin, if they supplied only the stage 
seats and scenery within the walls of these theatres, requiring the actors and actresses to give their services for nothing, and be content that the best performer was to draw a sum which was made up entirely by subscriptions among themselves, while Sir Augustus and Mr. Gunn were to take all the door money?

The analogy is by no means overdrawn. The principle is identical with that which governs owners and racecourse executives. In old times, when race meetings were got up really, not presumably, for sport, and when owners of horses were well off, it was right and proper that the latter should give their services to the promoters of the former, not alone gratuitously, but subscribe liberally in the shape of entries.

Now, however, times have changed, alas, lamentably for the worse as regards owners, but jubilantly for the better as regards racecourse companies, and as racing has degenerated into a matter of business, the relationship between the two must have its principle altered.

Out of the entrance fees, forfeits, and starting fees, which are paid by owners for the privilege of finding horses for the sport, the companies can in most instances pay the swagger stake 3 they advertise. By this means principally they have accumulated vast funds and are enabled to pay big dividends to the shareholders. These they should now be made disgorge, or, at all events, alter their system.

We, in Ireland manage these matters much better. We charge only a small fee for entry, and another for starting, while sweepstakes and forfeits are practically unknown. In England, owners are mulcted in entries and forfeits of sums which far exceed their trainers' bills. And in my chapter on Horse-breeding is shown the low fees we charge for horses possessed of the best blood in the Calendar, and who begat such cattle as Barcaldine, Bendigo, Cloister, and Kilwarlin.

If the relationship between promoters of race meetings and owners was to be carried out upon a righteous principle, the former should provide large stakes and pay the latter for providing the means for sport. After a time that may have to come to pass. Meanwhile owners should only be required to enter horses, say, three or four months before the race, and then to pay for each entry at most 1 per cent. on the added money and another 1 per cent. for either starters or horses left in, say, a month before the race. Sweepstakes, if not left optional, should not be entered for until a month before the race, and then be subject to only one-fourth forftit, which should go to the winner. The executive at Purchestown has always adopted a like principle, and it is in as round financial position as any meeting in the kingdom, and far better than most of them.

Take, for example, the Derby of 1892 already referred to. The entries numbered 259 (not 264 as stated at p. 174). In fees and forfeits the owners paid $£ 5,510$. That sum was given to the winner, whil $£ 1,000$ was divided between the nominator of the winner and the owners of the second and third horses. Qut of that large entry only thirteen started 
at $£ 50$ each, so that 246 entries, for which $£ 4,860$ was paid, together with the interest, was lost to the owners and went to the fund of the Epsom Grand Stand Company, it finding only $£ 1,000$ for the rac $\theta$ !

If owners had entered for that race, say, on February 1, 1892, at 1 per cent. on the $£ 6,500$, they would have had to pay $£ 65$ in the first instance and another $£ 65$ on whatever horses were left in on May 1 , which would practically represent the starters. No doubt heary sums, but the plan would be far better than that now existing. Besides, the public would have a pretty fair idea what the field would be. The effect of entering horses for races a long time before they can run for them is simply to gull the public, fleece the owners, and aggrandise the race companies. The practice should, therefore, be stamped out.

With all their keenness and ability to take care of themseives, owners have remained quiet over this question of stakes far too long. Many of them are constituted with the happy-go-lucky sentiment, and take for granted evergthiog is right that is laid before them by the powers that be ; while the remainder have got so accustomed to be skinned that they, like the eels, do not realise the enormity of the abuse.

The system, nevertheless, is manifestly preposterous, and would not for one moment be entertained by any community other than the owners of racehorses.

In addition to bringing entries and forfeits to a minimum, racecourse companies should be required to find free quarters and grub for horses attending their meetings as well as for the lads in charge.

Railway companies should also give a carte blanche to all racehorses and their attendants.

Under even the most favourable and fortunate circumstances, racing is not a profitab!e calling for any m?n, and then to make stakes balance expenses, much less show a profit, judgment and prudence, combined with rigid economy, must be practised systematically.

Owing to our monstrous system there are many men in England this moment whose racing accounts have often shown, for ten years on a stretch, a systematic loss of from $£ 5,000$ to $£ 10,000$ a year. One of the best known and most popular of our noblemen has for eleven years lost $£ 11,000$ a year through breeding and racing alone-for he does not bet. At last he has produced a really good horse, and could probably get for him $£ 10,000$ or $£ 15,000$, and if he turns out well and has good luck he may win in stakes perhaps $£ 30,000$; but what will that be to the owner in the face of a debit of $£ 121,000$ ?

Lucky it has been for racing that all through its history we have had from the ranks of the mercantile class accessions of wealthy men. To these sportsmen is owed a heavy debt of gratitude, for without that reinforcement the sport could not have been maintained in the high position it has always stood. There rich men have, however, done a serious injury without intention. They have run up the prices of yearlings, the offspring of fashionable stallions, to a figure altogether beyond their value. As a result, the fees for service of these stallions 
have been raised to an amount prohibitive to everyone of moderate means.

It is these mercantile magnates who should now run these prices down. If they don't do so, the gentry and aristocracy cannot carry on at the game, and before long the commercials themselves must succumb.

It is folly to think, beczuse racing is more popular than ever it was, that as a business it is in a healthy state. It is not in a healthy state, but very much on the contrary.

The multitudes who pay at the gates support only the promoters of the meeting. None of the money goes to the men who find the horses and provide the sport, and what they get for winning is subscribed by themselves. Owners are left to provide the piper and to pay him, while the executives call the tune and the public dance thereto.

In former days our owners could afford to maintain that position, and manfully they did so, Utopian though it may have been on their part. Now, however, with incomes reduced by half, and expenses increased by double, they can no longer perform the part of comedian .

These are facts indisputable; if, therefore, some great change be not brought about, the collapse of honest racing is inevitable.

Taking for a guide those who have their colours registered, we may estimate the number of men racing in England and Ireland at about 1,100. Looking over that list which is before me, I find a number lamentably large who are not worth a thousand pounds above their debts, while a great many are stone broke. There is, however, a large propsrtion who can well afford to race if the expenses be kept within a reasonable limit, but who cannot do so as things stand at present. We then have left those who, despite bad times and hard luck, can pay the piper, be the expenses what they may.

These men are well known, and by dissecting their names from the long list, it will be seen the number is so small that racing could not possibly be carried on by them alone. Even if it could, and gieat as b3 the riches of these men, and no matter how deeply may be planted in their souls the love of racing, is it reasonable to suppose they will, for any length of time, continue to fight a losing game? Will they always consider the game is worth the candle? But granted they will, will those who succeed them do so?

Now, suppose any of these aristocratic or commercial millionaires take it into their heads to chuck up racing, what is to become of the sport?

At present we cannot afford to lose one of them. I myself know two of these colossal pillars of the Turf who are meditating retirement, and that before long. There is nothing to prevent, but on the contrary, a great deal at present to momote, the retirement of others; and, in time, of the whole lot! What then?

Sorry I am to put these details in print, but for the good of the sport I love so well, and in the hope of preserving it, I feel bound to do so. They are facts which all who are behind the scenes know only oo well, but they fear to give utterance thereto. 
The general public know nothing about the "baby house" of racing. The executives of race meetings gauge the prosperity of the sport by the attendance, heedless or ignorant of the fact that their turnstiles record the visits of people who, not having anything to say to the horses or the sport, outnumber those who have by a hundred to one, and come for no other purpose than betting or the outing.

I doubt if times will ever be as good as they were with our aristocracy, gentry, or farmers. At all events they will not be for many a long year. Meanwhile, we should have our racing in spite of all financial depression.

Let, therefore, the Jockey Club and other of our great leaders exercise foresight by improvising measures, and carry them out with determination combined with discretion, which will preserve the sport from perdition.

In my humble opinion, all that is required is to have the expenses of our breeders and owners cut down to a minimum. To effect this purpose no one need be dealt with except the owners of stallions, racecourse and railway companies. The price of yearlings will adjust itself.

Trainers should not be interfered with. The fees they charge are not excessive considering their skill and the responsibility of their position, with the amount of attention and anxiety attendant upon a racing stable. Besides, men of such high class and character as are our trainers deserve to be properly remunerated for their services. As it is, many of them are paid with unjustifiable irregularity by their employers, and, in addition, are required to advance money to great amounts for travelling expenses.

P.S.-January, 1894. A year bas passed since I put together the foregoing. A year all round far more disastrous to trade and agriculture than any of the preceding five, hence probably the very worst that has ever been chronicled in our nation's history.

As regards racing: In March occurred the death of Mr. George Alexander Baird (Mr. Abington), whose loss to the Turf is estimated at from $£ 80,000$ to $£ 100,000$ a year. We now see by the papers that the Duchess of Montrose is going to give up racing, and there are rumours of other great patrons doing the same.

Loving the sport as much as her grace and the others do, I am very sure none of them would thro $\pi$ up the sponge but for the expense, which, under the present system, is in the most monstrous degree levied right and left upon owners.

With this state of aifairs staring them straight in the face, it is the bounden duty of the Jockey Club to bestir themselves and do what Lord George Bentinck, Admiral Rous, Mr. George Payne, or Lord Drogheda would have done under similar circumstances.

There is no time to be lost, for directly an example such as the Duchess of Montrisse's be set, it will be followed numerously. 


\section{N D E X.}

Abd-el-Kader, 131

Abdullah, 202

Aberdeenshire, 260

Abernethy, Dr., 349

Abingdon, Mr., 396

Absentees, 414

Accidents, xxviii

Ace of Hearts, 13

Achnasshellach, 260, 268

Act of Parliament, 305

Affarick, 272

Afternoon Tea, 298

Agitators, xxxi

Agricultural Ques!ion, The, xlvi

Agriculture, 418

Ailesbury, Lord, 315

Ailesbury, Marquis of, $x x x v, 414$

Ainslie, Colonel, 98, 163

Aintree, $\mathrm{xx}, 146,150$

Aladdin, 401

Alarm, xl

Albert, 196

Aldershot, xxxiii

Alexander, 201

Alhambra, 203

Alice Hawthorne, 188

Allen-a-dale, 168

All's Well, 162

Altcar, 281-288

Ambergate, 97

Ancotte, Major, 34

Anak, 90

Anarchists, 292

Anatis, 131

Anchor, 32

Anderson, Alec, : 3

Anderson, Mrs., 96

Anderson, T. W., 32-34

Andover, $x l$

André, A. von, 268

Angleseys, The, 201-212

Anti-Gambling Lesgue, xiv

Annagh Course, 129

Anne, Queen, 91

Annfield Runs, xiii. 19

Anson, Colonel, xxxiv, xxxix, 363 , 364,387

Anson, Lord, 355

Aphrodite, xl

Apjohn. Thomas, 160

Appendix to liacing, $x x i$

"Appleton, Mr.," $\mathrm{xx}$

Arabians, 91

Arbuthnot, Mr., 37

Archdale, Captain, 163

Archdales, The, 195

Archer, Fred, x i. 202, 340, 395

Archer, William, 402
Archery, 297

Ardverikie, 272

Argyllshire, 260, 267

Ariadne, 13

Aristocracy, Commercial, 417

Aristocracy, Territorial, $\mathbf{4 1 7}$

Artful Dodger, 390

Arthur, 29, 131

Ascetic, $x$ vii

Ascot, 155, 181, 186, 212, 224

Ascot, 1895, xxii

Ashburton, Lord, 243

Ashplant, 97

Aspacia, 168

Astrologer, 198

Atherstone, The, 55, 355, 356

Athgarvan Lodge, 197

Athole Daisy, 402

Athole, Duke of, xxviii, 366

Atlantic, xli, xlii

Attila, 385, 390

Augustine, 15

Autumn Handicaps, 1894, xxii

Aron, The, 310

Ayala, 239

Aylmer, M., xx, 98, 164

Ayrshire, 189

Ayrshire, horse, 398

Bacchus, 209

Back, sore, 117

Back-swording, 311

Badminton, 31

Badminton Library, 227, 243, 24t, 256

Bad Times, 421

Bagot, 210

Baily, Wm., 4

Baily's Magazine, xx. xxvi, 138

Baird, G. A., 396, 426

Baker, George, 330

Baker, Hugh, 34

"Bakers," 77

Bala, 257

Baldoyle, 141, 183, 203, 219

Balfe, Captain, 163

Ballinaboola, 52

Ballinafad, 215

Ballinasloe, 95

Ballyduff, 25

Ballydurn. 4, 25, 27, 38, 57

Ballydurn Country, 26

Ballyneale, 4, 27

Ballysbannon, 123

Balmacaan, 272

Bank Holidays, 305

Banting, 352

Barbarians, 307

Barbaries, 91 
Barcaldine, 97, 188, 189, 423

Barclay, Captain, xx, 154

Barclay-Allardice. Capt., xxxvii, 217, 299, 300, 371-382

Barkby Holt, xvii, 130

Barker, Miss, 385

Barkston, 211, 214

Barkston Lodge, 211

"Barnsley Chop," A, xxxvi

Baron, The, xli, xlii, 159, 197, 198, 207, 210,211

Baronetage, 416

Baronstown, 135, 139

Barony Boy, 129

Barrington, Charles 151

Barron, Misses, 220

Barron, P. Netterville, 297

Barry, Billy, 6, 18, 55

Barry, J. Harold, 163

Barry, Mr., 130

Barrymore, Lord, $\mathrm{xxx}^{-}$

Barton, Major, 163, 233

Barton, William, 2

Barton's Yard, xxxviii

Bass, Hamar, 260

Bates, Captain, 160

Bates, John, xxvii, 223

Bateson, Colonel, $\mathrm{xxx}$

Batthyany, Count, 189

Battle Powder, 238

Baxter, pedestrian, 375

Bayleaf, 204

Baylough, 25

Bay Middleton, $x l$

Bay of Biscay, 302

Beagle, 211

Beasley, Mrs., 215

Beasley, Harry，152，199，200，202, 203,205

Beasley, James, 202, 204

Beasley, John, 202, $20 t$

Beasley, Tom, xx, 199, 201, 202, 215

Beasley, William, 7, 162, 202, 204, 215

Bensleys, The, xxiv, 176, 199, 201, 204

Beatty, David, xir, 163, 248

Beauclerc, Lord F.. 362

Beaufort, Duke of, xxii, $9,31,49,163$, $227,387,401$

Becher's Brook, 148

Bective, Lord, 163

Belcher, Tom, 317

Bell, John, 32, 95

Bell's Life, xxxiii. xxxviii. 151, 321, $324,327,330,357,361,371$

Bellyse, Dr., 312

Belvidere, 230

Belroir, The, xx. 27, 55, 57

Ben Battle, 96, 97, $1 \cong 6$

Ben Bolt, 160

Bendigo, 97, 196, 207, 397, 423

Benicia Boy, The, 323

Benjamin, Bill, 323, 3 ?3
Bennett, "Farmer," xxxiii

Benuett, J. G., 151

Bentinck, Lord Geo., xxxv, 169, 170, $212,213,33 \approx, 336,+26$

Benyon, R., 314

Benzon, Ernest, 414

Beresford, Captain Pack, 4, 9. 13, 163

Beresford, Lord Charles, $32,34,56,58$, 189

Beresford, Lord Delaval, 32

Beresford, Lord Marcus, xli, 12, 14, 32, 3 t, 58, 76, 403

Beresford, Lord William, 32, 34, ถ8

Berkeley-Craven, General, xxx $\mathbf{v}$

Berkeley, The, 55

Berkhampsted Staghounds, 34

Berkshire, 311

Bernard, Captain, xx, 15 t, 163

Bernards, The, 98

Bernard, Colonel, 163

Berwickshire, 268

Bessborough, 25

Bessborough, Lord, 16, 28, 32, 40

Betagh, Michael, 163, 166

Bettors, $\mathrm{xxxy}$

Bianconi, Charles, xxvi

"Bian's Car," xxvi

Billesden Coplow, 130

Birdcatcher, 92, 196, 198, 203, 209, 211, 212, 422

Birgham Water, 233

Bishop's Wood, 248

Bismaıck, 196

Bittoon, Isaac, 315

Black. Jem, 311

Black-breasted Reds, $312,318,335$

Blackburn, Major, 6

Blacker, Wm.. xx, 164

Blackfoot, 212

Black Hamb?eton, 173

Blackmount Forest, 260

Blackrock Strand, 213

Black Rose, 405

Blackstairs Mountain, 250

Blackwell, Geo., 399

Blake, B., 129

Blake, C. J., 96, 164, 166, 405

Blake, Edmund, 128

Blake, J. G., 166

Blake, Martin, 129

Blake. Martin Joseph, 208

Blanche of Middlebie, xlii

Blanchland, 406

Blandford, Marquis of, 314

Bleeding، to stop, 117

Blews, Mr., xxxvii

Blind Harper, 136

Blind Vet, 135

Blink Bonny, 189

Bloomfield. Miss, 31, 32

Bloomfield, F. G., 32, 31

Blubberhouse, 247 
Blucher, 215

Blueskin, 6, 137

Boadicea, 90

Boat-races, 291

"Bobbie," 89

Bob Booty. 209

Bogside, xli

Boherbawn, 167

Bolger, Ned, ร5

Bolton Starling, 91

Bond, Mr., 6

Bookey; Mrs., 31, 32

Bootham Bar, 313

Boots, to waterproof, 117

Borodale, 248

Boulevard, 96

Bourton, 148, 149, 205

Bowater, Edward, 358

Bowers, Edward, 33

Bowers, Henry, 28, 33, 48, 87

Bowes, John, xxxix. 385

Boxing, 293-297

Boyce, Mr., 154

Boynton, Sir F., 313

Bracebridge, 363

Bradgate Park, 245

Brady, John. 249

Braidwood, Mr., 226

Brazenface, 2.28

Breadalbane District, $\mathrm{xxx}$

Breadalbane, Marquis of, 260

Breast, Sore, 117

Breen, Wat, 34

Brettle, Bob, xxxiii, 323, 333

Brighton Downs, 139

Brindley, Thomas, 176

Briscoe, Edward, 28, 33, 48, 87

Briscoe, Henry W., xiii, 3, 4, 9, 15-22. $28,30,32,54,61,95,119,126,163$

Brittle Feet, 117

Brixworth, 357

Brocklesby lot, 16

Brocklesby Puppy Show, $8 t$

Broderick, Dan, xxi, 195

Broderiık, Jim, $\mathrm{xxi}$

Bromhead, $\mathrm{xxx}, 2+7$

Bromley-Davenport, 72, 77, 136

"Brooke's," 335

Brooke, Sir Victor, 246

Brophy, William, 13, 96

Brother to Flnrry, xxxv

"Brothers' Race," The, 58

Brown Bess, 129

Brownstown, $\mathrm{xxy}, 24$

Brownstown Lodge, 196, 208

Brownstown Run, 37

Brown Tommy, 312

Bruckshaw, T., 393

Bruges, 309

Brummell, Squire, 314

Brunette, 137, 208

Bruntगn, Harry, xxxiv, 325, 326
Bruree, 96

Bryan, George, 4, 9, 99, 163

Buckle, F., xxxviii, 376, 388

Buckstone, xli

Buckstone and Tim Whiffler, 397

Buckstone and The Marquis, 397

Budd, Ed., : $00,361,371$

Bullfighting, 307

Bulmershe Court, 311.319

Bumble Bee, 13, 14

Bunbury, Ben, 32

Bunbury, Ralph, 34

Bunbury, Sir Charles, 335

Burgho, Sir R. de, xx

Burkes, Blakes, and Bodkins, 129

Burke. Deaf, 375

Burke and De Brett, 320

Burke, Richard, 2, 66

Burke, Major, 157

Burn-Murdock, Mrr., xx

Burns, 117

Burrows, Major, $16 t$

Burton Country, 355, 356

Burton, Dick, 35̃

Burton, Lord, 260, 272

'Bus Drivers, xxvi

Busybody, xli1, 396

Butler, F., 388

Butler, Lor d J zmes, 4, 9, 163

Butler, Walter, 129

Butterscotch, 97

Buttevant, 128

Buxton, Mr. Gurney, 246

Cabmen, xxvi

Cadland. 388

Cahir, 34

Cahirmee, 95

Caithness-shire, 267

Callan, 29, 397

Caller Ou, 7, 189

Cauballo, xlii

Cambridge, Duke of, $\mathrm{xxx}$

Cambridge Gap, 35s

Cambridgeshire, The, 181, 207, 336

Cambusmore, 405

Campbell, Colonel, xxix, 154

Canavan, Charley, xxiv

Canavan, Davy, xxi, 206

Canavan, D. and W., xxi, 206

Candy, Captain, $\mathrm{xx}$

Canezou, 385

Cannobie, xli

Cannon, Joseph, 175, 195, 407

Cannon's, Morny, Doncaster, xxiii

Cannon, Tom, 175, 397

Canny, Dan, $x \mathbf{x}$

Captain, 5, 12

Caravan, 212

Carden, Colonel, 163

Cardinal Puff, 6, 212

Carlisle Bridge, 218 
Carlow, Lord, 166

Carmarthen steeplechase, 13

Carmelite, 201, 202

Carrick-on-Suir, xiv, 25, 31

Carrig-a-nure, 25

Carrig-a-tubrid, 25

Carrigreen, 25

Carrigeen Run, 36

Carr gtrus, 3, 26, 27

Carrigtrus Run, 28

Carsun, Mr., 302

Cashel, 132, 139

Cassidy, James, 163

Castingline, Mr., 231

Castledermot, 95

Castleknock, 167

Castlemilk, 288

Castlemorres, 3, 16, 31

Castle Plate, 406

Cathal, xvii

Catherine Hases, xli, xlii. 188

Cavendish, Hon. George, xxxv

Cecile. The, 167

Cecilia, xlii

Celt, The, 6

Cesarewitch, The, 181, 336

Chaine, James, $16 t$

Chaloner, 'Tom, 397

Chancery, 201

Chanticleer, 188, 207

Chantilly, 200, 399

Chaplin, Mr. H., 56, 835

Charibert, $x$ lii

Charity Boy, 160

Charlemonts, The, 195

Charles II., xxxviii, 172

Charles XII., 92

Charrité, Colonel, 357, 362

Chaseawas, 215

Chasseur d'Afrique, 36

Chatterbox, 202

Cheasty, 16

Cheltenham, 212

Cheroot, 15

Cheshire, 312-319, 335

"Cheshire Drop," 312

"Cheshire Piles," 312, 335

Chester, 171, 313

Chesterfield Stakes, 213

Chichester, Captain, 154

Chifney Rush, 312

Chifney, Sam, 388, 401

Chilblains, 116

Childeric, xli, xlii

Chippenhain Park, 245

Choleric Tom, 213

Cholmondeleys, The, 312, 314

Chop, Mutton, xxxpi

Christian Dick, 362

Christmas Gift, 202

Chrysalis, $1 t$

Chrystabel, 14
Churchtown, 25

"City Man," The, 303

Clancy, Tom, „5

Clanricarde, Lord, 9, 99, 130, 163, 195

Clarke's Lotion, 116

Clarke's Ointment, 114

Clasher, 30, 362

Classic Races, 1896, xxii

Clayton, Captain, 34

Clear the Way, 31

Clibborn, Ned, xiii

Clifton, 173

Clinker, 130, 362

Cloister, xvii. xviii, 97, 132, 150, 152, 205, 423

Clonassey, 26

Clonassey Run, 37

Cloncurry, Lord, 154, 163

Clonea Castle, 25

Clonmel, 25, 95

Clonmell, Lord, 9, 25, 154, 155, 159 163,164

Clooney, Tom, 4

Cloth, to waterproof, 117

Clown, The, 29

Coach, Waterford, Dungarvan, and Lismore, $\mathrm{xxvi}$

Coachmen, l.ondon, xxv

"Coal Hole," The, 303

Cockfighting, 308-3:9

Cockneys, 230

Cogan, Right Hon. WV., 164

Coghlan, P., 33

Coke, Arch, 287

Coke, John, 287

Coke, Wm , 367, 368

Collestown, $\mathrm{xx}$

Co'lins, 322,333

Colonel, The, xviii

Coltness, 97

Combe, Harvey, 357

Combermere, Lord, 312

Comeaway, xvii, xviii, 132, 149, 150, 203,205

Commercial Buildings, Dublin, 304

Commercial Community, $30 t$

Commodore, 210

Commodore Trunnion, 168

Common, 176

Confessor, 123

Confiscation, 417

Congreve, Ambrose, 28, 33, 220

Congress, $x$ viii

Connaught, Duke of, 32

Connaught Ranger, 208, 209

Connellan, Major, 34

Connolly, John, 168

Connolly, John, xxi

Connolly, Tom, 207

Conolly, Thomas, 9, 163

Conoran, Nickey, 300

Conrad, 6 
Conservative Majority, 1545, xlvi

Conyngham Cup, 152, 157, 200, 202, 204

Conyngham Lodge, 196

Conyngham, Marquis of, 154, 163, 196

Cook, 13

Cooke, Robert, xiii

Coolnamuck, 25

Coolnamuck Run, 53

Cooney, Dick, 55

Cooper, Colonel, 9

Cooper, the Gipsey, 205

Coote, Captain, 163

Coote, Sir C., 96

Coppenagh, 7

Corbally, 25

Corbally Run, 5

Corbally, Mr., 96. 166

Corinthian Cup, 135, 153

Cork Park. $140,141,1 £ 0,183,200,202$, 229, 230

Corriebran, 269

Cortolvin, 131, 149

Cosby, Captain, 163

Cotherstone, xl, 336, 385

Cottons, The, 312

Couch, Abey, 322, 333

Coughs, 117

Countess, 162

Country Gentleman, The, xxix, 274

Coursing versus Hunting, xxxi

Courtenay, H., 32, 34

Courtenay, Ned, xiii

Courtenay, John, 4, 9s, 131, 195

Coventry, Captain, $\mathbf{x x}$

Coxes, The, 4, 9, 208

Cracked Heels, 116

Craithynaird, 375

Crampton, Sir P., 154

Craven, Fulwar, 315

Craven, Lord, 314

Craw furd, Mr.W. Sterling. xxiii, xxviii, 401

Cremorne, Lord, 212

Cribb, Tom, 380

Crib-biting. 117

Cricket, 291

Crockford, 335

Crocus, 27, 58

Croft, 385

Crofter Commission, 260

Croker, Harry, 164

Crokers, 93

Croly, Surgeon, 221

Cromwell, 129

Cronootes, 91

Croquet, 297

Cross, Mr. R. K., Xxx

Crotanstown, 205

Crotanstown Stud. xxi

Crowberry, xli, xlii

roxteth Park, 247
Croydon, 172, 202

Cruelty, 412

Cruiser, 202

Cruiskeen, 210, 212

Cruiskeen Lawn, 122

Cuffe, Captain, 32

Cullen, F. F., 207

Cullen, W. P., 207

Cullen', Toe, 176

Culverine, 168

Cumberland, Duke of, $\mathbf{x x v}$

Cummins, D. K., 32, 33

Cummins, William, xxvii

Cunard, Sir B., 57

Cure, The, 37

Curragh, 'The, 91, 183, 193.215, 200, 405

Curragh Course, 206

Curragh Gorse, xxiv, 206

Curragh Ranger, 196

Curragh Rangership, 169, 169

Curragh Stables, 203

Curragh View, 207

Curraghbaha Run, 21

Curlaghmore Blood, 17

Curraghmore Country, 3, 4, 25, 26

Curraghmore Hounds 20, 83

Curraghmore Races, $48,58,74,125$, $132,200,203,343$

Curry, Recipe for, xxxvi

Cusack, Wm., xxi

Cushgam Hill, 22 t

Cusick, pugilist, 323,326

Custance, xli

Cuts, 116

Cycling, 297, 299

Cypriad, 390

Cyrus, 200, 201, 202

Daily Telegraph, xxix, 266, 268

Dainty Davie, 169

Dalbiuc, Charles, 311, 314, 316

Dalnaspidal, $\mathrm{xxviii}$

Daly, Denis Bowrs, 195, 197, 209

Daly, James, 95, 96, 107

Damascus Twist, 328

Dame Street, 217

Daniel O'Rourke, $336,335,39$ t

D'Arcy, Giles, 95, 107

Dirley Arabian, 91

Daryell, Sir Henry, 315

Dashwood, Sir George, 315

David and Goliath, 322

Davies, William, 335

Davies, Mr., 96

Dawson, Captain H., 33

Dawson, George, 189, 195, 396, 397

Dawson, John, 39 t

Dawson, John, jun., 396

Dawson, Mr. Mat., xli. xlir, xlv, 188, 394-399, fण1, 405

Dawson, Mrs. Matt. xli, xliv

Dawson, Miss Nellie, 405 
Dawson, R. C., 96

Days, The, 175

Deanes, The, 34

Debeau, John, xxi

De Burgho, Sir R., xx, 9s, 135, 163

Deer Forest Commission, xxxi, 267

Deformed. The, 13

D'Egville, 212

De la Poer, A., 32

De la Poer, W., 32

"Lemon, The," 402

Dennehey, Michael. 195

Dennis, John, 130, 212

Denny, Abram, 47

Denny, C. E., 32

Denny, Mr, 36

Dent, Edward. 287

Departure, 343

Derby, Lord, xxxii. xxxix, 172, 28s, 312,387

Derby of $1892,174,423$

Derby of 1894 , The, xlii

l'erby of $1895, \mathrm{xly}$

Derby, The, xxxii, xli, 136, 151, 172, $174,191,285,306,312,335,338$

Derg, Lough, 230

De Robeck, Barou, xx, 163

Desart, Lord, 9

Devil's Ditch, 358, 375

Dewdrop, 169

Dewe. W. H , 2 it

Dewhurst, Captain, 166

Dickenson, Bernard, 315

Dickson. Major, 154

Dinner Parties, 298, 319

Discount, 149

Disgraceful Exhibition, A, xxxviii

Disney. William, 195, 19j, 209

Distemper, 279

"Dixie," 282

Dobbyn, James, 34, 58, 152

Dobbyn, Larry, 9, 135

Doctor, The, 6

Dogs, Species of, 284

Dog Shows, 291

Doncaster, 171,186

Doncaster, 1894, xxiii

Doneraile, Lord, 163

Don Juan, 56

Donnelly, Dan, 205

Donnelly's Hollow, 205

Donoughmore, Lord, 32

Dooovan, 1 ?

Donoran, F., 95

Doolan, Larry, 218

Dormouse, 212

Douglas, Captain, 130

Dowling. 25

Dowling, Mr. Frank, xxxiii, 32t, 331

Downfall of England, 418

Down Harriers, 74

Down Stagbounds, it
Pownsbire Course, $10 j$

Downshire, Marquis of, 15i, 163

Doyle, John, xxi, 7

Drawing Room Stakes, 212

Drewitt, 399

Driving, $\mathrm{xxv}, 216-228,291$

Drogheda, Earl of, xxi

Drogheda, Marqu's of, xxi, 98, $15 t$, $165 \cdot 170,201,426$

Droghed 7 , Marchioness of, 166

" Druid," Tne, 388

Drumnachdar, 266

Drury Lane, 422

Dublin Horse Show, xvi, xxi. 13, $100-$ $103,219,221,222$

Dublin Jarries, xxri

Duc an dluurras, 7

Duchess de Guise, 13-15

Duff, Mr. C. G., xviii

Duke, John, xiv, 18, 2t, 27, 32, 37, 54, 5.. 121

Duleep Singh, 246

Dumb-bells, xxxvi

Dunbar, Wm. J., 151, 283

Dundalk, 219

Dundee, xli. 394

Dungarvan, 21, 25

Dungarran Coach, 223

Dunmore, 25, 301

Dunne, James, 206

Dunne, Michael, 9S, 132, 163, 21 \%

Dunue, William, 96, 164, 166

Dunottar, 370, 371

Dunsandle, Lord, 163

Dunsden, 311

Durham, Bishop of, 340

Dutch Oren, xlii. xliv. $18 \mathrm{~s}$

Earl, The, 336

Earlies Gorse, 25

Eaton Hall, 389

Ebberson, 361

Echidna, 196, 211

Eclipse, xxiv, 211

Eclipse Stakes, 191

Economist, 212

Ede, George, $x x, 131$

Eden, The, 233

Edge, S. T., 298

Edgware Road, 362

Edwards, Arthur, 397

"Edwards, Mr.," xx, 210

Effeminacy, 409

Egertons, The, 312, 314, 319

Eglinton, Lord, xli, 394

Egremont, Lord, 337

" Eight Hours," 306

El Dorado, 400

Ellesmere, Lord, 398

Elveden, xxx. 246

Elmhirst, Mr., 34

Elmore, Mr., 362 
Elvina, 390

Elwes, Captain Richard, 12

Emo Fox Hounds, 166

Empress, 132, 199, 200-202

Empress Eugénie, xxxiii

rngland, Downfall of, 418

English Moors, 257

Lnid, 32

Epirus, 213, 391

Epsom, 172, 186, 219

Epsom Grand Stand Company, 424

Escape, 210

Euclid, 389

Evans, Mr., 362

"Evans's," 303

Everard, Mr., xxviii

Exeter, Marquis of, 387

Exning, xxxviii, xlii, 397

Eyre, Giles, 130

Eyrefield, 201, 202

Eyrefield House, 201, 20 t

Eyrefield Lodge, 199

Fair Maid of Kent, 142

Fairwind, 200, 201

Fairyhouse, 58, 137, 139, 145, 150, 152, 183, 201, 219

Fairyland, 195

Faithlegg, 27, 249

Fallacy, xxxvii

Falls, bad, 117

Falmouth, Lord, xli, 181, 395, 396, 404,406

Fancy, The, 167

Farley and Boyes, 303

Farmers, The, 28, 62, 68, 82, 83, 99, $127,139,159,290,410,418$

Farmer's' Race, Kildare, 159, 200

Farnborough, xxxiii, 309, 326

Farquharson, Mr., 366

Farrier, xxxvii

Fashnakyle, 272

Father Mathew, xviii

Father O'Flynn, xvii

Fauconberg, Lord, 373

Faugh-a-ballagh, 207, 208, 209

Favo, 96, 198

Fazzoletto, 385

Feeling of Anima's, $\mathrm{x} v$

Fellowes, Mr. R., xxsi.i

Feloar, 366, 370

Fenwick, Noel, 396, 397

Fereda, The, 167

Ferguson, pedestrian, 373

Ferguson, Tom, 207, 211-215

Fethard Course, 147

Fethard, xiv

Fetische, 202

Ffrench Furze, 196

Ffrench House, 195

Fiddown Bridge, 52

Field, The, xxviii, xxx, xlvi, 15 ’,248,289
Fife, Duke of, 260

Figg, 325

Filgate, Mr., 18, 163

Filho da Puta, Xxxv, 385

Fingall, Lough, 269

Firefly, 15

"Fistiana," 310

Fists, 294, 295

Fitzgerald, William, 2, 220

Fitzgerald, Lord Otho, 159

Fitzgeralds, The, 21

Fitzhardinge, Lord, 55

Fitzwilliam, Hon. H., 163

Fitzwilliam, Lord, 387

Fitzwilliam Square, 221

"Flags," The Liverpool, 304

Flatman, El., sss

Fleming, Arthur, xiii

Fleming, J. Congreve, xiii, 50, 55

Fletcher, 373

"Flickering Twilight," 410

Flight, 210

Flirt, 361

Flood, Wm., 4

Florizel II., xvii

Flourisher, xxxvii

Flowers, Harry, xxxiii, 311-319

Flurry, Brother to, xxxy

Flying Column, 7, 204

Flying Childers, 142

Flying Dutchman, $x^{1}$, xliv, 397

Flynn, Father Martin, 5

Fochabers, 233

Foley, Lord, 335

Foley, Mr., 129

Foljambe, George, 366

Folkestone, Lord, 314

Football, 290, 297

Foot-races, 291

Forager, 160

Fordham, xli, 397, 359

Forebodings fulfilled, xxi

Forster, Colonel, 98, 163

"Forty-Font," The, 302

Four-in-Hand, The, 219

Fowke, Sir F., 56

Fcx, Chas. J., xxxiv

Foxes and sheep, xvi

Foxes, 85.89

Foxhall, 336

Foxhound, The, 284

Foxhunter's Jig, 122

Francis Joseph, 168

Franks, 385

Frazer, General, 9

Freeman's Journal, 79

French, J., 129

French, Joe, 207

French, Tom, xli, 404

French, W., 129

Freney, 209, 212

Freney the robber, 208 
Frigate, 133, 142. 202.204

Full Cry, 105

Fullerton, 286

Furley, 196

Furlongs, The, 21

Fyfield, $x$ l

Gaiety Theatre, 422

Gaffney, Groom, xx

Galliard, xli

Gallinule, $x x v$

Galloway, 268

Galopin, 97

Galore, xli

Galway, 230

Galwey, James, 194, 280

Gamebird, 199, 201

Gamecock, 132

Gamesters of Wilts, 310

Gandy, Captain, 32

Gandy, Mrs., 31, 32

Gaper, 336

Gardenmorris, 21, 25

Gardenmorris Run, 36

Gardiner, Will, 356

Garlies, Lord, 370

Garterly, 172

Gartlans, The, 98, 163

Gaultier, 51, 63

Gavin, Paddy, xxi, 196

Geheimness, xliv

Gemma de Veryi, 12, 13

General Election, 157

Gentleman Riders, $\mathrm{xx}$

George, 209

George I., 172

George IV., 197

Germany, Emperor of, 399

Ghuznee, 390

Gibbons, Bill, 31 , 316

Gideon; Johnny, 327

Gillard, Frank, 55

Gilliver, Joe, 313

Gilmour, Mr. W. L., xxviii

Giraffe, 169

Giraldus, 92

Girl, The, 31

Gladiator, $x l$

Glascott, James, 34

Glascott, W. M., 4, 19, 20, 34

Glasgow, Lord, xli, 387

Glenbower Run, 20

Glenfeshie, 260

Glengariff, 230

Glenmasson, 123

Glenmore, xi v

Glenquoich, 260, 272

Gloaming, 169

Globe, The, 341

Gloucester'shire, 310

Glove Fights, 310, 338

Godolphin Arabian, 91
Goff, Robert J., 13

Goff, Mrs., 31

Goff, W. G. D., 32

Going, John, xiv. 24, 163

Golden Horn, 215

Golf, 291

Gooch, Sir Thomas, 243

Goodall, Stephen, 164

Goodall, Will, $\mathrm{xx}$

Good Runs, 5, 19.21, 35-38

Goodwood, 172, 181, 186, 31 t

Goodwood Cup, 212, 213

Googawnbarragh, 230

Gordon, T. G., 96, 196

Gordon Castle, 375

Gordon, Duke of, 375

Gorse Covert Foxhounds, 67, 306

Gorse Coverts, 25

Gortrush, 80

Gough, George, 4, 34

Gough, Hugh, 5

Gougb, Tom, 4, 34

Gough, Judge, 163

Goughs, The, 93

Goulbourne, Mr., 375

Gout, The, : 72

Grace, II., xvii

Graceful, 53

Grafton Street, 218

Graham, Bellingham, 355

Graham, Mr. Bellingbam, xxxvii

Graham, Sir Reginald, xxxvii

Grand Duke Michael Stakes, 212

Grand National, xrii, 7, 7t, 113, 131, $142,147,181,202-204,338,407$

Grand Prix, xlii

Grange, The, $\operatorname{xxx}$

Grant, Jack, 322, 333

Grantully, 246

Gray, George, xxi

Greatheart, 123

Grecian. 307

Grecian Bend, 203

Greek and Latin, $\$ 10$

Greer, Captain, xxv. 96, 166

Gregory, C., 32

Gregson, xxx viii, 335

Gretton, Fred, xxxv

Greville, Captain, 367

Greville, Lord, 74,96

Greville, Reggie, Xx. 207

Greyhounds, 275, 280-284

Grey, Lord De, xxx, 246

Grey Momus, 212

Grimaldi, 362

Grosvenor Gallery, 409

Grosvenor, Lord, 314, 315, 319

Ground Game Act, 264

Gubbins, Captain S., 96, 98, 152, 164, 195

Gubbins, John, 34, 96, 98, 164, 405

Gubbins, Rev. William, 34, 36 
Guiccioli, 196, 208, 209

Guilcagh Cross, 30

Guilford, Lord, 53

Guisachan, 272

Gullane, xli, 394

Gully, John, xxxviii, 335, 358, 375

Gunboat, 142

Gunn, Michael, 422

Guns, xxxi

Gurteen, 25

Gymnastics, 297

Hackfall, 6

Hackneys, xvi

Hall Farm, 246

Hamilton, Duke of, 395

Hamilton, Mr., 13

Hamilton, R., 206, 209, 210

Hamilton Lodge, 206

Hampshire, 319, 356

Hampton, xlii, 56, 97

Hampton Stud, xxii

Hand Ball, 297

"Handicapping," 8, 134

Hanlon, Johnny, xxi

Hanway, W., 75

"Happy Family," 411

Hard Times, 160

Hardwicke Stakes, 340

Hardy, Harry, 8

Hares, Turned down, xxviii

Harford, Colonel, xx, 163

Harkans, G., 129

Harkaway, 105, 190, 198, 207, 211-215, 422

Harper, Thomas, 98, 163

Harris, Sir Augustus, 422

Harrow Hill, 362

Harvester, 189, 396

Hastings, Lord, 25, 396

Hastings, Ladies S. and L., 30

Hastings, Marquis of, 335

Hatchetts, 225

Haughton, Bold, 312

Hawkes \& Co.. 217

Hawley, Sir Joseph, xxxv, xl, 335, 336

Hay, Sir A. K., 366

Haywood, W., 399

Heath Cottage, xxxviii

Heath Farm, xli, 398

Heath House, 394, 397

Heavy Bettors, xxxv

Heenan, J. C., xxxiii, 309, 321-333

Helys, The, 21

Henry, 15

Henry II., 172

Henry V III., 90

Herbert, Rev. N., 4

Herbert, Walter, 4

Hermeberry, P., 33

Hermit, x1, 97, 336

Hermit (hound), xxxvii
Hero, The, 7

Heron, 29

Heron Court Manor, 244

Hibernian Jehu, 217

Hickey, John, 223

Hickman, Mr., $\mathrm{xx}$

Highfield, 189

Highflyer Hall, 210

Highflyer Mare, 210

Highgate Cemetery, 3:3

Highland Lassies, 263

Highland Mary, 201

Highlands, The, 252-272

Higginson, Sir James. $x x$

Hiland, John, 33

Hillier, Mr., 96

Hind Shooting, xxviii

Hindlip, Lord, 260

Hirsch, Baron, 181

Hobbie Noble. $337,337,39 t$

Hocks, Capped, 117

Hodgson, J., 222

Hoeys, The, 98, 163

Hoffman, Charles, 161

Holderness, The, 350

Holkam, 243, 246, 367, 370

Hollyhock, 210

Holman and Harris, 278

Holt and Crook, 337

Holyoake, F., 130

Hook Cottage, xxxiii

"Hoplemuroma," 114

Hop Pole Inn, 312

Horne, Colonel, 233

Horn of Chase, 215

"Horse and Groom," xxxviii

Horse Breedier, The, 107

Horse Breeding, 90-103

Horse Sales, 12, 14, 392, 396

Horse Shows, 91-95, 100, 123, 168, 291

Horses ridden by Osbaldeston, $35 \$-360$

$" \quad$ W. Scott, 388, 389

" $\quad$ Archer, 403

" , Fordham, 400

Horses trained by J. Scott, $385-994$

Hospodar, 123

M. Dawzon, 394-399

Houghton Stakes, 406

Houldsworth, Mr., 385

House of Lords, 56

Howth, Lord, 4, 9, 98, 139, 141, 154, 163,195

Hudsons, The, 21

Humble, Miss, 30, 31

Humble, Sir N., 4, 163

Humble, R. and C., 21, 34

"Hume, Mr.," xx

Humming Bird, 196

Hunt, Thomas, 33

Hunt, William and John, 21

Hunter, Hon. Horner, 67

Hunter, R. J., 59, 129, 209, 209, 211 
Hunting, 6t, 78

Hunting, Cost of, 79-84

Huntingdon, Lord, 4, 21, 25

Huntingfield, Lord, xxx

Huntley Lodge, 375

Huntsman, 131

Hırdle Race, Paris, 203

"Humanitarians," xv, xxxi

Hurricane, 385

Hutchinson, Hon. H., $15 t$

Hutchinson, John, $\mathrm{xx}$

Hutton Bushell. 355

Hutton, Captain, xx, 154

Hutton, John, 95, 96

Hyde Park, 77, 172, 217, 220

Hyland, Larry, xxi

Hypatia, 168

I'Anson, William, 189

Idle Boy. 215

Ierne, 209

Igoe, John, xxi

lidegarda, 210

Ilex, 97, 132

Illuminata, 399 , xlii

Ilsley, $39 t$

Imperieuse, 385

Inchageela, 230

Insurance Companies, $3 \pm 1$

Interchange of Mtets, xiv

Inverlair Moors, $\mathrm{xxx}$

Invermark, 260

Inverness-shire, 260, 267, 367

Ireland, 263

Ireland, John, 375

I. N. H. S. Com., $140,143-14$ b

Irishman, 29, 37

Irish Queen, 215

Irish Shooting, 257

Irish Sportsman, 40, 79, 97, 138. 157, $182,183,283$

Irish Times, 100

Irish Town Councillor, 217

Iroquois, 271, 336

Irvine, William, 288

Irvines, The, 195, 207

Isabella, 399

Isherwood, Jobn, 316

Isinglass, xliii

Islington, xvii

Iveagh. Lord, $\mathrm{xxx}$

Ivers. Mr., 135

Izod, Colonel, 3 t

Jacob, Captain, 2

Jacomb. 316

James I., 90

Jameson, Wm., 152

Jannette, xlii, 188

Jardine, Robert, $2 s 8$

Jephson, Harry, 4, 9, 12

Jereed, 390
Jockey Club, The, xxii, xxxis, xii $172,173,213,421,426$

Jockey Hall, 196, 210, 211

Jockejs' Riding, xxiii

Jockeys' Ring, 40 t

Jockeys' wins-

W. Scott's, 388

Fordham's, 401

Archer's, 403

"Joes," 77

Joggleberry, 238

"John Jameson," 231, 238

John Kane, 75

Johnny, 12

Jones, Aaron, xxxiii, 322, 323, 333

Jones, John H., 4, 9, 33, 20s, 211

Jorrocks, 68, 71, 76, 109, 237, 274, 350

Joy, Captain, 196, 201

J. P., 58

Jusnita Perez, 1;

Juggler, 195

Julius, xlii, 188

Julius Cæsar, 90

July Course, 398

Kate Fisher, 140, 160

Kavanagh, $3 \pm 1$

Keate, William, xxxiii. 314-319

Keegan, Larry, 196

Keene, Alec, 325

Kellett, Captain, xiii

Keily's Gorse, 25

Kelly's Rocks, 301

Kelly, Stephen, xxi

Kelly, Tom, xxi, 196

Kelso, 393

Kendal, 96, 97

Kendal, jockey, 399

Kenmare, 230

Kennedy, Captain F., xx

Kenuedy, Lord, xxxv, 130, 271, 300, $366,369-371$

Kennedy, Sir Edward, 163

Kemedy, IVilliam, 154

Kennet, The. 310

Kennet Ale, 315

Kennett, Charles, 50, 55

Keogh, Dr., 32

Keogh, Tom, xxvi

Kerry, 231

Kettledrum, 394

Kick up the Dust, 13

"Kid, The," 402

Kilcash, 25

Kildare Club House, 195

Kildare Hunt, 73

Kildare Hunt Cup, 168, 200, 202

Kildare Hunt Plate, 162

Kildare Stakes, 209

Eildermorie, 272

Kilkenny Hunt, 8, 120

Killarney, horee, 6 
Killarney, 230, 231

Killeen, ?, 16, 89

Kilmacow, 26

Kilmacthomas, xxvii, 21, 22, 25, s̃

Kilmeadan, 88

Kiltorcan, 3, 16

Kilwarlin, 97, 423

Kingeraf $r$, xli, 188

King Reve, 168

King Tom, xxxiv, 309, 332

Kingsclere, $x$ liv

Kinnear, A. W., 372

Kirby Gate, 217

Kirkwood, Captain, 16 t

Kirwans, The, 212

Knavesmire, 173, 389

Knees, Big, 117

Knight, The, $1^{2} 5$

Knockaderry, 26

Knockany, 29, 96

Knockbrack, 25, 27

Knockbrack Runs, 5, 35, 36

Knockmore, Tom, 83

Knocktopher Abbey, 208

Knowsley, xxxix

Knox, Captain "Curley," $\mathrm{xx}$

Linox, George, xx, 160, 168, 196, 208

Knox, Maurice, 4, 3 t

Knutsford, 313

Ladas, xvii, xli, xlii, xliii, 399

Lady Elizabeth, 336

Lady Ellen II., xvii

Lady Golightly, xlii

Lady Kirk, 215

Lady Waterford's Gorse, 25

La Flêche, 92, 100, 181, 388

Laird, Mr. and Mrs., 233

Lalor, Thos., 4, 9, 16, 32, 34, 38, 40, 45

Lamb, The, 132, 282

Lambert, A., 32

Lambert, H., 34

Lambert, Mr., s0

Lambkin, xlii, 396

Lancashire, 312

Lancashire Plate, 191

Lavcers IX., 298

Land and Water, 84, 148, 232, 237, 263

Landed Proprietors, 418

Land League, The, $28,40,60,63,97$

Landnothing, Lord, 231

Landseer, 106, 145

l.ane Foxe's Covert, 26

Langar, 129

Langford, 212

Langford, Lord, 208

Langham, Nat, 77, 303, 322, 325, 333

Langrish, Sir H., 208

Langrish, Sir J., 4.34

Lington Wold, 38 ?

Laodamia, 14
Laragh Pun, xx, 164

Lark Lodge, 196, 209

La Rose, 168

Lascelles, Lord, 395

Latin and Greek, 410

La Touche, Percy, 156, $16 t$

Lauderdale, Lord, 268

Laurence, " Pig," $\mathrm{xx}$

Launcelot, 390

Lawley, Hon. Frank, xxxix. xl

Laycock, T. F., 2 ;2

Leatherhead, 390

Lecturer, $3: i^{\circ}$

Lee Barber, Captain, xx, 198

Logatee, 123

Legrer of $1851, \mathrm{xl}$

Legh, Peter, 314

Legh, Thomas, 31 2-319

Leicester, Lord, 243

Leicestershire Handicap, 141

Lentulus, 97

Leolinus, xlii

Lenpardstown, 137, 139, 141, 146, $150,183,200$

Leonie, $x l i$

Leprechaun, 215

Leslie, Sir John, 11

Letterewe. 272

Lewes, 3.9

Liberator, The. xviii, 132

Licensed Victuallere' Gaztte, xxxiv, 299

Licensed Tic'uallers' Mirror, 30s

"Limb, The," 207

Limerick, 95,179

Limerick Drag Hunt, 135

Linde, Eyre, 199

Lindé, Mr. H.. x viii, 152, 164, 196, 199.201

Lismore, 129

Little Brocklesby, 56

Little, ('aptain, xx. 7

Little Charley, 402

Liverpool, 186

Liverpool Echo, 546

Live Stock Journal, 225

Lizzie, 215

Lloyds, 331, 341

Loates, Tom, xli, xliv

Londesborougb, Lord, 24i, 392

London Fire Brigade, 226

Lיndonderry, Lord, 74, 395, 405

Longfellow, 311

Long, Willie, $\mathrm{xx}$

Longs, The, 98, 163

Lonsdale, Lori, 49

Lord's Crichet Ground, 375

Lord George, 6, 7, 12, 15, 160

Lord Gough, 97

Lord Lvon, xxxy

Lord Tara, 211

Lough Keunard, xxx 
Lough Leven, 233

Lowesby Hall, 56

Low, George, 189

Luke the jockey, 397

Lumbago, xxxvi. $27 \mathrm{~L}$

Luna, 31

Luryan, Lord, 167. 230-234

Lyall, Watson, 252-255, 260

Lycurgus, $16 i$

Lynn, Mr., xxxii

Macaroni, 336

Macaulay, Lord, 346

VcAuliffe. Mr. Wm.. xxr

McCarthy, Trant. xiii

IIcCraith. Capt.. xx

$11 \cdot$ Craith, Tom, 13, 98, 135, 160, 176

IcDermot, E., 21

McDonagh, Alan, 196, 198, 202, 211, 362

McDonagh, William, 131, 202, 211, 362

McDonald, Edward. 95, 107

McIntosh. The, xxxi

Macdonald, Jack, 326, 328

Macdonald, jockey, 168

Macdonnell, J. Miles, 209

Mace, Jim, xxxir, 309, 331

Machell, Captain, хxхจ, xxxviii, 15̌2, 396,407

McNally, Dan, 199

Macorchy, James, $3 t$

Madeira, 363

Maesgwynn, 13

Magee, Mrs., 31

Magistrate, 385

Mag on the Wing, 13

Magpie, 6

Magrane, William, 98, 163

Maguire, J., 33

Maher, George, 142, 164, 166

Maher, Mat. A, 96, 142, 164, 166, 175

Maher, Val, 370

Mahony, David, 15\&, 153

Maid of Trent, 402

"Main Bags," 3.3

Mainsail, 53

Mainspring, 29

Malahide, 152

Malcomson, Darid. 4, 16

Malcomson, Fred, 4, 16. 25, 239

Malcomson, George, 4, 16

Malmesbury, Lurd, $24 t$

Malton, 173, 195, 392

Mameluke, 388

Manchester, 186

Manchester Handicap, 209

Mandeville, J., 32

Manliness, 408, 409

Manly Games, 293-307

Manners, Lord John, 57

Manners, Lord, 152

Manserghs, The, 98
Mansfield, 385

Mansfield, Ed., '63

Mansfield, O., 32

Maple, Blundell, 176

Mar Forest, 260, 367

Maria, 210

Mark, 361

Markham, Mr., 90

Marlow. xli

Marquis, The, 12, 15, 38j

"Marquis, The," 10

Marquis and Buckstone, 397

Marsh, Richard, 190

Marsh. The. xli

Marske, xxv

Marson, Job, 389

Marston, Captain, 375

Martha, 20C, 201, 202

Martin, Bradley, 272

Martin, Jack, 322, 333

Martins, The, 129

Mary O'Toole, 132

Mason, Jem, 102

Masseys, The, 98

Master Bagot, 210

Master McGrath, 280-2St

Master Ned, 198

Masters of Schools, $29 j$

"Master, The," 398

Matchbox. xxiv, xliv

Matchless, 21

Mathers, 372

Mathew, 131

Mathews, H., 32

Maxwell of Moorhill, 21

Maxwell, Sir William, 370

Mayboy, 11, 12, 97, 201, 202

Masnioon, 169

Meany, Dan., xxi, 136, 168

Meara, George, 5

Meath Hounds, 345

Meaux, 389

Medlycott, J. T., 4, 16, 28, 33

Meets, Interchange of, xiv

Melbourne, 212, 422

Melbourne Race Course, 156

Melitta Lodge. 207

Mellish, Colonel, 313, 335

Melton, xli. xlii, 18\&, 183

Melton House, xli, 397

Members of Parliament, 331

Memorable Races, xl

Mlemore, 272

Menzies, Mr., 331

Mercury, 212

Meredith, Henry, xx, 9, 163

Meredith, Rice, 207

Meredith, Mrs., 209

Merrick, Mr., 362

Merrion Square, 221

Merry, A. W., 272

Merry, James, 335, 336, 39 ! 
Merton, xxx

Merryman, 6, 16, 129

Merry Monarch, xl

Metcalf, pedestrian, 375

Meteor, xli, xlii, 385

Methuen, Paul, 315, 316

Mexboroughs, The, 312

Meynells, The, 312

Miami, xl

Mickey Free, 207

Mickleham, 399

Middleham, 385

Middleton, Lord, xxviii

Milaine, xxxii

Milbank, Sir F., 246

Milesius, 210

Millet, Mr., 3

Mill Flill, xxxviii, 377

Millionaires, 425

Miltown, Lord, 163, 210

Milward, D., 33, 220

Mimi, xlii, 396

Mincing Lane, 304

Minette, 168, 169

Minting, xlii

Minting, 106, 176, 188, 340, 396, 397

Minthe, xlii

Miriam, 168, 169

Miss Adrien, 212

Miss Elis, xxxv

Miss Pitt, 169

Miss Sarah, xl

Miss Tooley, 212

Mist, The, 31

Mohican, 199, 200, 201, 203

Molyneaux, Lord, xxxii

Molyneaux, pugilist, $3 \& 0$

Monadhliath, 266

Monaghan, James, xxi

Moness, xxx

Moneypenny, Michael, 169

Mons Meg, 168

Monson, Lord, 35̌

Monte Carlo, 336

Montgomery, J. F., 141. 161

Montgomery, Lord, xli

Montmorency, John, 4, 10, 21

Montmorency, Harvey, 4

Montrose, 369

Montrose, Duchess of, xxi, xxiii, 426

Monzie, xxix

Moonraker, 362

Moore Abbey, 166

Moore, Garret, xviii, xx, 132, 196, 202, 203

Moore, J. Hubert, xviii, 141, 163, 196, 204

Moore, Richard, 163

Mooresfort, 208

Mordaunt, Sil C., 272

Mol'ny, Count, 387

Morris, H., 33
Morris, Mr. W. B , sx

Morris, $\mathrm{R}_{\text {. and }} \mathrm{T} ., 4$

Morrissey, John, 323

Morrogh, Leonard, 1193

Morton, Nathaniel, 75, 95, 2 23

Moseley, Sir 0., 314

Moss Rose, 402

Mountebank, 17

Mount Neil, 26

Mount Neil Run, 37

Moureith, 370

Monzie, xxix

Mowerina, xli

Moy Fair, 95

Moy Hall, xxxii

Moy River, 237

Mud Fever, 116

Mulcahey, W. B., 32, 33

Mullinavat, 25

Mullins, 134

Mundig, 3-5

Muriel, 288

Murland, Mr., xx

Murphy, Dominick, xx

Murphy, J. C., 96

Murphy, J. O'C., 96

Murphy, Martin, 139

Murphys, trainers, 196, 210

Musgrave \& Sons, 156

Musgrave, Sir James, 357

Musjid, 336

Musters, John, 2, 296, 355, 356, 371

Naas, Lord, $\mathrm{xx}, 163,164$

Nabocklish, 212

Nantwich, 314

Nap, 202

Narraghmore, 202

National Debt, xv

National Income. $x v$

National Hunt Steeplechase, 157

Naughtan, Thomas, 93, 163

Naylor, Mr. R. C., xl, 335, 337, 39;

Nelson, 391

Nereid, 196

"Neuras," 116

Nevard, Wm., 166

New Broom, 137

Newbrook, 74

Newburgh Prio-y, 373

Newcastle, 132, 140

Newcastle, Duke of, 3 Э

Newcomen, R., 196

Newmarket, xxii, 91, 172, 360, 375, 376

Newminster, xl, 185, 198, 390

Newry, 214

Newtown Chapel, 21

Newtown Wood, $25,4 n, 125$

New York Spirit of tike Times, xxxiii

Niblick, 201

Nicholson, "Chief Baron," xxxiv

Night Walke: 58 
Nightingale, Arthur, xrii

Nimrod, 217

Nisbet. Mr., 233

" Nobbling," 390

"Noble Art," 293-297

Noble, John, xxi

"Noble Science," 71

Nolan. Jerry, 31

Nor', The, 25

Norfolk, 207, 365

Normanby Lodge, 196

Normanby, Lord, 196

Norris, MIr., xxxii

North Camp, xxxiii

North, C'lone', 286, 397

Northumberland Handic. $p, 212$

Ninith Wales, 257

"Notitia Venatica," 2, 25t;

Nugent, Percy, xvii

Nugent, Sir Walter, 163

Nunnykirk, 385

I'unquam Dormio, 15', 32t, 3 !)

Oaks, The, xlii. 174, 192

Oberon, 12. 168

O'Brians of Dromolaud, 128

O'Brien, Mr.. 95

O'Brien, J., 389

O'Callaghan, Mr., 128

O'Connell, 131

O'Connell, Daniel, 132

O'Connors, The, 311

Odells, The, 21

O'Hanlon, Redmond, 208

O'Kelly, Colonel, '2l1

"Old Bones," $13 t$

Old Court, 36

" Old Ship," The, 225

"Old Stock," The, 417

"Old Times," The, 225

Oliver, Tom, jockey, 20:3, 402

Oiver, Tom, pugilist, 326

One Thousand Guir eas. The, xl i

O'Reilly, Joseph, 103, 223

Orlaudo, 6, 390

Orme, 92, 181

Ormonde, $1 \& 8,18:, 340,399$

Ormonde, Lord, 9. 25

Ormonde's Gorze. 25

Orr-Ewing, Captain, xx. 15 ?

Orwell Park, 24j

O'lijan, Dr., 11. 32

O'Ryans, The, 98

Osbaldeston, George, xxvii 2, 271, 3c0, 355-364, 398

Osbaldeston's Hounds xxxvii

Osborne. Dan, 4, 33

Osborne, John, 175, 397, 401

Osborne, Jneeph. xiii

Osborce, William, 32

O'Shea, J. P., 4

Osmond, F. S., $29 ?$
Ossian Lodye, 269

Ossif rage, 13

Otter Hunting, 291

Outrages, 2. 40-48, šl, 155

Own-r's' Expenses, xxii

Owning, 24, 25

Owston Wooà, 56

Paddock, Tom, 323, 333

Paddy, 20!

Padwick, H., 39J

Palin, Wm., 96, 197

Pallisser, Wray, $4,32,33,47$

Palmer, Wm., 13

Paris, Comte de, xxx

Paris Hurdle Race, 203

Paris Steep'echase, 202, 203

Parkinson, Mr., xxxviii

Parr, Mr., 401

Pas-ion Flower, 339

Pathfinder, xli

Paul, Sir R., 4 9, 16, 29, 32, 33, 43, 220

Paul, R. G., 32

Paul, W. J., 32. 3 !

Pavis, Arthur, 389

Payne. George, xxxv, 420

P. B. A. xxxiii

Peacemaker, 211, 215

Pracock, 5, 12

Peard, John, 394

Peard, J. H., 16.J

Peck, Kobert, 190

Peel, Captain A., 163

Peel, Captain E., 4, 6, 9, 164, 210

Peel, General, ;

Peel Cup, $2 \subset 9$

Pell Mell, xxxy

Peep o' Day Boy, 215

Peerage, 416

Pelagia, 168

Pembrokestown, 26

Pender, J., 32

Pennefather, Captain, 32

Penrhyn, Lord, $31 t$

Peri, 13

Pericles, xli

Perinita, 13

Perrin, James, 387, 394

Perry, Samuel, 32, 34

Perry, William, 32:3, 333 .

Persse, Burton, 163

Persses, Thə, 98

Perthshire, 260, 268

Peter Finnerty, 129

Pet Fox, 169, 202

Petrárch, 97

Petre, Hon. E., 385

Phil, 169

Philadelphian, 169

Philammon, 97, 168, 169

Philips, Godfrey, 34

Fhilistine, 169 
Philomel, 169

Philtre, 169

Phyllida, 169

Pickernel, Mr. Tu_a, xx, 160, 203

Piltown, 34

Pitman, 169

Pleiad, 210

Plunket, Mr., 12!)

Pocahontas, 197, 210

Polo, 291, 298

Pompadour, 393

Ponsonby, Captilin,?

Ponsonby, Mr. W. xxi

Pope!Lodge, 196, 210

Popham. General, 315

Porter, John, xliv, 181

Portland, 34

Portland, Duke of, xliv, 18!, 395

Portumna Castle, 130

Postilion, 15

Poul-a-Phouca, 29

Poulson, Harry, 322, 333

Powell, W. H.. 13

Power, Billy, is

Power, Edmund, $2+9$

Power, E. N., 32

Power, F., 32

Power, J. O'N., 32

Power, J. H., 32

Power. P. M., 33. 249

Power, P. W., 32

Power, R., 32

Power, R. A., 32

Power, Sir John, 3. 4, 5, 8. 9, 120, 163

Power, Sir Richard, 34, 163

Power, J. Talbot, 10 1, 22.3

Power, The Misses, 31

Power, John, 4, 9, 131, 195, 206;

Power, William, 4

Power, T. Talbot, 223

Preston, 312, 313, 335

Preston, John, 98, 15t, 163

Priam, 103

Price of Brynprys, 312

Price, Rose, 232

Price, J., of Rhiwlas, 246 .

Price, Mr., $15 t$

Pritchard-Rayner. Mr.. xx

Pride of Kildare, 202

Priestholm, xliii

Primate, xlii

Primrose League, 201, 203

Prince of Wales, H.R.H. the, 161, 242

Prince of Wales' Plate, 200. 201, 202

Princess, $x l, 390$

Prism, 13

Prize Fighting, 308-319

Prize Ring, The, xxxiii

"Professional Horse," xvii

Professional Riders. xx

Punchestown, 58, 132, 137, 139. 145, 150, 153.164, 182, 183, 201, 207, 219, 423
Punchestown Courses, 157

Punchestown Double, xviii. 147,160 .

Punchestown Luncheons, xix

Punster, 169

Pyrrhus the First, $3 \& 9$

Pytch'ey, The, xxv, xxxvii. 355, 356.

Queen, H.M. the, $16^{\prime}, 263$

Queen Bee, 14, 215

Queen's Messenger, xli

Queen's Plates, 179, 202, 206, 209, 212\% 213

Queen Marga. et, 13

Queensberry, Marquis of, 310

Queensberry, Duke of, 335

Quenby Hali, 57

Quin, Billy (whip), 55

Quin, Captain Wm., 34, 36, 133

Quin, Edward, 33

Quin, Miss, 31

Quin, William, 4, 76, 98, 163, 210.

Quinine, 37

Quinlan, P., 33

Qui-va-a, 169

Quorn, The, 57, 355, 356

Race Companies xxii

Races of the Century, 395, 397

Races won by John Scott, 385-3ง7

$\begin{array}{lll}" & \quad & \text { Wat Dawson. 394-397 } \\ " & \quad \text { Wm. Scott, 388, 389 } \\ " & \quad \text { G. Fordham, 399 } \\ & \text { F. Archer, 403 }\end{array}$

Racing Calendar, 172, 176, 185

Racing. Financial Position. xxii

Rackets, 297

Rackbam's Medicines, 279

Rada, 396

Radcliffe. Mr., 402

Radical, 130

Radicals, 188, 261, 292, 306, +13

Ragdale Bottom, 29

Ramsden, Sir J., 272

Rasper, 129

Rasselas. xxxvii

Rathbride Cottage, 207

Rathbride Manor, 207

Ratheroghan, 129

Rathgormack, 4, 27, s1

Rawle, Will, $34,50,54,55$

Rawlin Station, 332

Reading, 314

Receiver. The. xlii

Recipes, 116, 117, 118, 271, 272

"Records of the Racecourse," xxxviii

Red Coat Races, 73

Red Coat Stains, 117

Red Hart, 123

Red Herring, 31

Red House, The, 361,367

Redman, 160

Red Prince, 202 
Red Rose, 13

Reed, Fletcher, 376

Keese, John, 96

Reeres, John, 399

Regattas, 2.1

legent, 53

Regiment, 85th, 6,9

Repentance colt. xli

Revenge, 196

Revoke, 196

Revolutions, 415

Reyne'l, Samuel, 67, 154. 163

Reynolds and Fisher, 337

Rheumatism, xxxvi, 271

Ricardo. Captain. xx

Richards, John F., 360

Richardson. Captain, 166

Richmond, Duke of, 172

Riders. Gentlemen. xx

Professional. xx

liiddlesworth, 244

Rigby, W. and J., 238

Riggs, Mrs., 32

Ripon, Lord, 246

Ruanmore, 26

Roleck. Baron de. xx

Roberts, Charles, $16+$

Roberts, Mrs., 220

Roberts, Arthur, 5

Roberts, Edward, 5

Roberts, Richard, 5, 22

Koberts, Mrs. Richard, 22-30, 31

Fioberts, Samuel U., xiii, 5, 102

Robertson, David, 215

iiobin Hood, 168

Robinson, Jim, $38 \mathrm{~s}$

Roche, sir Darid, 163

Roche, yictor, $2 \mathrm{l}$

Rochford, Horace, 4,9

Rock, Thค, 5, 6, 12

Rocket. xxxrii

Rockhill, 385

Rock Stakes, 135

Rockwell, 2

Rogers, Congreve, 4, 33

Rog ${ }_{1} \mathrm{~s}$, Sam, 327,397

Roll+r, 196, 209

Roman Oak, 97

Rocodee, The, 312

Roos, Lord de, 365

Rosamond, 13

Rose. Miss Mary, xli

Rostbery, Lord, xvii, xlii, xlir; 3 ; 397.399

Ro etud, 5:3

Rosa Price, 232

Rosicrucian, 97

Ro-s, Captain, 130, 249, 271, 300, 364309,381

hoss, Mre.. 369

Lioss Country, 24, 26

Ross, Sir Chas., 248
Rossallagh, 95

Rossett, 311

Ross'yn, Lord, 395

Rossmore, Lord, 98

Rossmore Lodge, 207, 211

Ross-shire, 260, 267

Rothschilds, 401

Rous, Admiral, 309, 426

$\mathrm{R}$. ver, 210

Roy Neil, 97

Royal Dublin Society, 92

Royal Duke, 3:35

Royal Meatb, xviii, $15 \cap, 203$

Ruff s Guide, 179

Rug, The, 13

Rugby, 53

“Rupert of Debate," xl

Russborough, 210

Russell, Dan, xx

Russell, Mr., 53

Russell, Pat. xx. 98, 135, $16 t$

Russley, 394

Rust, 211

Rusticus, 192

Kyall, W. A., 34

Rjan, Dan, 18, 55

Ryan, Johnnie, huntsman, 2, 16, 18, 27,54

Ryan, Johnnie, groom and jockey, 7 , $14,29,32,59,89$

Ryan, Tom, xxi, 55

Ryau, T. \& WV., xxi, 55, 196

Rye, Captain, 163

Rynd, Christopher, 163

Rynd, Fleetwood, 154

Sackville Street, 217

Sadler, Arthur, 195

Sadlier, Clement. xiii

Sadlier, Ћ̌ichard, 196

Sadliers, The, 98

Sagitta, 385

Sailor, 195

Sailor Prince, 405

Sainfoin, 151

St. Albans, Duke of, 395

St. Bennett. 212

st. Gatien, 396

St. George's, The, 195, 207

sit. Giles, 385

"St. James, Mr.," xx. 207

St. Lawrence, Lord, $98,154,163$

St. Leger Church, 128

St. Leger, The, xlii, 172, 174, 181, 192, $212,312,336,338$

St. Loger, The, 1894, xliv

st. Marnock, x viii

St. Mirin, 403, 405

St. Serf, 398

St Simon xliv, 188, 159, 346

Saladin. xxxivi

Sal vano., 4() 2 
Samson, 53

Siandown, 146, 150, 186, 207, 219

Sappho, 368

Sarah Bernhardt, $20 t$

Sarah Ellis, 13

sargent, H. R., 32, t8

Satanella, 168, 169

Saurin, P. M. V., 163

Savernake, xxxv

Sayers' Meadow, xxxiii

Sazers, Tom, xxxiii, 309, 321-3:

Scalds, 117

Schickler, Baron, 399

Schroeder, Baron, 260

Sciences, 415

Scotch Fishing, 253-25:

Scotch Mail Coach, 350

Scotch Noors, 255-257

Scots Grey, 106, 202, 343

Scott, Bill, xl, 336, 388, 389, 390

Scott. John, xxxix. 183, 23t, 38t-39t

Scott, Mrs., 390, 393

Ecott, Lord John, 394

Scott, W., 401

Scottish Chief, xli

Scottish Widows, $3+1$

Seaman, xviii, 132, 152, 200, 201, 23

Seffert, Dan, 362

Sefton, Lord, 247, 312

Sefton Steeplechase, 200, 203

Selborne Natural IIistor'y, 213

Selby, James, 224, 298

Severn, Captain, 154

Shannon, Lord, 163

Shannon, The, 230

Shaw, Captain, xx. 125, 136

Shawyer's Pills, 278

shee. Jimmy, xx

Sherwood Forest, 3 २5

Shinrone, 7

Ship Inn, xxxiii

Shoolbred, F., 272

Shoolbred, W., 272

Shooting, $234-272$

Shooting, Remarkablo, xxviii

Shooting Tenants, 263-266

Shotover, xliv

Silenus, xli

Silks, The, 341

"Silks and Satins," 290

Silvio, xli, xlii, 188

Sims, George, 322, 333

Sir Arthur, 7

Sir Berys, 401

Sir Hercules, 208, 211

Sir John, 7, 15

Sir Joshua, xxxv, 385

Sir Nick, 6, 12

Sir Peter Teazle, xxxii

Sir Tatton Sykes, $\mathrm{xl}$

Sir Visto, xli, xlv

Sisyphus, 168
Six Mile Bottom, 245

Ska ${ }^{\text {ing }}, 312$

Slacke, Captain, 32, 34, 37, 5 .

Slacke, Mrs., 30

Slate Quarries, 3

Slave, $x 1$

Slavin, F., 309

Sleive-na-Mon, 24,40

Sleive-na-Moona Run, 2)

Sligo, Earl of, 129

Sligo, Marquis of, 129, 195;

Sligo Whip, The, 129

Smallhopes, 210

Smith, Captain Arthur. xx, $16 x$

Smith, Captain Unwin, 315

Smith of Headboro. 21

Smith, T. Assheton, 2, 130, 296, 6ij 371

Smith, pugilist, 309

Smithfield, 172

Smithwick, Dan, 34

Smithwick, Ed., 34, 96, 16t

Snow, John, 2:0

Snow Hill, 25

Snuffy, 31

Soapy Sponge, 71, 238

Socialists, 292

Soldiers' Home, 206

Solon, 97

Somerset House, 337

Someret, Lady Blanche, 31

Somersetshire, 311

Southwell, George, 55

Spahi, 168, 201, 202,405

Srancil Hill, $9 \tilde{s}$

Speculum, xli

Spencer, T., 33, 47

Spendthrift, 413

Spey, The, 233

Spiletta, xxv

Spilsby Country, 356

Spinaway, xlii

Sport, 289-292

"Sport a National Benefactor." xir. xxxii

Sportascrapiana, 243, 299, 354

sporting League, xir. xxxii. xlv

Sporting Magazine, 12

"Sporting Man," 41.3

Sportsman, The, xviii

Sportsman's Guide, 252-260

Sports and Pastimes, 2!!;

Sprains, 116

Spratts Biscuits, 277

Sprig o' Shillelagh, 215

Springfield, 9-

Springfield, T. O. $35,49.55$

Squire, The, 105

"squire, The," 355-364

Stackpools, The, y8, 163

Stallions, 421

st:imford, Lord, 245 
Standarel, The, 360, 361

Stand House, Curragh, 206

Stanton, 169

Stanley, Mr. Massey, xxxr. xl

Statistics, 419

Stephenson, J., 33

Sterling, 1ss

Sterens. Jack. 355

-Stewards, Pattern, 230

Sticking Plaster, 118

Stick-play. 311

Sting, $x l$

Stock Exchange, 304, 333, 341. 313

stockwell, xl. 1!6, 198, 209, 210, 211. $337,394,422$

Stokestoun, xiv

Sionehaven, 370

strafford. Lord. 395

"Straight," 410

strains, 116

Strangman, Joseph, xiv 4, 16. ㄴ.1. 2?. $32,33.48$

Strangman, L. G., 32

Streatlam. xxxix

streatlom Hall. 387

Strougbow, 221

Stuart, Miss, $\$ 2$

Stubber, Captain, 166

Stubber, Miss, 37

studdert, Capt., 163

studderts. The. $9 \mathrm{~s}^{\prime}$

Stud Farms, 96

Studley Royal, 247, 248

vubduer. xi

sudbourne Hall, 248

Suetonius, 90

Suftield, Lord, ?

suffolk, $24 \%, 319,356,36$.

Suir, The, 25

Sulby Hall, :356

Sultana, 202

Summerhill, 208

Sun, The, 341

Sunshine. 16

surplice. 390

Surrey, The. 97

surtees, R. G.. 72

Sutherland, Duke of, $2 \times 6,250$

Sutherlandshire. 267,366

Sutton, Sir R, ::61

Swainestown. xx

Sweetmeat, xl, 198

Sweetsauce, 215

Sweet William, 210

Swift, Owen, 25

Swimming, 301

Swivel, 168

sykes, Sir Francis, 214

Sylies, Sir Tatton, xl. 313

"Sylvanus," $3 \& 9$
Tables referring to :

Fishing, 25t, 255, 259

Hunting. 5t, 80.81 .83

liacing, $148,149,173,174,176.177$, $184,186,191,204,388,395.41: 0$, 107

Sale: of Horses. $12,14,392,396$

shooting, xxix, 243, 24t, 247. $250-$ 255,259

Tarious, 113, 204, 222, 290, 33:3, 3ะs, $\pm 0$

Talbot, R. N., 96

Tally Ho, Thomas, 70

Tambourine, 163

Tantive, The, 217

Tate, Colonel, 31

Tattersall. Mr., 210

Tattersalls, 53, 172, 341, 34:

Tautz, 217

Taylor Alec. xxxv. xl

Taylor, Colonel Brooke, 6

Tearaway, 210

lieddington, $\mathrm{x} x \mathrm{x}, 336$

Teetntum: 211

Tegetmeier, IIr., 248

Tempest, Captain, xx. 136

Templeman, sim, 28.

Templemore, $16 \mathrm{~s}$

Ten Broeck, Mr., 401

Thales. 307

Thames, The, 310

Tharp. J. sidney, 24j

Thebais, 401

Thellusson, T.. 3is

"The Marquis," 10

The Marquis, 12, 15

The Princess. $x l$

Theseus. 193

Thomas. Mr.." xx, 160. 203

Thompson, Anstruther, 55

Thompson, Colonel. 166, 96

Thompsun, John, 217, 22:3

Thompson, Lieutenant, 6

Thompson, Mr.. xx

Thormanby, xli, 1s8, 336, 394

Thorn, 21 J

Thorney Bridge, 25

Thornhill, Mrr., 244

Thornton, Culonel, 313

Thornton. Pat, xxvii

Thoughts upon Hunting, 71

Throstle, xxiv, xliii

Thrush. 116

Thurlow Country, 355

Tibbie shiels, 99

Tidy, 236

Tilton. 57

Timekeeper, 221

Tim Whiffler and Buckstoze, 397

Tin rane, $16,50,124$

Tipperary, 132, 177

Tipton Slasher, xxxiii, 323, 333 
Titania, 13

Tockenham Park, 311

Tom Brown's School Days. 311

Tom King, pugilist, 309, 332

Tom King, horse, 198, 215

Tomlins, Mr., 245

Tom Tug, 210

Tommy Tittlemnuse, $s 06$

Too Good, 199, 200, 203

Tooley Street Fire, 226

Torpedo, $39 \mathrm{~S}$

Torrent, 154

Tory, A, 415

Tory Hill, 25, 37

Touchstone, 389, 422

Tourists. xxxi

Touts, 392, 397

Townley, Captain Tom. xx

Tradesman's Cup. 212

Tradesman's Plate, 13.;

Tragedy, 202

Tramore, 13!

Trencb, B. B., 96

Trent, xlii

Trent Lock, 324

Trewerne, $24 \mathrm{~S}$

Tribes, The, 1:30

Tristan, $18 \mathrm{~s}$

Trocke, Ciptain, xx. 13J, 162, 164, 175

Trump. 210

Tuite, Joseph, 1:B

Tullagher, 25

Turco, 201, 203

Turf and Sod, The, 312

Turf Club, 165

Turf Lodge, 196, 208, 209

Tweed, The, 233

Tweedmouth, Lord, 2\%:2

"Twelfth, The," 266

Two Thousand Guineas. xli. xlii

Two-year-olds, xxiii

Tydd, Jack, 121

Tynte, J. P., 163

Tynte, Fortescue, 163

Tyrone, Lord, xiv, 32

Ugly Buck, xl

Umpire, 97, 123

Uncas, 97

Unicus, xxxii

Ury, $372,375,3 \& 1$

Usna, 201, 204

Ussher, Chris'opher, xx

Valentine, 131, 160, 206

Valentine, xxxvii

Valentine's Brook, 14S, 204

Vauban, 336

Vaulter, xxxvii

Venison, $\mathrm{xl}$

Verdant Green, 228

Vernon. Hon. Richard. xxxiv
Vernon Lord, 355,356

Vesta, 13

Victor, 97

Vigilant, 17

Villager, 17, 53

Voltaire, 388

Voltigeur, '210, 397

Volunteer System, 305

Vyner, Clare. $3 ! 5$

Vyner, Robert 'T., 2, 166, 176, 356, 3!.5)

W. A. C. B., 226

Wade, John, t, 9

Wakefield, John, 163, 16t

Wales, H.K H. the Prinec of, xvii 161, 242

Walker, Isaac, 391, 392

Walker, W. H., 272

Wall, 16

Wall, Patrick, 51, 63

Wall, Peter, 48

Wallasey, 172

Walsh, John, xiii

Walsh, John, 22, 23

Walshe's Hotel, 8

Walshe, P., 32

Walsingham, Lord, xxx, xxxi. 247

Walton, 336

Wanderer, 131

Warbles, 117

Warburton, Captain, xx, 15̆t, 16t, 168

Warburtons, The, 312

Ward Bennett, Colonel, 34

Ward, Joe, 315, 316

Ward, Mr., s62, 374

Ward, pugilist, 375

Ward Union, The, 74, 75

Wardrop, Colonel, 34

Warner, $1 \tilde{s}$

Warts, 117

Wary, 54

Watercress, $1(0,3 \mathrm{ss}$

Waterford Club, 344

Waterford Country, 7, 34, 59, 60, 74

Waterford, Dowager Lady, 30, 31, 32

Waterford, Lady, 29, 31, 32, 56, 59

Waterford Lodge, xxv, 206

Waterfords, The (Curragh), 202

Waterford. III. Marquis, $1-15,54,56$. $98,120,130,154.170,175,195,2: 0$, 398

Waterford, IV. Marquis, 15,16

Waterford, V. Marquis, 21-48, 5t, 56. $59-61,81,353$

Waterloo Cup, xxxii, 280-287

Waters, Robert, 156

Waters, T. G., 59, 140, 142, 154, 207

Watson, Robert, 4, 122, 163

Watts, John, xli. 397

Watts, Mr., 197, 207, 210, 211

Waugh, R., 399

Waxy, 129 
Weatheral, 398

Weatherby, Messrs., 90, 172, 185

Weatherstown, 25

Weazel, 58

Webb, 399

Webb. John G.. xiii

Wedderburn, Webster, 299, 376

Welch, Jemmy, 226

Velch Mountains, 3. 26

TVelcome, 6

Wellington, 129, 391

Wellingtons, The, 212

Wells, jockey, 400

TVelters, Curragh, 203

Welters, Liverpool, 203

Wemmergill, 216,247

T'enlock, xxxr

West Australian, гхxix. 189, 336, 385, 391

Wcst. James. 300

West, W. H., 166

IVest Kent, The, 77

Westenra, C.slonel, 98, 195

Westmeatb, $16 \mathrm{~s}$

Westmeath Lakes, 230

Westminster, Lord. 387

TVestminster Pit, 31:3, 31!

Weston, Colville, 245

TVexford Hounds, $24 \mathrm{~s}$

Wharncliffe. Lord. xxi

"What's to Win?" 339

Wheble, Major, 310-319

Wheel, 210

Wheeler, C. A., 35̃, \pm 371

Wheel of Fortune, slii. 1ss

Wheel of Life, The, 41 j

Whelan, Johnny. xxi. 168

Whisper Low, 199, 200-203

White, Alfred, 405

White, Captain, 312

White, Colonel Charles, 16:3

White, Colonel John, 163

Whitefields, 7

White Horse Cellar, 217, 225

White, John, 163

"White Piles," 312

"Whites," 335

Whitehouse, xli

Whitewall, 1s8, 38t-39t

Whoo Whoop, xly

Why Not, $x$ vii, 97

Widger, Joe, xviii

Widger, John, xviii, 107

Widger, Mick, xviii, 339

Widger, Thomas, 33, 95, 96
Wild Huntsman, 215

Wild Man from Borneo. xrii. xriii

Wild Oats, xli, 210

Wilkes, George, xxxiii

Wilkin, Mre, 15t

Williams, Mriss, 30

Williamstown, 59, (30, 74, 13:)

Willoüghby, Mr.. xxviii

Willoughby, Sir J., 396

Wilson, Arthur, 32, 55

Wilson, John, 221

Wilson, Mr. Remington, $\mathbf{x x}$. 2 2 lf;

Wrilton, Lord, xl. 313

Wiltshire, $311-319$

Wimborne, Lord. $26 \mathrm{~s}$

Winans, Mr., xxxi, 260, 268, 27?

Winchilsea, Lord, xlvi

Wiudham, William, $31 \pm$

Windbound. 394

Winterton, Lnrd, 233

Wizard, The, 3s.

Wombrell, Captain, 154

Wood, Abran, 375

Woodbrook, 1:2, 14s, 199, 200, 201, 202

Woodland Hunting. xxxrii

Woodlark, 58

Woods, George, 4

Woodstock, 3

Wordsworth, 203

TVorms, 278

Wortley, Mr. Stuart, xxx

Wounds, 116

Wragby Woods, xxxvii

Wrestling, 294

Wynne, D. and T., xxi, 168

IVynue, Joe, xxi, 131

Wynnes Gorse, 3, 16, 31

Wyvis, 272

Yachting, 289, 290

Yarborough, Lord, $8 t$

Yarborough Lot, 16

Yearlings, 422

Yellows, 277, 279

York, 171, 173, 313

York and Ainsty, 55

Yorkshire Moors, 234, 246, 257

Young Blacklegs, 12y

Zazelle, 32

Zenophon, 97, 415

Zingaree, 39

Zitella, 202 

Mhebser Family Library of Velerinary Miedicine Cummings School of Veterinary Medicine at Tufts University 200 Westboro Road

Marth Grafton, MiA 01536 
SYDNEY R. SMITH 
